\title{
Rechterlijke vaststelling van het bezit van de nationaliteit in Nederland en Duitsland : een onderzoek naar proces- en bewijsrechtelijke aspecten van de rechterlijke vaststelling van nationaliteitsbezit in rechtsvergelijkend perspectief
}

Citation for published version (APA):

Poortman, C. (1996). Rechterlijke vaststelling van het bezit van de nationaliteit in Nederland en Duitsland: een onderzoek naar proces- en bewijsrechtelijke aspecten van de rechterlijke vaststelling van nationaliteitsbezit in rechtsvergelijkend perspectief. [Doctoral Thesis, Maastricht University]. Koninklijke Vermande. https://doi.org/10.26481/dis.19960606cp

Document status and date:

Published: 01/01/1996

DOI:

$10.26481 /$ dis. $19960606 \mathrm{cp}$

Document Version:

Publisher's PDF, also known as Version of record

Please check the document version of this publication:

- A submitted manuscript is the version of the article upon submission and before peer-review. There can be important differences between the submitted version and the official published version of record. People interested in the research are advised to contact the author for the final version of the publication, or visit the DOI to the publisher's website.

- The final author version and the galley proof are versions of the publication after peer review.

- The final published version features the final layout of the paper including the volume, issue and page numbers.

Link to publication

\footnotetext{
General rights rights.

- You may freely distribute the URL identifying the publication in the public portal. please follow below link for the End User Agreement:

www.umlib.nl/taverne-license

Take down policy

If you believe that this document breaches copyright please contact us at:

repository@maastrichtuniversity.nl

providing details and we will investigate your claim.
}

Copyright and moral rights for the publications made accessible in the public portal are retained by the authors and/or other copyright owners and it is a condition of accessing publications that users recognise and abide by the legal requirements associated with these

- Users may download and print one copy of any publication from the public portal for the purpose of private study or research.

- You may not further distribute the material or use it for any profit-making activity or commercial gain

If the publication is distributed under the terms of Article $25 \mathrm{fa}$ of the Dutch Copyright Act, indicated by the "Taverne" license above,

Download date: 26 Apr. 2023 


\section{Rechterlijke vaststelling van het bezit van de nationaliteit in Nederland en Duitsland}

Een onderzoek naar proces- en bewijsrechtelijke aspecten van de rechterlijke vaststelling van nationaliteitsbezit in rechtsvergelijkend perspectief

\section{PROEFSCHRIFT}

ter verkrijging van de graad van doctor aan de Rijksuniversiteit Limburg te Maastricht op gezag van de Rector Magnificus, prof. mr M.J. Cohen, volgens het besluit van het College van Dekanen, in het openbaar te verdedigen

op donderdag 6 juni 1996 te 16.00 uur

$$
\text { door }
$$

Carola Poortman 


\section{Promotor: $\quad$ Prof. mr G.R. de Groot}

Beoordelingscommissie: Prof. mr F.A.M. Stroink (voorzitter)

Prof. mr H.A. Groen

Prof. mr M.R. Mok (Rijksuniversiteit Groningen, Advocaat-Generaal bij de Hoge Raad der Nederlanden)

CIP gegevens / Den Haag

Omslagontwerp: C. Koevoets

Uitgever: Koninklijke Vermande bv. Lelystad

ISBN 9054583606

NUGI 693 / 695

- 1996, C.S. Poortman

Alle rechten voorbehouden. Niets uit deze uitgave mag worden verveelvuldigd, opgeslagen in een geautomatiseerd gegevensbestand, of openbaar gemaakt, in enige vorm of op enige wijze, hetzij elektronisch, mechanisch, door fotokopieẻn, opnamen, of enige andere manier, zonder voorafgaande schriftelijke toestemming van de uitgever.

Voor zover het maken van kopieën uit deze uitgave is toegestaan op grond van artikel $16 \mathrm{~b}$ Auteurswet 1920 $\mathrm{j}^{\circ}$, het Besluit van 20 juni 1974, Stb. 1974, Stb. 351, zoals gewijzigd bij het Besluit van 23 augustus 1985 , Stb. 471 en artikel 17 Auteurswet 1912, dient men de daarvoor wettelijk verschuldigde vergoedingen te voldoen aan de Stichting Reprorecht (Postbus 882, 1180 AW Amstelveen). Voor het overnemen van gedeelte(n) uit deze uitgave in bloemlezingen, readers en andere compilatiewerken (artikel 16 Auteurswet 1912) dient men zich tot de uitgever te wenden. 


\section{Voorwoord}

Bij de afronding van een proefschrift slaakt menig auteur, en met deze diens omgeving, een zucht van verlichting. Hoewel ik met plezier en veel interesse aan het onderzoek heb gewerkt, gaat het voorgaande in mijn geval zeker op. Het moment van afronding was dan ook zeer welkom. Gedurende de laatste jaren heb ik wel het gevoel gehad in een permanente staat van efficiency-operatie te verkeren, er mocht vooral geen tijd verloren gaan.

Het moment van afronden betekent tevens het moment van het uitspreken van een dankwoord. De meest geëigende plaats daarvoor is het voorwoord van het uiteindelijke boek.

Graag wil ik een ieder die gedurende de totstandkoming van het boek een bijdrage daaraan heeft geleverd daarvoor bedanken. Mijn dank gaat uit naar degenen die mij door mentale steun te leveren deden voortschrijven. Tevens geldt mijn dank degenen die meer daadwerkelijke bijdragen leverden door behulpzaam te zijn bij het opsporen van literatuur en jurisprudentie, door vragen te beantwoorden, door mee te (moeten) lezen en te becommentariëren. Iedereen bedankt voor de inzet! Wat betreft de meelezers zijn er kleine en grote slachtoffers. De meesten waren betrokken bij een bepaald onderdeel; een enkeling heeft aan de ontwikkeling van het hele boek deelgenomen. In het bijzonder mijn promotor, Prof. mr G.R. de Groot wil ik danken voor de opmerkingen die hij naar aanleiding van mijn schrijfsels maakte. Van zijn hand is de Duitse vertaling van de samenvatting. Ook de tweede vertaler, mevrouw L. Rayar, ben ik dankbaar voor haar bereidheid om de samenvatting in het Engels te willen vertalen. Een boek is het pas geworden nadat mevrouw M. van Woerden zich erover had ontfermd. Alle mooie lay-out is aan haar te danken.

Dankbaar ben ik ook de vakgroep Staat en Politiek van de faculteit Bestuurskunde aan de Universiteit Twente, die mij in de gelegenheid heeft gesteld het onderzoek te voltooien. Zonder de ruimte die mij daar is geboden, was het boek waarschijnlijk nooit verschenen.

Enschede, 29 februari 1996 



\section{Inhoudsopgave}

Voorwoord

Nederlandstalige afkortingen en periodieken

Duitstalige afkortingen en periodieken

\section{Inleiding en probleemstelling}

0.1 Inleidende opmerkingen en probleemstelling

0.2 Plan van behandeling

0.3 Verantwoording van het Nederlandse onderzoeksmateriaal

0.4 Verantwoording van het Duitse onderzoeksmateriaal

Hoofdstuk 1 Inleidende opmerkingen betreffende het Nederlandse nationaliteitsrecht

$1.1 \quad$ Inleiding

1.2 De ontwikkelingen voorafgaand aan de huidige wetgeving

1.2.1 Ontwikkelingen in de literatuur

1.2.2 Ontwikkelingen op het gebied van wetgeving

Hoofdstuk 2 Procesrechtelijke aspecten in het Nederlandse nationaliteitsrecht Vaststelling van de Nederlandse nationaliteit door rechterlijke instanties

2.1 Inleiding

2.2 Vereisten voor ontvankelijkheid (art. 17 RWN)

2.2.1 Algemene beschouwingen

2.2.2 De exclusieve werking van artikel 20 RWN

2.2.2.1 Rechterlijke instantie of in administratief beroep 25

2.2.2.2 "Aanhangige zaak"

2.2.2.2.1 Op welk moment is een zaak aanhangig bij een artikel 20 RWN-instantie?

2.2.2.2.2 Naar welk moment beoordeelt de rechtbank de aanhangigheid van de zaak?

2.2.3 Onmiddellijk belang bij de vaststelling

2.2.3.1 Algemene beschouwingen

2.2.3.2.1 Nationaliteitsvaststelling van personen die in leven zijn 
2.2.3.2.2 Nationaliteitsvaststelling van een overleden persoon 43

2.2.3.3 Illustratief historisch overzicht 44

$\begin{array}{lll}2.2 .4 & \text { Processueel belang bij de vaststelling } & 47\end{array}$

2.2.4.1 Algemene beschouwingen 47

2.2.4.2 Rijkswet op het Nederlanderschap 48

2.2.4.2.1 Contemporaine vaststelling volgens de Hoge Raad 50

2.2.4.2.2 Retrospectieve vaststelling volgens de Hoge Raad 51

2.2.4.2.3 Nadere uitwerking van het processueel belang bij contemporaine vaststelling

2.2.4.2.4 Een futuristische vaststelling? 57

$\begin{array}{lll}2.2 .4 .3 & \text { Divergerende belangen } & 60\end{array}$

2.3 De positie van het openbaar ministerie (art. 18 lid 1 RWN) 63

2.3.1 De conclusie van het openbaar ministerie in feitelijke instantie 63

2.3.1.1 Algemene beschouwingen 63

2.3.1.2 Rijkswet op het Nederlanderschap 66

2.3.2 Onderzoek naar feiten en bewijsmiddelen door het openbaar ministerie

2.3.2.1 Algemene beschouwingen

2.3.2.2 Rijkswet op het Nederlanderschap

2.4 De toepasselijkheid van de artt. 429d, 429f-4291 en 429s-429t Wetboek van Burgerlijke Rechtsvordering (art. 18 lid 1 RWN)

2.4.1 Algemene beschouwingen

2.4.2 De positie van de "belanghebbende" in verzoekschriftprocedures (art. 429f Rv)

2.4.2.1 De Staat der Nederlanden als belanghebbende 78

2.4.2.2 Motief voor het oproepen van de Staat 79

2.4.2.3 Procureurstelling door de belanghebbende? 82

2.5 Cassatie (art. 18 lid 2 RWN) 85

2.5.1 Algemene beschouwingen 85

2.5.1.1 Een uitzondering op artikel $426 \mathrm{Rv} \quad 88$

2.5.2 Ambtshalve cassatie mogelijk dan wel wenselijk? 89

2.6 De bindende werking van de vaststellingsbeschikking

2.6.1 Algemene beschouwingen 92

2.6.2 Rijkswet op het Nederlanderschap 93

2.6.2.1 Reikwijdte van de bindende werking 94

2.6.2.1.1 Subjectieve reikwijdte 94

2.6.2.1.2 Objectieve reikwijdte 96

2.6.2.1.3 Duur van de bindende werking 97

2.7 Herziening van een vaststellingsbeschikking 98

2.7.1 Algemene beschouwingen 98

2.7.2 Rijkswet op het Nederlanderschap 103

2.7.3 Herziening in het administratief procesrecht 105 
2.7.4 Kan de Staat het rechtsmiddel herziening instellen tegen een vaststellingsbeschikking?

2.8 De impliciete vaststellingsprocedures (art. $20 \mathrm{RWN}$ )

2.8.1 Algemene beschouwingen

2.8.2 Grote verscheidenheid aan procedures

2.8.3 Advisering inzake het Nederlanderschap

2.8.3.1 Historisch overzicht

Hoofdstuk 3 Bewijsrechtelijke aspecten in het Nederlandse nationaliteitsrecht

3.1 Inleiding

3.2 Bewijsrecht in civiele procedures

3.2.1 Algemene beschouwingen aangaande bewijsrecht

3.2.2 Bewijsrecht in verzoekschriftprocedures

3.2.3 Het bewijzen van feiten en het bewijzen van een recht

3.3 Bewijs van de Nederlandse nationaliteit

3.3.1 Algemene beschouwingen

3.3.2 Nationaliteitsbeslissingen vanaf 1948 tot 1967

3.3.2.1 Jurisprudentie categorie A: Beroep op verwerving van het Nederlanderschap

3.3.2.1.1 HR 28 oktober 1952

3.3.2.1.2 HR 3 juni 1958

3.3.2.2 Jurisprudentie categorie B: Beroep op behoud van het Nederlanderschap

3.3.2.2.1 HR 13 april 1948

3.3.2.2.2 HR 5 oktober 1948

3.3.2.2.3 HR 4 oktober 1949

3.3.2.2.4 HR 10 september 1959

3.3.2.3 Eerste tussenevaluatie

3.3.3 Nationaliteitsvaststelling en bewijslastverdeling in procedures op grond van artikel 43 (oud) Vreemdelingenwet (1967-1989)

3.3.3.1 Algemene beschouwingen

3.3.3.2 Jurisprudentie categorie A: Beroep op verwerving van het Nederlanderschap

3.3.3.2.1 HR 23 oktober 1979

3.3.3.2.2 HR 15 september 1980

3.3.3.2.3 HR 23 maart 1984

3.3.3.2.4 HR 15 juli 1985

3.3.3.2.5 HR 8 december 1989

3.3.3.3 Jurisprudentie categorie B: Beroep op behoud van het

Nederlanderschap 
3.3.3.4 Subcategorie B(-TOS): Beroep op behoud van het Nederlanderschap door betwisting van de toepasselijkheid van de Toescheidingsovereenkomst Nederland-Suriname

3.3.3.4.1 HR 4 maart 1980

3.3.3.4.2 HR 1 juni 1982

3.3.3.4.4 HR 23 december 1983

3.3.4 Nationaliteitsvaststelling en bewijslastverdeling in procedures op grond van artikel 17 Rijkswet op het Nederlanderschap (1986-heden)

3.3.4.1 Algemene Beschouwingen

3.3.4.2 Jurisprudentie categorie A: Beroep op verwerving van het Nederlanderschap

3.3.4.2.1 HR 28 september 1990

3.3.4.2.3 Rb. 's-Gravenhage 4 november 1992

3.3.4.3 Jurisprudentie categorie B: Beroep op behoud van het Nederlanderschap

3.3.4.3.1 Rb 's-Gravenhage 29 januari 1992

3.3.4.4 Subcategorie B(-TOS): Beroep op behoud van het Nederlanderschap door betwisting van de toepasselijkheid van de Toescheidingsovereenkomst Nederland-Suriname

3.3.4.4.1 Rb 's-Gravenhage 15 juli 1987

3.3.4.4.3 Rb 's-Gravenhage 27 april 1988

3.3.4.4.4 Rb 's-Gravenhage 29 juni 1988

3.3.4.4.5 Rb 's-Gravenhage 9 november 1988

3.3.4.4.8 Rb 's-Gravenhage 9 november 1988; HR 14 februari 1992;

$\begin{array}{ll}\text { 3.3.4.5 Derde tussenevaluatie } & 259\end{array}$

$\begin{array}{lll}3.3 .5 & \text { Bewijsmiddelen } & 267\end{array}$

$\begin{array}{ll}\text { 3.3.5.1 Algemene beschouwingen } & 267\end{array}$

3.3.5.2 Voorkomende bewijsmiddelen in de vaststellingsbeschikkingen $\quad 269$

3.3.5.3 Waardering van het bewijs 
Hoofdstuk 4 Inleidende opmerkingen betreffende het Duitse nationaliteitsrecht

$4.1 \quad$ Inleiding 275

4.1.1 Artikel 73 Grundgesetz en de nationaliteit op federaal niveau 276

4.1.2 Artikel 74 Grundgesetz en de nationaliteit op deelstatelijk niveau 276

4.1.3 De federale nationaliteit 280

4.1.4 Beperkingen in het onderzoek 281

4.2 Introductie in het rechterlijk systeem van de Bondsrepubliek 283

4.2.1 Algemene beschouwingen 283

$\begin{array}{ll}\text { 4.2.2 Administratief recht } & 284\end{array}$

$\begin{array}{lll}\text { 4.2.3 Privaatrecht en strafrecht } & 284\end{array}$

4.2.4 Aparte bescherming tegen schending van grondrechten (constitutionele toetsing)

4.3 Administratieve uitvoering van het Reichs- und

Staatsangehörigkeitsgesetz geen federale taak $\quad 286$

$\begin{array}{ll}\text { 4.3.1 Algemene beschouwingen } & 286\end{array}$

\begin{tabular}{lll} 
4.3.2 Naturalisaties & 287 \\
\hline 4.3 .3 & Administratieve vaststling van de Duise nationalieit
\end{tabular}

4.3.3 Administratieve vaststelling van de Duitse nationaliteit 287

Hoofdstuk 5 Procesrechtelijke aspecten in het Duitse nationaliteitsrecht Vaststelling van de Duitse nationaliteit door rechterlijke instanties

$5.1 \quad$ Inleiding

5.2 De administratieve rechtspraak 293

5.2.1 De administratieve Verpflichtungsklage ( $\$ 42$ VwGO) 294

$\begin{array}{lll}\text { 5.2.1.1 Algemene beschouwingen } & 294\end{array}$

$\begin{array}{ll}\text { 5.2.1.2 Nationaliteit } 295 & 295\end{array}$

5.2.1.3 Bindende werking van het vonnis 297

5.2.2 De administratieve Feststellungsklage (\$ 43 VwGO) 297

$\begin{array}{lll}\text { 5.2.2.1 Algemene beschouwingen } & 297\end{array}$

$\begin{array}{ll}\text { 5.2.2.2 Nationaliteit } & 299\end{array}$

5.2.2.3 Bindende werking van het vonnis 301

5.2.3 Subsidiaritätsklausel, de samenhang tussen $\$ \S 42$ en 43 VwGO 303

5.3 De overige rechtspraak 305

$\begin{array}{lll}\text { 5.3.1 De civiele procedures } & 305\end{array}$

$\begin{array}{lll}\text { 5.3.2 De strafrechtelijke procedures } & 306\end{array}$

$\begin{array}{lll}\text { 5.3.2.1 Strafrecht } & 306\end{array}$

$\begin{array}{ll}\text { 5.3.2.2 Internationale rechtshulp bij strafzaken } & 307\end{array}$

$\begin{array}{lll}\text { 5.3.3 Bindende werking van het vonnis } & 307\end{array}$

5.4 De beslissingen van het Bundesverfassungsgericht 308

$\begin{array}{ll}\text { 5.4.1 Algemene beschouwingen } & 308\end{array}$ 
5.4.2 Nationaliteit

5.4.3 Bindende werking van de uitspraak van het BVerfG 315

5.4.3.1 Algemene beschouwingen

5.4.3.2 Reikwijdte van de bindende werking

Hoofdstuk 6 Bewijsrechtelijke aspecten in het Duitse nationaliteitsrecht

6.1 Inleiding 323

$\begin{array}{ll}\text { 6.2 Administratief bewijsrecht } & 324\end{array}$

6.2.1 Onderzoeksverplichting ( $\$ 86$ VwGO) 325

6.2.1.1 De bewijslastverdeling 328

6.2.1.2 Beweislastnormen 330

6.2.2 De bewijswaardering ( $\$ 108$ VwGO) 334

6.2.2.1 Beweismaß 335

6.3 Bewijsrecht in administratiefrechtelijke procedures ter zake van de Duitse nationaliteit 337

$\begin{array}{lll}\text { 6.3.1 Algemene beschouwingen } & 337\end{array}$

6.3.2 Jurisprudentie categorie A: Beroep op verwerving van de Duitse nationaliteit

6.3.2.1 BVerwG 10 januari 1961

6.3.2.2 BVerwG 6 oktober 1966

6.3.2.3 BVerwG 22 augustus 1979

345

6.3.2.4 BayVGH 7 december 1983

6.3.2.5 VG Bremen 14 maart 1988

6.3.2.6 BVerwG 15 maart 1994

6.3.3 Jurisprudentie categorie B: Beroep op behoud van de Duitse nationaliteit

6.3.3.1 BGH 14 december 1955

6.3.3.2 BVerwG 14 december 1972

6.3.3.3 VG Freiburg 3 oktober 1978

6.3.3.4 BVerwG 21 mei 1985

Hoofdstuk 7 Conclusies en rechtsvergelijkende opmerkingen

7.1 Inleiding

7.1.1 De begrippen "zelfstandige vaststellingsprocedure" en "impliciete vaststellingsprocedure"

7.2 Procesrechtelijke conclusies

7.2.1 Procesrechtelijke conclusies Nederland

7.2.2 Procesrechtelijke conclusies Duitsland 
7.3 Bewijsrechtelijke conclusies

7.3.1 Bewijsrechtelijke conclusies Nederland

7.3.2 Bewijsrechtelijke conclusies Duitsland

7.4. Afsluitende en vergelijkende opmerkingen

402

7.4.1 Overeenkomsten tussen beide rechtsstelsels

406

7.4.2 Verschillen tussen beide rechtsstelsels

407

Samenvatting

409

Summary

419

Zusammenfassung

427

Literatuurlijst Nederlands recht

Literatuurlijst Duits recht 



\section{Nederlandstalige afkortingen en tijdschriften}

\section{AA}

aant.

$\mathrm{AB}$

ABRS

afd.

A.-G.

AGRS

alg.

AOW

ARRS

art.

a.w.

Awb

B. \& W.

Bijl. I.

Bijl. II.

bijv.

$B \& R$

BW

CCB

cf.

CRvB

d.d.

d.i.

d.w.z.

e.a.

etc.

e.v.

EVRM

FJR

gem.

Hand. II.

HPS

HR

i.c.

i.h.b.

Ind.
Ars Aequi

aantekening

Administratiefrechtelijke Beslissingen

Afdeling bestuursrechtspraak van de Raad van State (sinds 01.01.1994)

afdeling

Advocaat-Generaal

Afdeling geschillen van bestuur van de Raad van State algemeen

Algemene Ouderdomswet

Afdeling rechtspraak van de Raad van State (tot 01.01.1994) artikel

aangewezen werk

Algemene wet bestuursrecht

Burgemeester en Wethouders

Bijlage bij de Handelingen van de Eerste Kamer

Bijlage bij de Handelingen van de Tweede Kamer

bijvoorbeeld

Burgerzaken en Recht

Burgerlijk Wetboek

College van Beroep voor het Bedrijfsleven

conform

Centrale Raad van Beroep

de dato

dit is

dat wil zeggen

en anderen

etcetera

en volgende

Verdrag tot bescherming van de rechten van de mens en de fundamentele vrijheden

Tijdschrift voor Familie en Jeugdrecht

gemeente

Handelingen van de Tweede Kamer der Staten-Generaal

Het Personeel Statuut

Hoge Raad

in casu

in het bijzonder

Indonesische 
Int.

i.w.t.

JB

jo.

KB

KG

$\mathrm{Ktg}$.

losbl.

m.b.t.

m.i.

$\min$.

m.nt.

MR

MvA

m.u.v.

N.B.

Ned.

NILR

NIPR

NJ

NJB

$\mathrm{nl}$.

n.m.m.

NTB

NTBR

$\mathrm{nr}$.

o.a.

o.g.v.

$\mathrm{OM}$

o.m.

OvJ

p.

par.

P.-G.

pp.

Pres.

Prg.

prft.

$\mathrm{Rb}$.

rkstnr.

RMTh internationaal

inwerkingtreding

Jurisprudentie Bestuursrecht

juncto

Koninklijk Besluit

Kort Geding (tijdschrift)

Kantongerecht

losbladige

met betrekking tot

mijns inziens

minister/ministerie

met noot

Migrantenrecht

Memorie van antwoord

met uitzondering van

nota bene

Nederland(s)

Netherlands International Law Review

Nederlands Internationaal Privaatrecht. Repertorium op verdragenrecht, wetgeving, rechtspraak en literatuur

Nederlandse Jurisprudentie

Nederlands Juristenblad

namelijk

naar mijn mening

Nederlands tijdschrift voor bestuursrecht

Nederlands tijdschrift voor Burgerlijk Recht

nummer

onder andere

op grond van

Openbaar Ministerie

onder meer

Officier van Justitiie

pagina

paragraaf

Procureur-Generaal

partijen

President (in Kort Geding)

Praktijkgids

proefschrift

rechtbank

rekestnummer

Rechtsgeleerd Magazijn Themis 
Rv

RV

RvdW

RWN

RWW

SJ

Stb.

Sv

TCR

Trb.

Trema

TOI

TOS

TvO

v.

vgl.

Vrz. ARRS

Vw

Vw 1849

Wet Arbo

Wet Arob

Wet Ned, 1892

Wet RO

w.o.

WPNR

WRvS

$\mathrm{WvSr}$

WWV

zgn.
Wetboek van Burgerlijke Rechtsvordering

Rechtspraak Vreemdelingenrecht

Rechtspraak van de Week

Rijkswet op het Nederlanderschap

Rijksgroepsregeling werkloze werknemers

Surinaamse Jurisprudentie

Staatsblad

Wetboek van Strafvordering

Tijdschrift voor Civiele Rechtspleging

Tractatenblad

Tijdschrift voor de Rechterlijke Macht

Overeenkomst betreffende de toescheiding van staatsburgers

Toescheidingsovereenkomst inzake nationliteiten, gesloten tussen het Koninkrijk der Nederlanden en de republiek

Suriname

Tijdschrift voor Overheidsadministratie

van

vergelijk

Voorzitter van de ARRS

Vreemdelingenwet (Stb. 1965, 40). I.w.t. 01.01.1967.

Wet van den 13den Augustus 1849, tot regeling der toelating en uitzetting van vreemdelingen (Stb. 1849, 39). vervallen per 01.01.1967

Wet administratieve rechtspraak bedrijfsorganisatie

Wet administratieve rechtspraak overheidsbeschikkingen

Wet van 12 december 1892 , Stb. 268, op het

Nederlanderschap en het ingezetenschap. I.w.t. 01.07.1893;

vervallen per 01.01.1985

Wet op de Rechterlijke Organisatie

wetsontwerp

Weekblad voor Privaatrecht, Notariaat en Registratie

Wet op de Raad van State

Wetboek van strafrecht

Wet Werkloosheidsvoorziening

zogenaamd(e) 


\section{Duitstalige afkortingen en tijdschriften}

$\S$

Abs.

Abt.

a. F.

ArchVR

B.

BayVBl.

BayVerfGH

Bekl.

BerGer.

BGBI.

BGH

BGHst

BRD

BT-Drs.

BVerfG

BVerfGG

BVerfGE

BVerwG

BVerwGE

BVFG

BVGG

Buchst.

bzw.

DDR

d.h.

DÖV

DVB1

Entsch.

EWG

gem.

GG

HessVGH

InfAuslR

IPRspr

i. S.

i.V.m.
Paragraph

Absatz

Abteilung

alte Fassung

Archiv des Völkerrechts (tijdschrift)

Beschluß

Bayerische Verwaltungsblätter

Bayerische Verfassungsgerichtshof

Beklagte(r)

Berufungsgericht

Bundesgestezblatt

Bundesgerichtshof

Entscheidungen des Bundesgerichtshofs in Strafsachen

Bundesrepublik Deutschland

Drucksache des Deutschen Bundestages

Bundesverfassungsgericht

Gesetz über das Bundesverfassungsgericht (ook: BVGG)

Entscheidungssammlung des Bundesverfassungsgerichts

Bundesverwaltungsgericht

Entscheidungssammlung des Bundesverwaltungsgerichts

Gesetz über die Angelegenheiten der Vertriebenen und

Flüchtlinge

Gesetz über das Bundesverfassungsgericht (ook: BVerfGG)

Buchstabe

beziehungsweise

Deutsche Demokratische Republik

das heißt

Die Öffentliche Verwaltung

Deutsche Verwaltungsblatt

Entscheidung

Europäische Wirtschaftsgemeinschaft

gemäß

Grundgesetz

Hessischer Verwaltungsgerichtshof

Informationsbrief Ausländerrecht

die deutsche Rechtsprechung auf dem Gebiete des inter nationalen Privatrechts

im Sinne

in Verbindung mit 
JZ

$\mathrm{Kl}$.

LG

NJW

n. F.

NStZ

NVwZ

OVG

Par.

Rdnr.

RGBl.

RuStAG

StARegG

2.StARegG

StAUrkVwV

StAZ

StPO

U.

usw.

v.

VGH

VwGO

VwVfG

z. B.

ZaöRV

Ziff.

ZPO
Juristenzeitung

Kläger/Klägerin

Landgericht

Neue Juristische Wochenschrift

neue Fassung

Neue Zeitschrift für Strafrecht

Neue Zeitschrift für Verwaltungsrecht

Oberverwaltungsgericht

Paragraph

Randnummer

Reichsgesetzblatt

Reichs- und Staatsangehörigkeitsgesetz

Gesetz zur Regelung von Fragen der Staatsangehörigkeit vom 22.02.1955

Zweite Gesetz zur Regelung von Fragen der Staatsangehörigkeit vom 17.05.1956

Allgemeine Verwaltungsvorschrift über Urkunden in Staatsangehörigkeitssachen

Das Standesamt

Strafprozeßordnung

Urteil

und so weiter

vom/von

Verwaltungsgerichtshof

Verwaltungsgerichtsordnung

Verwaltungsverfahrensgestez

zum Beispiel

Zeitschrift für ausländisches öffentliches Recht und

Völkerrecht

Ziffer

Zivilprozeßordnung 



\section{Inleiding en probleemstelling}

\subsection{Inleidende opmerkingen en probleemstelling}

Voor de meeste mensen zal de vraag of zij een nationaliteit bezitten en zo ja, welke nationaliteit, niet veel moeilijkheden opleveren. Maar behalve dat het voorkomt dat een persoon geen nationaliteit heeft, komt het evenzeer wel voor dat het bezit van een bepaalde nationaliteit onzeker is. Het is de opzet van dit boek om te onderzoeken welke rechtsregels van invloed zijn op de vaststelling door de rechter van de nationaliteit in het geval dat sprake is van nationaliteitsonzekerheid of nationaliteitsbetwisting. Het onderzoek spitst zich daarbij toe op de vraag naar het voor de rechter bij zijn beoordeling toepasselijke proces- en bewijsrecht.

Nationaliteitsonzekerheid kan vanzelfsprekend voorkomen met betrekking tot iedere nationaliteit die bestaat. Een zodanige onzekerheid kan ontstaan indien de interpretatie van een nationaliteitsregeling onzeker blijkt of wanneer de regeling een onvoorziene leemte vertoont. Maar ook kan onzekerheid over het bezit van een nationaliteit ontstaan in het geval dat de feitelijke omstandigheden die leiden tot nationaliteitsverwerving of verlies niet duidelijk zijn vast te stellen. Met dit laatste punt is de bewijsrechtelijke dimensie in het nationaliteitsrecht aangesneden. Het bewijsrecht ten aanzien van de vaststelling van de nationaliteit is een sinds lang onderbelichte materie. In de Nederlandse literatuur is tot op heden slechts minimaal tot geen aandacht geschonken aan de bewijsrechtelijke aspecten van het nationaliteitsrecht.

Nationaliteitsbeoordeling zal in vele gevallen primair plaatsvinden op ambtelijk niveau. In de meeste gevallen zal het daarbij blijven. In dit boek wordt dit aspect van de vaststelling niet over het hoofd gezien, maar de nadruk in het onderzoek ligt op de nationaliteitsvaststelling door een rechterlijke instantie. Met betrekking tot die rechterlijke vaststelling van de nationaliteit vormt de vraag naar het toepasselijk procesrecht en bewijsrecht de leidraad in het onderzoek. Ter aanduiding van het proces- en bewijsrecht dat betrekking heeft op rechterlijke nationaliteitsvaststelling is wel het begrip formeel nationaliteitsrecht geïntroduceerd. ${ }^{1}$

De vraag naar het door rechterlijke instanties toegepaste proces- en bewijsrecht bij de beoordeling van het bezit van de nationaliteit staat in het onderzoek centraal. Door middel van de onderhavige studie wordt getracht een antwoord te geven op de vraag welke regels het formele nationaliteitsrecht bevat.

Tegenover het formele nationaliteitsrecht kan het materiële nationaliteitsrecht worden geplaatst. Het materiële nationaliteitsrecht bevat de verwervings- en verliesgronden voor een bepaalde nationaliteit. Het in het middelpunt plaatsen van

\footnotetext{
${ }^{1}$ De Groot/Tratnik, Nationaliteitsrecht, i.h.b. Hoofdstuk 8 daarvan.
} 
het formele nationaliteitsrecht betekent overigens niet dat in het onderzoek het materiële nationaliteitsrecht afwezig zou zijn. Waar dat nodig is voor het begrip van het betoog komt het materiële nationaliteitsrecht aan bod en wordt daarop dieper ingegaan. Het is echter niet de bedoeling een uitputtende verhandeling te geven inzake materiële nationaliteitsrechtelijke rechtsregels.

Op grond van hetgeen hierboven is opgemerkt, is ten behoeve van het onderzoek een voorlopige probleemstelling geformuleerd. Deze voorlopige probleemstelling luidt: welke procesrechtelijke en bewijsrechtelijke regels spelen een rol bij het in rechte vaststellen van het bezit van een nationaliteit.

Een ander aspect van het onderhavige onderzoek is dat het een studie betreft die is gebaseerd op een rechtsvergelijkend onderzoek naar een tweetal rechtsstelsels. Ten einde het onderzoek binnen de perken te houden en niet te laten uitmonden in een encyclopedische vorm is gekozen voor een onderzoek naar een tweetal nationaliteiten. De twee rechtsstelsels waarop de navolgende hoofdstukken zijn gebaseerd, zijn het Nederlandse en het Duitse. De keuze voor een onderzoek binnen het Nederlandse rechtsstelsel ligt, voor een onderzoek verricht door een in het Nederlandse recht geschoolde jurist, voor de hand. De keuze voor het Duitse recht vraagt echter om een meer expliciete verklaring. Enerzijds ligt aan die keuze de toegankelijkheid van de taal en de bronnen ten grondslag. Anderzijds is van het Duitse recht bekend dat dit, vooral waar het betreft het administratief procesrecht systematischer is opgebouwd dan het Nederlandse. ${ }^{2}$ Deze systematischere opbouw leidt wellicht tot interessante conclusies bij een vergelijking met het Nederlandse recht.

Naar aanleiding van het zoëven gestelde kan de probleemstelling meer worden aangescherpt. De definitieve probleemstelling wordt dan: welke procesrechtelijke en bewijsrechtelijke regels zijn van toepassing in hetzij het Nederlandse recht, hetzij het Duitse recht, bij het door de rechter vaststellen van het bezit van de nationaliteit.

Uit de hierboven geformuleerde probleemstelling volgen vier onderzoeksvragen. De eerste onderzoeksvraag luidt: welke procesrechtelijke regels zijn van toepassing bij het door de rechter vaststellen van de Nederlandse nationaliteit? De pendant daarvan met betrekking tot het Duitse recht luidt dan: welke procesrechtelijke regels zijn van toepassing bij het door de rechter vaststellen van de Duitse nationaliteit? De twee onderzoeksvragen met betrekking tot het bewijsrecht luiden achtereenvolgens: welke bewijsrechtelijke regels zijn van toepassing bij het door de rechter vaststellen van het bezit van de Nederlandse nationaliteit? En: welke bewijsrechtelijke regels zijn van toepassing bij het door de rechter vaststellen van het bezit van de Duitse nationaliteit?

\footnotetext{
${ }^{2}$ Al kent sinds kort het Nederlandse bestuursrecht als gevolg van de inwerkingtreding van de Algemene wet bestuursrecht een zekere stroomlijning.
} 
Over het belang van het bezit van een nationaliteit kan worden getwist. De praktijk laat echter zien dat het in het algemeen eerder nadelige dan voordelige gevolgen voor de betrokken persoon heeft indien blijkt dat hij of zij geen nationaliteit bezit dan wel dat het bezit van een nationaliteit niet kan worden vastgesteld. ${ }^{3}$ Een aanwijzing dat, althans in de ogen van de opstellers van de Universele Verklaring van de Rechten van de Mens uit 1948 van de Verenigde Naties, ter bescherming van de menselijke waardigheid het bezit van een nationaliteit een belangrijke voorwaarde is, blijkt uit artikel 15 van de Universele Verklaring. Het artikel stelt dat aan ieder mens het recht toekomt een nationaliteit te verwerven. ${ }^{4}$ Tevens stelt het artikel dat een nationaliteit niet willekeurig mag worden ontnomen alsmede dat het recht om van nationaliteit te veranderen niet kan worden ontzegd.

Tegen de bovengenoemde fraaie bepaling uit de Universele Verklaring is wel aangevoerd dat zij een mooi beginsel weergeeft, maar dat geen mens daaraan in de praktijk daadwerkelijk een nationaliteit ontleent. ${ }^{5}$ Dit is een visie op de nationaliteitsbepaling in de Universele Verklaring die ik alleen maar kan onderschrijven. De nationale staten zijn nog immer grotendeels autonoom in het opstellen van de eigen nationaliteitsregeling. ${ }^{6}$ Verwerving en verlies van een nationaliteit wordt bepaald door het nationale recht, waaronder het nationale bewijsrecht, van de desbetreffende staat. ${ }^{7}$

Enige inperking in de autonomie tot regelgeving inzake de eigen nationaliteit wordt gevonden in het Volkenrecht. ${ }^{8}$ Een tweede beperking in de autonomie zou afkomstig kunnen zijn van de Europese regelgeving en wordt wel gelezen in een uitspraak van het Hof van Justitie. ${ }^{9}$ In die uitspraak erkent het Hof de nationale autonomie van staten ten aanzien van de eigen nationaliteitsregeling, maar stelt dat de uitoefening van die autonomie "met inachtneming van het gemeenschapsrecht" dient te geschieden. ${ }^{10}$

\footnotetext{
${ }^{3} \mathrm{Vgl}$. Van Krieken, NILR 1979, p. 29: "(........) the often desperate status of stateless persons".

${ }^{4}$ In gelijke zin art. 5 International verdrag inzake de uitbanning van alle vormen van rassendiscriminatie (verdrag in het kader van de Verenigde Naties; Trb. 1967, nr. 48). In het verlengde hiervan stelt art. 24 lid 3 Internationaal verdrag inzake burgerrechten en politieke rechten (BUPO-verdrag, opgesteld in 1966 in het kader van de Verenigde Naties; Trb. 1978, nr. 177): "Elk kind heeft het recht een nationaliteit te verwerven. " Art. 7 lid 1 Verdrag inzake de rechten van het kind (tot stand gekomen in VN-verband in 1989; Trb. 1990, nr. 170) doet dit nog eens dunnetjes over: "Het kind heeft vanaf de geboorte het recht een nationaliteit te verwerven."

${ }^{3}$ Zie De Groot, p. 28; Jessurun d'Oliveira, NJB 1990, p. 1024; Tratnik, p. 40 en 44.

${ }^{6}$ Zie Duijvendijk-Brand/Wortmann, p. 7; De Groot, Justicia 1993, p. 205; R. de Lange, Recht en kritiek 1995, p. 292 en 295; De Haas-Engel, p. 56; Heijs (II), p. 6.

7 Jessurun d'Oliveira, NJB 1990, p. 1023.

"Een staat wordt geacht zijn nationaliteit niet toe te kennen aan bevolkingsgroepen in andere staten, tenzij daarvoor gegronde historische redenen bestaan.

${ }^{9}$ Hof v. Justitie v.d. Europese Gemeenschappen 07.07.1992, NJ 1994, nr. 620. Een beperking die derhalve slechts geldt voor staten die zijn aangesloten bij de Europese Unie.

${ }^{10}$ Zie De Groot, Justicia 1993, p. 206.
} 
Een volgende beperking bestaat sinds geruime tijd uit het streven op internationaal niveau om staatloosheid tegen te gaan. In het kader van dit streven zijn multilaterale verdragen gesloten. ${ }^{11}$ Desondanks worden ook heden ten dage nog veel mensen met staatloosheid geconfronteerd.

\subsection{Plan van behandeling}

Het boek bestaat in eerste instantie uit twee delen. Ieder deel betreft het formele nationaliteitsrecht van één onderzocht rechtsstelsel. Ieder deel vangt aan met een historisch getinte introductie. Het volgende hoofdstuk betreft het procesrecht en de plaats daarbinnen van de rechterlijke vaststelling van de nationaliteit. Ieder deel kent als laatste een hoofdstuk over het bewijsrecht ter zake van de rechterlijke vaststelling.

Door deze opbouw worden de vier uit de probleemstelling voorvloeiende onderzoeksvragen elk in één hoofdstuk behandeld. De hoofdstukken 1 en 4 hebben ten behoeve van respectievelijk het Nederlandse en het Duitse recht elk een inleidende functie. De onderzoeksvraag: welke procesrechtelijke regels zijn van toepassing bij het door de rechter vaststellen van de Nederlandse nationaliteit? wordt behandeld in hoofdstuk 2 . In hoofdstuk 3 wordt de vraag naar de bewijsrechtelijke regels ter zake van het in rechte vaststellen van de Nederlandse nationaliteit behandeld. Hoofdstuk 5 gaat in op de onderzoeksvraag: welke procesrechtelijke regels zijn van toepassing bij het door de rechter vaststellen van de Duitse nationaliteit? De vierde onderzoeksvraag luidt: welke bewijsrechtelijke regels zijn van toepassing bij het door de rechter vaststellen van het bezit van de Duitse nationaliteit? Deze vraag komt aan de orde in hoofdstuk 6.

In het afsluitende hoofdstuk vloeien de twee delen samen, en wordt ten aanzien van de afzonderlijke rechtsstelsels conclusies getrokken. Tevens worden in dat hoofdstuk de beide rechtsstelsels, voor zover het de vaststelling van de nationaliteit in rechte betreft, vergeleken.

"Bijv, het Protocol betreffende een geval van staatloosheid van 12.04.1930, gesloten te 's-Gravenhage (i.w.t. voor het Koninkrijk op 01.07.1937); het Verdrag tot beperking der staatloosheid van 30.08.1961 te New York (een verdrag in Verenigde Naties verband; i.w.t. voor het Koninkrijk op 11.08.1985); de Overeenkomst inzake beperking van het aantal gevallen van staatsloosheid van 13.09.1973 te Bern (i.w,t. voor het Koninkrijk op 19.05.1985). De bovengenoemde verdragen zijn opgenomen in de editie Schuurman \& Jordens, Nationaliteitswetgeving (1994) nr. 209. Vgl. art. 7 lid 2 Verdrag inzake de rechten van het kind (Trb. 1990, nr. 170, VN-verdrag van 20.11.1989; het Koninkrijk is partij (art. 1 Rijkswet tot goedkeuring v.h. verdrag, Stb. 1994, 862; i.w.t. voor Nederland op 08.03.1995 (Trb. 1995, nr. 92). 


\subsection{Verantwoording van het Nederlandse onderzoeksmateriaal}

Ten behoeve van het onderzoek is naast de algemeen toegankelijke rechtspraak en literatuur mede gebruik gemaakt van niet gepubliceerde uitspraken van de arrondissementsrechtbank te 's-Gravenhage. In totaal zijn ten behoeve van het jurisprudentieonderzoek vierenvijftig vaststellingsbeschikkingen, waarvan een groot deel ongepubliceerd, van de rechtbank 's-Gravenhage bestudeerd. Daarbij gaat het om twaalf beschikkingen waarin de verzoeker niet-ontvankelijk is verklaard. Als gevolg hiervan resteert aan beschikkingen waarin een oordeel wordt gegeven aangaande het Nederlanderschap van de betrokkene minder dan het genoemde getal van vierenvijftig. Aan materiële eindbeschikkingen heb ik tweeënveertig beschikkingen bestudeerd.

Vanwege het feit dat het bij deze jurisprudentie vaak gaat om ongepubliceerde rechtspraak heb ik mij ter ondersteuning van mijn betoog genoodzaakt gezien veelvuldig gedeelten uit deze rechtspraak integraal over te nemen in de eigen tekst.

De beschikkingen van de rechtbank in Den Haag die ik in dit onderzoek heb verwerkt, stammen grotendeels uit de periode 1986-1989, een periode die gekenmerkt kan worden als de beginfase van de vaststellingsprocedure ingevolge artikel 17 Rijkswet op het Nederlanderschap. Over de periode daarna beschik ik over wat minder beschikkingen, waaronder verhoudingsgewijs wat meer gepubliceerde uitspraken, maar ook ongepubliceerde.

Voorts heb ik ten behoeve van het onderzoek naar de totstandkoming van een procedure die rechtstreekse vaststelling van het bezit van het Nederlanderschap beoogt, gebruik gemaakt van ongepubliceerde documenten uit het archief van het ministerie van Justitie.

\subsection{Verantwoording van het Duitse onderzoeksmateriaal}

Voor het onderzoek naar het Duitse recht is gebruik gemaakt van algemeen toegankelijke literatuur en jurisprudentie. Wat de jurisprudentie betreft gaat het steeds om in de vakbladen gepubliceerde rechtspraak. 



\section{Hoofdstuk 1}

\section{Inleidende opmerkingen betreffende het Nederlandse nationaliteitsrecht}

\subsection{Inleiding}

Zoals is opgemerkt in paragraaf 0.1 , is het de opzet van dit boek beantwoording te vinden van de onderscheidenlijke vragen naar het toepasselijk procesrecht en het toepasselijk bewijsrecht indien het betreft de vaststelling in rechte van het bezit door een natuurlijke persoon van de Nederlandse nationaliteit. Het kan daarbij ook gaan om de vaststelling in rechte dat de betrokken persoon niet in het bezit is van het Nederlanderschap. Ter zake van de nationaliteitsvaststelling is het van belang te beseffen dat deze vaststelling slechts een momentopname is. Wat dat betreft kan een vergelijking worden gemaakt met bijvoorbeeld het eigendomsrecht: de situatie op een bepaald moment kan verschillen van verleden én toekomst.

In paragraaf 0.1 is tevens reeds opgemerkt dat aan het materiële nationaliteitsrecht niet meer aandacht zal worden geschonken dan strikt noodzakelijk is voor het begrip van het betoog. Wel volgt hieronder een korte opsomming van de belangrijkste regelingen waarin in de loop van de tijd het voornaamste materiële nationaliteitsrecht is opgenomen. Voor besprekingen van het vigerende materiële nationaliteitsrecht verwijs ik hier naar de literatuur op dit gebied. ${ }^{12}$

De voornaamste wettelijke regeling die heden ten dage inzake de Nederlandse nationaliteit geldt, is de Rijkswet op het Nederlanderschap. ${ }^{13}$ Voor de tijd daarvoor zijn bovenal noemenswaardig de Wet van 12 december 1892, Stb. 268, op het Nederlanderschap en het ingezetenschap en de direkte voorganger daarvan, de Wet van den 28sten Julij 1850, Stb. 44, ter uitvoering van art. 7 der Grondwet. Nog verder in het verleden kan voor het eerste blijken van datgene wat reeds dan als het Nederlanderschap zou mogen worden omschreven, voor de periode 1838-1893 worden gewezen op de artikelen 5 tot en met 12 van het toenmalige Burgerlijk Wetboek. ${ }^{14}$

${ }^{12}$ Uitgebreid: De Groot, losbl. uitgave Personen- en Familierecht; De Groot/Tratnik, a.w.; Zilverentant e.a., losbl. uitgave Nationaliteitswetgeving. En in het kort: Van Duijvendijk-Brand/Wortmann, p. 7-10; Koens, p. 1-24; Kortmann (I), p. 377-380; Schrijvers/Smeets, p. 35 en 36.

${ }^{13}$ Rijkswet van 19.12.1984, Stb. 628. Inwerkingtreding, m.u.v. hoofdstuk 6 RWN, op 01.01.1985.

${ }^{14}$ De artt. 5 tot en met 12 BW 1838 zijn pas in 1893 (Stb. 1892, 268) vervallen bij de inwerkingtreding van de Wet op het Nederlanderschap en het ingezetenschap (Wet Ned. 1892). Sinds 1850 zijn zij tegelijkertijd met de Wet van den 28sten Julij 1850, Stb. 44, ter uitvoering van art. 7 der Grondwet van 
Naast de hier genoemde wetten hebben in de loop der jaren ook diverse andere wetten en wettelijke regelingen het materiële nationaliteitsrecht beïnvloed. Ook verdragen zijn voor het materiële nationaliteitsrecht van belang. In het recente verleden heeft bijvoorbeeld een groot aantal personen het Nederlanderschap verloren op grond van de Toescheidingsovereenkomst inzake nationaliteiten, gesloten tussen Nederland en Suriname. ${ }^{15}$ Ook zijn er velen die op grond van deze Toescheidingsovereenkomst de Nederlandse nationaliteit hebben herkregen. In een enkel geval kan het Nederlanderschap zijn verworven op grond van de Toescheidingsovereenkomst tussen Nederland en Suriname. ${ }^{16}$

Het Nederlanderschap, en derhalve mede de wettelijke regeling ervan, is overeenkomstig artikel 3 Statuut voor het Koninkrijk een aangelegenheid van het Koninkrijk. ${ }^{17}$ De Rijkswet ${ }^{18}$ op het Nederlanderschap is als gevolg hiervan van kracht in het territoir van het gehele Koninkrijksverband. ${ }^{19}$ Dit blijkt bijvoorbeeld zeer duidelijk in het hoofdstuk van de Rijkswet dat de procedure tot rechterlijke vaststelling van het Nederlanderschap bevat. Ook de nationaliteitsvaststelling in de Nederlandse Antillen en op Aruba heeft daarin een basis gevonden.

Hierboven is het begrip materieel nationaliteitsrecht reeds een aantal maal gevallen. Daaronder dient, als gezegd, te worden verstaan de regelgeving ter zake van de verwerving en het verlies van de Nederlandse nationaliteit. Dit boek handelt over

$14 \rightarrow$

kracht geweest. Zie voorts De Groot/Tratnik, p. 39-58 en Heijs (II), p. 32. De regeling van het Nederlanderschap heeft sinds 1850 organieke wetgeving betroffen; vgl. Heijs (II), p. 29. Zie art. 2 lid 1 Grondwet voor de huidige Rijkswet.

is Toescheidingsovereenkomst inzake nationaliteiten, gesloten tussen het Koninkrijk der Nederlanden en de republiek Suriname (Trb. 1975, nr. 132). Inwerkingtreding op 25.11.1975.

${ }^{16}$ Bijvoorbeeld in het volgende geval: In 1970 vindt in Paramaribo het huwelijk plaats tussen een man van Nederlandse nationaliteit en een vrouw met de Guyaanse nationaliteit. De vrouw opteert niet voor de Nederlandse nationaliteit (vgl. art. 8 Wet Ned. 1892). Op 25.11.1975 verwerft de man de Surinaamse nationaliteit. De vrouw blijft in het bezit van de Guyaanse nationaliteit. In mei 1976 opteert de man op grond van art. 10 TOS voor het Nederlanderschap. In april 1980 opteert de vrouw voor het Nederlanderschap. Aan de optie van de vrouw kunnen twee bepalen ten grondslag worden gelegd. Ten eerste art. 7 lid 1 TOS en ten tweede art. 8 Wet Ned. 1892.

${ }_{17} \mathrm{Vgl}$. Ahmad Ali, MR 1992, p. 71; Heijs (II), p. 144.

is Art. 14 Statuut bepaalt dat aangelegenheden van het Koninkrijk in beginsel worden geregeld bij rijkswet. Vgl. omtrent het Nederlanderschap: "Naturalisatie van personen die woonachtig zijn in de Nederlandse Antillen of Aruba, geschiedt bij of krachtens de rijkswet." (art. 14 lid 4 Statuut).

${ }_{19}$ Voor de Wet van 12 december 1892, Stb. 268, op het Nederlanderschap en het ingezetenschap is dit oorspronkelijk niet het geval geweest. Deze wet heeft in 1893 slechts territoriale werking in het Europese gedeelte van het Koninkrijk gekregen. Pas in 1951 (bij Wet van 21.12.1951, Stb. 593; ingevolge art. 5 van de wet geschiedde de inwerkingtreding met terugwerkende kracht tot 27.12.1949) kreeg de Wet Ned. 1892 werking in het territoir van Nederland, Suriname en de Nederlandse Antillen. Het bovenstaande is van belang voor verwervingsbepalingen van het Nederlanderschap waarin de geboorteplaats, de vestigingsplaats van de ouders of de vindplaats van een kind van belang zijn. Zie ook par. 3.3.1. Vgl. De Groot/Tratnik, p. 54. 
het formele nationaliteitsrecht. De begrippen formeel en materieel nationaliteitsrecht zijn geïntroduceerd door De Groot/Tratnik. ${ }^{20}$ Als behorend tot het formele nationaliteitsrecht noemen deze auteurs "procedurele voorschriften betreffende opties, naturalisaties en verklaringen van afstand" alsmede "de regels omtrent vaststelling van het Nederlanderschap", dit laatste inclusief de vraag op wie de bewijslast ter zake van het beweerde Nederlanderschap rust. In dit boek wordt alleen ingegaan op het gedeelte van het formele nationaliteitsrecht dat betrekking heeft op de vaststelling in rechte van het bezit van de Nederlandse nationaliteit. De administratieve voorschriften ter zake van naturalisaties, het afleggen van opties en het doen van verklaringen van afstand van het Nederlanderschap blijven buiten beschouwing.

De Groot/Tratnik stellen bij hun bespreking van het formele nationaliteitsrecht de vraag: "Rust de bewijslast op degene die beweert Nederlander te zijn, of op degene die dat betwist?" Op deze ogenschijnlijk zo eenvoudige, maar in wezen zeer complexe vraag, wordt in dit boek een beantwoording gegeven in hoofdstuk 3 . Alvorens dat te doen wordt in hoofdstuk 2 aandacht besteed aan het procesrecht dat geldt voor de nationaliteitsvaststelling. In hoofdstuk 2 wordt uitgegaan bij de bespreking van artikel 17 e.v. RWN van de Nederlandse situatie, zodat steeds sprake zal zijn van de rechter in Nederland en het Nederlandse procesrecht. Mochten echter de omstandigheden in de Nederlandse Antillen of Aruba specifiek afwijken, dan wordt dat afzonderlijk vermeld, zonder dat ik daarbij volledigheid nastreef.

In de hoofdstukken 2 en 3 wordt afwisselend gesproken over het Nederlanderschap, de Nederlandse nationaliteit en de staat van Nederlander. Deze drie juridische begrippen hebben inhoudelijk dezelfde betekenis. Vooral in oudere (nationaliteitsrechtelijke) wetgeving, ${ }^{21}$ rechtspraak ${ }^{22}$ en literatuur ${ }^{23}$ komt het gebruik van het begrip de staat van Nederlander vaak voor.

\subsection{De ontwikkelingen voorafgaand aan de huidige wetgeving}

De Rijkswet op het Nederlanderschap kent in hoofdstuk 6, dat het opschrift Vaststelling van het Nederlanderschap draagt, enkele specifieke regels die enerzijds betrekking hebben op het vaststellen van het Nederlanderschap door een rechterlijke instantie (artt. 17, 18 en 20 lid $1 \mathrm{RWN}$ ) en die anderzijds het vaststellen van het

\footnotetext{
${ }^{20}$ De Groot/Tratnik, a.w., i.h.b. hoofdstuk 8 daarvan.

${ }^{21} \mathrm{Vgl}$. art. 8 Statuut voor het Koninkrijk; art. 1 Wet Ned. 1892; art. 1 lid 2 Wet betreffende de positie van Molukkers.

${ }^{2}$ A.-G. Van Oosten, concluderend bij HR 29.03.1966, NJ 1966, nr. 453, stelt dat de nationaliteit, het Nederlanderschap, in het Nederlandse recht wordt beschouwd als een staat. Zie tevens voetnoot 596.

${ }^{2} \mathrm{Vgl}$. Boersma, Tijdschrift voor Politie 1939, p. 44; Meijers, WPNR 1947, nr. 4014, p. 434, onder rechtsvraag I; Septer/Schouten, p. XX.
} 
bezit van de Nederlandse nationaliteit betreffen in het geval dat het gaat om een nationaliteitsvaststelling in een administratieve beroepsprocedure (art. 20 lid 2 RWN).

In historisch perspectief geplaatst is de opname in 1985 van een rechttreekse nationaliteitsactie ter vaststelling van het Nederlanderschap in de nieuwe Fijkswet een legislatief novum. ${ }^{24}$ Aan de vraag of invoering van een rechtstreekse rationaliteitsactie wenselijk zou zijn, werd in het verleden door de wetenschappelijke literatuur zelden aandacht geschonken. Zeer sporadisch vindt men tot het begin van de jaren tachtig in juridische publicaties opmerkingen inzake het ontbreken van een rechtstreekse vaststellingsprocedure. In die publicaties wordt vooral gewezer op het feit dat, als gevolg van de grote hoeveelheid instanties die een oordeel kunnen vellen over het Nederlanderschap, de rechtseenheid in de uitspraken niet is gewaarborgd.

Hetgeen hieronder volgt, is een korte weergave van de in de oudere lieratuur geplaatste opmerkingen over deze lacune in de nationaliteitswetgeving. Daarop volgt een weergave van de door de wetgever ondernomen acties met betrekking tot de totstandkoming van een rechtstreekse vaststellingsprocedure.

\subsubsection{Ontwikkelingen in de literatuur}

De eerste maal dat kritisch wordt gewezen op het ontbreken van een procesrechtelijke garantie tot uniforme vaststelling van het Nederlanderschap is veertig jaar nadat op 1 juli 1893 de voorganger van de huidige Rijkswet op het Nederlanderschap, de Wet op het Nederlanderschap en het ingezetenschap in werking is getreden. De auteur die als eerste op deze lacune in de regelgeving wijst, Huart, doet tegelijkertijd het voorstel de vaststelling van het Nederlanderschap of van het, toen nog bestaande, Nederlands onderdaanschap ${ }^{25}$ bij één instantie, de Hoge Raad, te centraliseren. ${ }^{26}$

$\mathrm{Na}$ de tweede wereldoorlog, toen in veel gevallen onduidelijkheid heeft bestaan of het Nederlanderschap nu wel of niet verloren is gegaan wegens het "zonder Ons verlof zich te begeven in vreemden krijgs- of staatsdienst $"{ }^{27}$ blijkt de situatie niet verbeterd. Van Nijnatten heeft dienaangaande opgemerkt: "Nu van vele landgenooten het dubieus is of zij Nederlanders volgens de wet zijn en aangezien aan den status van vreemdeling zooveel nadeelen verbonden zijn, lijkt het ons zeer gewenscht, dat de gelegenheid wordt geboden om in een eenvoudige procedure te

\footnotetext{
${ }^{24} \mathrm{Vgl}$. Brinkman, p. 70; Van Duijvendijk-Brand/Wortmann, p. 9. Zie voor historische informatie tevens: De Groot, losbl, uitgave Personen- en Familierecht, hoofdstuk 6 Rijkswet, aant. 1 en Van den Blink, p. 3-5, 7 en 13.

${ }^{23}$ Vervallen bij Rijkswet van 14.09.1962, Stb. 358. Vgl. De Groot/Tratnik, p. 54.

${ }^{26}$ Huart, NJB 1932, p. 406.

27 Verliesgrond voor het Nederlanderschap ingevolge art, 7 sub 4 Wet Ned. 1892.
} 
doen vaststellen wie de Nederlandsche nationaliteit wel of niet bezit. Thans zijn het de administratieve ambtenaren en niet de rechterlijke macht die in voorkomend geval een beslissing geven. Dat die beslissingen uiteen zullen loopen, dat willekeur zal optreden, is daarbij onvermijdelijk. "28

Desalniettemin kan ruim zes jaar later Van Sasse van Ysselt nog droogjes constateren: "Wel levert het soms inconveniënten op, dat de wet geen rechter aanwijst om in een procedure, waarvan de nationaliteit de inzet is, uitspraak te doen." ${ }^{29}$ En in 1962 maakt Prins de wetgever uitdrukkelijk het verwijt dat de kwestie niet behoorlijk is geregeld. Daarbij benadrukt hij dat in zijn visie een goede regeling een rechtsgang bij de gewone rechterlijke macht betekent. ${ }^{30}$ Wat dat betreft, volgt hij derhalve een zelfde lijn als Huart.

Het is een opvallend gegeven te noemen dat de bovengenoemde auteurs hun artikelen hebben geschreven op tijdstippen die na turbulente ontwikkelingen in de geschiedenis vallen. De problematiek naar aanleiding waarvan Huart in de pen klimt, is een gevolg geweest van de Russische revolutie en de totstandkoming van de Sovjet-Unie. Ten aanzien van personen die naar de Sovjet-Unie zijn vertrokken en aldaar werkzaam zijn geweest, rees de vraag of zij "in vreemden staatsdienst" zijn getreden, iets dat zonder voorafgaand Koninklijk verlof leidde tot verlies van het Nederlanderschap dan wel het Nederlands onderdaanschap. ${ }^{31}$ Enige tijd later veroorzaken de Spaanse burgeroorlog, de tweede wereldoorlog en de soevereiniteitsoverdracht van Indonesië ${ }^{32}$ onder verschillende groepen in de samenleving onzekerheid omtrent het bezit van het Nederlanderschap. Mannoury maakt bijvoorbeeld melding van 180 personen die, in de veronderstelling het Nederlanderschap te hebben verloren ten gevolge van deelname aan de Spaanse burgeroorlog, naturalisatie tot Nederlander hebben aangevraagd. Tijdens de behandeling van deze verzoeken tot naturalisatie blijkt evenwel dat ten aanzien van zestien van hen het veronderstelde rechtsgevolg niet is ingetreden. ${ }^{33}$ Dit voorbeeld maakt duidelijk hoezeer dezen in die tijd gebaat zouden zijn geweest met een eenvoudige vaststellingsprocedure, die desondanks weinig belangstelling genoot bij de juridische auteurs uit die tijd..$^{34}$

\footnotetext{
${ }^{28}$ Van Nijnatten, NJB 1947, p. 187.

${ }^{29}$ Van Sasse van Ysselt, HPS 1953, p. 56.

${ }^{30}$ Prins (I), HPS 1962, p. 47.

$31 \mathrm{Vgl}$. Valkhoff, RMTh 1932, p. 413-487.

${ }^{32}$ Zie Heijs, p. 65.
}

${ }^{33}$ Mannoury, p. 158, alwaar de schrijver zijn informatie baseert op Bijl. II. 46-47, nrs. 399-417-418. stuk 5, p. 1. Zie ook Heijs (II), p. 117.

${ }^{34} \mathrm{Zie}$, naast de hierboven vermelde publicaties, voor de weinige uitzonderingen: "Proeve van een ontwerp van een nieuwe nationaliteitswet" in Hartmans tijdschrift ter beoefening van het administratief recht, 1947, p. 82 e.v.; Van der Haven, TvO 1961, p. 116 en 117; Mannoury, p. 167 e.v.; F.J.F.M. Duynstee, p. 33 en 34; Septer/Schouten, p. XX. 
Hoewel vooral naar aanleiding van dergelijke gebeurtenissen de noodzaak van een rechtstreekse nationaliteitsactie is gebleken, is ook in rustiger tijden een zodanige rechtsgang niet overbodig en derhalve niet zonder betekenis.

\subsubsection{Ontwikkelingen op het gebied van wetgeving}

Uit de jurisprudentie zijn enkele gevallen bekend die aantonen hoezeer het gebrek aan een rechtstreekse nationaliteitsactie de betrokkenen destijds in de kou heeft laten $\operatorname{staan}^{35} \mathrm{Min}$ of meer ten gevolge hiervan en van de incidenteel ook in de latere juridische literatuur ${ }^{36}$ onderkende behoefte aan een slechts op vaststelling van het bezit van het Nederlanderschap gerichte rechtsgang, heeft de wetgever in de loop der jaren pogingen gedaan te voorzien in een zodanige procedure.

$\mathrm{Er}$ is verscheidene malen getracht een op zich zelf staande procedure in het leven te roepen waarvan een unificerende werking met betrekking tot de beoordeling van het bezit van het Nederlanderschap zou uitgaan. Tot driemaal toe zijn de pogingen tevergeefs geweest. Pas de vierde heeft wel, zij het onder langdurig vallen en opstaan, tot resultaat geleid.

Binnen deze pogingen tot regelgeving kan, vanuit wetgevingstechnisch oogpunt gezien, onderscheid worden gemaakt tussen het voorstel dat tot een zelfstandige wet op de nationaliteitsvaststelling zou moeten leiden en de voorstellen waarbij de vaststellingsprocedure zou worden opgenomen in de wet die de tevens de materiële bepalingen omtrent het Nederlanderschap bevat.

Een eerste aanzet tot wetgeving is gedaan in $1954 .{ }^{37}$ In antwoord op vragen uit de Tweede $\mathrm{Kamer}^{38}$ bagatelliseert de minister van Justitie Donker de toenmalige situatie enigszins en oordeelt daarover als volgt: "Op het eerste gezicht zou men kunnen menen, dat deze gang van zaken tot tegenstrijdige beschikkingen en rechtsonzekerheid moet voeren. In de practijk van het rechtsleven valt het echter mee, omdat de administratie, hoewel daartoe formeel niet verplicht, zich pleegt te houden aan de beslissingen van de Minister van Justitie, die ten deze wordt

${ }^{35}$ Hof 's-Gravenhage 06.11.1952, NJ 1953, nr. 59 (zie tevens voetnoot 306); Gerecht in Eerste Aanleg 02.09.1961, Antilliaans Juristenblad 1962, p. 152, waarin een rechterlijke verklaring omtrent verzoekers Nederlanderschap is verzocht. Het Gerecht: "Overwegende immers, dat verzoeker van Ons een declaratoire beslissing verlangt houdende dat hij de Nederlandse nationaliteit heeft bekomen; dat echter de Wet van 12 december 1892 (Ned. Staatsblad 268) op het Nederlanderschap en ingezetenschap, die krachtens de Wet nadere regelen omtrent nationaliteit en ingezetenschap 1951 ook van toepassing is op Suriname en de Nederlandse Antillen, noch enige andere Wet, hoezeer wenselijk, een Rechter of administratief orgaan aanwijst, die over de vraag of iemand al dan niet Nederlander is met bindende kracht kan beslissen. "Volgt niet-ontvankelijkverklaring van de verzoeker.

${ }^{36}$ Jessurun d'Oliveira, HPS 1980, p. 20; en nog in 1984 Prins (II), p. 183 en 194.

${ }^{37}$ Zie tevens Van den Blink, p. 4 en 7.

${ }^{38}$ Zie voor deze vragen: Bijl. II. 54-55, 3700, Hfdst. IV (Rijksbegroting Justitie), nr. 9, p. 4. 
geadviseerd door de Permanente Commissie van Advies voor de zaken van de Burgerlijke stand en nationaliteitsaangelegenheden (...). ${ }^{39}$ Ondanks het bovenstaande geeft de minister toe dat "aan de bestaande situatie ook onloochenbare bezwaren kleven" en kondigt de instelling van een onderzoekscommissie aan.

Dit wordt de Commissie Nationaliteitsprocedure onder voorzitterschap van R.D. Kollewijn. De commissie komt in 1956 met een doorwrocht en zeer gedetailleerd ontwerp voor een Rijkswet op de Nationaliteitsuitwijzing. ${ }^{40}$ Volgens het ontwerp kan de "uitwijzingsprocedure" zich afspelen in alle gebiedsdelen van het Koninkrijk: Nederland, Suriname, Nederlandse Antillen en Nederlands Nieuw-Guinea. In al deze gebieden is de hoogste rechter geroepen, in Nederland derhalve de Hoge Raad. ${ }^{41}$ De rechtseenheid in het Koninkrijk is gewaarborgd door cassatie bij de Hoge Raad open te stellen voor de buiten Nederland gewezen beslissingen. ${ }^{42}$

Uit het voorstel van deze commissie is geen legislatief resultaat voortgekomen. Dit is mede het gevolg geweest van het negatieve standpunt dat de Hoge Raad, na om advies te zijn gevraagd, ${ }^{43}$ heeft ingenomen inzake het wetsontwerp in het algemeen $^{44}$ en zijn aanwijzing als feitelijke instantie in het bijzonder ${ }^{45}$.

Naar mijn mening is evenwel een veel belangrijkere oorzaak van het op dat moment alsnog beëindigen van de wetgevingsinspanningen het feit geweest, dat

${ }^{39}$ Bijl. II. 54-55, 3700, Hfdst. IV (Rijksbegroting Justitie), nr. 11, p. 9.

${ }^{40}$ Volgens Van der Haven, TvO 1961, p. 116, is het voorstel van de commissie nimmer openbaar gemaakt. Wel is het te vinden in het archief van het Ministerie van Justitie. Voor de verklaring van het gebruik van de term "uitwijzing", zie Van den Blink, p. 28 (noot 7). Kennelijk heeft in die tijd een zekere voorliefde bestaan voor het gebruik van de term "uitwijzing" in plaats van "vaststelling". Visser, p. 66 , spreekt over "eigendomsuitwijzing".

${ }^{41}$ Voor de andere gebiedsdelen worden het Hof van Justitie van Suriname en het Hof van Justitie van de Nederlandse Antillen (art. 24 van het ontwerp) of het Hof van Justitie voor Nieuw-Guinea (art. 35 van het ontwerp) aangewezen.

${ }^{42}$ Artikelen 30 en 39 van het ontwerp.

${ }^{43}$ Het komt wel meer voor dat de HR wordt gevraagd een advies te geven over een (ontwerp)voorstel van wet. Het verzoek tot advisering is gegrondvest op art. 22 Wet RO. Martens, p. 168-175, geeft naast het hiervermelde voorbeeld ter zake van de Nederlanderschapsuitwijzing nog andere voorbeelden. Recentelijk heeft de HR op verzoek van de regering geadviseerd over hoger beroep in vreemdelingenzaken; advies HR d.d. 14.03.1995. Zie daarover: MR 1995, p. 181-186.

${ }^{44}$ Uit een brief d.d. 22.08.1958 van Kollewijn aan de minister van Justitie blijkt dat de Hoge Raad zijn afwijzing van het voorstel grondt op vier overwegingen: eerstens zou de problematiek aangaande de Toescheidingsovereenkomst met Indonesiê van voorbijgaande aard zijn, ten tweede gaven reeds bestaande wegen de mogelijkheid een beslissing inzake de nationaliteit te verkrijgen (bijv. via de Kieswet), ten derde was de Wet beroep administratieve beschikkingen in de maak en ten vierde acht de HR een actie uit onrechtmatige daad (art. 1401 (oud) BW) een niet onwaarschijnlijke weg. (Kritiek op de rechtsgang via art. 1401 (oud) BW levert Van der Haven, TvO 1961, p. 117).

${ }^{45}$ Kollewijn schrijft in zijn brief van 22.08.1958: "(...), dat de werkzaamheid, die in het ontwerp aan de Hoge Raad werd toegedacht, by dit College op bezwaar zou stuiten. Nu dit toch het geval blykt te zyn is een ingrypende wyziging natuurlyk onvermydelyk. " $\mathrm{Vgl}$. Martens, p. 170; alsmede de opmerking van Van Rijckevorsel tijdens de begrotingsbehandeling van 1960: Hand. II. 60-61, p. 2480. Zie tevens het Voorontwerp december 1976, p. 38. 
men bij het ministerie van Justitie van de noodzaak tot een wettelijke regeling met een unificerende werking aangaande de vaststelling van de Nederlandse nationaliteit niet overtuigd is geweest. Dit is al naar vorengekomen in de bovenaangehaalde uitlatingen uit 1954 van de minister, maar bovendien is in 1958 een ambtelijke nota geschreven waarin volgens Kollewijn: "De behoefte aan de regeling van een zelfstandige actie tot nationaliteitsuitwyzing nog sterker dan door de Hoge Raad in twyfel wordt getrokken. De Nota bestrydt de door de Commissie aangevoerde motieven vóor een regeling. ${ }^{46}$

Getuige de volgende uitspraken van de minister van Justitie blijft ook de volgende jaren deze opvatting de heersende. Zo deelt in 1959 minister Beerman de Kamer mede: "(..) indien handhaving van de status quo zou neerkomen op laten voortbestaan van een ernstige leemte. Dit is echter geenszins het geval. De geldende wetgeving biedt een aantal mogelijkheden om een nationaliteitsbeslissing te verkrijgen en in de praktijk wordt van deze mogelijkheden gebruik gemaakt. ${ }^{n+7}$ En wederom de minister ruim een jaar later: "De ondergetekende blijf van oordeel, dat de bestaande toestand niet onbevredigend is en dat de indiening van een ontwerp van Rijkswet op de nationaliteitsuitwijzing niet urgent is. ${ }^{48}$

Desalniettemin zal een speciale, alleen op de vaststelling van het Nederlanderschap gerichte procedure er wel degelijk komen; de totstandkoming ervan zal evenwel nog 25 jaar op zich laten wachten. Tussentijds is eind jaren zestig gewerkt aan een herziening van de Wet op het Nederlanderschap en het ingezetenschap in verband met de toetreding van het Koninkrijk tot het verdrag van Straatsburg betreffende meervoudige nationaliteit en het verdrag van New York betreffende vermindering van staatloosheid. ${ }^{49}$ Een onderdeel van deze voorbereidingen vormt het voorstel om in de Wet op het Nederlanderschap een artikel op te nemen krachtens welk men de minister van Justitie kan verzoeken een uitspraak te doen omtrent het bezit van het Nederlanderschap. Van de ministeriële beslissing is vervolgens beroep mogelijk op grond van de Wet $\mathrm{Bab} .{ }^{50}$ Tot enige wetswijziging, noch tot toetreding tot de twee genoemde verdragen, hebben deze voorbereidende activiteiten overigens niet geleid.

${ }^{46}$ Citaat uit de brief d.d. 22.08.1958 van Kollewijn aan de minister van Justitie. Deze brief (zie tevens de twee voorafgaande voetnoten) is ongepubliceerd en bevindt zich in het archief van het ministerie van Justitie.

${ }^{47}$ Bijl. II. 59-60, 5700, Hfdst. IV (Rijksbegroting Justitie), nr. 8, p. 15.

${ }^{48}$ Bijl. II. 60-61, 6100, Hfdst. IV (Rijksbegroting Justitie), nr. 9, p. 15.

${ }^{49}$ Bijl. II. 67-68, 9300, Hfdst. VI (Rijksbegroting Justitie), nr. 2, p. 6.

so Wet beroep administratieve beschikkingen (Wet van 20.06.1963, Stb. 268). Deze wet is van kracht geweest van 01.01.1964 tot 01.07.1976, het moment van inwerkingtreding van de Wet Arob (Wet van 01.05.1975, Stb. 284). 
In tegenstelling tot het uitgebreide wetsontwerp uit 1956 zien we met het bovengenoemde voorstel een poging de vaststellingsprocedure op te nemen in de wet die de nationaliteit regelt.

Dit laatste geldt ook voor een voorontwerp uit 1971; het betreft hier echter eveneens een ontwerp dat voortijdig strandt. Het uit dat jaar stammende wetsontwerp betreffende nationaliteitsvaststelling is een wetsontwerp van 14 artikelen en is, net als de vorige twee ontwerpen nooit ter behandeling aan het Parlement toegezonden. ${ }^{51}$ In dit ontwerp is sprake van een civiele verzoekschriftprocedure bij het gerechtshof in Den Haag ${ }^{52}$ met mogelijkheid tot cassatie bij de Hoge Raad. De 14 artikelen betreffende de nationaliteitsvaststelling zouden deel gaan uitmaken van een nieuwe Rijkswet op het Nederlanderschap, een wet die evenwel toen niet is gerealiseerd..$^{53}$

$\mathrm{Na}$ enige rust wordt de draad in 1976 weer opgenomen in het voorontwerp van Rijkswet vaststelling van nieuwe, algemene bepalingen omtrent het Nederlanderschap; een voorontwerp dat, net als in 1971, geen herziening van, maar vervanging van de Wet op het Nederlanderschap en ingezetenschap ten doel heeft. ${ }^{54}$ Dit voorontwerp heeft gediend als basis voor het ontwerp van Rijkswet tot vaststelling van nieuwe, algemene bepalingen omtrent het Nederlanderschap ter vervanging van de Wet van 12 december 1892, Stb. 268 op het Nederlanderschap en het ingezetenschap uit $1981 .^{55}$

Zowel in het voorontwerp als in het wetsontwerp is een speciale procedure gericht op het doen vaststellen van het bezit van de Nederlandse nationaliteit opgenomen. ${ }^{56}$ De voorgestelde procedure is in beide ontwerpen min of meer dezelfde en behelst een vaststelling door de minister van Justitie. In het voorontwerp wordt daarbij uitdrukkelijk beroep op de Afdeling rechtspraak van de Raad van State opengesteld. ${ }^{57}$ In het latere wetsontwerp echter is de uitdrukkelijke

\footnotetext{
51 Vgl. De Groot, losbl. uitgave Personen- en Familierecht, hoofdstuk 6 Rijkswet, aant. 1, p. 6-1; Heijs (II), p. 161; Van den Blink, p. 5.

${ }^{52}$ Voor Suriname en de Antillen bij "gewoon verblijf" in die landen of het Hof van Justitic te Suriname dan wel het Hof van Justitie van de Nederlandse Antillen (art. 12 van het ontwerp).

${ }^{53} \mathrm{Vgl}$. Bijl. II. 71-72, 11500, Hfdst. VI (Rijksbegroting Justitie), nr. 2, p. 7.

${ }^{54}$ De regering stuurde op 29.12.1976 dit voorontwerp ter kennisneming naar de Tweede Kamer. Bijl. II. 76-77, 14319, nr. 1. Zie tevens Jessurun d'Oliveira, NJB 1977, p. 597 en 598.

55 Bijl. II. 1981, 16947, nrs. 1-2.

56 Vgl. De Groot, NJB 1981, p. 1118 en 1119; Jessurun d'Oliveira, NJB 1982, p. 251-255; Loeb (1983), p. 291.

57 Art. 20 lid 5 van het voorontwerp. In de toelichting wordt gesproken over de Afdeling rechtspraak van de Raad van State als "volledige beroepsrechter" en "De Afdeling rechtspraak geeft haar beslissing alsof zij daartoe in eerste instantie zou zijn geroepen en zij onderzoekt alle feiten en omstandigheden welke voor de vaststelling van belang kunnen zijn zonodig opnieuw. Zij beperkt zich bij dat onderzoek niet tot de gronden welke in het beroepschrift zijn aangevoerd. " Zie het Voorontwerp december 1976. p. 38 en 39 .
} 
vermelding van deze beroepsmogelijkheid verdwenen, omdat beroep op grond van de Wet Arob mogelijk wordt geacht. ${ }^{58}$ In feite is dit voorstel een wederopstanding van hetgeen reeds eind jaren zestig is ontworpen, maar toen niet aan het Parlement is toegezonden.

Tijdens de behandeling in de Tweede Kamer van het ontwerp Rijkswet op het Nederlanderschap heeft de hierboven beschreven procedure het niet gehaald. Naar aanleiding van bedenkingen die in de Tweede Kamer naar voren zijn gekomen tegen met name de doorslaggevende factor die de minister van Justitie zou zijn bij de nationaliteitsvaststelling, is bij nota van Wijziging een radicaal andere procedure voorgesteld. ${ }^{59}$ Daarbij heeft men teruggegrepen op het in 1971 ontworpen voorontwerp. ${ }^{60}$ Uiteindelijk heeft deze procedure in werking kunnen treden als hoofdstuk 6 van de Rijkswet op het Nederlanderschap. ${ }^{61}$

De Rijkswet op het Nederlanderschap is per 1 januari 1985 met uitzondering van hoofdstuk 6 in werking getreden. ${ }^{62}$ Op grond van het bepaalde in artikel 24 lid 1 RWN is de inwerkingtreding van hoofdstuk 6 RWN uitgesteld tot 1 oktober $1986 .{ }^{63}$ Deze vertraagde inwerkingtreding is veroorzaakt door een destijds nog te verrichten aanpassing van de Vreemdelingenwet, waarin de in artikel 43 Vreemdelingenwet geregelde procedure waarin men bij de Hoge Raad kon klagen ten onrechte als vreemdeling te worden behandeld, diende te worden geschrapt. Met ingang van 1 oktober 1986 is de in dat artikel voorziene beklagprocedure vervallen. ${ }^{64}$

De vraag waarom het zo lang heeft moeten duren voordat, na de eerste signalering van het ontbreken van een rechtstreekse nationaliteitsactie en het vervolgens groeien van de overtuiging dat een dergelijke procedure wenselijk is, een dergelijke regeling het levenslicht heeft aanschouwd, kan niet met de aanwijzing van één duidelijke oorzaak worden beantwoord. Van den Blink gaat in haar lezing "De

57 $\rightarrow$

En in de (latere) memorie van Antwoord is namens de minister van Justitie opgemerkt: "(...) geeft de mogelijkheid van volle toetsing van de ministeriële vaststelling door de Afdeling rechtspraak van de Raad van State -aan het bestaan van welke mogelijkheid ik, (...) niet twijfel- voldoende garantie tegen willekeurige beslissingen. "Zie Bijl. II. 82-83, 16947 nr. 7, p. 31.

${ }^{58}$ Bijl. II. 1981, 16947, nrs. 3-4, p. 22.

${ }^{59}$ Bijl. II. 82-83, 16947, nr. 7 (MvA), p. 31-33 en nr. 8 (nota van Wijziging).

${ }^{\infty} \mathrm{Vgl}$. de beschrijving van de procedure uit 1971 bij Van den Blink, p. 7.

61 Tratnik, MR 1988, p. 31, merkt hierover op dat de vaststellingsprocedure eindelijk binnen het juridische bouwwerk terecht is gekomen op de plaats van behoren, $\mathrm{nl}$. in de wet die de nationaliteit regelt.

a2 Vgl. Koens, p. 2.

${ }^{6} \mathrm{Vgl}$. De Groot/Tratnik, p. 128. De inwerkingtreding van hoofdstuk $6 \mathrm{RWN}$ is geregeld in het koninklijk besluit van 22.08.1986, Stb. 436.

${ }^{o}$ Wet van 02.07.1986, Stb. 373. Van 01.03.1990 tot 01.01.1994 heeft de Vreemdelingenwet een ander artikel 43 gekend. 
procedure tot vaststelling van het Nederlanderschap" in op deze vraag en noemt een drietal mogelijke oorzaken. Zo veronderstelt zij ten eerste dat in de praktijk weinig is gebleken van een behoefte aan een regeling waardoor een declaratoire verklaring over de nationaliteit kon worden verkregen. Ten tweede wordt door haar verondersteld dat de weinige behoefte, die er derhalve zeker was, zich juist manifesteerde bij personen die te gering in getal en tevens te weinig invloedrijk waren om een aanpassing in de wet te genereren. Dit zou een verklaring kunnen zijn van het feit dat, zoals in het voorgaande is gebleken, de wijze van vaststelling van het Nederlanderschap nooit een zaak van veel politieke aandacht is geweest. Ten derde wordt door Van den Blink het vermoeden uitgesproken dat, toen eenmaal de behoefte aan een procedure tot vaststelling van het Nederlanderschap werd erkend, het een moeilijkere taak is gebleken een regeling te ontwerpen dan op het eerste zicht werd verwacht. ${ }^{65}$

${ }^{65}$ Van den Blink, p. 2. 



\section{Hoofdstuk 2}

\section{Procesrechtelijke aspecten in het Nederlands nationaliteitsrecht Vaststelling van de Nederlandse nationaliteit door rechterlijke instanties}

\subsection{Inleiding}

Als vermeld in paragraaf 1.2 .2 heeft uiteindelijk de, reeds geruime tijd wenselijk geachte, rechtstreekse vaststellingsprocedure waarin de verkrijging van een rechterlijk oordeel over het bezit van het Nederlanderschap de enige inzet is in hoofdstuk 6 van de Rijkswet op het Nederlanderschap zijn beslag gekregen. Bij eerste beschouwing van hoofdstuk 6 Rijkswet op het Nederlanderschap blijkt echter dat met de vier artikelen die hoofdstuk 6 RWN vormen (art. 17 tot en met 20 RWN) de vaststelling van de Nederlandse nationaliteit in drie uiteenlopende situaties aan de orde is. De artikelen 17 en $18 \mathrm{RWN}$ betreffen de rechtstreekse vaststelling van het bezit van het Nederlanderschap door de rechtbank te Den Haag of door het Gemeenschappelijk Hof van Justitie van de Nederlandse Antillen en Aruba. De vaststelling van het Nederlanderschap tijdens ieder andere gerechtelijke procedure waarin de nationaliteit een onzekere voorvraag is gebleken, wordt bestreken door artikel 20 lid 1 RWN. Hetzelfde artikel heeft tevens betrekking op de vaststelling van het Nederlanderschap door een bestuursorgaan tijdens een administratieve beroepsprocedure waarin het bezit van de Nederlandse nationaliteit een onzekere factor in de besluitvorming blijkt te zijn (art. 20 lid 2 RWN).

In de artikelen 17 en 18 Rijkswet op het Nederlanderschap krijgt de rechtstreekse vaststellingsactie vorm. Met de invoering van de onderhavige procedure is het voor het eerst dat de beslechting van de nationaliteitsvraag niet langer per definitie geschiedt als een beslechting van een prealabele vraag (voorvraag) in het kader van een bepaald recht of een bepaalde verplichting. ${ }^{66}$ Ook de beide vreemdelingenrechtelijke voorgangers van de huidige vaststellingsprocedure zijn, naar mijn mening, procedures geweest waarin het niet betrof een rechtstreekse vaststelling van het bezit van het Nederlanderschap. Bedoeld zijn de procedures uit artikel 20

\footnotetext{
${ }^{66}$ Aan de nationaliteit zijn immers vele rechtsgevolgen verbonden; vgl. De Groot (II), p. 43-48; Heijs (II), p. 1. Indien in een rechtsgeschil de vraag centraal staat of én van die rechtsgevolgen is ingetreden (hoofdvraag), is de nationaliteitsvraag een essentiele voorvraag. Zie over de koppelingsfunktie van de nationaliteit: De Groot, p. 13 en 14; Mannoury, p. 157.
} 
Vreemdelingenwet 1849 en artikel 43 Vreemdelingenwet $1965 .{ }^{67}$ Zonder meer is waar dat het in die twee procedures ging om de beoordeling het bezit van het Nederlanderschap, maar het heeft altijd de beoordeling van het Nederlanderschap als prealabele vraag voor de toepassing van het vreemdelingenrecht betroffen. Op dezelfde wijze functioneert de prealabele vraag naar de nationaliteit ook in het kiesrecht of in het uitleveringsrecht. Het aanhangig maken van de beide vreemdelingenrechtelijke procedures is slechts mogelijk geweest binnen de context van toepassing van het vreemdelingenrecht. Dit heeft voor de Nederlanderschapvaststelling een restrictie betekend, die voortvloeide uit de onrechtstreeksheid van de procedures. De procedures op grond van de vreemdelingenwetgeving hebben namelijk slechts opengestaan voor personen op wie een maatregel uit de Vreemdelingenwet werd toegepast. Deze restrictie heeft ertoe geleid dat personen die een oordeel over het bezit van de Nederlandese nationaliteit in een niet-vreemdelingenrechtelijke situatie wensten, geen toegang tot de rechter uit artikel 20 Vreendelingenwet 1849 of artikel 43 Vreemdelingenwet 1965 hadden. ${ }^{68}$ Tevens leidde de koppeling van het nationaliteitsrecht met het vreemdelingenrecht ertoe dat een rechterlijke uitspraak over het standpunt dat men niet in het bezit van het Nederlanderschap is niet kon worden vitgelakt.

In de vaststellingsprocedure op grond van artikel 17 Rijkswet op het Nederlanderschap betreft de vraag naar het bezit van het Nederlanderschap de hoofdvraag in het geding. Ten behoeve van welk recht of welke verplichting de verzoeker de uitspraak wil verkrijgen, is om het even. Omdat de vraag naar het bezit van het Nederlanderschap tevens de hoofdvraag is, vormt in de procedure op grond van artikel 17 RWN de uitspraak over het bezit van het Nederlanderschap het dictum. Dit is evident anders dan in de procedures waarin het Nederlanderschap een prealabele vraag vormt. In dit type procedures bevat het dictum een uitspraak over een andere rechtskwestie dan het Nederlanderschap. Bovendien wordt de uitspraak over het Nederlanderschap in de procedure op grond van artikel $17 \mathrm{RWN}$ gegeven in declaratoire vorm. ${ }^{69}$

Ten gevolge van het feit dat in de artikel 17 RWN-procedure de nationaliteitsvraag is losgekoppeld van andere rechtsvragen is deze procedure aan te merken als

\footnotetext{
${ }^{67}$ Zie daarover par. 2.8.2. en 3.3.3.1.

${ }^{68} \mathrm{Vgl}$. HR 08.04.1988, rkstnr. 7049, Zilverentant e.a., losbl. uitgave Nationaliteitsrecht, art. 8 Wet Ned. 1892. Een ander voorbeeld is dat waarin iemand die ingevolge de bepalingen van de Wet betreffende de positic van Molukkers als Nederlander wordt behandeld, maar meent in het bezit te zijn van de Nederlandse nationaliteit, tot 1986 geen rechtstreekse rechtsingang heeft gehad ter vaststelling van zijn Nederlanderschap. Vgl. tevens voetnoten 35 en 626.

${ }^{\circ} \mathrm{Vgl}$. Beukers, p. 67; Hugenholtz/Heemskerk, p. 93; Visser, p. 49, omschrijft declaratoir als: "(......) het resultaat van een proces waarin alleen gevraagd wordt het constateren of qualificeren van een rechtsverhouding. "Zie Asser/Anema/Verdam, p. 292, waar de auteurs vermelden dat een statusproces leidt tot een declaratoire uitspraak; $\mathrm{cf}$. Heemskerk, p. 13.
} 
een rechtsgang waarin de rechterlijke vaststelling van het Nederlanderschap op een zelfstandige, van andere rechten of plichten losgemaakte, wijze geschiedt. De in de onderhavige procedure niet meer als prealabel te beschouwen nationaliteitsvaststelling kan mijns inziens vanwege de hierboven genoemde ontkoppeling tussen de nationaliteit en een aanklevend recht of verplichting dan ook worden aangemerkt als een "zelfstandige vaststelling". ${ }^{70}$

Ter aanduiding van de procedure uit artikel 17 Rijkswet op het Nederlanderschap gebruik ik in de navolgende hoofdstukken over het Nederlandse recht een bepaalde benaming. Wegens het bovenbeschreven zelfstandige karakter van de nationaliteitsvaststelling is de keuze gevallen op de omschrijving "zelfstandige vaststellingsprocedure". In dit en volgende hoofdstukken wordt deze omschrijving gehanteerd als werkbegrip voor de procedure op grond van artikel 17 RWN waarin, zoals gezegd, de vaststelling van de nationaliteit de hoofdvraag is.

Als tegenhanger van de "zelfstandige vaststellingsprocedure" geldt ieder rechtsgeding waarin de vraag naar de nationaliteit voorkomt als prealabele vraag. Reeds in 1915 stelt Kramers dat in wezen de vraag naar de nationaliteit altijd een prealabele vraag vormt. ${ }^{71}$ Dat dit zo is, is het gevolg van het feit dat het rechtsbegrip nationaliteit op zich genomen inhoudsloos is. Eerst in verbinding met door de wetgever aan die nationaliteit gekoppelde rechten en verplichtingen krijgt het begrip zin. ${ }^{72}$ Een zodanige procedure, waarin zowel over de nationaliteit (als prealabele vraag) als over een andere rechtsvraag (de hoofdvraag in het geding) wordt geoordeeld, wordt in dit boek betiteld als een "impliciete vaststellingsprocedu$r e " .{ }^{73}$ In de Rijkswet op het Nederlanderschap heeft artikel 20 RWN betrekking op de "impliciete vaststellingsprocedures".

Zoals in paragraaf 1.2.2 is vermeld, is, na de in de Tweede Kamer geopperde bezwaren tegen de eerdere opzet van de "zelfstandige vaststellingsprocedure" ${ }^{74}$ bij wege van nota van Wijziging het huidige hoofdstuk 6 Rijkswet, met daarin de procedure voor het "zelfstandig" vaststellen van het bezit van het Nederlanderschap en met een regeling ten behoeve van "impliciete vaststellingsprocedures" geïntroduceerd.

In de bijbehorende memorie van Antwoord wordt de nieuw voorgestelde rechtsgang uit artikel $17 \mathrm{RWN}$ omschreven als een regeling die "voorziet in een

\footnotetext{
${ }^{70}$ In de MvA wordt in dit verband gesproken over "eigenlijk", Bijl. II. 82-83, 16947, nr. 7, p. 32.

$"$ Kramers, p. 23.

${ }^{72}$ De Groot/Tratnik, p. 12; Van Wissen, p. 70.

"De term "oneigenlijk" is naar mijn mening minder gelukkig omdat deze misschien de indruk zou wekken dat de vaststelling van de nationaliteit in een art. $20 \mathrm{RWN}$-procedure voor het nationaliteitsrecht van minder belang zou zijn dan in de "eigenlijke" vaststellingsprocedure van art. 17 RWN. Als alternatief voor "impliciet" zouden ook termen als "afhankelijk" of "indirekt" denkbaar zijn.

74 Waarin de vaststelling zou worden gedaan door de minister van Justitie, waarna beroep van diens beslissing ingevolge de Wet Arob op de Afdeling rechtspraak van de Raad van State zou openstaan.
} 
extra-judiciële vaststelling van het Nederlanderschap".75 Het is niet helfmaal duidelijk wat met deze laatste opmerking is bedoeld, ${ }^{76}$ maar aangenomen moet worden dat het niet méér wil benadrukken dan dat het met deze nieuwe procedure gaat om een rechterlijke vaststelling van het Nederlanderschap buiten enig ander reeds aanhangig gemaakt rechtsgeschil. ${ }^{n}$

Absoluut en relatief bevoegd in de "zelfstandige vaststellingsprocedure" is de arrondissementsrechtbank te Den Haag of, indien de verzoeker in de Nederlandse Antillen of Aruba woonachtig is, het Gemeenschappelijk Hof van Justitie van de Nederlandse Antillen en Aruba (art. 17 lid 1 RWN). ${ }^{78}$ De procedure wordt ingeleid met een verzoekschrift en leidt tot een beschikking van de rechtbank of het Gemeenschappelijk Hof.

Uit artikel 17 RWN volgt dat indien iemand buiten het Koninkrijk woolt het verzoek dient te worden gericht aan de rechtbank te Den Haag. ${ }^{79}$ Het voorgaande geldt dan merkwaardig genoeg óók ten aanzien van iemand die alvorens $z^{\mathrm{i}}$ ch te vestigen buiten het Koninkrijk zijn gehele leven in de Nederlandse Antillen of Aruba heeft gewoond. Dit is merkwaardig te noemen omdat in dergelijke gevallen de relevante gegevens en getuigen zich veelal niet in Nederland zullen bevinden

${ }^{79}$ Bijl. II. 82-83, 16947, nr. 7, p. 32.

${ }^{76}$ Reeds Jessurun d'Oliveira, NJB 1983, p. 1309, vraagt zich af waarom in dit verband deze term wordt gehanteerd.

De term "extra-judicieel" is wel bekend, maar wordt gewoonlijk niet gebruikt om de gehele zgn. noncontentieuze jurisdictie ( $=$ alle verzoekschriftprocedures) aan te duiden; vgl. Hugenholtz/Heemskerk, p. 28. Star Busmann, p. 10, noemt "buitengerechtelijke of extra-judiciële werkzaamheden" een onderdeel van "oneigenlijke rechtspraak". De ingang tot "oneigenlijke rechtspraak" is meestal een verzoekschrift. Maar dat wil niet zeggen dat iedere verzoekschriftprocedure betrekking heeft op zgn. extra-judiciële werkzaamheden van de rechter. Funke, p. 177, laat zien dat "extra-judicieel" in de negentiende eeuw gebruikelijk is geweest in de betekenis van "buiten eigenlijk regtsgeding". Hij citeert een toenmalig lid van de Tweede Kamer om het onderscheid judiciële procedures versus extra-judiciēle procedure zoals dat toen werd gezien, te verduidelijken: "de inroeping van den regter tot handhaving van regt, hetgeen bij de extra-judiciële procedure geene plaats heeft." Hieruit blijkt dat begripsmatig gezien in een "extrajudiciële" procedure de rechter geacht wordt geen rechterswerk te verrichten, maar meer een bestuurlijke activiteit te ontplooien: zoals bijvoorbeeld in adoptieprocedures (art. 1:227 BW) of procedures ter wijziging van de voornaam (art. 1:4 lid 4 BW). Vgl. tevens Röder, p. 2-4.

$n$ Jessurun d'Oliveira, NJB 1983, p. 1309, vermoedt dat is bedoeld: "zonder dat er een geschil hoeft te zijn."

${ }^{7}$ Uit art. 17 RWN wordt overigens niet helemaal duidelijk of iemand die woonachtig is in de Antillen of Aruba nu twee mogelijkheden heeft (Den Haag en het eigen Hof) of slechts één (het eigen Hof). De MvA geeft in dezen niet volledig uitsluitsel, maar het komt mij voor dat is bedoeld de inwoners van de Antillen en Aruba slechts één forum in eerste aanleg open te stellen. Dit is echter nergens uitdrukkelijk zo gesteld.

${ }^{7}$ Vgl. HR 07.04.1989, NJ 1990, nr. 791, m.nt. GRdG. Vgl. tevens Rb. 's-Gravenhage 25.11.1987, rkstnr. 86.2110: Rb. 's-Gravenhage 10.02.1988, rkstnr. 87.5801: Rb. 's-Gravenhage 27.04.1988, rkstnr. 87.5870; Rb. 's-Gravenhage 27.04.1988, rkstnr. 87.5871 en Rb. 's-Gravenhage 29.06.1988, rkstnr. 87.6089 (= HR 07.04.1989, NJ 1989, nr. 531); HR 28.10.1994, RvdW 1994, nr. 216; HR 11.11.1994, NJ 1995, nr. 100. De verzoekers zijn woonachtig in Suriname, het Verenigd Koninkrijk, Isračl en Indonesiê. 
maar in een van de andere twee landen. Waarom het Gemeenschappelijk Hof in deze zaken niet gelijkelijk bevoegd is, is een vraag die onbeantwoord blijft in de totstandkoming van de Rijkswet op het Nederlanderschap. Naar mijn mening geeft het hierboven gesignaleerde ontbreken van bevoegdheid voor het Gemeenschappelijke Hof de Rijkswet evenwel een enigszins koloniale karaktertrek. ${ }^{80}$

Gedurende de betrekkelijk korte tijd dat hoofdstuk 6 Rijkswet op het Nederlanderschap van kracht is, heeft vooral artikel 17 RWN geleid tot vanuit procesrechtelijk oogpunt bezien interessante jurisprudentie. De ontvankelijkheid in zijn verzoek van de verzoeker, het belang dat deze dient te hebben bij de vaststelling, de posities van het openbaar ministerie en van de Staat zijn onderwerpen die reeds in een vroeg stadium aanleiding hebben gegeven tot rechtspraak van de Hoge Raad. Aan de hand van de ontwikkelingen in de rechtspraak zal eerst worden ingegaan op de vereisten voor ontvankelijkheid. Daarna komen de positie en rol van het OM (paragraaf 2.3) en de positie van de Staat (paragraaf 2.4.2.1) aan de orde. Paragraaf 2.5 behandelt de cassatie. De bindende werking die op grond van artikel 19 RWN uitgaat van de vaststellingsbeschikking wordt besproken in paragraaf 2.6. In paragraaf $2.7 \mathrm{komt}$ de in de rechtspraak ontwikkelde mogelijkheid tot herziening van een vaststellingsbeschikking aan de orde. Hoofdstuk 2 wordt afgesloten met een bespreking van artikel $20 \mathrm{RWN}$ in paragraaf 2.8 .

\subsection{Vereisten voor ontvankelijkheid (art. 17 RWN)}

\subsubsection{Algemene beschouwingen}

Een algemene stelregel in het civiel procesrecht is dat, alvorens in te kunnen gaan op de eigenlijke zaak, de rechter ambtshalve dient te beoordelen of de eiser, dan wel de verzoeker, ontvankelijk is. ${ }^{81}$

Ten behoeve van de overzichtelijkheid van het verdere betoog wordt door mij in het navolgende een onderscheid aangebracht tussen enerzijds ontvankelijkheidsvereisten die in het burgerlijk procesrecht algemeen voor alle procedures gelden en anderzijds ontvankelijkheidsvereisten die specifiek gelden voor de procedure die wordt gevoerd op grond van artikel 17 Rijkswet op het Nederlanderschap. Verschil voor de ontvankelijkheidstoetsing makt dit onderscheid overigens niet. Uit de

\footnotetext{
${ }^{50} \mathrm{Het}$ wetsontwerp uit 1971 daarentegen bevat wel de volgende bepaling: "Een natuurlijke persoon die zijn gewoon verblijf buiten het Koninkrijk, doch in Amerika zuidelijk van de Verenigde Staten van Noord-Amerika heeft, kan zijn verzoek ook, (....), richten tot het Hof van Justitie van Suriname of het Hof van Justitie van de Nederlandse Antillen, (...). "

"Van Baars, p. 90, 91 en 136; Verhagen-Maat, p. 138; Vriesendorp, p. 182 en 192.
} 
zoëven vermelde stelregel mag duidelijk zijn dat door de rechter alle vereisten voor ontvankelijkheid ambtshalve moeten worden getoetst.

Eén van de algemene ontvankelijkheidsvereisten, een vereiste derhalve dat geldt voor iedere procedure ongeacht het onderwerp, is dat de eiser of de verzoeker "belang" bij zijn eis of verzoek heeft. Deze eis wordt algemeen gekend onder het adagium "point d'intérêt, point d'action" 82 . Alleen deze regel zal in het navolgende worden behandeld aangezien zich op het terrein van de vaststelling van het Nederlanderschap met betrekking tot dit ontvankelijkheidsvereiste jurisprudentie heeft gevormd. Derhalve blijven buiten beschouwing andere algemeen geldende regels die leiden tot niet-ontvankelijkheid van de eiser of verzoeker. ${ }^{83}$ In paragraaf 2.2.4 zal op de rechtspraak van de Hoge Raad waarin het beginsel "point d'intérêt, point d'action" met betrekking tot de vaststelling van het Nederlanderschap aan de orde komt, worden ingegaan.

Naast de algemene vereisten die ten aanzien van de ontvankelijkheid gelden, stelt artikel 17 RWN daarvoor nog twee specifieke vereisten. Eén van die specifieke vereisten met betrekking tot de ontvankelijkheid is dat de verzoeker een "onmiddellijk belang" bij de vaststelling heeft. Op dit vereiste wordt in paragraaf 2.2.3 ingegaan.

Een volgende eis die in artikel $17 \mathrm{RWN}$ wordt gesteld, is dat het verzoek bij de Haagse rechtbank niet gelijktijdig valt met "een bij enige in een der delen van het Koninkrijk gevestigde rechterlijke instantie of een in administratief beroep aanhangige zaak". Mocht de rechtbank tot het oordeel komen dat wél sprake is van een zodanig aanhangige zaak, dan dient de verzoeker op grond daarvan niet-ontvankelijk in zijn verzoek te worden verklaard. Artikel $17 \mathrm{RWN}$ verwijst met deze bepaling naar aanhangige "impliciete vaststellingsprocedures". Procedures derhalve waarop artikel 20 RWN betrekking heeft en waarin mogelijkerwijs de facultatieve advisering uit artikel 20 lid 1 RWN een rol kan gaan spelen en, in geval van nationaliteitsonzekerheid in een administratief beroep, de verplichte advisering uit artikel 20 lid 2 RWN een rol gaat spelen.

\footnotetext{
$n$ Tot voor kort een regel van ongeschreven recht, tegenwoordig opgenomen in art. 3:303 BW. Vgl. Van Baars, p. 159 en 160; Hugenholtz/Heemskerk, p. 15; Snijders, p. 13.

s Bijvoorbeeld dat indien verplicht met procesvertegenwoordiging wordt geprocedeerd (vgl. Boekman, p. 104; Rutgers, p. 92). Zie voorts Hugenholtz/Heemskerk, p. 104: niet-ontvankelijkheid o.a. bij het zijn verstreken van de termijn om een vordering of een rechtsmiddel in te stellen. Art. $334 \mathrm{Rv}$ : de partij die heeft berust kan geen hoger beroep meer instellen en is niet-ontvankelijk. Polenaar, p. 131 en Wesseling-van Gent, p. 81: niet-ontvankelijkheid volgt indien de procedure niet met het juiste inleidende gedingstuk (dagvaarding of verzoekschrift) is aangevangen. Ook kan niet-ontvankelijkheid worden uitgesproken in het geval van (Coops, p. 40 en 41) "vaagheid, duisterheid of onvolledigheid van de als grond van de eis gestelde feiten". Misbruik van procesrecht kent volgens de losbl. uitgave BRv., Boek I, titel 1, alg. gedeelte, aant. 3, als sanctie niet-ontvankelijkheid. Heemskerk (II), p. 319 , noemt nog: de actie tegen een niet bestaande gedaagde of het ontbreken van de hoedanigheid. Zie tevens Vriesendorp, p. 182.
} 
Uit dit laatste ontvankelijkheidsvereiste blijkt dat, in de verhouding tussen de artikelen 17 en $20 \mathrm{RWN}$, in het geval dat een gelijktijdigheid van procedures aan de orde zou zijn, er sprake is van dominantie van de procedures die vallen onder de werking van artikel 20 RWN. De wetgever heeft hiermee getracht het gevaar te bezweren dat met betrekking tot één persoon terzelfdertijd tegenstrijdige nationaliteitsvaststellingen zouden worden gegeven. Om de dominantie van de procedures die vallen onder artikel $20 \mathrm{RWN}$ te omschrijven, gebruik ik in het navolgende daarvoor als werkbegrip de omschrijving "exclusieve werking van artikel $20 \mathrm{RWN}$ ". Aan de problematiek die de "exclusieve werking van artikel $20 \mathrm{RWN}$ " met zich brengt voor wat betreft de toegankelijkheid van de vaststellingsprocedure van artikel 17 RWN is de hieronder volgende paragraaf gewijd.

\subsubsection{De exclusieve werking van artikel $20 \mathrm{RWN}$}

\subsubsection{Rechterlijke instantie of in administratief beroep}

Het zal duidelijk zijn dat in verband met de "exclusieve werking" van artikel 20 Rijkswet op het Nederlanderschap de definiëring van de begrippen "rechterlijke instantie" en "in administratief beroep" van groot belang wordt.

Onder "rechterlijke instantie" vallen vanzelfsprekend alle rechtsprekende instanties: de gewone rechter (art. 1 Wet RO) en de gerechten die niet tot de rechterlijke macht behoren (art. 112 lid 2 Grondwet) ${ }^{84}$. Voor de begripsinvulling van "administratief beroep" valt heden ten dage aan te sluiten bij de begripsomschrijving die artikel 1:5 lid 2 Algemene wet bestuursrecht (Awb) ${ }^{85}$ geeft.

In de oorspronkelijke redactie van artikel $17 \mathrm{RWN}$ is sprake geweest van een bij een "administratieve beroepsinstantie" aanhangige zaak. ${ }^{86}$ Met ingang van 1 januari 1994 is het begrip "administratieve beroepsinstantie" uit de tekst van de Rijkswet uit 1985 gewijzigd in "in administratief beroep $" .{ }^{87}$ De reden voor deze wijziging heeft gelegen bij de inwerkingtreding van de Algemene wet bestuursrecht waarbij in veel (Rijks)wetten, ook in de Rijkswet op het Nederlanderschap, een terminologische aanpassing aan de Awb is doorgevoerd.

In de op grond van de oorspronkelijke redactie van artikel 17 RWN gevormde jurisprudentie is mede gebleken dat in de Rijkswet niet is gedacht aan administra-

\footnotetext{
${ }^{2}$ Bijvoorbeeld: de Afdeling bestuursrechtspraak van de Raad van State (art. 26 WRvS); de Centrale Raad van Beroep (art. 1 e.v. Beroepswet); het College van Beroep voor het bedrijfsleven (art. 2 e.v. Wet bestuursrechtspraak bedrijfsorganisatie); het College van beroep studiefinanciering (art. 108 Wet op de studiefinanciering).

ss Wet van 04.06.1992, Stb. 315. Inwerkingtreding 01.01.1994.

${ }^{85}$ Het hier relevante gedeelte van art. 17 RWN luidde: "(......) een bij enige in een der delen van het Koninkrijk gevestigde rechterlijke instantie of administratieve beroepsinstantie aanhangige zaak, (.....)". ${ }^{87}$ Rijkswet van 22.12.1993, Stb. 692.
} 


\section{Hoofdstuk 2}

tieve bezwaarprocedures. Aangezien aan dat feit met de gewijzigde tekst van artikel 17 RWN niets is veranderd, heb ik gemeend de op deze procedures betrekking hebbende jurisprudentie toch te moeten behandelen. Scherp onderscheid tussen administratieve bezwaarprocedures en administratieve beroepsprocedures blijft voor de "exclusieve werking van artikel $20 \mathrm{RWN}$ " nog steeds van belang. Ten behoeve van de leesbaarheid wordt in het navolgende van deze paragraaf nog incidenteel door mij gesproken over het inmiddels vervallen begrip "administratieve beroepsinstantie". Dit doe ik op grond van de overwegingen dat de te bespreken jurisprudentie betrekking heeft op dat begrip alsmede dat de wijziging van "administratieve beroepsinstantie" door "in administratief beroep" geen materiële wijziging maar louter een terminologische unificatie in het kader van de Algemene wet bestuursrecht heeft beoogd. In de hieronder aan de orde gestelde jurisprudentie speelt het begrip "rechterlijke instantie" uit artikel 20 RWN geen rol, omdat alle beschikkingen van de rechtbank in Den Haag betrekking hebben op een geschil dat (nog) in de fase van administratieve afhandeling door bestuursorganen verkeert.

In de periode direct volgend op de inwerkingtreding van de "zelfstandige vaststellingsprocedure" heeft de rechtbank te Den Haag verscheidene malen ${ }^{88}$ een verzoeker niet-ontvankelijk in zijn verzoek verklaard wegens het feit dat diens beweerd Nederlanderschap eveneens onderwerp van geschil uitmaakt in een reeds aanhangige administratiefrechtelijke bezwaarschriftprocedure of een herzieningsprocedure (dit laatste bijvoorbeeld op grond van de tot januari 1994 geldende procedures uit de Vreemdelingenwet). ${ }^{89}$

In de hier aan de orde gestelde oordeelsvorming van de rechtbank betreffende de ontvankelijkheid maakt deze, anders dan later de Hoge Raad ter zake, geen verschil tussen de omstandigheid of de aanhangige administratieve procedure zich al dan niet afspeelt bij een hiërarchisch hoger bestuursorgaan dan wel dat de procedure zich afspeelt bij het bestuursorgaan dat de oorspronkelijke beslissing heeft gegeven. Daarenboven overweegt de rechtbank in de onderhavige zaken steevast dat tegen een eventueel negatieve beslissing op het herzieningsverzoek, bezwaar of beroep voor de verzoeker verdere beroepsmogelijkheden openstaan, inclusief de gang naar een (administratieve) rechter.

Ter verduidelijking van het bovenstaande volgen hieronder de overwegingen van de rechtbank in één van de desbetreffende zaken. Het gaat hierbij om een voorbeeld waarin de betrokkene reeds is verwikkeld in een bezwaarschriftprocedure bij de Uitkeringsraad, een zelfstandig bestuursorgaan dat is opgericht ter uitvoering

${ }^{s}$ Zie bijv.: Rb. 's-Gravenhage 27.05.1987, rkstnr. 86.2446; Rb. 's-Gravenhage 27.05.1987, rkstnr. 87.5021: Rb. 's-Gravenhage 15.07.1987, rkstnr. 87.5097; Rb. 's-Gravenhage 15.07.1987, rkstnr. 87.5271 en Rb. 's-Gravenhage 29.06.1988, rkstnr. 87.6089.

voor een handzaam overzicht van de wijzigingen met ingang van 01.01.1994 in de procedures op grond van de Vreemdelingenwet: B.A. van Vondelen, Herziening Vreemdelingenwet, AA 1994, p. 224-230. 
van de Wet uitkeringen vervolgingsslachtoffers $1940-1945 .^{90}$ De Uitkeringsraad had de betrokkene wegens het niet in het verleden bezeten hebben van het Nederlanderschap een uitkering geweigerd. Tegen deze weigering heeft de betrokkene ingevolge artikel 42 (oud) ${ }^{91}$ Wet uitkeringen vervolgingsslachtoffers bezwaar aangetekend bij de Uitkeringsraad. Ook start de betrokkene een procedure op grond van artikel 17 RWN ten einde door de rechtbank te Den Haag haar voormalig Nederlanderschap te laten vaststellen. De rechtbank acht de verzoekster nietontvankelijk met de volgende overwegingen: "Verzoekster heeft de mogelijkheid te zijner tijd beroep in te stellen tegen de beschikking op haar bezwaarschrift bij de $C R v B$, terwijl zowel in de bezwaarschriftprocedure als in de procedure bij de CRvB verzoeksters stelling dat zij de Nederlandse nationaliteit bezit, dan wel heeft bezeten, aan de orde zal komen op de wijze zoals bepaald in art. 20 Rijkswet op het Nederlanderschap.

(.......) is derhalve niet-ontvankelijk in haar verzoek tot vaststelling van het Nederlanderschap. ${ }^{192}$

Uit bovenvermeld citaat komt naar voren dat de oorspronkelijke visie van de rechtbank met betrekking tot de ontvankelijkheid in de "zelfstandige vaststellingsprocedure" in het geval van een elders aanhangig zijnde "impliciete vaststellingsprocedure" twee aspecten heeft vertoond. Enerzijds is het daarbij gegaan om de invulling van het begrip "administratieve beroepsinstantie" en anderzijds om de benadering door de rechtbank van het "aanhangig zijn" van een nationaliteitsrechtelijk relevante zaak bij enig door artikel 20 RWN bedoelde instantie.

Wat het eerste aspect, de wijze waarop de rechtbank invulling heeft gegeven aan het begrip "administratieve beroepsinstantie" betreft, blijkt uit de bovenvermelde overweging dat naar het inzicht van de rechtbank een bezwaarschriftprocedure een procedure is die valt onder de "exclusieve werking van artikel $20 \mathrm{RWN}$ ".

Ook in andere beschikkingen interpreteert de rechtbank het begrip "administratieve beroepsinstantie" op gelijke, nogal ruime, wijze. Zo acht zij bijvoorbeeld een verzoeker niet-ontvankelijk omdat een herzieningsverzoek met betrekking tot een verblijfsvergunning aanhangig is bij de staatssecretaris van Justitie; een verblijfsvergunning die de verzoeker eerder was geweigerd door dezelfde staatssecreta-

\footnotetext{
${ }^{90}$ De Uitkeringsraad is een uitvoerende instantie ingesteld bij de Wet uitkeringen vervolgingsslachtoffers 1940-1945 (Wet v. 22.11.1972, Stb. 669). In een analoge wet, de Wet uitkeringen burger-oorlogsslachtoffers 1940-1945 (Wet v. 10.03.1984, Stb. 94), waarbij in art. 3 lid 1 en lid 2 eveneens het Nederlanderschap van de aanvrager als voorwaarde wordt gesteld, fungeert op een zelfde wijze de Raad uitkeringen burgeroorlogsslachtoffers (art. 46 Wubo). Inmiddels is de Uitkeringsraad als "Raadkamer WUV" een onderdeel geworden van de Pensioen- en Uitkeringsraad: vgl. CRvB 30.12.1993, AB 1994, nr. 224; CRvB 05.01.1995, AB 1995, nr. 187.

${ }^{91}$ In het kader van de inwerkingtreding op 01.01.1994 van de Awb is mede art. 42 Wuv gewijzigd. Zie de aanpassingswet van 23.12.1993, Stb. 690 .

${ }^{92}$ Rb. 's-Gravenhage 29.06.1988, rkstnr. 87.6089 (=HR 07.04.1989, NJ 1989, nr. 531).
} 
ris. ${ }^{93}$ In één van deze zaken oordeelt het openbaar ministerie in zijn conclusie, dat sprake is van een "aanhangige administratieve beroepsprocedure". De rechtbank verklaart in deze zaak de verzoeker niet-ontvankelijk op grond van de volgende overweging: "Verzoeker heeft echter de mogelijkheid te zijner tijd beroep in te stellen tegen de beschikking van de Staatssecretaris van Justitie bij de Afdeling Rechtspraak van de Raad van State, terwijl in elk van deze procedures verzoekers stelling dat hij de Nederlandse nationaliteit bezit aan de orde zal komen op de wijze zoals bepaald in artikel 20 van de Rijkswet op het Nederlanderschap.

Het verzoek tot vaststelling van het Nederlanderschap van (......) is derhalve niet-ontvankelijk. "

Als gezegd, het tweede aspect in de toetsing door de rechtbank is geweest, dat zelfs het mogelijkerwijs nog door de verzoeker adiëren van een hogere instantie mede tot niet-ontvankelijkheid leidt. De twee hierboven gegeven casus zijn ieder daarvan een voorbeeld. Een ander geval betreft een verzoeker die van de weigering door de burgemeester tot afgifte van een nationaal paspoort reeds in hoger beroep is gegaan bij de commissaris van de Koningin. Betrokkene zou van de beslissing van de commissaris te zijner tijd nog in beroep kunnen gaan bij de minister van Buitenlandse Zaken en vervolgens van diens beschikking beroep kunnen aantekenen bij de Afdeling rechtspraak van de Raad van State. ${ }^{95}$ Terwijl in deze zaak de overweging dat de commissaris van de Koningin functioneert als "administratieve beroepsinstantie" voldoende zou zijn geweest om tot niet-ontvankelijkheid te beslissen, neemt de rechtbank de eventualiteit dat de verzoeker zich ter zake van het geweigerde paspoort nog tot de Raad van State zou kunnen wenden mede in aanmerking als reden voor niet-ontvankelijkheid in de "zelfstandige vaststellingsprocedure ${ }^{.9}{ }^{96}$

In april 1989 makt de Hoge Raad korte metten met de tot op dat moment door de rechtbank gevolgde invulling van de ontvankelijkheidsvereisten. In de eerste plaats sneuvelt het in de ontvankelijkheidstoets betrekken van de, door de verzoeker, eventueel in de toekomst adiëren van hogere instanties dan de instantie waar de zaak nu aanhangig is. De Hoge Raad stelt: "Anders dan de Rb. kennelijk heeft aangenomen doet niet ter zake dat een belanghebbende tegen een beslissing van de

\footnotetext{
${ }^{93} \mathrm{Vgl}$. Bolten, MR 1988, p. 233.

9 Rb. 's-Gravenhage 15.07.1987, rkstnr. 87.5271.

${ }^{2}$ Cf. art. 89 Paspoortinstructie Nederland 1952 en de aanvullende rechtsbescherming (tot 01.01.1994) op grond van de Wet Arob. De Paspoortinstructie (zie daarover Vrz. ARRS, 08.11.1979, RV 1979, nr. 14) is inmiddels vervangen door de Paspoortwet. De Paspoortwet, Rijkswet van 26.09.1991, Stb. 498 en, curieus genoeg, de eerste wet op het gebied van de reisdocumenten die het Koninkrijk kent, geeft een andere rechtsgang dan de in het voorbeeld genoemde. Ten behoeve van de rechtsbescherming geldt in Nederland inmiddels de rechtsgang uit de Awb, in de Nederlandse Antillen en op Aruba dient in de landsverordeningen een regeling te worden getroffen.

${ }^{9} \mathrm{Rb}$. 's-Gravenhage 27.05.1987, rkstnr. 86.2446.
} 
Uitkeringsraad op een bezwaarschrift beroep kan instellen bij de CRvB. Het komt immers aan op de aard van de instantie bij welke de zaak aanhangig is. ${ }^{27}$

Ter beoordeling van de rechtbank staat derhalve alleen hetgeen in artikel 17 RWN uitdrukkelijk is gesteld: en wel of de zaak reeds elders in het Koninkrijk aanhangig is, en wel bij een rechterlijke instantie dan wel in een administratief beroep.

In de tweede plaats gaat de Hoge Raad in de onderhavige uitspraak in op "de aard van de instantie bij welke de zaak aanhangig is". Met het oog daarop geeft de Hoge Raad twee omschrijvingen die houvast moeten bieden bij het als zodanig identificeren van een "rechterlijke instantie" dan wel een "administratieve beroepsinstantie". Voor het eerste begrip wordt een positieve definiëring gekozen: een rechterlijke instantie is een instantie die "behoort tot de met rechtspraak belaste organen". Het tweede begrip wordt door de Hoge Raad op een meer omzichtige wijze benaderd. Het begrip "administratieve beroepsinstantie" wordt in de beschikking namelijk niet positief gedefinieerd, daarentegen stelt de Hoge Raad vast wat niet onder het begrip valt.

Onder "administratief beroep" wordt in de literatuur algemeen verstaan het in al zijn aspecten opnieuw beoordelen van het bestreden besluit door een in de bestuurlijke hiërarchie hoger geplaatst orgaan. ${ }^{98}$ De zaak wordt nogmaals door het hogere administratieve orgaan beoordeeld, waarbij ruimte is voor zowel doelmatigheidsals rechtmatigheidstoetsing. ${ }^{99}$ Een "administratieve beroepsinstantie" is geen instantie die (slechts) met rechtspraak is belast, maar is daarentegen een onderdeel van de uitvoerende macht. ${ }^{100}$

De Hoge Raad hanteert in de bovenvermelde beschikking van april 1989, zoals gezegd, ten aanzien van het begrip "administratieve beroepsinstantie" een negatieve afbakeningsmethodiek en in casu is dat voldoende om bij de algemeen gangbare begripsinvulling van "administratief beroep" aansluiting te kunnen vinden. De Hoge Raad volstaat met de constatering dat een instantie die een eerdere beslissing van zichzelf heroverweegt géén administratieve beroepsinstantie is.

\footnotetext{
${ }^{97}$ HR 07.04.1989, NJ 1989, nr. 531. Vgl. De Groot, losbl. uitgave Personen- en Familierecht, art. 17 RWN, aant. 1.

98 Om te kunnen spreken van administratief beroep gaat van ouds de literatuur ervan uit dat de behandeling van het herzieningsverzoek plaatsvindt binnen een in de bestuurshiërarchie hoger geplaatst orgaan: Van Apeldoorn/Leyten, p. 252; Ten Berge/Tak, p. 7-9; Boeles, p. 213; Franken e.a., p. 438 en 439; De Goede, p. 164; Van der Hoeven, p. 119 en 120; T. Koopmans, p. 204 en 205; Tonnaer, p. 284; Widdershoven, p. 43; Van Wijk/Konijnenbelt (1979), p. 26 en 155 . Vindt de behandeling van het herzieningsverzoek plaats bij hetzelfde orgaan dat het bestreden besluit heeft genomen, dan wordt dat gevat onder de term "(administratief) bezwaar". Deze in de literatuur ontwikkelde invulling van de begrippen "(administratief) bezwaar" en "administratief beroep" heeft inmiddels haar neerslag gevonden in artt. $1: 5$ en 6:4 Awb.

${ }^{99} \mathrm{Al}$ ontbreekt bij de beoordeling van het wel of niet bezitten van de Nederlandse nationaliteit, uit de aard van de materie, de toets op doelmatigheid.

${ }^{100}$ Leclercq, p. 24; Tonnaer, p. 284; Wendels, Trema 1994, p. 198.
} 
Het zoëven vermelde heeft tot gevolg dat een op grond van artikel 7:1 lid 1 Algemene wet bestuursrecht aanhangig bezwaarschrift de rechtsgang van artikel 17 Rijkswet op het Nederlanderschap niet in de weg staat.

Uit het bovenstaande betoog volgt tevens dat de in de Rijkswet op het Nederlanderschap opgenomen "exclusieve werking van artikel $20 \mathrm{RWN}$ " niet waterdicht is. De beoogde doelstelling van de "exclusieve werking", namelijk dat (ten einde tegenstrijdige beslissingen over de nationaliteit van dezelfde persoon te vermijden) de rechter in de "zelfstandige vaststellingsprocedure" de verzoeker niet-ontvankelijk verklaart indien het Nederlanderschap van de betrokkene al in een andere zaak aan de orde komt, wordt niet onder alle omstandigheden gerealiseerd.

Het is duidelijk dat heel goed sprake kan zijn van een gelijktijdig plaatsvinden van een artikel $17 \mathrm{RWN}$-procedure en een eerder aangevangen andere procedure waarin het kwestieuze Nederlanderschap van de betrokkene eveneens dient te worden beoordeeld. Dit is namelijk het geval wanneer de aanhangige "impliciete vaststellingsprocedure" een administratieve bezwaarschriftprocedure betreft.

Een voorbeeld van een zodanige gelijktijdigheid levert natuurlijk de zaak die de directe aanleiding heeft gevormd tot de in deze paragraaf weergegeven ontwikkeling: de hierboven weergegeven beschikking van de Hoge Raad van 7 april 1989 (NJ 1989, nr. 531) waarin een oordeel wordt gegeven over de status van de Uitkeringsraad. De Uitkeringsraad blijkt dan als uitvoerende instantie dat een eerder besluit van zichzelf opnieuw in ogenschouw dient te nemen door de Hoge Raad niet te worden gekwalificeerd als "administratief beroepsinstantie". ${ }^{101}$ Het nadeel van het gelijktijdig kunnen plaatsvinden van de "zelfstandige" en een "impliciete" vaststellingsprocedure is vanzelfsprekend dat de totstandkoming van twee elkaar tegensprekende nationaliteitsbeslissingen niet ondenkbaar is.

Aangezien doel en functie van bezwaar en van administratief beroep hetzelfde zijn, is het merkwaardig dat de Rijkswet op het Nederlanderschap met de bovenvermelde consequentie onderscheid maakt tussen beide vormen.

\subsubsection{2 "Aanhangige zaak"}

De "exclusieve werking" van artikel 20 Rijkswet op het Nederlanderschap blijft beperkt tot zaken die "aanhangig" zijn in het Koninkrijk bij hetzij "een rechterlijke instantie", hetzij in een "administratief beroep". In hetgeen hieronder volgt, wordt nader ingegaan op twee vragen die deze bepaling oproept. De eerste vraag luidt:

\footnotetext{
${ }^{101}$ Aardig om hier nog te vermelden is dat de Uitkeringsraad, zelf ook in de veronderstelling verkerend bij de behandeling van het bezwaarschrift op te treden als administratief beroepsorgaan, conform art. 20 RWN advies aan de minister van Justitie heeft gevraagd inzake het mogelijk vroegere bezit van het Nederlanderschap van de betrokkene in kwestie. Zie Van den Blink, p. 6 en 29 (i.h.b. noot 12).
} 
vanaf welk moment kan een zaak als aanhangig worden beschouwd bij enig van de instanties waarnaar artikel 20 RWN verwijst? Deze vraag wordt beantwoord in paragraaf 2.2 .2 .2 .1 .

De tweede vraag luidt: welk ogenblik tijdens de artikel $17 \mathrm{RWN}$-procedure geldt voor de rechtbank te Den Haag als peilmoment? Anders geformuleerd luidt deze laatste vraag: welk moment in de "zelfstandige vaststellingsprocedure" zal hiervoor in acht worden genomen door de rechtbank? Deze vraag vindt beantwoording in paragraaf 2.2.2.2.2.

\subsubsection{Op welk moment is een zaak aanhangig bij een artikel $20 \mathrm{RWN}$ - instantie?}

Met betrekking tot de vraag op welk moment een "impliciete vaststellingsprocedu$r e "$ als aanhangig kan worden beschouwd, kan hier allereerst op het onderzoek van Boon en Van der Wal worden gewezen. Dezen besteden, zij het slechts in het kader van de civiele dagvaardingsprocedure, aandacht aan de vraag vanaf welk moment er kan worden gesteld dat een zaak aanhangig is. Voorop stellen zij dat de wet hiervoor geen algemeen geldende regel geeft. De auteurs en jurisprudentie die zij vervolgens aanhalen, geven geen eensluidende visie. Boon en Van der Wal melden dat de meningen van de schrijvers in overwegende mate uiteenlopen tussen het moment van het uitbrengen van de dagvaarding ${ }^{102}$ dan wel het ter rolle inschrijven van de zaak. ${ }^{103}$

Zeer uitgebreid wordt dit onderwerp behandeld door Van Rossem/Cleveringa, ${ }^{104}$ waar onder meer de wel zeer archaïstisch geformuleerde zin "Als een President in kort geding bij een zaak betrokken kan worden zonder inschrijving ter rolle, moet haar aanhangigheid daarzonder gedacht kunnen worden." is opgenomen. Cleveringa trekt uit de gehele verhandeling de slotsom dat er feitelijk niets anders opzit "(.......) dan dat men steeds opnieuw ten aanzien van iederen regel, die met het criterium der aanhangigheid werkt, vaststelt, wat hij er mee bedoelt; (........)."

Over de vraag vanaf welk moment een verzoekschriftprocedure aanhangig is bij een rechterlijke instantie bestaat meer eenduidigheid. Een verzoekschriftprocedure is aanhangig na indiening bij de griffie van het daartoe betreffende verzoekschrift. ${ }^{105}$

\footnotetext{
${ }^{102}$ In ieder geval met betrekking tot een dagvaarding in cassatie sluit de HR aan bij dit standpunt (HR 18.02.1994, NJ 1994, nr. 606, m.nt. HER).

${ }^{103} \mathrm{Boon} / \mathrm{Van}$ der Wal, p. 13.

${ }^{104}$ Van Rossem/Cleveringa, p. 34-39.

${ }^{108} \mathrm{Vgl}$. Hammerstein, NJB 1993, p. 11; Snijders, Ynzonides en Meijer, nr. 788. Zie voor de indiening ter griffie door toezending per post van het verzoekschrift aan het postbusnummer van het Kantongerecht: HR 10.06.1994, NJ 1995, nr. 284, m.nt. HJS.
} 
Voor de zeldzame gevallen waarbij het al dan niet bezit van de Nederlandse nationaliteit een rol zou kunnen spelen in een strafproces, valt te verwijzen naar artikel 258 lid $1 \mathrm{~Sv}$, dat de aanhangigheid van het rechtsgeding laat aanvangen met het moment dat de officier van Justitie de dagvaarding uitbrengt. ${ }^{106}$

Wat betreft de aanvang van administratiefrechtelijke procedures binnen de uitvoerende macht ${ }^{107}$ kan hier worden gewezen op een in 1989 wat terloops gemaakte opmerking van de Hoge Raad: "Wanneer een bezwaarschrift bij de Uitkeringsraad is ingediend (.....) en daarop door die raad nog niet is beslist, is de in dat bezwaarschrift bedoelde zaak bij de Uitkeringsraad aanhangig (....). ${ }^{108}$

2.2.2.2.2 Naar welk moment beoordeelt de rechtbank de aanhangigheid van de zaak?

De tweede vraag die wordt gesteld met betrekking tot de aanhangigheid van een "impliciete vaststellingsprocedure" (die valt onder de werking van artikel 20 RWN $)^{109}$ is de vraag op welk moment in de "zelfstandige vaststellingsprocedure" de rechtbank beoordeelt of er sprake is van aanhangigheid van een zodanige andere procedure.

Met het oog op het feit dat vooral in de administratiefrechtelijke sfeer in "impliciete vaststellingsprocedures" de betrokkene zal worden geconfronteerd met bezwaar- of beroepstermijnen, waarbij het verlopen van deze termijnen gewoonlijk betekent dat het besluit formele rechtskracht heeft gekregen, kan onder omstandigheden de wetenschap van belang zijn wanneer men het best een "zelfstandige vaststellingsprocedure" kan starten, indien men tevens de "impliciete vaststellingsprocedure" tegen de door enig bestuursorgaan genomen beslissing wil volgen.

In de memorie van Antwoord van 5 september 1984 op het Voorlopig Verslag van de Eerste Kamer is aandacht besteed aan de situatie waarin ná indiening van het verzoekschrift uit artikel $17 \mathrm{RWN}$ ó́k een procedure uit artikel $20 \mathrm{RWN}$ wordt gestart. De memorie wijdt de volgende opmerking aan de, alsdan ontstane, gelijktijdigheid: "Het is mogelijk, dat zo'n geding ${ }^{I 0}$ aanhangig wordt gemaakt terwijl een procedure op grond van artikel 17 loopt. Het is aannemelijk dat de uitkomst van die procedure wordt afgewacht, indien de rechter of administratieve beroepsinstantie die in het aanhangige geding moet beslissen, daarvan op de hoogte is. De administratie is voor het vervolg alleen gebonden aan de met toepassing van

\footnotetext{
${ }^{106} \mathrm{Vgl}$. Enschedé, p. 80; F.A.J. Koopmans, p. 11; Minkenhof/Reijntjes, p. 187.

in Administratieve bezwaarschrift- en administratieve beroepschriftprocedures.

ios HR 07.04.1989, NJ 1989, nr. 531.

${ }^{109}$ Administratieve bezwaarprocedures vallen daar niet onder; zie par. 2.2.2.1.

${ }^{110}$ Gedoeld wordt op een geding waarop art. $20 \mathrm{RWN}$ van toepassing is.
} 
artikel 17 gegeven beschikking. "111 Boeles sluit zich aan bij deze passage uit de memorie van Antwoord en is bovendien van mening dat de verzoeker in het kader van artikel 17 RWN ook ontvankelijk moet worden geacht: "als pas na het indienen van het verzoekschrift in een dàn al aanhangige zaak bij een rechterlijke instantie of een administratieve beroepsinstantie, de nationaliteitsvraag opkomt. ${ }^{n 112}$

Hetgeen in de memorie van Antwoord aan de Eerste Kamer is gesteld, pleit voor de stelling dat voor de rechtbank te 's-Gravenhage het moment van indiening van het verzoekschrift ex artikel $17 \mathrm{RWN}$ als peilmoment geldt en dat het nadien starten van een "impliciete vaststellingsprocedure" op de ontvankelijkheid van de verzoeker in de "zelfstandige vaststellingsprocedure" geen invloed heeft.

De bovenstaande stelling zou erop wijzen dat voor de rechtbank te 's-Gravenhage als peilmoment voor de ontvankelijkheid het moment van indiening van het verzoekschrift ex $17 \mathrm{RWN}$ geldt. Immers, het is niet aan te nemen dat in de aan de Eerste Kamer geschetste situatie het de bedoeling is dat op het moment van het nemen van de vaststellingsbeschikking door de Haagse rechtbank de verzoeker nietontvankelijk moet worden verklaard indien de "impliciete vaststellingsprocedure" eveneens nog aanhang is, wellicht omdat, zoals de wetgever zich dat voorstelt, de rechter in de "impliciete vaststellingsprocedure" wacht op de uitslag in de "zelfstandige vaststellingsprocedure".

In de jurisprudentie zijn slechts twee voorbeelden voor handen waarin de gelijktijdigheid van "impliciete vaststellingsproceure" en "zelfstandige vaststellingsprocedure" een rol speelt. Beide uitspraken stammen uit de aanvangsperiode van de procedure op grond van artikel $17 \mathrm{RWN}$. In beide gevallen is sprake van een eerder aanhangig gemaakte "impliciete vaststellingsprocedure". In het ene geval is de verzoekster tijdens de "zelfstandige vaststellingsprocedure" overgegaan tot intrekking van de eerder aanhangig gemaakte "impliciete vaststellingsprocedu$r e^{n 113}$ en doet de rechtbank uitspraak in de zaak. ${ }^{114}$ In het andere geval zet de verzoekster de eerder aanhangig gemaakte "impliciete vaststellingsprocedure"

\footnotetext{
I" Bijl. I. 83-84, 16946, nr. 216a, p. 12. De suggestie wordt derhalve gedaan dat in de "impliciete vaststellingsprocedure" zal worden gewacht op cen uitkomst in de "zelfstandige vaststellingsprocedure". 112 Boeles, p. 212.

$113 \mathrm{Rb}$. 's-Gravenhage 27.04.1988, rkstnr. 87.5416, waarbij in de conclusie van het OM (d.d. 24.07.1987) wordt vermeld: "Voorts heeft \{de raadsman\} ter terechtzitting een akte genomen, waarin hij namens verzoekster verklaart dat de zgn. "bodemprocedure" -ingesteld tegen intrekking van verzoeksters Nederlandse paspoort bij de Afdeling Rechtspraak van de Raad van State is "ingetrokken", aangezien verzoekster de voorkeur geeft aan een oordeel van Uw rechtbank. " Vgl. Van den Blink, p. 24, die "forum-shopping" voorziet.

114 Dit betekent tevens dat een "impliciete vaststellingsprocedure" die aanhangig was op het moment van indiening van het verzoekschrift ex art. 17 RWN, en die is beěindigd met een uitspraak voordat de rechter in de art. 17 RWN-procedure een uitspraak heeft gedaan geen beletsel voor de ontvankelijkheid vormt.
} 
daarentegen voort en deze procedure is nog aanhangig op het moment dat de rechtbank in de "zelfstandige vaststellingsprocedure" uitspraak doet. De rechtbank overweegt dienaangaande: "Verzoekster heeft de rechtbank bij brief van 30 maart $1988^{1 / 5}$ laten weten haar bezwaarschrift tegen de beschikking van de Uitkeringsraad niet te zullen intrekken. ${ }^{m 16}$ Deze verzoekster werd niet-ontvankelijk in haar verzoek verklaard.

Anders dan de eerder vermelde gevolgtrekking uit het citaat uit de memorie van Antwoord van 5 september 1984 geven de hierboven weergegeven twee uitspraken geen aanleiding om aan te nemen dat het peilmoment voor de ontvankelijkheid naar het inzicht van de rechtbank ligt op het moment dat het verzoekschrift ex 17 RWN wordt ingediend. Zou dat namelijk wel zo zijn, dan had in beide bovenstaande voorbeelden niet-ontvankelijkheid moeten volgen. Eerder lijkt het dat de rechtbank het moment aanhoudt waarop de vaststellingsbeschikking wordt gegeven: op dat moment mag geen "impliciete vaststellingsprocedure" aanhangig zijn.

Deze handelwijze van de rechtbank lijkt in overeenstemming te zijn met hetgeen de Hoge Raad heeft gesteld in HR 7 april 1989 (NJ 1989, nr. 531) ${ }^{117}$ inzake het aanhangig zijn van een "impliciete vaststellingsprocedure", nl. dat de aanhangigheid, eenmaal aangevangen, voortduurt zolang door de betrokken instantie "nog niet is beslist".

Uit dit alles kan mijns inziens met betrekking tot de ontvankelijkheid in de "zelfstandige vaststellingsprocedure" niet anders dan een evidente tegenstrijdigheid worden geconstateerd tussen enerzijds hetgeen volgt uit de memorie van Antwoord van 5 september 1984 en anderzijds hetgeen meer strookt met de rechtspraak.

Ter afsluiting van deze paragraaf zou ik met betrekking tot de reeds eerder aangehaalde uitspraak in de memorie van Antwoord aan de Eerste Kamer nog het volgende willen opmerken. Aan de bewuste uitspraak kan de conclusie worden verbonden dat het door de wetgever niet geheel uitgesloten wordt geacht dat in beide vaststellingsprocedures, de "zelfstandige" en de "impliciete", een beslissing wordt genomen. Het is immers, volgens de memorie, slechts "aannemelijk" dat de rechter (van artikel $20 \mathrm{RWN}$ ) dan wel het bestuursorgaan oordelend in administra-

\footnotetext{
${ }^{115}$ Het verzoekschrift in deze zaak is op 15.12.1987 bij de rechtbank ingediend. Verzoekster had haar bezwaarschrift bij de Uitkeringsraad tegen de weigering een uitkering als vervolgingsslachtoffer te verlenen, ingediend op 15.01.1987. De mondelinge behandeling door de rechtbank is gehouden op 16.03.1988 en de beschikking wordt op 29.06.1988 gegeven. De rechtbank accepteert derhalve op een moment na de mondelinge behandeling aanvullende gegevens van de kant van de verzoekster.

${ }^{116}$ Rb. 's-Gravenhage 29.06.1988, rkstnr. 87.6089 (=HR 07.04.1989, NJ 1989, nr. 531).

117 Zie par. 2.2.2.1 (i.h.b. voetnoot 40).
} 
tief beroep de uitkomst van de artikel 17 RWN-procedure zal afwachten. ${ }^{118}$ Voor het geval dat in beide vaststellingsprocedures een uitspraak wordt gedaan, is het vanzelfsprekend niet uitgesloten dat, wat betreft het oordeel over het Nederlanderschap van de betrokkene, in de beide procedures twee elkaar tegensprekende beslissingen tot stand komen.

De ten behoeve van een dergelijke situatie, waarin het dus gaat om ten aanzien van één betrokkene uiteenlopende nationaliteitsvaststellingen, voorziene remedie is, zo leest men tevens in de memorie van Antwoord, de volgende: "De administratie is voor het vervolg alleen gebonden aan de met toepassing van artikel 17 gegeven beschikking. "119

Met betrekking tot het op deze wijze kortsluiten van tegenstrijdige beslissingen, kan naar mijn mening worden gesteld dat het geen fraaie bepaling is. Voorzover de ene uitspraak afkomstig is van een bestuursorgaan oordelend in administratief beroep (art. 20 lid 2 RWN) stuit de voorgestelde oplossing niet op bezwaar; de administratie dient zich, zoals in het citaat wordt gesteld, aan de uitspraak van de rechtbank te Den Haag te houden. De administratie laat de binnen de administratie genomen tegendraadse uitspraak terzijde.

In het geval van toepassing van artikel 20 lid 1 RWN is de gegeven remedie echter niet fraai. In die situatie is de uitspraak afkomstig van een met rechtspraak belaste instantie. Deze rechterlijke uitspraak dient vervolgens terzijde te worden gelegd door de administratie. Gaat het om een uitspraak van een bestuursrechter, dan zal in beginsel de administratie een nieuw besluit moeten nemen. Daarin houdt de administratie zich derhalve aan de uitkomst in de "zelfstandige vaststellingsprocedure". Het kan echter ook voorkomen dat de bestuursrechter zelf heeft afgedaan. Ook dan legt de administratie de uitspraak naast zich neer. Weliswaar gebeurt dit om een andere rechterlijke uitspraak wel uit te voeren, maar vanuit rechtsstaatelijk oogpunt is het niet fraai te constateren dat de administratie een rechterlijke uitspraak naast zich neer legt. ${ }^{120} \mathrm{Er}$ is onder omstandigheden derhalve sprake van een terzijde gestelde rechterlijke beslissing.

\footnotetext{
${ }^{118}$ Waarbij ik nogmaals benadruk dat m.i. slechts kan worden gewacht op een niet-ontvankelijkverklaring van de verzoeker wegens een elders aanhangige zaak. Wellicht een reden om de rechter oordelend op grond van artikel 17 RWN maar in het ongewisse te laten van cen aanhangige "impliciete vaststellingsprocedure" en zodoende twee ijzers in het vuur te hebben.

119 Bijl. I. 83-84, 16946, nr. 216a, p. 12.

$120 \mathrm{Vgl}$. Ten Berge/Tak, p. 239.
} 


\subsubsection{Onmiddellijk belang bij de vaststelling}

\subsubsection{Algemene beschouwingen}

Het volgend vereiste voor ontvankelijkheid dat specifiek geldt voor de "zelfstandige vaststellingsprocedure" is dat bij de verzoeker "onmiddellijk belang" met betrekking tot de vaststelling aanwezig is. Dit vereiste geeft Jessurun d'Oliveira reeds in 1983 aanleiding tot de vraag waarom in de (toen nog ontwerp) wettekst "onmiddellijk" is opgenomen, terwijl toelichting noch memorie van Antwoord dit begrip preciseren. ${ }^{121}$ De Groot wijst in de losbladige uitgave Personen en Familierecht eveneens op de onduidelijkheid inzake de inhoudelijke betekenis van "onmiddellijk belang ". ${ }^{122}$

De memorie van Antwoord stipt nog wel aan dat het vereiste van "onmiddellijk belang" ook geldt voor de verzoeker die een verzoek doet betreffende de nationaliteitsvaststelling van een overledene, maar laat ook daarbij uitleg omtrent de invulling van het begrip achterwege. ${ }^{123}$

Naar aanleiding van het bovenstaande rijst de vraag of wellicht nu, geruime tijd na de inwerkingtreding van artikel 17 Rijkswet op het Nederlanderschap, aan de hand van de gevormde jurisprudentie kan worden bepaald welke invulling de woorden "onmiddellijk belang" hebben gekregen.

Dienaangaande moet echter worden geconstateerd dat de beschikkingen van de rechtbank geen concrete aanwijzingen geven. Het blijkt dat in de vierenvijftig voor dit onderzoek bestudeerde beschikkingen krachtens artikel 17 RWN de rechtbank het vereiste nauwelijks vermeldt en zeker niet expliceert. Zeker zal de rechtbank het vereiste op indirekte wijze hebben getoetst, maar uit zich derhalve niet over de hiervoor gehanteerde criteria.

In slechts twee van de vierenvijftig beschikkingen vindt het begrip vermelding. Daarbij luidt in het ene geval de desbetreffende rechtsoverweging: "Verzoeker, (......), heeft een onmiddellijk belang bij zijn verzoek, aangezien hij door de Staat als vreemdeling wordt aangemerkt. Dit leidt de rechtbank af uit het feit dat verzoeker, (.....), inmiddels uit Nederland is verwijderd. ${ }^{124}$ In het andere geval stelt de rechtbank: "Verzoeker, (......), heeft een onmiddellijk belang bij zijn verzoek, aangezien hij door de Staat als vreemdeling wordt aangemerkt en als zodanig met uitzetting wordt bedreigd. ${ }^{n 125}$

\footnotetext{
121 Jessurun d'Oliveira, NJB 1983, p. 1309.

12 De Groot, losbl. uitgave Personen- en Familierecht, art. 17 RWN, aant. 1.

${ }^{123}$ Bijl. II. 82-83, 16947, nr. 7, p. 33.

${ }^{124}$ Rb. 's-Gravenhage 24.06.1987, rkstnr. 86.2266 (= HR 04.03.1988, NJ 1989, nr. 875, m.nt. EAA).

${ }^{125} \mathrm{Rb}$. 's-Gravenhage 24.06.1987, rkstnr. 87.5002.
} 
In cassatie is het begrip tot nu toe slechts éénmaal aan de orde gekomen. ${ }^{126} \mathrm{De}$ Hoge Raad spreekt in deze ene beschikking wel over "onmiddellijk belang ", maar plaats daarbij naar mijn visie, zoals ik in paragraaf $2.2 .4 \mathrm{zal}$ proberen duidelijk te maken, het begrip in een verkeerde context. In de andere beschikkingen in cassatie die aan dit onderzoek ten grondslag liggen, vindt het begrip "onmiddellijk belang" geen vermelding.

\subsubsection{Eigen visie op "onmiddellijk belang"}

Bij het aanhangig maken van een artikel $17 \mathrm{RWN}$-procedure zal veelal op de achtergrond een bepaald geschil meespelen. Geheel zonder redenen stapt men niet snel naar de rechter. Zou men dit wel doen, dan volgt zonder twijfel niet-ontvankelijkverklaring van de verzoeker wegens gebrek aan belang bij de vaststelling. Voor de "zelfstandige vaststellingsprocedure" geldt immers, zoals dat voor ieder (burgerlijk en bestuursrechtelijk) geding geldt, de zegswijze "geen belang, geen actie"; ook wel aangeduid met "point d'intérêt, point d'action". Sinds 1 januari 1992 is met de inwerkingtreding van artikel 3:303 BW dit principe in de wet opgenomen, ${ }^{127}$ maar reeds lang voor die tijd is het in brede kring aanvaard als algemene regel van procesrecht. ${ }^{128}$

$\mathrm{Nu}$ is belang in het recht een vaag en daardoor lastig begrip. ${ }^{129}$ "Point d'intérêt, point d'action" verwijst naar en heeft betrekking op de verandering in juridische zin die door de rechterlijke uitspraak zal worden teweeggebracht in de (juridische) positie van de eiser of de verzoeker. Indien de rechterlijke uitspraak in de juridische wereld van de eiser of de verzoeker geen baat of verandering brengt, ontbreekt het belang bij de rechtsvordering. ${ }^{130}$ Het adagium "point d'intérêt, point d'action" duidt derhalve niet op de directe, feitelijke gebeurtenis ten gevolge waarvan het noodzakelijk is gebleken de vraag naar de nationaliteit op te helderen;

\footnotetext{
${ }^{126}$ HR 04.03.1988, NJ 1989, nr. 626, m.nt. GRdG. Zie par, 2.2.4.2.2.

127 Snijders, p. 13. Vgl. Jessurun d'Oliveira, p. 292.

$128 \mathrm{Vgl}$. Van Baars, p. 92-101; Meijknecht, p. 36; Parser, p. 282-287; Polenaar, p. 234; Star Busmann, p. 116; Vriesendorp, p. 191; de annotaties van Veegens onder HR 12.06.1953, NJ 1954, nr. I en HR 30.01.1959, NJ 1959, nr. 548; Vrij, WPNR 1927, nr. 2991, p. 271. Zo geldt het eveneens in het administratief proces: Ten Berge/Tak, p. 73; Van Wijmen, p. 117 en 141.

$129 \mathrm{Vgl}$. Van Baars, p. 42, 43 en 156; Cleveringa, RMTh 1964, p. 222-227: "(....) blijkt dan al enigszins, dat "belang" en "belang" nog zeer wel twee kunnen zijn." (p. 223); Jessurun d'Oliveira, p. 273. Vgl. Ten Berge/Tak, p. 63, 68-74; Van Wijmen spreekt over "het dubbelzijdig karakter van het begrip belang", p. 117 en 135.

130 In HR 15.12.1939, NJ 1940, nr. 206, m.nt. EMM, hét standaard-arrest over deze materie formuleert de Hoge Raad als volgt: "dat een belang bij de verkrijging van dusdanig gewijsde echter niet aanwezig is, indien een vonnis van de rechter niet vermag baat te brengen ten opzichte van de wederpartij: (.....). "Van Dijk, p. 15, omschrijft dit op de volgende wijze: "zonder dat het doel van het proces gerealiseerd kan worden." Zie tevens par. 2.2.4.1.
} 
alsdan betreft het meer de aanleiding tot de procedure. Ook wordt ernee niet gedoeld op het bij die feitelijke gebeurtenis betrokken recht ${ }^{131}$ of het belang ${ }^{132}$ dat daarbij aanwezig is. Het dan aan de orde zijnde "belang" wordt in de iteratuur omschreven als het "materieel belang". ${ }^{133}$

Het voorgaande kan kort in andere woorden ook als volgt worden geformuleerd: "point d'intérêt, point d'action" betreft de eis tot het hebben van "pricessueel belang" bij de vordering en dat is als zodanig altijd, ook zonder vermeldng in de wet, vereist. ${ }^{134}$ Als "belang" duidt op "processueel belang", duidt mijn inziens "onmiddellijk belang" op een verdergaand vereiste dat, met betrekking tot de actie tot nationaliteitsvaststelling nóg een specifieke eis stelt aan de verzoeker. Ik ga ervan uit dat, willen de woorden "onmiddellijk belang" in artikel $17 \mathrm{RWN}$ enige zin hebben, zij niet naar het "processueel belang" van de verzoeker verwizen. De wetgever had zich dan kunnen beperken tot een bepaling waarin alleen "bilang" in stond en zelfs dat had achterwege kunnen blijven. Het opnemen van "onmddellijk" voegt naar mijn mening wel degelijk iets toe.

Bij een eerste lezing van de twee op pagina 36 weergegeven overweginget van de rechtbank IJKt het or met het begrip "onmiddellijk belang" het benodigde "processueel belang" wordt bedoeld. Maar ik constateer evenwel dat nog een andere lezing denkbaar is. Wellicht wordt door de rechtbank slechts geconstateerd dat de verzoeker en de persoon op wie het verzoek betrekking heeft identiek zijn. Het is, mijns inziens, niet geheel ondenkbaar dat de woorden "onmiddellijk belang" betrekking hebben op de eis dat de identiteit van de verzoeker en van degene van wie de nationaliteit moet worden vastgesteld dezelfde is. De bijkomende, specifieke eis die "onmiddellijk belang" alsdan inhoudt, betreft een ten opzichte van de persoon van de verzoeker geldende kwalitatieve eis, inhoudende dat de verzoeker en de te onderzoeken persoon identiek dienen te zijn. Van deze veronderstelling uitgaande is, naar mijn opvatting "onmiddellijk belang" een vereiste waardoor

${ }^{131}$ Bijv, het kiesrecht, het erfrecht of het recht op verblijf in Nederland.

132 Bijv, het (financiēle) belang om de erfenis via Nederlands erfrecht af te handelen.

${ }^{13}$ In zijn proefschrift onderscheidt Van Baars "materieel belang" en "processueel belang" (p. 44). Het matericel belang betreft de (gewenste) feitelijke, materiēle wijziging in een situatie (p. 44), ofte wel "het verschil dat voor een bepaald persoon kan bestaan tussen twee situaties" (p. 43). Daarnaast staat, als gezegd, het "processueel belang". Dit is het belang bij een rechtsmiddel om het materiēle belang te kunnen behartigen (p. 128); bijv, dat men een rechterlijke uitspraak, inclusief het bijbehorende gezag van gewijsde, nodig heeft om de materiēle wijziging te kunnen effectueren (vgl. p. 134 en 146). Van Dijk, p. 19, spreekt over enerzijds "procesbelang" als "het belang dat met een proces wordt beoogd" en anderzijds over "rechtsbelang": "het belang dat bij het proces in het geding wordt gebracht"; Van Wijmen, p. 132 en 135, stelt kort en bondig: "wat men met de vordering beoogt, is iets anders dan waarop zij berust".

134 Vgl. Van Baars, p. 128, 134 en 146; Ten Berge/Tak, p. 73; Van Wijmen, p. 126 en 142. Van Dijk, p. 15-20, spreekt in dit kader over "procesbelang". 
wordt gewaarborgd dat slechts de rechtstreeks bij het Nederlanderschap betrokkene het verzoek kan indienen. ${ }^{135}$

Met het oog op de bovenstaand door mij voorgestane interpretatie van de woorden "onmiddellijk belang" kan worden gewezen op artikel 3:302 BW, dat de weg naar een declaratoire uitspraak openstelt voor "een bij een bij een rechtsverhouding onmiddellijk betrokken persoon". De beschikking die de rechtbank op grond van artikel $17 \mathrm{RWN}$ geeft, is zuiver declaratoir van aard. ${ }^{136}$ Zeer interessant is in dit verband de toelichting die Meijers heeft gegeven over het ontwerp van dit artikel en het daarop volgende artikel 3:303 BW, het artikel waarin de regel "point d'intérêt, point d'action" is gecodificeerd. ${ }^{137}$ Meijers schrijft bij het ontwerp-artikel 3.11.7. (=3:302 BW): "Het is niet in het algemeen te zeggen wanneer men met 'bij een rechtsverhouding onmiddellijk betrokken personen' te maken heeft. Er zij intussen op gewezen, dat de in dit artikel bedoelde categorie van personen niet samenvalt met de in het volgend artikel bedoelde personen, die belang bij de rechtsvordering moeten hebben. Iemand die belang heeft bij de rechtsvordering is niet steeds een onmiddellijk daarbij betrokken persoon in de zin van het onderhavi-

\begin{abstract}
${ }^{135} \mathrm{Bij}$ mijn weten wordt het begrip "onmiddellijk belang " buiten het terrein van het Nederlanderschap in de overige wetgeving en literatuur nauwelijks gehanteerd. Ik ben het énmaal tegengekomen, via een opmerking bij Zuidema, p. 127, in een oude conclusie van P.-G. Noyon bij HR 10.11.1910, W 9085, waarin door de P.-G. "onmiddellijk belang" wordt gereserveerd voor de personen die rechtstreeks bij de uitspraak zijn betrokken en waartegenover worden gesteld de personen "die slechts zijdelingsch en verwijderd belang hebben".
\end{abstract}

Artikel $839 \mathrm{Rv}$ kent de categorie "onmiddellijk belanghebbende personen", dit ook weer ter afbakening van een andere categorie van belanghebbenden, namelijk: "hunne erfgenamen of regt verkrijgenden". In een over dit artikel gewezen arrest stelt het Hof in Den Haag: "zoodat het onmiddellijk belang bestaat in eene onmiddellijke rechtsbetrekking tot de acte". In het daarop volgend cassatieberoep sluit de Hoge Raad daarbij aan: HR 20.06.1913, NJ 1913, p. 790. Gevolg hiervan is dat de losbl. uitgave BRv. opmerkt bij art. $839 \mathrm{Rv}$, aant. 1: "De onmiddellijk belanghebbenden zijn dus zij, die de akte hebben doen opmaken." Vgl. tevens hierover Cleveringa, RMTh 1964, p. 225 (i.h.b. voetnoot 5). Ook de artt. 42 en 43 Wet op het Notarisambt onderscheiden de "onmiddellijk belanghebbende" bij cen notariële akte van "deszelfs erfgenamen of regtverkrijgenden". Blijkens HR 11.03.1994, NJ 1995, nr. 3, m.nt. HJS, kiest de HR inmiddels voor een ruimere uitleg en is in het kader van art. 42 Wet o.h. Notarisambt de onmiddellijk belanghebbende evenwel "in elk geval niet beperkt tot de partijen bij de akte zelf". (Maar opgemerkt moet worden dat art. 42 niet betreft een declaratoire rechterlijke uitspraak). Artt. 3:55 en 3:58 BW kennen eveneens "onmiddellijk belanghebbenden"; art. 1:69 lid 1 sub c BW: kent personen die daarbij een "onmiddellijk rechtsbelang" hebben een bepaald vorderingsrecht toe.

${ }_{136} \mathrm{Vgl}$. De Groot, losbl. uitgave Personen- en Familierecht, art. $19 \mathrm{RWN}$, aant. 1. Zie Asser/Anema/Verdam, p. 292 , waar de auteurs vermelden dat een statusproces leidt tot een declaratoire uitspraak; cf. Heemskerk, p. 13.

137 Beide artikelen zijn geplaatst in Boek $3 \mathrm{BW}$, dat "vermogensrecht in het algemeen" is getiteld. De toepassing van beide artikelen op niet-vermogensrechtelijke rechtsvorderingen wordt mogelijk gemaakt door de schakelbepaling in art. 3:326 BW. Vgl. losbl. uitgave BRv., Boek I, titel 1, alg. gedeelte, aant. 3. over misbruik van procesrecht, waarin de losbladige het beginsel van "point d'intérêt, point d'action" via art. 3:326 BW van overeenkomstige toepassing verklaart in het personen- en familierecht (een rechtsgebied waarbinnen, zoals bekend, veel verzoekschriftprocedures voorkomen). 
ge artikel; omgekeerd kan een onmiddellijk bij de rechtsvordering betrokken persoon geen belang bij het instellen van de actie hebben. In dat laatste geval zal de actie hem niet toekomen; het door het volgende artikel gestelde vereiste van een voldoende belang voor het hebben van een rechtsvordering geldt uiteraard hier ook, ${ }^{m 138}$

Meijers maakt in zijn toelichting bij deze twee artikelen een duidelijk onderscheid tussen twee verschillende belangen die in het spel kunnen zijn. Het zijn naar mijn idee deze twee onderscheidenlijke belangen die aan de orde zijn in de "zelfstandige vaststellingprocedure" van het Nederlanderschap. Het gaat hierbij enerzijds om "onmiddellijk belang", dat naar een bepaalde kwaliteit van de verzoeker verwijst en anderzijds om "point d'intérêt, point d'action". ${ }^{139}$

Een recente beslissing van de Hoge Raad met betrekking tot artikel 3:302 BW sluit hierop aan. In de desbetreffende uitspraak gaat het om een vordering tot een verklaring voor recht inhoudende dat de toekenning in 1950 vanwege de Staat van een weduwe-pensioen aan de weduwe Rost van Tonningen, wegens het enkele jaren durende Tweede Kamerlidmaatschap van haar overleden echtgenoot, "in strijd met en met schending van het recht" heeft plaatsgevonden. De vordering is tegen de Staat ingesteld door enkele organisaties van oud-verzetsstrijders. De Hoge Raad overweegt met betrekking tot de ontvankelijkheid in feitelijke instantie van de eisers: "Een verklaring voor recht kan slechts worden uitgesproken op vordering van één der bij een bepaalde rechtsverhouding onmiddellijk betrokkenen en kan enkel dienen tot het op jegens de andere betrokkenen bindende wijze vaststellen van haar bestaan of preciseren van haar inhoud. ${ }^{n 140}$

Een andere mogelijkheid van de term "onmiddellijk belang", namelijk dat het een bepaalde mate van tijdsdruk tot uitdrukking wil brengen, lijkt mij niet aannemelijk. Uit het weinige dat de analyse van de beschikkingen hieromtrent wel duidelijk makkt, blijkt dat de onmiddellijkheid met betrekking tot de vaststelling niet als "dringend" of "ogenblikkelijk" wordt geïnterpreteerd.

Als gezegd, naar mijn inzicht verwijst het "onmiddellijk belang" dat door artikel 17 RWN bij de nationaliteitsvaststelling wordt geëist niet naar het "processuele belang" van de verzoeker. Dit is echter wel een belang dat eveneens aanwezig dient te zijn. ${ }^{141} \mathrm{Er}$ wordt daarentegen, mijns inziens, verwezen naar een bepaalde

\footnotetext{
${ }^{138}$ E.M. Meijers, toelichting I, p. 301.
}

${ }^{139}$ Eenzelfde onderscheid is te vinden in het proefschrift van Van Dijk als hij, in het kader van de ontvankelijkheid van de verzoeker, spreekt van "het vereiste van een bepaalde hoedanigheid" (p. 13 e.v.) en van "het vereiste van een procesbelang" (p. 15 e.v.).

140 HR 22.01.1993, AB 1993, nr. 198, m.nt. FHvdB; NJ 1994, nr. 734, m.nt. CJHB. Vervolgens concludeert de HR: "De stichting c.s. zijn niet onmiddellijk betrokkenen bij de rechtsverhouding waarop de door hen gevorderde verklaring voor recht betrekking heeft, de rechtsverhouding tussen de Staat en de weduwe Rost van Tonningen."

${ }^{141}$ Hierop wordt ingegaan in par. 2.2.4. 
kwalificatie, een hoedanigheid, waaraan de indiener van het verzoekschrift moet voldoen. ${ }^{142}$ Deze kwalitatieve eis komt volgens mij erop neer dat van de verzoeker wordt geëist dat hij, nationaliteitsrechtelijk gezien, de rechtstreeks betrokkene is. Op deze manier sluit de eis tot "onmiddellijk belang" de eventualiteit uit dat een derde om vaststelling van het wel of niet bezit van het Nederlanderschap van iemand anders kan verzoeken. Derden-belanghebbenden kunnen immers onder omstandigheden een (processueel) belang hebben bij de wel of niet vaststelling van het Nederlanderschap van een ander. ${ }^{143}$ Jessurun d'Oliveira heeft voorgesteld de "onmiddellijkheidseis" te laten vervallen. ${ }^{144}$ Mijns inziens verdient dit voorstel geen bijval, aangezien het tot gevolg zou hebben dat een ruimere kring van rechtssubjecten ontvankelijk in de "zelfstandige vaststellingsprocedure" zou zijn dan mét hantering van de eis tot onmiddellijk belang .

Het bovenstaande in een notedop weergegeven: het vereiste van "onmiddellijk belang " regardeert in mijn visie het antwoord op de vraag wie in de procedure ter vaststelling van het Nederlanderschap het "ius agendi"145 toekomt. En ten einde

\begin{abstract}
${ }^{142} \mathrm{Vgl}$. Boekman, p. 103, die aangeeft hoe van oudsher het antwoord op de vraag wie gerechtigd is tot het aanleggen van een procedure per verzoekschriftprocedure, aan de hand van steeds onderling afwijkende criteria, verschillend is ingevuld. Het oordeel of iemand een verzoekschrift kon indienen heeft aanleiding heeft gegeven tot de vorming van de nodige jurisprudentie.

${ }^{143} \mathrm{Vgl}$. artt. $358 \mathrm{~b} \mathrm{WvK}$ en $443 \mathrm{WvK}$, of denk aan de werkgever van een werknemer wiens nationaliteit onzeker is. Ook een (huwelijks)partner kan in het kader van echtscheiding of vreemdelingenrechtelijke bepalingen belang hebben bij de vaststelling van de nationaliteit van zijn of haar partner.

Rb. 's-Gravenhage 08.04.1947, NJ 1948, nr. 34 laat zien hoe eiser W.F. Meyer de rechtbank tracht te bewegen tot de uitspraak dat A.E. Meyer het Nederlanderschap heeft verloren ten gevolge van het zonder Koninklijk verlof treden in vreemde krijgsdienst van de echtgenoot van gedaagde, H.V.J.K.. Gelukkig voor de gedaagde neemt de rechtbank een nationaliteitsrechtelijk onjuiste beslissing en oordeelt dat zij haar Nederlanderschap heeft behouden.
\end{abstract}

In Hof 's-Gravenhage 18.03.1954, NJ 1954, nr. 575, (zie ook Brouwer, p. 165) een procedure aangaande betaling van levensonderhoud van een zoon ten behoeve van zijn moeder, heeft één van de grieven van de zoon in hoger beroep de strekking dat het Hof de toetsing door de rechtbank inzake het bezit van de Nederlandse nationaliteit door de moeder opnieuw beoordeelt (haar nationaliteit is van belang voor de vraag welk recht i.c. van toepassing zou zijn en de rechtbank is uitgegaan van het Nederlanderschap van de moeder). Het Hof verwerpt daarbij de desbetreffende grief van de zoon. Deze heeft tevens gesteld zelf alleen de Britse nationaliteit te bezitten. Hoogst waarschijnlijk tot verbazing van de zoon stelt het Hof en passant voor hem vast dat hij tevens de Indonesische nationaliteit heeft. Vgl. tevens HR 05.11.1952, NJ 1952, nr. 782 (eiser, die zijn Nederlanderschap heeft verloren, procedeert om zijn vrouw op de kiezerslijst geplaatst te zien. Als gevolg van zijn nationaliteitsverlies heeft ook zijn vrouw haar Nederlanderschap verloren). Hof 's-Gravenhage 09.12.1959, NJ 1960, nr. 352 (competentic rechter bij echtscheidingsprocedure).

De Staat kan eveneens belang hebben bij de vaststelling van iemands Nederlanderschap, maar mist dan toch het "onmiddellijk belang".

is Jessurun d'Oliveira, NJB 1983, p. 1309.

145 Door Heemskerk in zijn oratie, p. 18, omschreven als "procesrechtelijk vorderingsrecht". Star Busmann, p. 112, spreekt over "de bevoegdheid om dat recht geldend te maken door middel van een uitspraak van de rechter, het recht om te vorderen (vorderingsrecht), het jus agendi;"; Storme 
te bepalen of een verzoeker inderdaad "onmiddellijk belang" heeft, dient centraal te worden gesteld de relatie die de verzoeker heeft met degene wiens nationaliteit wordt verzocht vast te stellen.

In de onderstaande twee subparagrafen wordt besproken hoe in mijn visie de relatie er uit dient te zien tussen de verzoeker en degene van wie de nationaliteit wordt verzocht vast te stellen.

\subsection{Nationaliteitsvaststelling van personen die in leven zijn}

In het geval dat de vaststelling van het Nederlanderschap wordt verzocht betreffende een in leven zijnde persoon, is, zoals hierboven reeds is uitgelegd, in mijn visie het "onmiddellijk belang" van artikel 17 RWN gelegen in het feit dat slechts de persoon te wiens aanzien de nationaliteitsvaststelling wordt verzocht, het verzoek tot vaststelling kan doen. ${ }^{146}$ Als kleine uitzondering op deze regel, maar omdat zij voortvloeit uit de vereisten van het burgerlijk procesrecht kan dit niet worden beschouwd als een echte uitzondering, kan hier worden genoemd dat wettelijke vertegenwoordigers in dezen dienen op te treden voor de door hen te vertegenwoordigen. ${ }^{147}$

Derden-belanghebbenden zullen, naar mijn mening, de procedure derhalve niet aanhangig kunnen maken. ${ }^{148}$ Een andere mening hierover is verkondigd door Boeles, die de voorkeur heeft uitgesproken voor een interpretatie van artikel 17 RWN waarin, ook in het geval dat de vaststelling betrekking heeft op een nog in leven zijnde persoon, het recht de vaststellingsactie te starten niet beperkt blijft tot degene die het object van de vaststelling is. ${ }^{149}$ Wat betreft een mogelijke rechtsingang op grond van artikel $17 \mathrm{RWN}$ ten behoeve van de Staat is zulks reeds expliciet ontkend door Van den Blink. ${ }^{150}$ In de regel zal de Staat ook geen be-

$145 \rightarrow$

omschrijft "ius agendi" afwisselend als "de processuele rechten om te vorderen, de rechten op gedingvoering en gewijsde" (p. 258) en "recht om een eis in te stellen" (p. 260). Vgl. Beukers, p. 108; Brenninkmeijer, p. 8.

$146 \mathrm{Vgl}$. Van den Blink, p. 17.

147 Zoals is gebeurd in HR 13.01.1989, NJ 1990, nr. 266, m.nt. GRdG (= Rb. 's-Gravenhage 10.02.1988, rkstnr. 87.5813); HR 13.01.1989, NJ 1990, nr. 267, m.nt. GRdG (= Rb. 's-Gravenhage 10.02.1988, rkstnr. 87.5801); Rb. 's-Gravenhage 20.07.1988, rkstnr. 87.6047; Rb. 's-Gravenhage 20.07.1988 rkstnr. 88.5027. Illustratief in dit verband is HR 31.01.1992, NJ 1993, nr. 261, m.nt. GRdG, waarin de wettelijke vertegenwoordiger van een 17-jarige het verzoekschrift bij de rechtbank aanbrengt. De mondelinge behandeling vindt plaats als de jongen 18 jaar is. Met inachtneming van artikel 1 sub b RWN treedt in de verdere procedure de jongen mede als verzoeker op.

148 Zie tevens het einde van par. 2.2.3.3.

149 Boeles, p. 212.

150 Van den Blink, p. 13 en 17. Idem De Groot, losbl. uitgave Personen- en Familierecht, art. 19 RWN, aant. 1. Vgl. voetnoot 143. 
hoefte hebben aan een zodanig actierecht. Bezit iemand niet de Nederlandse nationaliteit dan zal een overheidsorgaan de betrokkene als niet-Nederlander behandelen. De uitzondering op de regel kan zich voordoen indien de betrokkene in het bezit is van een rechterlijke beschikking waarin zijn bezit van het Nederlanderschap is vastgesteld (in een "zelfstandige vaststellingsprocedure)". Mocht twijfel bestaan aan de juistheid van die vaststelling, dan zal de Staat naar mogelijkheden zoeken om de vaststellingsbeschikking aan te kunnen tasten. In paragraaf 2.7.4 wordt in dit kader de mogelijkheid tot herziening van de vaststellingsbeschikking aan de orde gesteld. In paragraaf 2.7.4 wordt geconcludeerd dat de mogelijkheid tot herziening van de beschikking op verzoek van de Staat onder bepaalde omstandigheden, maar niet alle, wenselijk is. Dit houdt in dat herziening van een vaststellingsbeschikking niet altijd mogelijk zou zijn. In een geval waarin geen herziening mogelijk zou zijn, is de Staat gehouden aan een vaststellingsbeschikking waarvan de materiële juistheid aan twijfel is onderhevig. Op zo'n moment kan de vraag opkomen of het aanhangig maken door de Staat van een vaststellingsactie (losstaand van de reeds bestaande vaststellingsbeschikking) tot de mogelijkheid behoort. Met het oog op het vereiste van "onmiddellijk belang" bij de vaststelling moet, mijns inziens, die vraag ontkennend worden beantwoord.

\subsection{Nationaliteitsvaststelling van een overleden persoon}

Het tweede lid van artikel 17 RWN behelst de mogelijkheid een verzoek in te dienen tot vaststelling of niet-vaststelling van de Nederlandse nationaliteit van een overleden persoon. In een zodanig geval volgt uit de aard van de zaak dat het verzoek niet door de persoon die het object van de vaststelling is, kán worden gedaan.

Zoals aan het begin van paragraaf 2.2.3.1 is vermeld, dient volgens de memorie van Antwoord ook in het geval van een nationaliteitsvaststelling met betrekking tot een overleden persoon bij de indiener van het verzoekschrift "onmiddellijk belang" aanwezig te zijn.

Wat moet daaronder worden verstaan? Het "onmiddellijk belang" zou ik in een dergelijk geval slechts aanwezig willen achten indien de verzoeker zijn eigen nationaliteit rechtstreeks afleidt van de nationaliteit van de overledene. Tenslotte zijn het de personen die hun nationaliteit rechtstreeks afleiden van de nationaliteit van de overledene, die bij de vaststellingsprocedure vanuit een nationaliteitsrechtelijk oogpunt beschouwd de meeste "risico's" lopen. De "risico's" waarop ik hier doel vloeien voort uit de gebondenheid ingevolge artikel 19 RWN van alle administratieve organen aan een beschikking die is gegeven op grond van artikel 17 RWN.

Naast "onmiddellijk belang" dient de verzoeker vanzelfsprekend ook "processueel belang" bij deze nationaliteitsvaststelling te hebben. Als voorbeeld van zodanig 
"processueel belang" bij de nationaliteitsvaststelling van een overledene noemt Brinkman een erfeniskwestie. ${ }^{151}$

De door Brinkman genoemde erfeniskwestie mag vanzelfsprekend met het oog op de "exclusieve werking van artikel $20 \mathrm{RWN}$ " (nog) niet aanhangig zijn bij enige in dat artikel bedoelde instantie. Ook geldt vanzelfsprekend dat de rechtbank te 'sGravenhage in de "zelfstandige vaststellingsprocedure" alleen de nationaliteit vaststelt en met de verdere erfenisproblematiek niets van doen heeft. Voor de beslechting van de erfeniskwestie zelf is alleen ruimte in een "impliciete vaststellingsprocedure", waarin de afhandeling van de erfenis de hoofdzaak is en waarin de nationaliteit van de overledene een voorvraag betreft.

Eventuele derden die wel bij de erfeniskwestie belang hebben, maar "onmiddellijk belang" bij de nationaliteitsvaststelling missen en derhalve geen "zelfstandige vaststellingsprocedure" kunnen starten, staan dus niet met lege handen. $\mathrm{Zij}$ kunnen in een "impliciete vaststellingsprocedure", waarin de hoofdvraag de erfenis betreft de nationaliteit als voorvraag aan de orde stellen en door de rechter laten beoordelen.

\subsubsection{Illustratief historisch overzicht}

In paragraaf 1.2.2 is een uiteenzetting gegeven van de diverse wetsontwerpen die een ontwerpversie voor een "zelfstandige vaststellingsprocedure" tot onderwerp hebben betroffen. In het licht van mijn beantwoording van de vraag naar de betekenis van het in de huidige wetgeving voorkomende begrip "onmiddellijk belang" wordt onderstaand een overzicht gegeven op welke wijze in de desbetreffende wetsontwerpen het "ius agendi" wordt benaderd. Onderstaand overzicht is slechts bedoeld als illustratief overzicht ter zake van de verschillende ideeën die dienaangaande klaarblijkelijk bij de wetgever hebben geleefd. Het doel van onderstaand overzicht is achtergrondinformatie te verstrekken over de in de wetsontwerpen opgenomen verschillende wijzen van afbakening van de kring van personen die de vaststellingsprocedure zou kunnen starten. Aangezien de wijzen waarop in de onderscheidenlijke wetsontwerpen de kring van de beroepsgerechtigden geen historische grondslag hebben gevormd voor de huidige regeling uit artikel 17 Rijkswet op het Nederlanderschap heb ik gemeend dit overzicht in de tekst te

151 Brinkman, p. 71. De nationaliteit heeft immers invloed op de vraag volgens welk nationaal erfrecht de erfenis wordt afgehandeld. Het Nederlandse internationaal privaatrecht wijst hiervoor de nationale wet van de erflater aan: zie Kollewijn, WPNR 1968, nr. 5016, p. 474. Idem Gerver, p. 44; Lemaire, p. 29; Sauveplanne, p. 28. Uit het voorbeeld dat Brinkman geeft, wordt overigens niet duidelijk of hij het aanhangig kunnen maken van de art. 17 RWN-procedure beperkt acht tot verzoekers die rechtstreeks hun nationaliteit afleiden van de overledene of dat hij een ieder die bij de erfeniskwestie belang heeft tot het vaststellingsverzoek gerechtigd acht. 
moeten plaatsen ná de behandeling van en de uiteenzetting van mijn eigen visie op het begrip "onmiddellijk belang".

De toegankelijkheid van de vaststellingsprocedure heeft in de aan de huidige regeling in de Rijkswet voorafgaande ontwerpen zeer uiteenlopend vorm gekregen. Met het onderstaand overzicht wordt aangetoond dat de ontwerpen een rijke diversiteit op dit gebied kennen.

In het wetsontwerp van de commissie Kollewijn uit 1956 wordt de mogelijkheid een verzoekschrift tot vaststelling ${ }^{152}$ van iemands nationaliteit opengesteld, in de eerste plaats, voor degene van wie de nationaliteit wordt verzocht vast te stellen (artt. 1, 24 en 35), maar daarnaast voor het Koninkrijk der Nederlanden (artt. 2 sub a, 25 sub a en 36 sub a) en tevens voor "rechtspersonen, die geen publiekrechtelijk lichaam zijn en natuurlijke personen, die geen orgaan van een publiekrechtelijk lichaam zijn, indien zij aantonen, dat zij daarbij gegrond belang hebben. " (artt. 2 sub b, 25 sub b en 36 sub b). Opmerkelijk is dat de eis om "gegrond belang" bij het verzoek te hebben niet wordt gesteld ten aanzien van het Koninkrijk.

In het eind jaren zestig opgesteld "Voorontwerp ter wijziging van de Wet op het Nederlanderschap en ingezetenschap" bepaalt artikel 20: "Ieder die meent het Nederlanderschap te bezitten of niet te bezitten kan aan Onze Minister van Justitie verzoeken daaromtrent uitspraak te doen." In dit ontwerp kan slechts de direct betrokkene het verzoek doen en is ten aanzien van overledenen geen regeling getroffen.

De regeling die in het ontwerp van 1971 voorkomt, is de meest beperkende. Ten eerste blijkt dat het verzoek slechts kan worden gedaan door een natuurlijke persoon. ${ }^{153}$ Daarnaast kan het verzoek "niet worden gedaan door minderjarigen die de leeftijd van zeventien jaar nog niet hebben bereikt, noch door meerderjarigen die onder curatele zijn gesteld wegens een geestelijke stoornis waardoor zij, al dan niet met tussenpozen, niet in staat zijn of bemoeilijkt worden hun belangen behoorlijk waar te nemen. ${ }^{n 154}$ Ook dit ontwerp mist een regeling ten aanzien van overledenen.

De ontwerp-memorie van Toelichting bij het onderhavige ontwerp geeft een uitvoerige motivering voor de beperkte opzet van het recht een verzoek te kunnen indienen: "De bevoegdheid om aan de rechter te verzoeken vast te stellen of iemand Nederlander is, is in het ontwerp niet aan anderen (waarbij zowel aan andere natuurlijke personen als aan overheidslichamen gedacht zou kunnen worden) dan aan de betrokkenen zelf toegekend. Wegens de vérstrekkende gevolgen van de vaststelling betreffende het Nederlanderschap, met name wegens de hieraan

\footnotetext{
"Uitwijzing" in de terminologie van het wetsontwerp.

150 Artikel 1 van het ontwerp.

is Artikel 2 van het ontwerp.
} 


\section{Hoofdstuk 2}

verbonden blijvende en algemene werking, ${ }^{155}$ zou een dergelijke vaststelling niet met bindende kracht mogen geschieden zonder dat volstrekt zeker was, dat de betrokkene van het gedane verzoek kennis had genomen en de gelegenheid had gehad om verweer te voeren. Maar ook wanneer de mogelijkheid voor derden (daaronder begrepen de overheid) om de hier bedoelde vaststelling over iemands nationaliteit te verzoeken van deze voorwaarde afhankelijk zou worden gesteld, zou nog het bezwaar blijven bestaan, dat de betrokkene zich op het moment dat hij van het verzoek in kennis wordt gesteld niet altijd bewust behoeft te zijn van alle voor hem aan de vaststelling verbonden consequenties, en wellicht om die reden weinig behoefte zal gevoelen moeite en kosten te besteden aan het verdedigen van zijn standpunt. Ook kan het feit dat hij de opvatting van de verzoeker over zijn nationaliteit deelt, hem er toe brengen niet te verschijnen, terwijl dan de rechter, die immers aan de opvatting van de verzoeker niet is gebonden, uiteindelijk tot een afwijkende beslissing zou kunnen komen. "156

Het volgende wetsvoorstel, dat uit 1981, is het ontwerp waarin, ten gevolge van bedenkingen in de Tweede Kamer tijdens de parlementaire behandeling, de voorgestelde procedure is vervangen door de huidige vaststellingsprocedure van artikel 17 Rijkswet op het Nederlanderschap. ${ }^{157}$ In het voorstel uit 1981 ligt de beslissingsbevoegdheid in eerste instantie bij de minister van Justitie, met beroep op de Afdeling rechtspraak van de Raad van State op grond van de inmiddels vervallen Wet Arob. Een verzoek kan worden ingediend door "Een ieder die daarbij belang heeft" en het verzoek dient betrekking te hebben op de "vaststelling van zijn Nederlanderschap of tot vaststelling dat hij het Nederlanderschap niet bezit." Ook aan de vaststelling op een moment in het verleden is gedacht: "Het verzoek kan betrekking hebben op die vaststelling op een bepaald tijdstip. "158

Dit betekent derhalve dat, wat betreft de nationaliteitsvaststelling van personen die in leven zijn, in het wetsontwerp uit 1981 de verzoeker en het rechtssubject dat object is van het vaststellingsverzoek identiek zijn. In vergelijking met de huidige bepaling bestaat er, kan hier dan ook worden geconstateerd, ten aanzien van een zodanige nationaliteitsvaststelling geen verschil. In de huidige regeling kan immers voor een zodanige nationaliteitsvaststelling het woord "onmiddellijk" net zo goed bij het lezen worden overgeslagen zonder dat de strekking van artikel 17 Rijkswet verandert. Op deze plaats wordt derhalve als conclusie getrokken dat voor deze gevallen de toevoeging van het woord "onmiddellijk" geen wezenlijke betekenis heeft.

${ }^{155}$ De werking van de uitspraak zou erga omnes zijn: art. 6 lid 2 van het ontwerp. Vgl. Van den Blink, p. 5.

196 Ontwerp-memorie van toelichting, p. 4. Dit stuk is niet gepubliceerd en bevindt zich in het archief van het ministerie van Justitie.

157 Zie par. 1.2.2.

158 Artikel 17 lid 1 wetsontwerp. Bijl. II. 1981, 16947, nr. 2, p. 5. 
Maar in het wetsontwerp uit 1981 is eveneens een regeling opgenomen met betrekking tot de nationaliteitsvaststelling van overleden personen. Artikel 17 lid 2 w.o. stelt dienaangaande: "Een ieder die daarbij belang heeft, kan Onze Minister verzoeken ten aanzien van een overledene vast te stellen dat deze op het tijdstip van zijn overlijden of op een bepaald vroeger tijdstip het Nederlanderschap bezat of niet bezat." Nu valt de vergelijking met de huidige bepaling anders uit. Bij vergelijking met de huidige regeling kan worden geconstateerd dat volgens het ontwerp uit 1981 met betrekking tot de nationaliteitsvaststelling van een overledene een ruimere kring van personen zou bestaan die het verzoek zou kunnen indienen. In het wetsontwerp uit 1981 is slechts (processueel) "belang" vereist in plaats van de onder de huidige regelgeving gestelde eisen "onmiddellijk belang" én "processueel belang". Uit het bovenstaande betoog volgt tevens dat de opname van de eis tot "onmiddellijk" belang eigenlijk alleen doorslaggevende betekenis heeft gehad voor nationaliteitsvaststelling betreffende een overleden persoon.

\subsubsection{Processueel belang bij de vaststelling}

\subsubsection{Algemene beschouwingen}

Het in deze paragraaf te behandelen vereiste dat wordt gesteld voor de ontvankelijkheid van de verzoeker is, zoals reeds bij de algemene beschouwingen in paragraaf 2.2.1 is uiteengezet, niet een door artikel 17 Rijkswet op het Nederlanderschap gesteld vereiste. Het is daarentegen een algemeen procesrechtelijk vereiste, namelijk het altijd geldende "point d'intérêt, point d'action", een begrip waarvoor ook wel "processueel belang" wordt gebezigd. In paragraaf 2.2.1 is tevens opgemerkt dat de rechter dit vereiste ambtshalve dient te toetsen. ${ }^{159}$

In paragraaf 2.2.3.2 is vervolgens vermeld dat de eis tot belang bij het instellen van een actie heden ten dage is gecodificeerd in artikel 3:303 BW. Voor dit artikel geldt uiteraard datgene wat Meijers indertijd bij het opnemen ervan in het ontwerp Nieuw Burgerlijk Wetboek heeft opgemerkt. Meijers schrijft dienaangaande: "Om te kunnen uitmaken of aan de eiser de rechtsvordering op deze grond moet worden ontzegd, moet de rechter niet alleen nagaan of de eiser enig belang bij de vordering heeft, maar ook, of dit belang voldoende is om een procedure te rechtvaardigen. In het algemeen mag voldoende belang voor de eiser worden verondersteld. Slechts bij uitzondering zal de eiser moeten bewijzen, dat hij voldoende belang heeft. Tot die uitzonderingen behoort de rechtsvordering tot verklaring van recht (......... "160

\footnotetext{
159 Zie ook losbl. uitgave BRv., Boek I, titel 1, afd. 4, aant. 5 over declaratoir vonnis; en de memorie van Antwoord aan de Tweede Kamer bij art. 3.11.8. NBW, Bijl. II. 70-71, 3770, nr. 5, p. 313.

${ }^{160}$ E.M. Meijers, toelichting I, p. 301.
} 
Afgezien van de consensus over de uitzonderingspositie voor de declaratoire uitspraak, zoals die door Meijers wordt benadrukt in het bovenstaande citaat en die in de literatuur algemeen wordt onderkend, ${ }^{161}$ blijkt echter bij verdere kennisneming van die literatuur dat met betrekking tot de criteria volgens welke het "processueel belang" bij een declaratoire uitspraak dient te worden beoordeeld grote verschillen van inzicht zijn te onderkennen. ${ }^{162}$

Bijvoorbeeld Houwing heeft met betrekking tot de eis van belang bij een declaratoire uitspraak gesteld dat dit belang "meestal, doch niet altijd op een betwisting" berust. ${ }^{163}$ Met deze uitspraak wijkt Houwing af van hetgeen Parser eerder heeft opgemerkt omtrent het belangvereiste bij een declaratoire uitspraak, namelijk dat het belang altijd gelegen dient te zijn in een betwisting van het recht (ten aanzien waarvan het declaratoir wordt verzocht). ${ }^{164}$ Daarenboven stelt Parser dat voor de ontvankelijkheid het noodzakelijk is dat de betwisting afkomstig is van iemand die daadwerkelijk invloed kan uitoefenen op het gepretendeerde recht: "Alleen dan levert betwisting geen gevaar op, indien degene, die mijn rechtstoestand betwist, mijn rechtstoestand niet zou kunnen benadeelen, al blijft hij ook bij zijn bewering. "165

Zuidema daarentegen heeft zich aan het begin van deze eeuw nog zeer ruim opgesteld en acht een declaratoire uitspraak ook dan mogelijk indien bij de eiser belang bij de eis afwezig is. Volgens hem is het voldoende dat de eiser zijn recht stelt en is het niet willen doen van de declaratoire uitspraak rechtsweigering. ${ }^{166}$ Uit het feit dat het beginsel "point d'intérêt, point d'action" na de tijd dat Zuidema zijn uitspraak neerschreef eerst als ongeschreven rechtsregel is erkend en naderhand een wettelijke basis heeft verkregen, volgt wel dat dit standpunt voor het huidige recht niet als juist kan worden beschouwd. ${ }^{167}$

\subsubsection{Rijkswet op het Nederlanderschap}

Voor een declaratoire uitspraak geldt, zoals in paragraaf 2.2.4.1 naar voren is gebracht, Meijers' opmerking "De rechterlijke macht is echter niet ingesteld om

${ }^{161}$ De bijzondere positie van de declaratoire uitspraak vindt eveneens vermelding bij Van Baars, p. 164; idem Cleveringa, RMTh 1964, p. 229 en 230, zie tevens de bij Cleveringa op p. 265 weergegeven opmerkingen door andere auteurs met gelijke strekking.

$162 \mathrm{Vgl}$. behalve de hieronder aan de orde gestelde auteurs tevens Van Baars, p. 103; Cleveringa, RMTh 1964, p. 229 en 230; Polenaar, p. 234 en 235; Star Busmann, p. 4, 5, 115 en 116.

${ }^{163}$ Annotatie bij HR 30.03.1951, NJ 1952, nr. 29.

${ }^{104}$ Parser, p. 297 en 299. Vrij, WPNR 1927, nr. 2991, p. 270, is dezelfde mening toegedaan. Idem Hirsch Ballin, WPNR 1951, nr. 4201, p. 344.

is Parser, p. 294. In gelijke zin Hirsch Ballin, WPNR 1951, nr. 4201, p. 344.

${ }^{106}$ Zuidema, p. 50.

${ }^{167} \mathrm{Vgl}$. HR 07.09.1990, NJ 1990, nr. 781. 
een eischer zonder eenig belang aan een uitspraak te helpen ${ }^{m 168}$ in versterkte mate. In paragraaf 2.2.3.2 is "processueel belang", als synoniem aan "point d'intérêt, point d'action", omschreven als de baat of de verandering die de rechterlijke uitspraak zal (kunnen) brengen in de juridische positie van de eiser of de verzoeker.

In de "zelfstandige vaststellingsprocedure" op grond van artikel 17 Rijkswet op het Nederlanderschap wordt om een declaratoire uitspraak van de rechter verzocht. ${ }^{169}$ De vraag kan dan ook worden gesteld hoe in de "zelfstandige vaststellingsprocedure" het belang van de verzoeker bij de vaststelling van zijn Nederlanderschap wordt beoordeeld. Onder welke omstandigheden is er wel sprake van "processueel belang" bij de vaststelling en onder welke omstandigheden is dit er niet (meer)?

In het onderstaande komt een beschikking van de Hoge Raad in het kader van de "zelfstandige vaststellingsprocedure" aan de orde waarin de nadruk ligt op het "processueel belang" dat de verzoeker dient te hebben bij zijn verzoek tot vaststelling. Ten behoeve van de overzichtelijkheid van het betoog is de uitspraak van de Hoge Raad in twee onderdelen (2.2.4.2.1 en 2.2.4.2.2) gesplitst, aangezien er, naar mijn mening, twee verschillende regels worden gegeven. Ieder onderdeel behandelt één regel. Na de globale behandeling van de beide regels ga ik in paragraaf 2.2.4.3 nog iets uitgebreider in op de eerste van de twee regels.

In de jurisprudentie op grond van artikel $17 \mathrm{RWN}$ is tot op heden slechts één uitspraak bekend geworden waarin de verzoekster niet-ontvankelijk is verklaard wegens gebrek aan belang. In deze zaak, waarin de verzoekster ná indiening van het verzoekschrift, maar vóór de uitspraak van de rechtbank is genaturaliseerd tot Nederlandse, spreekt de rechtbank te Den Haag uit dat de verzoekster "enig belang" bij de vaststelling ontbeert. ${ }^{170}$ De rechtbank spreekt dus niet van "onmiddellijk belang", maar sluit in haar woordkeus daarentegen frappant aan op hetgeen door Meijers is opgemerkt in zijn uiteenzetting bij het ontwerp van artikel 3:303 BW. Meijers stelt immers in zijn Toelichting bij het ontwerp Nieuw Burgerlijk Wetboek ten aanzien van de verklaring van recht dat de eiser "enig belang" bij de vordering heeft.

\footnotetext{
${ }^{168}$ Annotatie bij HR 15.12.1939, NJ 1940, nr. 206.

${ }^{16}$ In de literatuur wordt wel onderscheiden tussen positieve en negatieve declaratoire uitspraken. Het onderscheidend criterium hierbij is de eis die wordt gedaan. De benoeming als positief of negatief is afhankelijk van het feit of in de eis een vaststelling van een rechtsverhouding is gevraagd of dat is gevraagd vast te stellen dat een rechtsverhouding niet bestaat. In dit laatste geval spreekt Parser, p. 125. over de "actio negatoria". Zie tevens Cleveringa, RMTh 1964, p. 250; Hirsch Ballin, WPNR 1951, nr. 4201, p. 345 . Vgl. par. $5 \cdot 2 \cdot 2.1$.

$170 \mathrm{Rb}$. 's-Gravenhage 18.03.1987, rkstnr. 86.2159 (=HR 04.03.1988, NJ 1989, nr. 626, m.nt. GRdG).
} 
Naar aanleiding van het onderhavige verzoek valt ter zijde nog de volgende kanttekening te plaatsen. Zou de rechtbank wel het verzoek hebben behandeld en alsdan tot de conclusie zijn gekomen dat de verzoekster reeds voor het moment van de naturalisatie in het bezit van het Nederlanderschap is geweest, dan vervalt door die vaststelling de rechtsgrond tot naturalisatie. De naturalisatie heeft in een zodanig geval geen rechtsgevolg gehad.

Het, wegens het feit dat de betrokkene eventueel al Nederlander is, tot stand brengen van mogelijk een naturalisatie zonder rechtsgevolg, is een kwestie waarmee de overheid in het verleden meermalen is geconfronteerd. Naar gelang de mate van twijfel omtrent het bezit van het Nederlanderschap is in de betreffende gevallen besloten tot naturalisatie of tot afwijzing daarvan. ${ }^{171}$

\subsection{Contemporaine vaststelling volgens de Hoge Raad}

Van de niet-ontvankelijkverklaring in de bovenvermelde zaak heeft de verzoekster beroep in cassatie aangetekend. In cassatie ${ }^{172}$ sluit de Hoge Raad aan bij het inzicht van de rechtbank. Primair stelt de Hoge Raad met betrekking tot de ontvankelijkheidsvraag: "(...) dat het in beginsel aan de verzoeker is om aan te geven welk belang hij bij de vaststelling heeft, maar dat in de regel reeds aan dit vereiste zal zijn voldaan als omtrent zijn Nederlandse nationaliteit twijfel bestaat. "

Uit de context van de uitspraak blijkt dat de regel die de Hoge Raad aldus stelt, geldt in de gevallen waarin sprake is van een "contemporaine vaststelling". Met

171 Vgl. Prins (II), p. 197, over het verzoek tot naturalisatie uit 1920 van M.V.E.H.J.M. graaf de Marchant et d'Ansembourg die gegronde redenen had om zijn Nederlanderschap te betwijfelen (om niet te zeggen dat de feiten nogal duidelijk uitwezen dat hij het Nederlanderschap ofwel zelfs nooit heeft bezeten, dan wel zeker aan een verliesbepaling ervoor heeft voldaan); de minister bericht naar aanleiding van het verzoek de graaf het volgende: "dat waar niet gebleken was, dat hij zijn door geboorte verkregen Nederlanderschap had verloren, zijn verzoek, als niet op de wet gegrond, voor inwilliging niet vatbaar was". Vgl. De Haas-Engel, p. 83 (i.h.b. voetnoot 316), die melding maakt van afwijzing van een ander naturalisatieverzoek op grond van gelijkluidende motivering, namelijk dat betrokkene het Nederlanderschap reeds bezit.

In tegenstelling tot de hierboven genoemde voorbeelden is het inwilligen van een naturalisatieverzoek van iemand die waarschijnlijk al het Nederlanderschap bezit onder vigeur van de Wet op het Nederlanderschap en het ingezetenschap uit 1892 in bepaalde gevallen zelfs bewust gebeurd. De reden waarom deze "naturalisaties" plaatsvonden, was om in nationaliteitsrechtelijke twijfelgevallen het Nederlanderschap van de desbetreffende personen een duidelijke(re) basis te verschaffen, met dien verstande dat ook het bewijs van het bezit van het Nederlanderschap eenvoudiger (en soms voor het eerst) te leveren was. Zie bijv. Bijl. II. 37-38, 567, nrs. 2, 3; Bijl. II. 46-47, 417, nrs. 2, 3; Bijl. II. 62-63, 6903, nrs. 2, 3; Bijl. II. 63-64, 7693, nrs. 2, 3 en 7697, nrs 2, 3. Ook onder de Wet uit 1850 die een regeling voor het Nederlanderschap treft (Wet van den 28sten Julij 1850, Stb. 44) zijn zodanige naturalisaties voorgekomen. Zie Stb. 1892, 193 en de opmerking van het Tweede Kamerlid Levysohn Norman over de betrokken naturalisandus, vermeld door Schreuder, p. 272.

in HR 04.03.1988, NJ 1989, nr. 626, m.nt. GRdG. 
een "contemporaine vaststelling" bedoel ik een vaststelling waarin de datum waarvoor de nationaliteit wordt vastgesteld en de datum waarop de beschikking wordt gegeven samenvallen. ${ }^{173} \mathrm{Bij}$ de regel die de Hoge Raad hiervoor opstelt, is het opmerkelijk dat (net als eerder in de beschikking van de rechtbank) de term "onmiddellijk" geheel ontbreekt in de zinsnede. Eveneens opmerkelijk mag de wijze worden genoemd waarop de Hoge Raad tot de hierboven weergegeven omschrijving is gekomen. Om tot de betreffende begripsinvulling te komen, baseert de Hoge Raad zich met name op de memorie van Toelichting uit 1981.

Dit laatste betreffend moet echter erop worden gewezen dat deze memorie hoort bij het toenmalige wetsontwerp waarin de vaststellingsprocedure was gericht op een vaststelling door de minister van Justitie met de mogelijkheid van beroep op de Afdeling rechtspraak van de Raad van State. ${ }^{174}$ Het ontwerp uit 1981 kent het begrip "onmiddellijk belang" niet: een verzoek tot vaststelling kan worden gedaan door "Een ieder die daarbij belang heeft". In het betreffende wetsontwerp is met dat laatste zonder twijfel gedoeld op "processueel belang". Op de desbetreffende memorie en het daarin genoemde belang baseert de Hoge Raad zich derhalve bij het formuleren van de bovenvermelde stelregel inzake het benodigde belang bij de huidige nationaliteitsvaststelling. ${ }^{175}$

Of de Hoge Raad met deze stelregel het oog heeft gehad op een begripsinvulling van "onmiddellijk belang" uit artikel $17 \mathrm{RWN}$ is naar mijn mening nog maar de vraag. Mijn twijfel dienaangaande is gestoeld op enerzijds het in het geheel niet noemen van het begrip "onmiddellijk" en anderzijds het zoeken van de grondslag voor het belang in het wetsontwerp uit 1981 dat, als gezegd, het begrip "onmiddellijk belang" in het geheel niet kent. In paragraaf 2.2.3.2 heb ik mijn eigen visie op het begrip "onmiddellijk belang" weergegeven en betoogd dat daarmee niet het "processueel belang" bij de vaststelling is gemeend.

\subsection{Retrospectieve vaststelling volgens de Hoge Raad}

Echt interessant wordt de onderhavige uitspraak van de Hoge Raad evenwel pas door het vermelden van een tweede rechtsregel inzake het belang bij de vaststelling. Secundair namelijk op het hierboven vermelde stelt de Hoge Raad een "zwaardere" regel voor de beoordeling van het belang in het geval dat het vaststellingsmoment niet gelijk valt met de dag waarop de beschikking wordt gegeven,

\footnotetext{
${ }^{73}$ Bijv. op 9 juli 1996 wordt vastgesteld dat $\mathrm{X}$ het Nederlanderschap niet bezit.

${ }^{174}$ Zie par. 2.2.3.3.

175 Geheel los van de vraag of met "belang" en "onmiddellijk belang" hetzelfde is bedoeld of niet (ik meen van niet), is het mijns inziens zeer de vraag of het wel zo aanbevelenswaardig is om een wetsartikel te interpreteren aan de hand van de parlementaire stukken behorend bij de (niet tot wet verheven) ontwerp-voorganger van het te interpreteren artikel.
} 
maar in het verleden ligt, terwijl over het wel of niet bezit van het Nederlanderschap op het moment van de beschikking geen twijfel bestaat. Kenmerkend voor deze situatie is derhalve dat de vaststellingsdatum en het moment waarop de vaststellingsbeschikking wordt gegeven niet samenvallen. ${ }^{176}$ Aangaande het belang bij een zodanig retrospectief oordeel luidt de overweging van de Hoge Raad: "In een zodanig geval dient nader te worden aangegeven welk onmiddellijk belang de verzoeker bij de vaststelling van zijn nationaliteit over een reeds verstreken periode heeft".

Het is ten eerste opmerkelijk dat ten aanzien van een "retrospectieve vaststelling" de Hoge Raad wél spreekt over "onmiddellijk belang". Dit gebeurt echter in een context waarbij het duidelijk over het "processueel belang" gaat. Ten tweede is opmerkelijk dat nu niet naar de memorie van Toelichting uit 1981 wordt verwezen, hoewel toch ook in het wetsontwerp uit 1981 een bepaling is opgenomen die vaststelling voor een moment in het verleden mogelijk maakt. ${ }^{177}$

Hoewel dit achterwege blijven van de verwijzing misschien wel opmerkelijk mag worden genoemd, is het daarentegen niet verwonderlijk. Een zodanige verwijzing zou namelijk niet mogelijk zijn geweest, aangezien ook met betrekking tot de vaststelling in retrospectief van de nationaliteit in het wetsvoorstel uit 1981 niet meer wordt geëist dan "belang ". ${ }^{178}$

Naar inmiddels duidelijk zal zijn geworden, vermeldt de Hoge Raad, die hier doelt op het "processueel belang" dat de verzoeker bij de vaststelling dient te hebben, naar mijn inzicht, het begrip "onmiddellijk belang" in deze beschikking ten onrechte. ${ }^{179}$ Verzoekster heeft (en behoudt) immers gedurende de gehele procedure "onmiddellijk belang" bij de vaststelling, want het verzoek betreft de vaststelling van haar nationaliteit. Alleen gaandeweg de procedure verliest zij, ten gevolge van haar naturalisatie, ${ }^{180}$ het "processueel belang" bij de vaststelling. ${ }^{181}$ Dat ten gevolge van een tussentijdse naturalisatie het belang bij een Nederlanderschapsactie wegvalt, is overigens in de rechtspraak geen nieuw verschijnsel. ${ }^{182}$

\footnotetext{
${ }^{176}$ Bijv. op 26 maart 1996 wordt vastgesteld dat Y op 2 februari 1965 het Nederlanderschap bezat of dat $\mathbf{Z}$ tot 25 november 1975 het Nederlanderschap heeft bezeten.

in Artikel 17 lid 1 wetsontwerp. Bijl. II. 1981, 16947, nr. 2, p. 5.

${ }^{178}$ Zie par. 2.2.3.3.

179 Vgl. par. 2.2.3.2.
}

${ }^{190}$ En het feit dat de verzoekster geen ander belang stelt, bijv. inzake een recht op een uitkering o.i.d. over die reeds verstreken periode.

I81 Vgl. de gedachtengang van Parser, p. 295, als hij schrijft: "Evenals de gedaagde het belang bij het declaratoir vonnis kan doen ontstaan, ligt het ook in zijn macht het te doen tenietgaan. In die gevallen waarin men veroordeeling eischt kan dit geschieden door geheele vervulling. (......). In alle gevallen, waarin men recht op echtscheiding heeft, kan het belang worden weggenomen door verzoening."

$182 \mathrm{Vgl}$. de volgende uitspraken op grond van art. 43 (oud) Vreemdelingenwet: HR 08.04.1988, NJ 1988, nr. 631; financieel belang bij de retrospectieve vaststelling wegens het feit dat voor de naturalisatie is betaald, is niet een belang dat wordt behartigd door art. $43 \mathrm{Vw}$; beklag niet-ontvankelijk. HR 
2.2.4.2.3 Nadere uitwerking van het processueel belang bij de contemporaine vaststelling

$\mathrm{Na}$ achtereenvolgens te zijn ingegaan op contemporaine en retrospectieve vaststelling van de Nederlandse nationaliteit en het daarbij vereiste belang in processuele zin wordt in deze paragraaf nogmaals aandacht besteed aan het "processueel belang" indien een vaststelling aan de orde is waarbij de datum waarvoor de vaststelling wordt gegeven en de datum van de beschikking door de rechtbank samenvallen. In paragraaf 2.2 .4 .2 .1 is voor een zodanige vaststelling het werkbegrip "contemporaine vaststelling" ontwikkeld.

Als vermeld, heeft de Hoge Raad ten behoeve van de "contemporaine vaststelling" de regel geformuleerd: "(...) dat het in beginsel aan de verzoeker is om aan te geven welk belang hij bij de vaststelling heeft, maar dat in de regel reeds aan dit vereiste zal zijn voldaan als omtrent zijn Nederlandse nationaliteit twijfel bestaat. "183

Mijns inziens volgt aan de ene kant uit hetgeen de Hoge Raad aldus stelt dat bij het ontbreken van enige "twijfel" aan het wel of niet bezit van het Nederlanderschap de vaststellingsprocedure toch kan openstaan voor de verzoeker die kan aangeven desondanks op enige wijze "processueel belang" bij vaststelling van zijn Nederlandse nationaliteit te hebben. Aan de andere kant is het mogelijk de beslissing van de Hoge Raad tevens zo te lezen dat, uitgaande van het bestaan van enige "twijfel", niet alle "twijfel" voldoende belang oplevert om de "zelfstandige vaststellingsprocedure" te kunnen volgen. Ten aanzien hiervan is het denkbaar dat de Hoge Raad wellicht heeft gedoeld op een situatie zoals die door Parser is omschreven. ${ }^{184}$

$182 \rightarrow$

08.04.1988, NJ 1988, nr. 750; voor de beoordeling van de vraag of de klaagster over een eerdere periode recht zou hebben op een uitkering WWV dan pas vanaf het moment van de naturalisatie (naturalisatie tijdens de aanhangigheid van het beklag) staat een andere rechterlijke voorziening dan art. $43 \mathrm{Vw}$ open; beklag niet-ontvankelijk. HR 23.09.1988, NJ 1989, nr. 34; de klaagster baseert, ná naturalisatie tijdens de aanhangigheid van haar beklag, haar belang op de argumenten dat de nationaliteitsvaststelling "voor haar een principiēle zaak is" en dat zij "een uitspraak omtrent de kostenveroordeling wenst," Respons door de Hoge Raad: "Het strookt evenwel niet met het karakter van de in art. 43 (oud) Vreemdelingenwet bedoelde voorziening dat deze nog zou kunnen worden gegeven in geval vaststaat dat daarmede geen enkel ander belang van de klager is gemoeid dan vastgesteld te zien dat hij op enig tijdstip in het verleden het Nederlanderschap (reeds) bezat. Zulks klemt te meer nu de wet inmiddels op andere wijze voorziet in de mogelijkheid een dergelijke vaststelling te verkrijgen (art. 17 Rijkswet op het Nederlanderschap). "

Deze laatste uitspraak komt in een merkwaardig perspectief indien men zich realiseert dat zij later is gedaan dan de in deze paragraaf aan de orde gestelde beschikking van de Hoge Raad op grond van de Rijkswet op het Nederlanderschap, waarin de betrokkene ook bot ving!

${ }^{183}$ HR 04.03.1988, NJ 1989, nr. 626, m.nt. GRdG.

${ }^{184}$ Zie het citaat van Parser op pagina 48. 
Het bovenstaande leidt mijns inziens tot de gevolgtrekking dat, uitgaande van de twee basissituaties (nl. wel of geen twijfel) vier eindsituaties kunnen worden onderscheiden. In het geval dat "twijfel" aanwezig is, is er sprake van of voldoende óf onvoldoende "processueel belang". In het geval dat de "twijfel" ontbreekt, behoren dezelfde twee gevolgen tot de mogelijkheden. ${ }^{185}$

Hoe in concreto het vereiste van "processueel belang" bij de vaststellingsprocedure van het Nederlanderschap wordt ingevuld, blijft hiermee overigens hoogst onzeker. Opgemerkt moet worden dat, als gevolg van de schakelbepaling uit artikel 3:326 $\mathrm{BW}$, geldt dat het belangvereiste niet alleen vermogensrechtelijk kan worden ingevuld. De losbladige uitgave Burgerlijke Rechtsvordering merkt aangaande de invulling van de woorden "zonder voldoende belang komt niemand een rechtsvordering toe" (art. 3:303 BW) op: "Daarbij mag echter niet uit het oog worden verloren, dat de bepaling van art. (3.11.)8 blijkens art. 3:326 overeenkomstig wordt toegepast in het personen- en familierecht, zodat aldaar ook buiten-vermogensrechtelijke belangen -bijvoorbeeld van affectief-familiale aard- relevant zijn." Aansluitend daarop wijst de losbladige nog op de betekenis van het begrip belang: "Het vermogensrechtelijk belang is volgens de thans bestaande jurisprudentie eerst aanwezig, wanneer de rechterlijke beslissing baat kan brengen tegenover de wederpartij. ${ }^{186}$ Een op louter morele gronden gebaseerd belang wijst de losbladige als onvoldoende belang af.

In de nationaliteitsrechtelijke literatuur is met betrekking tot dit onderwerp weinig te vinden. Jessurun d'Oliveira wijdt er een, helaas zeer vage, opmerking aan. Want wat de lezer moet begrijpen onder de opmerking "dat het invullen van de belang-eis op het terrein van het nationaliteitsrecht met een speciaal gekleurd potlood kan geschieden" maakt de auteur, ook in de loop van zijn artikel, niet duidelijk. ${ }^{187}$ De stellingname van Van den Blink is daarentegen duidelijker. In de door haar gepubliceerde lezing wordt de "zelfstandige vaststellingsprocedure" vanwege de publiekrechtelijke aard van het nationaliteitsrecht sterk in de administratiefrechtelijke sfeer geplaatst. In dat kader plaatst zij ook het "processueel belang" dat de verzoeker dient te hebben: "Het ligt dus voor de hand dat het bedoelde "belang" zal zijn gelegen in de wens van betrokkene iets van de administratie gedaan te krijgen waarop alleen Nederlanders recht hebben; (.......). Het belang zal dus en dat blijkt ook- vrijwel altijd zijn: door de administratie als

\footnotetext{
is Schematisch kan dit worden weergegeven als volgt:

1. Twijfel $\rightarrow$ voldoende processueel belang.

2. Twijfel $\rightarrow$ onvoldoende processueel belang (situatie Parser).

3. Geen twijfel $\rightarrow$ toch voldoende processueel belang.

4. Geen twijfel $\rightarrow$ onvoldoende processueel belang.

${ }^{186}$ Losbl. uitgave BRv., Boek. I, titel 1, alg. gedeelte, aant. 3. Vgl. tevens voetnoot 137.

187 Jessurun d'Oliveira, NJB 1983, p. 1309.
} 
Nederlander te worden behandeld. ${ }^{188}$ Uit dit citaat blijkt evenwel dat Van den Blink een ander dan op overheidshandelen gericht belang toch niet uitsluit. Dat laatste lijkt Brinkman echter wel te beogen als hij schrijft: "Redenen genoeg dus om een uitspraak te vragen dat men Nederlander is (als tenminste de administratie er anders over denkt!). ${ }^{189}$

Eerder is reeds vermeld ${ }^{190}$ dat met het begrip "point d'intérêt, point d'action" niet wordt gedoeld op de directe, feitelijke aanleiding ten gevolge waarvan het noodzakelijk is gebleken de vraag naar de nationaliteit op te helderen. Desalniette$\min$ is het van belang om enige aandacht te schenken aan deze feitelijke oorzaken, die tenslotte een aanwijzing kunnen vormen bij de vraag naar de aard van de gevallen waarin een verzoek op grond van artikel $17 \mathrm{RWN}$ wordt gedaan.

Uit de meeste beschikkingen waarop dit onderzoek is gebaseerd, blijkt wel waar voor de verzoeker de pijn ligt: de meerderheid van de verzoekers ondervindt moeilijkheden bij voortgezet verblijf in Nederland of krijgt geen Nederlands paspoort. Recentelijk is een aantal beschikkingen gegeven waarin de aanleiding voor de verzoeker om de "zelfstandige vaststellingsprocedure" aanhangig te maken, was gelegen in het feit dat de gemeente de registratie als Nederlander doorhaalde. ${ }^{191}$ De meerderheid van de verzoekers blijkt volgens de beschikkingen verwikkeld in een conflict (van publiekrechtelijke aard) met een overheidsinstantie. ${ }^{192}$ Maar er zijn ook beschikkingen waaruit niet blijkt van enig conflict (van welke aard dan ook). Van het feit dat voor het kunnen instellen van de rechtsgang uit artikel 17 RWN niet noodzakelijkerwijs sprake hoeft te zijn van een geschil over verzoekers Nederlanderschap tussen de verzoeker en een derde (al dan niet een overheidsinstantie), geeft reeds de toelichting bij het amendement Haas-Berger bij het ontwerp van artikel 19 RWN blijk. ${ }^{193}$ De hierboven genoemde jurisprudentie

\footnotetext{
148 Van den Blink, p. 22.

159 Brinkman, p. 70.

${ }^{190}$ Zie par. 2.2.3.2.

${ }^{191}$ Rb. 's-Gravenhage 08.12.1993, rkstnr. 93.5506, B\&R 1994, p. 144; Rb. 's-Gravenhage 29.12.1994, rkstnr. 93.5525, B\&R 1994, p. 145; Rb. 's-Gravenhage 29.12.1994, rkstnr. 93.5589, B\&R 1994, p. 145 ; Rb. 's-Gravenhage 29.12.1994, rkstnr. 93.5529, B\&R 1994, p. 145; Rb. 's-Gravenhage 29.12.1994, rkstnr. 93.5588, B\&R 1994, p. 112 en 145; Rb. 's-Gravenhage 19.01.1994, rkstnr. onvermeld, B\&R 1994, p. 119, m.nt. Vat.

192 Soms betreft het een buitenlandse overheidsinstantic. $\mathrm{Vgl}$. Rb. 's-Gravenhage 09.12.1992, rkstnr. 91.6217, Zilverentant e.a., losbl. uitgave Nationaliteitswetgeving, art. 6 TOS. I.c. zijn de Surinaamse autoriteiten van mening dat de verzoekster de Surinaamse nationaliteit bezit. De rechtbank stelt voor de verzoekster, en dit conform het standpunt van de (Nederlandse) Staat, het bezit van het Nederlanderschap vast.

${ }^{193}$ Bijl. II. 83-84, 16947, nr. 49. De toelichting op dit, niet aangenomen, amendement stelt o.m.: "De uitkomst van de procedure ex artikel $17 \mathrm{kan}$ in strijd komen met de uitkomst van de procedure ex artikel 20. Artikel 19 lijkt daarvoor in alle gevallen een oplossing te bieden, maar dat is het niet. Voorrang moet toekomen aan de uitkomst van een procedure die gevoerd is ter gelegenheid van een controverse of
} 
waarin geen sprake lijkt van enig geschil naar aanleiding waarvan word geprocedeerd, kan naar mijn mening als exemplarisch worden beschouwd voor het (hiervoor op p. 48 vermelde) standpunt van Houwing dat het "processuel belang" bij een declaratoire uitspraak niet noodzakelijk in een geschil of een retwisting hoeft te liggen.

Ter afsluiting van dit onderdeel is hieronder een beknopt overzicht van $d$ in dezen relevant jurisprudentie van de rechtbank te Den Haag opgenomen. Daanee wordt beoogd een illustratie te geven van het functioneren van het vereiste van processueel belang".

Eerst komt een beschikking aan de orde waaruit niets kan worden pgemaakt met betrekking tot het onderwerp "belang". Ten tweede volgt een veroeker die meermalen inzake het Nederlanderschap heeft geprocedeerd. Tot slot volen enkele uitspraken die aantonen dat de verzoeker ontvankelijk is in het geval dat deze redelijk zeker is van het feit dat het Nederlanderschap is komen te vervalen. Voor de "contemporaine vaststelling" leidt dit overzicht mijns inziens tot de gvolgtrekking dat het aanwezig ziin van "processueel belang" vrii snel wordt aanuard door de rechtbank.

De eerste beschikking betreft het verzoek van een in Nederland wonende man van Indonesische nationaliteit. Uit de beschikking blijkt niet van enig conflict tussen de verzoeker en de Nederlandse overheid betreffende het wel of niet bezit van het Nederlanderschap. Naar aanleiding waarvan de man zijn Nederlanderschap wil zien vastgesteld, wordt niet duidelijk. In de beschikking wordt van de kant van de rechtbank omtrent het belang om te procederen slechts de opmerking geplaatst: "Hij stelt voorop dat hij de Indonesische nationaliteit bezit. Hij meent dat hij (daarnaast?) de Nederlandse nationaliteit bezit. ${ }^{{ }^{194}}$

Eveneens is door de rechtbank ontvankelijk geacht de verzoeker ten aanzien van wie de Hoge Raad in een uitspraak in 1987 op een beklag ingevolge artikel 43 (oud) Vreemdelingenwet betreffende zijn minderjarig dochtertje reeds in de overwegingen heeft opgenomen dat hij (de vader) o.g.v. de Toescheidingsovereenkomst inzake nationaliteiten tussen Suriname en Nederland de Surinaamse nationali-

$193 \rightarrow$

geschil. Daardoor zijn in het algemeen grotere waarborgen te verwachten omtrent de innerlijke juistheid van de beslissing omtrent de nationaliteit dan in een situatie waarin van een geschil geen sprake hoeft te zijn, zoals in artikel 17."

im Rb. 's-Gravenhage 29.06.1988, rkstnr. 87.5993. Ook in Rb. 's-Gravenhage 25.11.1987, rkstnr. 86.2110 is enig conflict met de Nederlandse overheid afwezig. Verzoeker is van Australische nationaliteit en woont in Engeland, maar beweert tevens (als oud-Nederlander) het Nederlanderschap (nog) te bezitten. Uit de beschikking blijkt niets aangaande een belang inzake de vaststelling dat zou zijn getoetst door de rechtbank. Uit de conclusie van het OM blijkt evenwel dat de verzoeker een dreigende uitlevering naar Australie̋ door het Verenigd Koninkrijk vreest. 
teit heeft verkregen. ${ }^{195}$ Het rechtsgevolg dat de Toescheidingsovereenkomst verbindt aan het op grond van die overeenkomst verwerven van de Surinaamse nationaliteit is het verlies van de Nederlandse nationaliteit. Ten opzichte van deze beslissing uit 1987 is ten tijde van het indienen van het verzoekschrift bij de rechtbank te Den Haag in het feitencomplex waarop de betrokkene zich baseert geen verandering opgetreden. In de beschikking van de rechtbank is ten aanzien van de ontvankelijkheid geen overweging opgenomen. Het openbaar ministerie werpt in zijn conclusie nog wel de vraag op: "of verzoeker nog een rechtens te respecteren belang heeft bij zijn verzoek tot vaststelling van zijn Nederlandse nationaliteit, aangezien hij zich klaarblijkelijk ${ }^{196}$ geheel kan verenigen met 's Hogen Raads vaststelling dat hij op grond van artikel 5, tweede lid, van de Toescheidingsovereenkomst de Surinaamse nationaliteit heeft verkregen, met als gevolg het verlies van het Nederlanderschap. ${ }^{n 197}$ Als gezegd, de rechtbank wijdt hieraan geen overwegingen, maar acht de verzoeker ontvankelijk.

Het oordeel dat de rechtbank vervolgens in deze zaak uitspreekt, wijkt niet af van de eerdere overwegingen van de Hoge Raad en het verzoek resulteert derhalve in een afwijzing. Voor de verzoeker is hiermee de kous overigens niet af. $\mathrm{Na}$ verloop van tijd dient hij een nieuw verzoekschrift in. Daarin verzoekt hij de rechtbank de bovenvermelde beschikking te herzien op grond van relevante nieuwe feiten. Ook dit verzoekschrift is ontvankelijk en de tweede beschikking wordt op 30 augustus 1989 gegeven. ${ }^{198}$ Op deze boeiende ontwikkeling inzake een herzieningsmogelijkheid wordt in paragraaf 2.7.2 ingegaan.

Eveneens ontvankelijk blijken verzoekschriften waarin uitdrukkelijk wordt gesteld dat de verzoeker overtuigd is van het feit dat hij volgens (verdrags)bepalingen zijn Nederlandse nationaliteit is kwijtgeraakt, maar waarin de verzoeker tevens van mening is dat deze nationaliteit hem in strijd met (andere) internationale of nationale rechtsregels is ontnomen en dat hij derhalve Nederlander is gebleven. ${ }^{199}$

\subsection{Een futuristische vaststelling?}

Een geheel andere kwestie betreft de vraag of met het oog op een toekomstige gebeurtenis een "futuristische vaststelling" tot de mogelijkheid behoort. Kan, met

\footnotetext{
${ }^{195}$ HR 05.06.1987, NJ 1988, nr. 134, m.nt. GRdG.

${ }^{19}$ De raadsman van de verzoeker had namelijk de in de vorige voetnoot vermelde uitspraak van de HR naar de rechtbank gestuurd met het verzoek de uitspraak en de overwegingen (!) ervan in acht te willen nemen.

${ }^{19}$ Conclusie bij Rb. 's-Gravenhage 25.11.1987, rkstnr. 87.5536.

${ }^{198} \mathrm{Rb}$. 's-Gravenhage 30.08.1989, rkstnr. 89.5271; Van den Blink, p. 14 en 15; De Groot, losbl. uitgave Personen- en Familierecht, art. 19 RWN, aant. 1.

${ }^{19} \mathrm{Rb}$. 's-Gravenhage 24.06.1987, rkstnr. 86.2266 (= HR 04.03.1988, NJ 1989, nr. 875, m.nt. EAA); Rb. 's-Gravenhage 24.06.1987, rkstnr. 87.5002; Rb. 's-Gravenhage 27.04.1988, rkstnr. 87.5964.
} 
betrekking tot een toekomstig rechtsfeit waarvan vooralsnog de implicaties voor het verlies of de verwerving van de Nederlandse nationaliteit onduidelijk zijn, de onmiddellijk belanghebbende op grond van artikel 17 RWN een verzoekschrift indienen dat het op het gebied van het Nederlanderschap ongewisse rechtsgevolg regardeert?

Indien het wel of niet voorvallen van de toekomstige gebeurtenis door de betrokkene is te beïnvloeden, dan kan de nationaliteitsrechtelijke implicatie van zijn toekomstig handelen, zoals de rechtbank dat blijkens haar uitspraak ziet, wellicht voor de betrokkene aanleiding zijn de beoogde handeling achterwege te laten.

Een verzoek als bovenstaand is bedoeld, is naar mijn inzicht niet mogelijk. Mijn afwijzing met betrekking tot de mogelijkheid van een "futuristische vaststelling" steunt vooral op een tweetal procesrechtelijke overwegingen en daarnaast op een praktische overweging. De eerste procesrechtelijke overweging is dat, naar algemeen in literatuur en rechtspraak wordt erkend, verzoekschriftprocedures een gesloten systeem vormen. ${ }^{200}$ Dit betekent dat aan de rechter slechts een zodanig verzoek kan worden gedaan als waartoe in de specifieke wet de mogelijkheid wordt geboden. Aan die wettelijke bepaling ${ }^{201}$ ontleent de rechter immers in concreto zijn jurisdictie. In het geval van de "zelfstandige vaststellingsprocedure" heeft de wetgever in de Rijkswet op het Nederlanderschap een antal verzoeken mogelijk gemaakt. Deze zijn in de wet terug te vinden als het verzoek om een "contemporaine vaststelling" dan wel een "retrospectieve vaststelling". Bovendien kan het verzoek betreffen het vaststellen van het wel of niet bezitten van de Nederlandse nationaliteit. Daarnaast kent de wet de mogelijkheid het verzoek het Nederlanderschap van een overledene te laten betreffen. Onder deze wettelijke mogelijkheden ontbreekt het verzoek aangaande een vaststelling die wordt gedaan met het oog op het toekomstig voorvallen van een nationaliteitsrechtelijk relevant rechtsfeit. Mijn conclusie luidt op grond van het bovenstaande dat ten aanzien van een "futuristische vaststelling " geen rechtsmacht bestaat. ${ }^{202}$

Het tweede procesrechtelijke bedenken tegen een zodanige vaststelling betreft een argument dat niet alleen voor verzoekschriftprocedures opgaat, maar dat ook voor de gewone procedure geldt. Ten aanzien van het noodzakelijke "processueel

\footnotetext{
${ }^{200}$ Boekman, p. 100 en 101; Funke, p. 226 en 227; Gras, p. 84 en 196; Hugenholtz/Heemskerk, p. 137; Korthals Altes, p. 159; Röder, p. 51-55; Stein, p. 164 (met literatuurverwijzingen); Wesseling-van Gent, p. 78. Vgl. HR 28.06,1985, NJ 1985, nr. 839; en zie tevens de in voetnoot 306 toegelichte uitspraak Hof 's-Gravenhage 06.11.1952, NJ 1953, nr. 59.

201 Alsmede aan art. 55a Wet RO.

${ }^{202}$ Struycken, p. 52, stelt evenwel: "De kennisneming van een verzoek tot het geven van een beschikking die niet onmiddellijk op de wet steunt kan een blijk zijn van voortvarendheid in de rechtsontwikkeling voor de éen, een klaarblijkelijke overschrijding van rechtsmacht voor de ander. "Gras, p. 85, is in het kader van het bepalen van rechtsmacht in een verzoekschriftprocedure en het soms daarvoor noodzakelijk interpreteren van een wetsartikel van mening: "dat bij deze materie een erg vrije manier van interpretatie niet past. "
} 
belang " bij de vordering of het verzoek wordt in de literatuur algemeen gesteld dat dit tevens ${ }^{203}$ moet betreffen een "dadelijk belang ". ${ }^{204}$ Het materiële belang is onder de voorgestelde omstandigheden als zodanig duidelijk: iemand wil bij voorbeeld weten of hij ten gevolge van een toekomstige handeling moet vrezen voor zijn Nederlandse nationaliteit. Het "dadelijk belang" (als bestanddeel van het "processueel belang") is daarentegen zonder meer afwezig indien de rechter over een hypothetisch te verrichten handeling dient te oordelen. Wat dit betreft, kan nog op het volgende worden gewezen. Aan de ontwikkeling van het concept inzake het vereiste van "processueel belang" heeft mede ten grondslag gelegen het van ouds afwijzen door de literatuur van de idee dat de rechter wordt geadieerd alleen om een oordeel van de rechter over een slechts fictief bestaand juridisch vraagstuk te verkrijgen. ${ }^{205}$

Nog afgezien van bovenstaande procesrechtelijke bezwaren bestaat er, mijns inziens, tevens een praktisch bezwaar dat spreekt tegen de mogelijkheid van een "futuristische vaststelling". Toekomstige wetswijzigingen in het Nederlandse of mogelijk relevant vreemd nationaliteitsrecht kunnen door de rechter niet worden voorzien, laat staan reeds worden toegepast. De waarde van een "futuristische" vaststellingsbeschikking zou vanzelfsprekend nihil zijn als blijkt dat naderhand een relevante wetswijziging is doorgevoerd.

Echter, los van bovenstaande opmerkingen aangaande de mogelijkheid van een "futuristische vaststelling" is er mijns inziens toch wel een situatie denkbaar waarin een verzoeker voldoende "processueel belang" heeft bij vaststelling van zijn Nederlanderschap, ook al hangt dat belang samen met een alsnog onzekere toekomstige gebeurtenis. Het is bijvoorbeeld mogelijk dat een persoon in een procedure ressorterend onder artikel $20 \mathrm{RWN}$, een "impliciete vaststellingsprocedu$r e^{\prime \prime}$ derhalve, is verwikkeld geweest. Uiteindelijk is daarin een uitspraak verkregen die mede is gebaseerd op de overweging dat de betrokkene Nederlander is. Deze kan zich realiseren dat aan deze beslissing, met uitzondering van de wederpartij verder niemand is gebonden. Om te vermijden dat hij in de toekomst (van overheidswege) eventueel weer wordt geconfronteerd met problemen rond het Nederlanderschap kan de betrokkene het wenselijk achten een uitspraak op grond van artikel 17 RWN te verkrijgen. Deze wens is dan in het bijzonder gestoeld in het feit dat aan de uitspraak in de "zelfstandige vaststellingsprocedure" volgens artikel 19 RWN "elk met de uitvoering van enige wettelijke regeling belast orgaan is

\footnotetext{
${ }^{2003}$ Bedoeld is: naast de verdere kenmerken van "processueel belang".

204 Zie losbl. uitgave BRv., Boek I, titel 1, afd. 4, aant. 5 (met verwijzingen naar jurisprudentie); Van Baars, p. 137; Gras, p. 157.

${ }^{205} \mathrm{Vgl}$. Gras, p. 39; Hirsch Ballin, WPNR 1951, nr. 4201, p. 344; Parser, p. 78 en 79; Vrij, WPNR 1927, nr. 29911, p. 271. Alleen Cleveringa, RMTh 1964 , p. 266 , neemt hierover een afwijkend standpunt in.
} 
Hoofdstuk 2

gebonden". Een verzoek als hier beschreven is mijns inziens mogelijk en wel omdat in feite geen "futuristische vaststelling", maar een "contemporaine vaststelling" wordt verzocht.

\subsubsection{Divergerende belangen}

Het specifiek voor artikel 17 Rijkswet op het Nederlanderschap geldende vereiste voor ontvankelijkheid dat inhoudt dat de rechtsgang slechts openstaat voor verzoekers wier nationaliteit niet reeds een onzekerheid vormt in een aanhangig geschil bij een rechterlijke instantie dan wel een in administratief beroep oordelende instantie is een voor de "zelfstandige vaststellingsprocedure" zeer kenmerkend gegeven.

In paragraaf 2.2.1 is ten aanzien hiervan gesteld dat er sprake is van een "exclusieve werking" van de "impliciete vaststellingsprocedures" uit artikel 20 RWN. Op de verwikkelingen die deze "exclusieve werking" van artikel 20 RWN met zich brengt, is vervalgens in naragraaf 222 e.v. nader ingegaan. De "exclusieve werking " van artikel 20 RWN houdt in dat, indien het verzoekschrift bij de rechtbank in Den Haag wordt ingediend op een moment dat binnen het Koninkrijk een procedure aanhangig is, hetzij bij een rechterlijke instantie dan wel in administratief beroep, waarin de onzekerheid omtrent verzoekers Nederlanderschap een rol speelt én deze situatie van aanhangigheid duurt nog voort op het moment dat de rechtbank haar beschikking in de "zelfstandige vaststellingsprocedure" geeft, de rechtbank de verzoeker niet-ontvankelijk in zijn verzoek verklaart. In paragraaf 2.2.2.2.2 is gesteld dat voor de ontvankelijkheid het moment waarop de rechtbank in het kader van de "zelfstandige vaststellingsbeschikking" haar beschikking geeft doorslaggevend is.

Over de hierboven beschreven gang van zaken, leidend tot niet-ontvankelijkheid van de verzoeker, kan worden opgemerkt dat deze in overeenstemming is met hetgeen in de memorie van Antwoord aan de Tweede Kamer wordt gesteld omtrent de werking en toepassing van artikel 17 RWN. ${ }^{206}$

In de literatuur geeft daarentegen Boeles een andersluidende, evenwel interessante, interpretatie aan de "exclusieve werking" die in artikel 17 RWN besloten ligt. Boeles is namelijk van mening dat de verzoeker ontvankelijk is bij de Haagse rechtbank, ook al komt diens Nederlanderschap als onzeker voor in een reeds aanhangige zaak (bij een rechterlijke instantie dan wel bij een instantie oordelend in

\footnotetext{
${ }^{206}$ Bijl. II. 82-83, 16947, nr. 7, p. 32. Wel is in par. 2.2.2.2.2 een controverse geconstateerd tussen de feitelijke gang van zaken bij de rechtbank en hetgeen is opgemerkt in de MvA aan de Eerste Kamer omtrent het door de rechter in een "impliciete vaststellingsprocedure" afwachten van de beslissing in de "zelfstandige vaststellingsprocedure".
} 
administratief beroep), zolang het belang dat de verzoeker probeert veilig te stellen met de artikel 17 RWN-procedure niet "uitsluitend is gelegen in een belang bij de beoordeling van de nationaliteitsvraag in een al aanhangige zaak" ${ }^{207}$ Ter illustratie noemt Boeles een plotselinge uitzettingsdreiging tijdens een zodanig onder de "exclusieve werking " van artikel 20 RWN vallende zaak. ${ }^{208}$

Boeles snijdt hier zeker een belangrijke kwestie aan. Aan de orde is immers de rechtsbescherming van de onderscheidenlijke belangen. In het onderstaande betoog wordt door mij ter aanduiding van de problematiek inzake de rechtsbescherming van verschillende rechtsbelangen de omschrijving "divergerende belangen" als werkbegrip gehanteerd.

Terwijl in het door Boeles aangedragen voorbeeld de verzoeker door middel van de, alsnog te initiëren, artikel 17 RWN-procedure zijn recht tot verblijf in Nederland wil zien vastgesteld (het ene belang), betreft de eerder aanhangig gemaakte zaak $^{209}$ mogelijkerwijs de registratie als kiesgerechtigde ${ }^{210}$ (het andere belang).

Ook het volgende betreft een voorbeeld met betrekking tot de kwestie van rechtsbescherming van "divergerende belangen". Indien iemand, woonachtig buiten het Koninkrijk, na aanvraag een Nederlands nationaal paspoort wordt geweigerd door de minister van Buitenlandse Zaken ${ }^{211}$ wegens het vermeend ontbreken van het Nederlanderschap dan is tegen die weigering achtereenvolgens bezwaar, beroep op de rechtbank en uiteindelijk beroep op de Afdeling bestuursrechtspraak van de Raad van State mogelijk. ${ }^{212}$ Op het moment dat, gedurende de procedure bij

\footnotetext{
${ }^{2 m}$ Boeles, p. 212.

${ }^{208}$ Boeles, p. 215. Met dit voorbeeld refereert Boeles aan de gedane belofte van de staatssecretaris van Justitie, mw. Korte-van Hemel, aan de Tweede Kamer (Bijl. II. 85-86, 19139, nr. 5, p. 2) om de praktijk van art. 43 (oud) Vreemdelingenwet voort te zetten, $\mathrm{nl}$. om iemand die een Nederlanderschapsactie voert niet uit te zetten, tenzij de actie zonneklaar van iedere grond is gespeend en duidelijk alleen wordt gevoerd om verblijf in Nederland te rekken. Vgl. Pres. Rb. Breda 26.04.1982, KG 1982, nr. 141; Pres. Rb. 's-Gravenhage 31.08.1982, RV 1982, nr. 47; Pres. Rb. Amsterdam 06.12.1984, KG 1985, nr. 9. Onder verwijzing naar de Kamerstukken is door de staatssecretaris deze belofte nogmaals gedaan in Migrantenrecht 1986, p. 248. Zie Pres. Rb. 's-Gravenhage 08.06.1990, KG 1990, nr. 211; Pres. Rb. 's-Gravenhage 22.10.1993, RV 1993, m.nt. HAA.

209 Ten aanzien van de "impliciete vaststellingsprocedures" is het in dit verband van belang te bedenken dat de eerder aanhangig gemaakte zaak door anderen aanhangig kan zijn gemaakt dan door degene wiens nationaliteit in het geding is en die de "zelfstandige vaststellingsprocedure" wil starten. $\mathrm{Vgl}$. de (slordig geformuleerde) opmerking bij het amendement Haas-Berger op art. 19 RWN: "Te bedenken is, dat artikel 17 door anderen kan worden aangespannen dan die van artikel 20. " Bijl. II. 83-84, 16947 , nr. 49.

${ }^{210}$ Waarbij de rechtsgang is: bezwaarschriftprocedure bij B. \& W. (art. D5 Kieswet) en beroep bij de Afdeling bestuursrechtspraak van de Raad van State (art. D9 Kieswet).

${ }^{211}$ Art. 44 Paspoortwet (Rijkswet van 26.09.1991, Stb. 498).

212 De Paspoortwet kent ter zake van de rechtsbescherming geen eigen regeling. Op de hierbedoelde weigering door de min. van Buitenlandse Zaken zal voor rechtsbescherming een beroep moeten worden gedaan op de Alg. wet bestuursrecht. Dit betekent: eerst een bezwaarschrift bij de min. van Buitenlandse Zaken (art. $7: 1$ lid 1 jo. art. 8:1 lid $1 \mathrm{Awb}$ ), daarna beroep (ingevolge art. 7:1 lid 2 Awb) op de
} 
rechtbank of ABRS, de betrokkene, met een beroep op het bezit van het Nederlanderschap, Nederland wil inreizen en er wil verblijven, terwijl dit óók wordt geweigerd, wordt het verschil tussen de uiteenlopende interpretatie van Boeles en de memorie van Antwoord over de "exclusieve werking van artikel $20 \mathrm{RWN}$ relevant.

Maakt de betrokkene de "zelfstandige vaststellingsprocedure" aanhangig en is bij het nemen van de artikel 17 RWN-beschikking door de rechtbank in Den Haag nog niet in de "impliciete vaststellingsprocedure" uitspraak gedaan in de paspoortkwestie, dan volgt volgens de wetgever niet-ontvankelijkheid van de verzoeker in de "zelfstandige vaststellingsprocedure". Echter, in de visie van Boeles zou de verzoeker wél ontvankelijk zijn in de "zelfstandige vaststellingsprocedure". Dit alles omdat de procedure bij de rechtbank (6́ók rechtbank 's-Gravenhage, maar dan de sector bestuursrecht) of de ABRS over de afgifte van een paspoort gaat en bij het inreizen van Nederland het gaat om de uitoefening van het verblijfsrecht. ${ }^{213}$

Hoe moet nu worden gedacht over het mogelijk niet-ontvankelijk zijn van de verzoeker in de artikel $17 \mathrm{RWN}$-procedure en de terechte aanspraak op bescherming in rechte van de "divergerende rechtsbelangen" die mogelijkerwijs in het spel zijn? Hierbij komt derhalve de vraag aan de orde of de visie van Boeles, inhoudende dat de verzoeker in de "zelfstandige vaststellingsprocedure" ontvankelijk dient te zijn in het geval van behartiging van een ander belang dan waarvoor reeds een "impliciete vaststellingsprocedure" aanhangig is, navolging verdient.

Vóór de visie van Boeles en derhalve tégen de bovenstaand vermelde uitleg van artikel 17 RWN (al is deze in overeenstemming met de memorie van Antwoord op de Rijkswet op het Nederlanderschap) lijkt een latere opmerking in de memorie van Toelichting bij de Kieswet te pleiten. Daar wordt als volgt opgemerkt: "Een ieder die buiten het verband van een aanhangige rechtszaak belang heeft bij de beantwoording van de vraag of hij Nederlander is, kan die vraag aan de rechtbank te 'sGravenhage voorleggen, (..........). "214 Wat deze opmerking betreft, ben ik evenwel van mening dat in het kader van de beperkingen die de "exclusieve werking"

${ }^{212} \rightarrow$

administratieve rechter: dit is de rechtbank (art. 8:1 lid 1 Awb) en wel de rechtbank 's-Gravenhage (art. 8:7 lid 2 Awb). Daarna is hoger beroep op de ABRS mogelijk op grond van art. 37 WRvS.

${ }^{213} \mathrm{Vgl}$. de opmerking van A.-G. Mok in HR 27.11.1979, NJ 1980, nr. 550, m.nt. MS onder NJ 1980, nr. 551: "Het recht op toelating in het grondgebied van de staat waarvan men onderdaan is lijkt mij het meest wezenlijke kenmerk van nationaliteit." Dit recht is neergelegd in: art. 13 Universele Verklaring van de Rechten van de Mens; in art. 12 lid 4 Int. verdrag inzake burgerrechten en politieke rechten; in art. 5 Int. verdrag inzake de uitbanning van alle vormen van rassendiscriminatie; in art. 3 lid 2 van het vierde protocol bij het Verdrag tot bescherming van de rechten van de mens en de fundamentele vrijheden (het EVRM). Vgl. Ahmad Ali, MR 1992, p. 73; Strijards, p. 47.

at Bijl. II. $87-88,20264$, nr. 3, p. 89. 
van artikel 20 RWN met zich brengt, aan deze uitspraak niet te veel waarde moet worden gehecht. Gezien de plaatsing ervan in de memorie van Toelichting bij een wetsontwerp dat een ander rechtsgebied betreft dan het Nederlanderschap lijkt het mij vrij aannemelijk dat hier eerder sprake is van een nogal onzuiver gestelde redactie, ${ }^{215}$ dan van een zorgvuldig afgewogen standpunt inzake wat in dit boek de "exclusieve werking" van artikel 20 RWN wordt genoemd.

Naar mijn mening dient bij de beoordeling van de problematiek inzake "divergerende belangen" voorop te worden gesteld dat het tweede in het geschil zijnde recht waarbij het Nederlanderschap eveneens een rol speelt in de meeste gevallen een bepaalde eigen rechtsgang zal kennen. Mijns inziens wordt het tweede rechtsbelang dat in het spel is geraakt door het aanhangig maken van de eigen "impliciete vaststellingsprocedure" voldoende beschermt. In een dergelijke situatie lijkt mij een blokkering van de "zelfstandige vaststellingsprocedure" niet onredelijk en bovendien zoveel mogelijk in overeenstemming met hetgeen de regering in de memorie van Antwoord heeft gesteld. Echter, in gevallen waarin geen sprake is van een behoorlijke eigen "impliciete vaststellingsprocedure", en de weigering van de toegang tot en het verblijf in Nederland op grond van het oordeel dat de betrokkene het Nederlanderschap niet bezit, lijkt mij zo'n geval, bepleit ik ontvankelijkheid in de "zelfstandige vaststellingsprocedure". Voor alle duidelijkheid moet ik hierbij aantekenen dat naar mijn mening de mogelijkheid om een kort geding te voeren niet een behoorlijke "impliciete vaststellingsprocedure" betekent. ${ }^{216}$

\subsection{De positie van het openbaar ministerie (art. 18 lid 1 RWN)}

\subsubsection{De conclusie van het openbaar ministerie in feitelijke instantie}

\subsubsection{Algemene beschouwingen}

De taken en bevoegdheden van het openbaar ministerie in civielrechtelijke zaken vinden een regeling in de artikelen 322-328 Wetboek van Burgerlijke Rechtsvordering. Deze artikelen zijn eveneens van toepassing op verzoekschriftprocedures. ${ }^{217}$

\footnotetext{
${ }^{215}$ Opmerkelijk is bijvoorbeeld dat, als gevolg van de beperking tot "een aanhangige rechtszaak", de bij instanties handelend in administratief beroep aanhangige zaken niet zijn vermeld. M.a.w. het citaat in de MvT bij de Kieswet bestrijkt slechts de "helft" van datgene wat deel uitmaakt van de exclusieve werking van art. 20 RWN.

${ }^{216} \mathrm{Vgl}$. J.E.F.F.M. Duynstee, Trema 1990, p. 204, die onder verwijzing naar HR 12.12.1986, NJ $1987, \mathrm{nr} .381$, stelt dat het "bij een voorlopige voorziening, (..........). niet gaat om de vaststelling van burgerlijke rechten en verplichtingen als bedoeld in artikel 6 EVRM."

$217 \mathrm{Vgl}$. Bijl. II. 32-33, 139, nr. 3, p. 2.
} 
Tot in de jaren dertig van deze eeuw heeft voor het openbaar miniterie ten aanzien van een bepaald aantal ${ }^{218}$ civielrechtelijke zaken een verplicting tot concluderen bestaan. Door een wetswijziging in 1933 is deze verplichting op twee gevallen na, gewijzigd in een door het OM naar eigen inzicht uit te oefenen bevoegdheid om een conclusie te nemen. ${ }^{219}$ Deze aldus op facultatieve wijze uit te oefenen bevoegdheid tot concluderen is geregeld in artikel 324 lid 1 sub a Wetboek van Burgerlijke Rechtsvordering. Hetzelfde artikel geeft teves aan in welke twee gevallen van civielrechtelijke aard het openbaar ministerie $\mathrm{Dg}$ steeds verplicht is te concluderen. Het gaat daarbij om "disciplinaire zaken" en seroep in cassatie".

Ook komt het in een beperkt aantal situaties voor dat in een specifiek wet ten aanzien van de rechter de verplichting is opgenomen tot het horen van hetopenbaar ministerie. ${ }^{220}$ Aan de conclusie genomen in een zodanig geval liggen, afgezien van de desbetreffende bepaling in de specifieke wet, mede de artikelen 4 Wet RO en 324 lid 1 sub b Rv ten grondslag.

Uit het bovenstaande kan worden afgeleid dat indien door het openbaa ministerie in een civiele procedure een conclusie wordt genomen, de wettelijke jrondslag

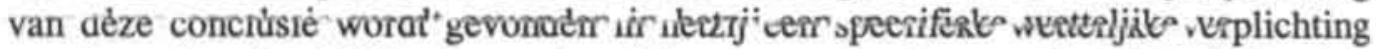
van de rechter het OM te horen, hetzij in een op grond van artikel 324 lid 1 sub a Rv aan het OM toekomende bevoegdheid. Voor beide grondslagen geldt artikel 324 lid 2 Rv. Daarin wordt bepaald dat, wederom behalve in "disciplinaire zaken" en "beroep in cassatie", het openbaar ministerie het concluderen op facultatieve basis kan uitoefenen. ${ }^{221}$

De bevoegdheid een conclusie in een civiele procedure te nemen, is door artikel 324 lid 1 sub a Rv beperkt tot bepaalde onderwerpen. In de literatuur lopen de meningen uiteen over het antwoord op de vraag of op grond van artikel 324 lid 1 sub a Rv de bevoegdheid tot het nemen van een conclusie beperkt blijft tot de in dat artikellid genoemde onderwerpen dan wel of het openbaar ministerie, indien het zulks wenselijk zou achten, ook in andere civielrechtelijke zaken ongeacht het onderwerp zou kunnen concluderen. ${ }^{22}$

\footnotetext{
${ }^{218}$ Van Dullemen, p. 163, spreekt over "een veertiental gevallen"; Lucas, p. 133, over "vele gevallen". 219 Zie o.m. Hugenholtz/Heemskerk, p. 40; Polenaar, p. 31; Verpaalen, WPNR 1990, nr. 5950, p. 125.

${ }^{220}$ Naast art. 18 lid 1 RWN kan worden gewezen op art. 785 Rv; art. 4 en 10 lid 5 Faillissementswet; art. $63 \mathrm{a}$ en 65 lid $4 \mathrm{WvK}$.

z2. Vgl. losbl. uitgave BRv., art. 324, aant. 2 en 4; Van Rossem/Cleveringa, art. 324 Rv, aant. 2, i.h.b. noot 1 .

$22 \mathrm{Zie}$ voor de mening dat het OM niet die vrijheid heeft: losbl. uitgave BRv. aant. 2 bij art. $324 \mathrm{Rv}$; Van Rossem/Cleveringa, art. $324 \mathrm{Rv}$, aant. 2. Tot een tegenovergestelde mening hieromtrent komt A.G. Berger in zijn conclusie bij HR 31.01.1975, NJ 1976, nr. 146; deze laatste visie wordt eveneens vertolkt door Lucas, p. 133 en 134.
} 
Onder de onderwerpen die artikel 324 lid $1 \mathrm{Rv}$ noemt, valt "den staat der personen, de aanvullingen en verbeteringen der akten van den burgerlijken stand" (art. 324 lid 1 sub a, onder $2^{\circ} \mathrm{Rv}$ ). Dit maakt het mogelijk dat (los van de hieronder aan de orde gestelde artikel $17 \mathrm{RWN}$-procedure) in zaken betreffend "den staat der personen" waarin de nationaliteit een rol speelt het openbaar ministerie op eigen initiatief voor de burgerlijke rechter een conclusie kan nemen. Dit betekent dat in een civielrechtelijke "impliciete vaststellingsprocedure" het nemen van een conclusie door het openbaar ministerie tot de mogelijkheid behoort. ${ }^{223}$

Naar inhoud is de conclusie in de literatuur op het terrein van het burgerlijk procesrecht van oudsher omschreven als een juridisch advies ter zake van het OM aan de rechter. ${ }^{224}$ De positie die het openbaar ministerie daarbij in de procedure inneemt, wordt wel enigszins onzorgvuldig omschreven als "het openbaar ministe-

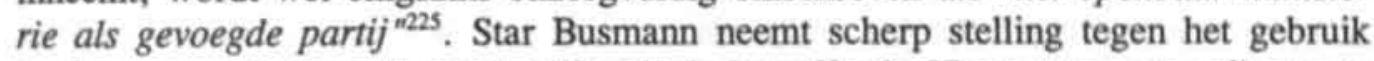
in dezen van de term "partij". Hij stelt desbetreffend: "De vertegenwoordiger van het O.M. is concluderende niet partij: met de partijen treedt hij dus niet in debat. "226 Onder andere de behartiging van het algemeen belang is één van de doelstellingen die het openbaar ministerie richting geeft bij het nemen van een conclusie. ${ }^{27}$ Het $\mathrm{OM}$ behartigt met zijn conclusie dan wel het algemeen belang, maar, zoals uit de bespreking van de hieronder volgende rechtspraak inzake de vaststelling van het Nederlanderschap zal blijken, behartigt het OM geen partijbelang, ook al is incidenteel een partij, verweerder of belanghebbende in het geding tot wiens doelstelling ook de behartiging van het algemeen belang behoort.

Redelijk snel na de wetswijziging in 1933 is het aantal conclusies dat wordt genomen drastisch verminderd. ${ }^{228}$ Van het feit dat sindsdien in deze situatie geen verandering is opgetreden, getuigt de aantekening dienaangaande in de losbladige uitgave Burgerlijke Rechtsvordering, waarin voor de huidige tijd wordt gesteld: "Een en ander heeft tot gevolg gehad dat, anders dan in cassatie, de conclusies nagenoeg geheel in onbruik zijn geraakt". ${ }^{29}$ Van Rossem/Cleveringa noemt de

\footnotetext{
23 Met inachtneming van de uitzonderingen die Van Rossem/Cleveringa noemen in art. $324 \mathrm{Rv}$, aant. 3.

$224 \mathrm{Vgl}$. Corstens/Tak, p. 148; Hardenberg, NJB 1961, p. 291 en 295; Hugenholtz/Heemskerk, p. 41; Pieterman, p. 187; Rutgers, p. 37; losbl. uitgave BRv., art. 324 Rv, aant. 3; A.-G. Ten Kate spreekt in zijn conclusie bij HR 25.05.1984, NJ 1984, nr. 737 over "neutrale voorlichting van de rechter"; Polenaar, p. 31: "onafhankelijk advies"; Van Rossem/Cleveringa, aant. 1 bij art. 323 Rv: "onpartijdig advies"; Star Busmann, p. 41: "bovenpartijdig wetenschappelijk betoog".

$23 \mathrm{Vgl}$. Corstens/Tak, p. 146, die tevens uitleggen dat de term "gevoegde partij" niet correct is. Zie tevens Van Rossem/Cleveringa, aant. 1 bij art. 323 Rv; idem Rutgers, p. 38.

226 Star Busmann, p. 238.

22 Zie Struycken, p. 21.

228 Polenaar, p. 32.

229 Losbl. uitgave BRv., art. 322 , aant. 1.
} 
conclusies in feitelijke instantie "zeer zeldzaam". ${ }^{230}$ Wat betreft de toepassing van artikel $324 \mathrm{Rv}$ is Gras onlangs zelfs zover gegaan dat hij stelt dat in feitelijke instantie van de in het artikel geboden mogelijkheid (tot concluderen) geen gebruik pleegt te worden gemaakt. ${ }^{231}$ Getuige hetgeen hieronder volgt aangaande de Rijkswet op het Nederlanderschap blijkt dat, wat dit betreft, Gras zich vergist.

\subsubsection{Rijkswet op het Nederlanderschap}

Ingevolge artikel 18 lid 1 Rijkswet op het Nederlanderschap wordt het openbaar ministerie verplicht gehoord door zowel de rechtbank te Den Haag als het Gemeenschappelijk Hof van Justitie. Als redengeving voor de verplichting het openbaar ministerie te horen, laat de memorie van Antwoord niets anders weten dan dat: "Daardoor is verzekerd dat -zo nodig- het oordeel van de administratie tot gelding kan komen. "1232

In het bijzonder gedurende de eerste tijd na de inwerkingtreding van de "zelfstandige vaststellingsprocedure" heeft de rechtbank te Den Haag uitgebreide overwegingen gewijd aan de taak en de positie van het openbaar ministerie in de procedure. De rechtbank heeft in haar eerste beschikkingen op grond van de Rijkswet op het Nederlanderschap vrijwel zonder uitzondering de volgende overweging kenbaar gemaakt: "Het openbaar ministerie beschouwt zich niet als procesvertegenwoordiger van de Staat, welke opvatting door de rechtbank wordt gedeeld, mede omdat zij past in de in het burgerlijk procesrecht algemeen aanvaarde opvatting omtrent de procesvertegenwoordiging van de Staat en in het kader van artikel 18 van de Rijkswet op het Nederlanderschap waarin beroep in cassatie niet wordt opengesteld voor het openbaar ministerie. " 233 Geheel in deze lijn is tevens een keer overwogen dat: "De officier van justitie, die ten deze niet als vertegenwoordiger van de

\footnotetext{
${ }^{230}$ Van Rossem/Cleveringa, aant. 1 bij art. 322 Rv. Vgl. ook Coops, p. 19; idem Van Dullemen, p. 163; Den Hartog Jager, p. 116; Rutgers, p. 41; Star Busmann, p. 41; Veegens/Korthals Altes/Groen, p. 277.

${ }^{231}$ Gras, p. 47.

232 Bijl. II. 82-83, 16947, nr. 7, p. 33. Deze passage uit de MvA is door Jessurun d'Oliveira, NJB 1983, p. 1309, als volgt geīnterpreteerd: "De rechtbank 'hoort' het openbaar ministerie, dat aldus, net als in aanhangige zaken het oordeel, het advies, van de minister kan laten doorklinken." Dezelfde auteur in gelijke zin tevens in AA 34(1985), p. 214.

${ }^{23}$ Deze formulering is standaard gehanteerd, men vindt haar 0. a. in de beschikkingen van de rechtbank 's-Gravenhage d.d.: 27.05.1987, rkstnr. 86.2446; 27.05.1987, rkstnr. 87.5021; 24.06.1987, rkstnr. 87.5002; 24.06.1987, rkstnr. 86.2266 (= HR 04.03.1988, NJ 1989, nr. 875, m.nt. EAA); 27.05.1987, rkstnr. 86.2775 (= HR 04.03.1988 NJ 1989, nr. 627, m.nt. GRdG); en twee tussenbeschikkingen van 18.05.1987, rkstnrs. 87.5387 en 87.5299 (deze laatste beschikking is gepubliceerd in MR 1987, nr. 50 en leidde tot HR 04.03.1988, NJ 1989, nr. 628, m.nt. GRdG).
} 
Staat kan worden beschouwd, maar die gelet op art. 18 Rijkswet op het Nederlanderschap in deze procedure een zelfstandige positie bekleedt, (....). ${ }^{1234}$

Met deze overwegingen treedt derhalve een discrepantie aan het licht tussen de visie van de wetgever en de rechter ter zake van de positie die het openbaar ministerie inneemt in de "zelfstandige vaststellingsprocedure". Uitsluitsel ter zake van dit verschil in inzicht is uiteindelijk gegeven door de Hoge Raad. In cassatie sluit de Hoge $\operatorname{Raad}^{235}$ zich aan bij de zienswijze van de rechtbank en stelt: "Het Openbaar Ministerie wordt gehoord, maar is noch vertegenwoordiger van de Staat noch belanghebbende (...)." Hiermee maakt de Hoge Raad ondubbelzinnig duidelijk dat het $\mathrm{OM}$ geen procespartij ${ }^{236}$ is, noch optreedt in de hoedanigheid van "procesvertegenwoordiger van de staat". 237

De Hoge Raad gaat bovendien in zijn uitspraak in op de hierboven geciteerde passage uit de memorie van Antwoord en stelt daartegenover: "Wat er ook verder zij van de in het citaat voorgestelde mogelijkheden om het standpunt van de Staat ter kennis van de rechter te brengen, zij zijn in ieder geval ontoereikend te achten."

Ook A.-G. Mok is in zijn conclusie bij de hierboven aangehaalde uitspraak van de Hoge Raad ingegaan op de in de memorie van Antwoord aldus gepretendeerde aanwijzingsbevoegdheid van de administratie. Eerst wijst de A.-G. erop dat, buiten cassatie, in civiele zaken een conclusie van het openbaar ministerie zeer zelden voorkomt. ${ }^{238}$ Vervolgens merkt de A.-G. op dat hem daarbij geen gevallen bekend zijn waarin het $\mathrm{OM}$ in opdracht van het bestuur ("de administratie") een bepaald standpunt heeft ingenomen.

In de idee dat "de administratie" via de conclusie van de officier van justitie "-zo nodig- zijn oordeel tot gelding kan brengen" valt een verwijzing te lezen naar artikel 5 Wet RO. Dit artikel gebiedt de leden van het openbaar ministerie "de bevelen na te komen, welke hun in hun ambtsbetrekking door de daartoe bevoegde macht, vanwege de Koning, zullen worden gegeven." Met "de bevoegde macht" wordt verwezen naar de minister van Justitie. ${ }^{239}$ Artikel 5 Wet RO, dat in ongewijzigde vorm uit 1827 stamt, maakt, door zijn ruime bewoording, geen onderscheid tussen de strafrechtelijke en de civielrechtelijke activiteiten van het openbaar ministerie.

\footnotetext{
${ }^{24}$ Rb. 's-Gravenhage 18.03.1987, rkstnr. 86.2159 (= HR 04.03.1988, NJ 1989, nr. 626, m.nt. GRdG).

${ }^{235}$ HR 04.03.1988, NJ 1989, nr. 628, m.nt. GRdG.

$236 \mathrm{Vgl}$. tevens A.-G. Ten Kate in zijn conclusie bij HR 25.05.1984, NJ 1984, nr. 737.

${ }^{27} \mathrm{Vgl}$. Struycken, p. 24, die schrijft: "Het $O M$ is niet meer de vertegenwoordiger ten processe van de Staat, en nauwelijks nog van de Koningin, Rv. art. 6."

${ }^{238}$ Hetgeen overeenstemmend is met hetgeen door de losbladige uitgave Burgerlijke Rechtsvordering en Van Rossem/Cleveringa desbetreffend is opgemerkt. Zie voetnoten 229 en 230.

299 Duisterwinkel, p. 5; Hugenholtz/Heemskerk, p. 40; Stein, p. 34
} 
Van Dullemen is van mening dat het oorspronkelijke uitgangspunt met betrekking tot artikel 5 Wet RO is geweest dat het van toepassing is op zowel het strafrechtelijk requisitoir als op de conclusie in civilibus. Hij komt derhalve tot de gevolgtrekking dat ook met betrekking tot civielrechtelijke zaken instructies van de minister van Justitie aan het OM niet onmogelijk zijn. ${ }^{240} \mathrm{Hij}$ merkt hierover op: "Ofschoon hij ${ }^{24 I}$ de civiele procedure geheel overliet aan de procederende partijen en aan het oordeel van de geheel onafhankelijke civiele Rechter, achtte hij in sommige civiele zaken het toch nodig de mening der Regering te kunnen doen horen in die procedure, en om die mening te kunnen doen horen maakte hij gebruik van zijn ,,agent" of zaakwaarnemer van het Staatsbelang bij de zittende magistratuur het O.M.-.

Enige jaren later volgt Duisterwinkel hem in deze visie. ${ }^{243}$ Van Dullemen en Duisterwinkel hebben ongetwijfeld, historisch gezien, het gelijk aan hun kant gehad. $^{244}$ Vooral het uitgebreide onderzoek naar de parlementaire geschiedenis van artikel 5 Wet RO door Van Dullemen toont dit, naar mijn mening, duidelijk aan.

Van Dullemen laat echter tevens zien dat artikel 5 Wet RO in civielrechtelijk opzicht nooit enige praktische betekenis heeft gekregen, want, net zo goed als later A.-G. Mok in verband met de hierboven besproken beschikking van de Hoge Raad zal vermelden dat hem zulke gevallen niet bekend zijn, wijst Van Dullemen erop "dat zulke vergaande "bevelen" -tot op heden- (.......) nimmer in ons land werden gegeven! ${ }^{\text {m245 }}$

Uit het bovenvermelde volgt dat de rechtsontwikkeling derhalve zodanig is geweest dat ten aanzien van civielrechtelijke conclusies vanuit "de administratie", bijvoorbeeld het ministerie van Justitie, nooit is overgegaan tot het geven van hetzij algemene, beleidsmatige hetzij concrete aanwijzingen. Hoe zou dit ook zijn te rijmen met de communis opinio sedert lang dat de conclusie een bovenpartijdig juridisch advies behoort te zijn?

Het moge duidelijk zijn dat het uitgangspunt uit het begin van de vorige eeuw, zoals dat is neergelegd in artikel 5 Wet RO, inhoudende dat in het geval het openbaar ministerie wordt gehoord door de rechter het OM kan worden beschouwd

\footnotetext{
${ }^{240}$ Van Dullemen, p. 150 en 163.

${ }^{241}$ Bedoeld is de wetgever.

242 Van Dullemen, p. 163.

${ }^{243}$ Duisterwinkel, p. 6. Duisterwinkel meent dat de OvJ de rechter kan inlichten hoe de overheid "de interpretatie van een al dan niet op het te berechten geval toe te passen bepaling ziet en welke argumenten daartoe kunnen worden aangevoerd. " Dit betekent derhalve wel het verschaffen van een juridisch advies aan de rechter, met de aantekening dat het gaat om een de OvJ voorgekauwd advies. Dit is, mijns inziens, niet bedoeld door de wetgever met art. 18 lid $1 \mathrm{RWN}$ en de uitleg daarbij in de MvA.

$24 \mathrm{Vgl}$. ook Mosterd, p. 295; Pieterman p. 40-44; Struycken, p. 24.

245 Van Dullemen, p. 150; vgl. echter voor het midden van de 19 e eeuw Bruinsma, p. 30 en Pieterman, p. 187 (i.h.b. voetnoot 7).
} 
als vertegenwoordiger van de Staat, waaraan naar believen door de minister van Justitie opdrachten kunnen worden verstrekt, niet levensvatbaar is gebleken.

Niettemin steekt het verschijnsel af en toe toch de kop weer op. Het misverstand dat het $\mathrm{OM}$, indien het wordt gehoord, optreedt als procesvertegenwoordiger of in ieder geval als belangenbehartiger van de Staat blijkt een taai bestaan te hebben. ${ }^{246}$ Daarentegen heeft Meijers in een artikel, gewijd aan het functioneren van het $\mathrm{OM}$ in zowel straf- als civiele zaken, benadrukt dat "de vertegenwoordiger van het $O M$ bij de behandeling van het geding onpartijdig is, dat wil zeggen, niet gebonden aan enig particulier belang of één bepaald overheidsbelang (daarom mag in een civiele procedure de Staat zijn belang niet door de officier van justitie als goedkope landsadvokaat laten behartigen (....). " 247

Op hetgeen in de hierboven behandelde beschikking in het kader van de "zelfstandige vaststellingsprocedure" door de Hoge Raad is gesteld, lijken de rechtsontwikkeling sinds de vorige eeuw en de door Meijers uitgedragen visie aan te sluiten. In de opvatting van de Hoge Raad is het duidelijk niet zo dat het openbaar ministerie, indien het wordt gehoord inzake kwesties over het Nederlanderschap, de visie daaromtrent van de minister van Justitie weergeeft. Het lijkt zelfs dat de Hoge Raad een dergelijke gang van zaken volstrekt onmogelijk acht.

Met betrekking tot de conclusie in feitelijke instantie in de "zelfstandige vaststellingsprocedure" is voorts nog vermeldenswaardig dat het in het geval van artikel 18 RWN gaat om een bepaling ten aanzien ingevolge artikel 324 lid 2 Rv geldt, dat het nemen van een conclusie voor het openbaar ministerie facultatief is. Dit betekent dat het $\mathrm{OM}$ in een artikel $17 \mathrm{RWN}$-procedure kan afzien van concluderen.

Het blijkt overigens uit de aan dit onderzoek ten grondslag liggende beschikkingen dat het openbaar ministerie altijd een conclusie heeft genomen. Ook blijkt dat de rol van het openbaar ministerie in de "zelfstandige vaststellingsprocedure" de laatste tijd in toenemende mate marginaliseert. Anders dan in de periode dat de "zelfstandige vaststellingsprocedure" nog in de kinderschoenen stond en waarin bij de beschikkingen altijd een schriftelijke conclusie is gevoegd, blijkt dat na verloop van tijd het $\mathrm{OM}$ incidenteel, maar wel in toenemende mate, ook mondeling conclusie neemt. ${ }^{248}$ Het marginale gehalte van de rol die het $\mathrm{OM}$ inmiddels

\footnotetext{
${ }^{266}$ Bijv. Princen, p. 67, is van mening: "(.....), dat het Openbaar Ministerie niet gehoord dient te worden in het civiele proces, wanneer de Staat geen partij is, zodat dienovereenkomstig de artt. 322-328 $R v$ geschrapt dienen te worden. "

207 L.C.M. Meijers, RMTh 1991, p. 173.

${ }^{248}$ Bijv. Rb. 's-Gravenhage 04.11.1992, rkstnr. 91.5105: dat de officier mondeling heeft geconcludeerd tot afwijzing van het verzoek is in de beschikking vermeld (zonder de overwegingen van de officier ten aanzien van de zaak daarbij te vermelden). Uit Rb. 's-Gravenhage 08.12.1993, rkstnr. 93.5506, B\&R 1994 , p. 144; Rb. 's-Gravenhage 29.12.1993, rkstnr. 93.5525, B\&R 1994, p. 145; Rb. 's-Gravenhage 29.12.1993, rkstnr. 93.5589. B\&R 1994, p. 145; Rb. 's-Gravenhage 29.12.1993, rkstnr. 93.5529.
} 
inneemt in de actie tot vaststelling van het Nederlanderschap blijkt eveneens uit het feit dat in de conclusie de officier van Justitie nog nooit iets anders heeft gedaan dan zich aansluiten bij "het standpunt dat de Staat naar voren heeft gebrccht" en "te concluderen tot afwijzing van het verzoek". 249 In gevallen waarin wezenlijke inbreng van het OM ontbreekt, is het naar mijn mening zinvoller incien het openbaar ministerie afziet van het nemen van een conclusie.

\subsubsection{Onderzoek der feiten en bewijsmiddelen door het openbaar ministerie}

\subsubsection{Algemene beschouwingen}

Zoals in het bovenstaande betoog naar voren is gekomen, dient volgens algemeen inzicht de conclusie van de officier van Justitie naar inhoud een onpartijdig juridisch advies aan de rechter te zijn. Een volgend uitgangspunt met betrekking tot de conclusie is dat deze in beginsel wordt geschreven op basis van door partijen overgelegde feiten.

Het komt echter in de praktijk soms voor dat de conclusie een ander karakter krijgt doordat het openbaar ministerie enerzijds zelfstandig een onderzoek naar de gestelde feiten verricht dan wel anderzijds geheel nieuwe feiten naar voren brengt in plaats van zich te beperken tot het formuleren van een oordeel over de reeds door partijen in het geding gebrachte gegevens. ${ }^{250}$

Over het verwerken in de conclusie van gegevens die niet zijn aangevoerd door de partijen, maar die op eigen initiatief van het $\mathrm{OM}$ in het geding worden gebracht, oordeelt Hardenberg in 1961 dat in zo'n geval de "(....) conclusie moet dienen tot een ander doel dan de wet veronderstelt, (.......). ${ }^{m 251}$ In verband hiermee zal verderop blijken dat inderdaad de artikelen 322-328 Rv, gezien de doelstelling in de wet, niet zijn geëquipeerd voor de situatie waarin het $\mathrm{OM}$ zelfstandig feiten bijbrengt. Behoudens het recht uit artikel 328 lid $2 \mathrm{Rv}$ kunnen namelijk volgens de wet na de conclusie van het OM de partijen, de verzoeker of de verweerder/belang-

\section{$248 \rightarrow$}

B\&R 1994, p. 145; Rb. 's-Gravenhage 29.12.1993, rkstnr. 93.5588, B\&R 1994, p. 112 en 145 blijkt evenwel niet dat de conclusie (tot niet-ontvankelijkheid) mondeling tot stand is gekomen, maar is mij dat medegedeeld op de griffie van de rechtbank. Voorts Rb. 's-Gravenhage 09.03.1994, rkstnr. 93.6181 (= HR 16.09.1994, NJ 1995, nr. 563, m.nt. GRdG); HR 28.10.1994, rkstnr. 8487 (ongepubliceerd); HR 11.11.1994, NJ 1995, nr. 100.

${ }^{249}$ Bijv. HR 11.11.1994, NJ 1995, nr. 100.

${ }^{250}$ Zie bijv. Hof 's-Hertogenbosch 17.03.1959, NJ 1959, nr. 656: om in een echtscheidingszaak de bevoegdheid van de Nederlandse rechter te creëren, stelt eiseres dat beide partijen Nederlander zijn. Het OM informeert de rechtbank echter, zonder in de zaak te concluderen, maar door overlegging van stukken(!), dat de man, woonachtig in Duitsland, staatloos is.

${ }^{251}$ Hardenberg, NJB 1961, p. 292. Idem Gras, p. 48. 
hebbende in het geding niet meer aan het woord komen. ${ }^{252}$ Ten aanzien van dit wettelijk stelsel is echter sinds enige jaren sprake van een aanvullende regel. Naar aanleiding van rechtspraak van het Europese Hof voor de rechten van de mens ${ }^{253}$ is inmiddels het recht van partijen een reactie te geven op de conclusie van het openbaar ministerie erkend. ${ }^{254}$

Bij de eerdervermelde visie van Hardenberg uit 1961 sluit Verpaalen zich in 1990 tot op zekere hoogte aan. Hoewel in het civiele proces het openbaar ministerie volgens Verpaalen niet de taak heeft de rechter of de partijen ter wille te zijn door middel van het aanleveren van bewijsmateriaal, maakt hij voor de verzoekschriftprocedure op dit beginsel een uitzondering. ${ }^{255}$

Op deze uitzonderingspositie van de verzoekschriftprocedure is eerder al door Struycken gewezen. ${ }^{256}$ Daarbij benadrukt Struycken ten zeerste dat in zodanige procedures vaak rechtsgevolgen die niet ter vrije beschikking staan van de betrokkenen aan de orde zijn. In het geval dat een rechtsgevolg aan de orde is dat niet ter vrije beschikking staat van het rechtssubject, en het bezit van een nationaliteit is daarvan een voorbeeld, is een intensievere bemoeienis van de rechter en het openbaar ministerie met de zaak gerechtvaardigd. Struycken maakt een vierdeling in de civiele werkzaamheden van het openbaar ministerie. In het geval dat het OM de rechter inlichtingen over feiten verschaft, acht hij de artikelen 327 en $328 \mathrm{Rv}$ niet van toepassing. Het wel toepassen van deze artikelen is volgens Struycken in strijd met de goede procesorde, aangezien de partijen dan niet kunnen reageren op de door het openbaar ministerie overgelegde informatie.

Hier wordt de essentie van de opmerking eerder door Hardenberg gemaakt duidelijk: het blijkt dat de wet geen regeling kent voor de gevallen waarin het openbaar ministerie door middel van zijn conclusie nieuwe feiten in het geding brengt, omdat dit niet het doel van de conclusie is geweest. Met betrekking tot de artikelen 327 en $328 \mathrm{Rv}$ is het zonder twijfel dat daarmee is gedoeld op de situatie waarin het $\mathrm{OM}$ concludeert, ten eerste op grond van hetgeen partijen hebben aangevoerd (en overgelegd) en, ten tweede op het moment dat de zaak in staat van wijzen is. ${ }^{257}$ Op dat moment dient het openbaar ministerie een conclusie, van onpartijdige en adviserende aard, op te stellen aan de hand van de tot dusverre in het geding gebrachte gegevens. ${ }^{258} \mathrm{Bij}$ een zodanige gang van zaken zijn de artikelen 327 en $328 \mathrm{Rv}$ niet alleen zinvol, maar ontstaat er ook geen tegenspraak

\footnotetext{
${ }^{252} \mathrm{Vgl}$. Gras, p. 48.

${ }^{253}$ Eur. Court H. R., Borgers judgement of 30 October 1991, Series A no. 214-B, p. 24-73.

234 Zie NJB 1992, p. 1191.

2ss Verpaalen, WPNR 1990, nr. 5950, p. 128. Zie tevens par. 3.2.2.

236 Struycken, HPS 1976 , p. 82-85.

2ร Vgl. Hardenberg, NJB 1961, p. 294; idem de conclusie van A.-G. Berger bij HR 31.01.1975, NJ 1976, nr. 146 en de conclusie van A.-G. Ten Kate bij HR 25.05.1984, NJ 1984, nr. 737; Gras, p. 48. $25 \mathrm{Vgl}$. Star Busmann, p. 238.
} 
Hoofdstuk 2

met een beginsel van goede procesorde, zoals het beginsel van hoor en wederhoor. ${ }^{259}$

\subsubsection{Rijkswet op het Nederlanderschap}

Ook met betrekking tot de procedure uit artikel 17 Rijkswet op het Nederlanderschap geldt dat het $\mathrm{OM}$ aangaande het verzoekschrift in beginsel in de conclusie een onafhankelijk, onpartijdig juridisch advies geeft (schriftelijk of mondeling) omtrent de gegrondheid van het verzoek. Dit gebeurt dan aan de hand van het door de verzoeker ingediende verzoekschrift, de eventueel daarbij geleverde bescheiden en het behandelde ter zitting.

Evenwel heeft in het verleden de activiteit van het openbaar ministerie zich in de "zelfstandige vaststellingsprocedure" niet beperkt tot het formuleren van (slechts) een juridisch advies ter zake aan de rechter. Het OM heeft zich, vooral in de periode dat de vaststellingsprocedure net in werking was getreden, tevens beziggehouden met het opsporen van rechtens relevante gegevens.

Vooropgesteld zij echter dat in de meerderheid van de conclusies in het kader van artikel $17 \mathrm{RWN}$-zaken het openbaar ministerie zich terughoudend opstelt en het verzoekschrift slechts bespreekt in het licht van de daarbij (al of niet) aangeleverde bewijsstukken. Slechts een enkele keer in het verleden heeft het OM een feitenonderzoek ingesteld. ${ }^{260}$ Worden de twaalf in dit onderzoek opgenomen beschikkingen terzijde gelaten waarin het $\mathrm{OM}$ tot niet-ontvankelijkheid van de verzoeker concludeert, dan resteren tweeënveertig eindbeschikkingen ten aanzien waarvan het openbaar ministerie een op de zaak toegespitste, inhoudelijke, conclusie geeft. Onder deze tweeënveertig beschikkingen blijken er vijf te zijn waarin het openbaar ministerie in de zaak een feitenonderzoek heeft geïnitieerd. ${ }^{261}$ Zoals hierboven reeds is aangestipt, betreft het hier bovenal beschikkingen uit de aanloopfase van de "zelfstandige vaststellingsprocedure".

\footnotetext{
${ }^{29}$ Zie voetnoot 263

200 Zie bijv, de conclusies bij Rb. 's-Gravenhage 27.05.1987, rkstnr. 86.2446; Rb. 's-Gravenhage 15.07.1987, rkstnr. 86.2117 en Rb. 's-Gravenhage 10.02.1988, rkstnr. 87.5387 (= HR 04.11.1988, NJ 1989, nr. 100, m.nt. WHH). Vgl. tevens de opmerking van de rechtbank: "Blijkens door de officier van justitie ingewonnen informatie (...)" in Rb. 's-Gravenhage 25.05.1988, rkstnr. 87.5994. Zo ook de opmerking van de rechtbank: "Blijkens door de officier van Justitie bij zijn conclusie overgelegde brief van het Ministerie van Buitenlandse Zaken", vermeld in HR 28.09.1990. NJ 1991, nr. 293, m.nt. GRdG.

261 De 37 resterende gevallen waarin het OM zonder meer concludeert, zijn te verdelen in een groep met een conclusie die toewijzing direct gegrond acht (1 geval: zie daarover uitgebreider par. 3.3.4.4.4) en een groep met een conclusie die toewijzing van het verzoekschrift direct afraadt ( 36 gevallen).
} 
Daarnaast is het voorgekomen dat het OM naar aanleiding van een verzoek van de kant van de rechtbank overgaat tot het instellen van een onderzoek naar de authenticiteit van door de verzoeker aangeleverde bewijsstukken. ${ }^{262}$

In het geval dat als gevolg van gegevensvergaring door het openbaar ministerie nieuwe informatie in het geding is gebracht, dan dient, alvorens een beslissing valt, eerst de verzoeker in de gelegenheid te worden gesteld een reactie op de informatie te kunnen geven. Deze gedragsregel vloeit voort uit het beginsel van hoor en wederhoor; één van de algemeen erkende beginselen van behoorlijke procesvoering. ${ }^{263}$ Het beginsel van hoor en wederhoor bepaalt dat partijen hun mening kenbaar moeten kunnen maken over aan de rechter ter beschikking staande stukken. ${ }^{264}$ Het doel van het beginsel is te voorkomen dat de beslissing wordt genomen op grond van gegevens waarop de procespartijen niet hebben kunnen reageren. ${ }^{265}$

Wegens schending van het beginsel van hoor en wederhoor heeft de Hoge Raad enkele jaren geleden een beschikking krachtens artikel 17 RWN gecasseerd. ${ }^{266}$ Daarbij was de grond tot cassatie gelegen in het feit dat de rechtbank te Den Haag de door middel van de conclusie ingebrachte inlichtingen van het $\mathrm{OM}^{267}$ zonder meer (mede) tot grondslag voor haar overwegingen had genomen.

Het gaat in deze aangelegenheid niet zozeer om het gebruik van de ingebrachte gegevens op zich, als wel om het gebruik ervan zonder de partij in de gelegenheid

\footnotetext{
${ }^{262}$ HR 31.01.1992, NJ 1993, nr. 261, m.nt. GRdG.

${ }^{263}$ Hugenholtz/Heemskerk, p. 9; Stein, p. 18; Struycken, p. 39. Schaafsma-Beversluis, p. 292, stelt terecht dat dit beginsel evenzeer zonder beperkingen van toepassing is in verzoekschriftprocedures; idem Asser (I), p. 5 en Snijders, p. 59. Al in 1962 noemt Ten Kate, p. 46 "hoor en wederhoor" een regel die in het procesrecht "van groot belang wordt geacht".

${ }^{264} \mathrm{Vgl}$. Bosch-Boesjes, p. 177.

${ }^{265}$ De tegenovergestelde situatie, namelijk dat de verzoeker na de (laatste) mondelinge behandeling aanvullende gegevens overlegt, is ook voorgekomen. In dat geval heeft de OvJ in een akte blijk gegeven van de volgende visie: "Aangezien de \{bewijsmiddelen\} na afloop van de door uw Rechtbank op 20.01.1988 vastgestelde behandeling van de zaak zijn ingekomen -en mitsdien geen onderwerp van discussie ter openbare terechtzitting kunnen zijn- is het Openbaar Ministerie van oordeel dat op deze stukken geen acht meer kan worden geslagen." Aan deze bezwaren van de OvJ gaat de rechtbank voorbij en stelt op grond van de na de behandeling aangeleverde gegevens het bezit van de Nederlandse nationaliteit door de verzoekster vast. Rb. 's-Gravenhage 27.04.1988, rkstnr. 87.5416 (zie ook par. 3.3.4.4.3).

Heemskerk stelt in zijn annotatie onder HR 04.11.1988, NJ 1989, nr. 100, dat het recht op "hoor en wederhoor" slechts voor partijen geldt. Het $\mathrm{OM}$ is geen partij in de "zelfstandige vaststellingsprocedu$\mathrm{re}^{\text {"; }}$ want het $\mathrm{OM}$ is geen partij indien het in een civiele procedure wordt gehoord, vgl. Rutgers, p. 38 (i.h.b. voetnoot 81) en hierboven par. 2.3.1.

${ }^{266}$ HR 04.11.1988, NJ 1989, nr. 100, m.nt. WHH (zie ook par. 3.3.4.4.2).

$\mathrm{V}$ gl. Rb. 's-Gravenhage 29.06.1988, rkstnr. 87.5994 voor een zelfde gebruik van de conclusie door de rechtbank.

${ }^{267}$ Overigens een conclusie die 6 maanden op zich heeft laten wachten! Het zal duidelijk zijn dat de onderzoeksactiviteiten van het OM de nodige tijd in beslag kunnen nemen.
} 
te hebben gesteld een reactie te geven. ${ }^{268}$ Ook na de hierboven beschrven uitspraak van de Hoge Raad is de rechtbank in de "zelfstandige vaststellingrocedure" gebruik blijven maken van door het OM ná de zittingsdag aaneleverde informatie, maar stelt de verzoeker, tot tweemaal toe zelfs, in de gelegeheid op die informatie te reageren. ${ }^{269}$

\subsection{De toepasselijkheid van de artt. 429d, 429f-429l en 429s-429t Wetioek van Burgerlijke Rechtsvordering (art. 18 lid 1 RWN)}

\subsubsection{Algemene beschouwingen}

Op het geding in feitelijke instantie dat plaatsvindt in Nederland verklaart rtikel 18 lid 1 Rijkswet op het Nederlanderschap enkele artikelen uit de twaalfdetitel van Boek I van het Wetboek van Burgerlijke Rechtsvordering van toepasing. De desbetreffende titel, over "de rechtspleging in zaken die met een verzekschrift worden ingeleid", ${ }^{270}$ is slechts gedeeltelijk van toepassing verklaard ten einde te kunnen aansluiten bij dẻ specifièkè eis̉en van dẻ vaststeliîngsprocedưre bij de Haagse rechtbank. ${ }^{271}$ Dat op de "zelfstandige vaststellingsprocedure" deze artikelen van toepassing zijn verklaard, volgt uit het streven van de wetgever om het procesrecht voor verzoekschriftprocedures waar mogelijk te harmoniseren. Dit geschiedt door, indien de desbetreffende materie geen uitzonderingen met zich brengt en zich verder daartoe leent, op zoveel mogelijk procedures de algemene regeling uit de artikelen $429 \mathrm{a}-429 \mathrm{r} \mathrm{Rv}$ van toepassing te verklaren. ${ }^{272}$

De meeste op het geding in eerste aanleg van toepassing verklaarde artikelen uit het Wetboek van Burgerlijke Rechtsvordering behoeven in het kader van de

${ }^{268} \mathrm{Vgl}$. Bosch-Boesjes, p. 163 en 164 . Zie voor een verzwaring van de eis tot hoor en wederhoor: HR 06.03.1992, NJ 1993, nr. 79, m.nt. HJS. En hoor en wederhoor betreffend inzake tijdens de mondelinge behandeling wel getoonde, maar niet eerder overgelegde bescheiden: HR 04.11.1994, NJ 1995, nr. 98.

${ }^{269}$ Zie Rb. 's-Gravenhage 11.10.1989, rkstnr. 89.5224 (= HR 28.09.1990, NJ 1991, nr. 293, m.nt. GRdG; MR 1991, 9, m.nt. H.A.A.).

${ }^{270}$ Zie voor verzoekschriftprocedures in het algemeen: Hugenholtz/Heemskerk, hoofdstuk VII; Stein, hoofdstuk 11; Losbladige uitgave Burgerlijke Rechtsvordering.

271 Tot op heden is bekend dat in de Nederlandse Antillen en op Aruba én zelfstandige vaststellingsprocedure is gevoerd. Zie de beschikking van het Gemeenschappelijk Hof d.d. 17.01.1990; gepubliceerd door Van Aller/Van Rijn, p. 596-598. De procesrechtelijke regels die volgens Van den Blink, p. 9, in zo'n geval van toepassing zouden zijn, zouden betreffen de derde titel van boek II Wetboek van Burgerlijke Rechtsvordering van de Nederlandse Antillen (RvNA): "Van de wijze van procederen voor het Hof van Justitie, rechtdoende in eerste aanleg"; waarover zij opmerkt: "een overigens vrijwel in onbruik geraakte rechtsgang". (Waarschijnlijk abusievelijk vermeldt de schrijfster boek II RvNA, dit moet zijn boek I RvNA). Ook Tillema/Tjittes, p. 96 (i.h.b. noot 9) melden dat de onderhavige procedure weinig toepassing vindt.

${ }^{272} \mathrm{Vgl}$. Bosch-Boesjes, p. 91; Gras, p. 196. 
procedure uit artikel 17 RWN geen nadere bespreking, aangezien zij in de "zelfstandige vaststellingsprocedure" niet anders functioneren dan in overige civiele procedures. ${ }^{273}$ Wel wordt in het navolgende aandacht besteed aan het onverwachte gevolg dat artikel $429 \mathrm{f} \mathrm{Rv}$ in het kader van de "zelfstandige vaststellingsprocedu$r e^{\prime \prime}$ bleek te hebben. De toepassing van artikel $429 \mathrm{f} \mathrm{Rv}$ heeft geleid tot boeiende cassatierechtspraak.

Deze jurisprudentie zal aan de orde komen in paragraaf 2.4.2.3. Het is naar aanleiding van de toepassing van artikel $429 \mathrm{f}$ Rv geweest dat A.-G. Mok tot de navolgende uitspraak is gekomen: "In de parlementaire stukken over het ontwerp$R N$ heb ik niets kunnen vinden over de betekenis van de van toepassing verklaarde artikelen uit de twaalfde titel van Boek I Rv. voor de onderhavige procedure. Het is niet duidelijk of men zich rekenschap heeft gegeven van alle implicaties, zoals die van de positie van de belanghebbenden volgens art. $429 f .{ }^{m 274}$

\subsubsection{De positie van de "belanghebbende" in verzoekschrifiprocedures (art. $429 \mathrm{f}$ $R v)$}

Veel rekestprocedures kennen uit de aard van de materie geen andere partij dan de verzoeker. ${ }^{275}$ Evenwel is van oudsher, afhankelijk van de onderhavige materie, ten aanzien van bepaalde verzoekschriftprocedures de vraag opgekomen of, ondanks het feit dat er bij de aanvang van de procedure slechts sprake is van een verzoeker, er toch niet een verweerder dan wel een belanghebbende bij de zaak dient te worden betrokken. ${ }^{276}$ Daarnaast komen verzoekschriftprocedures voor waarin wel zonder meer sprake is van twee partijen. ${ }^{277}$

\footnotetext{
${ }^{273}$ In de losbl. uitgave BRv., alg. bespreking van de $12 \mathrm{e}$ titel v. Boek I, aant. 77, wordt opgemerkt dat de expliciete van toepassing verklaring van de artt. $429 \mathrm{~s}$ en $429 t \mathrm{Rv}$ overbodig is, aangezien deze artikelen in iedere verzoekschriftprocedure gelden. Zie Boekman (II), p. 36; Hebly, WPNR 1991, nr. 6028 , p. 837; Snijders, p. 61 , i.h.b. noot 1.

${ }^{274}$ Conclusie bij HR 04.03.1988, NJ 1989, 628, m.nt. GRdG. Een opmerking van gelijke strekking maakt ook Van den Blink, p. 8.

${ }^{275}$ Zoals het verzoek tot wijziging van het vermelde geslacht in de geboorteakte (art. 1:29a BW), het verzoek van een minderjarige aan de kantonrechter tot vervangende toestemming voor het aangaan van een huwelijk (art. 1:36 jo. 1:39 BW); de literatuur noemt verder nog het verzoek tot benoeming van een voogd en adoptieverzoeken. Hiertegenover staan rekestprocedures waarbij, buiten de verzoeker, wel sprake is van een "wederpartij": bijv. de ontbinding van de arbeidsovereenkomst ingevolge art. 7A:1639w BW, het verzoek tot echtscheiding (vgl. art. $815 \mathrm{Rv}$ ) en levensonderhoud (artt. 798 e.v. Rv). Meer voorbeelden geeft Snijders, p. 58.

$276 \mathrm{Vgl}$. Boekman, p. 104, 112 e.v.; Haardt, p. 144; Ten Kate, p. 76; Meijknecht, oratie, p. 7; Polenaar, p. 137; Röder, p. 30; Zuidema, p. 67 en 93.

$2 \pi \mathrm{Vgl}$. de hierboven in voetnoot 275 genoemde verzoeken tot ontbinding van de arbeidsovereenkomst, echtscheiding en levensonderhoud.
} 
In verzoekschriftprocedures waarop de artikelen $429 a-429 r$ Rv van toepassing zijn, kent de verzoeker overigens niet eens de verplichting om in zijn verzoekschrift een eventuele wederpartij te vermelden. ${ }^{278}$ Tegenover deze wettelijke omissie staat dat in het algemeen voor verzoekschriftprocedures geldt dat de rechter wordt geacht ambtshalve tegen benadeling van eventuele belanghebbenden te waken. ${ }^{279}$ Hierin kan een aanwijzing worden gevonden van het, in beginsel, actievere optreden dat de rechter aan de dag legt in verzoekschriftprocedures in vergelijking met de dagvaardingsprocedure. ${ }^{280}$

Op grond van artikel $429 \mathrm{f}$ lid $1 \mathrm{Rv}$ kan de rechter gedurende de behandeling van de zaak "belanghebbenden, bekende of onbekende" oproepen. Een dergelijke oproeping door de rechter van een niet in het verzoekschrift bekendgemaakte belanghebbende heeft tot gevolg dat de verzoeker wordt geconfronteerd met een andere, soms onvermoede, ${ }^{281}$ procesdeelnemer, wiens inbreng de uitkomst van de procedure kan beïnvloeden. ${ }^{282}$ De "belanghebbende" tegen wie, in geval van toewijzing, hetgeen is verzocht zal gelden, wordt wel betiteld als de gerequestreerde of verweerder. ${ }^{283}$ In geval van toewijzing van het verzoek zal de juridische positie van de gerequestreerde of verweerder in die zin een verandering ondergaan dat hij in het vervolg gehouden kan worden aan de gegeven beschikking. Daarnaast kunnen in een verzoekschriftprocedure nog "overige belanghebbenden " voorkomen. Dezen hebben een verder verwijderd belang bij de zaak dan een verweerder en zij worden in de literatuur wel omschreven als "derden-belanghebbenden". ${ }^{284}$

Ten gevolge van de ambtshalve introductie in het geding door de rechter van een andere procesdeelnemer verandert het proces enigszins van karakter. Daarvan is met name sprake indien een gerequestreerde/verweerder door de rechter wordt opgeroepen. Röder heeft als één van de eersten onderkend dat door het aanwezig zijn van een gerequestreerde de procedure meer een contradictoir karakter krijgt. ${ }^{285}$ In de verhouding tussen de verzoeker en de belanghebbende(n) hoeft evenwel niet altijd sprake te zijn van een wederzijds elkaar tegensprekend belang (of belangen). Vooral ten opzichte van derden-belanghebbenden hoeft daarvan geen sprake te zijn.

${ }^{278}$ Snijders, p. 59; Stein, p. 165; Verhagen-Maat, p. 91; Wesseling-van Gent, p. 87. Het is in verzoekschriftprocedures van oudsher zo geweest dat, tenzij de wet anders aangaf, een eventuele wederpartij in het verzoekschrift niet behoefde te worden vermeld: vgl. Zuidema, p. 67.

279 Wesseling-van Gent, p. 94; Bijl. II. 1967, 7753, nr. 5, p. 4. Vgl. de opmerking van Röder, p. 30 : "De aan 'partijen' ontnomen invloed op den gang van zaken kan alleen maar aan de rechter ten deel vallen, die trouwens wel de meest geschikte persoon is om voor de vreemde belangen te waken."

${ }^{250} \mathrm{Vgl}$. Bosch-Boesjes, p. 94; Hugenholtz/Heemskerk, p. 137; Verhagen-Maat, p. 51; losbl. uitgave BRv., art. $429 f$, aant. 8.

$2 s 1 \mathrm{Vgl}$. Boekman, p. 112 en 113.

$282 \mathrm{Vgl}$. Gras, p. 7.

280 Coops, p. 303; Stein, p. 165.

$2 s 4$ Vgl. Rutgers, p. 8.

2ss Röder, p. 59. Zie ook Snijders/Ynzonides, NTBR 1995, p. 146; Veegens/Korthals Altes/Groen, p. 327. 
Indien tegenstrijdige belangen wel een rol spelen, kan al snel blijken dat het geding over een geschil tussen beide partijen gaat. Bij tegenstrijdige belangen is er namelijk in feite sprake van een geschil tussen de partijen, zo is Zuidema reeds van mening in $1917 .{ }^{286}$ Een tegenstrijdigheid in wederzijds belang zal eerder aan de orde zijn tussen de verzoeker en de belanghebbende die in de positie van verweerder wordt geplaatst. Maar ook in een zodanig geval hoeft dit niet noodzakelijk het geval te zijn. In de literatuur wordt wel gesteld: "Het onderscheid tussen tegenpartij (verweerder) en derde (belanghebbende) is niet altijd duidelijk te maken. ${ }^{287}$ Over de relatie tussen het kunnen worden aangemerkt als belanghebbende en het mogelijk bestaan van een conflict met de verzoeker maakt Caris de volgende opmerking: "In de gevallen dat er geen sprake is van een duidelijke tegenpartij is er wel vaak een belanghebbende aan te wijzen. Een geschil hoeft er dan niet te bestaan, maar een geschil is wel denkbaar. ${ }^{288}$ Bestaat er een geschil tussen de verzoeker en de belanghebbende/verweerder dan is in wezen sprake van eigenlijke rechtspraak of contentieuze jurisdictie. ${ }^{289}$

Vanwege het, althans in het oorspronkelijke model van de verzoekschriftprocedure, ontbreken bij een verzoekschrift van duidelijke "partijen" in de zin van een eiser en een gedaagde is in de wetgeving de term "partij" zoveel mogelijk vermeden. ${ }^{290}$ In tegenstelling tot de algemene wettelijke regeling op het gebied van verzoekschriftprocedures wordt in de literatuur wel degelijk zonder schroom gesproken over partijen. ${ }^{291}$ Ook in rechtspraak op grond van verzoekschriftprocedures wordt het begrip "partij" niet op geforceerde wijze vermeden, maar wordt het daarentegen in ruime mate gehanteerd. ${ }^{292}$

\footnotetext{
${ }^{286}$ Zuidema, p. 52.

${ }^{287}$ Bosch-Boesjes, p. 93. Cf. Wesseling-van Gent, p. 91.

${ }^{288}$ Caris, p. 79.

299 Pitlo/Hidma \& Rutgers, p. 11.

${ }^{250}$ Het Wetboek van Burgerlijke Rechtsvordering spreekt in de artt. $429 \mathrm{a}-429 \mathrm{t}$ redelijk consequent over "belanghebbende" en slechts éénmaal over "partijen" (art. 429b). Ook het gebruik van "verweerder" is, in eerste instantie, zorgvuldig vermeden. Alleen in de, later toegevoegde, artt. $429 \mathrm{~s}$ en $429 \mathrm{t}$ vindt "verweerders" vermelding. In individueel geregelde verzoekschriftprocedures wordt evenwel door de wetgever wel gesproken van "wederpartij" en "verweerder", zie art. 146 Pachtwet alsook art. 6 Handelsnaamwet.

${ }^{291} \mathrm{Vgl}$. Boekman, p. 105; Bosch-Boesjes, p. 91 c.v.; Brenninkmeijer, p. 20 en 21; Hugenholtz/Heemskerk, p. 139; Schaafsma-Beversluis, p. 297; Snijders, p. 59; Wesseling-van Gent, p. 91; Winters, p. 251. In de oudere literatuur wordt m.b.t. verzoekschriftprocedures nog omzichtig omgegaan met de term partijen, zie Funke, p. 229 en 230 ; Röder, p. 29 e.v..

${ }^{292}$ Losbl. uitgave BRv., alg. bespreking van de $12 \mathrm{e}$ titel v. Boek 1, aant. 24 en 32.
} 


\subsubsection{De Staat der Nederlanden als belanghebbende}

De zelfstandige procedure tot vaststelling van het Nederlanderschap is een procedure waarbij de verzoeker in beginsel geen wederpartij heeft. In de Rijkswet op het Nederlanderschap wordt niets bepaald omtrent een eventueel tegenover de verzoeker te stellen wederpartij en zodoende ontbreekt in de opzet van de Rijkswet met betrekking tot de "zelfstandige vaststellingsprocedure" een gerequestreerde of verweerder.

Reeds Van den Blink vermeldt in haar lezing uit 1989 echter het feit dat vanaf de eerste procedure uit artikel 17 RWN de rechtbank op basis van artikel $429 \mathrm{f}$ Rv de Staat der Nederlanden heeft opgeroepen als belanghebbende. ${ }^{293}$ Tevens vermeldt zij dat de Staat vervolgens niet ter zitting verscheen, noch een verweerschrift ${ }^{294}$ op grond van art. $429 \mathrm{~h} \mathrm{Rv}$ indiende. ${ }^{295}$ De rechtbank deed de zaak vervolgens af zonder rekening te kunnen houden met de visie van de Staat aangaande verzoekers bezit van het Nederlanderschap.

Het curieuze is echter dat de rechtbank wel de visie van de Staat in deze zaken heeft vernomen. Van den Blink, die kennelijk is afgegaan op hetgeen in de desbetreffende beschikkingen is vermeld, ${ }^{296}$ is kennelijk niet op de hoogte geweest met wat Zilverentant eerst in 1994 schrijft: "Hoewel de rechtbank uitsprak dat de staat, hoewel behoorlijk opgeroepen, niet was verschenen, moet voor de historie worden vastgelegd dat dit feitelijk onjuist is. De staat was wel degelijk verschenen: een ambtenaar van het ministerie van Justitie is altijd aanwezig, namens de staat, (......), heeft zelfs ter zitting het woord gevoerd. De rechtbank was echter in de beginperiode van procedures ex art. 17 Rijkswet op het Nederlanderschap van mening dat de staat alleen vertegenwoordigd kon worden door een advocaat (Landsadvocaat). Naderhand is de rechtbank van mening veranderd (.............. ${ }^{n 297}$

Volgens de bevindingen in mijn onderzoek wordt de Staat inderdaad in de meerderheid van de gevallen, maar niet in alle, opgeroepen. Uit de vierenvijftig vaststellingsbeschikkingen van de rechtbank te Den Haag waarop dit onderzoek is

\footnotetext{
${ }^{293}$ Van den Blink, p. 9.

${ }^{294}$ Een belanghebbende "verschijnt" ter zitting als hij een verweerschrift heeft ingediend, ook al komt hij niet fysiek. Zie het Besluit Oproepingen, Mededelingen en Zendingen Verzoekschriftprocedure, KB 14.11.1986, Stb. 578. Opgenomen in de losbl. uitgave Burgerlijke Rechtsvordering bij art. 429r Rv, aant. 3 .

${ }^{208}$ Gelijkluidende informatie vindt men in de conclusie van A.-G. Mok bij HR 04.03.1988, NJ 1989, nr. 628, m.nt. GRdG. Hierin vindt ook vermelding dat gaandeweg de Staat wel verscheen; een voorbeeld hiervan is Rb. 's-Gravenhage 07.02.1990, rkstnr. 89.5732.

296 Namelijk dat de Staat "hoewel behoorlijk opgeroepen, niet is verschenen". In de negenentwintig uitspraken van de rechtbank te Den Haag die ik ter beschikking heb uit de desbetreffende periode, blijkt inderdaad met geen woord van het horen van een ambtenaar van het ministerie. In alle betreffende beschikkingen is vermeld dat, hoewel behoorlijk opgeroepen, de Staat niet is verschenen.

297 Zilverentant, B\&R 1994, p. 114. Vgl. Bolten, MR 1988, p. 233; zie voetnoot 318.
} 
gebaseerd, blijkt dat de Staat éénmaal niet is opgeroepen. ${ }^{298}$ Van de drieënvijftig maal dat de Staat wèl is opgeroepen, is deze slechts in drieëntwintig beschikkingen, grotendeels beschikkingen van na 1991, geregistreerd als op de zitting verschenen.

Wat de wijze van oproepen in het kader van de "zelfstandige vaststellingsprocedure" zelf betreft, wekt het enige bevreemding dat in artikel 18 Rijkswet op het Nederlanderschap niet tevens artikel $429 \mathrm{r}$ Rv van toepassing is verklaard. Aan te nemen is echter dat de oproeping van de belanghebbende(n) conform dit artikel zal plaatshebben. Hugenholtz/Heemskerk laten op dit punt weten: "In de praktijk dient het Besluit ${ }^{299}$ ook als richtlijn in zaken die buiten de werking van de art. $429 a$ 429 r vallen, voor zover de wet geen regeling van de oproeping geeft. ${ }^{m 30}$

\subsubsection{Motief voor het oproepen van de Staat}

In de beschikkingen die de rechtbank heeft gegeven gedurende de periode direct na de inwerkingtreding van artikel 17 Rijkswet op het Nederlanderschap zijn de overvloedige overwegingen betreffende de redengeving waarom de rechtbank het raadzaam heeft geacht in deze procedure de Staat op te roepen als belanghebbende wel zeer opvallend. Deze uitgebreide overwegingen betreffen zowel de positie van de Staat als de taak en de positie van het openbaar ministerie in de onderhavige procedure (waarop onder paragraaf 2.3 reeds is ingegaan). In latere beschikkingen blijven deze overvloedige overwegingen achterwege.

Het motief van de rechtbank om de Staat op te roepen als "belanghebbende" is zeer verrassend. Het blijkt dat, interessant genoeg, niet zozeer de wens de mening ter zake van de minister van Justitie te vernemen de doorslaggevende factor voor de rechtbank heeft gevormd. De belangrijkste overweging voor het krachtens artikel $429 \mathrm{f} \mathrm{Rv}$ als belanghebbende oproepen van de Staat blijkt te zijn geweest dat daardoor, wegens het bepaalde in artikel 18 lid $2 \mathrm{RWN}$, beroep in cassatie voor de Staat mogelijk werd gemaakt. Dit laatste artikel stelt cassatie namelijk open voor "belanghebbenden". ${ }^{301}$ Een voorwaarde hiervoor is dat men eerst als zodanig door de rechtbank is aangemerkt en opgeroepen voor de behandeling in feitelijke instantie. De rechtbank verwoordt zijn zorg voor het recht tot cassatie van de Staat als volgt: "Indien de staat geen belanghebbende zou zijn, zou voor hem géén

\footnotetext{
${ }^{296}$ Rb. 's-Gravenhage 29.06.1988, rkstnr. 87.6118. Zie voor bespreking van deze casus par. 3.3.4.4.4. ${ }^{299}$ Het op art. 429r Rv gebaseerde Besluit Oproepingen, Mededelingen en Zendingen Verzoekschriftprocedure, KB 14.11.1986, Stb. 578. Opgenomen in de losbl. uitgave BRv. bij art. 429r Rv, aant. 3.

${ }^{300}$ Hugenholtz/Heemskerk, p. 137.

${ }^{301}$ Ten tijde van de onderhavige beschikkingen van de rechtbank was in art. 18 lid 2 RWN nog sprake van cassatie voor "de verzoeker en iedere andere belanghebbende". Vgl. hieronder voetnoot 337.
} 
beroep in cassatie mogelijk zijn, hetgeen redelijkerwijze niet de bedoeling van de wetgever ${ }^{302}$ geacht kan worden. ${ }^{1303}$

Wat naar mijn mening bovenal naar voren komt uit de, hierboven vermelde, uitgebreidheid van de overwegingen, is dat de rechtbank op zeer aftastende wijze de procesrechtelijke regels betreffende de vaststelling van het Nederlanderschap tracht te ontwikkelen. In dit verband is een uitspraak van Van den Blink zeer treffend. Hoewel Van den Blink met deze uitspraak niet alleen op de problematiek in de "zelfstandige vaststellingsprocedure" doelt aangaande het oproepen als belanghebbende van de Staat of de positie die het openbaar ministerie in de procedure inneemt, is de uitspraak hier zeer op haar plaats. Van den Blink schrijft: "Rechtbank en Hoge Raad zijn genoodzaakt als een soort genietroepen eerst zelf bailey-bruggen van procesregels te bouwen om daarover met de verzoeker het eveneens nauwelijks ontgonnen terrein van de nationaliteitsvaststelling te kunnen betreden. ${ }^{304}$

De conclusie uit de hierboven weergegeven gang van zaken kan kort zijn: de rechtbank te Den Haag, geconfronteerd met een verzoekschriftprocedure zonder verweerder, waarin niet op enigerlei wijze in de betrokkenheid van de overheid is voorzien, waarin tevens hoger beroep ontbreekt, heeft het raadzamer geacht een weg te banen ten behoeve van de Staat, waardoor deze alsnog de mogelijkheid verwerft een rechtsmiddel aan te kunnen wenden tegen de beschikking.

Mijns inziens zou in het geval dat het de rechtbank slechts te doen zou zijn geweest om de mening van de Staat inzake het eventuele Nederlanderschap van de verzoeker, de rechtbank ook een alternatieve route hebben kunnen volgen. Zou het de rechtbank namelijk slechts te doen zijn geweest om te worden ingelicht over het standpunt van de Staat betreffende verzoekers mogelijke Nederlanderschap, dan had de rechtbank door gebruik te maken van artikel 20 lid 1 RWN zich kunnen

\footnotetext{
${ }^{302}$ Het beroep van de rechtbank op "de bedoeling van de wetgever" is nogal twijfelachtig. Dat het recht van cassatie voor de Staat als zodanig niet in de RWN was opgenomen, gaf "de wetgever" zelf toe, aangezien op dit punt een wetswijziging van de RWN was aangekondigd in de justitiebegroting voor 1987. (Zie Bijl. II. 86-87, 19700, Hfdst. VI (Rijksbegroting Justitie), nr. 2, p. 39). Opmerkelijk is dat de wetswijziging werd aangekondigd op een moment dat Hoofdstuk 6 van de RWN nog niet in werking was getreden! De begroting werd namelijk 16.09.1986 het Parlement aangeboden. De "zelfstandige vaststellingsprocedure" is op 01.10.1986 in werking getreden (zie par. 1.2.2). Overigens is de aldus aangekondigde wetswijziging nimmer gerealiseerd. Als gevolg van de in deze paragraaf beschreven ontwikkeling heeft de Staat via de "belanghebbende ex art. $429 \mathrm{f} R v$-weg" de gewenste toegang tot de cassatieprocedure.

${ }^{303}$ Rb. 's-Gravenhage 27.05.1987, rkstnr. 86.2446; Rb. 's-Gravenhage 27.05.1987, rkstnr. 87.5021; Rb. 's-Gravenhage 27.05.1987, rkstnr. 86.2775 (=HR 04.03.1988, NJ 1989, 627, m.nt. GRdG); Rb. 's-Gravenhage 24.06.1987, rkstnr. 87.5002; Rb. 's-Gravenhage 24.06.1987, rkstnr. 86.2266 en Rb. 'sGravenhage 18.05.1987, rkstnr. 87.5299 in de vorm van een tussenbeschikking, waarin de 0.a. de Staat werd opgeroepen en waartegen de rechtbank cassatie openstelde. Het cassatieberoep leidde tot HR 04.03.1988, NJ 1989, 628, m.nt. GRdG; deze beschikking van de Hoge Raad komt hieronder aan de orde.
}

${ }^{304}$ Van den Blink, p. 6. 
beperken tot het vragen van een advies aan de minister van Justitie. ${ }^{305}$ Het voordeel hiervan zou dan zijn geweest dat de rechtbank zeker zou zijn geweest van een reactie van de kant van de Staat. Nu moest maar worden afgewacht of de Staat zich zou melden als belanghebbende. Zoals hierboven is vermeld, verscheen de Staat in de aanvangsperiode van de "zelfstandige vaststellingsprocedure" nooit (officieel) als belanghebbende, in de periode daarna zelden en pas sinds enige tijd frekwent.

Het is vrijwel direct na de inwerkingtreding van de "zelfstandige vaststellingsprocedure" een strijdpunt geworden of het een juiste handelwijze is als de Staat door de rechtbank te Den Haag wordt opgeroepen als "belanghebbende".

Bij de beoordeling van de vraag of de Staat inderdaad een belanghebbende in de zin van artikel $429 \mathrm{f} R v$ is, heeft de Hoge Raad volledig ingestemd met de zienswijze van de rechtbank. De Hoge Raad acht bij de vraag naar het Nederlanderschap "het algemeen belang altijd nauw betrokken". ${ }^{306}$ Daarbij overweegt de Hoge Raad tevens: "dat ingevolge art. 19 van genoemde Rijkswet aan een onherroepelijk geworden beschikking, gegeven met toepassing van art. 17, elk met de uitvoering van enige wettelijke regeling belast orgaan gebonden is." Ten gevolge hiervan moet volgens de Hoge Raad "de Staat worden aangemerkt als belanghebbende in de zin van art. 18 en van de art. $429 f$ en $429 h R v$., die ingevolge evengenoemde bepaling te dezen van toepassing zijn. ${ }^{307}$ In zijn annotatie onder deze beschikking van de Hoge Raad concludeert Bolten dat, zeker wat betreft de zaken met een verblijfsrechtelijke achtergrond, als gevolg van het oproepen van de Staat de vaststellingsprocedure zweemt naar een contentieuze procedure. ${ }^{308}$

Gezien de door de Hoge Raad gehanteerde formulering valt naar mijn mening de opvatting te verdedigen dat de Staat met betrekking tot de zelfstandige vaststellingsactie van het Nederlanderschap altijd als belanghebbende geldt. Dit geldt dan ook voor het (zeldzame) geval waarin de rechtbank afziet van het oproepen van de Staat

\footnotetext{
${ }^{305}$ Zie tevens par. 2.8.3.

${ }^{306} \mathrm{Vgl}$. in dit verband de curieuze procedure die ruim 45 jaar geleden is gevoerd voor de rechtbank te 's-Gravenhage en waarin de rechtbank uitspreekt dat de verzoeker "rechtsgeldig de Indonesische nationaliteit heeft verworpen". In het verzoekschrift was tevens de rechtbank verzocht te beschikken dat de verzoeker dientengevolge de Nederlandse nationaliteit zou hebben herkregen. Tot het uitspreken van een zodanig uitdrukkelijke Nederlanderschapsverklaring achtte de rechtbank zich onbevoegd (al was herkrijging van de Nederlandse nationaliteit het rechtsgevolg van het rechtsgeldig verwerpen van de Indonesische nationaliteit). De verzoeker laat de beschikking van de rechtbank dat hij "rechtsgeldig de Indonesische nationaliteit heeft verworpen" aan de Nederlandse Staat betekenen. De Staat gaat vervolgens als "belanghebbende" ingevolge art. 345 lid $2 \mathrm{Rv}$ in hoger beroep. De Staat onderbouwt zijn stelling "belanghebbende" te zijn met de stelling dat de verzoeker "jegens de Staat bepaalde financiële aanspraken kan geldend maken, die hem niet toekomen, indien zijn verwerpingsverklaring ongeldig is". Hof 's-Gravenhage 06.11.1952, NJ 1953, nr. 59. (Vgl. tevens Bijl. II. 51-52, 2378, nr. 5).

${ }^{307}$ HR 04.03.1988, NJ 1989, 628 m.nt. GRdG. Vgl. De Groot, losbl. uitgave Personen- en Familierecht, art. 18 RWN, aant. 1; Snijders, Ynzonides en Meijer, nr. 636.

${ }^{308}$ HR 04.03.1988, RV 1988, nr. 46, m.nt. JJB.
} 
in feitelijke instantie. ${ }^{309}$ Voor de bevoegdheid van de Staat om beroep in cassatie te kunnen instellen, ook in die gevallen waarin de Staat in feitelijke instantie niet is opgeroepen en als gevolg daarvan niet is verschenen, kan deze zienswijze gevolgen hebben. Dit onderwerp wordt nader aan de orde gesteld in de volgende paragraaf, die over cassatie handelt. Van de bevoegdheid tot cassatie heeft de Staat tot op heden slechts éénmaal gebruik gemaakt. ${ }^{310}$

De hierboven weergegeven gang van zaken met betrekking tot de vraag of de Staat der Nederlanden kan worden aangemerkt als belanghebbende bij de raststelling van de Nederlandse nationaliteit is niet afwijkend met de gang van zaken van oudsher in verzoekschriftprocedures. Het is in het verleden veelvuldig gebleken dat in verzoekschriftprocedures niet bij voorbaat vaststaat wie als belanghebbende bij het verzoek geldt. Over die vraag is alleen door de vorming van recttspraak uitsluitsel verkregen. ${ }^{311}$ Nog in 1991 heeft de Hoge Raad de stelling herhald dat "voor ieder type verzoekschriftprocedure uit de aard van de procedure en de daarmee verband houdende wetsbepalingen moet worden afgeleid wie als belanghebbende $(n)$ in aanmerking kunnen worden genomen. ${ }^{312}$

\subsubsection{Procureurstelling door de belanghebbende?}

Om tijdens de mondelinge behandeling als belanghebbende in een verzoekschriftprocedure te worden gehoord, is het niet nodig procureur te stellen (art. 429f lid 4 Rv). ${ }^{313}$ Het indienen van een verweerschrift door dezelfde belanghebbende moet in beginsel daarentegen wel door middel van een procureur geschieden (art. $429 \mathrm{~h}$ jo. $429 \mathrm{~d} \mathrm{Rv}){ }^{314}$ In de literatuur wordt gesteld dat niet alleen een verweerschrift bij procureur dient te worden ingediend, maar dat dit tevens geldt voor andere (van de verweerder/belanghebbende) afkomstige processtukken. ${ }^{315}$

Wat dit vereiste van procureurstelling betreft, kan evenwel worden gewezen op artikel $429 \mathrm{~h} \mathrm{Rv}$ waarin de belanghebbende, indien de rechter zulks toestaat, tijdens de mondelinge behandeling een verweerschrift kan overhandigen aan de verzoeker en aan de rechter. ${ }^{316}$ Gezien het feit dat de belanghebbende, om te worden gehoord, in persoon kan verschijnen op de mondelinge behandeling resulteert het

\footnotetext{
${ }^{309}$ Zoals is gebeurd in Rb. 's-Gravenhage 29.06.1988, rkstnr. 87.6118. Zie par. 3.3.4.4.4.

${ }^{110}$ HR 13.10.1995, RvdW 1995, nr. 204.

31 Boekman, p. 112 en 113, Wesseling-van Gent, p. 91, Zuidema, p. 125-127 en 135.

${ }^{312}$ HR 25.10.1991, NJ 1992, nr. 149, m.nt. Ma.

$313 \mathrm{Vgl}$. Haardt, p. 149; Rutgers, p. 93; Wesseling-van Gent, p. 84.

$314 \mathrm{Vgl}$. Haardt, p. 149; Hugenholtz/Heemskerk, p. 137; Veegens/Korthals Altes/Groen, p. 322; Wesseling-van Gent, p. 58 en 84.

313 Boekman (II), p. 36.

$316 \mathrm{Vgl}$. losbl. uitgave BRv. art. 429d, aant. 14, waar wordt benadrukt dat de mogelijkheid om het verweerschrift tijdens de zitting te overhandigen afhankelijk is van de welwillendheid hiertoe van de rechter.
} 
voorgaande hierin dat de indiening van het verweerschrift op dat moment geschiedt zonder tussenkomst van een procureur. Wesseling-van Gent beschrijft in haar proefschrift dat het in de praktijk wel vaker voorkomt dat een verweerder in persoon en niet door middel van een procureur "pleitaantekeningen" aan de rechtbank overhandigt. Naar het inzicht van de bovengenoemde auteur is een dergelijke gang van zaken "geheel in overeenstemming met de soepele, informele procesgang van de verzoekschriftprocedure. ${ }^{\text {"317 }}$

In 1988 besteedt Bolten al aandacht aan de vraag of de als belanghebbende opgeroepen Staat eventueel procureur dient te stellen. Op dat moment is de "zelfstandige vaststellingsprocedure" slechts sinds korte tijd in werking en de tot dan gedane beslissingen van de rechtbank ontlokken haar de opmerking: "Het is een nog niet uitgemaakte zaak of de Staat derhalve bij procureur moet optreden in een procedure ex art. 17 van de Rijkswet. De Rechtbank te 's-Gravenhage pleegt in haar beschikkingen naar aanleiding van verzoeken ex art. 17 nog steeds te vermelden dat de Staat wel is opgeroepen, maar niet is verschenen, ook wanneer een ambtenaar van het departement van Justitie ter zitting wordt gehoord. ${ }^{318}$

Als hierboven reeds is opgemerkt, is conform artikel $429 \mathrm{f}$ lid $4 \mathrm{Rv}$ procureurstelling niet vereist om te worden gehoord als belanghebbende. Procureurstelling is volgens de wettelijke bepalingen in beginsel wel vereist voor het indienen van een verweerschrift. Tot op heden is van de kant van de Staat nog geen enkele keer een officieel verweerschrift ingediend. Een wel ingediend verweerschrift zou zonder twijfel vermelding hebben gevonden in de desbetreffende vaststellingsbeschikking. ${ }^{319}$

Uit de beschikkingen van de rechtbank te Den Haag blijkt wél dat indien een vertegenwoordiger van het ministerie op de zitting verschijnt de Staat in de hoedanigheid van belanghebbende incidenteel stukken overlegt aan de rechtbank (zonder procureur te stellen). ${ }^{320}$ Tevens stuurt het ministerie van Justitie zowel

\footnotetext{
${ }^{317}$ Wesseling-van Gent, p. 84. Vgl. als voorbeeld voor een soepele procesgang: HR 04.11.1994, NJ 1995, nr. 98.

${ }^{318}$ Bolten, MR 1988, p. 233. Met de laatste zinsnede verwijst Bolten naar de curieuze omstandigheid dat in de aanvangsperiode van de "zelfstandige vaststellingsprocedure" wel vanwege het ministerie van Justitie een ambtenaar op de mondelinge behandeling aanwezig is geweest, maar deze niet door de rechtbank werd beschouwd als het in rechte verschijnen van de opgeroepen Staat. Zie hierboven p. 78. ${ }^{319} \mathrm{Vgl}$. Caris, p. 85: "Verweerschriften worden ook ingeschreven. Dit gebeurt ten behoeve van het heffen van griffierechten (............)".

${ }^{130} \mathrm{Rb}$. 's-Gravenhage 04.09.1991, rkstnr. 91.5072 (=HR 04.12.1992, rkstnr. 8058, niet gepubliceerd). Voor de mondelinge behandeling informeert het ministerie van Justitie de raadsman van de verzoeker dat de verzoeker een optie heeft afgelegd ter verkrijging van de Surinaamse nationaliteit. (Een zodanige optie impliceert verlies van het Nederlanderschap). Op de zitting is de vertegenwoordiger van het ministerie van Justitie gehoord en een fotocopie van de bewuste optie wordt opgenomen in het procesdossier. In de conclusie van het $\mathrm{OM}$ is vermeld: "Door de Staat der Nederlanden is in het geding gebracht een (........) door verzoeker gedane kennisgeving inzake de toescheidingsovereenkomst (........).
} 
voor als na de mondelinge behandeling processtukken naar de griffie zonder tussenkomst van een procureur. ${ }^{321}$ Hoewel de Staat in deze gevallen niet een verweerschrift als zodanig indient, brengt hij dus wel bescheiden in het geding waarop de rechtbank vervolgens haar beslissing laat rusten.

De bovenstaande gegevens roepen mijns inziens de vraag op waarop de bevoegdheid voor de Staat is gebaseerd om, buiten de mondelinge behandeling, zonder tussenkomst van een procureur stukken in het geding te brengen. Naar mijn mening dient het antwoord hierop te luiden dat een wettelijke basis ontbreekt om op deze wijze bescheiden aan de rechtbank te overleggen. De bevoegdheid vindt in ieder geval geen steun in een wettelijke bepaling. Met betrekking tot de Staat der Nederlanden in de rol van "belanghebbende" in een procedure tot vaststelling van het Nederlanderschap ben ik echter veeleer van mening dat het gewenst is dat indien de Staat buiten de mondelinge behandeling om over wil gaan tot het indienen van stukken en/of een verweerschrift dit door middel van een procureur dient te geschieden. Als van iets of iemand mag worden verwacht dat hij zich zou houden

${ }^{320} \rightarrow$

uit welker kennisgeving blijkt dat verzoeker (.......) heeft geopteerd voor de Surinaamse nationaliteit." De Staat heeft geen procureur gesteld. De rechtbank neemt in haar beschikking de bewuste optie op onder de vaststaande feiten.

321 Rb. 's-Gravenhage 11.09.1991, rkstnr. 91.5109 (=HR 27.11.1992, NJ 1993, nr. 285, m.nt. GRdG). De behandeling van het verzoekschrift is in deze zaak aangehouden om het ministerie van Justitie in de gelegenheid te stellen bij de gemeente Rotterdam nadere inlichtingen in te winnen. De brief van het ministerie d.d. 11 april 1991 met daarbij als bijlage een schrijven van de gemeente Rotterdam d.d. 4 april 1991 zijn ter griffie van de rechtbank ontvangen zonder tussenkomst van een procureur. Niettemin worden beide stukken in het procesdossier opgenomen. Dezelfde brief van 11 april 1991 is verstuurd naar de raadsman van de verzoekster.

Rb. 's-Gravenhage 25.03.1992, rkstnr. 91.6197 (=HR 04.12.1992, NJ 1993, nr. 272, m.nt. GRdG). Ook in deze zaak stelt de Staat geen procureur. Desondanks valt te lezen in de beschikking van de rechtbank:

onder het kopje "Het standpunt van de Staat":

"Blijkens het schrijven van de Staatssecretaris van Justitie d.d. 27 jan. 1992, zoals ook bij de mondelinge behandeling door de (ambtenaar van het ministerie) nader is toegelicht, is de Staat van oordeel dat de minderjarigen niet de Nederlandse nationaliteit bezitten."

en direct daarna onder het kopje "Het standpunt van de officier van justitie":

"De officier van justitie heeft zich in zijn conclusie van 5 februari 1992 aangesloten bij de inhoud van het voornoemde schrijven van de staatssecretaris van Justitie dd. 27 januari 1992. De officier van justitie is van oordeel dat op de in die brief genoemde gronden het verzoek moet worden afgewezen."

De brief van het ministerie van Justitie kan m.i. niet anders worden beschouwd als een verweerschrift. Toch is het niet via een procureur bij de rechtbank ingediend, maar is het twee dagen voor de behandeling van het verzoekschrift door het ministerie van Justitie verzonden aan het openbaar ministerie.

$\mathrm{Rb}$. 's-Gravenhage 04.11 .1992 , rkstnr. 92.5105 . $\mathrm{Na}$ de mondelinge behandeling zendt het ministerie van Justitie stukken naar de rechtbank. 
aan een goede procesorde dan is dat toch wel de Staat, en in het bijzonder het ministerie van Justitie. ${ }^{322}$

Een andere vraag die deze ontwikkeling oproept, is of voor iedere andere belanghebbende gelijkelijk geldt dat schriftelijke stukken buiten de mondelinge behandeling zonder de medewerking van een procureur kunnen worden ingebracht. De rechtsgelijkheid zou een bevestigend antwoord op die vraag eisen. Overigens blijkt uit de aan dit onderzoek ten grondslag liggende jurisprudentie dat tot op heden bij de behandeling van de verzoekschriften geen andere "belanghebbenden" zijn opgeroepen dan de Staat der Nederlanden. ${ }^{323}$

\subsection{Cassatie (art. 18 lid 2 RWN)}

\subsection{Algemene beschouwingen}

De Rijkswet op het Nederlanderschap sluit de mogelijkheid hoger beroep in te stellen tegen de vaststellingsbeschikking van de rechtbank of het Gemeenschappelijk Hof van Justitie van de Nederlandse Antillen en Aruba uit. In het streven naar een zo eenvoudig mogelijke procedure, die tevens weinig tijd in beslag zou nemen, is gemeend van een tweede feitelijke behandeling te moeten afzien. ${ }^{324}$

Cassatie is op grond van artikel 18 lid 2 RWN wel mogelijk, maar de Rijkswet bepaalt niet nader welke de aangaande het beroep in cassatie te volgen formele regels dienen te zijn. Een indicatie dat de wetgever de artikelen 426-429 Rv ("Van beroep in cassatie tegen beschikkingen op rekest") van toepassing acht, geeft de navolgende opmerking in de memorie van Antwoord: "Ingevolge artikel 426 van het Wetboek van Burgerlijke Rechtsvordering bedraagt de termijn voor het instellen van het cassatieberoep twee maanden. ${ }^{n 325}$

\footnotetext{
${ }^{32} \mathrm{Vgl}$. A. de Lange, NJB 1995, p. 441: "Daarbij komt (...) dat men juist van een administratie mag verwachten dat zij haar eigen regels respecteent (........)."

${ }^{32}$ Als andere belanghebbenden zijn denkbaar andere staten waarvan de nationaliteit (en het nationaliteitsrecht) mede in het geding kan zijn. Bijv. de Republiek Suriname in het geval van toepasselijkheid van de Toescheidingsovereenkomst inzake nationaliteiten tussen Nederland en Suriname.

324 Uit de parlementaire behandeling van de "zelfstandige vaststellingsprocedure" blijkt dat dit streven bij de wetgever sterk heeft overheerst. Zie de toelichting op het Voorontwerp van Rijkswet vaststelling van nieuwe, algemene bepalingen omtrent het Nederlanderschap uit 1976, p. 38 en ook Bijl. II. 82-83, 16947 , nr. 7, p. 31 en 33.

${ }^{22}$ Bijl. II. 82-83, 16947 , nr. 7, p. 33. N.B. mijns inziens geldt ingevolge art. 4 Cassatieregeling voor de Nederlandse Antillen en Aruba voor beschikkingen op grond van art. 17 RWN gegeven door het Gemeenschappelijk Hof van Justitie van de Nederlandse Antillen en Aruba een cassatietermijn van drie maanden. Ondanks de in de memorie van Antwoord gesuggereerde toepasselijkheid van art. $426 \mathrm{Rv}$ op verzoeken in cassatie van beschikkingen van het Gemeenschappelijk Hof (althans deze beschikkingen worden niet uitgezonderd) dient naar mijn mening voor de cassatietermijn de Cassatieregeling voor de
} 
Voor de artikelen 426-429 Rv wordt in de procesrechtelijke literatuur een algemene toepasselijkheid aangenomen. ${ }^{326}$ Door Meijknecht is deze heersende mening als volgt onder woorden gebracht: "Vanuit wetssystematisch oogpunt is van belang dat deze artikelen, anders dan de algemene regeling van de verzoekschriftprocedure in eerste aanleg en in hoger beroep zoals opgenomen in de art. 429a$429 r R v$, van algemene gelding zijn. Hun werking is niet beperkt tot met zoveel woorden aangewezen verzoekschriftprocedures (...)". 327

De Rijkswet op het Nederlanderschap kent evenwel met betrekking tot artikel $426 \mathrm{Rv}$ een afwijkende regel, die hieronder in paragraaf 2.5.1.1 zal worden besproken.

Sinds de inwerkingtreding van de "zelfstandige vaststellingsprocedure" is de Hoge Raad ruimschoots met de procedure geconfronteerd. $\mathrm{Zo}_{\mathrm{o}}$ is van de vierenvijftig (eind)beschikkingen van de rechtbank waarop dit onderzoek is gebaseerd, in éénentwintig zaken cassatie verzocht. Daarnaast is van één tussenbeschikking van de rechtbank, waarin o.a. de Staat als belanghebbende op grond van artikel $429 f$ $\mathrm{Rv}$ is opgeroepen, cassatie aangetekend (zie par. 2.4.2.2). ${ }^{328}$

Het bovenstaande betekent derhalve dat van ruim éénderde van de bij dit onderzoek betrokken beschikkingen beroep in cassatie is ingesteld. Worden echter de elf beschikkingen waarin de rechtbank de verzoeker niet-ontvankelijk heeft verklaard wegens (vermeende) gelijktijdigheid met een procedure uit artikel 20 RWN (zie par. 2.2.2.1); de ene beschikking waarin de verzoeker niet-ontvankelijk werd verklaard wegens gebrek aan belang (zie par. 2.2.4.2); de zes beschikkingen met voor de verzoekers positief resultaat én de zaak waarin de Staat cassatie heeft aangetekend, ${ }^{329}$ buiten beschouwing gelaten, dan ontstaat een iets ander beeld. In die vergelijking wordt dus slechts gekeken naar beschikkingen waarin het verzoek

${ }^{325} \rightarrow$

Nederlandse Antillen en Aruba te worden aangehouden en niet het Nederlandse Wetboek van Burgerlijke Rechtsvordering.

326 Vgl. Coops, p. 309; Gras, p. 197; Haardt, p. 148; Stein, p. 167; Veegens/Korthals Altes/Groen, p. 318.

${ }^{327}$ Meijknecht, p. 69.

${ }^{32 s}$ Bij dit onderzoek zijn niet alle op grond van art. 17 RWN gegeven beschikkingen betrokken, maar is getracht een representatief gedeelte daarvan aan de orde te stellen. In haar in oktober 1989 afgesloten lezing spreekt Van den Blink, p. 6, over "ruim veertig uitspraken" die tot dan zijn gedaan door de rechtbank, "waarvan ruim tien aan cassatie zijn onderworpen". Exactere aantallen worden vermeld in de Rijksbegrotingen voor 1989 en 1990 . In 1989 blijken 12 uitspraken te zijn gedaan door de rechtbank (Bijl. II. 88-89, 20800, Hfdst. VI (Rijksbegr. Justitie), nr. 2, p. 33), in 1990 zijn het er 17 geweest (Bijl. II. 89-90, 21300, Hfdst. VI (Rijksbegr. Justitie), nr. 2, p. 43). Door een vertegenwoordiger van de Immigratie- en Naturalisatiedienst (ministerie van Justitie) is mij (in 1995) mondeling meegedeeld dat per jaar gemiddeld een vijftigtal vaststellingsverzoeken worden behandeld door de rechtbank.

32 HR 13.10.1995, RvdW 1995, nr. 204. 
is afgewezen, vijfendertig in totaal, en dan blijkt dat daarvan twintig maal cassatie (door de verzoeker) is verzocht. ${ }^{330}$

De bovenstaande gegevens leiden tot een beduidend hoger percentage dan de $5 \%$ die Snijders noemt als geschat gemiddelde aan ingestelde cassatieberoepen op einduitspraken. Het percentage dat Snijders noemt, geldt evenwel voor uitspraken in appel gegeven. ${ }^{331}$ Mogelijk ligt aan het hogere percentage cassatieverzoeken bij de "zelfstandige vaststellingsprocedure" van het Nederlanderschap het ontbreken van hoger beroep in de procedure ten grondslag. ${ }^{332}$

In het geval van vernietiging van de in feitelijke instantie gegeven beschikking waarbij de Hoge Raad besluit de zaak niet zelf ten principale af te doen, is het college niet verplicht de zaak terug te wijzen naar de rechtbank in Den Haag. Met betrekking tot verwijzen, geldt als hoofdregel dat wordt verwezen naar de instantie waarvan de beslissing is vernietigd (art. 422a Rv). ${ }^{333}$ Maar op grond van artikel $423 \mathrm{Rv}$ bestaat ook de mogelijkheid voor de Hoge Raad te kiezen voor verwijzing naar het Gerechtshof in Den Haag. ${ }^{334}$

Tot nu toe heeft de Hoge Raad zonder uitzondering de zaak verwezen naar de rechtbank te Den Haag. Naast het volgen van de hoofdregel kan daarbij een aanvullende reden voor de terugverwijzing naar de rechtbank te Den Haag aan de orde zijn. Een zodanige gang van zaken is namelijk geheel in lijn met hetgeen Winters in zijn proefschrift constateert. Uit het betoog van Winters kan worden opgemaakt dat de Hoge Raad, vanwege de bij de betreffende instantie opgebouwde deskundigheid, een voorkeur voor terugverwijzen toont indien het gaat om een rechtsgang waarin sprake is van een gespecialiseerde rechter. Of zoals Winters het stelt: "Terugverwijzing ${ }^{335}$ ligt voor de hand als doorverwijzing ertoe zou leiden, dat het geding afgedaan moet worden door een rechter die ingevolge de betreffende wettelijke regeling over geschillen als het voorliggende niet oordeelt. ${ }^{3336}$

\footnotetext{
${ }^{330}$ Van deze 20 zaken heeft de HR er drie met voor de verzoeker positief resultaat zelf afgedaan, de HR heeft het Nederlanderschap van twee verzoekers en, in het derde geval, één minderjarige vastgesteld. Van de overige zaken is in vijf gevallen de gewraakte beschikking vernietigd en de zaak terugverwezen, in twaalf gevallen heeft het cassatieberoep geen gevolg gehad.

331 Snijders, p. 56. Cf. Snijders, Ynzonides en Meijer, nr. 574.

332 Ook een andere procedure waarin de mogelijkheid van hoger beroep ontbreekt, kent een hoog percentage aan cassatieberoepen. Royer, p. 134 en 135, meldt dat gedurende de periode 1976-1979 bij uitleveringsprocedures in gemiddeld $50 \%$ tegen de uitspraken van de rechtbanken cassatie is aangetekend.

${ }^{33}$ Veegens, p. 304; Winters, p. 25. Vgl. tevens P. Abas, Huurrecht bij de hoven?, NJB 1993, p. 1084 en 1085.

${ }_{34} \mathrm{Vgl}$. losbl. uitgave BRv., art. 423, aant. 1; Hugenholtz/Heemskerk, p. 228.

335 Winters gebruikt de term "terugverwijzing" voor het verwijzen naar de rechter wiens uitspraak is vernietigd en "doorverwijzing" voor verwijzing naar een andere rechter. Zie Winters, p. 25.

366 Winters, p. 26.
} 


\subsubsection{Een uitzondering op artikel $426 R v$.}

Een uitzondering op de algemene regel van artikel 426 lid $1 \mathrm{Rv}$ dat slechts "degenen, die in een der vorige instantiën verschenen zijn" cassatie kunnen aantekenen, wordt bewerkstelligd door de redactie van artikel 18 lid 2 RWN. ${ }^{337}$ Ten gevolge van de ruime redactie van dit artikel kunnen ook de in feitelijke instantie niet-verschenen verzoeker en belanghebbende(n) cassatie instellen. Waarom deze afwijking van wat in beginsel als algemene regel geldt voor de mogelijkheid tot cassatie in verzoekschriftprocedures noodzakelijk is geacht, is onbekend. ${ }^{338}$

De Hoge Raad heeft bij gelegenheid deze ten opzichte van artikel $426 \mathrm{Rv}$ afwijkende werking van artikel 18 RWN bevestigd. In de reeds in de paragrafen 2.3.1.2 en 2.4.2.2 aan de orde gestelde beschikking van de Hoge Raad van 4 maart 1988 vermeldt een obiter dictum aangaande het recht op cassatie van een nietverschenen belanghebbende (i.c. de Staat): "...dat de Staat als belanghebbende beroep in cassatie kan instellen, ook indien deze in eerste instantie niet is verschenen. In zoverre derogeert de bijzondere regeling van art. 18 lid 2 van de Rijkswet op het Nederlanderschap aan de algemene regeling van art. $426 R v{ }^{n 339}$ Dat voor een niet-verschenen verzoeker hetzelfde geldt, blijkt uit een andere beschikking van de Hoge Raad van dezelfde dag. Verzoeker noch diens raadsman is in dat geval in eerste instantie verschenen. ${ }^{340}$

Naar aan het eind van paragraaf 2.4.2.2 door mij is gesteld, wordt, naar mijn mening, de Staat door de Hoge Raad beschouwd als permanent belanghebbende bij iedere "zelfstandige vaststellingsprocedure". Voor deze kwalificatie als belanghebbende, heb ik gesteld, is het van geen belang of de rechtbank in het concrete geval de Staat heeft opgeroepen voor de mondelinge behandeling.

De bovenstaande uitgangspunten gecombineerd met het hiervoor vermelde, waaruit is gebleken dat om beroep in cassatie te kunnen aantekenen niet het vereiste geldt dat de bewuste belanghebbende tijdens de feitelijke instantie is verschenen, leiden mijns inziens tot de gevolgtrekking dat, de Staat der Nederlanden niettemin cassatie van de vaststellingsbeschikking kan verzoeken ook al is in casu de Staat door de Haagse rechtbank niet als belanghebbende opgeroepen. ${ }^{341}$ Indien in een zodanige situatie de Staat beroep in cassatie zou instellen, benut deze zijn positie als permanent belanghebbende bij de vaststellingsprocedure.

\footnotetext{
337 Tot 01.01.1994 luidde de redactie van art. 18 lid 2 RWN: "Voor de verzoeker en iedere andere belanghebbende staat van de beschikking uitsluitend beroep in cassatie open." In verband met de inwerkingtreding van de Algemene wet bestuursrecht is deze redactie gewijzigd in "Voor belanghebbenden staat van de beschikking uitsluitend beroep in cassatie open. "

$338 \mathrm{Vgl}$. losbl. uitgave BRv., alg. bespreking van de $12 \mathrm{e}$ titel v. Bock I, aant. 77.

390 HR 04.03.1988, NJ 1989, nr. 628, m.nt. GRdG.

${ }^{300}$ HR 04.03.1988, NJ 1989, nr. 875, m.nt. EAA (=Rb. 's-Gravenhage, 24.06.1987, rkstnr. 86.2266).

${ }^{34}$ Zoals is gebeurd in Rb. 's-Gravenhage 29.06.1988, rkstnr. 87.6118. (Zie par. 3.3.4.4.4).
} 
Naast de Staat der Nederlanden zijn er ook andere belanghebbenden denkbaar. ${ }^{342}$ Dezen kunnen even goed niet zijn opgeroepen in feitelijke instantie. In de literatuur is aangaande artikel $426 \mathrm{Rv}$ gepleit voor de aanvaarding van de regel dat cassatieberoep mogelijk is voor belanghebbenden die buiten hun schuld niet eerder zijn verschenen. ${ }^{343}$ Een belanghebbende kan immers ten onrechte niet zijn opgeroepen of er heeft iets geschort aan de oproeping. Zeker aangezien het gaat om een procedure die slechts één behandeling in feitelijke instantie kent, geldt dat de nationaliteitsvaststelling wellicht reeds gedaan is voordat de belanghebbende weet heeft gekregen van het geding. Een gelijke benadering als de literatuur inzake artikel $426 \mathrm{Rv}$ voorstaat, is naar mijn inzicht ook aan te bevelen met betrekking tot onbekend gebleven belanghebbenden of belanghebbenden die buiten hun schuld niet zijn verschenen in de procedure tot vaststelling van het Nederlanderschap.

\subsubsection{Ambtshalve cassatie mogelijk dan wel wenselijk?}

De Hoge Raad behandelt de cassatieberoepen in het kader van de "zelfstandige vaststellingsprocedure" uit de Rijkswet op het Nederlanderschap in de eerste Kamer. Dit is de Kamer waarin in de eerste plaats de civiele zaken, maar waarin tevens andere zaken ${ }^{344}$ worden behandeld.

Ambtshalve cassatie is onbekend in het burgerlijk procesrecht. ${ }^{345}$ Het begrip ambtshalve cassatie houdt in dat de Hoge Raad op ieder onderdeel van de bestreden uitspraak mag vernietigen, ongeacht of daartegen een cassatiemiddel is gericht of niet. In het civiele procesrecht daarentegen mag de Hoge Raad niet treden buiten de cassatiemiddelen (art. 419 lid 1 Rv). De Hoge Raad is derhalve gebonden, zowel aan die middelen ${ }^{346}$ als aan het aangevochten oordeel in feitelijke instantie voor zover de cassatiemiddelen dat niet bestrijden. ${ }^{347}$ In artikel 429 lid 2 Rv

\footnotetext{
${ }^{362}$ Zie voetnoot 323 .

${ }^{303}$ Veegens/Korthals Altes/Groen, p. 322.

${ }^{34}$ Zie het Reglement van orde van de Hoge Raad (opgenomen in de losbl. Gids voor de rechterlijke macht). De HR kent vier meervoudige en twee enkelvoudige kamers (Gids voor de rechterlijke macht, suppl. okt. 1994). Naast de civiele kamer, is er de strafkamer en de belastingkamer; vgl. Den Hartog Jager, p. 198; Snijders, Ynzonides en Meijer, nr. 179. De derde kamer (belastingkamer) is gesplitst in twee afdelingen; vgl. Van Koppen/Ten Kate, p. 11 en 12; Niessen, p. 31.

34 Den Hartog Jager, p. 201; Stein, p. 180; Veegens/Korthals Altes/Groen, p. 282; Vriesendorp, p. 240, 249-252.

${ }^{306}$ Met dien verstande dat bij de beoordeling van het middel het ambtshalve aanvullen van de rechtsgronden ingevolge art. $48 \mathrm{Rv}$ een belangrijke rol kan spelen. Franx, p. 10, stelt dienaangaande: "Men zal dit niet aldus mogen uitleggen dat (.........) uitsluitend is getoetst aan de daartegen door eiser aangevoerde gronden. Als het gaat om een door eiser met een cassatiemiddel als onjuist bestreden rechtsopvatting, pleegt de Hoge Raad zich, in het licht van art. $48 \mathrm{Rv}$, immers niet te beperken tot een onderzoek naar de door eiser ter ondersteuning van zijn klacht aangevoerde gronden (.......)."

${ }^{367}$ Pels Rijcken, RMTh 1987, p. 180; Veegens/Korthals Altes/Groen, p. 286.
} 
wordt het verbod uit artikel 419 lid $1 \mathrm{Rv}$ op het treden buiten de cassatiemiddelen van toepassing verklaard in verzoekschriftprocedures. ${ }^{348}$

In principe dient derhalve ervan uit te worden gegaan met betrekking tot verzoekschriften op grond van artikel $17 \mathrm{RWN}$, dat de cassatierechter gebonden is aan de middelen uit het cassatierekest. ${ }^{349}$ A.-G. Mok acht in de "zelfstandige vaststellingsprocedure" ambtshalve cassatie inderdaad uitgesloten. ${ }^{350}$

In de voordracht over de vaststellingsprocedure die zij enkele maanden na bekendmaking van het bovenvermelde standpunt van de A.-G. heeft gehouden, sluit Van den Blink evenwel het toepassen van ambtshalve cassatie in de toekomst niet per definitie uit. Van den Blink leidt uit het feit dat in de Rijkswet op het Nederlanderschap niet uitdrukkelijk de artikelen 426-429 Rv van toepassing zijn verklaard voor de Hoge Raad een mogelijkheid af om de beperkingen van de civiele cassatie te ontlopen. Dienaangaande merkt zij op: "De tot nu toe gedane uitspraken geven geen uitsluitsel over de vraag of de Hoge Raad de artikelen 426 e.v. onverkort op de onderhavige cassatie van toepassing acht en dus geen ruimte ziet voor ambtshalve cassatie, dan wel te gelegener tijd in de aard van de materie aanleiding zal vinden om voor wat de omvang van de toetsing betreft aansluiting te zoeken bij de cassatieregeling voor straf-en belastingzaken. ${ }^{n 351}$

A.-G. Mok heeft naderhand evenwel kenbaar gemaakt bij zijn tegenovergestelde opvatting te zijn gebleven en te volharden in de opvatting dat de Hoge Raad bij zijn beslissing gebonden is aan de middelen uit het cassatierekest. ${ }^{352}$

Naar mijn mening is veel te zeggen voor het standpunt dat, gelet op het publiekrechtelijk karakter van het nationaliteitsrecht en het grote belang dat de vaststelling van de nationaliteit vertegenwoordigd, ambtshalve cassatie mogelijk zou moeten zijn. Hiertegenover moet echter worden gesteld dat onder de huidige regelgeving de argumentatie van Van den Blink nogal zwak lijkt, gezien de algemene aanvaarding van de toepasselijkheid van de artikelen $426-429 \mathrm{Rv}$ voor de gevallen waarin deze artikelen niet door de specifieke wet van toepassing zijn verklaard en het in

\footnotetext{
${ }^{348} \mathrm{Vgl}$. Snijders, p. 63; Snijders, Ynzonides en Meijer, nr. 723.

${ }^{349} \mathrm{Vgl}$. art. 1 lid 1 Cassatieregeling voor de Nederlandse Antillen en Aruba.

350 Zie de conclusie bij HR 13.01.1989, NJ 1990, nr. 267, m.nt. GRdG en tevens de conclusie (i.h.b. bij de bespreking van het tweede middel) bij HR 07.04.1989, NJ 1990, nr. 791, m.nt. GRdG.

35 V Van den Blink, p. 11. In deze rechtsgebieden mag de Hoge Raad wel ambtshalve casseren (vgl. art. 25 Wet administratieve rechtspraak belastingzaken en art. 441 lid $1 \mathrm{~Sv}$ ). Ook in het nauw aan het strafrecht verwante uitleveringsrecht kan de Hoge Raad ambtshalve casseren: art. 31 Uitleveringswet verklaart art. $441 \mathrm{~Sv}$ van toepassing op de procedure in cassatie (vgl. HR 01.09.1987, NJ 1988, nr. 262 m.nt. AHJS; HR 24.04.1990, NJ 1991, nr. 57; HR 14.09.1993, NJ 1994, nr. 155, m.nt AHJS). Interessante gedachte is hierbij dat in het straf- en uitleveringsrecht de kwestie van de nationaliteit af en toe aan de orde is als voorvraag. In een "impliciete vaststellingsprocedure" in het kader van eén van deze rechtsgebieden, is derhalve wel ruimte voor een ontwikkeling van het nationaliteitsrecht die ambtshalve door de Hoge Raad kan worden geïnitieerd.

${ }^{32}$ Conclusie bij HR 31.01.1992, NJ 1993, nr, 261, m.nt. GRdG.
} 
dit opzicht ontbreken van een aanvullende eigen regeling in de Rijkswet op het Nederlanderschap.

Aan de andere kant is het mijn opvatting dat de ratio van het verbod van ambtshalve cassatie is gelegen in het beginsel van de, in het civiele vermogensrecht vooropstaande, partij-autonomie. Neemt men de verschillende rechtsgebieden in ogenschouw, dan blijkt het verbod van ambtshalve cassatie een buitenbeentje. Het komt alleen voor in het burgerlijk procesrecht. Binnen dat rechtsgebied is het te beschouwen als een zinvol instrument ten bate van de, aldaar hoog aangeschreven, partij-autonomie en de daarbij behorende op lijdelijkheid ingestelde rechter. ${ }^{353}$ Partijen beslissen waarover de rechtsstrijd zal gaan, ook in cassatie. ${ }^{354}$ In de andere rechtsgebieden (straf-, administratief- of belastingrecht) ontbreken begrippen zoals "partij-autonomie" en "lijdelijke rechter". Deze ontbreken omdat het in die rechtsgebieden handelt om "rechten die niet ter vrije beschikking staan". Met betrekking van zodanige rechten is het derhalve niet mogelijk om door middel van partij-afspraken de strijd voor de rechter te beperken tot hetgeen de partijen wenselijk achten. Voor de bij de civiele rechter gevoerde zaken waarin sprake is van een "recht dat niet ter vrije bepaling van partijen staat" volgt mijns inziens, wegens het alsdan ontbreken van partij-autonomie en de daaraan inherent verbonden lijdelijke(re) rechter, dat de cassatierechter ook niet lijdelijk dient te zijn. Het voorgaande betekent dat ambtshalve cassatie ook bij rechtspraak inzake zodanige "niet vrije" rechten die valt onder het Wetboek van Burgerlijke Rechtsvordering zou moeten worden aanvaard. Ik ben derhalve van mening dat in rechtsgebieden waar partijautonomie ontbreekt, rechtsgebieden derhalve waarbinnen de desbetreffende rechten niet ter vrije beschikking van partijen staan en waarover partijen geen afspraken kunnen maken, het verbod van ambtshalve cassatie oneigenlijk en derhalve niet op zijn plaats is.

Hiertegenover staat dat ik naar huidig recht evenwel de mening van A.-G. Mok de juiste acht. Daarbij acht ik het zonder wijziging van de Rijkswet niet goed mogelijk dat de Hoge Raad zal beslissen een vaststellingsbeschikking op een ambtshalve aangebracht grond te casseren. Tot op heden heeft de Hoge Raad bij cassatieberoepen op grond van artikel $18 \mathrm{RWN}$ inderdaad nog nooit op ambtshalve aangebrachte gronden gecasseerd.

Dat ambtshalve cassatie naar mijn mening wel mogelijk dient te zijn, steun ik op de hierboven gegeven visie omtrent de samenhang van het verbod van ambtshalve cassatie, partij-autonomie en lijdelijke rechter. Wat dit betreft, dient mijns inziens de wetgever te voorzien in een wetswijziging.

\footnotetext{
${ }^{353} \mathrm{Vgl}$. Boon/Van der Wal, p. 3; Brenninkmeijer, p. 30; Elders, p. 3; Pitlo/Hidma \& Rutgers, p. 8; Princen, p. 57. Gras, p. 29, noemt de partij-autonomie de "harde kern" van lijdelijkheid.

$354 \mathrm{Vgl}$. Hugenholtz/Heemskerk, p. 12.
} 


\subsection{De bindende werking van de vaststellingsbeschikking (art. 19 RWN)}

\subsubsection{Algemene beschouwingen}

"Dat een beschikking, evenals een vonnis, een verplichting in het leven kan roepen, spreekt vanzelf. Dus behoeft ook geen betoog dat deze gevolgen in stand blijven totdat de beschikking is uitgewerkt of op de voorgeschreven wijze is vernietigd, ingetrokken of vervangen. Dit heeft echter niets te maken met gezag van gewijsde in de zin van gebondenheid aan de inhoud van het vonnis in een later proces. ${ }^{\prime 355}$

De bovenstaande uitspraak verwoordt de algemeen onderschreven stelregel dat een rechterlijke uitspraak voor de partijen die het aangaat bindend is en dient te worden nageleefd. ${ }^{356}$ Het is een onbetwist uitgangspunt dat iedere rechterlijke uitspraak, vonnis hetzij beschikking, een bindende werking kent die zich doet gelden tussen de bij het proces betrokken deelnemers (en hun eventuele rechtsopvolgers). ${ }^{357}$ Deze werking tussen de partijen wordt ook wel de materiële rechtskracht of een werking inter partes genoemd.

Een enkele maal kent de wet een bepaling waardoor een rechterlijke uitspraak een ruimere bindende werking verkrijgt dan slechts de bindende werking tussen de partijen. Aan de orde is dan de vraag naar "de omvang van de kring waarbinnen een rechterlijke beslissing over dat onderwerp gerespecteerd moet worden. ${ }^{m 358}$ Indien sprake is van een bindende werking tegen een ieder, dan is sprake van een werking erga omnes. ${ }^{359}$ Ook kan het voorkomen dat in een wettelijke bepaling niet is gekozen voor een erga omnes gelding, maar dat toch sprake is van een

\footnotetext{
${ }^{353}$ Asser/Anema/Verdam, p. 336.
}

$356 \mathrm{Vgl}$. Asser/De Ruiter, p. 112; Beukers, p. 20; Boekman, p. 125; Gras, p. 66; Scheltema, p. 120; Star Busmann, p. 388: "(........), desniettemin doen zij [= beschikkingen] de rechtsgevolgen intreden welke de wet er aan verbindt, zodat zij als zodanig moeten worden geëerbiedigd tot het ogenblik waarop ze zijn veranderd of ingetrokken."; Visser, p. 65; losbl. uitgave BRv., Boek 1, alg. bespreking van de 12e titel v. Boek I, aant. 43 en 44.

Vgl. Meijers in zijn annotatie bij HR 17.04.1928, NJ 1928, p. 1427: "Door den bevoegden rechter uitgesproken heeft deze beschikking steeds het door de wet daaraan gehechte gevolg en zal dit niet alleen door den verzoeker en de gehoorde personen, maar zelfs door een ieder erkend moeten worden, zoolang de beschikking niet op wettige wijze door een andere vervangen is. "; HR 20.02.1942, NJ 1942, nr. 351; HR 16.04.1948, NJ 1948, nr. 532, m.nt. D.J.V.: "dat de uitspraken van een (.......) rechter rechtskracht hebben, zolang zij niet (.......) zijn te niet gedaan (.......). " Hierbij gaat het om datgene wat Beukers, p. 22, 24 en 37, verstaat als rechtskracht. Gras, p. 14, spreekt in dit verband over formele rechtskracht (rechtskracht volgens het rechtsmiddelenstelsel, p. 14 en vgl. Gras, p. 205, tevens verbod van herhaalde berechting, dat hij onderscheidt van gezag van gewijsde. Zie ook par. 2.7.1.

$357 \mathrm{Vgl}$. Gras, p. 300.

358 Gras, p. 349.

359 Zie Visser, p. 68. Vgl. art. 2:16 BW en art. 2:19 lid 2 BW. In het verleden bijv, art. 1957 (oud) BW, waarin werd bepaald dat het zgn. staatvonnis tegenover een ieder bindende werking had (mits gewezen tegen "dengenen die wettiglijk bevoegd was om den eisch tegen te spreken"). In het NBW is geen equivalent van art. 1957 (oud) BW opgenomen. 
ruimere bindende werking dan inter omnes. In een zodanig geval is in de wettelijke regeling een afgebakende kring van rechtssubjecten opgenomen ten aanzien van wie de desbetreffende rechterlijke uitspraak ook bindende werking heeft. Van dit laatste is artikel $19 \mathrm{RWN}$ een voorbeeld.

\subsubsection{Rijkswet op het Nederlanderschap}

Volgens artikel 19 Rijkswet op het Nederlanderschap is aan een onherroepelijk ${ }^{360}$ geworden beschikking die is gegeven met toepassing van artikel $17 \mathrm{RWN}$ "elk met de uitvoering van enig wettelijke regeling belast orgaan" gebonden. De memorie van Antwoord concretiseert dit nader door op te merken dat artikel 19 RWN leidt tot gebondenheid van de "administratie" aan de onherroepelijk geworden vaststellingsbeschikking. ${ }^{361}$

Artikel 19 Rijkswet op het Nederlanderschap kent derhalve een bijzonder rechtsgevolg toe aan de beschikking van de rechtbank te 's-Gravenhage alsook aan de beschikking van het Gemeenschappelijk Hof van Justitie van de Nederlandse Antillen en Aruba. Onder de werking van artikel $19 \mathrm{RWN}$ vallen vanzelfsprekend ook de (feitelijke) vaststellingsbeschikkingen in cassatie waarbij de Hoge Raad volgens de artikelen $420-422 \mathrm{Rv}$ de zaak zelf afdoet. ${ }^{362}$

Behalve ten opzichte van de Staat (als belanghebbende al partij bij de beschikking en uit dien hoofde reeds inter partes gebonden) en ten opzichte van de verdere "administratie" (gebonden op grond van artikel 19 RWN) heeft de vaststellingsbeschikking geen verder reikende bindende werking. In de memorie van Antwoord aan de Tweede Kamer is al de opmerking geplaatst dat andere rechters niet zijn gebonden aan het oordeel in de vaststellingsbeschikking. ${ }^{363}$ Naderhand, tijdens de behandeling in de Eerste Kamer spreekt de wetgever wel de verwachting uit dat een in een later geding oordelende rechter, hoewel formeel niet gebonden, desal-

\footnotetext{
${ }^{360}$ Een vraag die in verband met de bindende werking uit art. 19 RWN en het daarin opgenomen vereiste van onherroepelijkheid van de vaststellingsbeschikking kan opkomen, is of na de introductie van de mogelijkheid tot herziening (zie par. 2.7.2) nog kan worden gesproken van beschikkingen die onherroepelijk worden. In de literatuur wordt evenwel in algemene zin m.b.t. rechterlijke uitspraken ervan uitgegaan dat onder onherroepelijk dient te worden verstaan dat de rechterlijke uitspraak in kracht van gewijsde, ook wel de formele rechtskracht genoemd, is gegaan. Dit betekent dat een onherroepelijk geworden uitspraak een uitspraak is waartegen geen gewoon rechtsmiddel (meer) openstaat. Zie Den Hartog Jager, p. 161; Polenaar, p. 75; Star Busmann, p. 385-387.

${ }^{361}$ Bijl. II. 82-83, 16947, nr. 7, p. 33: "De bepaling van het voorgestelde artikel 19, volgens welke de administratie aan onherroepelijke rechterlijke beschikkingen tot vaststelling van het Nederlanderschap is gebonden, dient om aan die beschikking zoveel mogelijk werking jegens een ieder te verlenen."

${ }^{162}$ Bijv. HR 13.01.1989, NJ 1990, nr. 266, m.nt. GRdG; HR 28.09.1990, NJ 1991, nr. 293, m.nt. GRdG; HR 13.10.1995, RvdW 1995, nr. 204. Vgl. par. 2.5.1.

${ }^{363}$ Bijl. II. 82-83, 16947, nr. 7, p. 33. Vgl. De Groot/Tratnik, p. 129; Jessurun d'Oliveira, NJB 1983. p. 1309.
} 
niettemin niet zal afwijken van de in de "zelfstandige vaststellingsprocedure" gegeven beslissing. Terzelfdertijd wordt echter aangaande deze verwachting een uitzondering geformuleerd. In het geval "nieuwe relevante feiten aan het licht treden" is een afwijking van de eerder in de "zelfstandige vaststellingsprocecure" genomen beslissing volgens de memorie van Antwoord op het voorlopig verslag van de Eerste Kamer wèl een te verwachten consequentie. ${ }^{364}$

Met betrekking tot artikel $20 \mathrm{RWN}$, het artikel dat op "impliciete vaststellingprocedures" betrekking heeft, resulteert uit hetgeen artikel $19 \mathrm{RWN}$ bepaalt het volgende. De rechterlijke instanties waarop artikel 20 lid $1 \mathrm{RWN}$ doelt, zijn niet gebonden aan een uitspraak in het kader van artikel $17 \mathrm{RWN}$. De instanties die vallen onder artikel 20 lid 2 RWN zijn echter organen van de uitvoerende macht, waarvan buiten twijfel staat dat zij geen rechterlijke instanties zijn. ${ }^{365}$ Deze uitvoerende bestuursorganen, die beslissen in een administratieve beroepsprocecure, zijn derhalve op grond van artikel 19 RWN gebonden aan een vaststellingsbeschikking ex artikel 17 RWN. ${ }^{366}$

\subsubsection{Reikwijate van de bindiende werking}

\subsection{Subjectieve reikwijdte}

Op de vraag wat de actieradius is van de omschrijving "elk met de uitvoering van enige wettelijke regeling belast orgaan" dan wel "de administratie" is niet eenvoudig een antwoord te geven. Wat is nu de omvang van "de administratie"? ${ }^{367}$

Valt bij voorbeeld een notaris, als openbaar ambtenaar, nog onder de werking van artikel $19 \mathrm{RWN} ?^{368}$ Of de Tweede Kamer op het moment dat de geloofsbrieven van een verkozen Kamerlid dienen te worden beoordeeld en er twijfel rijst over het bezit door de betrokkene van de Nederlandse nationaliteit? ${ }^{369}$ Is de Kamer op dat moment een "orgaan dat belast is met de uitvoering van enige wettelijke regeling", in dit geval de Grondwet en Kieswet, en derhalve gebonden aan een vaststellingsbeschikking mocht de belanghebbende daarover beschikken?

\footnotetext{
${ }^{364}$ Bijl. I. 83-84, 16946, nr. 216A, p. 12.

36 Zie par. 2.2.2.1.

${ }^{306}$ Net zo goed gebonden aan de vaststellingsbeschikking zijn de niet onder art. 20 RWN vallende bestuursorganen die zijn belast met de beoordeling van een bezwaarschrift.

${ }^{367}$ Kortmann (I), p. 380, interpreteert "de administratie" als "elk met de uitvoering van enige wettelijke regeling belast ambt." Helder, p. 139, omschrijft het met "besturende overheid".

${ }^{368}$ Art. 1 Wet op het Notarisambt: "De notarissen zijn openbare ambtenaren, (..........). .

$360 \mathrm{Vgl}$. art. 58 Grondwet: "Elke kamer onderzoekt de geloofsbrieven van haar nieuwbenoemde leden en beslist met inachtneming van bij de wet te stellen regels geschillen welke met betrekking tot de geloofsbrieven of de verkiezing zelf rijzen."
} 
Als bekend, heeft de Rijkswet op het Nederlanderschap in verband met de inwerkingtreding op 1 januari 1994 van de Algemene wet bestuursrecht enkele wijzigingen ondergaan. Het karakter van de desbetreffende wijzigingen is bovenal geweest de Rijkswet op het Nederlanderschap terminologisch met de Awb op één lijn te brengen. ${ }^{370}$ Daarbij is echter niet voorzien in een wijziging van "orgaan" uit artikel 19 RWN in het in artikel 1:1 Awb genoemde "bestuursorgaan". Dat "de administratie" bestaat uit "bestuursorganen" lijkt mij echter buiten twijfel te staan. ${ }^{371}$ Dit betekent voor de toepasselijkheid van artikel 19 RWN, mijns inziens, dat in ieder geval de "bestuursorganen" in de zin van artikel 1:1 Awb zijn gebonden aan de vaststellingsbeschikking. ${ }^{372}$

Vanwege het wel aanbrengen van andere wijzigingen in de Rijkswet op het Nederlanderschap in het kader van de inwerkingtreding van de Algemene wet bestuursrecht roept het achterwege laten van de wijziging van "orgaan dat belast is met de uitvoering van enige wettelijk regeling" in "bestuursorgaan dat belast is met de uitvoering van enige wettelijk regeling" vragen op. De vraag naar de ratio waarom niet is overgegaan tot de wijziging van "orgaan" in "bestuursorgaan" is bij gebrek aan informatie dienaangaande van de kant van de wetgever slechts speculatief te beantwoorden. Daarbij komt als eerste de vraag op of het achterwege laten van de wijziging een bewuste dan wel een onbewuste daad is geweest. Indien het gaat om een bewust achterwege gelaten wijziging is de vraag naar de reden daarvan, gezien het al vermelde gebrek aan informatie, niet zonder meer te beantwoorden.

In het geval dat sprake is van een bewuste omissie zou een voor de hand liggende reden kunnen zijn het feit dat de Awb niet geldt voor alle landen waarin de Rijkswet op het Nederlanderschap van kracht is; namelijk Nederland, de Nederlandse Antillen en Aruba. ${ }^{373}$ Hiertegenover kan worden gesteld dat dit argument de wetgever niet ervan heeft weerhouden wel andere aanpassingen aan de Awb in de Rijkswet op het Nederlanderschap door te voeren.

Een andere reden zou eventueel kunnen zijn dat er toch een materieel verschil tussen "bestuursorgaan" en "orgaan" in de zin van artikel 19 RWN blijkt te zijn.

\footnotetext{
${ }^{370}$ Zie par. 2.2.2.1. Vgl. De Groot, MR 1994, p. 211.

37 De begripsonduidelijkheid in het bestuursrecht is evenwel tamelijk groot. Vgl. Bense/Zijlstra, Het begrip bestuursorgaan, NTB 1994, p. 253-270.

372 Bijloos/Lindner, p. 29, noemen als voorbeeld van een "bestuursorgaan" personen die in het buitenland voor het Koninkrijk consulaire handelingen verrichten. In overeenstemming met hun opmerking heeft eerder Offerhaus, p. 28 , al verklaard dat, hoewel in het buitenland opgemaakt, in het geval van een procedure voor een Nederlandse rechter op akten van Nederlandse consuls Nederlands bewijsrecht van toepassing is. Ook Joekes, p. 26, gaat uit van bewijskracht volgens Nederlands recht voor consulaire akten.

${ }^{3 n} \mathrm{Vgl}$. Bijl. II. 92-93, 23252, nr. 3, p. 4: "dat voor zover rijkswetten bevoegdheden toekennen aan Nederlandse bestuursorganen, op de uitoefening daarvan de Awb van toepassing is, terwijl de wijze van bevoegdheidsuitoefening door bestuursorganen van de Nederlandse Antillen en van Aruba geregeld blijft in de desbetreffende rijkswetten. "
} 
Denk aan de hierboven geschetste situatie inzake de toetreding als Tweede Kamerlid. Dat de Tweede Kamer in een zodanig geval geen "bestuursorgaan" is, is geregeld in artikel 1:1 leden 2 en 3 Awb. Maar is de Kamer wellicht op dat moment toch een "orgaan" dat is belast met de uitvoering van enige wettelijke regeling, i.c. de Grondwet en de Kieswet? Naar mijn overtuiging is dat inderdaad het geval.

\subsection{Objectieve reikwijdte}

In de vaststellingsbeschikking wordt een oordeel geveld over het, door de verzoeker, ${ }^{374}$ wel of niet in het bezit zijn van de Nederlandse nationaliteit. Het bezit dan wel de afwezigheid van het bezit wordt vastgesteld voor een bepaalde datum, in de meeste gevallen is dat de datum waarop de beschikking is gegeven.

Dit betekent dat de rechter vaststelt dat een bepaalde persoon op een bepaalde datum wel of niet de Nederlandse nationaliteit bezit. Deze vaststelling zal tot stand komen aan de hand van hetgeen in het verzoekschrift is gesteld, op de mondelinge behandeling ter sprake is gekomen en de aan de rechter overgelegde bewijsstukken. Naar aanleiding van de concrete omstandigheden van de casus beperkt het nationaliteitsonderzoek in de "zelfstandige vaststellingsprocedure" zich in de praktijk veelal tot één verlies- of verwervingsgrond.

In de reeds verscheidene malen aan de orde gekomen lezing van Van den Blink wordt in verband met de bindende werking van de vaststellingsbeschikking zoals die mede gestalte heeft gekregen door middel van artikel 19 RWN een tweetal bedenkingen geuit.

In de eerste plaats kan, al dan niet na verloop van enige tijd, zijn gebleken dat ten tijde van het totstandkomen van de beschikking ingevolge artikel 17 RWN niet alle rechtens relevante gegevens bij de rechter bekend zijn geweest. Wat indien blijkt dat men een eerdere verwervings- of verliesgrond uit het oog heeft gelaten? $\mathrm{Er}$ is bijvoorbeeld het bezit van het Nederlanderschap vastgesteld na een feitenonderzoek naar verliesgrond A (bijvoorbeeld een optie ingevolge artikel 5 lid 1 TOS waaraan de rechter niet het verlies van het Nederlanderschap verbindt), terwijl na geruime tijd waarschijnlijk wordt dat verliesgrond B (bijvoorbeeld artikel 3 TOS) enkele jaren vóór het voorvallen van verliesgrond A zich heeft gerealiseerd. Nochtans is van de betrokkene het bezit van het Nederlanderschap bij rechterlijke uitspraak vastgesteld voor een tijdstip dat ook verliesgrond B omvat.

Hetzelfde kan worden gesteld voor de gronden tot verwerving van het Nederlanderschap. Betekent een negatieve beschikking op een beroep op verwerving van het Nederlanderschap (bijvoorbeeld een optie) dat een mogelijk andere, eerdere, maar niet door de rechter beoordeelde verwervingsgrond (bijvoorbeeld verwerving bij de

\footnotetext{
${ }^{374}$ Dan wel een overledene.
} 
geboorte op grond van de derde-generatierege ${ }^{375}$ ) dat, door het afwijzen van het verzoek tot vaststelling van het Nederlanderschap naar aanleiding van het beroep op de optie, een mogelijke verwerving bij de geboorte eveneens negatief is beantwoord?

In gevallen als hierboven beschreven, is naar later aan het licht treedt een wellicht onjuiste dan wel een apert onjuist blijkende vaststelling gedaan. De problematiek inzake de objectieve reikwijdte van een vaststellingsbeschikking, ten aanzien waarvan naderhand twijfels rijzen aan de materiële juistheid ervan, wordt aan de orde gesteld in paragraaf 2.7.4. De objectieve reikwijdte betreft de vraag waaraan "de administratie" is gebonden indien blijkt dat waarschijnlijk een foutieve vaststellingsbeschikking is gegeven.

\subsection{Duur van de bindende werking}

De tweede bedenking die Van den Blink opwerpt, is dat de vaststelling correct is geschied, maar dat nadien ten aanzien van de nationaliteit een verandering is ingetreden. Een zodanige situatie roept in het kader van de bindende werking van artikel 19 RWN de vraag op welke werking in die situatie nog uitgaat van de vaststellingsbeschikking.

Het in een zodanig geval eenvoudig negeren van de vaststellingsbeschikking door "de administratie", waarna de betrokkene dan indien hij dat wenst, een nieuwe vaststellingsprocedure kan starten, acht Van den Blink "moeilijk te verenigen met art. 19 van de Wet. ${ }^{n 376}$ Op dit punt constateert Van den Blink een leemte in de Rijkswet en al veronderstellend meent zij: "Men heeft aan deze mogelijkheid van een verandering van omstandigheden na de uitspraak waarschijnlijk niet gedacht. ${ }^{n 37}$ Ten einde voor dit dilemma een oplossing te vinden, prefereert Van den Blink een wijziging van de RWN boven het bij een ongewijzigde Rijkswet door "de administratie" simpelweg negeren van de vaststellingsbeschikking. ${ }^{378}$ De Groot is daarentegen van mening dat indien ten gevolge van een posterieur aan de vaststellingsbeschikking voorgevallen rechtsfeit het werkelijk bezit van het Nederlanderschap niet meer strookt met de vaststellingsbeschikking "de administratie" niet gehouden is de beschikking nog na te leven. ${ }^{379}$

De vraag is derhalve of een "met de uitvoering van enig wettelijke regeling belast orgaan", dat ingevolge artikel $19 \mathrm{RWN}$ is gebonden aan een vaststellingsbeschikking, nog is gebonden indien bij het orgaan de overtuiging heeft post gevat dat de

\footnotetext{
375 Zie daarover par. 3.3.1.

376 Van den Blink, p. 13.

in Van den Blink, p. 13.

Van den Blink, p. 17.

${ }^{379}$ De Groot, losbl. uitgave Personen- en Familierecht, art. 19 RWN, aant. 1.
} 
Hoofdstuk 2

nationaliteitsrechtelijke situatie na het geven van die vaststelling is gewijzigd. Met De Groot meen ik dat van een voortdurende bindende werking van de beschikking geen sprake kan zijn. Indien het gaat om een verwerving van het Nederlanderschap, bijvoorbeeld een naturalisatie na een eerdere negatieve vaststellingsbeschikking, dan zullen zowel de justitiabele als de overheid het eens zijn dat de vaststellingsbeschikking is "ingehaald" door een later rechtsfeit. Ook bij een, na een eerdere positieve vaststellingsbeschikking, opgetreden verliesgrond kunnen zowel de justitiabele als de overheid het eens zijn over het verlies van het Nederlanderschap en de vaststellingsbeschikking eveneens beschouwen als door het latere rechtsfeit "ingehaald". Ook in het geval dat de justitiabele wenst dat de administratie zich, niettegenstaande de daarbinnen gevestigde overtuiging dat de nationaliteit is gewijzigd, blijft houden aan de eerder geven vaststellingsbeschikking moet toch ervan worden uitgegaan dat de bindende werking van artikel 19 RWN met de realisering van het posterieure rechtsfeit is beëindigd. Ter zake van dit posterieure rechtsfeit kan de justitiabele de rechterlijke toetsing van de rechtbank in Den Haag inroepen. ${ }^{380}$

Vanzelfsprekend behoudt de "ingehaalde" vaststellingsbeschikking haar rechtskracht: voor het moment dat in de beschikking het bezit van het Nederlanderschap wel of niet is vastgesteld, blijft het een rechtsgeldige declaratoire uitspraak. Voor dat vaststellingsmoment en tot aan het moment van het rechtsfeit dat tot nationaliteitswijziging leidt, geldt dan ook onverminderd de bindende werking die uitgaat van artikel 19 RWN.

Met Van den Blink deel ik echter de voorkeur voor een aanpassing van de Rijkswet op het Nederlanderschap. Een aanvulling op artikel 19 RWN inhoudende dat de bindende werking slechts voortduurt zolang niet een posterieur rechtsfeit een verandering in de nationaliteit heeft teweeggebracht, lijkt mij, omdat dat de duidelijkheid ten goede komt, wenselijk.

\subsection{Herziening van een vaststellingsbeschikking}

\subsubsection{Algemene beschouwingen}

Ter behartiging van het rechtsbeginsel "lites finiri oportet ${ }^{m 81}$ huldigt de Hoge Raad sedert lange tijd het uitgangspunt dat een rechterlijke uitspraak slechts haat rechtskracht kan worden ontnomen door middel van het met succes tijdig aanwen-

\footnotetext{
380 Cf. De Groot, losbl. uitgave Personen- en Familierecht, art. 19 RWN, aant. 1.

381 Vgl. Coops, p. 198: "de rechtmatige eis, dat partijen op een bepaald moment definitief weten waaraan ze toe zijn"; Ten Berge/Tak, p. 239: "aan de rechtsstrijd behoort een einde te komen"; Stein, p. 184: "dat een eenmaal afgedane zaak niet opnieuw aan de rechter kan worden voorgelegd"; Tonnaer, p. 358: "het ongeschreven rechtsbeginsel dat aan een geschillenprocedure een einde mot komen"; Veegens, p. 18, "het beginsel dat aan alle procederen een einde moet komen".
} 
den van een rechtsmiddel. ${ }^{382}$ Het beginsel staat ten dienste van het vereiste van rechtszekerheid. ${ }^{383}$

De justitiabelen staat ten behoeve van de wens om een rechterlijke uitspraak aan te kunnen tasten een beperkt aantal rechtsmiddelen ter beschikking. Het aldus beschikbare stelsel van mogelijkheden om een rechterlijke uitspraak aan te tasten, wordt door de Hoge Raad getypeerd als "het gesloten stelsel van rechtsmiddelen". 384

In het burgerlijk procesrecht worden de rechtsmiddelen onderverdeeld in gewone en buitengewone rechtsmiddelen. ${ }^{385}$ Het begripsmatig onderscheid tussen gewone en buitengewone rechtsmiddelen is dat de gewone rechtsmiddelen binnen een in de wet gestelde termijn tegen een nog niet in kracht van gewijsde gegane uitspraak dienen te worden ingesteld, terwijl de buitengewone rechtsmiddelen zijn gericht tegen uitspraken die al formele rechtskracht ${ }^{386}$ hebben verkregen. ${ }^{387}$

\footnotetext{
3E Standaardarrest in dezen is HR 16.04.1948, NJ 1948, nr. 532, m.nt. D.J.V.: de Hoge Raad stelt daarin: "dat de uitspraken van een (.....) rechter rechtskracht hebben, zolang zij niet langs den bepaaldelijk daarvoor in de wet aangewezen weg zijn te niet gedaan (........). "

30 Gras, p. 81.

$33 \mathrm{Vgl}$. HR 07.06.1991, NJ 1991, nr. 577. Zie tevens Beukers, p. 14-20; Gras, p. XVI.

3ts Onder de gewone civielrechtelijke rechtsmiddelen worden verstaan: (schriftelijke verklaring ingevolge art. 116 lid $5 \mathrm{Rv}$ ); verzet, hoger beroep, revisie en cassatie. Onder de buitengewone civielrechtelijke rechtsmiddelen worden rekest-civiel en derden-verzet gerekend (Gras, p. 66 (i.h.b. voetnoot 2); Hugenholtz/Heemskerk, p. 188).

Verzet is een rechtsmiddel dat niet algemeen toelaatbaar is in verzoekschriftprocedures, toepassing ervan is slechts mogelijk indien de wettelijke bepalingen aangaande de desbetreffende verzoekschriftprocedure de mogelijkheid uitdrukkelijk noemen (losbl. uitgave BRv., alg. bespreking van de $12 \mathrm{e}$ titel v. Boek I, aant. 50).

Rekest-civiel en derden-verzet worden alleen mogelijk geacht tegen vonnissen en derhalve niet in verzoekschriftprocedures (Hugenholtz/Heemskerk, p. 232 en 235). Desondanks heeft de kantonrechter in Amsterdam 22.01.1986, NJ 1986, nr. 775, wegens het "uiterst contentieus karakter" van de "voorafgaande rechtsstrijd" rekest-civiel toegelaten tegen een beschikking op een verzoek tot ontbinding van een arbeidsovereenkomst (art. 1639w (oud) BW). Dit standpunt wordt herhaald in Ktg. Amsterdam 19.03.1992, NJ 1992, nr. 782 en Ktg. Sittard 11.03.1994, Prg. 1994, nr. 4076. Evenwel, de kantonrechter in Amersfoort 21.10.1992, Prg. 1993, nr. 3833, is van oordeel dat "de artikel 7A: 1639 w-procedure behoort tot de zuivere rekestprocedure" en dat rekest-civiel niet mogelijk is tegen "beschilkingen in zuivere rekestprocedures". Waarop niet-ontvankelijkverklaring volgt. Vgl. Van Son, Advocatenblad 1994, p. 415.

De meningen lopen uiteen of cassatie in het belang der wet een rechtsmiddel kan worden genoemd. Volgens Zuidema, p. 109, is het geen rechtsmiddel. Naar de mening van Coops, p. 151; Bruinsma, p. 66 en Den Hartog Jager, p. 161, is het daarentegen cen buitengewoon rechtsmiddel. Hugenholtz/Heemskerk, p. 188, stelt dat indien cassatie in het belang der wet al kan worden gecategoriseerd als een buitengewoon rechtsmiddel, het daarbij tevens "een bijzondere plaats inneemt".

${ }_{30}$ D.w.z. reeds onaantastbaar (geworden) voor gewone rechtsmiddelen.

35 Het onderscheid tussen gewone en buitengewone rechtsmiddelen wordt ook wel gezocht in de schorsende werking van het rechtsmiddel; vgl. Coops, p. 151. Gewone rechtsmiddelen schorsen de tenuitvoerlegging van het vonnis. Buitengewone rechtsmiddelen kennen geen schorsende werking.
} 
In de literatuur ${ }^{388}$ en in een deel van de jurisprudentie van de Hoge Raad ${ }^{395}$ wordt de eis gesteld dat het aan te wenden rechtsmiddel als zodanig ten behoeve van het kunnen aantasten van de desbetreffende uitspraak in de wet is aangewezen. Evenwel is het uitgangspunt dat een rechterlijke uitspraak slechts kan worden aangetast door middel van een in de wet ten behoeve van een desbetreffende uitspraak genoemd rechtsmiddel niet absoluut houdbaar gebleken. ${ }^{390}$ Bekend is in dit opzicht de jurisprudentie ten aanzien van artikel $1639 \mathrm{w}$ (oud) $\mathrm{BW},{ }^{391}$ betreffende de verzoekschriftprocedure bij de kantonrechter tot ontbinding van de arbeidsovereenkomst. ${ }^{392}$ Hoewel rekest-civiel niet van toepassing is op verzoekschriftprocedures, is het met betrekking tot artikel 1639w (oud) BW menigmaal wel toelaatbaar geacht. ${ }^{393}$ En onder bepaalde voorwaarden is met betrekking tot dit artikel hoger beroep en cassatie wel toelaatbaar geoordeeld, ondanks het feit dat in artikel 1639w (oud) BW het instellen van beide rechtsmiddelen uitdrukkelijk is uitgesloten. ${ }^{394}$ Wat geldt met betrekking tot de beschikking op het verzoek tot

\begin{abstract}
$38 \mathrm{Vgl}$. Boekman, p. 120, over "vonnis": "kan slechts worden aangetast door één der in de wet aangewezen rechtsmiddelen"; cf. Heemskerk (II), p. 328; Ten Kate, p. 13 en 233: "Vele malen heeft men in de litteratuur en in de rechtspraak uitgesproken, dat uitspraken van de overheidsrechter als bindend moeten worden aangemerkt, zolang zij niet langs een bepaaldelijk in de wet daarvoor aangewezen weg zijn teniet gedaan."; Korthals Altes, p. 153, beschrijft in zijn opstel de in de rechtspraak heersende leer als "het beginsel dat rechterlijke uitspraken slechts door middel van door de wet toegekende rechtsmiddelen kunnen worden aangetast"; Meijers in zijn annotatie bij HR 17.04.1928, NJ 1928, p. 1427: "(......) daarmede niet aan de beschikking rechtskracht ontzegd wordt. Door den bevoegden rechter uitgesproken heeft deze beschikking steeds het door de wet daaraan gehechte gevolg en zal dit niet alleen door den verzoeker en de gehoorde personen, maar zelfs door een ieder erkend moeten worden, zoolang de beschikking niet op wettige wijze door een andere vervangen is. "; Röder, p. 64.
\end{abstract}

369 Behalve in de in voetnoot 382 genoemde uitspraak komt de eis dat het toe te passen rechtsmiddel specifiek moet zijn aangewezen in de wet voor in HR 28.10.1977, NJ 1978, nr. 284, m.nt. WHH (inzake rechtskracht van een voogdijbeschikking): "(..), zulks niet mee zou hebben gebracht dat aan de beschikking van de $R b$. (.....), nu zij niet langs de bepaaldelijk daarvoor in de wet aangewezen weg was tenietgedaan, haar geldigheid zou kunnen ontvallen".

Daarentegen is de eis van in de concrete procedure door de wet zijn aangewezen als rechtsmiddel niet toegevoegd in de uitspraken HR 27.01.1989, NJ 1989, nr. 588, m.nt. WHH, en HR 04.05.1990, NJ 1990, nr. 677, m.nt. PAS. In beide uitspraken overweegt de HR: "Het gesloten stelsel van in de wet geregelde rechtsmiddelen brengt mee dat een onjuiste rechterlijke uitspraak -(...........)-niet anders dan door het aanwenden van een rechtsmiddel kan worden aangetast (..........). "

$390 \mathrm{Vgl}$. Gras, p. 87.

394 Het huidige art. 7a:1639w BW.

392 Vgl. Dam, TCR 1994, p. 25-28; Gras, p. 68 e.v.; Ras, p. 65; Wendels, Trema 1994, p. 206.

${ }^{393}$ Zie voetnoot 385 .

$394 \mathrm{Vgl}$. HR 12.03.1982, NJ 1983, nr. 181; HR 03.07.1989, NJ 1989, nr. 857; Rb. 's-Gravenhage 29.05.1991, NJ 1992, nr. 127; Rb. Amsterdam 15.01.1992, NJ 1992, nr. 417; HR 24.09.1993, NJ 1993, nr. 758; HR 29.04.1994, NJ 1994, nr. 497, herstel van een kennelijke vergissing in het dictum (de namen van de pp. waren verwisseld), er volgt hoger beroep en beroep in cassatie. De HR beslist dat de kantonrechter ambtshalve kan dan wel op verzoek van én der partijen moet verbeteren. De HR 
ontbinding van de arbeidsovereenkomst geldt in beginsel voor alle verzoekschriftprocedures die eveneens geen hogere voorziening op grond van een wettelijk voorschrift kennen. ${ }^{395}$ In 1985 heeft de Hoge Raad namelijk de volgende regel vastgesteld: "dat indien de wet, (.......), hogere voorziening van een beschikking gegeven krachtens een bepaald wetsartikel, ${ }^{396}$ niet toelaat ten einde -zoals hieriedere discussie uit te sluiten over de wijze waarop de rechter van zijn aan dat artikel ontleende bevoegdheden heeft gebruik gemaakt, dit nog niet medebrengt dat hogere voorziening evenmin is toegelaten voor zover erover wordt geklaagd dat het artikel ten onrechte dan wel met verzuim van essentiële vormen is toegepast, of ten onrechte buiten toepassing is gelaten. ${ }^{1397}$

De visie dat incidenteel ruimte bestaat voor de mogelijkheid dat een rechtsmiddel kan worden aangewend dat niet ten behoeve van de desbetreffende uitspraak als zodanig door de wet is aangewezen, heeft van oudsher ondersteuning gevonden in de literatuur. Parser stelt reeds in 1903: "Ik geloof veeleer, dat wanneer de rechtsovertuiging het bestaan van een dergelijk rechtsmiddel voorschrijf, wij verheugd mogen zijn dat de wetgever het hun, die met de rechtsbedeeling belast zijn niet heeft verboden. ${ }^{m 98}$ Voor het huidige tijdsgewricht onderschrijft Heemskerk deze visie door in het kader van zijn betoog over "Nietigheid in het burgerlijk procesrecht" op te merken: "De wetgever zou bovendien de grenzen van zijn bevoegdheid overschrijden als hij de rechter zou verbieden leemtes in de wet aan te vullen. ${ }^{m 399}$

Tegenover hetgeen hierboven is opgemerkt betreffende het slechts door middel van het (tijdig) instellen van een (in beginsel bij de wet aangewezen) rechtsmiddel kunnen aantasten van een rechterlijke uitspraak, staat dat in verzoekschriftprocedures een herhaling van het verzoek in principe toelaatbaar is. Boekman heeft dien-

394

anticipeert in deze uitspraak op de artt. 2.11.10 en 3.4.13 uit het Voorontwerp tot aanpassing van het Wetboek van BRv. Wat hier gebeurt, is overigens cen fraai staaltje: door een niet in de wet voorziene hogere instantie wordt een nog niet tot wet verheven bepaling toegepast. Vgl. over de artt. 2.11.10 en 3.4.13 Voorontwerp: Meijknecht, Trema 1994, p. 212.

${ }^{39} \mathrm{Vgl}$. Dam, TCR 1994, p. 25.

${ }^{39}$ D.i. mijns inziens een verwijzing naar het gesloten stelsel van verzoekschriftprocedures: beschikkingen dienen op een bepaald wetsartikel terug te voeren te zijn, anders heeft rechter geen rechtsmacht gehad tot het geven van de beschikking.

${ }^{39}$ HR 29.03.1985, NJ 1986, nr. 242, m.nt. WHH en LWH. I.c. betreft het een beschikking inzake een voorlopig getuigenverhoor, waarvoor art. 878 lid 2 (oud) Rv "hogere voorziening" uitsloot. Wegens schending van het beginsel van hoor en wederhoor bij het inwilligen van het verzoek om cen voorlopig getuigenverhoor te houden, achtte de Hoge Raad hoger beroep toch mogelijk. Bij de inwerkingtreding op 01.04.1988 van het vernieuwde bewijsrecht is art. 878 (oud) Rv vervallen. Vgl. tevens Gras, p. 73; Ras, p. 65.

398 Parser, p. 125.

Heemskerk (II), p. 323. Vgl. Leijten, p. 157 en 158. 
aangaande als volgt opgemerkt: "Merkwaardigerwijs schijnt men wel aan te nemen, dat aan beschikkingen een zeker negatief gezag van gewijsde toe zou komen, zodat men niet ten tweede male hetzelfde verzoek zou mogen doen. Op wat voor grond men dit aanneemt, weet $i k$ niet. ${ }^{m 40}$ De mogelijkheid een herhaald identiek verzoek te richten aan de rechter is vanzelfsprekend wel onderhevig aan de eis dat geen sprake is van misbruik van procesrecht. ${ }^{401}$

Wat echter na de uitspraak op een tweede verzoek de rechtskracht van de eerste beschikking (nog) is, heeft geen nadere regeling gevonden. Struycken heeft bij gelegenheid de weliswaar terechte opmerking: "De eenheid van de rechtsorde verdraagt niet de gelding van tegenstrijdige beslissingen. ${ }^{m 02}$ geplaatst, maar met deze opmerking wordt vooralsnog geen duidelijkheid gegeven over de vraag of de totstandkoming van de tweede beschikking als rechtsgevolg heeft dat de eerste beschikking haar rechtskracht verliest. ${ }^{403}$ Evenwel, ondanks het feit dat de eerste beschikking niet wordt vernietigd "door het aanwenden van een (bij de wet aangewezen) rechtsmiddel" moet mijns inziens worden aangenomen dat de totstandkoming als gevolg van een herhaald verzoek van de tweede beschikking leidt tot het prevaleren van de laatstgegeven beschikking boven de voorafgaande beschikking.

\footnotetext{
${ }^{400}$ Boekman, p. 127. Zie tevens Van den Blink, p. 16; Den Hartog Jager, p. 236; Snijders, p. 14 (i.h.b, voetnoot 32). Ook in dagvaardingsprocedures mag een vordering worden herhaald, het is dan aan de meest gerede partij om een beroep te doen op art. 67 lid $2 \mathrm{Rv}$ (het gezag van gewijsde van een eerder vonnis wordt niet ambtshalve door de rechter toegepast; de herhaling van de vordering betreft dus niet een punt van openbare orde); vgl. Hugenholtz/Heemskerk, p. 108-110; Van Son, Advocatenblad 1994, p. 419.

De toepasselijkheid van de regel "ne bis in idem" wordt derhalve afgewezen; vgl. Beukers, p. $112 \mathrm{en}$ 118; Gras, p. XXIII; Ten Kate, p. 33 (i.h.b. voetnoot 14): "Gemis aan belang" kan volgens Ten Kate in een zodanig geval de vordering al doen stranden.

40i Van den Blink, p. 16. Vgl. de opmerking over de eventuele herhaling van een beklagschrift ingevolge art. 43 (oud) Vw-procedure door A.-G. Mok in zijn conclusie bij HR 26.10.1984, NJ 1985, nr. 112. Herhaling van het beklag onder aanvoering van beter bewijsmateriaal acht hij toelaatbaar. Nadien heeft de A.-G. zijn standpunt herhaald met betrekking tot een verzoek tot vaststelling van het Nederlanderschap op grond van art. 17 RWN: zie de conclusie bij HR 31.01.1992, NJ 1993, nr. 261, m.nt. GRdG. Vgl. tevens Beukers, p. 117 en 118; Vriesendorp, p. 203. Vgl. art. 3:13 jo. art. 3:15 BW.

402 Struycken, p. 38.

${ }^{403}$ Zowel Beukers, p. 37, als Gras, p. 78, menen van niet. En deze gedachtengang is m.i. correct; eetn uitspraak blijft inderdaad formeel bestaan, zolang deze niet door middel van aanwending van etn rechtsmiddel is vernietigd. Afgezien van het geval waarin een uitspraak van rechtswege op enig moment haar rechtskracht verliest (bijv, art. 826 Rv en art. 1:163 lid 3 BW) kan alleen vernietiging van de uitspraak de rechtskracht ervan wegnemen.
} 


\subsubsection{Rijkswet op het Nederlanderschap}

Een voor de verzoeker teleurstellend oordeel omtrent zijn Nederlanderschap door de rechtbank in Den Haag (of door de Hoge Raad indien deze bij het cassatieberoep de zaak zelf afdoet), kan voor de verzoeker wellicht aanleiding zijn op enig later tijdstip te trachten de begeerde vaststelling alsnog te verkrijgen. Het is immers niet onmogelijk dat de verzoeker pas na afloop van de procedure de beschikking heeft gekregen over bewijsstukken die wèl tot vaststelling van zijn ${ }^{404}$ Nederlandse nationaliteit zullen leiden.

In het geval van een situatie als hierboven is geschetst, lijken voor de verzoeker twee mogelijkheden open te staan. Enerzijds staat, onder de voorwaarde dat niet sprake is van misbruik van procesrecht, de mogelijkheid open een nieuw verzoek te doen: het moment van vaststellen is dan het moment waarop de rechtbank zijn beschikking geeft. ${ }^{405}$ Anderzijds kan, blijkens de jurisprudentie, een verzoek worden gedaan om de bestaande beschikking te herzien. Het moment waarop dan het bezit van het Nederlanderschap wordt gefixeerd, is de datum waarop de eerste, de te herziene, beschikking is gegeven. ${ }^{406}$

Is het verzoek gebaseerd op feiten die vóor de (eerste) vaststellingsbeschikking hebben plaatsgevonden, dan kan dit aanleiding zijn om een herzieningsverzoek in te dienen. Immers, nagestreefd kan worden een nationaliteitsvaststelling voor dezelfde datum als de eerste, oorspronkelijke, vaststelling. Is het verzoek daarentegen gebaseerd op feiten die ná de (eerste) vaststelling hebben plaatsgevonden en wordt de correctheid van deze eerste vaststelling in wezen niet in twijfel getrokken, dan is alleen een geheel nieuw verzoek op zijn plaats en zal de vaststelling geschieden naar het moment dat de rechtbank de tweede beschikking geeft.

Overigens ben ik van mening dat, wat betreft een feitelijke situatie waarin een herzieningsverzoek tot de mogelijkheid behoort, het de betrokkene vrij staat in zo'n geval te kiezen voor een geheel nieuw verzoek, ten gevolge waarvan een tweede vaststelling geschiedt naar een latere datum. De rechtbank is immers niet gebonden aan haar eerder gegeven beschikking. ${ }^{407}$

\footnotetext{
${ }^{404}$ Of dat van de overledene, indien het (eerste) verzoek de nationaliteitsvaststelling van een overledene heeft betroffen.

${ }^{205}$ Op dit laatste kan zich evenwel een uitzondering voordoen in het geval dat de verzoeker een Nederlanderschapsvaststelling heeft verzocht voor een moment in het verleden, bijvoorbeeld de datum van de eerste beschikking. Zie par. 2.2.4.2.2 voor de retrospectieve vaststelling.

${ }^{406}$ Dit onder de presumtie dat de herziening ex tunc zal plaats hebben. Dat de herziening ex tunc zal gebeuren, is nu net de essentie ervan. Een herziening ex nunc zou immers hetzelfde zijn als een beslissing op een nieuw verzoek tot nationaliteitsvaststelling.

${ }^{407}$ Volgens art. $19 \mathrm{RWN}$ zijn rechterlijke instanties niet gebonden aan de vaststellingsbeschikking. Vgl. Bijl. II. 82-83, 16947, nr. 7. p. 33. Vgl. De Groot/Tratnik, p. 129; Jessurun d'Oliveira, NJB 1983, p. 1309. Ook A.-G. Mok gaat uit van het niet-gebonden zijn van de rechtbank aan haar eerdere beslissing. Een herhaling van het verzoek onder aanvoering van nieuw bewijsmateriaal (zie hierboven voetnoot 401) zou anders niet mogelijk zijn.
} 
Terwill de mogelijkheid een herhald, verzoek in te dienen in het procerectit zelf besloten ligt, geld! ten annen van een rechtsmiddel in beginsell dat de mogelijkheld for het instellen daarvan aan de hand van wettelijke bepalingendient te blijken.

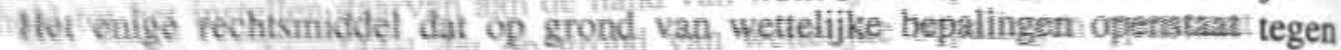

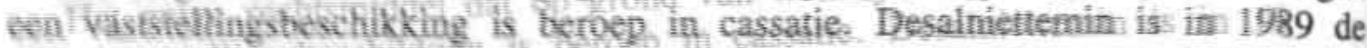

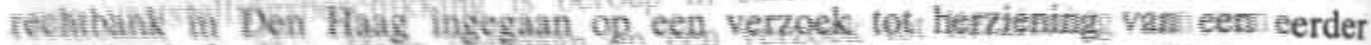

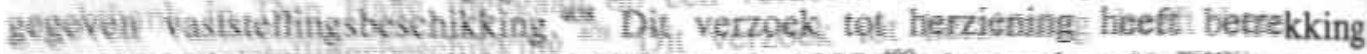

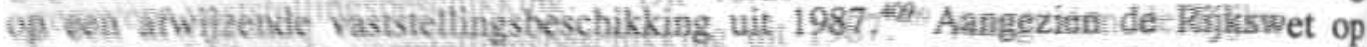
hef Noderlanderschap net voorzlet in de mogelijkbeid tat herciening van de visastollingskesthik king is het nogal opmerkelijk dat een herzicningsrerzsck wordt

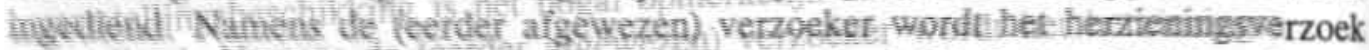

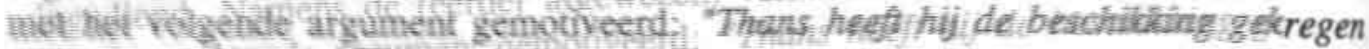

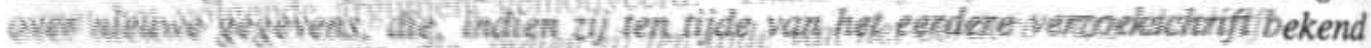

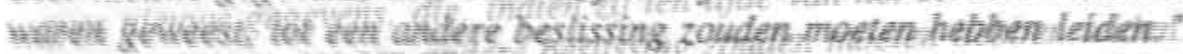

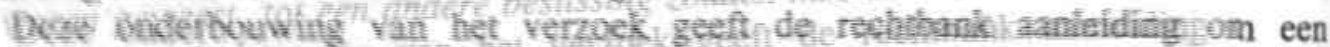

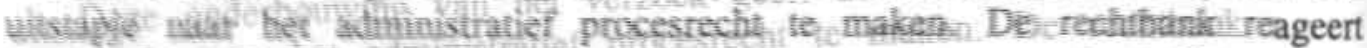

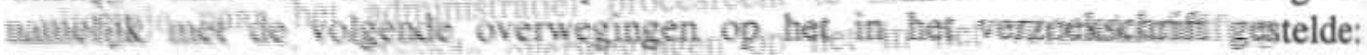
"Gelet op de verwantschap van deze formulering met artikel 61 lid 1 van de Wet op de Raad van State ${ }^{410}$ neemt de rechtbank aan dat met dit verzoek herziening wordt beoogd van de afwijzende beschikking dezer rechtbank van 25 november 1987, rekestnummer $87 / 5536$.

Noch hoofdstuk 6 van de Rijkswet op het Nederlanderschap, noch de van toepassing verklaarde artikelen van het Wetboek van Burgerlijke Rechtsvordering bieden de mogelijkheid tot herziening, maar sluiten haar ook niet uit. Hoewel in voormeld hoofdstuk gewone rechterlijke instanties worden aangewezen blijkt uit de tekst van de Rijkswet en haar parlementaire geschiedenis dat het daarin geregelde onderwerp in overwegende mate administratiefrechtelijk van aard is. In dat recht is herziening een vaker voorkomende mogelijkheid. De rechtbank neemt dan ook aan dat sprake is van een leemte in de Rijkswet, waarin dient te worden voorzien. " ${ }^{411}$

Uit de beschikking blijkt dat de procedure in herziening een zelfde verloop heeft gehad als gebruikelijk is bij een eerste verzoek. De Staat is opgeroepen als belanghebbende en het openbaar ministerie is verzocht een conclusie te nemen. I.c. is een vertegenwoordiger van het ministerie van Justitie op de mondelinge behandeling verschenen en uit de beschikking blijkt niet dat van de kant van de belangheb-

40 Rb. 's-Gravenhage 30.08.1989, rkstnr. 89.5271. Zie Van den Blink, p. 14-16; De Groot, losbl. uitgave Personen- en Familierecht, art. 19 RWN, aant. 1.

${ }^{409} \mathrm{Rb}$. 's-Gravenhage 25.11.1987, rkstnr. 87.5536. Zie voetnoot 198.

${ }^{410}$ Art. 61 WRvS, dat betrekking heeft gehad op de herziening door de Afdeling geschillen van bestuur, is vervallen met ingang van 01.01.1994.

"11 Mijns inziens valt het wel mee met de geconstateerde leemte. Indien de rechtbank het onderhavige verzoek had beschouwd als een verzoek voor een retrospectieve nationaliteitsvaststelling (zie par. 2.2.4.2.4) zou het verzoek geheel onder de mogelijkheden uit art. 17 RWN hebben gevallen. 
bende Staat bezwaar is gemaakt tegen de mogelijkheid tot herziening van een eerdere vaststellingsbeschikking.

Naar het uiteindelijk oordeel van de rechtbank bestaat in de onderhavige zaak geen aanleiding tot herziening. De afwijzing wordt gestoeld op de feitelijke overweging dat de "nieuwe gegevens" waarop de verzoeker zich beroept, voor de rechtbank geen aanleiding vormen in te gaan op het herzieningsverzoek, aangezien door deze gegevens bij de rechtbank "geen ernstige twijfel is ontstaan aan de juistheid van de eerdere uitspraak. " Hetgeen tot de volgende beslissing leidt: "De rechtbank wijst het verzoek om herziening af."

Ter zijde kan nog worden opgemerkt dat het criterium volgens hetwelk de rechtbank het herzieningsverzoek blijkt te toetsen, overigens niet afkomstig is uit het wel door de rechtbank aangehaalde artikel 61 lid 1 (oud) WRvS, ${ }^{412}$ maar dat de rechtbank het iets zwaardere criterium uit de (met ingang van 1 januari 1994 vervallen) bepalingen uit de Ambtenarenwet $1929^{413}$ en de Wet $\mathrm{Arbo}^{414}$ als maatstaf gebruikt. De beide laatste wetten eisten voor herziening immers "ernstige twijfel" bij de rechterlijke instantie met betrekking tot de juistheid van de te herziene uitspraak in het licht van de kennisneming van de nieuwe gegevens.

\subsubsection{Herziening in het administratief procesrecht}

Als in het bovenstaande naar voren is gekomen, is herziening een in het administratief procesrecht bekend rechtsmiddel. Voor de inwerkingtreding van de Algemene wet bestuursrecht op 1 januari 1994 hebben enkele bestuursrechtelijke wetten afzonderlijke bepalingen gekend waarin het rechtsmiddel werd opengesteld. ${ }^{415}$ Onderling hebben de verschillende redacties van de desbetreffende bepalingen overigens weinig van elkaar afgeweken. Met de inwerkingtreding van de Awb is

\footnotetext{
412 "Herziening van Onze beslissing kan plaatsvinden op grond van nader gebleken feiten of omstandigheden, die, waren zij eerder bekend geweest, tot een andere beslissing zouden hebben kunnen leiden." ${ }^{413}$ Art. 112 lid 2 (oud) Ambtenarenwet 1929: "(Herziening) wordt verzocht op grond, dat gebleken is van eenige omstandigheid, die bij de behandeling van het beroep aan het gerecht niet bekend was en die op zichzelf of in verband met andere feiten of omstandigheden ernstigen twijfel doet ontstaan aan de juistheid van de uitspraak. "

${ }^{414}$ art. 71 lid 2 (oud) Wet Arbo: "Het verzoek kan worden ingediend op grond, dat gebleken is van enige omstandigheid, die bij de behandeling van het beroep aan het College niet bekend was en die op zichzelf of in verband met andere feiten of omstandigheden ernstige twijfel doet ontstaan aan de juistheid van de uitspraak."

${ }^{415}$ Bijv. de al eerder vermelde artt. 61 (oud) WRvS, art. 112 (oud) Ambtenarenwet 1929; art. 71 (oud) Wet Arbo. Art. 120 (oud) WRvS heeft dezelfde strekking gehad als art. 61 (oud) WRvS en gold de herziening door de Afdeling rechtspraak. Art. 153 (oud) Beroepswet bevatte een procedure tot nietigverklaring van een eerder gedane uitspraak wegens het feit dat deze berustte op valse stukken of op valse verklaringen van getuigen of deskundigen.
} 
voorzien in een algemene bepaling inzake herziening. Artikel 8:88 Awb brreft de herzieningsprocedure bij de arrondissementsrechtbank ten behoeve van eerer door de rechtbank genomen beslissingen. ${ }^{416}$ Een enkele wet heeft de eigen herzeningsprocedure behouden. ${ }^{417}$

De grondslag voor het administratiefrechtelijke rechtsmiddel herziening isgelegen in een, naar achteraf blijkt, onjuiste feitelijke voorstelling van zaken bij derechterlijke instantie. Dezelfde grondslag is ook te herkennen in enkele gronder ${ }^{18}$ voor het buitengewoon civielrechtelijk rechtsmiddel rekest-civiel. ${ }^{419}$ In de adninistratiefrechtelijke literatuur wordt herziening van een rechterlijke uitspraak geategoriseerd onder de noemer "bijzondere procedures". ${ }^{420}$ Het bijzondere is daarbij gelegen in het feit dat het middel dient te worden ingesteld tegen een eeds in kracht van gewijsde gegane beslissing van een rechter. Dat het bij herziemg gaat om de aantasting van een uitspraak die formele rechtskracht heeft verkregeı is een karakteristiek waardoor het in het burgerlijk procesrecht zou worden geruriceerd onder de buitengewone rechtsmiddelen. ${ }^{421}$ Conform de aard van een bitengewoon rechtsmiddel ontbeert het verzoek tot herziening schorsende werking. ${ }^{2}$

Hierboven is reeds opgemerkt dat tot de inwerkingtreding van de Algemene wet bestuursrecht op 1 januari 1994 de diverse wettelijke bepalingen inzake herziening onderling weinig variatie hebben vertoond. Een iets aparte plaats hebben de Ambtenarenwet 1929 en de Wet administratieve rechtspraak bedrijfsorganisatie (Wet Arbo) ingenomen. Als reeds is opgemerkt aan het eind van paragraaf 2.7.2 is in deze twee wetten, voor het in behandeling nemen van het verzoek, vereist geweest dat bij de rechterlijke instantie waar de herziening wordt verzocht "ernstige twijfel ${ }^{\text {M23 }}$ ten aanzien van de juistheid van de te herziene uitspraak is ontstaan.

\footnotetext{
${ }^{416}$ In het kader van de Algemene Bijstandswet is herziening van een door de CRvB genomen beslissing mogelijk ingevolge art. 8:88 Awb jo. art. 17 Beroepswet: vgl. CRvB 27.07.1995, JB 1995, nr. 199.

${ }^{417}$ Bijv. art. 61 Wet uitkeringen vervolgingsslachtoffers 1940-1945. Vgl. CRvB 25.11.1993, AB 1994, nr. 158.

${ }^{418} \mathrm{Vgl}$. art. 382 sub 1,7 en 8 Rv.

${ }^{419}$ Schipper e.a., losbl. uitgave ambtenarenrecht, Band 3, V I, Inleiding, signaleert tevens een gelijkenis van de administratiefrechtelijke herziening met de strafrechtelijke herziening (art. 457 lid 1 sub 2 Sv), dat eveneens slechts tegen in kracht van gewijsde gegane uitspraken kan worden aangewend. Vgl. inzake een strafrechtelijke herziening: HR 26.04.1994, NJ 1994, nr. 736. Ook Ten Berge/Tak, p. 238, wijzen op het bestaan van mogelijkheden tot herziening in zowel administratief procesrecht, strafproces. recht als burgerlijk procesrecht. Deze auteurs melden tevens dat "om duistere redenen" het belastingrecht niet de mogelijkheid kent om een in kracht van gewijsde gegane uitspraak te wijzigen wegens pas later aan het licht gekomen essentiēle feiten. $\mathrm{Vgl}$. m.b.t. herziening in het belastingrecht: HR 24.02.1995, NJ 1995, nr. 469.

220 Ten Berge/Tak, p. 12; Van Wijk/Konijnenbelt (1991), p. 383.

${ }^{421}$ In de bestuursprocesrechtelijke literatuur wordt herziening inderdaad ook wel een buitengewoot rechtsmiddel genoemd. Vgl. Borman, p. 150; Ten Berge, p. 296; Langbroek/Spelt, p. 182.

${ }^{422} \mathrm{Vgl}$. Ten Berge/Tak, p. 239; Coops, p. 151; Hugenholtz/Heemskerk, p. 188; Snijders, p. 48.

${ }^{42}$ Vgl. CBB 27.07.1994, AB 1995, nr. 1, m.nt. JHvdV (herziening verzocht 0.g.v. art. 71 Wet Arbo).
} 
Naar Schipper e.a. menen, geldt voor de rechtspraak op grond van de Ambtenarenwet 1929 dat de eis tot ernstige twijfel "een klip is, waarop het merendeel van de verzoeken om herziening strandt". 24

Ten aanzien van de rechtspraak op grond van de inmiddels vervallen Wet Arob $^{425}$ merkt Borman in 1985 op dat het rechtsmiddel herziening in de praktijk weinig betekenis heeft. Enerzijds wordt volgens deze auteur weinig herziening aangevraagd, anderzijds leidt het instellen van herziening veelal niet tot resultaat. ${ }^{426}$ Het afwijzen van een verzoek tot herziening van een eerdere uitspraak door de Raad van State op grond van de overweging: "Het belang van een goede procesorde en het bijzonder karakter van het rechtsmiddel van herziening brengt met zich dat bij de beoordeling van een verzoek om herziening slechts rekening wordt gehouden met feiten en omstandigheden die de verzoeker redelijkerwijs niet naar voren heeft kunnen brengen in de procedure die geleid heeft tot de uitspraak waarvan thans herziening wordt gevraagd." is niet ongewoon geweest. De hier geciteerde overweging is sinds het midden van de jaren tachtig een standaardoverweging geworden van zowel de voormalige Afdeling geschillen van bestuur als de voormalige Afdeling rechtspraak. ${ }^{427}$

Niet slechts voor het ambtenarenrecht of de rechtspraak op grond van de met ingang van 1 januari 1994 vervallen Wet Arob, maar voor alle betrokken administratiefrechtelijke rechtsgebieden geldt de opmerking van Ten Berge/Tak dat herzieningsverzoeken zelden resultaat hebben gehad. ${ }^{428}$

Een essentieel kenmerk van herziening is dat het, als grondslag voor de herziening, aangevoerde "nieuwe" gegeven betrekking heeft op het oorspronkelijke feitencomplex op grond waarvan de te herziene uitspraak is gewezen. ${ }^{429}$ Voorts geldt dat ten aanzien van het recht de discussie gesloten is; op dat terrein biedt de herziening geen mogelijkheden. ${ }^{430}$ Dit houdt onder meer in, dat indien in latere rechtspraak sprake is van een gewijzigde rechtsinterpretatie dit geen grond voor

\footnotetext{
24 Schipper e.a., losbl, uitgave ambtenarenrecht, Band 3, V I, aant. 3.

${ }^{42}$ Herziening ingevolge art. 10 Wet Arob (oud) jo. art. 120 (oud) WRvS.

${ }^{25}$ Borman, p. 150.

${ }^{42}$ Zie Langbroek/Spelt, p. 182. Zie bijv. AGRS 08.11.1992, AB 1993, nr. 344, m.nt. JJIV. (Als datum van de uitspraak vermeldt $\mathrm{AB}$ abusievelijk 08.11.1990). Het herzieningsverzoek is gegrondvest op art. 4 lid 1 TwK (oud) jo. art. 120 lid 1 (oud) WRvS. De Tijdelijke wet Kroongeschillen is vervallen met ingang van 01.01.1994.

es Ten Berge/Tak, p. 239. Idem Langbroek/Spelt, p. 182. Gras, p. 66 (i.h.b. voetnoot 2), stelt m.b.t. de civielrechtelijke buitengewone rechtsmiddelen dat deze slechts "sporadisch" met succes worden ingesteld.

${ }^{6} \mathrm{Vgl}$. art. 8:88 sub a Awb.

${ }^{60}$ Schipper e.a., losbl. uitgave ambtenarenrecht, Band 3, V I, aant. 3.
} 
herziening is. ${ }^{431}$ Ook vormen twee met elkaar onverenigbare onherroeplijke uitspraken van twee verschillende rechters geen grond tot herziening. ${ }^{432}$

De literatuur vermeldt tevens jurisprudentie waarin is bepaald dat het $\mathrm{n}$ de herzieningsprocedure aanleveren van (schriftelijk) bewijs van hetgeen in de erdere procedure wel is gesteld, doch toen niet is aangetoond geen grond tot herzening oplevert. ${ }^{433}$

\subsubsection{Kan de Staat het rechtsmiddel herziening instellen tegen een vaststelings- beschikking?}

De mogelijkheid dat de Staat, belanghebbende in de "zelfstandige vaststellinsprocedure", herziening kan verzoeken van een vaststellingsbeschikking is afgevezen door Van den Blink. Van den Blink stelt dat slechts een wijziging in dat ozicht van de Rijkswet op het Nederlanderschap de Staat enige actiebevoegdheid nzake herziening van een vaststellingsbeschikking kan verlenen. ${ }^{434}$ Dit standpun heeft Van uden, Rlink ogeponeerd in . bet kader van de door haar aangesneden vraag betreffende de toepassing van artikel 19 RWN indien blijkt dat wegens hetzij onbekend gebleven anterieure feiten, hetzij aan het vaststellingsmoment posterieure feiten de gebondenheid aan de beschikking vraagtekens oproept. ${ }^{435}$ Van den Blink heeft terecht gewezen op de mogelijkheid dat pas geruime tijd na de uitspraak van de rechtbank te Den Haag kan zijn ontdekt dat de beschikking ex artikel 17 RWN niet steunt op alle rechtens relevante gegevens. ${ }^{436}$ Zoals hierboven (in par. 2.6.2.1.2) betreffende de objectieve reikwijdte van de vaststellingsbeschikking al is opgemerkt, kan de oorzaak van een materieel onjuiste beslissing zijn gelegen in het ten onrechte buiten beschouwing hebben gelaten van een verwervings- of verliesgrond. Een andere mogelijkheid die leidt tot een materieel onjuiste beschikking is

${ }^{41}$ Korteweg-Wiers e.a., p. 324; Schipper e.a., losbl. uitgave ambtenarenrecht, Band 3, V I, aant. 7. Vgl. ABRS 09.06.1994, NJ 1994, nr. 494, Gemeentestem 1994, nr. 7000, m.nt. HH (herzieningsverzoek op grond van art. 120 (oud) WRvS).

${ }^{432}$ Korteweg-Wiers e.a., p. 324; Schipper e.a., losbl. uitgave ambtenarenrecht, Band 3, V I, aant. 7.

43 Zie Korteweg-Wiers e.a., p. 324. Al denkt, blijkens het voorgaande, de rechtbank te Den Haag m.b.t. de "zelfstandige vaststellingsprocedure" daar kennelijk anders over. Of gaat het hier om een voorbeeld van het voor de civiele rechter (te) diepe administratiefrechtelijke water? De "nieuwe gegevens" waarop de verzoeker i.c. zich nl. beroept, betreffen een verklaring en een psychiatrisch rapport. Beide dienen om een al in het eerste verzoekschrift opgenomen stelling nader te ondersteunen. De verzoeker draagt derhalve aanvullende bewijsmiddelen aan ten behoeve van een in de eerste procedure reeds behandelde stelling.

In het voorgaande is op p. 104 met betrekking tot de "zelfstandige vaststellingsprocedure" al aan de orde gekomen dat in een zodanig geval wel ruimte is voor een herhaald verzoek.

434 Van den Blink, p. 17.

ass Zie voor de problematiek inzake de posterieure wijziging van de nationaliteit par. 2.6.2.1.3.

46 Van den Blink, p. 13. 
dat wel de juiste verwervings- of verliesgrond is getoetst, maar dat daarbij sprake is geweest van onvolledige feitelijke gegevens. Daarvan kan de oorzaak variëren van een onbewust manco bij het verstrekken van informatie omtrent de feitelijke gegevens tot en met het door middel van valse of vervalste bewijsstukken plegen van bedrog. Het zal hierbij overigens duidelijk zijn dat volgens de Rijkswet op het Nederlanderschap een onterechte vaststelling van het bezit van de Nederlandse nationaliteit niet de jure een verwerving van het Nederlanderschap betekent, net zomin een onterechte afwijzing van het verzoek tot vaststelling leidt tot het verlies van het Nederlanderschap. ${ }^{437}$ De Rijkswet kent immers een zodanige mogelijkheid tot verwerving of verlies van het Nederlanderschap niet. ${ }^{438}$ Inherent daaraan is het karakter van de vaststellingsbeschikking. Deze is inzake het Nederlanderschap uitsluitend declaratoir en zeker niet constitutief. . $^{439}$

De eventuele mogelijkheid voor de Staat om herziening te kunnen instellen, is, bij ontstentenis van een wettelijke regeling in de Rijkswet op het Nederlanderschap met betrekking tot het instellen van dit rechtsmiddel, in wezen strijdig met de bindende werking die uitgaat van de inter partes werking van een rechterlijke uitspraak die formele rechtskracht heeft verkregen. ${ }^{440}$ Een in wezen tweede gebondenheid aan de beschikking volgt uit de bindende werking van artikel 19 RWN ten gevolge waarvan de overheidsadministratie, en dat is mede de Staat der Nederlanden, aan de beschikking wordt gehouden.

Toch is het vanzelfsprekend ongewenst dat de overheidsadministratie een vaststellingsbeschikking moet respecteren indien, naar later blijkt, deze tot stand is gekomen op grond van fraude en bedrog. . $^{41}$

Mijns inziens komt op grond van de huidige regelgeving de Staat in beginsel geen bevoegdheid toe om herziening aan te vragen van een vaststellingsbeschikking. Daarentegen sta ik wel op het standpunt dat, indien sprake is van een ten

\footnotetext{
${ }^{437} \mathrm{Vgl}$. De Groot, losbl. uitgave Personen- en Familierecht, art. 19 RWN, aant. 1.

${ }^{43}$ Zie HR 16.09.1994, NJ 1995, nr. 563, m.nt. GRdG.

$49 \mathrm{Vgl}$. De Groot, losbl. uitgave Personen- en Familierecht, art. 19 RWN, aant. 1. Zie Asser/Anema/Verdam, p. 292, waar de auteurs vermelden dat een statusproces leidt tot een declaratoire uitspraak; cf. Heemskerk, p. 13.

${ }^{40}$ Zie par. 2.6.1 en par. 2.6.2.

41 Ten Kate, p. 41 , wijst erop dat een vonnis bindend is zolang niet met een rechtsmiddel daartegen is opgekomen, ook al is het vonnis in strijd met de feiten gewezen. In 1977 schrijft Korthals Altes, p. 165, dat "soms moeilijk valt te aanvaarden dat een onjuiste rechterlijke beslissing niettemin recht is, indien zij niet meer met rechtsmiddelen kan worden aangetast." Heden ten dage is er sprake van een rechtsontwikkeling waarin bij het geval van een frauduleuze uitspraak de ten uitvoerlegging van de uitspraak kan gelden als misbruik van bevoegdheid; vgl. HR 05.11.1993, NJ 1994, nr. 154, m.nt. PAS (in deze zaak is een aardige bijkomstigheid dat Korthals Altes éen van de raadsheren is). Is de uitspraak onder frauduleuze omstandigheden verkregen, dan kan derhalve een verbod tot executeren worden gevorderd. Hoewel een declaratoire uitspraak niet kan worden geèxecuteerd in de eigenlijke betekenis van het begrip, kan mijns inziens, analogisch aan het executieverbod m.b.t. frauduleuze condemnatoire uitspraken, het standpunt worden verdedigd dat op een frauduleuze declaratoire uitspraak eveneens wegens misbruik van bevoegdheid geen beroep kan worden gedaan.
} 
gevolge van frauduleus handelen door de verzoeker tot stand gekomen beslissing inzake het Nederlanderschap, het noodzakelijk is dat de rechtbank een in procesrechtelijk opzicht soepele houding inneemt en toestaat dat de Staat (als belanghebbende) herziening van de beschikking verzoekt. In het administratief procesrecht is wel vaker voorgekomen dat de herzieningsmogelijkheid die in een bepaalde wet voor de verzoeker openstaat, ook is toegekend aan het in de procedure verweer voerende bestuursorgaan en zelfs aan derden. ${ }^{442}$ In aanmerking genomen de positie van belanghebbende die de Staat in de vaststellingsprocedure inneemt, is de stelling dat de Staat wel, evenals als de oorspronkelijke verzoeker, herziening kan aanvragen mijns inziens goed verdedigbaar. Wel dient mijns inziens de herzieningsgrond beperkt te blijven tot het achteraf blijken van frauduleus handelen aan de kant van de oorspronkelijke verzoeker. Naar mijn mening is er daarentegen geen plaats voor een rechtsmiddel als herziening indien het oordeel in de vaststellingsbeschikking tot stand is gekomen als gevolg van een vergissing te goeder trouv door de verzoeker. Ten slotte heeft de Staat als belanghebbende in de procedure reeds voorheen de kans gehad de nationaliteitsrechtelijke rechtspositie van de verzoeker te onderzoeken en de relevante feiten aan de orde te stellen. ${ }^{443}$

Met Van den Blink ${ }^{444}$ ben ik echter van mening dat aangaande de mogelijkheid van herziening het noodzakelijk is dat in hoofdstuk 6 van de Rijkswet op het Nederlanderschap een bepaling wordt opgenomen dat de herziening van de vaststellingsbeschikking regelt. De mogelijkheid een herzieningsverzoek in te dienen, dient toe te komen aan de Staat, aan de onmiddellijk belanghebbende en in het geval van de vaststelling van het Nederlanderschap van een overledene aan degene wiens nationaliteit wordt beïnvloed door de nationaliteit van de overledene. In de wet dient te worden opgenomen op welke gronden herziening kan worden verzocht. ${ }^{445}$

\footnotetext{
${ }^{42} \mathrm{Vgl}$. Ten Berge/Tak, p. 239.

${ }^{43}$ Wel is het in een zodanige situatie wenselijk dat het Nederlanderschap van de betrokkene juridisch een deugdelijke basis krijgt, De Groot, losbl. uitgave Personen- en Familierecht, art. 19 RWN, aant. 1 , acht naturalisatie dan de aangewezen weg.

In verband met de hier aan de orde zijnde bindende werking van art. $19 \mathrm{RWN}$ is het niet onbelangrijk te vermelden dat de betrokkene niet onder vreemdelingenrechtelijke bepalingen valt. Art. $1 \mathrm{Vw}$ definieert vreemdeling namelijk als volgt: "ieder die de Nederlandse nationaliteit niet bezit en niet op grond van een wettelijke bepaling als Nederlander wordt behandeld. " Een zodanige wettelijke bepaling als bedoeld in art. $1 \mathrm{Vw}$ is naar mijn mening (wegens de bindende werking uit art. $19 \mathrm{RWN}$ ) een op grond van te goeder trouw aangeleverde informatie ten onrechte tot stand gekomen positieve vaststellingsbeschikking.

44 Van den Blink, p. 17.

4s Het ligt in de bedoeling dat in de toekomst "rekest-civiel" tevens in verzoekschriftprocedures mogelijk zal zijn. In het Voorontwerp tot aanpassing van het Wetboek van Burgerlijke Rechtsvordering wordt dit voorgesteld. In het Voorontwerp wordt tevens voorzien in een naamswijziging voor "rekestciviel". Als nieuwe naam is "herroeping" voorgesteld. Zie Gras, p. 122 (i.h.b. voetnoot 18); Meijknecht, Trema 1994, p. 211.
} 


\subsection{De impliciete vaststellingsprocedures (art. 20 RWN)}

\subsubsection{Algemene beschouwingen}

In deze afsluitende paragraaf van hoofdstuk 2 wordt het laatste artikel van hoofdstuk 6 Rijkswet op het Nederlanderschap, artikel 20 RWN, aan de orde gesteld. Dit artikel heeft betrekking op het geval waarin voor een rechterlijke instantie dan wel in een administratieve beroepsprocedure een geschil aanhangig is, dat primair een andere rechtsvraag betreft dan het Nederlanderschap, maar waarin blijkt dat voor de afhandeling van die primaire rechtsvraag een oordeel nodig is omtrent het (eventueel voormalig) bezit van het Nederlanderschap door de betrokken persoon. Ter aanduiding van procedures waarin de kwestie van het Nederlanderschap aan de orde komt als voorvraag heb ik in paragraaf 2.1 het begrip "impliciete vaststellingsprocedure" als werkbegrip geïntroduceerd.

Tot het moment van inwerkingtreding van hoofdstuk 6 van de Rijkswet op het Nederlanderschap zijn slechts procedures mogelijk geweest die vallen onder de typering "impliciete vaststellingsprocedure". ${ }^{446}$ Immers, pas met de totstandkoming van de rechtstreekse nationaliteitsactie op grond van artikel $17 \mathrm{RWN}$ is de in de voorafgaande paragrafen beschreven "zelfstandige vaststellingsprocedure" gerealiseerd.

Reeds in 1915 is het voor Kramers een uitgemaakte zaak dat naar Nederlands recht de rechterlijke macht de bevoegdheid toekomt te oordelen over de nationaliteit. ${ }^{447}$ Aan de juistheid van deze opvatting is nooit getwijfeld, noch is zij ooit serieus ter discussie gesteld. ${ }^{448}$ Dat iedere rechter vrij is om, indien noodzakelijk, een zelfstandig oordeel te vellen over een prealabele administratiefrechtelijke vraag is voor Nederlandse juristen welhaast vanzelfsprekend.

Wel kan tegen het bovenstaande worden aangevoerd dat, zoals blijkt uit paragraaf 1.2 waarin de historische ontwikkeling aangaande de "zelfstandige vaststellingsprocedure" is geschetst, dit de situatie toch rooskleuriger voorstellen is dan dat

\footnotetext{
${ }^{446} \mathrm{Vgl}$. Septer/Schouten, p. XVIII.

47 Kramers, p. 23. Idem Mannoury, p. 169. Kramers, p. 24, contrasteert dit met de toentertijd bestaande situatie in het toenmalige Turkse Rijk: "De bevoegdheid om nationaliteitsvragen uit te maken heeft nu echter de Ottomaansche rechter niet. De Ottomaansche regeering heeft (........) het noodig geoordeeld, het oordeel over de nationaliteit aan de administratie op te dragen. (.........). De Ottomaansche rechtbanken zijn derhalve onbevoegd de nationaliteitskwestie uit te maken." Dat de toenmalige situatie in het Turkse Rijk in het verleden niet eens zo uitzonderlijk is geweest, blijkt uit hetgeen Sannes, p. 85 , ruim 40 jaar eerder opmerkt bij zijn bespreking van een Frans vonnis waarbij werd bepaald dat iemand "door zijne naturalisatie had opgehouden Franschman te zijn". Sannes acht daarbij de volgende aantekening vermeldenswaardig: "In Frankrijk zijn dergelijke zaken aan de rechterlijke en niet zooals in andere staten aan de administratieve macht onderworpen."

${ }^{4} \mathrm{Vgl}$. evenwel par. 2.8.3.1 en de daar besproken wetsontwerpen uit 1976 en 1981.
} 
zij in werkelijkheid is geweest. Uit de in die paragraaf aangehaalde opmerking van Van Nijnatten uit 1947 blijkt bijvoorbeeld hoe in de tijd vóór de grootschalige ontwikkeling van de administratieve rechtspraak de vaststelling van de nationaliteit in overwegende mate niet door de onafhankelijk rechter, maar grotendeels alleen binnen de administratie heeft plaatsgehad. ${ }^{449}$ Binnen civielrechtelijke procedures is van oudsher de nationaliteitsvaststelling inderdaad zelfstandig door de rechter afgehandeld, maar op het terrein van het administratieve recht is slechts langzaam de weg naar de rechter opengesteld. In 1962 schrijft Prins nog met betrekking tot de nationaliteitsvaststelling: "En zeker past een verwijt aan de wetgever, die aan betrokkenen de gelegenheid onthoudt om in een zaak, die voor hen van zoveel belang is, rechtstreeks het oordeel van de rechter in te roepen. " 450

\subsubsection{Grote verscheidenheid aan procedures}

Als gevolg van het feit dat het vereiste van de hoedanigheid van Nederlander in de meest uiteenlopende wettelijke regelingen voorkomt, is het mogelijk dat de kwestie van het bezit van de Nederlandse nationaliteit in zeer uiteenlopende procedures als voorvraag dient te worden beoordeeld..$^{451}$

Wil men bijvoorbeeld opkomen voor de uitoefening van het actieve kiesrecht, dan gaat de rechtsgang via het college van B. \& W. direct naar de Afdeling bestuursrechtspraak van de Raad van State. ${ }^{452}$ In het verleden zijn het vooral de procedures op grond van de Kieswet geweest waarbij een "impliciete vaststelling" van het Nederlanderschap aan de orde is gekomen. ${ }^{453}$

${ }^{49}$ Zie voor de bedoelde ontwikkeling van de administratieve rechtspraak: Helder, p. 143, 144 en 153. ${ }^{450}$ Prins (I), p. 47.

${ }^{451}$ Zoals bijvoorbeeld op grond van de Algemene Bijstandswet om een bijstandsuitkering te ontvangen of op grond van de Wet Studiefinanciering i.v.m. een studiebeurs. Zie aangaande de intrekking van een paspoort: ARRS 08.06.1979, RV 1979, nr. 47; ARRS, 14.02.1985, Weekoverzicht RvSt 1985, nr. 50 (RO2.84.1781); ARRS 21.09.1989, AB 1990, nr. 198, m.nt. P.J.B.. Vgl. tevens de in par. 2.2.2.1 vermelde procedures; De Groot (II), p. 43-47; Lemaire, p. 28.

${ }^{452}$ Zie artt. D 5 en D 9 Kieswet, Stb. 1989, 423. De vorige Kieswet kende een andere rechtsgang, en wel via het college van B. \& W. naar de kantonrechter, met beroep in cassatie bij de Hoge Raad (artt. D 6, D 12 en D 16 Kieswet 1951). De oude Kieswet kende vanaf 1985 in art. D 2 lid 3 een interessante bepaling m.b.t. de vaststelling van het Nederlanderschap. Daarin werd gesteld dat aan de inwilliging van het verzoek om woonachtig zijnde in het buitenland te kunnen participeren aan de Tweede Kamerverkiezingen "geen aanspraak op het Nederlanderschap kan worden ontleend". In de huidige Kieswet ontbreekt een equivalent van deze bepaling.

453 Zie o.a.: HR 09.06.1920, NJ 1920, p. 929; Ktg. Emmen 03.04.1937, NJ 1937, nr. 476; Ktg. Amsterdam 25.04.1938, NJ 1938, nr. 530; HR 22.07.1940, NJ 1941, nr. 201 m.nt. P.S.; HR 02.06.1948, NJ 1948, nr. 646, m.nt. D.J.V.; Ktg. 's-Gravenhage 05.04.1950, NJ 1950, nr. 407; HR 07.06.1950, NJ 1950, nr. 625; HR 05.11.1952, NJ 1952, nr. 782; HR 03.12.1952, NJ 1953, nr. 784 m.nt. D.J.V.; HR 18.06.1954, NJ 1954, nr. 448 (cassatie in het belang der wet); HR 17.06.1955, NJ 
Daarentegen is het bij de inwerkingtreding van de "zelfstandige vaststellingsprocedure " vervallen beklag bij de Hoge Raad op grond van artikel 43 (oud) Vreemdelingenwet dat men ten onrechte als vreemdeling wordt behandeld pas relatief laat populair geworden ${ }^{454} \mathrm{Op}$ grond van de min of meer identieke voorganger van artikel 43 (oud) Vreemdelingenwet, artikel 20 Wet toelating en uitzetting van vreemdelingen uit 1849,455 zijn eveneens betrekkelijk weinig procedures gevoerd. ${ }^{456}$ Over artikel 20 Vreemdelingenwet 1849 merkt Van Sasse van Ysselt in 1953 op: "Dit bijkans vergeten artikel is in de na-oorlogse jaren tot nieuw leven gewekt. " ${ }^{457} \mathrm{Na}$ verloop van tijd neemt het beroep op artikel 20 Vreemdelingenwet 1849 weer af en deze verminderde belangstelling verandert niet na het van kracht worden in 1967 van het dan nieuwe artikel 43 Vreemdelingenwet. ${ }^{458}$ Pas in de laatste jaren van het bestaan laat de, algemeen als eigenaardig getypeerde, ${ }^{459}$ beklagprocedure een stijging van het aantal uitspraken zien. ${ }^{460}$

${ }^{453} \rightarrow$

1955, nr. 560; Ktg. 's-Gravenhage 05.05.1956, NJ 1958, nr. 23; HR 20.10.1958, HPS 1959, p. 36; HR 10.09.1959, NJ 1959, nr. 596. Valkhoff, RMTh 1932, p. 485, wijst in zijn bespreking van een aantal mogelijke vaststellingsprocedures er reeds op dat een rechterlijke uitspraak over het Nederlanderschap via een kiesrechtprocedure "de meest eenvoudige en minst kostbare weg" is.

${ }^{34}$ Jessurun d'Oliveira, AA 1986, p. 227. Vgl. de annotatie van Scheltema onder HR 23.10.1979, NJ 1980, nr. 551; Van den Blink, p. 8.

455 Wet van den 13den Augustus 1849, tot regeling der toelating en uitzetting van vreemdelingen (Stb. 39). In het navolgende kortheidshalve ook omschreven als: Vreemdelingenwet 1849. De wet is van kracht geweest tot de inwerkingtreding van de Vreemdelingenwet 1965.

${ }^{456}$ Geuljans, p. 40. Reuser (II) stelt in 1953 slechts 15 gevallen te kennen en vermeldt daarbij enkele niet in de NJ gepubliceerde uitspraken. Zie verder o.a.: HR 06.04.1948, NJ 1948, nr. 648, m.nt. D.J.V.; HR 13.04.1948, NJ 1948, nr. 647, m.nt. D.J.V.; HR 05.10.1948, NJ 1949, nr. 562; HR 21.06.1949, NJ 1950, nr. 1, m.nt. D.J.V.; HR 27.01.1953, NJ 1954, nr. 243, m.nt. D.J.V.; HR 03.06.1958, NJ 1959, nr. 50; HR 03.06.1958, NJ 1959, nr. 51; HR 29.03.1966, NJ 1966, nr. 453.

47 Van Sasse van Ysselt, HPS 1953, p. 56.

is $\mathrm{Vgl}$. de opmerking van A.-G. Mok in zijn conclusie bij HR 27.11.1979, NJ 1980, nr. 550, m.nt. M.S. onder NJ 1980, nr. 551 .

49 Van den Blink, p. 7; Jessurun d'Oliveira, AA 1986, p. 225; Loeb (1983), p. 289; Tratnik, MR 1988, p. 31; Scheltema onder HR 23.10.1979, NJ 1980, nr. 551; Zilverentant, HPS 1986, p. 80. Reuser (II), p. 452, betitelt al eerder de rechtsgang op grond van art. 20 Vreemdelingenwet 1849 als: "(.....) een van de oudste stukjes administratieve rechtspraak (......). " Tonnaer, p. 224, rangschikt het beklag bij de Hoge Raad onder de noemer: "administratieve rechtsprekende bevoegdheden bij de gewone rechter"; idem Struycken, p. 100 en Van Wijk/Konijnenbelt (1979), p. 149. Daargelaten het ongewone van het onderbrengen van administratieve rechtspraak bij de gewone rechter maakt het feit dat in de onderhavige procedure de HR is opgetreden als rechter in eerste instantic en derhalve als feitenrechter de procedure nog uitzonderlijker. Royer, p. 136 (i.h.b. voetnoot 36) vermeldt dat art. 43 Vw-procedures tot september 1981 door de strafkamer, daarna door de civiele kamer zijn behandeld.

40 Enigszins lastig is in te schatten hoeveel uitspraken de Hoge Raad in het kader van art. $43 \mathrm{Vw}$ heeft gedaan. Er zijn in totaal 41 uitspraken gepubliceerd.

Informatie uit Bijl. II. 85-86, 19139, nr. 5, p. 1, leert dat in mei 1986 sprake is van een totaal aantal (sinds 1967) van 77 bij de HR ingediende beklagschriften, waarvan er op dat moment nog aanhangig 
Zowel de rechtsgang op grond van artikel 20 Vreemdelingenwet 1849 als de opvolger daarvan zijn te scharen onder de classificatie van "impliciete vaststellingsprocedure". ${ }^{461}$ Het beklag bij de Hoge Raad heeft namelijk slechts open gestaan aan diegenen op wie, op dat moment, bepaalde alleen op vreemdelingen toepasbare maatregelen worden toegepast. ${ }^{462}$ De Vreemdelingenwet 1965 heeft daarbij de eis gesteld dat er geen andere wettelijk geregelde voorziening tegen de gewraakte maatregel voor handen is. ${ }^{463}$

Uit het geheel van de jurisprudentie blijkt dat in het verleden vooral de (inmiddels opgeheven) Afdeling rechtspraak van de Raad van State regelmatig met de prealabele vraag naar het Nederlanderschap is geconfronteerd. Uit de vele voorbeelden worden er hier twee aangehaald. Deze twee casus tonen duidelijk de omslag inzake de bereidheid van de Afdeling om in het kader van een beroep op grond van de

460

zijn. Maar niet alle beklagschriften hebben geresulteerd in cen uitspraak: Bijl. II. 85-86, 19139, nr. 5 , p. 1, vermeldt tevens dat tot mei 1986 reeds 29 beklagschriften voor de behandeling zijn ingetrokken. Het klinkt enigszins paradoxaal, maar de intrekking van het beklag is wel eens het directe gevolg geweest van het indienen van het beklag en de reactie van de minister van Justitie naar aanleiding van het ingediende beklag. Voor de behandeling ter zitting werd van de kant van de HR over een ingediend beklag contact opgenomen met het ministerie van Justitie. Dienaangaande merkt Van den Blink, p. 8, op: "Dit leidde meermalen tot intrekking van het beklag omdat de Minister op grond van nadere inlichtingen het Nederlanderschap van de klager alsnog aanvaardde, dan wel deze een vereenvoudigde naturalisatie aanbood. "

Ook de jaarverslagen van de Hoge Raad geven geen uitsluitsel over de vraag hoeveel uitspraken zijn gedaan in het kader van art. 43 (oud) Vw. Royer, p. 136, schrijft: "Tussen medio 1979 en medio 1987 heeft het College 36 uitspraken gedaan." (Tot 01.01.1988 telt de gepubliceerde rechtspraak 33 uitspraken, na die datum zijn nog 8 uitspraken gepubliceerd). Op grond van deze bovenstaande gegevens zijn, naar mijn inschatting, hoogstens rond de vijftig uitspraken op een beklag ex art. $43 \mathrm{Vw}$ gegeven.

${ }^{461}$ Vgl. par. 2.1. Volgens Van den Blink, p. 29 (i.h.b. noot 8), heeft de uitspraak van de Hoge Raad op grond van art. $20 \mathrm{Vw} 1849$ meer het karakter gehad van een advies dan van een rechterlijke uitspraak. Royer, p. 136, haalt uit de "Memorie van Beantwoording" uit 1849 aan dat volgens de toenmalige wetgever de Hoge Raad met zijn uitspraak: "geen arrest wijst. Hij geeft eene verklaring, en kan daarvoor zamengesteld zijn, gelijk hij zamengesteld is wanneer hij den Koning adviseert." Met deze historische achtergrond correspondeerden de twee dicta die op een beklag ex art. $20 \mathrm{Vw} 1849$ werden gegeven. Indien op het beklag positief voor de verzoeker werd geoordeeld, luidde de uitspraak: "Verklaart dat de wet van 13 Augustus 1849 S. 39 op verzoeker niet van toepassing is." Was de beoordeling voor de verzoeker negatief dan was het dictum: "Wijst het verzoek af."

42 Loeb (1983), p. 291; Van Sasse van Ysselt, HPS 1953, p. 57. Blijkens HR 24.12.1982, NJ 1983. nr. 388 alsmede HR 23.09.1983, NJ 1984, nr. 22 viel onder zodanige maatregelen niet de intrekking van een Nederlands paspoort.

48 $\mathrm{Vgl}$. HR 08.04.1988, NJ 1988, nr. 631. Tijdens het aanhangig zijn van het beklag is de klaagster genaturaliseerd. Zij stelt nog belang te hebben bij een uitspraak op het beklag omdat de naturalisatie $f$ 300 heeft gekost. Klaagster wordt desalniettemin niet-ontvankelijk verklaard, aangezien er een andere wettelijk geregelde voorziening open staat; en wel een actie uit onverschuldigde betaling bij de burgerlijke rechter. 
Vreemdelingenwet over te gaan tot vaststelling van het Nederlanderschap (en daarmee indirect tot bepaling of de Vreemdelingenwet daadwerkelijk van toepassing dient te zijn).

In de eerste zaak $^{464}$ stelt de ARRS bij een beroep aangaande de weigering tot een vergunning tot verblijf van een in Indonesië verblijvende man die beweert Nederlander op grond van afstamming te zijn: "De afdeling zal vooreerst de vraag bespreken of appellant kan worden beschouwd als vreemdeling in de zin van de Vreemdelingenwet. "

Slechts enkele jaren later volgt de Afdeling rechtspraak een ander beleid in het geval dat de betrokkene gedurende een vreemdelingenrechtelijk beroep tevens het bezit van het Nederlanderschap stelt: "Appellant heeft in de eerste plaats gesteld dat hij Nederlander is en derhalve ten onrechte is onderworpen aan regels die op vreemdelingen van toepassing zijn. De Afdeling merkt dienaangaande op dat de vraag of appellant Nederlander is in dit geding niet aan de orde kan komen. Appellant heeft immers met de indiening van een verzoek om een vergunning tot verblijf als bedoeld in de Vreemdelingenwet om toepassing van die wet gevraagd, hetgeen impliceert dat hij er in de onderhavige procedure vanuit gaat dat hij vreemdeling is en daarmee zodanige vergunning behoeft. " 465 In de annotatie bij deze uitspraak merkt Bolten vervolgens op: "Een beroep op het bezit van het Nederlanderschap laat de Afdeling, blijkens gelijkluidende overwegingen in een aantal uitspraken in 1984, consequent links liggen. ${ }^{n 66}$

De procedures die op grond van de Vreemdelingenwet kunnen worden gevolgd, zijn inmiddels grondig gewijzigd. Tegen beschikkingen in het kader van de Vreemdelingenwet heeft de rechtbank te Den Haag exclusieve bevoegdheid gekregen (art. 33a Vw). Hoger beroep van de uitspraak van de rechtbank op de Afdeling bestuursrechtspraak van de Raad van State is uitgesloten (art. 33e Vw). ${ }^{467}$ Tevens zijn andere reële rechtsmiddelen tegen de beslissing van de rechtbank niet mogelijk.

Behalve in administratiefrechtelijke procedures kan de vraag naar het bezit van de Nederlandse nationaliteit ook in straf- en civiele zaken opkomen. Het leidt geen twijfel dat de verscheidenheid aan rechtsgangen hierbij eveneens omvangrijk is.

\footnotetext{
${ }^{464}$ ARRS 14.08.1980, RV 1981, nr. 28.

4s ARRS 31.01.1984, RV 1984, nr. 46, m.nt. JJB.

4s6 $\mathrm{V} g 1$. hierover Jessurun d'Oliveira, AA 1986, p. 226.

${ }^{457}$ De invoering van de mogelijkheid om in beperkte gevallen toch hoger beroep in vreemdelingenzaken toe te laten, wordt momenteel overwogen. Vgl. NJB 1996, p. 36.
} 
Ten aanzien van strafzaken valt, naast het gewone strafrecht, ${ }^{468}$ tevens te denken aan het zgn. oorlogsstrafrecht. ${ }^{469}$ In het geval dat het Nederlanderschap van belang is in een strafzaak dient, volgens Mannoury, de rechter ambtshalve over te gaan tot toetsing van de nationaliteit. ${ }^{470}$ De Nederlandse wetgeving kent echter zeer weinig strafbepalingen waarin de nationaliteit als element in de delictsomschrijving voorkomt. ${ }^{471}$ Het militaire strafrecht vormt op het voorgaande de grootste uitzondering. ${ }^{472}$

Een enkele maal speelt de vraag naar het Nederlanderschap van de betrokkene in gevallen waarbij de Uitleveringswet ${ }^{473}$ in het geding is. ${ }^{474}$ Dit omdat artikel 4 lid 1 Uitleveringswet met zoveel woorden uitlevering van Nederlanders ver-

${ }^{465}$ Zie HR 20.06.1950, NJ 1950, nr. 646, m.nt. W.P. (cassatie in het belang der wet); Rb. Middelburg 15.02.1952, NJ 1953, nr. 344; Rb. Amsterdam 28.11.1994, parketnr. 13.017.044.93, databank Migrantenrecht. $\mathrm{Vgl}$. over de laatste zaak tevens voetnoot 491.

${ }^{469}$ Zie o.a. Rb. Roermond 14.12.1976, NJ 1977, nr. 299, m.nt. Th.W.v.V.; HR 29.05.1978, NJ 1978, nr. 358, m.nt. Th.W.v.V., alsmede Van Dorst, NJB 1977, p. 857-863. Na de tweede wereldoorlog heeft de nationaliteit een rol gespeeld in de rechtspraak door de Afdeling Rechtspraak van de Raad van het Rechtsherstel naar aanleiding van het Besluit Vijandelijk Vermogen (Stb. 1944, E 133). Zie tevens N.E. Algra, Enkele juridische aspecten van de zaak Menten, 1978.

${ }^{470}$ Mannoury, p. 168.

${ }^{471}$ Bijv. art. $101 \mathrm{WvSr}$.

${ }^{47}$ Swart (I), p. 108 en 109.

${ }^{473}$ Nederlands eerste uitleveringswet stamt uit 1875 (Stb. 66) en heeft zo'n typisch negentiende-eeuwse wijdlopige titel. Het is namelijk de Wet van 6 April 1875, tot regeling der algemene voorwaarden, op welke, ten aanzien van de uitlevering van vreemdelingen, verdragen met vreemde mogendheden kunnen worden gesloten. Het oorspronkelijke artikel 22 van de wet luidt: "Als Nederlanders beschouwt deze wet hen, die het zijn volgens het Burgerlijk Wetboek. " (vgl. par. 1.1). Voor de totstandkoming van de eerste Uitleveringswet kende de Vreemdelingenwet uit 1849 een regeling voor uitlevering: vgl. Geuljans, p. 15; Reuser (I), p. 86. Sinds 1967 (Stb. 139) is de huidige Uitleveringswet van kracht.

${ }^{474}$ Zie op grond van de Uitleveringswet 1875: HR 01.04.1920, NJ 1920, p. 607, een arrest waarover Van Sasse van Ysselt, HPS 1954, p. 162, opmerkt dat het nationaliteitsrechtelijk een "manifest mal juge" is; HR 08.04.1935, NJ 1935, p. 826, m.nt. T.; HR 28.10.1952, HPS 1952, p. 133, gepubliceerd in het (anonieme) artikel "De nationaliteit van Westerling". In deze zaak is uitlevering verzocht door Indonesiě van een man, die is geboren in Turkije uit voorouders die sedert generaties in dat land wonen. Van de vader en de grootvader, beiden eveneens in Turkije geboren, valt via de consulaire registers in Turkije nog vast te stellen dat zij hun Nederlanderschap nooit hebben verloren. Ook het bezit van Nederlanderschap door de huidige R(aymond) P.P. Westerling wordt in 1952 door de Hoge Raad aangenomen. In verband met deze geschiedenis is het grappig om in het, in 1923 verschenen, proefschrift van Spanjaard, p. 291, te lezen over ene R(ichard) Westerling, beschreven als: Nederlands horlogemaker, die anno 1816 in Turkije het aan de stok krijgt met een politie-ambtenaar, een nacht in de gevangenis moet doorbrengen en ten slotte hulp krijgt van de Nederlands zaakgelastigde te Constantinopel. Misschien heeft deze gebeurtenis de familie Westerling ervan overtuigd nooit de Nederlandse nationaliteit op te geven; HR 06.12.1955, NJ 1956, nr. 182.

Zie op grond van de Uitleveringswet 1967: HR 01.02.1977, NJ 1977, nr. 229 m.nt. Th.W.v.V.; HR 01.09.1987, NJ 1988, nr. 262 m.nt. AHJS; HR 24.04.1990, NJ 1991, nr. 57. 
biedt. $^{475}$ Evenwel maakt sinds 1 januari 1988 artikel 4 lid 2 Uitleveringswet onder bepaalde omstandigheden uitlevering van Nederlanders mogelijk. ${ }^{476}$

Met betrekking tot het civiele recht kan hier kortheidshalve Koens worden aangehaald die kernachtig heeft geformuleerd: "Voor het privaatrecht is de nationaliteit van geen belang. (.........). Omgekeerd is het privaatrecht wel van belang voor de nationaliteit. (.........). Zagen we hierboven dat de nationaliteit voor het privaatrecht niet van belang is, anders ligt dit voor het internationaal privaatrecht. " 477

Inderdaad is bij privaatrechtelijke aangelegenheden met internationale elementen voor de vraag welke rechter jurisdictie toekomt ${ }^{478}$ en welk recht van toepassing is, ${ }^{479}$ de nationaliteit van de partij(en) soms een bepalende factor.

${ }^{65} \mathrm{Vgl}$. Swart (II), p. 67, 284 e.v.
${ }^{78}$ Ahmad Ali/Klip, MR 1995, p.

en 81, Strijards, p. S9 en 60, Swart (II), p. 67, Van Wissen, p. 72. Indien op de uitlevering het Benelux uitleveringsverdrag (Trb. 1962, nr. 97, aanvullend Protocol, Trb. 1974, nr. 11) van toepassing is worden eigen onderdanen echter niet uitgeleverd (art. 5 lid 1 BUV). Doorslaggevend is het bezit van de nationaliteit op het tijdstip van de overlevering (art. 5 lid 2 BUV): vgl. HR 29.03.1994, NJB-katern 1994, p. 380, nr. 154. In het geval van toepasselijkheid van het Europees Verdrag betreffende uitlevering (Trb. 1965, nr. 9, twee aanvullende Protocollen) is daarentegen doorslaggevend het moment "van de beslissing over de uitlevering" (art. 6 lid 1 sub c EUV). Voor het geval dat tussen het moment van de beslissing en het moment dan de overlevering nationaliteitswisseling plaats vindt, geeft art. 6 lid 1 sub c EUV echter nog een nuancering op het bovenstaande. Vgl. HR 14.09.1993, NJ 1995, nr. 155, m.nt. AHJS.

${ }^{47}$ Koens, p. 4. In gelijke zin De Groot/Tratnik, p. 26-29 en 32-34. Thomas, p. 7, signaleert al in 1893 dat de verschillen in rechten tussen vreemdelingen en Nederlanders op privaatrechtelijk terrein meer en meer verdwijnen.

${ }^{478}$ Een voorbeeld uit de wetgeving: art. 814 lid 1 sub a Rv: niet in Nederland woonachtige echtelieden met Nederlandse nationaliteit kunnen hier te lande een verzoek tot echtscheiding, scheiding van tafel en bed dan wel tot ontbinding van het huwelijk na scheiding van tafel en bed aanhangig maken. Zie over echtscheiding van Nederlanders uit de Ned. Antillen voor de Nederlandse rechter het artikel van Ten Wolde, HPS 1993, p. 3-6. Jurisprudentie o.a.: Rb. Rotterdam 06.02.1967, NJ 1967, nr. 480; Hof Amsterdam 24.03.1977, NJ 1978, nr. 181; Het Hof 's-Hertogenbosch 17.03.1959, NJ 1959, nr. 656 overweegt in een echtscheidingszaak: "dat de rechter als bij zulk een vordering wordt gesteld het voor zijne bevoegdheid nodige feit, dat beide pp. Nederlander zijn, gerechtigd en zelfs verplicht is de eisende partij op te dragen de juistheid van die stelling aan te tonen, indien er voor hem gegronde reden is daaraan te twijfelen;". Rb. 's-Gravenhage 14.07.1992, NJ 1993, nr. 518: betreft cen vordering tot ontkenning van het vaderschap. Alle betrokkenen hebben de Nederlandse nationaliteit. De vader (eiser) woont in Tanzania, de moeder (gedaagde) en de minderjarige kinderen in Zambia. De rechtbank besluit Nederlands recht toe te passen. Ondanks herhaalde oproeping is de moeder niet verschenen, zodat zij geen verweer voert. De minderjarigen zijn vertegenwoordigd door een voor de gelegenheid benoemde bijzonder curator. De vader, ook niet aanwezig, procedeert bij procesvertegenwoordiger. De rechtbank wijst de vordering van de vader toe. Literatuur: o.a. Sauveplanne, p. 26. Oudere literatuur op dit terrein: Haan, p. 57-63 en 96-97; Struycken, p. 171-174; Voskuil, p. 68-78 en 127-137.

${ }^{49}$ Bijv. HR 09.11.1936, NJ 1937, nr 390, m.nt. PS; Rb. 's-Gravenhage 19.01.1948, NJ 1948, nr. 210; Rb. 's-Gravenhage 10.10.1951, NJ 1952, nr. 337; Rb. Roermond 19.11.1953, NJ 1954, nr. 556; Hof 's-Gravenhage 18.03.1954, NJ 1954, nr. 575; Rb. 's-Gravenhage 14.03.1966, NJ 1967, nr. 37; Rb. Haarlem 15.11.1966, NJ 1967, nr. 195 (toepassing Zweeds bewijsrecht op in Zweden voorgevallen 
In het kader van privaatrechtelijk handelen geschiedt van oudsher het bepalen of iemand minderjarig dan wel reeds meerderjarig is volgens de eigen nationale wetgeving van de desbetreffende persoon. ${ }^{480}$ Veelal vindt op dit punt een vereenzelviging plaats met het bezit van een bepaalde nationaliteit. Hierbij dient evenwel direkt te worden aangetekend dat, wat dit betreft, de ene Nederlander de andere niet is. Als gevolg van het uiteenlopen van de leeftijdsgrenzen voor meerderjarigheid in het Nederlands Burgerlijk Wetboek en de beide Burgerlijke Wetboeken in de andere delen van het Koninkrijk bestaat hier verschil. ${ }^{481}$ Wel geldt in het gehele Koninkrijk de regel dat de meerderjarigheid vóór de desbetreffende leeftijd intreedt in het geval van het aangaan van een huwelijk door een minderjarige. Alle drie vigerende Burgerlijke Wetboeken kennen namelijk deze regel.

Al geruime tijd is de tendens merkbaar dat, voor wat betreft sommige deelgebieden van het personen- en familierecht, de nationaliteit als aanknopingspunt in het internationaal privaatrecht in gewicht afneemt. ${ }^{482}$ Haandrikman constateert in 1981 dat dit verminderd belang niet lijkt te gelden voor de volgende onderwerpen: de naam, ${ }^{483}$ handelingsbekwaamheid, huwelijksbevoegdheid, curatele en afstamming. ${ }^{484}$

Buiten het terrein van het internationaal privaatrecht is eveneens, althans in Nederland, sprake van een verminderd belang van de nationaliteit als aanknopingspunt. Binnen de Nederlandse rechtsorde streeft de nationale wetgever naar een vermindering van het aantal gevallen waarin het Nederlanderschap een bepalende factor voor de toekenning van rechten en plichten is. ${ }^{485}$ Dit streven naar een

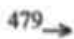

feitelijke handeling waaruit beweerd rechtsgevolg voortvloeit). HR 06.12.1991, NJ 1992, nr. 669, m.nt. JCS (zie de bespreking van deze uitspraak door Jessurun d'Oliveira in NJB 1993, p. 563-565). Rb. Zutphen 23.07.1992, NJ 1993, nr. 279, met daarin de overweging: "aangenomen moet worden dat $V$. en Kiona (ook thans nog) de Nederlandse nationaliteit bezitten. "(Oudere) literatuur: Vriesendorp, p. 119-131.

480 Gerver, p. 51 en 52; Jessurun d'Oliveira (I), p. 135; Kramers, p. 31; Sauveplanne, p. 30. Van Rooij/Polak, p. 212, brengen hierbij een nuancering aan: "Questions of age are usually determined in accordance with a person's national law."

${ }^{481}$ Meerderjarigheid wordt bereikt in Nederland op 18-jarige leeftijd (art. 1:233 BW), daarentegen op de Nederlandse Antillen en op Aruba op 21-jarige leeftijd (art. 332 Boek I Burgerlijk Wetboek van de Nederlandse Antillen en idem art. 332 Boek I Burgerlijk Wetboek van Aruba).

Deze divergentie leidt Haak, p. 4, tot de vraag: "Naar welk recht moet de Nederlandse rechter bijvoorbeeld beoordelen of een 19-jarige tijdelijk in Nederland verblijvende Arubaan meerderjarig is?" Zie tevens Haak, p. 18-21. Vgl. voorts Rb. Alkmaar 31.03.1988, NIPR 1988, nr. 475.

${ }^{42}$ Cohen Henriquez, p. 66; De Groot/Tratnik, p. 12 en 28; Sauveplanne, p. 23; Van Rooij/Polak, p. 175 en 178.

${ }^{483} \mathrm{Vgl}$. De Groot/Tratnik, p. 13.

44 Haandrikman, p. 61. Slechts twee jaar later komt Geuzinge, HPS 1983, p. 92, met betrekking tot de afstamming tot een tegenovergestelde conclusie.

4ss Ko Swan Sik, p. 15; Van Wissen, p. 70. 
vermindering in rechtspositionele verschillen tussen vreemdelingen en Nederlanders vindt zijn basis in het minderhedenbeleid dat de regering sinds het begin van de jaren tachtig heeft ontwikkeld. ${ }^{486}$ Als voorbeeld hiervan geldt de herziening van het kiesrecht. Sinds 1985 kunnen niet-Nederlanders die minimaal 5 jaar in Nederland verblijven actief en passief kiesrecht uitoefenen op gemeentelijk niveau. ${ }^{487}$

Dit streven om in moderne regelgeving steeds minder bij de toekenning van rechten of bij de oplegging van plichten de nationaliteit als bepalend element te noemen, mag de veronderstelling wettigen dat de instanties die hebben te oordelen over de betreffende rechten of plichten in steeds mindere mate zullen worden geconfronteerd met de vraag naar de nationaliteit. Dit laatste geldt evenzeer voor de rechterlijke macht met betrekking tot de rechtspleging in internationaal privaatrecht. De hier beschreven ontwikkeling heeft mijns inziens naar alle waarschijnlijkheid tot gevolg dat in de toekomst de "impliciete vaststellingsprocedures", misschien niet in hoeveelheid, maar wel in verscheidenheid zullen afnemen.

\subsubsection{Advisering inzake het Nederlanderschap}

In paragraaf 1.2.1 zijn in beperkte mate de kritische kanttekeningen naar voren gekomen die in het verleden zijn geuit ter zake van het ontbreken van een rechtstreekse nationaliteitsactie. Vanwege de versnipperde beoordeling van het bezit van de Nederlandse nationaliteit door betrekkelijk veel rechterlijke instanties alsmede administratieve instanties werd in de literatuur het voor niet onmogelijk gehouden dat rechtens vergelijkbare gevallen toch nationaliteitsrechtelijk verschillend zouden worden beoordeeld. In 1932 ontlokt het veelvoud aan procedures waarbinnen het Nederlanderschap aan de orde kan komen Huart de opmerking: "Er bestaat niet de minste waarborg voor een uniforme toepassing van de wetten op het Nederlanderschap en op het Nederlandsch onderdaanschap. ${ }^{488}$ Met deze opmerking indiceert Huart naar twee beginselen in het recht die mogelijkerwijs als gevolg van zodanige regelgeving in de knel kunnen komen: de rechtseenheid en de rechtsgelijkheid.

Vervolgens is in paragraaf 1.2.2 gebleken dat de wetgever, na lang aarzelen, de wenselijkheid van een zoveel mogelijk eenvormige toepassing van de wetgeving inzake de Nederlandse nationaliteit heeft onderkend. De realisering van wetgeving die een zo eenvormig mogelijke toepassing stimuleert, is een onverminderd streven geweest bij de ontwikkeling van de Rijkswet op het Nederlanderschap. ${ }^{489}$

\footnotetext{
${ }^{406}$ Zie Heijs (II), p. 235 en Van den Bedem, p. 114.

an Zie art. 130 Grondwet jo. art. 10 Gemeentewet alsmede art. 130 Grondwet jo. art. B3 leden 2 en 4 Kieswet. Vgl. ABRS 08.04.1994, AB 1995, nr. 197, m.nt. S.E. Zijlstra.

4s Huart, NJB 1932, p. 404.

4ol. Bijl. II. 1981,16947 , nrs. $3-4$, p. 20 en 21 ; Bijl. II. $81-82,16947$, nr. 6, p. 21; Bijl. Il. $82-$ 83,16947 , nr. 7, p. 32 ; Bijl. II. $83-84$, 16947 , nr. 10 , p. 13.
} 
Vanuit het perspectief van de nagestreefde rechtseenheid is het interessant om met betrekking tot de "impliciete vaststellingsprocedures" te bezien in hoeverre de tot vaststelling geroepen instantie zelfstandig over de nationaliteit beslist dan wel ter zake bijstand kan, of zelfs moet, inroepen van andere (overheids)instanties die meer gespecialiseerd zouden zijn op het gebied van het nationaliteitsrecht. Het blijkt dan dat, wat de zoëven bedoelde juridische ondersteuning aangaat, artikel 20 RWN, als gevolg van het bepaalde in de leden 1 en 2 , een duidelijke tweedeling kent.

Artikel 20 lid 1 RWN geeft rechterlijke instanties, die tijdens een geding worden geconfronteerd met onzekerheid inzake het bezit van de Nederlandse nationaliteit, de bevoegdheid zich tot de minister van Justitie ${ }^{490}$ te wenden ten einde over het kwestieuze Nederlanderschap een advies te verkrijgen. ${ }^{491}$ Naar mijn mening staat een zodanige adviesaanvrage ook open voor de rechtbank te Den Haag in het kader van een procedure volgens artikel $17 \mathrm{RWN} .{ }^{492}$

In artikel 20 lid 2 RWN is aangaande een zelfde onzekerheid met betrekking tot het wel of niet bezit van de Nederlandse nationaliteit, maar dan ditmaal niet in een gerechtelijk procedure maar tijdens een administratieve beroepsprocedure ${ }^{493}$ voor de instantie die oordeelt in administratief beroep de verplichting geschapen een advies aan te vragen bij de minister van Justitie. ${ }^{494}$ Op deze verplichte advisering

${ }^{490}$ Beide leden van art. 20 RWN wijzen de minister van Justite aan van het deel van het Koninkrijk waarin de betreffende procedure plaatsvindt.

491 Bijv. ABRS 27.07.1994, AB 1995, nr. 36 (verlies Nederlanderschap ingevolge art. 5 lid 2 TOS); Rb. Amsterdam 28.11.1994, MR 1995, p. 80, ter terechtzitting oordeelt een "deskundige", ambtenaar van het min. van Justitie, dat de verdachte de Surinaamse nationaliteit bezit, waarop de rechtbank dit oordeel overneemt. Ahmad Ali/Klip, MR 1995, p. 82 en 83, zijn (m.i. terecht) zeer kritisch over de onderbouwing van het desbetreffende nationaliteitsoordeel èn het feit dat de rb., in plaats van het relevante ontbreken van de Nederlandse nationaliteit vast te stellen, het bezit van een vreemde nationaliteit, de Surinaamse, vaststelt. (Het door de rechtbank niet-ontvankelijk verklaarde openbaar ministerie is in hoger beroep gegaan. Ook het gerechtshof oordeelt dat de Nederlandse strafwet niet op de verdachte van toepassing is omdat hij de Surinaamse nationaliteit heeft).

${ }^{492}$ Al zal een zodanig verzoek tot advisering in de praktijk wel niet (snel) voorkomen. Niettemin had, volgens mij, de rechtbank deze optie heel goed kunnen volgen om (indien dat louter het beoogde doel was geweest) op deze wijze de visie van de minister van Justitie op bij de rechtbank aanhangige zaken te verkrijgen. Zie het behandelde in par. 2.4.2.1. Een voordeel voor deze weg via artikel $20 \mathrm{RWN}$ zou voor de rechtbank zijn geweest dat een advies ex art. 20 lid 1 RWN (indien gevraagd) moet worden gegeven, terwijl een, via art. $429 \mathrm{f}$ Rv opgeroepen, belanghebbende niet verplicht is te verschijnen. Evenwel: zoals uit par. 2.4.2.2 is gebleken, was het motief voor het oproepen van de Staat niet zozeer gelegen in de wens de visie van de minister te vernemen als wel om het de Staat mogelijk te maken tegen de beschikking cassatie aan te kunnen tekenen.

${ }^{403}$ N.B. derhalve weer niet in een administratieve bezwaarschriftprocedure.

${ }^{494}$ Door Zilverentant, B\&R 1994, p. 142, wordt als voorbeeld van een verzoek om advies ingevolge art. 20 lid 2 RWN het verzoek in 1987 door de Raad van Beroep in een AOW-geschil tussen de Sociale Verzekeringsbank en een justitiabele genoemd. M.i. betreft het i.c. echter een verzoek om advies op grond van art. 20 lid 1 RWN, aangezien de Raad van Beroep een rechterlijke instantie is (geweest; de 
is voor Nederlandse $\mathrm{e}^{495}$ bestuursorganen de op 1 januari 1994 in werking getreden afdeling 3.3 betreffende advisering van de Algemene wet bestuursrecht van toepassing. ${ }^{496}$

Instanties die geen rechterlijke instantie noch een bestuursinstantie oordelend in administratief beroep zijn, ${ }^{497}$ schijnen, wat de advisering door de minister van Justitie aangaat, intussen buiten de boot te vallen. Naar mijn mening doen deze er zeker goed aan de minister advies te vragen indien zij worden geconfronteerd met een onzekerheid inzake de uitleg en de toepassing van het nationaliteitsrecht, ${ }^{498}$ maar zij zijn daartoe niet door de Rijkswet op het Nederlanderschap gelegitimeerd of verplicht. ${ }^{499}$

Het is eigen aan het karakter van een advies dat de geadviseerde niet verplicht is het op te volgen. $\mathrm{Al}$ is een oordeel van de minister vanzelfsprekend van gewicht, aan het advies behoeft niet een doorslaggevende betekenis te worden toegekend door de rechter of het orgaan dat oordeelt in administratief beroep. ${ }^{500}$ In het geval dat (in Nederland) een in administratief beroep oordelend bestuursorgaan wil afwijken van het advies van de minister is dit orgaan sinds de inwerkingtreding van de Awb gehouden in de beslissing de redenen op te nemen voor het niet volgen van het advies. . $^{501}$

$\stackrel{494 \rightarrow}{\rightarrow}$

Beroepswet is in het kader van de herstructurering van het administratief procesrecht ingrijpend gewijzigd).

${ }^{495} \mathrm{De}$ Algemene wet bestuursrecht geldt alleen in Nederland. Voor Antilliaanse en Arubaanse organen handelend in administratief beroep geldt afd. 3.3 Awb niet. Zie Bijl. II. 92-93, 23252, nr. 3, p. 2.

${ }^{496}$ Zie voor commentaar op afd. 3.3 Awb: Van der Vlies, Handboek Algemene wet bestuursrecht; Zoontjens, Commentaar Algemene wet bestuursrecht.

$477 \mathrm{Vgl}$. in het kader van toepassing van de RWN de in par. 2.2.2.1 behandelde jurisprudentie van de Hoge Raad.

${ }^{49}$ De uitleg van de Rijkswet op het Nederlanderschap, maar evenzeer de uitleg van de wat verlies- en verwervingsgronden betreft aktueel blijvende oudere wetgeving aangaande het Nederlanderschap (zie Van den Blink, p. 18; De Groot/Tratnik, p. 39 en 40) is niet altijd even gemakkelijk te volbrengen aan de hand van alleen de wetgeving. De uitleg van de, bijzonder vaak in het spel zijnde (vgl. Van den Blink, p. 22), Toescheidingsovereenkomst inzake nationaliteiten tussen Nederland en Suriname spant wat dit aangaat helemaal de kroon.

49 Deze adviesaanvrage kan mijns inziens worden beschouwd als een uitoefening van het recht van petitie (art. 5 Grondwet). Vgl. T. Koopmans, p. 252; Kortmann, p. 76-78; Van Wissen, p. 79 en 80. Ten aanzien van een petitie ontbreekt een verplichting tot beantwoording. maar Riezebos meldt in zijn proefschrift dat in de praktijk op de meeste verzoeken een reactie komt. Zie Riezebos, p. 98, 110, 119 , 120 en 151 . Vgl. tevens Zoontjens, p. 3.3.1-4: "Ook zonder wettelijke grondslag heeft een bestuursorgaan de bevoegdheid om advies te vragen, wanneer het meent dat het zelf niet voldoende in staat is om relevante feiten en omstandigheden op verantwoorde wijze vast te stellen en te beoordelen."

${ }^{500} \mathrm{Vgl}$. Boeles, p. 213, die het vreemd lijkt te vinden dat een hiërarchisch lager geplaatste instantie niet gehouden is het oordeel van de minister over te nemen.

\$01 Art. 4:20 Awb luidt: "Indien het bestuursorgaan een beschikking geeft die afwijkt van een krachtens wettelijk voorschrift met het oog daarop uitgebracht advies, wordt zulks met de redenen voor de 
Met de regeling in artikel $20 \mathrm{RWN}$ aangaande de advisering door de minister van Justitie zien we een zeer zwakke neerslag van de wens om te komen tot eenvormige interpretatie van de bepalingen inzake het Nederlanderschap. Dit bescheiden resultaat heeft Van den Blink aanleiding gegeven artikel 20 RWN zelfs te omschrijven als een "lapmiddel". ${ }^{502}$ Het blijkt dat alle instanties in wezen zelfstandig over de nationaliteitsrechtelijke kwestie kunnen beslissen. Het al of niet (verplicht) aangevraagde advies is slechts een leidraad en bindt geen van de instanties. Hoewel het advies derhalve niet bindend is voor de aanvrager ervan, verwacht Jessurun d'Oliveira dat "in de praktijk wel enige regulerende werking" van de advisering zal uitgaan. ${ }^{503} \mathrm{Nu}$ onlangs door de Algemene wet bestuursrecht verplicht is gesteld dat een bestuursorgaan, dat met zijn besluit afwijkt van een op grond van een wettelijke verplichting aangevraagd advies, in het desbetreffende besluit de reden vermeld waarom de afwijking plaatsvindt, is wellicht nog meer conformiteit aan de adviezen te verwachten.

\subsubsection{Historisch overzicht}

De wetgever heeft, in het reeds bovenvermelde streven naar een zo eenvormige uitleg van de regelgeving inzake het Nederlanderschap, in het verleden ruim aandacht geschonken aan de vraag of voor rechterlijke instanties een algemene verplichting zou moeten worden ingesteld om bij twijfel aangaande het bezit van het Nederlanderschap over te gaan tot het inwinnen van advies inzake de interpretatie van de nationaliteitsrechtelijke bepalingen. Het gaat hierbij in wezen om de vraag of het aan de rechter in een "impliciete vaststellingsprocedure" moet (en kàn) worden overgelaten om zelfstandig over het bezit van de Nederlandse nationaliteit als prealabele vraag te beslissen dan wel of de rechter een andere (ter zake meer deskundig geoordeelde) instantie dient in te schakelen.

Uit de onderscheidenlijke departementale ontwerpen ${ }^{504}$ inzake regeling van de rechterlijke vaststelling van de nationaliteit blijkt dat aanvankelijk het idee is geopperd om rechterlijke instanties in een aanhangig geding de mogelijkheid te bieden bij een hogere rechter een bindende beslissing inzake het Nederlanderschap van een betrokkene te verkrijgen. In het ontwerp uit 1956 namelijk, is de Neder-

so1 $\rightarrow$

afwijking in de motivering vermeld." Het ligt in de bedoeling dat met ingang van 01.01.1997 art. 4:20 Awb wordt vervangen door het nu nog wetsontwerp-artikel 3.6.5. Awb (afd. 3.7). Ontwerp-art. 3.6.5 Awb luidt: "Indien het bestuursorgaan een besluit neemt dat afwijkt van een met het oog daarop krachtens wettelijk voorschrift uitgebracht advies, wordt zulks met de redenen voor de afwijking in de motivering vermeld.

so2 Van den Blink, p. 6.

sej Jessurun d'Oliveira, NJB 1983, p. 1309.

${ }^{504}$ Zie par. 1.2.2. 
landse rechter de bevoegdheid toegekend om bij nationaliteitsonzekerheid de kwestie voor te leggen aan de Hoge Raad (art. 23 w.o.). De beslissing van de Hoge Raad bindt de rechter die haar heeft gevraagd (art. 16 w.o.). Een analoge regeling is voorzien voor de rechter in de toenmalige andere gebiedsdelen van het Koninkrijk, met dien verstande dat de rechters aldaar eerst een "nationaliteitsuitwijzing " verzoeken bij hun eigen hoogste rechter, waarna cassatie mogelijk is bij de Hoge Raad in Den Haag. In dit wetsvoorstel wordt de beslissing inzake het Nederlanderschap derhalve binnen de rechterlijke macht genomen. In de volgende ontwerpen uit 1976 en 1981 ligt dat anders.

Nadat het bovenstaande idee was verlaten, werd in de volgende ontwerpen de regeling opgenomen dat rechterlijke instanties de verplichting kregen om in de gevallen waarin het Nederlanderschap onzeker blijkt te zijn dienaangaande bij bestuursinstanties een oordeel in te winnen. Het "voorontwerp van Rijkswet vaststelling van nieuwe, algemene bepalingen omtrent het Nederlanderschap" uit december 1976 legt de rechter de verplichting op de zaak te schorsen gedurende een "impliciete vaststellingsprocedure" bij een aan de dag tredende onzekerheid over de Nederlandse nationaliteit van een partij. Vervolgens dient de rechter de meest belanghebbende partij op te dragen de minister van Justitie om een (bindende) beschikking inzake het Nederlanderschap verzoeken. ${ }^{505}$ Het voorontwerp gaat zodoende uit van een regeling waarin bij onzekerheid uitsluitsel aangaande de Nederlandse nationaliteit altijd wordt gegeven door de minister van Justitie. ${ }^{506}$ Hier ziet men een centraliserende bepaling waaraan de doelstelling om te komen tot eenvormigheid in de oordelen aangaande het Nederlanderschap ten grondslag heeft gelegen. Daarenboven blijkt de competentie inzake het oordelen over het bezit van het Nederlanderschap bij de uitvoerende macht te zijn gelegd.

Het bovenvermeld voorstel uit 1976 is door de regering ter advisering aan een tweetal staatscommissies toegezonden. De geraadpleegde staatscommissie voor de burgerlijke wetgeving uit kritiek op het voorstel. ${ }^{507}$ Een gelijkluidend bezwaar verwoordt de commissie voor advies inzake Volkenrechtelijke vraagstukken. ${ }^{508}$

Ondanks de bezwaren van de staatscommissies is in het volgende wetsontwerp uit 1981 de bepaling opgenomen dat indien "enige rechterlijke instantie" wordt geconfronteerd met onzekerheid aangaande het Nederlanderschap deze instantie het geding zou schorsen en een oordeel ter zake zou verzoeken aan de minister van

\footnotetext{
506 Art. 21 lid 1 van het voorontwerp. Jessurun d'Oliveira becommentarieert de procedure uit dit voorontwerp in NJB 1977, p. 597 en 598.

${ }^{50 \%}$ Met een beroepsmogelijkheid ingevolge art. 20 lid 5 w.o. op de Afdeling rechtspraak van de Raad van State.

Sor Bijl. II. 1981, 16947, nrs. 3-4, p. 50. De commissie spreekt in haar rapport van 9 december 1977 als oordeel uit: "Te zwaar vindt de commissie evenwel de verplichting om zo'n vaststelling steeds te doen vragen wanneer het bezit van de Nederlandse nationaliteit in een procedure aan de orde komt. Voor vele procedures zal een dergelijke maatregel te zwaar of te tijdrovend zijn."

Bijl. II. 1981, 16947, nrs. 3-4, p. 33.
} 
Justitie. ${ }^{509}$ En daarmee wordt de opzet uit het voorontwerp gehandhaafd. ${ }^{5 D}$ Als bekend uit paragraaf 1.2.2 is deze opzet van de vaststellingsprocedure evenwel onder druk van de Tweede Kamer gewijzigd in de huidige regeling, waarin srake is van de "zelfstandige vaststellingsprocedure" bij de rechtbank te Den Haag in de "impliciete vaststellingsprocedures" voor hetzij een rechterlijke instantie, hetzj een instantie oordelend in administratief beroep.

${ }^{900}$ Art. 18 van het ontwerp. Bijl. II. 1981, 16947, nrs. 1-2, p. 5. Zie hierover Ahmad Ali/Klip, MR 1995, p. 83 en 84 .

${ }^{310}$ De Groot, losbl. uitgave Personen- en Familierecht, hoofdstuk 6 Rijkswet, aant. 1, p. 6-2. 


\section{Hoofdstuk 3}

\section{Bewijsrechtelijke aspecten in het Nederlands nationaliteitsrecht}

\subsection{Inleiding}

Naast aandacht voor de procesrechtelijke aspecten van de wijze waarop de vaststelling van de Nederlandse nationaliteit op rechterlijk niveau geschiedt, benader ik in dit boek de nationaliteitsvaststelling tevens vanuit een bewijsrechtelijk gezichtspunt. In dit hoofdstuk wordt ingegaan op het bewijsrecht dat van toepassing is op de vaststelling van de Nederlandse nationaliteit. Schoordijk heeft ooit gesteld dat slechts door middel van "een voortdurend jurisprudentieonderzoek" een nieuw inzicht in het toepasselijk bewijsrecht kan worden verkregen. ${ }^{511}$ Deze stelling kan mijns inziens niet anders dan worden beaamd. Tevens geldt het vereiste van jurisprudentieonderzoek uiteraard ook indien men, naast het huidige bewijsrecht, ook het in het verleden toegepaste bewijsrecht wil beschrijven. Ook dan is onderzoek van rechterlijke uitspraken de enige weg.

In het navolgende wordt met het oog op het bewijsrecht en de bewijslastverdeling de op het terrein van de vaststelling van het bezit van de Nederlandse nationaliteit relevante rechtspraak besproken. Daarbij wordt ter inleiding eerst een algemeen beeld geschetst van het civielrechtelijke bewijsrecht (paragraaf 3.2). Paragraaf 3.3 omvat het bewijsrecht inzake het Nederlanderschap. Eerst komt de (beperkte) aandacht aan bod die de wetgever heeft gehad voor het bewijsrechtelijke aspect van het bezit van de Nederlandse nationaliteit (paragraaf 3.3.1). Daarna wordt gefaseerd de nationaliteitsrechtelijke jurisprudentie besproken. $\mathrm{Er}$ is in de opzet van het onderzoek gekozen voor een chronologisch gefaseerde bespreking van de rechtspraak. Deze chronologische fasering valt samen met de achtereenvolgende rechtsgangen die voor de vaststelling van het Nederlanderschap van groot belang zijn (geweest). Het gaat daarbij achtereenvolgens om de rechtsgang op grond van de Vreemdelingenwet uit 1849, de Vreemdelingenwet uit 1965 en de huidige procedure op grond van artikel 17 Rijkswet op het Nederlanderschap. Tevens zijn de uitspraken gescheiden in zaken waar het betreft een beroep op verwerving van het Nederlanderschap dan wel een beroep op behoud van het Nederlanderschap. Daarom wordt in de tekst met twee categorieën gewerkt. Onder categorie $\mathrm{A}$ is de rechtspraak opgenomen betreffende personen die een beroep

Schoordijk, WPNR 1989, nr. 5937, p. 680. Vgl. Dijksterhuis-Wieten (II), p. 9, die stelt: "Bij gebrek aan duidelijke, door de wet gegeven bewijsregels moeten die regels uit de jurisprudentie worden afgeleid. " 
gebonden aan bepalingen dienaangaande in de wet. ${ }^{524}$ Een ander aspect is dat de rechter vrij is in de waardering van een bewijsmiddel. ${ }^{525}$ Slechts een enkel bewijsmiddel heeft onder het huidige recht dwingende bewijskracht (vgl. art. 184 leden 1 en 2 Rv en art. $188 \mathrm{Rv}$ ). Daarnaast is voor één middel wettelijk vastgelegd dat de rechter het niet onder alle omstandigheden mag waarderen als zijnde van normale "vrije" bewijskracht. Immers, de getuigenis van een partij-getuige kan, in afwijking van de getuigenissen door andere getuigen, indien het gaat om "door haar te bewijzen feiten geen bewijs te haren voordele opleveren, tenzij de verklaring strekt ter aanvulling van onvolledig bewijs" (art. 213 lid $1 \mathrm{Rv}$ ). In de woorden van Snijders betekent dit: "de partij-getuigenis kan weliswaar steeds volledig bewijs ten nadele van die partij opleveren, maar slechts aanvullend bewijs (dus in aanvulling op ander bewijsmateriaal, ........) ten gunste van die partij. ${ }^{n 526}$

Ook van groot belang is aandacht te vestigen op artikel 179 lid $1 \mathrm{Rv}$ waarin wordt vastgesteld dat ter fine van bewijslevering alle middelen zijn geoorloofd, tenzij de wet uitdrukkelijk een bepaald bewijsmiddel voorschrijft. ${ }^{527}$ In het bijzonder in het kader van het in dit proefschrift behandelde onderwerp is hetgeen artikel 176 lid $1 \mathrm{Rv}$ bepaalt met betrekking tot "een rechtsgevolg dat niet ter vrije beschikking van partijen staat" vermeldingswaard. Volgens dat artikel heeft de rechter, ook bij niet of onvoldoende betwisting, aangaande een zodanig rechtsgevolg altijd de bevoegdheid om bewijs van een stelling te verlangen. Elders merkt dienaangaande op: "Onvoldoende tegenspraak of erkenning kan echter niet leiden tot een rechtsgevolg dat niet ter vrije bepaling van partijen staat. ${ }^{n 528}$

In het Nederlandse civiele proces heeft het begrip bewijzen inhoudelijk de betekenis gekregen een feit of recht voldoende aannemelijk te maken ten overstaan van de rechter. ${ }^{529}$ Dit houdt, volgens Veegens/Wiersma, in dat bij de rechter meer dan innerlijke overtuiging aanwezig moet zijn dat het te bewijzen feit zich daadwerkelijk heeft voorgedaan. ${ }^{530}$ Daarentegen wordt uit praktische overwegingen een volstrekte zekerheid over het feit of recht niet nagestreefd. ${ }^{531}$ Asser spreekt van: "een redelijke mate van zekerheid (........) omtrent het bestaan van

${ }^{524} \mathrm{Vgl}$. Boekman (II), p. 38; Stein, NJB 1988, p. 387.

$525 \mathrm{Vgl}$. Asser/Anema/Verdam, p. 49; Dijksterhuis-Wieten, p. 20; Mulder, p. 229; Van der NatVerhage, p. 10; Pitlo/Hidma \& Rutgers, p. 10; Rutgers/Flach/Boon, p. 98; Scheltema, p. 99. Zie art. 179 lid 2 Rv.

526 Snijders, p. 43, Vgl. Stein, p. 96.

$5 n$ Vgl. Snijders, p. 42; Verhagen-Maat, p. 45.

52 Elders, p. 6.

$529 \mathrm{Vgl}$. Dijksterhuis-Wieten (II), p. 1: Pitlo/Hidma \& Rutgers, p. 7; Snijders, p. 40. In het administratief procesrecht geldt hetzelfde; Ten Berge/Tak, p. 134, spreken in dit verband van redelijke zekerheid; vgl. Bolt, losbl. uitgave bestuursprocesrecht, B3 7.2 ad 2.

530 Veegens/Wiersma, p. 49. Idem Asser/Anema/Verdam, p. 39.

531 Veegens/Wiersma, p. 47-49. Vgl. Asser/Anema/Verdam, p. 38-39; Asser (II), p. 14; DijksterhuisWieten, p. 6; Polenaar, p. 54; Princen, p. 3-4; Scheltema, p. 35. 
bepaalde feiten. ${ }^{m 532}$ Is datgene wat dient te worden bewezen inderdaad de rechter in de juiste mate aannemelijk gemaakt, dan is het ten gevolge daarvan in het geding een vaststaand gegeven. ${ }^{533}$

\subsubsection{Bewijsrecht in verzoekschriftprocedures}

Het ligt in de lijn der verwachtingen dat het toe te passen bewijsrecht, als deel van het procesrecht, een vorm aanneemt welke passend is bij het type procedure. ${ }^{534}$ In de verzoekschriftprocedure geldt derhalve bewijsrecht dat is afgestemd op het in een zodanige procedure functioneren van een minder lijdelijke rechter. ${ }^{535}$

In de jaren voor 1988, het jaar waarin het vernieuwde bewijsrecht in werking is getreden, heeft als vaste regel gegolden dat het bewijsrecht zoals dat op dagvaardingsprocedures van toepassing was, niet op verzoekschriftprocedures van toepassing was. ${ }^{536}$ Als grondslag voor deze vaste regel is in het verleden algemeen het feit aangenomen dat, tenzij de wet anders voorschreef, beschikkingen op verzoekschrift niet behoefden te worden gemotiveerd. ${ }^{537}$

De hoofdregel dat in verzoekschriftprocedures het algemene bewijsrecht niet van toepassing is, heeft geen wijziging ondergaan bij de inwerkingtreding in 1988 van de herziene artikelen 176-232 Rv. ${ }^{538}$ Desondanks staan de algemene bewijsrechtelijke regels niet helemaal buiten spel. Artikel 182 lid $1 \mathrm{Rv}$ verklaart namelijk, onder het voorbehoud dat de wet dienaangaande niets anders voorschrijft, enkele artikelen uit de algemene bewijsrechtregeling van overeenkomstige toepassing in

\footnotetext{
32 Asser (II), p. 14. Ook Scheltema, p. 35, verwijst naar "een redelijke mate van zekerheid". Idem Pitlo/Hidma \& Rutgers, p. 7.

533 Asser (II), p. 13; Niessen-Cobben, p. 89.

$53 \mathrm{Vgl}$. Schaafsma-Beversluis, p. 297, waar zij een opmerking uit de memorie van Antwoord bij het ontwerp bewijsrecht aanhaalt. Er wordt in de memorie gesteld dat als alle regels van bewijsrecht van toepassing zouden worden verklaard op de verzoekschriftprocedure, het karakter van de procedure zou veranderen.

s3s Vgl. Gras, p. 54; Zuidema, p. 84.

$536 \mathrm{Vgl}$. Boekman, p. 114; Bosch-Boesjes, p. 162; Coops, p. 88; Funke, p. 215; Meijknecht, oratie, p. 11; Monte, p. 143; Rutgers/Flach/Boon, p. 10; Scheltema, p. 3; Stein, NJB 1988, p. 390; Wesselingvan Gent, p. 97; Vriesendorp, p. 96; Recht en regels: p. 35. Slechts bij Asser/Anema/Verdam, p. 53, vindt vermelding dat de gewone bewijsrechtregels wel van toepassing zijn op oneigenlijke ( $=$ contentieuze) verzoekschriftprocedures, als voorbeeld worden daar genoemd procedures uit arbeidsovereenkomst. Zuidema, p. 91 en 93, bepleit reeds in 1917 de toepassing van het gewone bewijsrecht in contentieuze verzoekschriftprocedures (vgl. voetnoot 799). Ook in Recht en regels, p. 36, wordt een voorkeur uitgesproken voor de toepassing van het gewone bewijsrecht in contentieuze rekestprocedures.

537 Boekman, p. 115; Struycken, p. 36; Veegens/Wiersma, p. 64; Recht en regels, p. 35.

$53 \mathrm{Vgl}$. Bosch-Boesjes, p. 162; Dijksterhuis-Wieten, p. 9; Rutgers/Flach/Boon, p. 10, die weergeven hoe in het voorontwerp bewijsrecht het voorstel is opgenomen het gewone bewijsrecht van toepassing te verklaren op contentieuze verzoekschriftprocedures. In het daarop volgende wetsontwerp is dit voorstel is niet overgenomen; Wesseling-van Gent, p. 97.
} 
verzoekschriftprocedures. Het gaat daarbij om procesregels inzake getuigenverhoor, deskundigenonderzoek, plaatsopneming en bezichtiging. Het betreft hier derhalve bepalingen van formele aard die betrekking hebben op de wijze van bewijslevering. ${ }^{539}$ Ook de artikelen 190 en $213 \mathrm{Rv}$ zijn van toepassing verklaard, zodat partijen in de verzoekschriftprocedure kunnen optreden als partij-getuige met de daaraan inherente beperkte bewijskracht van de getuigenis..$^{540}$

Een ander belangrijk bewijsrechtelijk kenmerk bij verzoekschriftprocedures is, in ieder geval voor procedures waarop artikel $429 \mathrm{j} R v$ van toepassing is, dat de in een verzoekschriftprocedure minder lijdelijke rechter zelf bepaalde personen kan aanmerken als getuigen en hen kan doen oproepen te verschijnen. ${ }^{541}$ In dagvaardingsprocedures mist de rechter de bevoegdheid zelf getuigen aan te wijzen. ${ }^{542}$

De rol van de minder lijdelijke rechter bij verzoekschriftprocedures blijkt eveneens uit het feit dat in die procedures de rechter voorbij mag gaan aan een voldoende aanbod van de verzoeker, verweerder of belanghebbende bewijs te leveren door getuigen. Ook een aanbod om tegenbewijs te leveren mag worden gepasseerd. $^{543}$

Dijksterhuis-Wieten heeft vijf (in de rechtspraak gevormde) regels betreffende de bewijsvoering in verzoekschriftprocedures beschreven, waarvan de vrijheid in de verdeling van de bewijslast en de vrijheid in de keuze van bewijsmiddelen ${ }^{544}$ naar mijn oordeel wel de belangrijkste zijn. ${ }^{545}$

De verschillen in het bewijsrecht tussen procedures die worden ingeleid met een dagvaarding dan wel met een verzoekschrift zijn wel enisgzins te relativeren, aangezien het de rechter in verzoekschriftprocedures van ouds vrij heeft gestaan en

\footnotetext{
539 Verschuur, p. 245. Idem Meijknecht, oratie, p. 11; Pitlo/Hidma \& Rutgers, p. 14; SchaafsmaBeversluis, p. 297.

${ }^{40} \mathrm{Vgl}$. Dijksterhuis-Wieten, p. 9.

${ }^{541} \mathrm{Vgl}$. Meijknecht, oratie, p. 12; Verhagen-Maat, p. 51; Wesseling-van Gent, p. 97.

${ }^{542} \mathrm{Vgl}$. art. $192 \mathrm{Rv}$. Dijksterhuis-Wieten, p. 80, over dat artikel: "De rechter kan niet zelf de getuigen aamwijzen." Rutgers/Flach/Boon, p. 243, citeren uit de memorie van Antwoord bij het ontwerp bewijsrecht: "De vraag of het vonnis, voor zover mogelijk, ook mag vermelden welke concrete getuigen de rechter wenst te horen, dient in zoverre bevestigend te worden beantwoord, dat de rechter in zijn beslissing te kennen kan geven dat hij het wenselijk acht dat bepaalde personen als getuigen worden gehoord."
}

343 Dijksterhuis-Wieten, p. 10; Meijknecht, oratie, p. 12.

s44 Een zelfde vrijheid ten aanzien van de bewijsmiddelen geldt in dagvaardingsprocedures net zo goed: art. 179 lid 1 Rv. De beperking uit art. 179 lid 1 Rv dat de vrijheid van bewijsmiddelen niet geldt daar waar de wet een bepaald bewijsmiddel voorschrijft of uitsluit, geldt naar mijn mening in beginsel ook voor verzoekschriftprocedures. Evenwel heeft de rechter in verzoekschriftprocedures vanwege het niet toepasselijk zijn van art. 179 lid 1 Rv een mogelijkheid om aan een zodanige wettelijke bepaling inzake bewijsmiddelen te ontsnappen. Vgl. Meijknecht, oratie, p. 11 en 12. In het administratief procesrecht zijn eveneens alle bewijsmiddelen toegelaten; vgl voetnoot 523 .

94s Dijksterhuis-Wieten, p. 11. De drie andere regels zijn: vrijheid een bewijsaanbod niet te accepteren, geen verplichting tegenbewijs toe te laten en als laatste: geen motiveringsplicht voor interlocutoire tussenbeschikkingen. 
ook heden ten dage nog vrij staat het 'gewone' bewijsrecht analogisch toe te passen. $^{546}$ Ook daarin heeft, naar de memorie van Antwoord stelt, het herziene bewijsrecht geen verandering willen brengen. ${ }^{547}$ De beslissing over analoge toepassing van het gewone bewijsrecht ligt bij de rechter. ${ }^{548}$ Uiteraard geldt daarbij als uitgangspunt dat in alle gevallen de procedure dient te voldoen aan beginselen van een behoorlijke procesorde.

Overigens laat het nieuwe bewijsrecht de rechter in dagvaardingszaken meer vrijheid dan voorheen. Aangezien naar zijn oordeel weinig belangrijke verschillen overblijven is Meijknecht van mening dat in verzoekschrift- en dagvaardingsprocedures wat betreft het bewijsrecht sprake is van een toenadering. ${ }^{549}$

\subsubsection{Het bewijzen van feiten en het bewijzen van een recht}

Uit de artikelen 176 en 177 Wetboek van Burgerlijke Rechtsvordering blijkt dat datgene wat aan bewijs onderhevig kan worden een (rechts)feit dan wel een (subjectief) $^{550}$ recht $^{551}$ kan zijn. Hoewel artikel 182 lid 1 Rv niet uitdrukkelijk artikel $176 \mathrm{Rv}$ op verzoekschriftprocedures van toepassing verklaart, mag mijns inziens worden aangenomen dat ook in zodanige procedures zowel feiten als rechten aan bewijsvoering onderhevig kunnen zijn.

Voor een onderwerp als de vaststelling in rechte van een nationaliteit is het interessant om op deze plaats even nadere aandacht te schenken aan de vraag op welke wijze(n) een subjectief recht kan te worden bewezen. Alsdan kan antwoord worden gegeven op de vraag of het mogelijk is het wel of niet bestaan van een rechtsverhouding aangaande de Nederlandse nationaliteit (als absoluut en subjectief $^{52}$ recht van publiekrechtelijke aard) bewezen te achten door middel van

\footnotetext{
${ }^{546} \mathrm{Vgl}$. Meijknecht, oratie, p. 11; Schaafsma-Beversluis, p. 297.

son Bijl. II. 1981, 10377, nr. 7, p. 13. Vgl. Hugenholtz/Heemskerk, p. 138; Rutgers/Flach/Boon, p. 11; Verschuur, p. 245.

34 Bosch-Boesjes, p. 162; Rutgers/Flach/Boon, p. 11.

549 Meijknecht, oratie, p. 12.

${ }^{550}$ Dijksterhuis-Wieten (II), p. 1; Hugenholtz/Heemskerk, p. 145; Niessen-Cobben, p. 89; Snijders, p. 41.

551 Rutgers/Flach/Boon, p. 79, tekenen aan dat het eigenlijk gaat om het bewijs van "stellingen aangaande de rechtsbetrekking in geschil". Vervolgens stellen zij dat het opnemen in de wet van de term "rechtsbetrekking" niet geheel gelukkig gekozen zou zijn, aangezien deze term "twijfel zou kunnen doen rijzen aan de mogelijkheid van het bewijs van een absoluut recht in gevallen, waarin niet anders dan een declaratoire uitspraak wordt gevraagd."

${ }^{552} \mathrm{Vgl}$. Tonnaer, p. 159: "Bij een subjectief recht is per definitie sprake van een tweezijdige rechtsbetrekking. Een subjectief recht is immers de aanspraak op de naleving van een rechtsplicht. Er is dan sprake van een (rechts)plicht aan de ene kant en een recht aan de andere kant. " En dezelfde auteur p. 163: "Subjectieve rechten betreffen de aanspraak van rechtssubjecten op de naleving van rechtsplichten." De anonieme schrijver in HPS 1951, p. 4, stelt duidelijk: "Nationaliteit kan omschreven worden
} 
sub a in zijn oorspronkelijke ${ }^{564}$ versie dat Nederlander is: "het kind ${ }^{565}$ van een ingezetene $^{566}$ des Rijks $^{567}$-hetzij vader, hetzij moeder, naar de in art. 1 gemaak-

${ }^{364}$ De eerste maal dat art. 2 sub a Wet Ned. 1892 wordt gewijzigd is in 1951 (met terugwerkende kracht tot 27.12.1949). Daarna volgen wijzigingen in 1953 (met terugwerkende kracht tot 01.07.1893), 1962 en 1975. Zie de wetgevingseditie Schuurman en Jordens, deel 209 (1994), p. 138-140.

s6s De geboorte van dit kind hoeft niet in Nederland plaats te vinden, aldus de regering in de memorie van Antwoord; Bijl. II. 1891-1892, 130, nr. 5, p. 18. Ook heden ten dage is het aldus geformuleerde regeringsstandpunt m.b.t. de derde-generatieregel geldend recht. Vgl. De Groot/Tratnik, p. 69 .

566 Met ingang van 27.05.1953, (Stb. 233; met terugwerkende kracht tot 01.07.1893) vervangen door het vereiste dat deze ouder tijdens de geboorte van de derde generatie "woonachtig" is in het door de Wet Ned. 1892 bestreken territorium. Het geldingsgebied betrof vanaf 1893 tot 1949 alleen het Europese grondgebied; en vanaf 1949 ook in Suriname (tot 25.11.1975) en de Nederlandse Antillen (sinds 01.01.1986 de Ned. Antillen en Aruba).

367 "Rijk" heeft de beperkte betekenis van "Nederland".

In de periode 1893-1949 is de Wet op het Nederlanderschap en het ingezetenschap alleen van toepassing geweest in Nederland en heeft de voorziening voor derde-generatie immigranten niet gegolden in de toenmalige overzeese gebieden van het Koninkrijk. Bij wetswijziging in 1951 (Stb. 593) wordt met terugwerkende kracht per 27.12.1949 (art. 5 van de wijzigingswet uit 1951) de derdegeneratieregel van kracht in Nederland, Suriname en de Nederlandse Antillen, aangezien "ingezetene des Rijks" wordt vervangen door "ingezetene van Nederland, van Suriname of van de Nederlandse Antillen" alsmede "Rijk" door "Koninkrijk". Een uitzonderingsbepaling ten aanzien van Nieuw-Guinea was noodzakelijk: in dat gebiedsdeel heeft de derde-generatieregel geen toepassing gevonden.

1838-1893: het Nederlanderschap op grond van art. 5 BW (1838) valt toe aan de bevolking van Nederland, Suriname, Curaçao (hiermee werden de gehele Ned. Antillen aangeduid) en Indonesië.

1893-1949: De Wet op het Nederlanderschap en het ingezetenschap uit 1892 is niet van kracht in Suriname, Curaçao en Ned.-Indiē. Echter, vanwege het feit dat door de overgangsbepaling bij de Wet Ned. 1892 wereldwijd (door de overgangsbepaling werden evenwel uitgezonderd de "inlanders in Nederlandsch-Indië en de daar te lande met dezen gelijkgestelden") de art. 5 BW (1838)-Nederlanders het Nederlanderschap naar de Wet Ned. 1892 verwerven, behoudt de bevolking in "de West" in meerderheid het Nederlanderschap. Op deze personen is derhalve van toepassing de Wet op het Nederlanderschap en het ingezetenschap. Als bekend, hanteert deze wet als hoofdbeginsel nationaliteitsverkrijging via afstamming.

1927-1949: Voor velen in "de West" is voor de nationaliteit primair de afstamming van een Nederlander van belang; ergo de Wet op het Nederlanderschap en het ingezetenschap uit 1892. Voor degene op wie de Wet Ned. 1892 niet van toepassing is, treedt in 1927 in werking de Wet houdende regeling van het Nederlandsch onderdaanschap van niet-Nederlanders uit 1910. (Deze wet is van 1910 tot 27.12.1949 ook van kracht geweest in Ned.-Indië). De wet kent een tweede-generatieregel, d.w.z. het onderdaanschap valt al toe aan het in Suriname of Curaçao geboren kind van een immigrant. Tevens is in de Wet uit 1910 niet de eis gesteld dat het kind geen andere nationaliteit bezit.

1949: De derde-generatieregel uit de Wet op het Nederlanderschap en het ingezetenschap uit 1892 wordt van kracht in Suriname en op de Ned. Antillen (zie boven). De Wet houdende regeling van het Nederlandsch onderdaanschap van niet-Nederlanders uit 1910 wordt voor deze gebieden ingetrokken. Ingevolge de overgangsbepaling in art. 1 van de Wet van 21.12.1951, (Stb. 593) wordt het Ned. onderdaanschap uit de Wet uit 1910 omgezet in het Nederlanderschap in de zin van de Wet Ned. 1892. Bij het aldus van kracht worden van de Wet op het Nederlanderschap en het ingezetenschap uit 1892 in "de West" verslechtert de nationaliteitsrechtelijke positie van immigrantenkinderen. (Van tweedegeneratieregel én het niet van belang zijn van een eventuele vreemde nationaliteit naar derde-generatieregel én het vereiste dat het kind indien geen verwerving van het Nederlanderschap zou plaatsvinden 
te onderscheidingen ${ }^{568}$ - die zelf geboren is uit eene in het Rijk wonende ${ }^{569}$ moeder, tenzij blijke dat het kind als vreemdeling tot een ander land ${ }^{570}$ behoort. ${ }^{571}$ Het doel van dit artikel is tweeledig geweest. Door opname in de wetgeving van deze bepaling is beoogd: "te voorkomen dat koloniën van vreemdelingen ${ }^{572}$ op den duur hier te lande zouden gevestigd zijn, als om casu quo het bewijs van het Nederlanderschap te vergemakkelijken.

Wat betreft het bewijsrechtelijke element is de Tweede Kamer in het Voorlopig Verslag waarin is aangedrongen op opname van deze regeling zeer kortaf en tevens niet geheel correct met de stelling: "Bij aanneming van de aangegeven bepaling zou men kunnen volstaan met de geboorte van twee geslachten in Nederland te bewijzen. ${ }^{m 574}$

Vele jaren daarna komt het bewijsrechtelijke element van deze regel andermaal aan bod bij de behandeling in de Tweede Kamer van een wetsontwerp dat o.a. beoogt de nadere vaststelling van artikel 2 sub a Wet op het Nederlanderschap en

$567 \rightarrow$

anders staatloos zou zijn; zie tevens voetnoot 570). In 1962 is door toevoeging van art. 2bis Wet op het Nederlanderschap en het ingezetenschap deze verslechtering ten aanzien van Suriname ten dele ongedaan gemaakt (Stb. 249, met een belangrijke overgangsbepaling voor personen geboren in Suriname na 26.12.1931 en voor 01.10.1951; zie voetnoot 588). Voor degenen in Suriname en de Nederlandse Antillen die op grond van afstamming het Nederlanderschap bezitten, brengt de wetswijziging in 1951 geen verandering; voor dezen gold de Wet Ned. 1892 immers al.

${ }^{6} 68$ Bedoeld onderscheid heeft bestaan uit: de wettige vader met Nederlandse nationaliteit, de wettigende vader met Ned. nationaliteit, de erkennende vader met Ned. nationaliteit en de ongehuwde moeder met Nederlandse nationaliteit die haar kind erkent. In 1893 bewerkstelligt art. 2 sub a derhalve dat het Nederlanderschap van rechtswege wordt toegekend aan de boreling van een wettige, wettigende, dan wel erkennende vader zonder nationaliteit, dan wel van onbekende nationaliteit, die zelf is geboren uit een in Nederland woonachtige moeder; alsmede van rechtswege toekenning aan het kind van de ongehuwde, haar kind erkennende (zie ook voetnoot 618) staatloze vrouw, die zelf is geboren uit een in Nederland woonachtige moeder.

${ }^{969} \mathrm{Om}$ nu uit te sluiten dat twee opeenvolgende geboorten die toevalligerwijs in Nederland plaatsvinden de toekenning van het Nederlanderschap als rechtsgevolg zouden kennen, is bepaald dat beide generaties, de eerste generatie (een grootmoeder) en de tweede (de "ingezetene" van art. 2 sub a Wet Ned. 1892), in Nederland woonachtig (d.w.z. sinds enige tijd gevestigd) moeten zijn.

50 De beperking dat het kind om het Nederlanderschap te verkrijgen geen andere nationaliteit mag hebben, is met ingang van 27.05.1953 (Stb. 233) vervallen. Ondanks het te dienaanzien ontbreken van enige overgangsbepaling wordt, enigzins onduidelijk is op grond waarvan, door de memorie van Toelichting ervan uitgegaan dat het vervallen van deze beperking inzake het verwerven van het Nederlanderschap terugwerkt tot 01.07.1893. Dit leidt bij de toepassing van de Wet Ned. 1892 tot de fictie te handelen of deze beperking nooit heeft bestaan; vgl. Heijs, (II), p. 135.

571 Zie Achterberg, p. 45.

572 Tot 1953 is het bereiken van dit doel vanzelfsprekend niet bevorderd door de bepaling dat de derdegeneratieregel slechts van toepassing zou zijn in het geval dat vaststond dat het kind geen vreemde nationaliteit bezat. Zie voetnoot 570 . Volgens Heijs (II), p. 69 en 72, heeft de regeling (tot 1953) dan ook weinig praktisch belang gehad.

${ }_{573}$ Bijl. II. 1891-1892, 130, nr. 5, p. 18.

524 Bijl. II. 1891-1892, 130, nr. 4, p. 10. 
het ingezetenschap. De minister van Justitie, Mulderije, maakt in de memorie van Toelichting met betrekking tot artikel 2 sub a Wet op het Nederlanderschap en het ingezetenschap de volgende opmerking met bewijsrechtelijke implicaties: "Eenvoudiger is, dat voor bewijs van iemands Nederlanderschap krachtens voormelde bepaling, in de regel kan worden volstaan met over te leggen een volledig afschrift van -geen extract uit- zijn geboorte-akte en die van zijn ouder. " 575

In het nationaliteitsrecht is het evenwel niet ongewoon dat de feitelijke situaties aanmerkelijk gecompliceerder zijn dan de hierboven aan de orde zijnde opeenvolgende geboorten op grondgebied waarop de generatieregel van toepassing is. Indien de situatie daartoe aanleiding geeft, beïnvloedt vreemd recht nogal eens het resultaat inzake de Nederlandse nationaliteit. Geheel terecht is door Jessurun d'Oliveira de volgende opmerking gemaakt: "De vaststelling van het nederlanderschap hangt af van het bewijs van allerlei rechtsfeiten die deels onder buitenlands en/of nederlands nationaliteitsrecht ressorteren, deels ook onder het eigen internationaal privaatrecht, het eigen of vreemde interne recht. ${ }^{1576}$ Het is inderdaad een feit dat het bewijzen en het vaststellen van het bezit van de Nederlandse nationaliteit in sommige gevallen zeker niet een eenvoudige zaak is. ${ }^{577}$ In de literatuur en in de praktijk is evenwel ook de constatering gedaan dat het verlies van het Nederlanderschap in vele gevallen eveneens moeilijk is vast te stellen. ${ }^{578}$

In de gevallen dat in het kader van de vaststelling van de Nederlandse nationaliteit tevens feiten die in het buitenland zijn voorgevallen aan de orde zijn, kunnen deze feiten de vaststelling zeer gecompliceerd maken. In het Nederlandse internationaal privaatrecht geldt inzake het bewijsrecht dat het formele bewijsrecht volgens het eigen recht van de rechter (lex fori) verloopt, terwijl het materiële bewijsrecht volgens de lex causae verloopt. ${ }^{579}$

De Groot/Tratnik wijzen in 1986 op het feit dat het Nederlandse nationaliteitsrecht geen specifiek eigen wettelijke voorschriften kent wat de bewijslastverdeling betreft. ${ }^{580}$ Met deze algemene constatering beslaan de auteurs zowel de nationaliteitsvaststelling in de "zelfstandige vaststellingsprocedure" als de vaststelling in "impliciete vaststellingsprocedures". Ten einde een beeld te verkrijgen van een eventuele bewijslastverdeling bij geschillen inzake het Nederlanderschap is het onderhavige onderzoek naar nationaliteitsrechtelijke uitspraken waaraan een bewijsrechtelijke dimensie zit, verricht. Om eventuele voor de bewijslast relevante

\footnotetext{
575 Bijl. II. 51-52, 2378, nr. 3, p. 1.

576 Jesssurun d'Oliveira, AA 1986, p. 227.

sn Zie bijv. Boersma, Tijdschrift voor de Politie 1939, p. 43-46. En voor een geval waarin iemand volgens de regering "vermoedelijk ook de Nederlandse nationaliteit" bezit: Bijl. II. 63-64, 7163, nr. 9, p. 9.

578 Spanjaard, p. 157; Valkhoff, RMTh 1932, p. 472, 480 en 481.

579 Kollewijn, p. 22; Pitlo/Hidma \& Rutgers, p. 16 en 17.

580 De Groot/Tratnik, p. 130.
} 
lijnen te kunnen ontdekken, heb ik, als gezegd in paragraaf 3.1 , de jurisprudentie onderverdeeld in twee categorieën. In de eerste categorie, categorie A, zijn de uitspraken ingedeeld waarin het gaat om gevallen waarin de betrokkene stelt de Nederlandse nationaliteit te hebben verworven. De tweede categorie, categorie B, betreft uitspraken die betrekking hebben op personen die een beroep doen op behoud van het Nederlanderschap door te stellen dat een verliesgrond voor het Nederlanderschap niet van toepassing is.

In het hieronder verwerkte jurisprudentieonderzoek wordt tevens aandacht besteed aan de inzake de vaststelling van het Nederlanderschap in het verleden toegepaste verdeling van de bewijslast. Als gesteld in paragraaf 3.1 ga ik eerst in op de bewijslastverdeling in "impliciete vaststellingsprocedures". Daarbij gaat het om oudere rechtspraak en wel voornamelijk om procedures die zijn gevoerd in het kader van Nederlanderschapsactie op grond van de Vreemdelingenwetten uit 1849 en 1965. Aan de hand van de bevindingen op grond van die oudere jurisprudentie kan een beeld kan worden verkregen van de situatie van voor de inwerkingtreding van de vaststellingsprocedure uit de Rijkswet op het Nederlanderschap. Daarna komt, als gezegd, de rechtspraak op grond van de "zelfstandige vaststellingsprocedure" aan de orde.

Een van het bewijsrecht losstaand onderwerp is dat bij het vaststellen van het bezit van het Nederlanderschap het in sommige gevallen voorkomt dat pas een oordeel over het Nederlanderschap kan worden gegeven indien een voorafgaand oordeel is genomen inzake het wel of niet bezit van een andere nationaliteit. De vraag in hoeverre zekerheid dient te bestaan over het daadwerkelijk bezit van die andere nationaliteit heeft meermalen aanleiding gegeven tot de vorming van jurisprudentie. Aan deze jurisprudentie wordt in dit hoofdstuk ook aandacht besteed. De hier naar voren gebrachte problematiek betreft in feite niet het bewijsrecht, laat staan het bewijsrecht inzake de Nederlandse nationaliteit, maar betreft, blijkens de jurisprudentie, de interpretatie van vreemd recht. Desondanks heb ik gemeend in dit hoofdstuk voorbeelden uit deze jurisprudentie op te moeten nemen, aangezien uit de jurisprudentie blijkt dat de kwestie van de bewijslastverdeling ten aanzien van het bezit van de vreemde nationaliteit daarvoor voldoende interessant is.

\subsubsection{Nationaliteitsbeslissingen vanaf 1948 tot 1967}

Met betrekking tot de bewijslastverdeling is in 1953 door Van Sasse van Ysselt het volgende uitgangspunt opgesteld: "Als algemene regel gelde, dat, van hem, die het Nederlanderschap heeft verkregen, niet gevergd kan worden, dat hij bewijze het Nederlanderschap niet te hebben verloren. Wie de door geboorte verkregen staat 
van Nederlanderschap zou willen betwisten, zal het rechtsfeit hebben aan te tonen, dat het Nederlanderschap verloren deed gaan. ${ }^{1581}$

Bij een nadere beschouwing blijkt dat met dit citaat bovenal gevolg wordt gegeven aan de bewijsrechtelijke regel volgens welke de bewijslast wordt verdeeld op grond van het adagium: "wie stelt, bewijst". ${ }^{582}$

Ook bij andere auteurs is de aldus door Van Sasse van Ysselt ingeroepen verdeling van de bewijslast te vinden. Bovenal in het geval dat de nationaliteitsvraag opkomt in een civiel geding acht de literatuur de bovenvermelde bewijslastverdeling van toepassing. ${ }^{583}$ Maar ook met betrekking tot strafzaken levert, voor zover het de vraag naar de bewijslastverdeling inzake het bezit van de Nederlandse nationaliteit betreft, de literatuur noch de jurisprudentie een andersluidende conclusie op. Wel stelt Mannoury dat, indien het Nederlanderschap van belang is in een strafzaak, de bewijsvoering voor wat betreft de nationaliteit niet is gebonden aan de bepalingen inzake strafrechtelijke bewijsvoering. ${ }^{584}$

In de bovenvermelde uitspraak door Van Sasse van Ysselt valt, naast de verwijzing naar de regel "wie stelt, bewijst", evenzeer een tweede regel te lezen. Bij deze tweede regel gaat het niet om de verdeling van de bewijslast, maar gaat het om een regel die duidelijk stelt wát moet zijn bewezen, wil verlies van het Nederlanderschap kunnen worden aangenomen. De aldus bedoelde regel houdt dan het volgende in: indien iemand ooit het Nederlanderschap heeft verkregen, dient te worden uitgegaan van het behoud van het Nederlanderschap zolang niet het rechtsfeit is bewezen ten gevolge waarvan het Nederlanderschap verloren zou zijn gegaan. Anders geformuleerd: het bovenstaande leidt tot de stelregel dat van het behoud van het Nederlanderschap dient te worden uitgegaan, tenzij een rechtsfeit waaraan het verlies is gekoppeld, is bewezen. De hier weergegeven stelregel op het gebied van het (Nederlandse) nationaliteitsrecht wordt in de volgende paragrafen van dit

\footnotetext{
581 Van Sasse van Ysselt, HPS 1953, p. 56.

$5 \times 2$ Hetgeen het uitgangspunt vormt in de theoric over bewijslastverdeling die de objectiefrechtelijke theorie wordt genoemd. Dijksterhuis-Wieten, p. 31, legt deze theorie als volgt uit: "dat elke partij de bewijslast draagt van het bestaan van de feiten, waarvan het objectieve recht het door haar ingeroepen rechtsgevolg afhankelijk heeft gesteld. " Door te benadrukken dat "alleen de feiten waarvoor een partij stelplicht heeft", dienen te worden bewezen door die partij wijst Asser (II), p. 45, erop dat de zegswijze "wie stelt, bewijst" in feite te simplificerend is.
}

583 Mannoury, p. 167: "Daarbij blijft het aan partijen overgelaten, hun stellingen in geval van tegenspraak te bewijzen."; Septer/Schouten, p. XVIII: "Zo zal degene, die toelating verzoekt om kosteloos of tegen verminderd tarief te procederen, ten genoegen van de burgerlijke rechter moeten bewijzen dat hij Nederlander is. Echter zal iemand, die in een civiele procedure verzoekt, dat de eisende partij als vreemdeling zekerheid stelt, moeten aantonen, dat deze de Nederlandse nationaliteit niet bezit. " Dit laatste is ook gesteld door Kan, p. 87. Vgl. Hof 's-Hertogenbosch 17.03.1959, NJ 1959, nr. 656, dat overweegt in een echtscheidingszaak: "dat de rechter als bij zulk een vordering wordt gesteld het voor zijne bevoegdheid nodige feit, dat beide pp. Nederlander zijn, gerechtigd en zelfs verplicht is de eisende partij op te dragen de juistheid van die stelling aan te tonen, indien er voor hem gegronde reden is daaraan te twijfelen; (.......). "

sM Mannoury, p. 168. 
hoofdstuk door mij aangeduid met "de continueringspresumtie" als werkbegrip. Op de vraag echter, wie ten aanzien van het bewuste rechtsfeit de bewijslast draagt en waar derhalve het bewijsrisico ligt, wordt evenwel met deze regel geen antwoord gegeven.

Naar alle waarschijnlijkheid heeft Van Sasse van Ysselt zijn bovenstaande uitspraak gedaan naar aanleiding van een aantal uitspraken die enige jaren eerder door de Hoge Raad zijn gedaan. ${ }^{585}$ Daarbij gaat het in meerderheid om uitspraken op grond van artikel 20 Wet toelating en uitzetting van vreemdelingen uit 1849 , alsmede om een enkele uitleveringszaak en een Kieswetzaak ${ }^{586}$; procedures derhalve van sterk administratiefrechtelijke inslag. Niet alle zaken die Van Sasse van Ysselt noemt, zijn bewijsrechtelijk interessant. Op enkele bewijsrechtelijk wel interessante uitspraken wordt in het navolgende uitgebreider ingegaan, de uitspraken die bewijsrechtelijk niet interessant zijn gebleken, zijn terzijde gelaten. Daarnaast is ook latere, voor de bewijslastverdeling relevante, jurisprudentie tot 1967 opgenomen.

\subsubsection{Jurisprudentie categorie A: Beroep op verwerving van het Nederlanderschap}

\subsection{HR 28 oktober 1952}

Cat. A. uitspr. I. Casusbeschrijving. Bewijs door middel van bezit van staat.

Het bewijs van het Nederlanderschap kan vooral moeilijk zijn voor personen wier familie reeds generaties niet (meer) woonachtig is in het Koninkrijk. Bij opeenvolgende geboorten buiten de gebieden waarin voor het Nederlandse nationaliteitsrecht de verkrijging op grond van langdurige vestiging mogelijk is ${ }^{587}$ (geweest), ${ }^{588}$ zijn deze personen volledig afhankelijk van nationaliteitsverkrijging via afstamming

\footnotetext{
ss De auteur geeft niet als zodanig aan uit welke informatiebron(nen) hij zijn bewijslastverdelingsregel induceert, maar bespreekt verderop in zijn artikel wel deze destijds recente uitspraken.

${ }^{5} \mathrm{ag} 6 \mathrm{Vgl}$. par. 2.8.2.

57) Dit betreft dan Nederland, de Nederlandse Antillen en Aruba.

ss Zie voor verwerving van het Nederlanderschap in Suriname via de "tweede-generatieregel" uit de Wet 1910 hierboven voetnoot 567. Sinds het van kracht worden van de Wet Ned. 1892 in Suriname op 27 december 1949 heeft daar tot 25.11.1975 de derde-generatieregel uit art. 2 sub a Wet Ned. gegolden. Maar tevens is sinds 01.10.1962 art. 2bis Wet Ned. 1892 van kracht. Art. 2 bis Wet Ned. 1892 bevat voor Suriname een tweede-generatieregel. Op grond van art. 2bis Wet Ned. 1892 vindt verwerving van het Nederlanderschap plaats: "(......) door het in Suriname geboren kind van een tijdens de geboorte aldaar wonende vader of moeder, bij het bereiken van de leeftijd van een en twintig jaar. indien het kind het kind gedurende een onmiddellijk daaraan voorafgegaan tijdvak van drie jaren in Suriname woonplaats of hoofdverbliif heeft gehad." Art. 2bis Wet Ned. 1892 is vervallen per 25.11.1975. Al met al kan worden gesteld dat Suriname een tweede-generatieregel heeft gekend van 1927 tot 1975.
} 


\section{Hoofdstuk 3}

van een Nederlander. Vanuit bewijsrechtelijke optiek betekent dit dat de desbetreffende personen over een belangrijk bewijsmiddel niet kunnen beschikken. Immers voor hen komt de mogelijkheid om door middel van het tonen van opeenvolgende geboorteakten een beroep te doen op de derde-generatieregel ${ }^{589}$ niet aan de orde.

Eén van de door Van Sasse van Ysselt genoemde zaken betreft een uitspraak inzake een voorgenomen uitlevering aan Indonesië. ${ }^{590}$ Als beletsel voor zijn uitlevering doet de betrokkene ${ }^{591}$ een beroep op het bezit van het Nederlanderschap. Zou het de gang van zaken zijn dat primair de betrokkene moet kunnen waarmaken ooit op enigerlei wijze het Nederlanderschap te hebben verworven, dan zou de betrokkene (geboren 1919) in deze zaak een harde dobber hebben gehad. Zijn familie woont al generaties in Turkije. De vraag is derhalve gewettigd of de betrokkene wel afstamt van een voorvader die ooit het Nederlanderschap ingevolge artikel 5 BW (1838) heeft verworven. ${ }^{592}$ Deze vraag blijkt i.c. niet eenduidig te beantwoorden, zodat de exacte verwervingsgrond van het gepretendeerde Nederlanderschap niet is bewezen. Toch beslist de Hoge Raad dat de man in kwestie in het bezit van de Nederlandse nationaliteit is. Dit wordt gebaseerd op uit "de archieven van het Consulaat-Generaal te Istanbul" afkomstige informatie waaruit het Nederlanderschap van klagers grootvader en vader blijkt. ${ }^{593}$ Dezen hebben altijd binnen de daarvoor wettelijk gestelde termijn aldaar een verklaring tot behoud van het Nederlanderschap afgelegd. ${ }^{594}$ Als gevolg van een daartoe strekkende opdracht aan de Nederlandse ambassade in Turkije van de kant van de minister van Buitenlandse Zaken zijn deze gegevens verkregen. Aan de hand van deze door respectievelijk klagers grootvader en vader afgelegde en in de consulaire registers ingeschreven verklaringen komt de Hoge Raad tot de constatering dat de (Nederlandse) overheid het Nederlanderschap van de desbetreffende voorouders steeds heeft erkend.

Reeds op grond van de bovenstaande feiten stelt de Hoge Raad dat dit alles: "impliceert, dat (.....) ook Nederlander is, aangezien hij na zijn 21ste jaar het Nederlanderschap niet heeft verloren wegens een der feiten, welke de wet als oorzaak van zulk een verlies opnoemt." Aanvullend noemt de Hoge Raad nog dat het Nederlanderschap van de betrokkene tevens blijkt uit het feit dat hij als dienstplichtig is opgeroepen voor Nederlandse militaire dienst. En afsluitend stelt de Hoge Raad: "Tenslotte zij opgemerkt, dat de Nederlandse Regering er steeds van

\footnotetext{
589 Of de tweede-generatieregel van de uit 1910 daterende Wet houdende regeling van het Nederlandsch onderdaanschap van niet-Nederlanders.

${ }^{590}$ HR 28.10.1952, HPS 1952, p. 133.

591 Vgl. par. 2.8 .2 (i.h.b. voetnoot 474).

$592 \mathrm{Vgl}$. De Groot, p. 125.

$393 \mathrm{Vgl}$. Joekes, p. 20 en 21.

${ }^{594}$ Deze verklaring betreft art. 7 aanhef sub 5 Wet Ned. 1892. Verlies van het Nederlanderschap kon worden voorkomen door tijdig een verklaring af te leggen. Een zodanige verklaring diende om de tien jaar te worden herhaald.
} 
uitgegaan is, dat (....) als Nederlander moet worden aangemerkt. Zulks werd b.v. met zoveel woorden schriftelijk aan de Britse Ambassadeur medegedeeld, naar aanleiding van een desbetreffende vraag zijnerzijds.

Overwegende voorts dat deze gegevens ook in de overige stukken van het dossier bevestiging vinden, terwijl niet blijkt van enige omstandigheid waaruit zou volgen dat verzoeker zijn Nederlanderschap zou hebben verloren, zodat het verzoek behoort te worden ingewilligd;

Verstaat dat (......) is Nederlander en dat de Wet van 6 April 1875 Staatsblad 66 op hem niet van toepassing is. ${ }^{m 595}$

\section{Aantekening.}

Deze uitspraak wordt in de literatuur wel aangehaald ten behoeve van de stelling dat het Nederlanderschap ook door middel van het bezit van staat ${ }^{596}$ kan worden bewezen. ${ }^{597}$ Dat dit inderdaad mogelijk is, is voornamelijk uitgemaakt ten behoeve van personen afkomstig uit het voormalig Nederlands-Indië, voor wie het leveren van bewijs uit het bevolkingsregister in Indonesië op een gegeven moment bijzonder moeilijk is geworden. ${ }^{598}$ Een analoge toepassing van de regel dat bewijs van het bezit van het Nederlanderschap mogelijk is door bezit van staat, is volgens de literatuur uit de jaren vijftig eveneens wenselijk ten aanzien van personen uit gebieden in het toenmalige Koninkrijk waar geen bevolkingsregister is bijgehouden. De gedachte is daarbij uitdrukkelijk uitgegaan naar de in het binnenland van Suriname wonende bevolking. ${ }^{599}$

Deze methode van bewijzen sluit aan bij de in paragraaf 3.2.3 beschreven manier waarop het bestaan van een recht kan worden bewezen. Indien, bij ontstentenis van het directe bewijs van het rechtsfeit waarbij of als gevolg waarvan het desbetreffende recht is ontstaan, de bestaansfeiten van dat recht wel kunnen worden bewezen, kan het bestaan van het recht worden aangenomen. Bij het aannemelijk

\footnotetext{
595 Jessurun d'Oliveira, AA 1986, p. 229, is van mening dat deze vaststelling van het Nederlanderschap is geschied "op grond van vrij magere gegevens".

996 Volgens de omschrijving in Asser/De Ruiter, p. 132, is "bezit van staat": "de uitwendige vorm van zekere (.......)betrekking, kenbaar uit de feiten en omstandigheden, die hetzij afzonderlijk, hetzij in onderling verband en samenhang het bewijs van die betrekking opleveren."

Bewijslevering door middel van het bezit van staat komt (naast het nationaliteitsrecht ook) voor in het personenen familierecht. Bijv. art. 1:79 BW: in het geval van het niet (meer) bestaan van het huwelijksregister of de huwelijksakte kan het bestaan van het huwelijk worden bewezen door getuigen en bescheiden, "mits er een uiterlijk bezit van de huwelijkse staat aanwezig is." Vgl. ook art. 1:205 lid 2 BW: "De afstamming van een wettig kind wordt bij gebreke van de akte van geboorte bewezen door het ongestoord bezit van de staat van wettig kind. "

97 Zie Anoniem (I), HPS 1952, p. 134; Prins (I), p. 44; vgl. tevens voetnoot 989.

sm Anoniem (III), HPS 1950, p. 31 en 32; Anoniem (VI), Gemeentestem 1950, nr. 5090, p. 174; Heijs. p. 65 .

${ }^{50}$ Anoniem (V), Gemeentestem 1950, nr. 5087, p. 160; Septer/Schouten, p. XX.
} 
maken van bezit van het Nederlanderschap door middel van het bezit van staat lijkt de, ten aanzien van die staat, gevolgde attitude van Nederlandse overheidsorganen van groot belang. Toch is daarmee niet alles gezegd. In zijn bespreking van het hierboven aangehaalde uitspraak inzake de uitlevering acht de annotator in 1952 wel degelijk alsnog een ontkenning van het Nederlanderschap mogelijk in het geval dat het bewijs door middel van bezit van staat is geleverd en er "een aperte vergissing in het spel is, er aanwijzing bestaat van bedrog of het Nederlanderschap ergerlijk misbruikt is, (......). ${ }^{m 00}$ Bewijs door middel van bezit van staat is naar alle waarschijnlijkheid slechts mogelijk indien inzake het rechtsfeit van de verwerving onduidelijkheid bestaat. Is het zeker dat er geen sprake is geweest van verwerving van het Nederlanderschap, dan kunnen navolgende generaties geen beroep doen op bezit van het Nederlanderschap, ook niet indien zij door de Nederlandse Staat altijd als Nederlanders zijn behandeld en de desbetreffende personen in de overtuiging leefden het Nederlanderschap te bezitten. ${ }^{601}$

Met het oog op de vraag naar de bewijslastverdeling inzake het bezit van het Nederlanderschap is het interessant te constateren dat in deze uitleveringszaak het niet de betrokkene, maar de Nederlandse overheid is die de feitelijke gegevens heeft overgelegd waarop het bezit van de nationaliteit wordt gestoeld.

\subsection{HR 3 juni 1958}

Cat. A. uitspr. II. Casusbeschrijving. Stelplicht aangaande verwerving van het Nederlanderschap.

In de navolgende uitspraak ${ }^{602}$ wordt meer inzicht gegeven omtrent de stelplicht die op de verzoeker rust in het geval dat deze zich beroept op verwerving van de Nederlandse nationaliteit. Onder het begrip stelplicht wordt verstaan dat de procespartij die de zaak aanhangig heeft gemaakt, tevens de rechtens relevante feiten stelt ter staving van de ingestelde vordering of verzoek. ${ }^{603}$

De onderhavige zaak betreft een uitspraak op grond van artikel 20 Wet toelating en uitzetting van vreemdelingen 1849 . De nationaliteitsrechtelijke regeling die in casu aan de orde is, is de Overeenkomst betreffende de toescheiding van Staatsburgers tussen Nederland en Indonesië. ${ }^{604}$

De Staat weigert de betrokkene toe te laten tot Nederland. Deze stelt evenwel het Nederlanderschap te hebben verworven als gevolg van het feit dat zijn moeder, die

\footnotetext{
${ }^{600}$ Anoniem (I), HPS 1952, p. 134.

${ }^{60 t}$ Althans zo was de situatic in de jaren vijftig ten aanzien van uit Indonesiê afkomstige onwettige (en niet-erkende) afstammelingen van Nederlanders. Zie Cleintuar, p. 30-33.

${ }^{\infty}{ }^{2}$ HR 03.06.1958, NJ 1959, nr. 50.

${ }^{003} \mathrm{Vgl}$. Niessen-Cobben, p. 90 en 91.

${ }^{804}$ Opgenomen in de Wet Souvereiniteitsoverdracht Indonesiē. Wet van 21.12.1949, Stb. J 570.
} 
na de echtscheiding van zijn ouders met de voogdij over de betrokkene is belast geweest, tijdens zijn minderjarigheid een optie voor het Nederlanderschap heeft uitgebracht. Aan de door zijn moeder ten tijde van verzoekers minderjarigheid gedane optie én het feit dat zij toentertijd met de voogdij over hem belast is geweest, verbindt de verzoeker als rechtsgevolg dat ook hij de Nederlandse nationaliteit heeft verworven.

$\mathrm{Nu}$ wil het geval dat van oudsher ${ }^{605}$ het Nederlanderschap van een wettig kind niet is bepaald door de moeder, maar door de vader. De Hoge Raad gaat in het geheel niet in op hetgeen is gesteld met betrekking tot de door de moeder verrichte optie, maar stelt daarentegen: " $O$. dat ingevolge art. 8 van de Overeenkomst betreffende de toescheiding van Staatsburgers (......), de minderjarige verzoeker de nationaliteit van den vader volgde, en noch is gesteld noch gebleken, dat deze de Nederlandse nationaliteit verwierf;

0 . dat het verzoek mitsdien niet op deugdelijke gronden berust. Wijst het verzoek af."

\section{Aantekening.}

Deze uitspraak betreft in de eerste plaats een aanwijzing voor de stelplicht bij het aanvangen van een procedure. Het ligt in de rede dat de rechtens relevante feiten voor de verwerving van het Nederlanderschap in beginsel worden gesteld door degene die een procedure start. De verzoeker i.c. doet dat niet, maar stelt daarentegen een verwervingsgrond die geen nationaliteitsrechtelijk rechtsgevolg heeft. Toch is de afwijzing van het verzoek niet slechts gebaseerd op het feit dat de betrokkene niet een juiste verwervingsgrond stelt. De Hoge Raad neemt in de beslissing tevens op dat niet is gebleken van verwerving van het Nederlanderschap door de (nationaliteitsrechtelijk relevante) vader. Het feit dat dit door de Hoge Raad in de afwijzing wordt opgenomen, geeft aanleiding om te menen dat indien deze verwerving wel was gebleken, zonder dat het eerder was gesteld, er toch aanleiding zou bestaan om het verzoek in te willigen. In dit opzicht is het gedurende de behandeling blijken van bepaalde feiten belangrijker dan het stellen van de juiste verwervingsgrond.

\footnotetext{
${ }^{100}$ Pas bij de inwerkingtreding in 1985 van de Rijkswet op het Nederlanderschap is bij wettige kinderen de eventuele Nederlandse nationaliteit van de moeder relevant geworden voor het kind. Het kind verwerft namelijk via de moeder het Nederlanderschap (art. 3 lid 1 RWN).
} 


\subsubsection{Jurisprudentie categorie B: Beroep op behoud van het Nederlanderschap}

\subsection{HR 13 april 1948}

Cat. B. uitspr. I. Casusbeschrijving. Bewijs van verwerving van een vreemde nationaliteit ten gevolge van huwelijkssluiting.

Eén van de zaken waarop Van Sasse van Ysselt kennelijk het oog heeft bij het formuleren van zijn regel van bewijslastverdeling, is bewijsrechtelijk beschouwd zelfs voor twee verschillende onderwerpen van belang. Tevens betreft het een uitspraak van de Hoge $\mathrm{Raad}^{606}$ die voor het nationaliteitsrecht ook materieelrechtelijk van groot belang is gebleken. ${ }^{607}$ Het gaat in de desbetreffende zaak om een van geboorte Nederlandse vrouw en de vraag of zij door haar huwelijk een vreemde nationaliteit aan haar echtgenoot ontleent, zodat zij ten gevolge daarvan het Nederlanderschap heeft verloren. ${ }^{608}$ Tegelijkertijd is de nationaliteit van de minderjarige kinderen van het echtpaar in twijfel. In 1948 ziet de vrouw zich

${ }^{606}$ HR 13.04.1948, NJ 1948, nr. 647, m.nt. D.J.V.

(6) Een anonieme schrijver in de Gemeentestem oordeelt zelfs: "Voor de thans gebruikelijke practijk staat de beschikking van de Hooge Raad van 13 April 1948 gelijk met een wetswijziging. " Anoniem IV, Gemeentestem 1948, nr. 4969, p. 135.

${ }^{608}$ 1893-1937: art. 5 Wet Ned. 1892: "De vrouw volgt staande huwelijk den staat van haren man." D.w.z. de niet-Nederlandse vrouw die een Nederlander huwt, verwerft de Nederlandse nationaliteit. De Nederlandse vrouw die cen man van vreemde nationaliteit huwt, verliest haar Nederlanderschap en verwerft afhankelijk van hetgeen de nationaliteitsregeling van haar man daaromtrent stelt wel of niet de nationaliteit van haar man. De vrouw die een staatloze huwt verliest haar Nederlanderschap en wordt ook staatloos.

In 1937 wordt art. 5 Wet Ned. 1892 aangevuld (art. III. Wijzigingswet van 21.12.1936, Stb. 209; inwerkingtreding 01.07.1937) in die zin dat een vrouw niet meer haar Nederlandse nationaliteit verliest, indien zij door het sluiten van een huwelijk met een man die niet het Nederlanderschap bezit niet van haar echtgenoot een andere nationaliteit deelachtig wordt. Dit ter vermijding van staatloosheid. Het is de bedoeling van de wetgever geweest deze aanvulling slechts te laten gelden voor huwelijken die worden gesloten na het van kracht worden van de wetswijziging (Bijl. II. 34-35, 425, nr. 16 (MvT), p. 44; Bockwinkel, NJB 1938, p. 196; Brouwer, p. 172-174; Reuser (I), p. 78). Derhalve zou de bepaling slechts een huwelijk gesloten na 01.07.1937 regarderen. Volstrekt tegenovergesteld aan deze uitdrukkelijke bedoeling van de wetgever oordeelt de Hoge Raad echter in de hier aan de orde gestelde uitspraak HR 13.04.1948, NJ 1948, nr. 647, m.nt. D.J.V.. De vrouw in casu is namelijk vó6r 01.07.1937 gehuwd met de staatloze man (Anoniem IV, Gemeentestem 1948, nr. 4969, p. 135; Reuser (I), p. 78; overigens is Reuser voor de vrouw in deze zaak opgetreden bij de Hoge Raad als advocaat). De beslissing van de Hoge Raad dat ten aanzien van de vrouw niet de Wet toelating en uitzetting van vreemdelingen mag worden toegepast, is in de literatuur sindsdien zo uitgelegd dat dit tevens het oordeel betekent dat een Nederlandse vrouw die vór 01.07 .1937 is gehuwd met een staatloze man op het moment van haar huwelijk het Nederlanderschap niet heeft verloren. In de uitspraak wordt niet gemotiveerd waarop deze, in wezen zeer opzienbarende, uitbreiding van de werking van art. 5 lid 1 Wet Ned. 1892 steunt. De literatuur neemt aan dat op deze wijze de wetswijziging uit 1937 van art. 5 Wet Ned. 1892 terugwerkende kracht tot 01.07.1893 heeft gekregen (Brouwer, p. 174 (i.h.b. yoetnoot 118); De Groot/Tratnik, p. 50; Reuser (I), p. 78). 
genoodzaakt tot een beroep op de Hoge Raad op grond van artikel 20 Wet toelating en uitzetting van vreemdelingen uit 1849 ten behoeve van zichzelf en de kinderen, aangezien zij gezamenlijk, terwijl de echtgenoot als krijgsgevangene in Engeland verblijft, met uitzetting uit Nederland worden bedreigd. ${ }^{609}$

Aangezien de nationaliteiten van de vrouw en de kinderen worden bepaald door de eventuele nationaliteit van de echtgenoot neemt in de beslissing van de Hoge Raad in wezen de nationaliteitsvaststelling betreffende de man een cruciale plaats in. Op grond van de overweging dat niet is gebleken dat de echtgenoot een bepaalde nationaliteit heeft bezeten (op het moment van het huwelijk) of bezit, komt de Hoge Raad tot de slotsom dat hij moet worden beschouwd als staatloos. Voor zijn echtgenote leidt deze uitkomst ertoe dat zij in ieder geval geen vreemde nationaliteit heeft kunnen verwerven. ${ }^{610}$ De HR verklaart dat "verzoeksters in het Rijk geboren wettige kinderen Nederlanders zijn. "611

\section{Aantekening.}

Het eerste dat aan deze uitspraak een bewijsrechtelijk interessant aspect vormt, is dat naar aanleiding van deze uitspraak unaniem is geconcludeerd dat de bewijslast van het door de echtgenoot bezitten van een vreemde nationaliteit (dan wel het niet bezitten van enige vreemde nationaliteit) bij de overheidsorganen ligt, terwijl het

\footnotetext{
${ }^{\infty}$ Deze feiten zijn ontleend aan Reuser (I), p. 77.

${ }^{610}$ Hetgeen tot consequentie heeft dat zij naar geen enkel land zou kunnen worden uitgezet. Dit maakt dat de precieze constatering of zij nog de Nederlandse nationaliteit bezit dan wel, net als haar echtgenoot, staatloos moet worden geacht van ondergeschikt belang. Vgl. de constatering van Boelens, RMTh 1950, p. 298: "Echter heeft naar volkenrechtelijk gewoonterecht een staat niet de bevoegdheid een zijnerzijds staatloos gemaakte onderdaan over zijn grens te zetten en is hij verplicht, wanneer een andere staat dezen ex-onderdaan niet langer wil herbergen, hem weder in zijn gebied op te nemen." Vgl. Heijs (II), p. 112 en Strijards, p. 60.

"II Materieelrechtelijk beschouwd, biedt deze uitkomst geen verrassing, aangezien in bovenvermelde Wijzigingswet uit 1936 (zie voetnoot 608) in een art. V. als overgangsbepaling is opgenomen de verlening van het Nederlanderschap aan een wettige kind uit cen huwelijk gesloten vór 01.07.1937 tussen een Nederlandse vrouw en een staatloze man. Art. V. Wijzigingswet 1936 betreft geen wijziging van de tekst van de Wet Ned. 1892 en bevat, als gezegd, verlening van het Nederlanderschap aan een bepaalde categorie personen, maar bevat evengoed een mogelijkheid voor dezelfden om afstand te doen van de aldus verworven nationaliteit.

Hetgeen in de onderhavige uitspraak wel een verrassing is, is het feit dat de HR het Nederlanderschap van de kinderen rechtstreeks baseert op art. 2 sub c Wet Ned. 1892 (art. 2 sub c is in de Wet Ned 1892 opgenomen bij art. I. Wijzigingswet 1936 en zou alleen geboorten na 01.07.1937 regarderen). Naar de nationaliteitsverwerving ingevolge art. V. Wijzigingswet 1936, Stb. 209 verwijst de HR in het geheel niet. Het gevolg van de handelwijze van de Hoge Raad is geweest dat sinds 1948 in de literatuur is aangenomen dat art. V. Wijzigingswet 1936 zijn betekenis heeft verloren en dat art. 2 sub c Wet Ned. 1892 terugwerkende kracht heeft tot 01.07 .1893 (Anoniem IV, Gemeentestem 1948, nr. 4969, p. 135; Groeneveld, p. 8; wetgevingseditie Schuurman en Jordens, deel 1A (1985), p. 58; wetgevingseditie Schuurman \& Jordens, Nationaliteitswetgeving, deel 209 (1994) bij art. 2 sub c Wet Ned. 1892, p. 140; De Groot/Tratnik, p. 50.
} 
toch de vrouw is die stelt aan haar echtgenoot geen nationaliteit te ontlenen. Algemeen is sindsdien in de literatuur aangenomen dat de bewijslast van het bezit van een vreemde nationaliteit dan wel van staatloosheid bij de overheidsadministratie ligt. Derhalve is ter zake van de vraag of een vreemdelingenrechtelijke maatregel, zoals een uitzetting, mag plaatsvinden de conclusie getrokken dat: "Niet requestrant moet aantonen dat hij Nederlander (..........) is, doch de administratie moet het bewijs leveren, dat requestrant of zijn familie noch Nederlander noch statenloos is. "

In haar lezing over de "zelfstandige vaststellingsprocedure" komt Van den Blink overigens tot de conclusie dat met betrekking tot de vaststelling van staatloosheid het huidige artikel 1 sub $\mathrm{f}$ Rijkswet op het Nederlanderschap uitgaat van de hierboven beschreven bewijslastverdeling. ${ }^{613}$

Het tweede bewijsrechtelijk belangwekkende aspect aan de onderhavige beslissing van de Hoge Raad is, dat (het rechtsfeit van) het verlies van het, zonder twijfel, ooit aanwezige Nederlanderschap vast moet komen te staan. Daarbij ligt, in beginsel, de bewijslast inzake de nationaliteit niet bij degene die zich beroept op het (voortdurende) bezit van het Nederlanderschap. Deze bewijslastverdeling heeft Reuser aanleiding gegeven tot de opmerking: "(.......) en algemeen heeft men hierin gezien een omkeer van den bewijslast. ${ }^{m 614}$ Aan de anonieme schrijver van een artikel in de Gemeentestem ontlokt het de opmerking: "Een vrouw, die in de aangewezen omstandigheden verkeert en er zich op beroept Nederlander te zijn, kan ten bewijze hiervan volstaan met aan te tonen, dat zij het Nederlanderschap op de een of andere wijze, b.v. door geboorte, verkregen heeft. Wie daartegenover stelt, dat zij het ingevolge art. 5 heeft verloren, moet dat verlies feitelijk bewijzen (art. 1902 B.W.). "

${ }^{612}$ Reuser (I), p. 79. Derhalve dient de administratie te bewijzen dat de betrokkenen een bepaalde nationaliteit bezit, naar welk desbetreffend land de betrokkene vervolgens kan worden uitgezet.

Vgl. Strijards, p. 60: "(.......) de normen uit het volkenrecht, waaronder het beginsel dat alleen de nationaliteitsstaat (dwz: de staat waarvan de te verwijderen persoon de nationaliteit geniet) gehouden is tot wedertoelating, en dit alleen als de uitzettende staat de nationaliteit genoegzaam kan bewijzen."

${ }^{613}$ Van den Blink, p. 19. In art. 1 sub f RWN is het begrip "staatloze" omschreven als "hij die geen nationaliteit heeft of wiens nationaliteit niet kan worden vastgesteld." Van den Blink: "Een mogelijke controverse wordt opgelost ten gunste van het betrokken individu. "

${ }^{614}$ Reuser (I), p. 79.

sis Anoniem IV. Gemeentestem 1948, nr. 4969, p. 135. Opvallend is hierbij het door de auteur aanhalen van een artikel uit het civiele bewijsrecht in het kader van een administratiefrechtelijke procedure. 


\subsection{HR 5 oktober 1948}

\section{Cat. B. uitspr. II. Casusbeschrijving. Bewijs van verlies van het Nederlanderschap.}

De volgende $z^{2 a k}{ }^{616}$ waarop Van Sasse van Ysselt zijn bewijslastregel kennelijk baseert, betreft een van geboorte Nederlandse man. Ook deze casus vindt plaats op grond van een verzoekschrift aan de Hoge Raad gebaseerd op artikel 20 Wet toelating en uitzetting van vreemdelingen uit 1849. Hoewel het in deze zaak bovenal gaat om rechtsinterpretatie (in het bijzonder van vreemd recht) geeft de motivering door de Hoge Raad van de uitspraak alle aanleiding om toch op deze zaak nader in te gaan. ${ }^{617}$ De vraag waarover de Hoge Raad zich in deze zaak heeft gebogen, betreft de vraag of een in 1915 uit een ongehuwde moeder met de Nederlandse nationaliteit geboren persoon het Nederlanderschap heeft verloren. In 1919 wordt de betrokkene erkend door zowel zijn moeder ${ }^{618}$ als door zijn vader, die de Duitse nationaliteit bezit. De vader verliest de Duitse nationaliteit in 1927, vervolgens huwen in 1937 de ouders in Nederlands-Indië met elkaar. De betrokkene stelt bij de gelegenheid van het huwelijk niet te zijn gewettigd. In 1939 dient de man een verzoek tot naturalisatie in. Als gevolg van de latere oorlogsomstandigheden wordt daarop geen beslissing genomen. ${ }^{619} \mathrm{Bij}$ zijn terugkeer uit Indonesië in 1949 wordt de betrokkene niet toegelaten in Nederland en wordt hij bedreigd met uitwijzing naar Duitsland.

A.-G. Langemeijer heeft in deze zaak een zeer uitgebreide conclusie genomen. Met deze uitgebreide conclusie als grondslag heeft de Hoge Raad maar één overweging nodig om tot de verklaring te komen dat de bovenvermelde wet uit 1849 niet van toepassing is op de verzoeker. Naar mijn mening is de formulering waarin deze overweging is gevat zeer essentieel. In deze ene overweging stelt de Hoge Raad namelijk in zeer minimale bewoording dat "uit de overgelegde stukken is gebleken, dat de verzoeker door geboorte is Nederlander, terwijl niet blijkt dat hij dit Nederlanderschap heeft verloren (..........)".

\section{Aantekening.}

\footnotetext{
${ }^{616}$ HR 05.10.1948, NJ 1949, nr. 562.

617 Aangezien de materieel nationaliteitsrechtelijke kant van deze zaak voor het verdere betoog niet relevant is, laat ik die onvermeld.

${ }^{618}$ De Nederlandse, ongehuwde vrouw heeft tot een wetswijziging uit 1947 (i.w.t. 01.09.1948) de mogelijkheid gehad haar kind wel of niet te erkennen; Asser/De Ruiter, p. 447. Vgl. De Groot/Tratnik, p. 50; Jagt, p. 72 .

${ }^{619}$ Dit detail is niet te vinden in NJ 1949, nr. 562, maar wel in WPNR 1947, nr. 4014, p. 434. De casus is nl. in WPNR besproken als rechtsvraag en werd door Meijers in positieve zin voor de betrokkene beantwoord. De aanvraag tot naturalisatie laat evenwel duidelijk uitkomen dat de betrokkene reeds langdurig over zijn Nederlanderschap in onzekerheid verkeerde.
} 
Naar mijn mening blijkt ook uit deze uitspraak dat indien de overheid een maatregel van vreemdelingenrechtelijke aard wil toepassen op een persoon die in het verleden op enigerlei wijze het Nederlanderschap heeft verkregen, de bewijslast inzake het verlies van de nationaliteit bij de overheid ligt en dat het niet aan de betrokkene is het behoud van zijn Nederlanderschap aannemelijk te maken. De twee uitgangspunten die Van Sasse van Ysselt verwoordt als algemene regel zijn duidelijk herkenbaar. Allereerst betekent dit dat degene die het verlies stelt het daartoe relevante rechtsfeit dient te bewijzen. En ten tweede dat tot het moment van blijken van een verliesgrond wordt aangenomen dat er sprake is van continuering van het bezit van de nationaliteit.

Deze lijn van de Hoge Raad is eveneens herkenbaar in jurisprudentie van dezelfde tijd. ${ }^{620}$

\subsection{HR 4 oktober 1949}

Cat. B. uitspr. III. Casusbeschrijving. Bewijs van verwerving van een vreemde nationaliteit ten gevolge van huwelijkssluiting.

Dat de bewijslast inzake het niet in het bezit zijn van het Nederlanderschap ${ }^{621}$ en zo nodig het daarvoor noodzakelijke verlies ervan berust bij de overheidsadministratie blijkt eveneens uit de onderstaande casus. ${ }^{622}$ Curieus is in deze zaak dat het (door de overheid aangeleverde) bewijsmateriaal strekt tot bewijs van het verlies van de Nederlandse nationaliteit, terwijl het originair bezit van het Nederlandschap door de betrokkene niet bij voorbaat komt vast te staan. De onderhavige zaak betreft een uitspraak van de Hoge Raad uit 1949, eveneens gegeven in het kader van artikel 20 Wet toelating en uitzetting van vreemdelingen uit 1849 . De uitspraak betreft een vrouw die weliswaar in Nederland is geboren, doch van wie tevens vaststaat dat haar (wettige) vader nimmer de Nederlandse nationaliteit heeft bezeten. Ook tijdens het verdere verloop van haar leven doet zich niet ondubbelzinnig een rechtsfeit voor dat aanleiding geeft om zonder voorbehoud aan te nemen

\footnotetext{
${ }^{620} \mathrm{Vgl}$. HR 06.04.1948, NJ 1948, nr. 648, m.nt. D.J.V. (eveneens een art. $20 \mathrm{Vw}$ 1849-verklaring: een tot Nederlander genaturaliseerde man, te wiens aanzien wordt beweerd dat hij deze nationaliteit heeft verloren: de HR stelt vast dat niet blijkt van het door de betrokkene hebben voldaan aan enige verliesbepaling van het Nederlanderschap "en mitsdien moet worden aangenomen dat verzoeker het Nederlanderschap (........) niet heeft verloren; (......). "HR 21.06.1949, NJ 1950, nr. 1, m.nt. D.J.V. (art. $20 \mathrm{Vw}$ 1849-verklaring): in wezen betreft deze zaak rechtsinterpretatie en bestaat er geen onduidelijkheid over de feiten. De feiten worden aldus beoordeeld dat zij voor de HR geen aanleiding geven te oordelen dat m.b.t. de betrokkene "blijkt dat hij dat Nederlanderschap heeft verloren".

2il Het niet in bezit zijn van het Nederlanderschap is te beschouwen als overkoepeling van het zijn van staatloos dan wel het bezitten van een vreemde nationaliteit.

22 HR 04.10.1949, Reuser (I), p. 82; verder ongepubliceerd.
} 
dat zij het Nederlanderschap heeft verkregen. Daarbij komt dat zij een onmiskenbaar niet-Nederlandse man huwt. ${ }^{623}$ Op het moment dat de vrouw wordt bedreigd met uitzetting uit Nederland, doet zij desalniettemin een beroep op de Hoge Raad ten einde een verklaring te verkrijgen dat op haar de Wet toelating en uitzetting van vreemdelingen uit 1849 niet van toepassing is.

Daarbij bevindt zij zich in zoverre in een zwakke positie dat ten aanzien van haar het op enigerlei wijze ooit hebben verkregen van de Nederlandse nationaliteit onzeker en tevens nogal onwaarschijnlijk is. Voor het geval dat zij inderdaad ooit het Nederlanderschap zou hebben verkregen, is het vervolgens voor haar als gehuwde vrouw van belang of zij eventueel een nationaliteit aan haar echtgenoot ontleent, dan wel dat de man als staatloos moet worden beschouwd.

Aan zijn, voor de vrouw negatieve, beslissing legt de Hoge Raad ten grondslag twee onderscheidenlijke verklaringen van beide echtelieden van enkele jaren eerder, waarin ieder voor zich verklaart Duitser te zijn. ${ }^{624}$ De Hoge Raad staat ten aanzien van de echtgenoot op het standpunt dat deze de Duitse nationaliteit bezit. De vraag of de vrouw ooit het Nederlanderschap heeft verworven, is irrelevant op het moment dat er een duidelijke verliesgrond aanwezig is. Wel dient, als eerder al is gezegd, die verliesgrond te worden bewezen door de overheidsadministratie.

De bij Reuser weergegeven opmerkingen van A.-G. Langemeijer in deze zaak geven iets meer inzicht over de vragen die de Hoge Raad kennelijk bij de nationaliteitsvaststelling aan de orde stelt. De A.-G. schrijft: "Verzoekster heeft feiten gesteld en aannemelijk gemaakt, zij het niet ten volle bewezen, die haar en haar kinderen de Nederlandse nationaliteit zouden verschaffen. Anderzijds is echter (.........) zeer gemakkelijk denkbaar, dat deze feiten doorkruist zouden zijn door andere, tengevolge waarvan zij die nationaliteit niet verkregen zou hebben (.......). $\mathrm{Nu}$ is weliswaar van feiten van deze laatste soort rechtstreeks niets gebleken. Wel echter blijft de verklaring van den General-kommissar für Verwaltung und Justiz, die verzoeksters echtgenoot zo stellig mogelijk voor Duitser verklaart, van groot gewicht. ${ }^{n 25}$ Reuser vermeldt verder nog dat de evenvermelde verklaring van de Duitse autoriteit uit een dossier over beide echtelieden van het ministerie van Justitie afkomstig is geweest. Dat dossier was door de A.-G. bij het ministerie opgevraagd en aan de Hoge Raad voorgelegd. De verzoekster is nog wel "in raadkamer" gehoord over deze aldus in het geding gebrachte feiten. Op grond van de schriftelijke verklaringen gaat de Hoge Raad evenwel uit van het feit dat de

\footnotetext{
23 Ook de man heeft een verzoekschrift bij de HR ingediend. De HR verklaart de verzoeker op 29.06.1948 niet-ontvankelijk: "overwegende, dat verzoeker volgens eigen opgave de Nederlandse nationaliteit niet bezit en hem mitsdien niet toekomt de bevoegdheid zich tot den Hogen Raad te wenden, tot het verkrijgen van de in art. 20 bedoelde verklaring, dat deze wet op hem van geen toepassing is." Zie Reuser (I), p. 81; uitspraak verder niet gepubliceerd.

er Enerzijds betreft het een verklaring uit 1941 van de man tegenover de politie van Kerkrade, anderzijds een verklaring van de vrouw afgelegd in 1942 "voor een burgemeester".

Reuser (I), p. 82.
} 
familie de Duitse nationaliteit heeft en "acht het tegendeel bij het verhoor voor den Hogen Raad niet aannemelijk gemaakt". De Hoge Raad verklaart de Vreemdelingenwet uit 1849 van toepassing op de vrouw. ${ }^{626}$

\section{Aantekening.}

Kernpunt in deze zaak is dat de echtgenoot van de vrouw volgens de Hoge Raad de Duitse nationaliteit bezit en zij derhalve, als zij al ooit de Nederlandse nationaliteit had verworven, na de huwelijkssluiting in ieder geval de Nederlandse nationaliteit niet (meer) bezit, maar tevens niet staatloos is geworden. ${ }^{627}$

Voor zover i.c. kan worden gesproken van een bewijslastverdeling, blijkt i.c. dat het bewijs van het bezit van een vreemde nationaliteit wordt geleverd door middel van gegevens afkomstig van de overheidsadministratie. Conform de hierboven reeds aangehaalde rechtspraak wordt het bewijs van het verlies door de overheidsadministratie geleverd. Mede door middel van het dossier van het ministerie van Justitie kan de overheid i.c. aan de opgelegde bewijsplicht voldoen.

\subsection{HR 10 september 1959}

\section{Cat. B uitspr. IV. Casusbeschrijving. Bezit van een vreemde nationaliteit.}

In de navolgende $z^{a} k^{628}$ vindt een nationaliteitsvaststelling plaats binnen een procedure op grond van de Kieswet uit $1951 .{ }^{629}$ De verzoeker beoogt opname als kiesgerechtigde in het kiesregister van Apeldoorn. Het nationaliteitsrechtelijke geschil dat in deze casus aan de orde is, is dat de verzoeker, anders dan hijzelf meent, naar het oordeel van het college van B. en W. van Apeldoorn het Nederlanderschap heeft verloren na naturalisatie in een ander land..$^{630} \mathrm{Na}$ eerst een vruch-

${ }^{626}$ Immers in het bezit van de Duitse nationaliteit zou zij naar Duitsland kunnen worden uitgezet. In het geval dat zij staatloos zou blijken te zijn, ten gevolge van haar huwelijk met een staatloze man, zou mijns inziens, de Vreemdelingenwet 1849 niet op haar van toepassing zijn verklaard. Een uitzetting zou immers onmogelijk zijn geweest. Uit cen verklaring dat de Vreemdelingenwet 1849 niet van toepassing is op de betrokkene volgt, naar mijn mening, dan ook niet voor alle gevallen per definitie dat de Hoge Raad m.b.t. de betrokkene de staat van Nederlander vaststelt. Zie tevens voetnoot 612 .

${ }^{627}$ Verwerving van de Duitse nationaliteit door de vrouw ingevolge de oorspronkelijke redactie van $\$ 6$ Reichsund Staatsangehörigkeitsgesetz van 22.07.1913: "Durch die Eheschließung mit einem Deutschen erwirbt die Frau die Staatsangehörigkeit des Mannes. " De werking van $\S 6$ RuStAG is met ingang van 01.04.1953 bečindigd (De Groot, p. 58; Schätzel, p. 240; zie par. 6.3.3.1). De eerste tekstuele wijziging van $\$ 6$ RuStAG heeft echter pas plaatsgevonden in 1957 ingevolge het Drittes Gesetz zur Regelung von Fragen der Staatsangehörigkeit. Zie Hailbronner/Renner, p. 528. Vgl. voetnoot 1021.

${ }^{628}$ HR 10.09.1959, NJ 1959, nr. 596. Zie tevens Van den Blink, p. 19.

029 Zie voetnoot 452 .

${ }^{60}$ De overheid doet een beroep op de verliesbepaling in art. 7 aanhef sub 1 Wet Ned. 1892. 
teloze poging te hebben gedaan de kantonrechter te overtuigen van het behoud van zijn Nederlanderschap stelt de verzoeker in de cassatieprocedure dat pas rechtens mag worden aangenomen dat hij in een ander land is genaturaliseerd indien vanwege de bevoegde autoriteiten van de desbetreffende vreemde staat blijk wordt gegeven van het feit dat hij (verzoeker) wordt beschouwd als een nationaal.

Verzoekers stelling "dat de Nederlandse rechter de verkrijging van een vreemde nationaliteit slechts mag aannemen, indien door de Regering van den Staat om wiens nationaliteit het gaat, het bezit van die nationaliteit is erkend" wordt echter niet gedeeld door de Hoge Raad, die daarentegen van mening is: "dat deze stelling echter in de wet geen steun vindt en het middel dus inzoverre niet tot cassatie kan leiden."

\section{Aantekening.}

De vraag in hoeverre het bezit van een vreemde nationaliteit dient vast te staan indien dit van invloed is op het oordeel inzake het Nederlanderschap vormt bewijsrechtelijk beschouwd een belangwekkend aspect. De Hoge Raad spreekt dienaangaande klare taal.

In de voorafgaande jurisprudentie is reeds duidelijk geworden dat de bewijslast inzake het bezit van een vreemde nationaliteit ligt bij de overheidsorganen. Uit de onderhavige uitspraak blijkt dat deze echter niet behoeven aan te tonen dat de desbetreffende vreemde staat de betrokkene ook daadwerkelijk beschouwt als onderdaan.

Aangaande deze uitspraak in het kader van een Kieswetprocedure valt nog te wijzen op de volgende curiositeit. In tegenstelling tot de huidige Kieswet ${ }^{631}$ hebben de daaraan voorgaande Kieswet uit $1850,{ }^{632}$ Kieswet $1896^{633}$ en de Kieswet uit $1951^{634}$ met betrekking tot de registratie van de kiesbevoegdheid een $\mathrm{zgn}$. "actio popularis" gekend. Onder het regiem van de vorige Kieswetten is het derhalve mogelijk is geweest de kiesbevoegdheid van een ander te laten beoordelen. ${ }^{635}$ Aangezien de kiesbevoegdheid altijd nauwe samenhang heeft vertoond met het wel of niet bezitten van het Nederlanderschap is het niet uitgesloten dat het in sommige Kieswetprocedures feitelijk heeft gehandeld om de vaststelling van kwestieus Nederlanderschap. ${ }^{636}$ Op grond van het voorgaande kan worden vastgesteld dat tot de inwerkingtreding van de huidige Kieswet de mogelijkheid heeft bestaan dat een derde bewerkstelligt dat de rechter een impliciet oordeel moet

\footnotetext{
6et van 28.09.1989, Stb. 423.

s2 Wet van 04.07.1850, Stb. 37.

Wet van 07.09.1896, Stb. 154.

34 Wet van 13.07.1951, Stb. 290.

6s Ingevolge art. 11 Kieswet 1850, art. 29 Kieswet 1896 en art. D 6 Kieswet 1951.

${ }^{636}$ Prins (II) geeft daarvan een paar voorbeelden.
} 
vellen over het Nederlanderschap van een andere persoon. Dit is incidenteel ook wel gebeurd. ${ }^{637}$

Daarnaast heeft de Kieswet uit 1951 enkele bepalingen gekend inhoudende dat een ieder een verweerschrift kan indienen tegen een aanhangig gemaakt verzoek tot wijziging van de kiesbevoegdheidregistratie. ${ }^{638}$ Een zodanig verweerschrift is in alle instanties mogelijk geweest; derhalve bij de behandeling van de zaak door het college van Burgemeester en Wethouders, de kantonrechter en de Hoge Raad.

In de zojuist aan de orde gestelde uitspraak uit 1959 is de procedure aanhangig gemaakt door de bij de uitoefening van het kiesrecht onmiddellijk betrokken belanghebbende zelf. Van de mogelijkheid een tegen het verzoekschrift gericht verweerschrift in te dienen is in het onderhavige geval gebruik gemaakt. Dit zou op zich niet opzienbarend zijn, ware het niet dat in de indiener van het verweerschrift het toenmalige hoofd van de afdeling nationaliteitszaken van het ministerie van Justitie wordt herkend. ${ }^{639}$ Het verweerschrift is op persoonlijke titel ingediend. In het verweerschrift noch in de uitspraak wordt enige aandacht geschonken aan de vragen waarom juist deze verweerder een verweerschrift indient en welk belang verweerder bij zijn verweerschrift heeft. Op het eerste zicht lijkt het of een willekeurige particulier een verweerschrift indient. Bij nader inzien blijkt dat bij de indiener van het verweerschrift niet zo zeer een eigen belang, maar een belang van de Staat aanleiding geeft tot inmenging in het geding. ${ }^{640}$

\subsubsection{Eerste tussenevaluatie}

Resumerend kan mijns inziens uit de tot hier toe aan de orde gestelde uitspraken, gegeven in het kader van de Wet toelating en uitzetting van vreemdelingen uit 1849, de Uitleveringswet uit 1875 en de Kieswet uit 1951, worden geconcludeerd

\footnotetext{
${ }^{637}$ HR 24.10.1851, Gemeentestem 1851, nr. 9, p. 4. Arrest in cassatie waarin de verzoeker "Mr. P.L. de Lom de Berg, lid der Tweede Kamer der Staten-Generaal, notaris te Venlo," opkomt "tegen een vonnis van de Arrond.-Regtb. te Roermond van den 4 Sept. 1851, bij hetwelk hij is verklaard ongegrond in zijn verzoek tot vernietiging der resolutie van den Gemeenteraad der stad Venlo van 9 Aug. bevorens, waarbij was besloten, dat de naam van Karel Hubert Leonard Bontamps niet zal worden weggenomen van de lijst der personen, aanwijzende die tot het kiezen van leden van den Gemeenteraad te Venlo bevoegd zijn, $(\ldots . . . .)$.$" . Volgens de Lom de Berg is Bontamps geen Nederlander. Vgl. de beschrijving$ van deze casus bij Prins (II), p. 183-185. Vgl. voor een ander geval: HR 02.06.1948, NJ 1948, nr. 646.

as Artt. D 9, D 12, D 13 en D 16 Kieswet 1951.

a9 En tevens bewerker van de nationaliteitswetgeving van Schuurman \& Jordens van 1956 tot 1973. Juist omdat het gaat om de bewerker van de nationaliteitswetgeving is de naam van de indiener van het verweerschrift tevens herkenbaar als het toenmalige hoofd van de afdeling nationaliteitszaken van het ministerie van Justitie. Die functie staat namelijk vermeld in de wetgevingsedities.

${ }_{640}$ Struycken, p. 41, haalt deze uitspraak in zijn proefschrift aan als een voorbeeld voor het onderwerp "onpartijdige voorlichting en advies" (aan de rechter). Hij merkt daarbij op: "De amicus curiae verdient een andere positie in de procedure!"
} 
dat inzake het bezit van een vreemde nationaliteit alsmede ter zake van staatloosheid de bewijslast bij de overheidsorganen ligt. Wordt het bovenstaande algemener geformuleerd, dan leidt dat tot de uitspraak dat inzake het niet in het bezit zijn van de Nederlandse nationaliteit de bewijslast bij de overheid ligt.

Overigens dient mijns inziens met betrekking tot de bewijslastverdeling een onderscheid in uitgangssituatie niet uit het oog te worden verloren. Hoewel alle betrokkenen hetzelfde stellen, $\mathrm{nl}$. het bezit van de Nederlandse nationaliteit, maakt het voor de verdeling van de bewijslast m.i. zeker uit of een betrokkene een beroep doet op verwerving dan wel op behoud van het Nederlanderschap.

Aangaande een beroep op verwerving van het Nederlanderschap kan op grond van de hiervoor besproken jurisprudentie niet veel meer worden geconcludeerd dan dat op de betrokkene in beginsel een stelplicht rust ${ }^{641}$ en dat voor een betrokkene in bewijsnood middellijke bewijsvoering ${ }^{642}$ mogelijk is. Op grond van deze rechtspraak en door de opmerkingen dienaangaande in de literatuur staat vast dat indien de betrokkene in zoverre in bewijsnood verkeert dat hij niet het rechtsfeit van de verwerving van het Nederlanderschap aannemelijk kan maken, het bezit van de Nederlandse nationaliteit aannemelijk kan worden gemaakt door middel van het middellijke bewijsmiddel bezit van staat.

In het geval dat het gaat om verlies van het Nederlanderschap en de overheid stelt in rechte het verlies, dan is de algemene regel dat de bewijslast inzake het verlies bij de overheid ligt. Het is daarbij ook mogelijk dat het oorspronkelijk bezit van het Nederlanderschap niet kan worden vastgesteld, maar het wel kunnen vaststellen van een rechtsfeit dat tot verlies leidt, is in zo'n geval voldoende. ${ }^{643}$

Uit het voorgaande volgt het opmerkelijke gegeven dat in de jurisprudentie strikter bewijs lijkt te worden geëist van beweerd verlies van het Nederlanderschap, $\mathrm{nl}$. in dat geval wordt minimaal geëist bewijs van het rechtsfeit dat tot verlies heeft geleid, ${ }^{644}$ dan dat wordt geëist bij het verwerven van het Nederlanderschap. Voor het laatste is het bewijs van het rechtsfeit dat heeft geleid tot verwerving niet de enige mogelijkheid, maar staat immers ook de mogelijkheid van bewijs door middel van bezit van staat open.

In bepaalde gevallen is het bezit van een vreemde nationaliteit een voorvraag van doorslaggevend belang voor de vraag of iemand het Nederlanderschap bezit. Met betrekking tot de mate van zekerheid die aangaande het bezit van een vreemde nationaliteit dient te bestaan, kan worden vastgesteld dat, in het geval dat de overheid zich beroept op verlies van het Nederlanderschap, de Nederlandse overheid niet aannemelijk hoeft te maken dat de vreemde overheid de betrokkene

\footnotetext{
"HR 03.06.1958, NJ 1959, nr. 50.

${ }^{\$ 1}$ HR 28.10.1952, HPS 1952, p. 133.

${ }^{S}$ HR 04.10.1949, Reuser (I), p. 82.

${ }^{m}$ HR 13.04.1948, NJ 1948, nr. 647; HR 05.10.1948, NJ 1949, nr. 562; HR 04.10.1949, Reuser (I), p. 82 ; HR 10.09.1959, NJ 1959, nr. 596.
} 
erkent als onderdaan. ${ }^{645}$ De Nederlandse rechter beoordeelt autonoom of sprake is van het bezit van een vreemde nationaliteit.

\subsubsection{Nationaliteitsvaststelling en bewijslastverdeling in procedures op grond van artikel 43 (oud) Vreemdelingenwet (1967-1989)}

\subsubsection{Algemene Beschouwingen}

Ook na de intrekking van de bijna honderd en twintig jaren oude Wet toelating en uitzetting van vreemdelingen is de Hoge Raad op grond van de nieuwe Vreemdelingenwet $^{646}$ nationaliteitsrechter in enige instantie gebleven. Gedurende een twintigtal jaren heeft de Hoge Raad op grond van het inmiddels vervallen artikel 43 Vreemdelingenwet als feitenrechter geoordeeld over beroepen op het Nederlanderschap ${ }^{647}$ Uit de gepubliceerde jurisprudentie is in het kader van deze procedure een veertigtal uitspraken van de Hoge Raad bekend. ${ }^{648}$ Over het proces- en bewijsrecht dat op de artikel 43 (oud) Vreemdelingenwetprocedure van toepassing is geweest, is in de literatuur slechts summierlijk een opmerking gemaakt. ${ }^{649}$ Zelf heeft het wetsartikel hieromtrent zeer weinig bepalingen gekend. Het weinige dat door het artikel werd bepaald, is geweest dat de Hoge Raad getuigen ${ }^{650}$ en deskundigen $^{651}$ kon oproepen, dat de verhoren in beginsel in het openbaar dienden te geschieden $^{652}$ en dat het openbaar ministerie ${ }^{653}$ over de zaak werd gehoord. De

\footnotetext{
${ }^{404}$ HR 10.09.1959, NJ 1959, nr. 596.

${ }^{406}$ Wet van 13.01 .1965 , Stb. 40. I.w.t. 01.01.1967.

on $\mathrm{Vgl}$. par. 2.8.2. Uit de Toelichting op de jaarcijfers 1982 en 1983, p. 13, blijkt dat de HR deze feitelijke procedure niet in zijn takenpakket vindt passen en spreekt de voorkeur uit voor een feitelijke behandeling bij een lagere instantie, met de mogelijkheid van cassatieberoep. Met die wens sloot de HR aan bij het toen aanhangige wetsontwerp op grond waarvan hoofdstuk 6 Rijkswet op het Nederlanderschap tot stand is gekomen. Vgl. par. 1.2.2.
}

${ }^{64} \mathrm{~V}$ gl. par. 2.8 .2 (i.h.b. voetnoot 460 ).

${ }^{49} \mathrm{Zie}$ Van den Blink, p. 7 en 8; Jessurun d'Oliveira, AA 1986, p. 224-227; Loeb (1983), p. 289-291; Royer, p. 136.

${ }^{650}$ HR 01.07.1983, NJ 1984, nr. 229; HR 21.09.1984 NJ 1985, nr. 111 (een pleegbroer en de echtgenote van de klager zijn als getuigen gehoord. Het betreft een zaak waarin de klager niet zelf is gehoord); HR 11.10.1985, NJ 1987, nr. 34, m.nt. JCS (de echtgenote van de klager is gehoord. Ook in deze zaak is de klager zelf niet gehoord, hem was namelijk de toegang tot Nederland geweigerd).

ast Vgl. HR 21.01.1969, NJ 1969, nr. 144: het hoofd van de afdeling Privaatrecht bij het ministerie van Justitie is opgeroepen als "getuige-deskundige"; HR 27.11.1979, NJ 1980, nr. 550, m.nt. MS onder NJ 1980, nr. 551: HR benoemt twee externe deskundigen ten einde advies te krijgen over het Chinese nationaliteitsrecht; HR 15.09.1980, NJ 1981, nr. 68: de HR benoemt een externe deskundige ten einde advies te krijgen over het Tunesische en Marokkaanse familierecht alsmede over het Tunesische nationaliteitsrecht.

62 Hierbij gaat het om verhoor in het openbaar van de klager en een vertegenwoordiger van de staatssecretaris van Justitie. Niet ongewoon is geweest dat dit verhoor werd afgenomen door een 
behandeling ter terechtzitting geschiedde eveneens openbaar. Uit de gepubliceerde uitspraken blijkt dat in ongeveer de helft van de zaken de klager van de mogelijkheid gebruik heeft gemaakt om persoonlijk te worden gehoord door de Hoge Raad. $^{654}$

Aangaande de beklagschriften heeft de Hoge Raad veelvuldig, zo niet in alle gevallen, een verzoek gericht aan de bevoegde bewindspersoon voor vreemdelingenzaken, de staatssecretaris van Justitie, ten einde inlichtingen over en een standpuntbepaling inzake het Nederlanderschap van de klager te verkrijgen. ${ }^{655}$ In tegenstelling tot de handelwijze van de administratie bij de eerste procedures op grond van artikel 17 Rijkswet op het Nederlanderschap, toen het ministerie van Justitie consequent niet heeft gereageerd op de oproeping door de rechtbank om als belanghebbende te verschijnen, ${ }^{656}$ heeft het in artikel 43 (oud) Vreemdelingenwetprocedures wél mededeling aan de Hoge Raad gedaan omtrent de positie die de Staat inneemt met betrekking tot klagers Nederlanderschap. In het bijzonder in de gevallen die kwesties van feitelijke aard betroffen, heeft de Staat regelmatig bescheiden in het geding gebracht die tot ondersteuning van het eigen standpunt dienden. ${ }^{657}$

In de meerderheid van de uitspraken op grond van artikel 43 (oud) Vreemdelingenwet is derhalve de, van de visie van de klager afwijkende, mening van de staatssecretaris opgenomen. In de gevallen waarin de klager bestrijdt aan een verliesbepaling voor het Nederlanderschap te hebben voldaan, vermeldt de uitspraak bij de weergave van het standpunt van de staatssecretaris op grond van

$652 \rightarrow$

"raadsheer-commissaris belast met het instellen van een nader onderzoek naar de juistheid van de aan het beklag ten grondslag gelegde feiten". Vgl. HR 23.10.1979, NJ 1980, nr. 551, m.nt. MS; HR 04.03.1980, NJ 1981, nr. 98, m.nt. MS; HR 01.06.1982, NJ 1983, nr. 314; HR 01.07.1983, NJ 1984, nr. 229.

Het hier bedoelde verhoor dient niet te worden verward met de mondelinge behandeling van de zaak ter zitting van de Hoge Raad.

${ }^{653}$ Ook het OM heeft een enkele keer de taak op zich genomen de HR indien nodig in te lichten omtrent vreemd recht. Vgl. HR 18.04.1986, NJ 1987, nr. 926, m.nt. JCS: inlichtingen betreffende Spaans familierecht.

Dat art. 18 Rijkswet op het Nederlanderschap de verplichting tot horen van het openbaar ministerie in feitelijke instantie voorschrijft, komt derhalve niet als een donderslag bij heldere hemel. Ook in de procedures die als de voorlopers van de art. $17 \mathrm{RWN}$-procedure mogen worden beschouwd, nl. art. 43 Vreemdelingenwet 1965 en art. 20 Wet toelating en uitzetting van vreemdelingen uit 1849 heeft de rechter de plicht gehad het OM te horen over de zaak.

Slechts in vier zaken is een klager niet gehoord wegens de omstandigheid dat hij het land niet mocht inreizen, dan wel reeds was uitgezet. HR 21.01.1969, NJ 1969, nr. 144; HR 25.02.1983, NJ 1983, nr. 725 , m.nt. A.H.J. Swart; HR 15.07.1985, nr. 854; HR 11.10.1985, NJ 1987, nr. 34, m.nt. JCS.

${ }^{55} \mathrm{Vgl}$. Van den Blink, p. 8.

Zie par. 2.4.2.1.

HR 01.06.1982, NJ 1983, nr. 314; HR 23.12.1983, NJ 1984, nr. 387; HR 23.03.1984, NJ 1984 , nr. 650, m.nt. AHJS; HR 08.05.1987, NJ 1987, nr. 682. 
welke wettelijke bepaling of verdragsbepaling dit beweerd verlies heeft plaatsgevonden. $\mathrm{Bij}$ beroepen op verwerving van het Nederlanderschap geeft het standpunt van de staatssecretaris de reden weer waarom de gepretendeerde verwerving niet heeft kunnen plaatsvinden ${ }^{658} \mathrm{Al}$ is de Staat in een artikel 43 (oud) Vreemdelingenwet niet te beschouwen als een door de klager in het proces betrokken procespartij, toch is in essentie de beklagprocedure, naar mijn mening, een contradictoire en derhalve contentieuze procedure geweest. ${ }^{659}$

Naast het weinige dat in de literatuur dienaangaande is opgemerkt, is inzicht in de proces- en bewijsrechtelijke karaktertrekken van de artikel 43 (oud) Vreemdelingenwetprocedure voor het grootste gedeelte te verkrijgen uit de uitspraken die op grond van het artikel zijn gedaan. In het bijzonder de door het openbaar ministerie geproduceerde conclusies zijn een rijke informatiebron. Dat de voormalige beklagprocedure enigszins als een buitenbeentje is te beschouwen, blijkt mede ${ }^{660}$ uit het feit dat ter zake van deze rechtsgang zich het gebruik heeft ontwikkeld dat steeds dezelfde advocaat-generaal de conclusies neemt. Dit is in afwijking van het beleid van het openbaar ministerie, dat in civiele verzoekschriftprocedures de conclusies ten behoeve van de Hoge Raad ongeacht het rechtsgebied in beginsel door alle A.-G.'s worden genomen. ${ }^{661}$ Ten Kate schrijft dat voor een specialisatie binnen het $\mathrm{OM}$ wel wordt gekozen indien: "het rechtsgebieden betreft die een duidelijk bijzonder karakter naar inhoud of procesvorm hebben, zoals bijv. kwesties betreffende de Nederlandse nationaliteit" ${ }^{662}$ Eén en ander heeft tot gevolg gehad dat alle conclusies bij de uitspraken die in deze paragraaf aan de orde komen van de hand van dezelfde advocaat-generaal zijn, en wel van A.-G. Mok. ${ }^{663}$

In haar al eerder aangehaalde lezing merkt Van den Blink over de wijze van bewijsvoering in de beklagprocedure op: "Daarbij konden de door de verzoeker

${ }^{658}$ In slechts vier uitspraken, alle ter zake van verwerving, ontbreekt het standpunt van de staatssecretaris als zelfstandig onderdeel van de uitspraak. Uit de bijbehorende conclusie blijkt evenwel dat ook in deze gevallen de staatssecretaris een ander oordeel had dan de klager over diens Nederlanderschap. Vgl. HR 15.09.1980, NJ 1981, nr. 68 (zie par. 3.3.3.2.2); HR 05.02.1982, NJ 1983, nr. 192; 10.08 .1983 , NJ 1983, nr. 726 en HR 25.02 .1983 , NJ 1983, nr. 725, m.nt. A.H.J.S.

ss9 Scheltema twijfelt in zijn annotatie onder tén van de eerste uitspraken krachtens art. 43 (oud) Vw (HR 23.10.1979, NJ 1980, nr. 551) nog over de mate van contentieusheid van de procedure. Hij merkt op dat het niet "Een gewone administratieve procedure" betreft en stelt tevens: "Indien men de vraag of iemand Nederlander is als een vraag van privaatrecht beschouwt (men kan daarover sterk aarzelen), dan zou hier sprake zijn van een niet contentieuze procedure, vergelijkbaar met de verzoekschriftenprocedure. " Anderzijds stelt hij: "Het zou bij het administratiefrechtelijk karakter van de procedure passen het betreffende overheidsorgaan zo veel mogelijk als verweerder bij het proces te betrekken." Dit laatste is inderdaad een handelwijze die, blijkens nadien gedane uitspraken, zich inderdaad heeft ontwikkeld.

${ }^{\infty}{ }^{\infty}$ Zie eveneens par. 2.8.2, (i.h.b. voetnoot 459 ).

061 Ten Kate (II), p. 215.

${ }_{02}$ Ten Kate (II), p. 214.

${ }^{63}$ Eveneens in de cassaticzaken op grond van het latere art. $17 \mathrm{RWN}$ zijn de conclusies genomen door A.-G. Mok. 
aangedragen feiten worden gecontroleerd en voor zoveel nodig aangevuld door de Procureur-Generaal bij de Hoge Raad die op het verzoek moest worden gehoord. ${ }^{664}$ Inderdaad heeft de Hoge Raad incidenteel in een beklagprocedure een onderzoek naar de feiten doen instellen. Ten behoeve van een zodanig feitenonderzoek heeft de Hoge Raad het openbaar ministerie wel verzocht behulpzaam te zijn. ${ }^{665}$ Ook is het OM een enkele maal zelfstandig overgegaan tot het instellen van een nader onderzoek naar feitelijke omstandigheden. ${ }^{666}$ In vergelijking met de huidige artikel $17 \mathrm{RWN}$-procedure is, naar mijn inzicht, de rol van het OM aangaande het traceren van rechtens relevante feiten derhalve actiever geweest dan dat hij op dit moment in de "zelfstandige vaststellingsprocedure" is. ${ }^{67}$ Deze actievere houding kan worden verklaard uit het feit dat, anders dan in de procedure op grond van artikel $17 \mathrm{RWN}$, op het functioneren van het openbaar ministerie in de artikel 43 (oud) Vreemdelingenwetprocedure het Wetboek van Burgerlijke Rechtsvordering niet van toepassing is geweest.

Meermalen wordt in de conclusies van het OM duidelijk dat in artikel 43 (oud) Vw-zaken, wegens het administratiefrechtelijk karakter dat aan de procedure werd toegeschreven, het in het administratief procesrecht gebruikelijke "vrij-bewijsstelsel" $^{\prime \prime}$ van toepassing is geweest. ${ }^{668}$ Zoals reeds is uiteengezet in paragraaf 3.1 houdt de "vrij-bewijsleer" in dat de rechter een zeer ruime vrijheid heeft ten aanzien van de bewijslastverdeling, de bewijsmiddelen en de waardering van het gevoerde bewijs.

Wat de bewijslastverdeling aangaat, plaatst A.-G. Mok, in het kader van een beklag waarin de betrokkene zich beroept op het niet hebben voldaan aan een verliesbepaling voor het Nederlanderschap, de volgende observatie: "In veel gevallen zou het vrij-bewijsstelsel in procedures als deze erop neerkomen dat het leeuwendeel van de bewijslast op de overheid rust. Zij immers zal doorgaans het gemakkelijkst aan de nodige gegevens kunnen komen. ${ }^{1669}$ Met betrekking tot een beklag waarin de betrokkene zich beroept op verwerving van het Nederlanderschap heeft de A.-G. daarentegen opgemerkt: "De HR heeft al beslist dat bepaalde feiten

\footnotetext{
Van den Blink, p. 8.

«s Bijv. HR 04.03.1980, NJ 1981, nr. 98, m.nt. MS: over de vraag of de klaagster op de onafhankelijkheidsdag van Suriname woonplaats buiten Suriname had, verschillen de Staat en klaagster van mening; de HR verzoekt de P.-G. bij de HR een politieonderzoek te doen instellen "naar de vraag of klaagster op 25 nov. 1975 in Nederland woonde".

Vgl. HR 15.09.1980, NJ 1981, nr. 68: OM vraagt aanvullende informatie op bij de advocaat van de klager. HR 23.12.1983, NJ 1984, nr. 387: blijkens de conclusie van het OM heeft de A.-G. bij de gemeentesecretarie van Den Haag om een bepaalde inlichting verzocht.

667 Vgl. par. 2.3.2.2.

Vgl. HR 27.11.1979, NJ 1980, nr. 550 en HR 23.10.1979, NJ 1980, nr. 551, m.nt. MS.; HR 01.06.1982, NJ 1983, nr. 314; HR 15.07.1985, NJ 1985, nr. 854.

Conclusie bij HR 01.06.1982, NJ 1983, nr. 314.
} 
of omstandigheden aannemelijk moeten worden, zonder dat van een duidelijke bewijslast sprake is. ${ }^{670}$

Aan de andere kant heeft de Hoge Raad wel de eis gesteld dat zowel de betrokkene als de staatssecretaris van Justitie zoveel mogelijk meewerken aan het ter beschikking stellen van de juiste, relevante feitelijke informatie. Zeer kortaf is de zaak afgedaan waarin eerder door middel van een tussenbeschikking de Hoge Raad heeft doen blijken "zich omtrent de feiten onvoldoende ingelicht te achten" en de klaagster heeft opgeroepen meer gegevens te verstrekken. Ondanks oproeping voor de mondelinge behandeling verschijnt de klaagster niet, noch wordt van haar kant op enigerlei wijze gereageerd. Dit leidt tot ongegrondverklaring van het beklag, waaraan ten grondslag wordt gelegd de overweging dat: "Van degene die zich op de voet van art. 43 (oud) Vreemdelingenwet tot de rechter wendt met de stelling Nederlander te zijn, mag immers worden gevergd dat hij naar vermogen de voor de beoordeling van die stelling nodige feiten bijbrengt en zonodig staaft. " ${ }^{1671}$

De aldus gestelde eis dat de klager "naar vermogen" de "nodige feiten bijbrengt en zonodig staaft" wijst op een lichtere inspanning ten aanzien van het bewijs aan de kant van de klager dan het geval zou zijn als de zegswijze "wie stelt, bewijst" ten volle zou gelden en impliceert, naar mijn mening, dat het slagen van het beklag niet volledig afhankelijk is van het bewijs dat de klager in staat is te leveren. Voor de hier gesignaleerde lichte bewijsplicht wordt in het navolgende het begrip "summiere bewijsplicht" als werkbegrip gehanteerd.

Ten behoeve van het onderzoek naar de bewijslastverdeling is ook de op grond van artikel 43 (oud) Vreemdelingenwet gevormde jurisprudentie onderverdeeld in twee categorieën. In de eerste categorie zijn de uitspraken ingedeeld waarin degene die zich tot de Hoge Raad heeft gewend een beroep doet op het hebben verworven van de Nederlandse nationaliteit (categorie A). De tweede categorie betreft de klagers die zich op het standpunt stellen niet te hebben voldaan aan een verliesbepaling voor het Nederlanderschap (categorie B).

In één zaak heeft de klager gesteld dat hij primair niet aan een verliesbepaling heeft voldaan en heeft hij zich secundair op het standpunt gesteld in ieder geval na het eventuele verlies van de Nederlandse nationaliteit een optie voor het Nederlanderschap te hebben gedaan. ${ }^{672}$ Deze zaak is in beide categorieën ingedeeld.

${ }^{670}$ Conclusie bij HR 15.07.1985, NJ 1985, nr. 854; waarbij de A.-G. verwijst naar HR 23.10.1979, NJ 1980, nr. 551.

"7 HR 23.09.1988, NJ 1989, nr. 53.

${ }^{n}$ HR 07.02 .1986$, NJ 1987, nr. 148, m.nt. GRdG. 


\subsubsection{Jurisprudentie categorie A: Beroep op verwerving van het Nederlanderschap}

Onder de in het kader van artikel 43 (oud) Vreemdelingenwet onderzochte jurisprudentie bevinden zich vijftien zaken waarin de betrokkene een beroep doet op verwerving van het Nederlanderschap. ${ }^{673}$ In slechts drie gevallen oordeelt de Hoge Raad voor de betrokkene positief. ${ }^{674}$ In de negatief uitvallende uitspraken laat de Hoge Raad in zes gevallen blijken tevens op grond van de vastgestelde feiten te hebben getoetst of eventueel een andere rechtsgrond ter verwerving van het Nederlanderschap dan de juridische grondslag waarop het beklag is gestoeld mogelijk zou zijn geweest. ${ }^{675}$

Op het totaal van vijftien uitspraken zijn slechts vijf zaken bewijsrechtelijk interessant, waaronder tevens twee uitspraken vallen die voor de betrokkene een positief resultaat hebben gehad. Aangaande deze vijf als bewijsrechtelijk interessant aan te merken uitspraken moet evenwel het volgende worden opgemerkt. Eigenlijk betreffen van de vijf zaken slechts drie gevallen daadwerkelijk een kwestie van bewijs. De andere twee zaken betreffen daarentegen veeleer de interpretatie van vreemd recht, waarbij de feitelijke omstandigheden van de zaak als zodanig duidelijk zijn. Ik heb desondanks besloten deze twee laatste zaken toch op te nemen, daar deze een beeld geven betreffende de vraag in hoeverre het daadwerkelijk bezit van een andere nationaliteit dient vast te staan, indien dit mogelijk bezit van een andere nationaliteit relevant is voor het bezit van het Nederlanderschap.

Uit de in paragraaf 3.3.2.1 behandelde jurisprudentie is duidelijk geworden hoe bij onzekerheid aangaande de verwerving van het Nederlanderschap in ieder geval de stelplicht met betrekking tot de rechtens relevante feiten bij de aanlegger van de procedure ligt. ${ }^{676}$

Met betrekking tot een beroep op grond van artikel 43 (oud) Vreemdelingenwet waarbij verwerving van de Nederlandse nationaliteit wordt gesteld, oordelen De Groot/Tratnik de volgende bewijslastverdeling van toepassing: "Indien iemand beweert de Nederlandse nationaliteit te hebben verworven moet hij in de regel op

\footnotetext{
${ }^{673}$ HR 23.10.1979, NJ 1980, nr. 551, m.nt. MS; HR 15.09.1980, NJ 1981, nr. 68; HR 13.10.1981, NJ 1982, nr. 137, m.nt. AHJS; HR 05.02.1982, NJ 1983, nr. 192; HR 25.02.1983, NJ 1983, nr. 725, m.nt. AHJS; HR 10.08.1983, NJ 1983, nr. 726; HR 23.03.1984, NJ 1984, nr. 650, m.nt. AHJS; HR 12.10.1984, NJ 1985, nr. 230, m.nt. G; HR 15.07.1985, NJ 1985, nr. 854; HR 20.06.1986, NJ 1987. nr. 902, m.nt. GRdG; HR 26.06.1987, NJ 1988, nr. 73; HR 18.04.1986, NJ 1987, 926, m.nt. JCS; HR 26.06.1987, NJ 1988, nr. 135, m.nt. GRdG; HR 08.12.1989, MR 1990, p. 40, m.nt. HAA.

${ }^{6} 4$ HR 23.03.1984, NJ 1984, nr. 650, m.nt. AHJS; HR 20.06.1986, NJ 1987, nr. 902, m.nt. GRdG; HR 08.12.1989, MR 1990, p. 40, m.nt. HAA.

${ }^{675}$ Hierbij gaat het om het ambtshalve aanvullen van de rechtsgronden door de rechter. Het blijkt bijv. uit de standaard geformuleerde overweging: "Nu evenmin aannemelijk is geworden dat klager de Nederlandse nationaliteit aan enig ander feit ontleent moet het beklag ongegrond worden verklaard. "

${ }^{676} \mathrm{Vgl}$. HR 03.06.1958, NJ 1959, nr. 50.
} 
zijn minst aannemelijk maken dat zich feiten of omstandigheden hebben voorgedaan die voor hem de verkrijging van het Nederlanderschap tot gevolg hebben gehad. ${ }^{1677}$ Volgens De Groot/Tratnik is het dus aan de betrokkene om de feiten aannemelijk te maken die voor hem het verkrijgen van het Nederlanderschap tot gevolg zouden hebben gehad. Aan de hand van de onderstaande jurisprudentie wil ik evenwel trachten duidelijk te maken dat de bewijslastverdeling toch iets genuanceerder ligt. Uit de als eerste te behandelen zaak blijkt bijvoorbeeld dat de negatieve uitslag voor de betrokkene niet is te wijten aan het feit dat deze niet over het gewenste aannemelijke bewijs beschikt, maar omdat de gegevens die afkomstig zijn van het ministerie van Justitie niet het door de betrokkene gewenste resultaat opleveren. In paragraaf 3.3.3.2.3 komt eveneens een casus aan de orde waarin de klaagster, wier beklag gegrond wordt geacht, ook niet over sluitend bewijs van haar verwerving beschikt. ${ }^{678}$ De genuanceerdheid kan ook worden gezien in het feit dat niet alleen de klager meewerkt aan de bewijsvoering, maar dat tevens de overheidsadministratie daaraan een bijdrage levert. De verwerving kan dan eventueel aannemelijk zijn op grond van hetgeen uit de overheidsadministratie naar voren komt. Naar mijn mening kan uit de jurisprudentie de conclusie worden getrokken dat het van groot belang is in hoeverre het door de staatssecretaris van Justitie ingenomen standpunt wordt gedragen door de feiten en is onderbouwd met bewijs.

Een volgende reden waarom de uitspraak van De Groot/Tratnik mijns inziens genuanceerd dient te worden, is het feit dat indien aan verwerving van het Nederlanderschap het eventueel hebben verworven van een vreemde nationaliteit in de weg staat, de bewijslast van de verwerving van die vreemde nationaliteit bij de overheid berust.

\subsection{HR 23 oktober 1979}

Cat. A. uitspr. III. Casusbeschrijving. Geen duidelijke bewijslastverdeling.

In de onderhavige $\mathrm{zaak}^{679}$ poneert een in 1955 geboren man de Nederlandse nationaliteit te bezitten door wettige afstamming van een Nederlander. ${ }^{680} \mathrm{De}$ feiten die de klager op tafel legt, zijn nogal summier te noemen. Zijn familie, van oorsprong afkomstig uit Duitsland, woont sinds 1888 in Indonesië, waar de klager ook is geboren. De klager is in het bezit van een (door een Nederlandse autoriteit

\footnotetext{
${ }^{67}$ De Groot/Tratnik, p. 131.

67 De Groot/Tratnik, p. 131, noemen deze zaak overigens als een uitzondering op de door hen geformuleerde hoofdregel.

679 HR 23.10.1979, NJ 1980, nr. 551, m.nt. MS.
}

${ }^{600}$ Dit is een beroep op art. 1 sub a Wet Ned. 1892. 
in Indonesië afgegeven) verklaring uit 1951 waarin de broer van klagers vader wordt aangemerkt als Nederlander krachtens de Wet op het Nederlanderschap en het ingezetenschap van 1892. Aan dit feit verbindt de klager de gevolgtrekking dat zijn oom de Nederlandse nationaliteit bezit ten gevolge van afstamming van een Nederlander (klagers grootvader derhalve). Dit kan voor klagers vader maar één gevolg hebben: dat ook deze Nederlander is.

In de conclusie van het OM wordt ruimschoots ingegaan op de desbetreffende ten name van de oom gestelde Nederlanderschapsverklaring, de Hoge Raad noemt in zijn latere overwegingen deze verklaring daarentegen in het geheel niet. De Hoge Raad concentreert zich op de nationaliteitsvaststelling van de grootvader en de vader van de klager. Voor klagers nationaliteit is het immers slechts van belang dat met betrekking tot één van deze voorouders aanwijzingen worden gevonden dat een rechtsfeit heeft plaatsgevonden dat heeft geleid tot de verkrijging van de Nederlandse nationaliteit. Aan de hand van gegevens die afkomstig zijn van het ministerie van Justitie komt de Hoge Raad tot de volgende beslissing: "in het Centraal Register van naturalisaties sinds 1850, gehouden bij het ministerie van Justitie, komt de geslachtsnaam (....) niet voor;

de geslachtsnaam (....) komt evenmin voor in de bij evengenoemde ministerie gehouden verzameling van verklaringen op grond van art. 5 jo art 12 Overeenkomst betreffende de toescheiding van Staatsburgers (Wet van 21 dec. 1949, Stb. J. 570) of in de publicaties in de Indonesische Stcrt. van tegenover Indonesische autoriteiten afgelegde verklaringen als evenbedoeld.

De grootvader van klager, (....), kon noch aan de bepalingen omtrent het Nederlanderschap in de in 1888 vigerende tweede titel van het eerste Boek van het BW, noch aan de Wet van 12 dec. 1892, Stb. 268, op het Nederlanderschap en het ingezetenschap -(........)- de Nederlandse nationaliteit ontlenen.

Uit het hiervoor vastgestelde volgt dat klagers vader, (.........) geboren als wettig kind van een niet-Nederlander, ingevolge art. 1, aanhef en onder 1c, Wet van 10 febr. 1910, Stb. 55, houdende regeling van het Nederlandsch onderdaanschap van niet-Nederlanders, ten tijde van de Souvereiniteitsoverdracht, de staat had van Nederlands onderdaan-niet-Nederlander en als uitheems Nederlands onderdaanniet-Nederlander op grond van art. 5 van eerder genoemde toescheidingsovereenkomst de Indonesische nationaliteit heeft verkregen.

Niet aannemelijk is geworden dat klagers vader een verklaring heeft afgelegd als bedoeld in art. 5 jo art. 12 van die overeenkomst en aldus de Nederlandse nationaliteit heeft herkregen.

De aan het beklag ten grondslag gelegde stelling dat klager Nederlander is door geboorte als wettig kind van een vader die tijdens die geboorte de staat van Nederlander bezat, kan derhalve niet als juist worden aanvaard.

$\mathrm{Nu}$ evenmin aannemelijk is geworden dat klager de Nederlandse nationaliteit aan enig ander feit ontleent moet het beklag ongegrond worden verklaard." 
Hoofdstuk 3

\section{Aantekening.}

Het is deze uitspraak geweest naar aanleiding waarvan A.-G. Mok later zijn, hierboven reeds aangehaalde, opmerking dat "van een duidelijke bewijslast" geen sprake is, zal plaatsen. ${ }^{681}$ Inderdaad is in de onderhavige uitspraak moeilijk te spreken van een bewijslastverdeling. In ieder geval is wel duidelijk dat het beklag niet reeds ongegrond wordt verklaard op grond van de overweging dat de betrokkene niet over sluitend dan wel aannemelijk bewijsmateriaal beschikt. Het beklag wordt naar mijn mening ongegrond verklaard omdat noch uit hetgeen de klager heeft overgelegd, noch uit de gegevens afkomstig van het ministerie van Justitie blijkt van verwerving van het Nederlanderschap door klagers nationaliteitsrechtelijk gezien relevante voorouders.

De overheidsadministratie (i.c. het ministerie van Justitie) wordt benaderd om de Hoge Raad van (meer) feitelijke gegevens te voorzien dan de klager heeft ingebracht. ${ }^{682}$ Het negatieve standpunt dat de overheid inneemt ten aanzien van klagers Nederlanderschap kan worden gedragen door hetgeen blijkt uit de overheidsadministratie. Hieruit volgt de, naar mijn mening, niet onbelangrijke constatering dat i.c. de Staat zijn standpunt heeft kunnen bewijzen.

Voor het geval dat uit de gegevens van het ministerie van Justitie wel informatie was gebleken die tot een positief resultaat voor de klager hadden geleid, was op grond van die gegevens het Nederlanderschap van de betrokkene vastgesteld. Hieruit volgt naar mijn mening de conclusie dat het niet noodzakelijk is, zoals De Groot/Tratnik menen, dat het de degene is die zich beroept op verwerving van het Nederlanderschap ook degene is, die van de verwerving het bewijs dient te leveren.

\subsection{HR 15 september 1980}

Cat. A. uitspr. IV. Casusbeschrijving. Bezit van een vreemde nationaliteit.

De volgende $\mathrm{zaak}^{683}$ waarin een beroep op een grond tot verwerving van het Nederlanderschap is gedaan, betreft een minderjarig meisje, dat in 1979 is geboren in Nederland. De moeder van het meisje heeft de Tunesische nationaliteit en is naar Nederlands recht gehuwd met de Marokkaanse vader. ${ }^{684}$ Over de nationaliteit van het meisje bestaat twijfel aangezien er zowel naar Marokkaans als naar Tunesisch

${ }^{*} 1$ Conclusie bij HR 15.07.1985, NJ 1985, nr. 854. Zie par. 3.3.3.2.4.

${ }^{60}$ Zoals dat eerder is gebeurd in HR 28.10.1952, HPS 1952, p. 133. Zie par. 3.3.2.1.1.

${ }^{603}$ HR 15.09.1980, NJ 1981, nr. 68.

os4 In zijn conclusie merkt de A.-G. nog op: "Ik ga er daarbij van uit, zoals ook het beklagschrift doet. dat in de nationaliteit van de moeder, door haar huwelijk, geen wijziging is gekomen." 
recht geen toekenning van nationaliteit zou geschieden. ${ }^{685}$ Ten behoeve van de minderjarige wordt gesteld dat zij het Nederlanderschap heeft verworven wegens geboorte in het Koninkrijk als niet-erkend onwettig kind te wiens aanzien niet blijkt van het bezit van een vreemde nationaliteit. ${ }^{686}$

Uit de bovenstaande beschrijving blijkt al dat het i.c. voornamelijk gaat om de interpretatie van vreemd recht. Omtrent de feitelijke omstandigheden van het geval bestaat geen twijfel. Bewijsrechtelijk is deze zaak dan ook in zoverre slechts interessant dat daaruit een indruk kan worden verkregen over de mate waarin een andere nationaliteit dient vast te staan, wil, in verband met het internationale streven naar beperking van staatloosheid, ${ }^{687}$ sprake kunnen zijn van het verwerven van de Nederlandse nationaliteit.

Ten einde voorlichting te verkrijgen over het relevante vreemde recht doet de Hoge Raad een beroep op deskundigen. Voorts blijkt uit de conclusie van het OM dat zich in het dossier een ambtsbericht van de Nederlandse ambassade in Tunis bevindt. Uit dit ambtsbericht blijkt dat de ambassade zowel bij de Tunesische autoriteiten als bij de Marokkaanse ambassade in Tunis inlichtingen heeft ingewonnen.

Zijn oordeel ondersteunt de Hoge Raad in sterke mate met de van deskundige zijde ingewonnen inlichtingen. De Hoge Raad overweegt: "Art. 6 tweede lid Code de la nationalité tunisienne kent de Tunesische nationaliteit toe o.m. aan "l'enfant né d'une mère tunisienne et d'un père inconnu". Voormeld rapport van P. Bourel houdt o.m. in:

dat naar zijn oordeel met de woorden "né d'un père inconnu" in voormeld art. 6 tweede lid geacht moet worden mede bedoeld te zijn het kind van een vader die in rechte niet als vader wordt erkend ("d'un père à l'égard duquel sa filiation n'est pas juridiquement ou légalement établie");

dat naar Tunesisch recht de vraag of een kind in familierechtelijke betrekking staat tot de echtgenoot van zijn moeder moet worden beantwoord naar het nationale recht van die echtgenoot;

dat naar Marokkaans recht een kind, hetwelk is geboren binnen zes maanden na het huwelijk van zijn moeder onwettig is -(.....)- ;

Op grond van voormelde gegevens acht de HR voor een bevestigende beantwoording van de vraag of (....) bij de toepassing van de Vreemdelingenwet als vreemdeling mag worden behandeld, voldoende aannemelijk dat (...) de Tunesische nationaliteit bezit en reeds uit dien hoofde niet voldoet aan het bepaalde in art. 1 ,

\footnotetext{
${ }^{605}$ Over het huwelijk en het daaruit geboren kind vermeldt het beklagschrift: "Nog daargelaten, dat dit naar Nederlands recht gesloten huwelijk in het Marokkaanse noch het Tunesische recht wordt erkend, staat vast dat naar Marokkaans en Tunesisch recht (....) de status heeft van onwettig kind. Zij is immers binnen 6 maanden na de huwelijkssluiting geboren."

${ }^{606}$ Dit is cen beroep op art. 1 sub d Wet Ned. 1892.

on $\mathrm{V}$. par. 0.1.
} 
aanhef en sub d, Wet van 12 dec. 1892, Stb. 268, op het Nederlanderschap en het ingezetenschap.

$\mathrm{Nu}$ voorts niet aannemelijk is geworden dat (....) de Nederlandse nationaliteit aan enig ander feit ontleent moet het beklag ongegrond worden verklaard. "

\section{Aantekening.}

Aan de hand van de eigen interpretatie van het vreemde recht concludeert de Hoge Raad dat "voldoende aannemelijk" is dat de minderjarige een bepaalde nationaliteit bezit. Hetgeen tot de consequentie voert dat geen beroep kan worden gedaan op een bepaling in het Nederlandse nationaliteitsrecht strekkend tot nationaliteitsverlening indien anders sprake zou zijn van staatloosheid.

Geheel in de lijn met het arrest uit $1959,{ }^{688}$ waarbij is uitgegaan van het gezichtspunt dat voor het aannemen van het bezit van een vreemde nationaliteit het niet noodzakelijk is dat van de kant van de desbetreffende vreemde autoriteiten dienaangaande een positieve erkenning voorligt, staat de Hoge Raad ook i.c. op het standpunt dat het bezit van de vreemde nationaliteit autonoom door de Nederlandse rechter kan worden vastgesteld. Volgens de literatuur dient het vaststellen van het bezit van een vreemde nationaliteit te geschieden aan de hand van de wettelijke bepalingen van het vreemde recht alsmede aan de hand van het bewijsrecht van de vreemde staat. ${ }^{689}$

Met betrekking tot de mate waarin het bezit van die vreemde nationaliteit dient vast te staan om reeds binnen het Nederlandse nationaliteitsrecht het effect te sorteren dat geen verwerving van het Nederlanderschap plaatsvindt, is blijkens deze uitspraak reeds voldoende dat het bezit van de vreemde nationaliteit "voldoende aannemelijk" is. En blijkens deze uitspraak is het bezit van een vreemde nationaliteit "voldoende aannemelijk" indien de rechter aan de hand van de vreemde regelgeving en daaromtrent ingewonnen inlichtingen tot de gevolgtrekking komt dat de vreemde nationaliteit is verworven.

Net als in de hier direct bovenstaand aan de orde gestelde zaak is het in het onderhavige geval moeilijk om van een bewijslastverdeling te spreken. In casu is dat naar mijn inzicht te wijten aan het feit dat het in wezen niet gaat om een bewijsrechtelijke kwestie (derhalve een kwestie aangaande de feiten), maar om een rechtskwestie. ${ }^{690}$ Wat in het onderhavige geval aan de orde is, is een kwestie van aanvulling van de rechtsgronden, ook al zijn dat rechtgronden van vreemd recht, en gaat het niet zozeer om een bewijsrechtelijk punt. ${ }^{61}$

\footnotetext{
${ }^{68 s}$ HR 10.09.1959, NJ 1959, nr. 596. Zie par. 3.3.2.2.4.

Kollewijn, p. 22; Lemaire, p. 310. Vgl. voetnoot 737.

${ }^{690} \mathrm{Vgl}$. Scheltema, p. 16, die eveneens concludeert dat bij het onderzoek naar de inhoud van vreemd recht "de regelen omtrent verdeeling van den bewijslast (.....) geen toepassing vinden."

${ }^{6} \mathrm{~V} \mathrm{Vgl}$. Pitlo/Hidma \& Rutgers, p. 23.
} 
Wel is het zo dat berichten en verklaringen van deskundigen worden gerangschikt onder de bewijsmiddelen. In het civiele proces is de regeling inzake de inbreng van deskundigen geplaatst onder de bewijsrechtelijke bepalingen in Burgerlijke Rechtsvordering. ${ }^{62}$ In het administratief procesrecht wordt de deskundigenverklaring eveneens beschouwd als een bewijsmiddel. ${ }^{693}$ Evenwel wordt bij inlichtingen door deskundigen blijkens de literatuur eerder gedacht aan verklaringen van medici, milieukundigen, arbeidsdeskundigen of financiële deskundigen. ${ }^{694}$ Kenmerk van een zodanige deskundigheidsinbreng is een (onafhankelijke, deskundige) beoordeling van de feitelijke omstandigheden van een zaak. De voorlichting betreft dan derhalve feitelijke beoordeling van de feiten, waarbij de rechter de beoordeling wegens zijn (betrekkelijke) ondeskundigheid op het desbetreffende gebied niet licht zal overdoen of tot een andere conclusie zal komen. ${ }^{695}$ Betreft de deskundigheidsinbreng echter juridische voorlichting, dan worden niet zozeer de feiten nader beoordeeld als wel verkrijgt de rechter hem ontbrekende juridische informatie die hijzelf op de feiten zal toepassen. In plaats van de feitelijke beoordeling van de feiten gaat het bij juridische voorlichting om de juridische beoordeling van de feiten. De inbreng van voorlichting door juridische deskundigen verschilt derhalve in karakter van de deskundigheidsinbreng van medici, arbeidsdeskundigen of andere deskundigheidsinbreng van niet-juridische aard. In het laatste geval betreft het hulp aan de rechter bij het beoordelen van een bewijskwestie, in het eerste geval gaat het erom de rechter in staat te stellen tot het ambtshalve aanvullen van de rechtsgronden. ${ }^{69}$

\subsection{HR 23 maart 1984}

Cat. A. uitspr. V. Casusbeschrijving. Bewijs door middel van bezit van staat.

De volgende $z^{2 a a k}{ }^{697}$ is bewijsrechtelijk zeer interessant omdat erin o.a. sprake is van bewijs van het Nederlanderschap door middel van het bezit van staat.

Klaagster, die stelt door afstamming van een ongehuwde Nederlandse vrouw de Nederlandse nationaliteit te bezitten, ${ }^{698}$ is in 1944 geboren in Indonesië. In feite gaat het in deze zaak om de onduidelijkheid die bestaat ten aanzien van het Nederlanderschap van klaagsters moeder.

\footnotetext{
${ }^{61}$ Artt. 221-225 Rv.

${ }^{\circ} \mathrm{Vgl}$. Ten Berge/Tak, p. 147.

Vgl. Bosch-Boesjes, p. 173; Pitlo/Hidma \& Rutgers, p. 137.

Pitlo/Hidma \& Rutgers, p. 137.

$\mathrm{Vgl}$. Jessurun d'Oliveira, p. 98.

(7) HR 23.03.1984, NJ 1984, nr. 650, m.nt. AHJS.

"Dit is cen beroep op art. 1 sub c Wet Ned. 1892.
} 
Deze moeder is zelf in 1921 geboren in Indonesië als buitenechtelijk kind. In 1924 wordt de moeder in Indonesië erkend door een Nederlander. Bij een zodanige erkenning volgt, in beginsel, toekenning van het Nederlanderschap aan de minderjarige. Voorwaarde voor enig daadwerkelijk rechtsgevolg met betrekking tot de erkenning is wel dat inderdaad van een erkenning kan worden gesproken. Met andere woorden: er dient sprake te zijn van een rechtsgeldige erkenning.

Klaagsters moeder overlijdt in 1951. Aan de bewuste erkenning van de moeder door klaagsters Nederlandse grootvader schijnt iets te hebben geschort. Althans, dat is de mening van de Nederlandse Staat. Deze stelt zich op het standpunt dat het geen rechtsgeldige erkenning betreft, aangezien op het moment van de verwekking van de moeder de grootvader gehuwd is met een andere vrouw dan de moeder van het te erkennen kind. ${ }^{69}$ De klaagster stelt hiertegenover dat niet met zekerheid vaststaat dat haar grootvader op het cruciale moment gehuwd was. Indien dat al het geval is geweest, is hij volgens de klaagster in ieder geval niet op de hoogte is geweest van de (alsdan) niet-rechtsgeldigheid van de erkenning. Voorts voert de klaagster aan dat in 1931 haar grootmoeder en grootvader alsnog met elkaar in het huwelijk zijn getreden. Ook voert zij aan dat van Nederlands-Indische overheidswege de rechtsgeldigheid van het voeren van grootvaders geslachtsnaam door klaagsters moeder en klaagster zelf nimmer in twijfel is getrokken en dat de geboorte van klaagsters moeder is ingeschreven in het geboortenregister voor Europeanen. Als laatste argument voert de klaagster aan dat in 1924 de bewuste erkenning door de betrokken autoriteiten is geaccepteerd.

Op het moment dat de Hoge Raad uitspraak op het beklag doet, gaat het om feiten die zich zestig jaren eerder in Indonesië hebben voltrokken. Uit alle ter beschikking staande feiten, in het geding gebracht door zowel de klaagster als de staatssecretaris van Justitie, kan gedurende de procedure niet worden achterhaald of de erkenning al dan niet rechtsgeldig heeft kunnen plaatsvinden.

De Hoge Raad oordeelt daarop als volgt: "Het gaat hier evenwel om feiten en omstandigheden die moeten worden gesitueerd in een samenleving die in tijd en plaats ver van de onze is verwijderd en waaromtrent zich van hieruit thans ook bezwaarlijk meer met genoegzame zekerheid gegevens laten verzamelen. Tegen die achtergrond, en mede in aanmerking genomen dat niet blijkt dat de NederlandsIndische autoriteiten ooit in twijfel hebben getrokken dat aan klaagster en haar moeder de achternaam $V$. en de Nederlandse nationaliteit toekwamen, is de HR door eerder genoemde vermoedens ten gunste van het standpunt van de staatssecretaris niet voldoende overtuigd om bewezen te oordelen dat (klaagsters moeder) door (de grootvader) "in overspel geteeld", en haar erkenning door hem deswege nietig is.

Een en ander leidt tot de slotsom dat het beklag gegrond is. "

${ }^{609}$ Toentertijd ook in Indonesiê een beletsel voor rechtsgeldige erkenning. De beperking dat "overspelige" kinderen nimmer konden worden erkend door de vader is in Nederland in 1970 vervallen. 


\section{Aantekening.}

De onderhavige zaak is in minstens tweeërlei opzicht bewijsrechtelijk interessant. Ten eerste kan worden geconstateerd dat geen van beide partijen voldoende bewijsmateriaal bezit om de eigen stelling overtuigend te doen vaststaan. Wat de huwelijkse staat van de grootvader betreft, verkeren beide partijen in bewijsnood. De staatssecretaris is niet in staat te bewijzen dat klaagsters grootvader op het cruciale moment was gehuwd en de klaagster kan niet bewijzen dat hij ongehuwd was.

Wel oordeelt de Hoge Raad dat voor het standpunt van de Staat (dat de moeder de Nederlandse nationaliteit niet heeft verworven wegens het gehuwd zijn van haar vader) "inderdaad vermoedens" kunnen bestaan. Echter, ten gevolge van de bewijsnood waarin de staatssecretaris van Justitie verkeert, blijven dit vermoedens. Het feit nu dat de overheid haar standpunt niet afdoende blijkt te kunnen onderbouwen met relevant bewijsmateriaal heeft mijn inziens consequenties voor het verdere verloop van de zaak.

De constatering namelijk dat de overheid niet in staat is haar standpunt te bewijzen legt, mijns inziens, voor de verdere bewijslastverdeling en het daaraan verbonden bewijsrisico een groot gewicht in de schaal. Het volgende patroon inzake de bewijslastverdeling valt, naar mijn inzicht, te onderkennen. Uit de onderhavige zaak blijkt dat de Hoge Raad in de beklagprocedure in feite eerst het standpunt van de Staat toetst op deugdelijkheid. Dit wijst m.i. op een "primaire bewijslast" ten laste van de Staat, nl. dat deze zijn standpunt inzake het nietNederlanderschap van de betrokkene deugdelijk met bewijsmateriaal kan onderbouwen. Dit betekent dat indien het verweer van de betrokkene uit de casus wordt weggedacht, er een deugdelijk onderbouwde nationaliteitsbeslissing van de kant van de overheidsadministratie dient voor te liggen. Nadat de Hoge Raad heeft geconstateerd dat de juiste feiten aangaande het wel of niet verwerven van het Nederlanderschap niet meer zijn te achterhalen, ${ }^{700}$ beoordeelt de Hoge Raad "tegen die achtergrond" de door de verzoekster aangevoerde bestaansfeiten van het Nederlanderschap van haar moeder en haarzelf. De klaagster heeft onder meer gewezen op het feit dat de bevoegde autoriteiten nimmer hebben betwijfeld dat haar moeder rechtsgeldig de familienaam van de grootvader droeg.

Met de bewijsvoering door middel van de bestaansfeiten van het Nederlanderschap komt het tweede bewijsrechtelijk interessante onderdeel van deze zaak aan de orde. Hierboven is gesteld dat ook de klaagster in bewijsnood verkeert. $\mathrm{Zij}$ is niet in staat door middel van onmiddellijke bewijsmiddelen (bijv. door het overleggen van documenten ter zake van echtscheiding van haar grootvader en zijn eerste

\footnotetext{
${ }^{700}$ De overweging: "Het gaat hier evenwel om feiten en omstandigheden die moeten worden gesitueerd in een samenleving die in tijd en plaats ver van de onze is verwijderd en waaromtrent zich van hieruit thans ook bezwaarlijk meer met genoegzame zekerheid gegevens laten verzamelen. "
} 
echtgenote of door getuigenverklaringen ter zake van zodanige echtscheiding ${ }^{701}$ de rechtsgeldige verwerving van het Nederlanderschap door haar moeder aan te tonen. Wél kan zij aannemelijk maken dat haar moeder door de bevoegde autoriteiten altijd als wettig kind van de grootvader is beschouwd. Dit leidt tot het aannemen van het Nederlanderschap van klaagsters moeder op grond van bewijs door middel van bezit van staat. Uit deze uitspraak blijkt nogmaals dat indien onmiddellijke bewijsmiddelen geen uitkomst brengen, het mogelijk is op middellijke wijze het bestaan van een recht aannemelijk te maken. ${ }^{702}$

Voor het geval dat de Hoge Raad i.c. wel bewezen zou hebben geacht dat de klaagsters moeder gedurende het huwelijk van haar vader is verwekt, dan zou in beginsel de niet-rechtsgeldige erkenning een beletsel zijn geweest voor de verwerving van de Nederlandse nationaliteit. Recentelijk wordt het uitgangspunt dat slechts een ongehuwde man een onwettig geboren kind kan erkennen meer en meer losgelaten. De doorslaggevende factor of een gehuwde man een onwettig geboren kind kan erkennen, wordt sinds enige tijd gevonden in de feitelijke omstandigheid of sprake is (geweest) van een gezinsleven van vader en kind. De rechter toetst in een voorkomend geval de mogelijkheid tot erkenning aan het begrip "family life" uit artikel 8 EVRM. ${ }^{703}$

Voor een betrokkene waarbij, anders dan bij de verzoekster in de onderhavige zaak, onomstotelijk vaststaat dat de erkennende vader op het moment van erkenning was gehuwd of die wegens het bestaan van een huwelijk heeft afgezien van erkenning en heden ten dage, door overlijden, niet meer kan erkennen, biedt het verkrijgen op grond van artikel 1:215 BW van brieven van wettiging wellicht een mogelijkheid. ${ }^{704}$ Voor de eventuele verwerving van het Nederlanderschap als gevolg van een wettiging door middel van brieven van wettiging moeten echter twee elkaar synchroon aanvullende aspecten in het oog worden gehouden. ${ }^{705}$ Ten eerste dat pas op het moment van het verlenen van de brieven het kind de status

\footnotetext{
${ }^{201}$ Het enige dat aangaande de eerste echtgenote met zekerheid was vast te stellen, was haar moment van overlijden op 06.10 .1930 .

${ }^{702} \mathrm{Vgl}$. HR 28.10.1952, HPS 1952, p. 133 (par. 3.3.2.1.1). Zie voorts par. 3.2.3.

${ }^{70} \mathrm{Vgl}$. Gerecht in eerste aanleg Curaçao, 22.11.1993, NJ 1994, nr. 446. Een slechts van tafel en bed gescheiden man en een ongehuwde vrouw leven ruim twintig jaar samen. Uit de relatie worden vijf kinderen geboren, die de man, twee weken voor zijn overlijden, bij notariēle akte erkend. Het Gerecht in eerste aanleg oordeelt de erkenning rechtsgeldig. Hiervan is het gevolg dat erkende kinderen, net als de wettige kinderen uit het huwelijk, als intestaat erfgenamen in de nalatenschap van de vader kunnen opkomen.

${ }^{0} \mathrm{~V}$ Vgl. HR 08.10.1992, NJ 1993, nr. 730, m.nt. WH-S: dit betreft een positief advies gegeven inzake het verlenen van brieven van wettiging ten behoeve van een onwettig kind, waarvan de overspelige vader voor 1970 (moment van invoering van het nieuwe afstammingsrecht) is overleden, maar die (de vader) wel jaren gehuwd is geweest met de moeder en langdurig met het kind in familieverband heeft geleefd. Zie Vonken, p. 75-79.

0 s Terzijde: verlening van brieven van wettiging is ook mogelijk indien de vader niet in het bezit is van de Nederlandse nationaliteit: HR 20.10.1994, NJ 1995, nr. 466, m.nt. ThMdB.
} 
van wettig kind krijgt. Het tweede aspect is dat artikel 2 RWN bepaalt dat verkrijging en verlies van het Nederlanderschap niet met terugwerkende kracht plaatsvindt. Als gevolg hiervan vindt verwerving van het Nederlanderschap door wettiging door middel van brieven van wettiging slechts plaats door minderjarigen (art. 4 lid 2 RWN).

\subsection{HR 15 juli 1985}

Cat. A. uitspr. VI. Casusbeschrijving. Vrij-bewijsstelsel.

De zesde zaak $^{706}$ waarin de betrokkene beroep doet op een grond tot verwerving van het Nederlanderschap heeft betrekking op een vrouw die huwt met een man van Nederlandse nationaliteit. De vrouw stelt na haar huwelijk te Londen in 1984 een optie voor het Nederlanderschap te hebben gedaan. ${ }^{707} \mathrm{Nu}$ bestaat ten aanzien van het afleggen van de optie door de betrokkene geen twijfel, daarentegen is wel onzeker of de vrouw zelf aanwezig is geweest bij de huwelijksvoltrekking. Het vermoeden bestaat dat in haar plaats een andere vrouw aanwezig is geweest. Dat vermoeden stoelt op twee ten behoeve van een strafrechtelijk onderzoek ${ }^{708}$ opgemaakte processen-verbaal, waarin beide echtelieden de verklaring hebben afgelegd dat de in Londen bij het huwelijk aanwezige vrouw niet degene is geweest die naderhand de optie voor het Nederlanderschap heeft gedaan. De staatssecretaris van Justitie stelt zich als gevolg van de hierboven weergegeven gang van zaken op het standpunt dat: "klaagster niet met $Y$. is gehuwd, (......), zodat de (....) kennisgeving geen rechtsgevolg heeft gehad. " Voor de klaagster resulteert dit erin dat zij het land dreigt te worden uitgezet, ${ }^{709}$ weshalve zij zich genoodzaakt ziet zich tot de Hoge Raad te wenden met een beroep op haar Nederlanderschap.

De Hoge Raad accepteert de processen-verbaal als bewijs voor de stelling van de Staat dat er geen sprake is van een huwelijk en stelt: "Deze verklaringen ontzenuwen het bewijs dat voor het gestelde huwelijk van klaagster met $Y$. aan voornoemde huwelijksakte zou kunnen worden ontleend. (...................).

$\mathrm{Nu}$ ook geen ander bewijs van het gestelde huwelijk is bijgebracht, bestaat er geen grond om aan te nemen dat dat huwelijk is tot stand gekomen, zodat de hiervoren onder 1 bedoelde kennisgeving niet heeft geleid tot verkrijging van klaagster van het Nederlanderschap."

\footnotetext{
${ }^{76}$ HR 15.07.1985, NJ 1985, nr. 854. Zie over deze zaak Wohlgemuth Kitslaar, Bondsblad 1986, p. 16.

${ }^{20}$ Dit is een beroep op art. 8 Wet Ned. 1892.

${ }^{m}$ Blijkens de conclusie van de A.-G. is tegen de klaagster strafvervolging ingesteld wegens valsheid in geschrifte en oplichting van de Staat.

${ }^{\infty 0}$ De klaagster heeft nog tevergeefs haar uitzetting aangevochten in Pres. Rb. Amsterdam 06.12.1984, KG 1985, nr. 9.
} 
In de conclusie heeft de A.-G. nog enige aandacht besteed aan het in de procedure geldende bewijsrecht door op te merken: "Men mag aannemen dat hier een vrijbewijs-stelsel geldt, zoals trouwens in het administratief procesrecht gebruikelijk is. De HR heeft al beslist dat bepaalde feiten of omstandigheden aannemelijk moeten worden, zonder dat van een duidelijke bewijslast sprake is."

\section{Aantekening.}

Op de klaagster rust in eerste instantie met betrekking tot het verwerven van het Nederlanderschap een stelplicht. Eerder is geconstateerd dat er tevens een "summiere bewijsplicht" aan de kant van de klager/klaagster bestaat. ${ }^{710}$ I.c. voldoet de klaagster aan haar "summiere bewijsplicht" door de in Groot-Brittannië opgemaakte huwelijksakte ${ }^{711}$ over te leggen.

Ten aanzien van de overheidsadministratie bestaat de verwachting dat deze de aangaande de betrokkene in haar bezit zijnde nationaliteitsrechtelijk relevante gegevens ter beschikking van de Hoge Raad te stelt. In de vorige casus is geconstateerd dat op de Staat een "primaire bewijslast" rust. Dit houdt in dat de Hoge Raad als eerste stap in de procedure het standpunt van de staatssecretaris van Justitie toetst op deugdelijkheid. In de voorafgaande casus slaagde de Staat niet in de "primaire bewijslast", in de onderhavige zaak slaagt hij als gevolg van het accepteren van de processen-verbaal als bewijsmiddel daarin wel.

Hiermee is de kous echter nog niet af. Blijkens de daarop volgende overweging ${ }^{712}$ hoeft in de ogen van de Hoge Raad met het, i.c. in beginsel als correct aan te merken, standpunt van de Staat de zaak nog niet afgesloten te zijn. Uit de desbetreffende overweging komt naar voren dat de klaagster eventueel nog op andere wijze de (eventueel later correcte) totstandkoming van het huwelijk aannemelijk zou kunnen maken. Hieruit volgt naar mijn inzicht dat indien de Staat slaagt in de "primaire bewijslast" de klager nog altijd de mogelijkheid heeft om tegen het standpunt van de Staat tegenbewijs te leveren.

Het patroon in bewijslastverdeling dat hiermee is te onderkennen, zal verderop bij de bewijslastverdeling in zaken waarin verlies van het Nederlanderschap ingevolge de Toescheidingsovereenkomst Nederland-Suriname aan de orde is ook veelvuldig naar voren treden. Dit patroon komt er op neer dat de Hoge Raad eerst beoordeelt of het standpunt van de Staat (gezien de mate van onderbouwing door de aan dat standpunt ten grondslag liggende feiten) houdbaar is. Is het standpunt van

\footnotetext{
${ }^{710}$ Zie voor het begrip "summiere bewijsplicht" par. 3.3.3.1.

71 Zie ook par. 3.3.4.2.2 ter zake van bewijs en tegenbewijs in het kader van in het buitenland opgemaakte authentieke akten. In wezen moet de Hoge Raad zich ervan hebben vergewist dat een Engelse huwelijksakte haar bewijskracht volgens Engels recht kan verliezen door middel van getuigenissen en processen-verbaal. In de uitspraak noch de conclusie blijkt evenwel hiervan. Vgl. voor de inhoudelijke betekenis van het vrij-bewijsstelsel waarover de A.-G. spreekt: par. 3.2.1.

${ }^{12}$ De overweging: "Nu ook geen ander bewijs van het gestelde huwelijk is bijgebracht, (........)."
} 
de Staat houdbaar geoordeeld, dan wordt in het licht daarvan het tegenbewijs van de klager beoordeeld.

Dit leidt ertoe dat er twee momenten zijn waarop het standpunt van de Staat ondeugdelijk kan blijken te zijn. Het eerste moment noem ik in het vervolg van het betoog het "moment van de primaire toetsing" of kortweg de "primaire toetsing". Het tweede moment waarop kan blijken dat het standpunt van de Staat niet houdbaar is, valt na afloop van de toetsing van het tegenbewijs van de klager.

Ook in de onderhavige zaak blijkt de bewijslast ten aanzien van het niet-bezit van het Nederlanderschap bij de Staat te liggen. De vrouw heeft in feite voldoende bewijs (de huwelijksakte) om rechtsgeldig te kunnen opteren en een beroep te doen op verwerving van de Nederlandse nationaliteit. De Staat kan echter ten behoeve van zijn standpunt inzake de niet-verwerving door middel van het overleggen van de processen-verbaal het "primaire bewijs" van de niet-verwerving leveren. De vrouw slaagt niet in het leveren van tegenbewijs.

\subsection{HR 8 december 1989}

Cat. A. uitspr. VII. Casusbeschrijving. Bezit van een vreemde nationaliteit.

De zevende en laatste zaak $^{713}$ in deze categorie vertoont veel gelijkenis met de vierde casus. Het onderhavige geval betreft een minderjarig meisje, dat in 1978 is geboren in Nederland. De moeder van het meisje heeft de Sri Lankaanse nationaliteit en is op grond van een bepaalde plechtigheid ${ }^{714}$ gehuwd met de Pakistaanse vader. Betreffende de gehouden plechtigheid staat niet vast welke juridische status daaraan in het Pakistaanse of Sri Lankaanse recht kan worden toegeschreven. Als gevolg daarvan is de status van het huwelijk als ook de status van het vervolgens geboren kind onduidelijk. Met betrekking tot het kind is de vraag gerezen welke nationaliteit het bezit. Dienaangaande wordt gesteld dat zowel naar Pakistaans als naar Sri Lankaans recht geen toekenning van nationaliteit zou geschieden. Er wordt derhalve ten behoeve van de minderjarige een beroep gedaan op het feit dat zij het Nederlanderschap heeft verkregen wegens geboorte in het Koninkrijk als nieterkend onwettig kind te wiens aanzien niet blijkt van het bezit van een vreemde nationaliteit. ${ }^{715}$

Tussen de ontvangst van het beklagschrift en de uitspraak ligt een periode van zes jaar. De A.-G. vermeldt desbetreffend in zijn conclusie dat een onderzoek via

\footnotetext{
${ }^{73}$ HR 08.12.1989, MR 1990, p. 40, m.nt. HAA.

${ }^{74}$ In de uitspraak wordt gesproken van een "Nikah Nama" plechtigheid en zou het huwelijk zijn voltrokken door een "Nikah registrar". De plechtigheid heeft plaatsgevonden in een woning in Nederland. Naar Nederlands recht is hier dus geen sprake van een rechtsgeldig huwelijk.

${ }^{71 s}$ Een beroep op art. 1 sub d Wet Ned. 1892.
} 
het ministerie van Buitenlandse Zaken en de Nederlandse ambassade in Pakistan veel tijd heeft gevraagd. Ook blijkt uit de uitspraak dat gedurende die periode namens de klaagster door haar raadsman bij de ambassades van Pakistan (te Den Haag) en Sri Lanka (te Brussel) om inlichtingen is verzocht. De uitspraak maakt tevens melding van twee pogingen van de moeder zelf om bij de ambassade van Sri Lanka in Parijs te weten te komen of haar kind als wettig moet worden beschouwd.

Kort samengevat: de status van het huwelijk is bepalend voor de status van het kind, hetgeen weer bepalend is voor de toekenning van enige nationaliteit. Het geval wil dat de Pakistaanse autoriteiten zich op het standpunt stellen dat het huwelijk naar Pakistaans recht hoogstwaarschijnlijk geen rechtsgeldig huwelijk betreft, zodat het kind geen wettig kind van een Pakistaanse vader is. Naar Pakistaans inzicht kan er wel sprake zijn van een geldig huwelijk indien het gaat om een plechtigheid volgens de islamitische wetgeving. ${ }^{716}$

Aan de Sri Lankaanse kant ligt de zaak ook gecompliceerd. Uit de uitspraak blijkt dat inzake de mening van de Sri Lankaanse autoriteiten over de status van het huwelijk geen duidelijkheid is verkregen. Wel stellen de Sri Lankaanse autoriteiten dat het kind niet de Sri Lankaanse nationaliteit heeft. ${ }^{717}$

De Hoge Raad oordeelt in deze zaak voor het betrokken meisje in positieve zin en overweegt: "dat niet gebleken is dat (....) de nationaliteit van Sri Lanka bezit. (..........).

Derhalve, en omdat overigens niet is gebleken van feiten die tot een andere conclusie leiden, moet worden geoordeeld dat niet is gebleken dat (....) de Pakistaanse nationaliteit bezit.

$\mathrm{Nu}$ voorts in deze zaak van het bezit van enige vreemde nationaliteit (........) geen sprake is, brengt art. 1, aanhef en onder d van de Wet op het Nederlanderschap en het ingezetenschap mee dat (...) de Nederlandse nationaliteit bezit, zodat het beklag gegrond is.

\section{Aantekening.}

De eerste parallel die kan worden getrokken met de eerder behandelde uitspraak inzake het dochtertje van het Tunesisch/Marokkaans ouderpaar ${ }^{718}$ is dat het ook

\footnotetext{
${ }^{76}$ Uit de uitspraak blijkt tevens dat de raadsman van de klaagster tevergeefs pogingen heeft ondernomen om van de Pakistaanse autoriteiten in Nederland uitsluitsel te krijgen of die autoriteiten de plechtigheid als een geldig gesloten islamitisch huwelijk beschouwen.

717 In zijn beslissing overweegt de HR: "Een brief van het "Departement of immigration and emigration" van Sri Lanka te Colombo van 17 juli 1987 aan de tweede secretaris van de Nederlandse ambassade aldaar houdt in dat (....) vader een Pakistani is, houder van een Pakistaans paspoort, zodat (....) onder de Citizenship Act niet in de registers kan worden opgenomen. " N.B. het gaat daarbij om de "Citizenship Act" van Sri Lanka, waarbij de bewuste opname dan zou betekenen dat het kind de Sri Lankaanse nationaliteit heeft.

${ }^{78}$ HR 15.09.1980, NJ 1981, nr. 68 (par. 3.3.3.2.2).
} 
in de onderhavige zaak eerder gaat om de interpretatie van vreemd recht, dan om onzekerheid ten aanzien van de feiten. De feiten als zodanig zijn duidelijk, alleen omtrent de rechtsgevolgen van die feiten bestaat onzekerheid. Toch gaat de Hoge Raad, anders dan in de Tunesisch/Marokkaanse casus, in het onderhavige geval niet over tot het inwinnen van informatie over het vreemde recht. Mijns inziens heeft dit vooral een praktische reden. De reden voor het achterwege laten van het inwinnen van informatie aangaande het Pakistaanse en Sri Lankaanse recht is wellicht gelegen in het feit dat vanaf de aanvang van de zaak duidelijke aanwijzingen bestaan dat de desbetreffende autoriteiten inderdaad het kind niet als één van hun burgers beschouwen.

Een tweede parallel tussen beide zaken is dat ook i.c. de vraag aan de orde komt welke mate van zekerheid dient te bestaan over het (niet) bezitten van een vreemde nationaliteit. In de Tunesisch/Marokkaanse casus is gebleken dat indien de Nederlandse rechter (autonoom) vaststelt dat het bezit van een vreemde nationaliteit "voldoende aannemelijk" is, er geen van verwerving van het Nederlanderschap plaatsvindt.

In de onderhavige zaak blijkt dat aan de feiten van het geval het Sri Lankaanse rechtsstelsel zeker geen en het Pakistaanse rechtsstelsel onder een voorbehoud een positief nationaliteitsrechtelijk rechtsgevolg (d.w.z. verlening van nationaliteit) verbinden. Ten aanzien van het door de Pakistaanse autoriteiten gemaakte voorbehoud dat de sluiting van het huwelijk een geldige islamitische huwelijksplechtigheid dient te betreffen, blijkt gedurende de procedure dat over de geldigheid in dat opzicht geen duidelijkheid wordt verkregen. Aangaande de verwerving van enige nationaliteit door het minderjarige meisje kan door de Hoge Raad nog slechts worden geconcludeerd dat van verwerving van één van beide nationaliteiten "niet is gebleken".

Ter zijde wordt hier nog opgemerkt dat een eventuele bewijslast van het bezit van een vreemde nationaliteit bij de overheidsadministratie zou berusten. Het bewijsrisico m.b.t. het bewijs van het bezit van de Pakistaanse nationaliteit door de minderjarige ligt derhalve bij de overheid. Wordt nu de vraag gesteld wat dit heeft te betekenen voor de vraag naar de bewijslast van de verwerving van de Nederlandse nationaliteit, dan kan de volgende (opmerkelijke) conclusie worden getrokken. De conclusie is dat het niet onder alle omstandigheden aan de klager is om aan te tonen dat hij het Nederlanderschap heeft verworven, maar dat het onder omstandigheden aan de overheidsadministratie is om aan te tonen dat de klager het Nederlanderschap niet heeft verworven. De klager zal, als gevolg van alle moeite dienaangaande bij de onderscheidenlijke ambassades, in de visie van de Hoge Raad i.c. aan de "summiere bewijsplicht" hebben voldaan.

Een ander opmerkelijk gegeven in deze zaak is de lange duur van de procedure die voornamelijk is te wijten aan het informatie-inwinnen bij de vreemde autoriteiten en het onderzoek naar het vreemde recht. Dat een zodanig langdurig onderzoek toch niet garant staat voor volledige duidelijkheid blijkt uit deze casus. De vraag of 


\section{Hoofdstuk 3}

i.c. de huwelijkse plechtigheid kan worden beschouwd als een plechtigheid waarbij is gehandeld in overeenstemming met de vereisten van de islamitische wetgeving blijft onbeantwoord.

\subsubsection{Jurisprudentie categorie B: Beroep op behoud van het Nederlanderschap}

Het aantal beschikkingen op grond van artikel 43 (oud) Vreemdelingenwet waarin de betrokkene stelt het Nederlanderschap niet te hebben verloren, is veruit het grootst. In totaal telt de onderzochte jurisprudentie twintig uitspraken waarin door de klager wordt bestreden dat aan een verliesbepaling voor het Nederlanderschap is voldaan. Ten aanzien van negen beklagschriften oordeelt de Hoge Raad vervolgens positief over het Nederlanderschap van de betrokkene.

Een opvallend gegeven met betrekking tot deze categorie beroepen op artikel 43 (oud) Vreemdelingenwet is, dat het in de meerderheid van de zaken niet gaat om een verliesbepaling op grond van de Wet op het Nederlanderschap en het ingezetenschap uit 1892, maar dat de Toescheidingsovereenkomst inzake nationaliteiten tussen Nederland en Suriname in het spel is. ${ }^{719}$ Dit in tegenstelling tot de meerderheid van de zaken uit de categorie waarin de beroepen op verwerving van het Nederlanderschap zijn opgenomen: daar betreft het in meerderheid beroepen op verwervingsgronden uit de Wet op het Nederlanderschap en het ingezetenschap uit $1892 .^{720}$

Voorts is het opvallend dat bij beklagschriften inzake behoud van het Nederlanderschap de feitelijke omstandigheden van het geval relatief vaker een rol spelen dan bij beklagschriften inzake verwerving van de Nederlandse nationaliteit. Terwijl bij de beklagschriften gebaseerd op een verwervingsgrond in de meerderheid van de gevallen de feiten vaststaan en het in de meeste gevallen er derhalve om blijkt te gaan de Hoge Raad te bewegen tot een bepaalde (voor de klager gunstige) interpretatie van een wettelijke bepaling of een verdragsbepaling, blijkt daarentegen in de gevallen waarin een verliesbepaling van de Nederlandse nationaliteit aan de orde is, relatief gezien vaker over de feiten onzekerheid te bestaan. Ten gevolge hiervan dienen bij zaken waarin de betrokkene zich beroept op het behoud van het Neder-

\footnotetext{
719 Slechts vijf zaken hebben geen betrekking op de Toescheidingsovereenkomst tussen Nederland en Suriname: HR 21.01.1969, NJ 1969, nr. 144; HR 27.11.1979, NJ 1980, nr. 550, m.nt. MS onder NJ 1980, nr. 551; HR 11.10.1985, NJ 1987, nr. 34, m.nt. JCS; HR 07.02.1986, NJ 1987, nr. 148, m.nt. GRdG en HR 29.09.1989, NJ 1989, nr. 877. Van deze vijf zaken zijn slechts de drie oudste bewijsrechtelijk interessant; zie voetnoot 722 .

${ }^{n 0}$ In drie gevallen zijn wel bepalingen uit de Toescheidingsovereenkomst tussen Nederland en Suriname als grondslag voor de verwerving van het Nederlanderschap gesteld: HR 13.10.1981, NJ 1982, nr. 137. m.nt. AHJS (interpretatie art. 6 lid 2 TOS); HR 20.06.1986, NJ 1987, nr. 902, m.nt. GRdG (interpretatie van art. 6 lid 4 TOS); HR 26.06.1987, NJ 1988, nr. 135, m.nt. GRdG (interpretatie art. 6 lid 4 TOS).
} 
landerschap dan ook vaker bewijsrechtelijke vragen te worden beantwoord. Het bewijsrecht en in het bijzonder de bewijslastverdeling nemen dientengevolge in belang toe.

Van de hierboven genoemde twintig uitspraken blijken er vijftien bewijsrechtelijk interessant te zijn en slechts vijf niet. Deze laatste vijf ${ }^{21}$ zijn buiten het verdere onderzoek gehouden, zodat het navolgende bewijrechtelijk onderzoek ter zake van het verlies van de Nederlandse nationaliteit is gebaseerd op de resterende vijftien $^{72}$ uitspraken.

Van deze vijftien uitpraken wordt in het onderstaande een geselecteerd aantal weergegeven. Allereerst volgt een bespreking van drie zaken die geen betrekking hebben op de Toescheidingsovereenkomst Nederland-Suriname. Daarna volgt een bespreking van de uitspraken waarbij de Toescheidingsovereenkomst een rol speelt. Daarbij worden niet alle twaalf resterende uitspraken behandeld, maar een geselecteerd aantal, dat als representatief is te beschouwen.

Ook in de hier te behandelen jurisprudentie ter zake van behoud van het Nederlanderschap blijkt de beantwoording van de vraag of de betrokkene in het bezit is (geraakt) van een vreemde nationaliteit van groot belang. Bij de beoordeling of iemand in het bezit is van een vreemde nationaliteit, gaat het vaak alleen om een rechtsvraag. Op grond van dezelfde overwegingen als in paragraaf 3.3.3.2 vermeld, is ook in de onderhavige paragraaf jurisprudentie betreffende dat onderwerp opgenomen. ${ }^{723}$

De Groot/Tratnik hebben met betrekking tot procedures waarin door de klager wordt gesteld dat hij niet heeft voldaan aan enige verliesbepaling betreffende Nederlandse nationaliteit de volgende regel ter verdeling van de bewijslast opgesteld: "Indien het Nederlanderschap van iemand, te wiens aanzien vaststaat, dat hij ooit de Nederlandse nationaliteit heeft verworven, wordt betwist, dan dient degene die dat betwist de feiten of omstandigheden die de Nederlandse nationaliteit van de betrokkene zouden hebben doen verliezen, aan te tonen. ${ }^{m 24}$ Met deze uitspraak

\footnotetext{
${ }^{71}$ HR 07.02.1986, NJ 1986, nr. 345; HR 07.02.1986, NJ 1987, nr. 148, m.nt. GRdG; HR 05.06.1987, NJ 1987, nr. 832: HR 05.06.1987, NJ 1988, nr. 134, m.nt. GRdG; HR 29.09.1989, NJ 1989. nir. 877.

72 HR 21.01.1969, NJ 1969, nr. 144; HR 27.11.1979, NJ 1980, nr. 550, m.nt. MS onder NJ 1980 , nr. 551; HR 04.03.1980, NJ 1981, nr. 98, m.nt. MS; HR 19.02.1982, NJ 1983, nr. 193, m.nt. AHJS; HR 01.06.1982, NJ 1983, 314; HR 01.07.1983, NJ 1984, nr. 229; HR 28.10.1983, NJ 1984, nr. 230, m.nt. AHJS; HR 23.12.1983, NJ 1984, nr. 387; HR 21.09.1984, NJ 1985, nr. 111, m.nt. AHJS; HR 26.10.1984, NJ 1985, nr. 112; HR 08.03.1985, NJ 1985, nr. 495; HR 11.10.1985, NJ 1987, nr. 34, m.nt. JCS; HR 08.05.1987, NJ 1987, nr. 682; HR 29.09.1989, NJ 1989, nr. 878; HR 23.09.1988, NJ 1989, nr. 53.

${ }^{72}$ HR 27.11.1979, NJ 1980, nr. 550, m.nt. MS onder NJ 1980, nr. 551. (par. 3.3.3.3.2).

tou De Groot/Tratnik, p. 131.
} 
sluiten De Groot/Tratnik volledig aan bij de eerder door Van Sasse van Ysselt gegeven regel. ${ }^{725}$

Uit hetgeen hieronder volgt, zal blijken dat de bovenstaande stelregel inderdaad de bewijslastverdeling inzake een beweerd verlies van de Nederlandse nationaliteit juist weergeeft.

\subsection{HR 21 januari 1969}

Cat. B. uitspr. V. Casusbeschrijving. T.a.v. het verweer en leveren van tegenbewijs ligt het bewijsrisico bij de klager.

Deze zaak ${ }^{726}$ heeft betrekking op de vraag of de klager in 1951 een rechtsgeldige optie heeft afgelegd voor de Indonesische nationaliteit. Klager meent van niet en staat derhalve op het standpunt het Nederlanderschap nog steeds te bezitten. De Nederlandse Staat is evenwel een tegenovergestelde mening toegedaan. ${ }^{27}$

Feitelijk staat vast dat de betrokkene in 1951 een schriftelijke optieverklaring voor de Indonesische nationaliteit heeft opgestuurd naar de bevoegde instantie, de President van het Landgerecht te Djakarta. De toenmalige Indonesische autoriteiten hebben de optie niet willen accepteren. Tevens is de schriftelijke verklaring geretourneerd aan de klager. De autoriteiten oordeelden namelijk dat de optie overbodig zou zijn, aangezien de klager in zijn verklaring stelt op het moment van de souvereiniteitsoverdracht te zijn geweest "vreemdeling, Nederlands onderdaan, geen Nederlander (van Europesche afstamming)". De retournering door de Indonesische overheid is gebaseerd op de overweging dat gezien de nationaliteitsrechtelijke rechtspositie die de klager, naar eigen zeggen op het moment van de souvereiniteitsoverdracht bezit, hij van rechtswege de Indonesische nationaliteit heeft verkregen en er derhalve geen optie voor kan afleggen.

Naar het schijnt, komt de klager er jaren later achter dat hij ten tijde van de optie zich heeft vergist inzake zijn nationaliteitsrechtelijke positie. De klager stelt in het beklag bij de Hoge Raad dat hij zowel op het moment van de souvereiniteitsoverdracht als het moment van de optie in het bezit is geweest van het Nederlanderschap. Aangezien de Indonesische autoriteiten de optie niet hebben geaccepteerd, is klager, naar hij stelt, nog immer Nederlander. Daarnaast bestrijdt de klager met een tweede grond de rechtsgeldigheid van de optie en wel met het argument dat hij onder dwang de bewuste optie heeft afgelegd.

Zie par. 3.3.2.

${ }^{n 6}$ HR 21.01.1969, NJ 1969, nr. 144.

${ }^{m}$ De Staat beroept zich op de verliesgrond van art. 3 Overeenkomst betreffende de Toescheiding van staatsburgers tussen Nederland en Indonesiě. Vgl. HR 28.10.1994, RvdW 1994, nr. 216 (par. $3.3 .4 .3 .2)$. 
Bewijsrechtelijk is in deze zaak allereerst de rol die het openbaar ministerie heeft vervuld interessant. Een dossier inzake klagers nationaliteit afkomstig van het ministerie van Justitie is bij de conclusie van de A.-G. ter kennisneming van de Hoge Raad gebracht. Het dossier is derhalve niet in het geding gebracht door het hoofd van de afdeling Privaatrecht van het ministerie, die in dit geding wel is opgeroepen als "getuige-deskundige". In dit dossier wordt uit gegevens, die o.a. door het ministerie van Buitenlandse Zaken in Indonesië zijn verzameld, duidelijk dat de klager inderdaad op het moment van de optie de Nederlandse nationaliteit heeft bezeten.

De vraag die vervolgens aan de orde komt, is: hoe te oordelen over de geretourneerde optie? Een essentieel punt hierbij is dat artikel 3 TOI bepaalt dat meerderjarige $^{728}$ Nederlanders tot $27.12 .1951^{729}$ een optierecht op de Indonesische nationaliteit hebben gehad.

Met betrekking tot de rechtsgeldigheid van de optie overweegt de Hoge Raad: "dat een verklaring van verkiezing van de Indonesische nationaliteit, als bedoeld in art. 3 van vorengenoemde Overeenkomst, het karakter heeft van een eenzijdige wilsverklaring; (.............);

dat dan ook de omstandigheid, dat in het onderhavige geval klagers optieverklaring door de Landrechter te Djakarta is geretourneerd, niet de gevolgtrekking vermag te dragen dat klager op 10 mei 1951 niet rechtsgeldig voor de Indonesische nationaliteit zou hebben geöpteerd;"

Een tweede bewijsrechtelijk interessant onderdeel in deze casus heeft betrekking op de beweerde uitoefening van dwang. Wat dit betreft moet worden opgemerkt dat de klager wel deze dwang stelt, maar dat hij ten aanzien daarvan niets aanvoert dat de stelling moet onderbouwen. Dat de Hoge Raad wel genegen zou zijn het uitoefenen van dwang, indien daarvoor enig bewijs aanwezig zou zijn, ten gunste van klagers behoud van zijn Nederlanderschap te laten spreken, blijkt naar mijn mening uit de formulering van het dictum. Dat luidt in deze zaak: "Verklaart het beklag, zoals dat is toegelicht, ongegrond. "

\section{Aantekening.}

Dat de klager ooit het Nederlanderschap heeft bezeten, wordt in feite bewezen door de overheid en niet door de klager.

Aan de formulering van het dictum kan volgens mij de gevolgtrekking worden verbonden dat indien de klager wel erin zou slagen de dwanguitoefening ten tijde van het opteren aannemelijk te maken, er tot behoud van het Nederlanderschap zou

\footnotetext{
${ }^{72}$ Ingevolge art. 1 TOI is dit achttien jaar en ouder, of voor het achttiende jaar gehuwd. Zie De HaasEngel, p. 132.

ro Art. 3 jo. art. 13 TOI.
} 
zijn beslist. Maar wat de dwanguitoefening betreft, is het beklag onvoldoende toegelicht, namelijk in het geheel niet. ${ }^{730}$

I.c. staat ten gevolge van de, als rechtsgeldig geoordeelde, optie het verlies van de Nederlandse nationaliteit voldoende vast. De Staat voldoet derhalve aan de op hem rustende "primaire bewijslast" ten aanzien van het eigen standpunt (verlies van de Nederlandse nationaliteit). Door gebrek aan bewijs slaagt de klager niet in het tegenbewijs. Zou de klager wel slagen in zijn tegenbewijs, dan zou inzake zijn Nederlanderschap een andere uitkomst zijn vastgesteld en wel het behoud van het Nederlanderschap. M.i. verloopt de bewijslastverdeling in deze casus ook volgens het stramien van de toetsing van standpunt van de Staat op houdbaarheid in een "primaire toetsing" en de mogelijkheid van de klager tot tegenbewijs.

\subsection{HR 27 november 1979}

Cat. B. uitspr. VI. Casusbeschrijving. Bewijs van een vreemde nationaliteit ligt niet bij de klager.

In de volgende zaak $^{731}$ is de klager geboren in 1951 te Suriname uit een ongehuwde moeder. Ingevolge artikel 1 sub c Wet op het Nederlanderschap en het ingezetenschap verkrijgt hij bij de geboorte het Nederlanderschap. In 1952 vindt erkenning plaats van de klager door de uit China afkomstige man met wie de moeder in 1954 in het huwelijk zal treden. Bij de gelegenheid van het huwelijk wordt de klager gewettigd. ${ }^{732}$

In de onderhavige zaak is de invloed op klagers nationaliteit van de erkenning en de wettiging door zijn vader de spil van de zaak. De vader overlijdt te Suriname in 1967, de moeder is sinds 1968 woonachtig in Nederland. Ook klager is sinds 1969, met een aan hem verstrekte vergunning tot verblijf, woonachtig in Nederland. In het midden van de jaren zeventig ontstaan moeilijkheden in verband met de verlenging van de verblijfsvergunning. Dit geeft de klager aanleiding een procedure op grond van artikel 43 (oud) Vreemdelingenwet aanhangig te maken, waarin hij

\footnotetext{
${ }^{30}$ In HR 28.10.1983, NJ 1984, nr. 230, m.nt. AHJS, is ook sprake van een beweerde dwangsituatie bij het opteren, in dit geval voor de Surinaamse nationaliteit. Desbetreffend bespreekt de A.-G.: "de vraag of het wilsgebrek dwang ook op eenzijdige rechtshandelingen kan worden toegepast. De wet gaat daar, althans als algemene regel niet van uit, maar in de literatuur wordt het wel verdedigd. Het N.B.W. stelt dit in artikel 3.2.10 lid 1, buiten twijfel. " In zijn uitspraak uit 1983 aanvaardt de HR, maar doet dit m.i. dus ook al in 1969, de gedachte dat dwang bij een optie het rechtsgevolg van die optie niet doet intreden. Vgl. tevens par. 7.3.1.
}

${ }^{31}$ HR 27.11.1979, NJ 1980, nr. 550, m.nt. MS onder NJ 1980, nr. 551.

${ }^{m 2}$ Naar, zoals de A.-G. opmerkt in zijn conclusie, Surinaams burgerlijk recht. 
stelt de staat van Nederlander te hebben. De Nederlandse overheid blijft een tegenovergesteld standpunt innemen. ${ }^{733}$

De vraag waar het om gaat, is natuurlijk of de klager aan de erkenning en/of wettiging door zijn vader een andere nationaliteit ontleent. Zo niet dan is op de klager (fictief vanaf zijn geboorte) artikel 2 sub c Wet op het Nederlanderschap en het ingezetenschap ${ }^{734}$ van toepassing en is hij (nog steeds) Nederlander.

Zoals is vermeld, is klagers vader afkomstig geweest uit China. Dat gebied heeft hij in het midden van de jaren dertig, derhalve voor de vestiging van de Volksrepubliek op het vasteland en de Nationalistische Republiek op het eiland Taiwan verlaten. Zoals wel meer tijdens de bespreking van de jurisprudentie is gebleken, ${ }^{735}$ handelt ook deze casus eerder om de beoordeling van de nationaliteit van een nationaliteitsrechtelijk relevante ouder, dan primair om een vaststelling inzake de betrokkene. De Nederlandse overheid gaat ervan uit dat klagers vader de nationaliteit van de Chinese Volksrepubliek heeft bezeten.

Is deze nationaliteit ook de klager ten deel gevallen? Ten einde voorlichting te krijgen op het terrein van het Chinese nationaliteitsrecht heeft de Hoge Raad in deze zaak twee deskundigen geraadpleegd. Uit de conclusie van het OM blijkt dat de uitspraken van de deskundigen aanleiding geven te betwijfelen of hetzij klagers vader de Chinese nationaliteit heeft behouden dan wel of de klager zelf deze nationaliteit via zijn vader heeft kunnen verwerven. Kort samengevat, op grond van de bevindingen van de deskundigen blijft onzekerheid bestaan over de verwerving van de Chinese nationaliteit.

A.-G. Mok blijkt in zijn conclusie nogal kritisch over de gang van zaken. In de conclusie komen desbetreffend de volgende opmerkingen voor: "Wat mij in deze zaak frappeert is het volgende. Het ministerie van Justitie ontkent het Nederlanderschap van betrokkene en zegt dat hij Chinees is. Gezien het feit dat verzoeker in het Koninkrijk is geboren, bij zijn geboorte de Nederlandse nationaliteit bezat en altijd in het Koninkrijk (.......) heeft gewoond, is dat een standpunt met ingrijpende consequenties. Men zou mogen verwachten dat zo'n standpunt slechts wordt ingenomen als daarover volstrekte zekerheid bestaat. Aangezien Nederland een ambassade in Peking heeft en de Chinese Volksrepubliek een ambassade in Den Haag, had de Nederlandse regering kunnen proberen te weten te komen hoe de Chinese autoriteiten tegenover een geval als het onderhavige staan. Uit het feit dat beroep is gedaan op een informatie uit 1955 kan men wel afleiden dat dit niet is gebeurd. Ik kan niet beoordelen hoe gemakkelijk of moeilijk het is dergelijke

\footnotetext{
${ }^{73}$ De Staat beroept zich op de verliesgrond uit art. 7 aanhef, sub 1 Wet Ned. 1892 en meent dat de klager de Nederlandse nationaliteit heeft verloren als gevolg van het als minderjarige verwerven van de Chinese nationaliteit.

${ }^{34}$ Art. 2 Wet Ned. 1892: "Nederlanders zijn ook: $c$. het in het Koninkrijk geboren kind, waarvan op het tijdstip van de geboorte de moeder de staat van Nederlander bezit en dat aan zijn niet-Nederlandse vader geen nationaliteit ontleent, (...........)".

ns Zie par. 3.3.3.2.3.
} 
gegevens van de Chinese autoriteiten te verkrijgen, maar ik zou menen dat dit voor de regering althans veel eerder mogelijk moet zijn dan voor een individu, zodat het op de weg van de overheid ligt te pogen langs deze weg klaarheid te verschaffen."

Het oordeel van de Hoge Raad luidt in deze zaak: "Uit het door de HR ingestelde onderzoek ${ }^{736}$ is, voor een bevestigend antwoord op de vraag of klager bij de toepassing van de Vreemdelingenwet als vreemdeling mag worden behandeld, niet voldoende gebleken dat hij, die bij zijn geboorte de Nederlandse nationaliteit bezat, aan de latere erkenning en wettiging door C.Y.T. een andere nationaliteit heeft ontleend, dan wel geacht moet worden ingevolge het bepaalde bij art. 2, aanhef en onder $c$, Wet op het Nederlanderschap en het ingezetenschap de staat van Nederlander nimmer te hebben bezeten.

(.........) verklaart het beklag gegrond."

\section{Aantekening.}

Ook uit de onderhavige casus blijkt dat het mogelijk bezit van een vreemde nationaliteit in sterke mate samenhangt met de interpretatie van vreemd recht. ${ }^{737}$

In de hiervoor behandelde jurisprudentie is reeds gebleken dat de bewijslast inzake staatloosheid dan wel het bezitten van een vreemde nationaliteit bij de overheid ligt. De Hoge Raad sluit in deze casus aan bij deze lijn door de bewijslast inzake de mogelijk vreemde nationaliteit van de klager inderdaad bij de overheid te leggen en niet van de klager te eisen dat hij zijn Nederlanderschap bewijst door aan te tonen dat hij niet de Chinese nationaliteit bezit.

Tevens heeft de Hoge Raad de taak om ambtshalve de rechtsgronden, al zijn dat i.c. rechtsgronden uit het Chinese recht, aan te vullen. Om zich over het Chinese recht te laten voorlichten, worden de deskundigen benoemd. Voorheen is reeds gebleken dat de Nederlandse rechter autonoom een oordeel velt of een persoon een bepaalde vreemde nationaliteit bezit ${ }^{738}$ en dat in een zodanig geval de mate van zekerheid omtrent het bezit van die vreemde nationaliteit "voldoende aannemelijk" dient te zijn. ${ }^{739}$

Aangezien de overheid er niet in slaagt haar stellingname dat de klager de Chinese nationaliteit heeft verkregen waar te maken, en de rechter aan de hand van deskundige voorlichting van het vreemde recht niet tot de conclusie geraakt dat de klager de Chinese nationaliteit zou hebben verworven, kan niet worden vastgesteld

\footnotetext{
${ }^{736}$ Waarmee wordt gedoeld op de informatie verstrekt door de deskundigen.

73 Vgl. HR 10.09.1959, NJ 1959, nr. 596 (par. 3.3.2.2.4); HR 15.09.1980, NJ 1981, nr. 68 (par. 3.3.3.2.2); HR 08.12.1989, MR 1990, p. 40, m.nt. HAA (par. 3.3.3.2.5). Terecht merkt Lemaire, p. 310 , op dat op de beoordeling van het bezit van een vreemde nationaliteit, waaronder "het bewijs van feiten, nodig ter vaststelling van de nationaliteit van een bepaald vreemd land", dient te geschieden volgens het bewijsrecht van de vreemde staat. Idem Kollewijn, p. 22.

${ }^{78}$ HR 10.09.1959, NJ 1959, nr. 596 (par. 3.3.2.2.4).

${ }^{39}$ HR 15.09.1980, NJ 1981, nr. 68 (par. 3.3.3.2.2).
} 
dat de klager aan een verliesgrond voor het Nederlanderschap heeft voldaan. Op grond van de continueringspresumtie moet dan worden uitgegaan van het voortduren van het Nederlanderschap.

In de casus blijkt dat de klager geruime tijd door de overheid is beschouwd en behandeld als vreemdeling, immers sinds 1969 beschikt de klager over een vergunning tot verblijf. Uit het onderhavige geval kan dan ook tevens de conclusie worden getrokken dat, in tegenstelling tot de in de rechtspraak erkende mogelijkheid waarin overheidshandelen leidt tot de aanname dat er sprake is van het bezit van de Nederlandse nationaliteit (bewijs van het Nederlanderschap door middel van bezit van staat), het tegenovergestelde, namelijk dat overheidshandelen leidt tot de aanname dat men geen Nederlander (meer) is, niet tot de mogelijkheid behoort. Immers, een zodanige aanname wordt zonder meer verhinderd door de in paragraaf 3.3.2 geformuleerde continueringspresumtie van het Nederlanderschap.

\subsection{HR 11 oktober 1985}

Cat. B. uitspr. VII. Casusbeschrijving. Beroep op rechtszekerheidsbeginsel in beginsel mogelijk.

De navolgende $\mathrm{zaak}^{740}$ in deze categorie is vooral interessant wegens het uitdrukkelijk beroep op het rechtszekerheidsbeginsel dat de betrokkene doet.

De casus heeft betrekking op een man die in 1952 is geboren op het Nederlandse gedeelte van het eiland Sint Maarten. Zijn moeder is ongehuwd en van onbekende nationaliteit. ${ }^{741}$ Op grond van het feit dat de klager is geboren in het Koninkrijk als niet-erkend onwettig kind te wiens aanzien niet blijkt van het bezit van een vreemde nationaliteit verkrijgt hij van rechtswege bij de geboorte het Nederlanderschap. ${ }^{72}$ In 1953 verkrijgt klagers moeder de Franse nationaliteit. Deze nationaliteitsverwerving door de moeder heeft op dat moment geen invloed op de nationaliteit van haar zoon, die behoudt het Nederlanderschap en verwerft niet de Franse nationaliteit. Een volgend rechtsfeit dat daarentegen wel van belang is, is dat klagers moeder in 1969 volgens Frans recht haar zoon erkent. De dan minderjarige zoon verwerft hierdoor de Franse nationaliteit. De eerste vraag waarover de Hoge Raad in deze zaak uitspraak dient te doen, is of tevens op dat moment de klager het Nederlanderschap heeft verloren. Bij een bevestigend antwoord op deze vraag komt een volgende vraag aan de orde. Deze vraag is of aan het feit dat pas in 1980 de Nederlandse autoriteiten klager zijn gaan behandelen als vreemdeling een voor de klager gunstig rechtsgevolg (en wel behoud van de Nederlandse nationaliteit) kan

\footnotetext{
${ }^{70}$ HR 11.10.1985, NJ 1987, nr. 34, m.nt. JCS. Vgl. Jessurun d'Oliveira, AA 1986, p. 224-229.

${ }^{74}$ De A.-G. veronderstelt in zijn conclusie dat zij wellicht Brits onderdaan was.

Art. 1 sub d Wet Ned. 1892.
} 
worden verbonden. De klager doet namelijk op grond van deze langdurige behandeling als Nederlander een beroep op het rechtszekerheidsbeginsel.

Over de vraag of in 1969 verlies van de Nederlandse nationaliteit heeft plaatsgevonden, oordeelt de Hoge Raad bevestigend. En ten aanzien van het beroep op het rechtszekerheidbeginsel stelt de Hoge Raad: "Ook dit betoog faalt, reeds omdat is gesteld noch gebleken dat bedoelde autoriteiten, die ervan mochten uitgaan dat klager bij zijn geboorte, op de voet van art. 1 lid 1 aanhef en onder $d$ de Nederlandse nationaliteit had verkregen, voor 1980 kennis hadden gekregen van de door klagers moeder -ten overstaan van vreemde autoriteiten- gedane erkenning van klager.

Het vorenoverwogene leidt tot de slotsom dat klager als gevolg van de erkenning door zijn moeder de Nederlandse nationaliteit heeft verloren. Nu niet is gesteld of gebleken dat hij die nationaliteit sedertdien heeft herkregen, is het beklag ongegrond."

\section{Aantekening.}

Wederom een casus waarin het niet zozeer gaat om een bewijsrechtelijke vraagstuk maar, aangezien de feiten als zodanig vaststaan, waarin het eerder is te doen om de interpretatie van het recht.

Aangezien het een kwestie van rechtsinterpretatie betreft (heeft de erkenning door de Franse moeder geleid tot verlies van de Nederlandse nationaliteit?) blijven de bewijsmiddelen waarmee het bezit van het Nederlanderschap kan worden bewezen buiten de orde. In een geval als het onderhavige is, naar mijn inzicht, dan ook geen ruimte voor een beroep op een middellijk bewijsmiddel als het bewijs door bezit van staat.

Voor een beroep op het rechtszekerheidbeginsel schept de Hoge Raad, naar mijn mening, in zoverre ruimte dat in het eventuele geval, waarin wel wordt gesteld en waarin tevens blijkt dat Nederlandse autoriteiten kennis hebben gekregen van het verlies van het Nederlanderschap, maar desalniettemin de betrokkene zijn blijven behandelen als in het bezit van de Nederlandse nationaliteit, inderdaad tot behoud van het Nederlanderschap kan worden geconcludeerd, ${ }^{743}$ zulks onder de voorwaarde dat de betrokkene dat wenst (al moet worden gezegd dat in zo'n geval een naturalisatie op zijn plaats zou zijn).

Of de Hoge Raad inderdaad bereid is de bovenstaande stap te nemen en derhalve behoud van het Nederlanderschap aan te nemen op grond van de werking van de

\footnotetext{
${ }^{76}$ HR 08.03.1985, NJ 1985, nr. 495, betreft een zaak waarin de betrokkene (ten onrechte) geruime tijd is behandeld als in het bezit van het Nederlanderschap omdat de door hem gedane optie voor de Surinaamse nationaliteit pas vier jaar na dato werd gepubliceerd in het Staatsblad van de Republiek Suriname. Pas na de bekendmaking van de gedane optie zijn de Nederlandse autoriteiten ertoe overgegaan de betrokkene te behandelen als vreemdeling.
} 
algemene beginselen van behoorlijk bestuur dient vooralsnog te worden afgewacht. $^{74}$

\subsubsection{Subcategorie B(-TOS): Beroep op behoud van het Nederlanderschap door betwisting van de toepasselijkheid van de Toescheidingsovereenkomst Nederland-Suriname}

Als vermeld in paragraaf 3.3 .3 .3 bevat de jurisprudentie ter zake van een beroep op behoud van het Nederlanderschap twaalf ${ }^{75}$ bewijsrechtelijk interessante uitspraken die alle betrekking hebben op bepalingen uit de Toescheidingsovereenkomst inzake nationaliteiten tussen Nederland en Suriname. Niet alle twaalf uitspraken worden besproken. $\mathrm{Er}$ is een keuze gemaakt en de meest sprekende voorbeelden zijn voor behandeling geselecteerd. Behandeling van de uitspraken die geen nieuwe gezichtspunten zouden opleveren, is achterwege gelaten. Op deze wijze worden zeven beklagschriften, waarin het verlies van de Nederlandse nationaliteit ingevolge de Toescheidingsovereenkomst Nederland-Suriname wordt betwist, behandeld. Naar mijn inzicht wordt zodoende een representatief beeld verkregen van de in totaal twaalf uitspraken.

Uit de twaalf uitspraken blijkt dat in het kader van de Toescheidingsovereenkomst de waardering van de feitelijke omstandigheden vaak een bepalende factor is geweest. Aangezien de waardering van de feitelijke omstandigheden in veel gevallen van doorslaggevend gewicht blijkt, is het voor de hand liggend dat tevens in die gevallen het bewijs van die feiten een belangrijke rol krijgt. In het bijzonder blijkt met betrekking tot de artikelen 3,5 lid $1^{746}$ en 5 lid 2 TOS dat sprake is van relatief veel jurisprudentie met een bewijsrechtelijke dimensie.

Als eerder reeds is opgemerkt, is de beklagprocedure naar mijn inzicht in wezen contentieus gevoerd. Hoewel de contentieusheid ook wel blijkt uit de andere (hiervoor behandelde) uitspraken krachtens artikel 43 (oud) Vreemdelingenwet, valt zij eerst goed op bij de procedures waarin de Toescheidingsovereenkomst tussen Nederland en Suriname speelt. Zo vindt in alle uitspraken vermelding op grond van welk(e) artikel(en) uit de Toescheidingsovereenkomst de staatssecretaris van Justitie het verlies van het Nederlanderschap gegrond acht.

\footnotetext{
74 In HR 16.09.1994, NJ 1995, nr. 563, m.nt. GRdG, wijst de HR alvast verwerving van het Nederlanderschap "door de werking van enig algemeen beginsel van behoorlijk bestuur" af.

${ }^{20}$ HR 04.03.1980, NJ 1981, nr. 98, m.nt. MS; HR 19.02.1982, NJ 1983, nr. 193, m.nt. AHJS; HR 01.06.1982, NJ 1983, 314; HR 01.07.1983, NJ 1984, nr. 229; HR 28.10.1983, NJ 1984, nr. 230 , m.nt. AHJS; HR 23.12.1983, NJ 1984, nr. 387; HR 21.09.1984, NJ 1985, nr. 111, m.nt. AHJS; HR 26.10.1984, NJ 1985, nr. 112; HR 08.03.1985, NJ 1985, nr. 495; HR 08.05.1987, NJ 1987, nr. 682; HR 29.09.1989, NJ 1989, nr. 878; HR 23.09.1988, NJ 1989, nr. 53.

the Volgens Haarmans, p. 67 , is van het optierecht uit art. 5 lid 1 TOS weinig gebruik gemaakt.
} 
Van zowel de klager als van de staatssecretaris verwacht de Hoge Raad in beginsel dat beiden hun standpunt kunnen staven aan de hand van bewijsmiddelen. Ondanks het uitgangspunt dat beide partijen hun stellingen moeten kunnen staven, ligt mijns inziens ten aanzien van verliesbepalingen de bewijslast in essentie bij de Staat. Uitgangspunt is dat door de Staat voldoende aannemelijk kan worden gemaakt dat de betrokkene aan de voorwaarde(n) leidend tot verlies van de Nederlandse nationaliteit heeft voldaan. Hiertegen kan de betrokkene dan verweer voeren en tegenbewijs leveren.

\subsection{HR 4 maart 1980}

Cat. B(-TOS). uitspr. VIII. Casusbeschrijving. Art. 3 TOS: bewijs van het voornemen zich blijvend buiten Suriname te vestigen ligt niet bij de klaagster; de bewijslast inzake het voornemen slechts tijdelijk Suriname te verlaten en derhalve "woonplaats" in Suriname te behouden ligt, als verliesgrond voor het Nederlanderschap, bij de Nederlandse overheid.

In één van de eerste zaken waarin de Hoge Raad moet oordelen ter zake van de Toescheidingsovereenkomst Nederland-Suriname wordt met betrekking tot artikel 3 TOS een belangrijk toetsingscriterium ontwikkeld.

Voor de toepassing van artikel 3 TOS is essentieel de vraag of de betrokkene geacht kan worden "woonplaats" in Suriname te hebben gehad op 25.11.1975, dan wel dat moet worden aangenomen dat de betrokkene vóór dat tijdstip zijn "woonplaats" heeft overgebracht naar een plaats buiten Suriname. Dat niet altijd duidelijk is of de "woonplaats" moet worden geacht te zijn verplaatst, blijkt vooral uit de jurisprudentie betreffende personen ten aanzien van wie sprake is van een korte verblijfsperiode buiten Suriname (meestal in Nederland) omstreeks 25.11.1975, de onafhankelijkheidsdag van Suriname. Aanname van een "woonplaats" in Suriname ten tijde van de onafhankelijkheidsdag leidt tot verwerving van de Surinaamse nationaliteit. Daarentegen leidt aanname van een "woonplaats" elders tot behoud van het Nederlanderschap.

In de onderstaand besproken casus $^{747}$ is de vraag aan de orde of de klaagster inderdaad, zoals het standpunt van de staatssecretaris van Justitie luidt, haar Nederlanderschap heeft verloren ingevolge artikel 3 TOS. De klaagster heeft, komend uit Suriname, van 25.09.1975 tot 13.12.1975 in Nederland verbleven en is toen in verband met een ernstige ziekte van een familielid teruggekeerd naar Suriname.

Ter toetsing van de vraag of op 25.09.1975 de "woonplaats" kan worden geacht te zijn verplaatst, ontwikkelt de Hoge Raad in deze uitspraak het hieronder

${ }^{747}$ HR 04.03.1980, NJ 1981, nr. 98, m.nt. MS. 
vermelde criterium. De "woonplaats" wordt geacht te zijn verplaatst indien "klaagster ten tijde van haar vertrek uit Suriname in 1975 het voornemen had zich blijvend in Nederland te vestigen. " De Hoge Raad neemt daarbij als uitgangspunt dat het bestaan van dit voornemen dient te worden vastgesteld "aan de hand van feitelijke omstandigheden".

De Hoge Raad is i.c. wat de feiten betreft niet over één nacht ijs gegaan. De klaagster is eerst gehoord door een raadsheer-commissaris ${ }^{748}$ en is vervolgens nogmaals gehoord op de terechtzitting. Daarnaast heeft op verzoek van de Hoge Raad de P.-G. bij de Hoge Raad een politieonderzoek "doen instellen naar de vraag of klaagster op 25 nov. 1975 in Nederland woonde".

Aan de hand van het in deze zaak geformuleerde toetsingscriterium voor artikel 3 TOS en de vastgestelde feiten komt de Hoge Raad tot het volgende oordeel: "Op grond van het hiervoor vastgestelde en van hetgeen klaagster bij haar verhoor heeft verklaard, en in aanmerking genomen dat van de zijde van de minister van Justitie geen feitelijke omstandigheden zijn aangevoerd welke tot een ander oordeel zouden moeten leiden, terwijl zodanige feitelijke omstandigheden evenmin zijn geleken bij het door de Proc.-Gen. ingestelde politieonderzoek, acht de HR aannemelijk dat klaagster (.........) op 25 nov. 1975 noch woonplaats noch werkelijk verblijf had in Suriname, zodat zij de Surinaamse nationaliteit niet heeft verkregen."

\section{Aantekening.}

Aan deze uitspraak valt vooral op dat de Hoge Raad zelf een feitenonderzoek heeft geỉnitieerd en ook heeft verricht. Toch is dat conform de mogelijkheden van een administratieve rechter in eerste aanleg, de positie die de Hoge Raad in de beklagprocedure heeft ingenomen.

Het onderhavige feitenonderzoek concentreert zich op de vraag of de klaagster ten tijde van haar vertrek uit Suriname al dan niet het voornemen had zich blijvend in Nederland te vestigen. Volledigheidshalve vermeldt de uitspraak dat noch uit het eigen feitenonderzoek door de Hoge Raad, noch van de kant van de administratie gegevens zijn gebleken waardoor de stellingen van de klaagster worden gelogenstraft. Naar mijn mening leidt dit in de gedachtengang van de Hoge Raad tot de gevolgtrekking dat het bewijs voor het verlies van het Nederlanderschap door de overheid niet kan worden geleverd aangezien de mogelijkheid open blijft dat de versie van de verzoekster de juiste is. Hieruit blijkt eens te meer dat de bewijslast inzake het verlies van het Nederlanderschap bij de overheidsadministratie ligt en dat het niet de klaagster is die de bewijslast voor het behoud van haar Nederlanderschap draagt.

${ }^{24}$ Cf. art. 43 (oud) Vw is dat in het openbaar gebeurd. 
Hoofdstuk 3

\subsection{HR 1 juni 1982}

Cat. B(-TOS). uitspr. X. Casusbeschrijving. Art. 3 TOS. Het gepresenteerde bewijsmateriaal moet voldoende "geloofwaardig" zijn.

Komt de Hoge Raad tot de conclusie dat de klager als tegenbewijs vervalste documenten heeft overgelegd dan kan aan dat bewijsmateriaal niet het door de klager gewenste gevolg worden verbonden.

De Nederlandse Staat neemt in deze, zonder aparte aantekening te bespreken, procedure $^{749}$ met betrekking tot klagers nationaliteit het standpunt in dat deze het Nederlanderschap heeft verloren op grond van artikel 3 van de Toescheidingsovereenkomst inzake nationaliteiten tussen Nederland en Suriname. Ter onderbouwing van dit standpunt legt de Staat schriftelijk bewijs over in de vorm van een verklaring van de burgerlijke stand en het bevolkingsregister van het district Suriname, inhoudende dat de klager daar ingeschreven heeft gestaan van januari 1975 tot juni 1980.

Met betrekking tot dit door de Staat ingebrachte bewijsmateriaal acht de Hoge

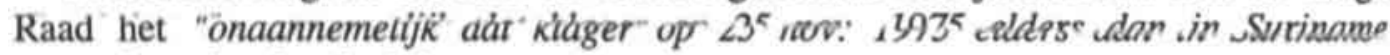
woonplaats heeft gehad.

In de uitspraak gaat de Hoge Raad na de bovenstaand geciteerde opmerking, waarin, naar mijn mening, reeds de aanvaarding van het verlies van het Nederlanderschap op grond van de "primaire toetsing" besloten ligt, in op het door de klager aangevoerde tegenbewijs. Want tegen het standpunt van de staatssecretaris kan de klager vanzelfsprekend verweer voeren. Het verweer luidt dat hij sinds juli 1975 woonachtig is geweest in Frans Guyana. Ter ondersteuning van zijn verweer legt de klager enige schriftelijke stukken over. Onder andere gaat het daarbij om een verklaring van de burgerlijke stand in Suriname. Deze verklaring is, wegens het ontbreken van een briefhoofd en het voorkomen van enkele fouten in de spelling, volgens de Hoge Raad "te weinig geloofwaardig om aannemelijk te doen zijn dat deze afkomstig is van de Surinaamse autoriteiten." Ook de andere bewijsstukken van de klager delen het lot dat onaannemelijk is dat zij daadwerkelijk afkomstig zijn van de daarin vermelde autoriteiten. Dientengevolge slaagt de klager niet in zijn tegenbewijs. Wel is het van belang te constateren dat de Staat erin slaagt het verlies van het Nederlanderschap voldoende aannemelijk te maken in het "primaire toetsingsmoment".

${ }^{749}$ HR 01,06,1982, NJ 1983, nr, 314. Vgl. Van den Blink, p. 14. 


\subsection{HR 28 oktober 1983}

Cat. B(-TOS). uitspr. IX. Casusbeschrijving. Artt. 3, 5 lid 1 en 5 lid 2 TOS. De verklaringen van de klaagster zijn aannemelijk, terwijl de overheidsadministratie daartegen geen tegenbewijs heeft.

De volgende $\mathrm{zaak}^{750}$ die aan de orde wordt gesteld, is opmerkelijk omdat het door de Hoge Raad aanvaarde verweer van de klaagster nagenoeg niet wordt onderbouwd met bewijsmateriaal.

Het standpunt van de staatssecretaris van Justitie inzake de nationaliteit van de klaagster houdt in dat verlies van het Nederlanderschap heeft plaatsgevonden op grond van het bepaalde in hetzij artikel 3 TOS, hetzij artikel 5 lid 1 TOS dan wel artikel 5 lid 2 TOS. Ten gevolge van dit uitdrukkelijk beroep op de onderscheidenlijke verdragsbepalingen toetst de Hoge Raad in deze uitspraak het mogelijk verlies van het Nederlanderschap aan deze drie bepalingen. Ten behoeve van de gevolgtrekking dat de rechtsfeiten waaraan deze bepalingen het verlies van het Nederlanderschap koppelen zich hebben voorgedaan, draagt de Staat verschillende bewijzen aan.

Zo heeft, volgens de staatssecretaris, de klaagster het Nederlanderschap verloren op grond van artikel 3 TOS aangezien zij slechts in Nederland heeft verbleven (dit feit staat vast en wordt niet weersproken) van 02.10.1975 tot 19.02.1976. Dit is, naar de mening van de staatssecretaris van Justitie, een te korte periode geweest om te oordelen dat de klaagster haar woonplaats in Suriname heeft willen opgeven. ${ }^{751}$ Het verweer van de klaagster hiertegen luidt dat zij naar Suriname is teruggereisd in verband met de ziekte van een aldaar wonende zoon. De Hoge Raad overweegt ten aanzien van dit verweer, en dat is opmerkelijk, dat het hier gaat om een "aannemelijke verklaring". ${ }^{752}$ Voorts overweegt de Hoge Raad aangaande de uitschrijving van de klaagster in februari 1976 uit het bevolkingsregister van Amsterdam: "Niet is gebleken dat het initiatief voor dit laatste van klaagster is uitgegaan, en evenmin dat zij zich in Suriname weer in een bevolkingsregister heeft laten inschrijven" en oordeelt met betrekking tot artikel 3 TOS dat klaagster wel degelijk in oktober 1975 haar woonplaats van Suriname naar Neder-

\footnotetext{
${ }^{750}$ HR 28.10.1983, NJ 1984, nr. 230, m.nt. AHJS.

${ }^{731}$ Toetsingscriterium voor art. 3 TOS (en derhalve voor behoud van het Nederlanderschap), zoals dat is ontwikkeld in HR 04.03.1980, NJ 1981, nr. 98, m.nt. MS (zie voetnoot 747), is of de betrokkene bij vertrek uit Suriname het voornemen had zich blijvend buiten Suriname (meestal is dit in Nederland) te vestigen. Idem HR 01.07.1983, NJ 1984, nr. 229; HR 21.09.1984, NJ 1985, nr. 111, m.nt. AHJS.

75 De A.-G. merkt in de conclusie over dit onderdeel in het verweer van de klaagster op: "Voor deze bewering ontbreekt bewijs, maar de onjuistheid is ook niet gebleken."
} 
land heeft overgebracht, zodat zij op 25.11.1975 het Nederlanderschap heeft behouden. ${ }^{753}$

Vervolgens komt de, door de Staat ingeroepen, verliesbepaling uit artikel 5 lid 2 TOS aan de orde. Dit artikel regelt het van rechtswege verlies van het Nederlanderschap en van rechtswege verwerven van de Surinaamse nationaliteit na een verblijf van twee jaar in Suriname. Na haar vertrek uit Nederland in februari 1976 arriveert klaagster eerst op 15.11.1979 weer in Nederland. Vast staat dat zij gedurende deze gehele periode verblijf heeft gehad in Suriname. Desalniettemin komt de Hoge Raad i.c. tot de gevolgtrekking dat geen verlies van de Nederlandse nationaliteit heeft plaatsgevonden. Naar interpretatie van de Hoge Raad sinds $1982^{754}$ is namelijk van verwerving van de Surinaamse nationaliteit en verlies van het Nederlanderschap ingevolge artikel 5 lid 2 TOS slechts sprake indien: "aan de wil van de betrokkene zijn tevoren bestaande woonplaats ${ }^{75}$ prijs te geven, in redelijkheid niet kan worden getwijfeld. ${ }^{1756}$ De Hoge Raad twijfelt i.c. dus wel aan klaagsters wil ter zake en deze twijfel is bovenal gebaseerd op het feit dat in april 1976 de Nederlandse autoriteiten in Suriname het (Nederlandse) paspoort van de klaagster hebben ingenomen en weigerachtig bleken het terug te geven, ten gevolge waarvan zij "buiten haar wil in een situatie is komen te verkeren waarin het voor haar zeer bezwaarlijk, zo niet onmogelijk was zich uit Suriname weer naar Nederland te begeven".

Als gezegd, ten derde is vanwege de Staat verlies van het Nederlanderschap ingeroepen op grond van artikel 5 lid 1 TOS. Dit artikel bepaalt dat een optie kan worden afgelegd voor de Surinaamse nationaliteit. Bij haar terugkomst in Nederland reist de klaagster op een Surinaams paspoort, dat zij heeft verkregen na op 17.03.1978 een optieverklaring voor de Surinaamse nationaliteit te hebben gete-

${ }^{73}$ Zie HR 21.09.1984, NJ 1985, nr. 111, m.nt. AHJS, voor cen casus waarin de HR cen vergelijkbaar korte verblijfsperiode in Nederland rondom de onafhankelijkheidsdag van Suriname niet heeft aangemerkt als het resultaat van "het voornemen zich blijvend buiten Suriname te vestigen " en een onverwachte gebeurtenis waardoor terugkeer naar Suriname noodzakelijk werd. Het enige verschil tussen de betrokkenen uit HR 28.10.1983, NJ 1984, nr. 230, m.nt. AHJS en HR 21.09.1984, NJ 1985, nr. 111, m.nt. AHJS is dat bij het oorspronkelijke vertrek uit Suriname de cerste onvoorwaardelijk naar Nederland vertrok, terwijl de tweede, volgens de HR, met een eventuele terugkeer naar Suriname rekening hield. Dat overigens in het tweede geval de reden tot terugkeer naar Suriname niet de reden is geweest waarvoor de betrokkene een eventuele terugkeer naar Suriname in het achterhoofd hield, heeft het oordeel van de HR niet mogen beinvloeden.

734 HR 19.02.1982, NJ 1983, nr. 193, m.nt. AHJS. Idem: HR 01.07.1983, NJ 1984, nr. 229; HR 26.10.1984, NJ 1985, nr. 112; HR 29.09.1989, NJ 1989, nr. 878; alsmede het hier aan de orde gestelde HR 28.10,1983, NJ 1984, nr. 230, m.nt. AHJS. Zie voor een voorbeeld van een betrokkene die in een nationaliteitsrechtelijk geschil met de Staat Suriname zich voor de Surinaamse rechter beroept op deze interpretatie van de HR: Hof v. Justitie 02.07.1993, SJ 1993, p. 250-257 [253].

735 Dit betreft dan een woonplaats buiten Suriname, in de meeste gevallen zal het gaan om een woonplaats in Nederland.

736 Voor deze interpretatie vindt de Hoge Raad een basis in de bij de Toescheidingsovereenkomst behorende toelichting. 
kend. De Staat beroept zich op de desbetreffende optieverklaring. De Hoge Raad echter is van oordeel dat de optie niet in alle vrijheid is afgelegd en derhalve geen rechtsgevolg heeft gehad. In het bijzonder het feit dat de Nederlandse autoriteiten het paspoort van de klaagster hadden ingetrokken en bovendien weigerachtig bleken het terug te geven, telt zwaar. De Hoge Raad komt tot de volgende, bewijsrechtelijk enigszins opmerkelijke, overweging: "Volgens haar verklaring -die de Hoge Raad aannemelijk voorkomt-zag klaagster ter verwezenlijking van haar wens naar Nederland terug te keren geen andere uitweg uit de aldus voor haar bestaande dwangpositie dan het aanvragen van een Surinaams paspoort (..........)."

Bovendien stelt de HR nog dat "niet is gebleken dat klaagster op enige andere grond haar Nederlandse nationaliteit heeft verloren".

\section{Aantekening.}

Veel concreet bewijsmateriaal voor haar stellingen kan de klaagster niet overleggen. Tegenover de klaagster die weinig van haar verweer kan bewijzen, staat de staatssecretaris die zich in eerste instantie kan beroepen op duidelijke en vaststaande gegevens. Met betrekking tot artikel 3 TOS staat zonder meer vast dat het verblijf in Nederland slechts een zeer korte periode heeft geduurd. Met betrekking tot artikel 5 lid 2 TOS is geen discussie mogelijk over de termijn dat het verblijf in Suriname heeft geduurd en met betrekking tot artikel 5 lid 1 TOS is er een copie van de schriftelijke optieverklaring. Maar in de conclusie van het openbaar ministerie stelt de A.-G. al tegenover het gebrek aan bewijs aan de kant van de klaagster echter meermalen dat de overheid ook niet beschikt over bewijzen waaruit zou blijken dat de stellingen van de klaagster onjuist zouden zijn. Daarbij ontvalt de A.-G. mede de uitspraak: "Wat zich precies heeft afgespeeld, zal wel nooit met zekerheid kunnen blijken."

Onder verwijzing naar de hierboven gesignaleerde bewijslastverdeling waarbij de Staat een "primaire (toetsings)bewijslast" heeft ter zake van het eigen standpunt kan i.c. worden gesteld dat de Staat voldoet aan dat onderhavige bewijs. Ook is al gesteld dat de betrokkene tegen de stellingen van de Staat tegenbewijs kan trachten te leveren. I.c. lukt het de betrokkene de Hoge Raad ervan te overtuigen dat, ondanks de vastgestelde feiten, deze feiten i.c. geen verlies van het Nederlanderschap opleveren omdat ondanks de uiterlijke schijn toch niet aan alle voorwaarden die tot verlies leiden is voldaan. De klaagster slaagt derhalve in haar tegenbewijs. Het heeft er alle schijn van dat voor dit tegenbewijs een lichte toetsing wordt gehanteerd. Daarbij dient niet te worden vergeten dat de overheidsadministratie geen feiten (waarvoor de overheid vanzelfsprekend de bewijslast draagt) aanvoert die de stellingen van de klaagster ontkrachten. 
Hoofdstuk 3

\subsection{HR 23 december 1983}

Cat. B(-TOS), uitspr. X. Casusbeschrijving. Art. 3 TOS. Woonplaats op 25 november 1975. Er bestaan wederzijds tegenstrijdige bewijzen.

In de onderstaande zaak $^{757}$ beschikken ter ondersteuning van hun wederzijdse standpunten de beide partijen over tegenstrijdige bewijzen. Op de precieze feitelijke omstandigheden in deze zaak wil ik niet uitgebreid ingaan, maar wel moet worden opgemerkt dat i.c. de daadwerkelijke feitelijke gang van zaken niet ten aanzien van alle punten duidelijk wordt. Blijkens de bijbehorende conclusie is door het openbaar ministerie een poging gedaan meer duidelijkheid omtrent de feiten te krijgen. Het OM heeft i.c. zelfstandig een onderzoek naar de feiten verricht door inlichtingen bij een (Nederlandse) gemeente in te winnen.

De staatssecretaris neemt het standpunt in dat de klager het Nederlanderschap heeft verloren en wel aangezien: "klager op en na het tijdstip van in werking treden van de Toescheidingsovereenkomst, en in ieder geval in februari 1976, in Suriname verblijf heeft gehouden." Ter ondersteuning van dit standpunt legt de Staat een verklaring over van de Surinaamse autoriteiten inhoudende dat de klager vanaf 05.11.1974 tot de datum van de verklaring (08.04.1982) staat ingeschreven in het bevolkingsregister van het district Suriname. Voorts beroept de Staat zich op een "mededeling door Surinaamse autoriteiten aan de Nederlandse ambassade in Paramaribo, dat aan de klager op 26.02.1976 in Suriname een Surinaams paspoort is afgegeven. " Volgens dit bericht van de Nederlandse ambassade is met betrekking tot dit uitgereikte Surinaamse paspoort artikel 3 TOS als verwervingsgrond voor de Surinaamse nationaliteit genoemd.

De klager echter stelt dat hij sinds eind september 1975 in Nederland woonachtig is. Ten behoeve van zijn stelling kan hij verscheidene bewijsstukken overleggen, onder andere een schriftelijk bewijsstuk gedateerd 01.10.1975 en verstrekt te Den Haag inzake de inschrijving in een ziekenfondsverzekering en een (schriftelijke) beschikking inzake de toekenning van een RWW-uitkering met ingang van 07.10.1975. Tevens beschikt de klager over een door de ambtenaar van de burgerlijke stand van het district Suriname d.d. 27.09.1975 afgegeven "getuigschrift van verandering van werkelijke woonplaats" met de verklaring dat klager "met zijn gezin het district Suriname metterwoon verlaat om zich te vestigen in Nederland. " Ook legt de klager een verklaring over van de gemeente 's-Hertogenbosch d.d. 27.02.1981 waaruit blijkt dat hij van 08.10.1975 tot 07.01.1980 stond ingeschreven in het Nederlandse bevolkingsregister.

De door de klager als tegenbewijs overgelegde schriftelijke bescheiden leiden de HR tot de overweging dat: "Aangenomen moet worden dat klager zich gedurende

${ }^{757}$ HR 23.12.1983, NJ 1984, nr. 387. 
het laatste kwartaal van $1975-(. . . . .$.$) - in Nederland heeft bevonden. Dit valt af$ te leiden uit de -(......)- omstandigheden dat klager van 08.10.1975 tot

07.01.1980 is ingeschreven geweest in het Bevolkingsregister van de gem. 'sGravenhage en dat hem op 8 dec. 1975 door die Gemeente een (Nederlands) paspoort is afgegeven."

Aangaande de stelling van de staatssecretaris van Justitie, gebaseerd op de mededeling van de Surinaamse overheid, dat de klager in februari 1976 in Suriname een Surinaams paspoort heeft ontvangen, wordt geoordeeld: "Er zijn onvoldoende aanwijzingen om aan te nemen dat klager in de periode gelegen tussen eind 1975 en 30 dec. 1978 (.........) aldaar is geweest.

Voor de -door klager bestreden- juistheid van de mededeling van de Surinaamse autoriteiten (........), bieden de stukken geen steun. (..........).

Tevens wordt de door de Staat overgelegde verklaring van 08.04.1982 en afkomstig van de Surinaamse overheid inzake klagers (kennelijk nog steeds doorlopende) inschrijving in het bevolkingsregister beoordeeld, en wel als volgt: "Van de juistheid van deze verklaring kan echter niet worden uitgegaan, aangezien zij niet valt te rijmen met een volgens zijn inhoud op 27 sept. 1975 door bedoelde ambtenaar afgegeven "Getuigschrift van verandering van werkelijke woonplaats" betreffende het metterwoon verlaten door klager met zijn gezin van het district Suriname ten einde zich in Nederland te vestigen. Weliswaar heeft de staatssecretaris aangevoerd dat dit "Getuigschrift" volgens de Surinaamse autoriteiten door die ambtenaar ten onrechte en eerst in of omstreeks het jaar 1980 zou zijn opgemaakt, maar dat dit het geval is, is niet gebleken."

De Hoge Raad concludeert dan ook "dat er onvoldoende grond bestaat om te oordelen dat klager op het tijdstip van in werking treding van de Toescheidingsovereenkomst in de Republiek Suriname hetzij woonplaats dan wel werkelijk verblijf heeft gehad (........). " Waarop het beklag gegrond wordt verklaard.

\section{Aantekening.}

Naar mijn mening wordt in deze casus naast de verliesgrond van artikel 3 TOS een tweede verliesgrond getoetst, en wel artikel 5 lid 1 TOS. Wat betreft de "primaire bewijslast" aan de kant van de overheid moet worden geconcludeerd dat aangaande artikel 3 TOS de staatssecretaris over bewijs beschikt om daaraan te voldoen. De staatssecretaris beschikt over een verklaring van de bevoegde autoriteiten in

\footnotetext{
${ }^{758}$ Over deze "mededeling" merkt de A.-G. in zijn conclusie het volgende op: "Het belangrijkste argument tegen verzoekers lezing van de feiten lijkt mij de aanvraag van een Surinaams paspoort en de inontvangsneming daarvan tegen inlevering van een oud "gouverneurspaspoort". Ik vestig er echter de aandacht op dat hiervoor geen hard bewijs geleverd is. De Nederlandse ambassadeur in Suriname heeft in zijn telexbericht slechts medegedeeld dit van het Centraal Bureau voor burgerlijke stand en bevolkingsregister te Paramaribo in april 1982 (mondeling?) te hebben vernomen. Een rechtstreeks bewijsstuk is niet overgelegd. "
} 
Suriname dat de klager, vanaf november 1974 tot het moment dat de verklaring in 1982, wordt afgegeven, staat ingeschreven in het bevolkingsregister van het district Suriname. Maar de klager beschikt over uiteenlopende bewijzen die aannemelijk maken dat hij zich op permanente basis in Nederland bevond en kan daarmee de onjuistheid van het standpunt van de staatssecretaris met betrekking tot artikel 3 TOS aantonen.

Interessant is de opmerking over het "getuigschrift van verandering van werkelijke woonplaats" uit 1975 dat de klager heeft overgelegd als tegenbewijs tegen de namens de staatssecretaris overgelegde verklaring van de Surinaamse autoriteiten uit 1982 inzake klagers inschrijving in het Surinaamse bevolkingsregister. De staatssecretaris bestrijdt de datering van het door de klager overgelegde tegenbewijs. Het argument dat het "getuigschrift" geantidateerd zou zijn, wordt ontleend aan het telexbericht dat afkomstig is van de Nederlandse ambassade. De Hoge Raad trekt hieruit slechts de conclusie dat van de beweerde antidatering niet is gebleken.

Met betrekking tot de "primaire bewijslast" aangaande artikel 5 lid 1 TOS blijkt i.c. de situatie anders te liggen dan bij artikel 3 TOS. Nu is vastgesteld dat artikel 3 TOS niet tot verlies van het Nederlanderschap heeft geleid, is alleen nog het verkrijgen van een Surinaams paspoort door middel van het afleggen van een optie op grond van artikel 5 lid 1 TOS een mogelijke verliesgrond. Immers, het "en in ieder geval in februari 1976" verblijf houden in Suriname levert geen verliesgrond voor het Nederlanderschap op. Dan blijkt evenwel dat ten aanzien van een optie (en zelfs van de afgifte van het paspoort aan de klager) geen bewijs aanwezig is. De "mededeling" waarop de Staat zich beroept, en die volgens informatie uit de conclusie van het OM bestaat uit een telexbericht van de Nederlandse ambassade in Suriname aan het ministerie van Justitie met daarin op een wellicht mondelinge mededeling steunende informatie, kan niet worden beschouwd als afdoende bewijs om te voldoen aan de "primaire bewijslast" voor het verlies van het Nederlanderschap. Naar ik meen, constateert de HR blijkens de formulering "Er zijn onvoldoende aanwijzingen om aan te nemen dat" en het daarop volgende: "Voor de door klager bestreden- juistheid van de mededeling van de Surinaamse autoriteiten $(. . . . . .$.$) , bieden de stukken geen steun. " precies die lacune in het betoog van de$ staatssecretaris. Op de tegenbewijzen van de klager hoeft dan niet meer worden ingegaan; en dat is inderdaad achterwege gelaten. Het bewijs van het verlies inzake artikel 5 lid 1 TOS is immers in de "primaire toetsing" niet geleverd. 


\subsection{HR 26 oktober 1984}

Cat. B(-TOS), uitspr. XI. Casusbeschrijving. Art. 5 lid 2 TOS: Betwisting van de wil de woonplaats over te brengen vanuit het buitenland naar Suriname.

Uit de eerder behandelde uitspraak NJ 1984, nr. $230^{759}$ is gebleken hoe op grond van weinig concreet bewijsmateriaal en de rechterlijke overtuiging dat de verklaringen van de klaagster aannemelijk zijn, het beklag gegrond is verklaard. Ook de volgende zaak laat eenzelfde beeld zien.

In de onderhavige casus uit $1984^{760}$ neemt de Staat het standpunt in dat de klaagster haar Nederlandse nationaliteit krachtens de toepassing van artikel 5 lid 2 Toescheidingsovereenkomst heeft verloren. De uit Suriname afkomstige klaagster is in Nederland woonachtig sinds 1972. Zij vertrekt in 1977 naar Suriname. Met betrekking tot de feiten staat buiten twijfel dat klaagsters verblijf in Suriname heeft geduurd van 22.05.1977 tot 01.10.1979. Een zodanig lange verblijfsperiode leidt (in beginsel) tot het van rechtswege verlies van de Nederlandse nationaliteit op grond van artikel 5 lid 2 Toescheidingsovereenkomst. In casu kan dan ook worden geconstateerd dat de Staat over voldoende bewijsmateriaal beschikt om de rechter, na "primaire toetsing" van het standpunt van de Staat, uit te laten gaan van mogelijk verlies van het Nederlanderschap. Naast het vaststaan van deze periode van verblijf in Suriname gelden in deze zaak als vaststaande feiten tevens dat de klaagster sinds 1972 tot haar vertrek in 1977 bij haar zoon in Rotterdam heeft ingewoond, dat zij na terugkomst in 1979 haar intrek neemt bij een dochter in Amsterdam en dat zij haar (sinds 1972 onafgebroken) inschrijving in het bevolkingsregister te Rotterdam laat wijzigen naar Amsterdam.

In de onderhavige zaak bestrijdt de klaagster het standpunt van de staatssecretaris met het volgende verweer. Als reden voor haar vertrek in 1977 naar Suriname stelt de klaagster dat haar daar woonachtige zuster wegens ziekte verzorging behoefde.

Bij de bespreking van de in paragraaf 3.3.3.4.3 behandelde casus is inzake de interpretatie van artikel 5 lid 2 TOS reeds gebleken dat sinds 1982 de Hoge Raad het standpunt inneemt dat het Nederlanderschap niet verloren gaat door tweejarig of langer verblijf in Suriname "indien in redelijkheid aan de wil van de betrokkene kan worden getwijfeld dat hij zijn tevoren bestaande woonplaats ${ }^{761}$ heeft willen prijsgeven." Aan de hand van de feitelijke omstandigheden dient te worden beoordeeld of het rechtsgevolg van verlies van de Nederlandse nationaliteit ingevolge artikel 5 lid 2 TOS is ingetreden. Ook is uit de in paragraaf 3.3.3.4.3 behandelde uitspraak gebleken dat het aannemelijk zijn van deze omstandigheden

\footnotetext{
${ }^{79}$ HR 28 oktober 1983, NJ 1984, nr. 230 (par. 3.3.3.4.3).

${ }^{7{ }_{0}}$ HR 26.10.1984, NJ 1985, nr. 112.

7 Hiermee is bedoeld de woonplaats buiten Suriname, in de meeste gevallen (ook in casu) zal het gaan om het opgeven van een "woonplaats" in Nederland.
} 


\section{Hoofdstuk 3}

reeds kan worden aangenomen ook indien conreet bewijs van die omstandigheden ontbreekt.

Ook in de onderhavige uitspraak uit oktober 1984 is het opvallend dat de klaagster voor haar stelling eigenlijk geen bewijzen kan overleggen. De A.-G. wijst hierop in zijn conclusie en stelt dienaangaande: "Ik heb er wel begrip voor dat het moeilijk zal zijn thans nog bewijzen aan te voeren over een ziektegeval dat zich in 1977 in Suriname heeft voorgedaan, maar dat lijkt mij onvoldoende om rechtsgevolgen te verbinden aan de enkele verklaring van een belanghebbende zelf. " De A.-G. concludeert vervolgens tot ongegrondverklaring van het beklag, maar refereert aan de mogelijkheid van een herhaald beklag in het geval dat de klaagster op een gegeven moment toch komt te beschikken over bewijs voor haar stelling.

Evenwel, naar hetgeen het oordeel van de Hoge Raad zal blijken, is een eventuele herhaling van het beklag door de klaagster niet noodzakelijk. De Hoge Raad oordeelt namelijk met betrekking tot klaagsters Nederlanderschap dat zij dit niet heeft verloren. Niet kan worden gesteld dat het feit dat de klaagster haar stellingen niet kan ondersteunen met bewijsmateriaal de Hoge Raad is ontgaan. Maar aan de hand van de summiere gegevens die wel vaststaan, is de Hoge Raad toch bereid aan te nemen dat twijfel mogelijk is omtrent de wil van de klaagster bij haar vertrek uit Nederland naar Suriname in 1977.

Tot dit oordeel komt de Hoge Raad op grond van de volgende overwegingen: "Weliswaar is niet komen vast te staan dat genoemde zuster en zwager ook reeds in het meergemelde tijdvak ziek waren en deswege verzorging door klaagster behoefden, maar de als voormeld gebleken bijzonderheden ${ }^{762}$ omtrent die zuster en zwager laten, mede gezien de omstandigheden dat klaagster zich gedurende haar verblijf in Suriname niet uit het bevolkingsregister te Rotterdam heeft laten uitschrijven, zodanige ruimte voor twijfel omtrent klaagsters wil haar woonplaats in Nederland -waar zij van 1972 af had gewoond en waar ook haar kinderen wonenop te geven, dat die wil uit bedoeld verblijf niet kan worden afgeleid."

\section{Aantekening.}

In wezen weerlegt de klaagster de feiten die de staatssecretaris van Justitie presenteert met de summiere gegevens dat zij sinds 1972 in Nederland heeft gewoond, dat haar kinderen in Nederland wonen en dat zij ingeschreven is gebleven in een Nederlands bevolkingsregister. ${ }^{763}$ Dit, tezamen met de verklaringen van de

\footnotetext{
${ }^{762}$ Hiermee is gedoeld op het overlijden van de zwager in september 1980 en van de zuster in januari 1982.

w In veel zaken die art. 5 lid 2 TOS betreffen, speelt inschrijving in Nederlandse of Surinaamse dan wel terzelfdertijd in beide bevolkingsregisters bewijsrechtelijk een rol. Maar de bewijswaarde van inschrijving in het bevolkingsregister moet zeker niet worden overschat, zie ARRS 25.07.1984, NIPR 1986, nr. 391: "Aangezien ingevolge art. 88 van het Besluit bevolkingsboekhouding bij aangifte van een
} 
klaagster omtrent de verzorging van de zieke familieleden, is al voldoende om de Hoge Raad in redelijkheid te doen twijfelen dat klaagster haar woonplaats in Nederland heeft willen opgeven.

Naar mijn mening is daarbij essentieel dat i.c. het enige argument waarop de Staat het verlies van het Nederlanderschap grondvest de duur van verblijf in Suriname door de klaagster is. Dat is weliswaar de grondslag voor de werking van artikel 5 lid 2 TOS, maar het is niet het enige vereiste dat van belang is om tot verlies van het Nederlanderschap te kunnen concluderen. In feite zou de Staat ook ten behoeve van dat tweede vereiste bewijsmateriaal moeten kunnen leveren. Hetgeen de klaagster naar voren brengt ten einde aannemelijk te doen zijn dat zij niet haar woonplaats van Nederland naar Suriname heeft overgebracht, wordt enerzijds niet door de Staat met tegenbewijs bestreden en is anderzijds niet strijdig aan de feiten die de Staat aanvoert ten einde het verlies aanwezig te achten. De feiten die de klaagster aanvoert vormen een aanvulling op de feiten die de Staat heeft aangevoerd. Indien de Hoge Raad een zodanige aanvulling aannemelijk acht, slaagt derhalve het tegenbewijs.

Dit tegenbewijs zou eventueel nog door de Staat met tegenbewijs van diens kant kunnen worden ontkracht. Uit de onderhavige zaak kan nogmaals de conclusie worden getrokken dat verlies van het Nederlanderschap dient te worden bewezen door de overheidsadministratie.

\subsection{HR 8 maart 1985}

Cat. B(-TOS), uitspr. XII. Casusbeschrijving. Art. 5 lid 1 TOS. Bewijs van dwaling bij het opteren. Afgaan op de verklaringen van de klager kan alleen indien de andere feiten van de zaak de eigen verklaringen niet tegenspreken.

Dat de Hoge Raad toch niet alleen op de verklaringen van de klager vaart, blijkt uit de onderhavige, zonder aparte aantekening te bespeken, casus. ${ }^{764}$ Een vaststaand feit in deze zaak is dat de betrokkene een optieverklaring voor de Surinaamse nationaliteit heeft getekend. ${ }^{765}$ De Nederlandse overheid beroept zich op deze optie en constateert derhalve verlies van het Nederlanderschap door de betrokkene. De Staat voldoet hiermee aan de "primaire bewijslast". De betrokkene stelt

\footnotetext{
${ }^{763} \rightarrow$

adresverandering zonder nader onderzoek de nodige wijzigingen in het bevolkingsregister worden aangebracht, kan aan de desbetreffende inschrijving geen bewijskracht worden toegekend." Ook gebeurde het incidenteel dat personen ambtshalve zijn uitgeschreven: zie HR 01.07.1983 NJ 1984, nr. 229.

${ }^{764}$ HR 08.03.1985, NJ 1985, nr. 495.

${ }^{76}$ De Staat wijst op een bekendmaking in het Staatsblad van de Republiek Suriname, waaruit blijkt dat de klager een optie heeft afgelegd ter verkrijging van de Surinaamse nationaliteit.
} 


\section{Hoofdstuk 3}

daartegenover dat "(......) hij, zijn handtekening (......) plaatsende, niet heeft beseft daarmee voor de Surinaamse nationaliteit te opteren, zodat de verklaring niet met zijn wil overeenstemt. " De klager beroept zich derhalve op een wilsgebrek. De verklaringen die de klager voor de Hoge Raad aflegt, sluiten naar het oordeel van de Hoge Raad echter niet aan bij de i.c. verder vastgestelde feiten. Naar aanleiding hiervan overweegt de Hoge Raad: "De aldus door klager ter toelichting van zijn standpunt gegeven lezing van de gang van zaken berust louter op zijn eigen mededelingen en vindt geen steun in de vastgestelde feiten en de overgelegde gedingstukken." alsmede "De juistheid van klagers lezing is dan ook niet aannemelijk geworden." Het door de klager aangevoerde wilsgebrek, ten aanzien waarvan de bewijslast bij de klager ligt, ${ }^{766}$ is niet bewezen. Aangezien de Staat wel is geslaagd in de "primaire bewijslast", maar de klager niet slaagt in het tegenbewijs verklaart de Hoge Raad het beklag ongegrond.

\subsection{HR 8 mei 1987}

Cat. B(-TOS). witspr XIII. Casusbeschrijwing. Art. 7 lid I TOS. Bewijs yan dwaling bij een optie.

In de onderhavige casus ${ }^{767}$ gaat het om een klaagster die in 1951 bij haar huwelijk de Nederlandse nationaliteit heeft verworven. Bij de onafhankelijkheid van Suriname verkrijgt haar echtgenoot ingevolge artikel 3 TOS de Surinaamse nationaliteit. Vanwege de omstandigheid dat de klaagster op 25.11.1975 geen woonplaats of werkelijk verblijf in Suriname heeft, behoudt zij op dat moment het Nederlanderschap. Vervolgens heeft zij in 1977 "in Paramaribo een verklaring ondertekend, inhoudende dat zij met toepassing van art. 7 lid 1 Toescheidingsovereenkomst haar wil tot het verkrijgen van de Surinaamse nationaliteit te kennen geeft."

In de procedure voor de Hoge Raad bestrijdt de klaagster de rechtsgeldigheid van de optieverklaring. Met betrekking tot de optie beroept zij zich op dwaling, daar zij nimmer de wil zou hebben gehad te opteren voor de Surinaamse nationaliteit. De klaagster stelt bij het ondertekenen in de veronderstelling te hebben verkeerd dat zij tekende voor het behoud van haar Nederlanderschap. De klaagster stelt tevens dat zij slechts gebrekkig het Nederlands beheerst.

De Hoge Raad acht de dwaling echter niet aannemelijk, aangezien de klaagster bij de ondertekening was vergezeld van haar dochter, die wel het Nederlands

\footnotetext{
${ }^{700}$ Dit is cf. HR 21.01.1969, NJ 1969, nr. 144 (par. 3.3.3.3.1), waarin de bewijslast inzake een wilsgebrek bij het opteren ook bij de klager ligt. En idem HR 28.10.1983, NJ 1984, nr. 230, m.nt. AHJS (par. 3.3.3.4.3).

${ }^{767}$ HR 08.05.1987. NJ 1987, nr. 682.
} 
machtig is. Ook neemt de HR in overweging dat het te ondertekenen optieformulier een overzichtelijke indeling heeft en een duidelijke tekst bevat. De Hoge Raad acht het "niet aannemelijk geworden dat klaagster bij het plaatsen van haar handtekening heeft gedwaald omtrent de strekking van de door haar ondertekende, in het Nederlands gestelde, verklaring."

\section{Aantekening.}

Wat kan heel kort worden gezegd over de bewijslastverdeling in de onderhavige zaak? Tijdens het "primaire toetsingsmoment", het moment waarop de deugdelijkheid van het door de Staat ingenomen nationaliteitsrechtelijke standpunt wordt onderzocht op de feitelijke onderbouwing en de bewijzen daarvoor, bewijst i.c. de Nederlandse overheid het verlies van het Nederlanderschap door het overleggen van de optie voor de Surinaamse nationaliteit. Het bewijs van het wilsgebrek bij het opteren dat door de klaagster eventueel kan worden geleverd, kan alsnog ertoe leiden dat de Hoge Raad bereid is te concluderen tot behoud van het Nederlanderschap. I.c. slaagt de klaagster niet in dit tegenbewijs.

Dat aangaande een wilsgebrek bij het afleggen van een optie de bewijslast en het bewijsrisico op de klager rusten, is overigens eerder in de jurisprudentie al gebleken. ${ }^{768}$

\subsubsection{Tweede tussenevaluatie}

De Hoge Raad is in de beklagprocedure op grond van artikel 43 (oud) Vreemdelingenwet feitenrechter geweest en dit heeft geïmpliceerd dat de vaststelling van de feiten door de Hoge Raad diende te geschieden. In een viertal uitspraken vindt vermelding dat ten behoeve van de feitenvaststelling een raadsheer-commissaris "belast met het instellen van een nader onderzoek naar de juistheid van de aan het beklag ten grondslag gelegde feiten" is aangesteld. De desbetreffende uitspraken vermelden verder dat deze raadsheer-commissaris vervolgens de klager en/of diens raadsman heeft gehoord. ${ }^{769}$ Een verdergaand, zelfstandig gevoerd feitenonderzoek, zoals dat past in het beeld van de niet-lijdelijke administratieve rechter, ${ }^{770}$ blijkt uit twee uitspraken. ${ }^{771}$

\footnotetext{
${ }^{76}$ HR 21.01.1969, NJ 1969, nr. 144 (par. 3.3.3.3.1); HR 28.10.1983, NJ 1984, nr. 230, m.nt. AHJS (par. 3.3.3.4.3); HR 08.03.1985, NJ 1985, nr. 495 (par. 3.3.3.4.6).

Zie voetnoot 652 .

${ }^{n} \mathrm{~V}$ Vl. Van den Haak, Trema 1995, p. 219; Ten Berge/Tak, p. 135.

${ }^{m}$ HR 04.03.1980, NJ 1981, nr. 98 (onderzoek naar de woonplaats op 25.11.1975); HR 23.12.1983, NJ 1984, nr. 387 (onderzoek bij gemeentelijke administratie).
} 
In de eerste tussenevaluatie (par. 3.3.2.3) is gebleken dat op grond van de rechtspraak uit de periode tot 1967 al kon worden vastgesteld dat op de aanlegger van een procedure waarin een beroep wordt gedaan op verwerving van de Nederlandse nationaliteit dienaangaande een stelplicht rust. Op grond van de rechtspraak in het kader van artikel 43 (oud) Vreemdelingenwet kan worden geconcludeerd dat zulks ook voor die procedure heeft gegolden.

Uit de in deze paragraaf behandelde jurisprudentie blijkt echter dat de klager, ongeacht of deze zich baseert op verwerving dan wel op behoud van de Nederlandse nationaliteit, niet alleen een stelplicht maar tevens een "summiere bewijsplicht" heeft. Met het begrip "summiere bewijsplicht" wordt gedoeld op een verplichting voor de klager al het bewijsmateriaal dat hem ter beschikking staat over te leggen. $^{m}$

Van de overheidsadministratie, in de beklagprocedure is dat de staatssecretaris van Justitie geweest, verwacht de Hoge Raad dat een standpunt inzake klagers nationaliteit wordt geformuleerd en ook dat de bij de overheid bekende nationaliteitsrechtelijk relevante gegevens ter beschikking van de rechter worden gesteld.

Ter zake van de in de beklagprocedure ex artikel 43 (oud) Vreemdelingenwet gevolgde verdeling van de bewijslast valt, naar mijn mening, in de besproken jurisprudentie het volgende patroon te onderkennen. In dat patroon ligt het initiële zwaartepunt bij het door de overheidsadministratie ingenomen standpunt. ${ }^{773} \mathrm{Het}$ door de staatssecretaris van Justitie ingenomen standpunt omtrent klagers Nederlanderschap dient (prima facie) als houdbaar (oftewel: deugdelijk) te kunnen worden gekwalificeerd. Het standpunt van de overheid kan als houdbaar worden gekwalificeerd indien de overheid voor de aan het standpunt ten grondslag liggende stelling(en) voldoende bewijs heeft. Met betrekking tot de vraag of het door de overheidsadministratie ingenomen standpunt houdbaar kan worden genoemd, ligt derhalve de bewijslast inzake de aan het standpunt ten grondslag gelegde feiten bij de overheid.

Voor de hierboven bedoelde bewijslast van de overheidsinstantie ter zake van het door de overheid ingenomen standpunt met betrekking tot klagers Nederlanderschap is tijdens de bovenstaande bespreking van de jurisprudentie als werkbegrip het begrip "primaire bewijslast" geïntroduceerd. Het begrip "primaire bewijslast" relateert aan het gegeven dat, nog voordat het relaas van de klager bij de rechter aan de orde komt, het standpunt van de overheid houdbaar dient te zijn gebleken. Daarbij is het onverschillig of dat standpunt inhoudt dat er geen sprake is van verwerving dan wel van behoud van de Nederlandse nationaliteit.

\footnotetext{
${ }^{m}$ Vgl. HR 23.09.1988, NJ 1989, nr. 53.

${ }^{m}$ Dit patroon blijkt overeen te komen met hetgeen gebruikelijk is in het administratief procesrecht. Vgl. Ten Berge/Tak, p. 139: "Eigenlijk begint normaliter verweerder met zijn visie op de feiten, namelijk in de motivering (indien aamwezig) van de bestreden beslissing. Vervolgens tracht appellant in zijn beroepsschrift de feiten aan te voeren die aannemelijk moeten maken dat het overheidsorgaan een onjuiste beslissing heeft genomen."
} 
De essentie van de "primaire toetsing" van het overheidsstandpunt is gelegen in de controle of op grond van de feiten en de bewijzen waarover de overheid beschikt een nationaliteitsrechtelijk standpunt tot stand is gekomen dat door de feiten kan worden gedragen. Het belang van de "primaire toetsing" van het door de staatssecretaris van Justitie ingenomen standpunt is gelegen in de omstandigheid dat indien het standpunt van de staatssecretaris tot stand is gekomen op grond van feiten waarvoor bewijs blijkt te ontbreken, er sprake kan zijn van onzorgvuldige voorbereiding van een overheidsbeslissing. ${ }^{774}$ Tegen een op een onbewezen rechtsgrond gefundeerd overheidsstandpunt, mocht dit standpunt door de rechter zonder toetsing als juist worden aangenomen, is het voor de betrokken klager wellicht zeer moeilijk, eventueel onmogelijk, om bewijs te leveren.

Uit de in het kader van artikel 43 (oud) Vreemdelingenwet onderzochte jurisprudentie blijkt overigens dat de staatssecretaris van Justitie slechts sporadisch een standpunt inzake klagers nationaliteit heeft ingenomen, dat niet met voldoende sluitend bewijs kon worden onderbouwd. Als voorbeelden waarin de overheid niet slaagt in de "primaire bewijslast" kan worden gewezen naar twee zaken. ${ }^{775}$

Aan de hand van de bovengenoemde twee gevallen waarin de Staat niet voldoet aan de "primaire bewijslast" kunnen twee onderscheidenlijke conclusies worden geformuleerd. Dat deze twee zaken tot twee verschillende gevolgtrekkingen aanleiding geven, is het gevolg van het feit dat het enerzijds gaat om een zaak waarin verwerving van het Nederlanderschap aan de orde is en anderzijds om een zaak waarin een beroep op behoud van het Nederlanderschap wordt gedaan.

De eerste gevolgtrekking luidt dan dat, in het geval van een beroep op verwerving onder de omstandigheid dat de Staat niet blijkt te voldoen aan de "primaire bewijslast", datgene wat de klager in het kader van zijn "summiere bewijslast" heeft overgelegd reeds voldoende kan zijn om verwerving van het Nederlanderschap aannemelijk te doen zijn. ${ }^{776}$ Onder deze omstandigheid is het derhalve zo dat de klager niet per se behoeft te beschikken over sluitend bewijs voor zijn verwerving van het Nederlanderschap.

De tweede gevolgtrekking heeft betrekking op een beroep op behoud van de Nederlandse nationaliteit. Voldoet de Staat niet aan zijn "primaire bewijslast", (in het onderhavige voorbeeld gaat het om het bewijs van de verwerving van een vreemde nationaliteit), dan is de verliesgrond niet bewezen en moet worden uitgegaan van het voortdurende bezit van het Nederlanderschap. ${ }^{m 7}$ Dit sluit aan

\footnotetext{
${ }^{\pi 4}$ En derhalve schending van het algemeen beginsel van behoorlijk bestuur dat zorgvuldige voorbereiding van overheidsbesluiten voorschrijft.

${ }^{73}$ HR 27.11.1979, NJ 1980, nr. 550 (par. 3.3.3.3.2) en HR 23.03.1984, NJ 1984, nr. 650 (par. 3.3.3.2.3). Zie echter ook HR 23.12.1983, NJ 1984, nr. 387 (par. 3.3.3.4.4), waarin ten aanzien van Cén van de aan de orde zijnde verliesgronden het "primaire" bewijs ook ontbreekt.

${ }^{76}$ HR 23.03.1984, NJ 1984, nr. 650 (par. 3.3.3.2.3).

${ }^{m}$ HR 27.11.1979, NJ 1980, nr. 550 (par. 3.3.3.3.2).
} 
bij hetgeen reeds in de eerste tussenevaluatie is geconcludeerd, namelijk dat, in het geval de overheid verlies van het Nederlanderschap stelt, de bewijslast van dat standpunt bij de Nederlandse overheidsadministratie ligt. Dezelfde bewijslastverdeling komt derhalve ook naar voren in de beklagprocedure op grond van artikel 43 (oud) Vreemdelingenwet. Ook in de artikel 43 (oud) Vreemdelingenwetprocedure ligt met betrekking tot beweerd verlies van de Nederlandse nationaliteit de bewijslast bij de Nederlandse overheid. Blijkt de overheid niet in staat tot een "primaire bewijslevering" van het vermeende verlies van het Nederlanderschap dan zal moeten worden geconstateerd dat het bewijs van het verlies niet rond is en dat derhalve moet worden uitgegaan van continuering van het bezit van het Nederlanderschap. Want kan de overheid de rechtsfeiten waarop het verlies wordt gebaseerd niet bewijzen dan geldt immers de continueringspresumtie ${ }^{778}$ van het Nederlanderschap en wordt behoud van de Nederlandse nationaliteit aangenomen. Hetgeen de klager aanvoert ter ondersteuning van zijn standpunt dat hij niet zijn Nederlanderschap heeft verloren, kan onder deze omstandigheid in feite buiten beschouwing blijven. Hieruit volgt dat inzake een beroep op behoud van de Nederlandse nationaliteit het onder de omstandigheid waarin de overheid niet voldoet aan de haar gestelde "primaire bewijslast" de klager niet behoeft te beschikken over voldoende en sluitend bewijs waaruit het behoud van de Nederlandse nationaliteit blijkt.

Op de twee hierboven genoemde voorbeelden na blijkt uit de jurisprudentie op grond van artikel 43 (oud) Vreemdelingenwet evenwel dat de Staat in de meerderheid van de onderzochte zaken voldoet aan de "primaire bewijslast". Van het initiële zwaartepunt in de beklagprocedure dat, als gezegd, bij het standpunt van de Staat en de onderbouwing daarvan ligt, verschuift de nadruk vervolgens in de richting van de beoordeling van klagers stelling(en).

Slaagt de overheid in de "primaire bewijslast" dan gaat de Hoge Raad prima facie ervan uit dat de overheid een nationaliteitsrechtelijk correct standpunt huldigt. Het is vanzelfsprekend dat de klager toch kan trachten tegenbewijs te leveren tegen dat, op voorlopige wijze als correct aan te nemen, overheidsstandpunt.

Indien het gaat om een beroep op verwerving van de Nederlandse nationaliteit, dan kan de klager, als i.c. de overheid voldoet aan de "primaire bewijslast", door middel van het leveren van tegenbewijs trachten de verwerving desondanks aannemelijk te maken. Uit de categorie van verwervingsberoepen waarin de overheid in de "primaire toetsing" wel slaagt in het waarmaken van het eigen

${ }^{m 8}$ Zie p. 138 en 139. 
standpunt en waarin het tegenbewijs van de klager niet slaagt, kan ter voorbeeld worden gewezen op twee zaken. ${ }^{m 9}$

De jurisprudentie kent geen voorbeeld waarin de Staat slaagt in de "primaire bewijslast" inzake het standpunt dat geen verwerving van de Nederlandse nationaliteit heeft plaatsgevonden, maar waarin de betrokkene slaagt in het leveren van tegenbewijs.

Gaat het daarentegen om een beroep op behoud van het Nederlanderschap dan geldt het volgende. Als gezegd, het is niet aan de klager om in eerste instantie aannemelijk te maken dat ten aanzien van hem het rechtsfeit dat leidt tot verlies van het Nederlanderschap niet is voorgevallen. Zoals hierboven uiteen is gezet, geldt daarentegen in eerste instantie de "primaire bewijslast" en wordt door de rechter beoordeeld of het negatieve oordeel over klagers Nederlanderschap door de staatssecretaris met voldoende bewijs wordt ondersteund om het als deugdelijk onderbouwd te beschouwen. Is de stellingname van de overheid inderdaad houdbaar te achten op grond van het door de overheid overgelegde bewijs, dan kan de klager trachten daartegen tegenbewijs aan te voeren. Zodoende kan het in tweede instantie wél voorkomen dat het aan de klager is om aannemelijk te maken dat ten aanzien van hem het rechtsfeit (reeds prima facie bewezen door de overheid) dat leidt tot verlies van het Nederlanderschap niet is voorgevallen.

In de in het kader van de ingevolge artikel 43 (oud) Vreemdelingenwet besproken jurisprudentie komt een viertal zaken voor waarin de staatssecretaris van Justitie slaagt in de "primaire bewijslast" en waarin vervolgens de klager niet slaagt in het tegenbewijs. ${ }^{780}$

De casus in NJ 1981 , nr. $98^{781}$ is daarentegen een zaak waarin de overheid eveneens de toets van de "primaire toetsing" doorstaat, maar waarin de klaagster vervolgens slaagt in het tegenbewijs. Dit laatste geldt ook voor NJ 1984, nr. $387 ;^{782}$ NJ 1984 , nr. $230^{783}$ en NJ 1985 , nr. $112^{784}$.

${ }^{79}$ HR 23.10.1979, NJ 1980, nr. 551 (par. 3.3.3.2.1) en HR 15.07.1985, NJ 1985, nr. 854 (par. 3.3.3.2.4). Zie ook HR 09.02.1982, rkstnr. 5756 (Zilverentant e.a., losbl. Nationaliteitswetgeving, art. 7 sub 1 Wet Ned. 1892).

${ }^{70}$ HR 21.01.1969, NJ 1969, nr. 144 (par. 3.3.3.3.1: t.a.v. het verweer en leveren van tegenbewijs ligt het bewijsrisico bij de klager); HR 01.06.1982, NJ 1983, nr. 314 (par. 3.3.3.4.2: het door klager gepresenteerde bewijsmateriaal moet voldoende "geloofwaardig" zijn); HR 08.03.1985, NJ 1985, nr. 495 (par. 3.3.3.4.6: afgaan op de verklaringen van de klager kan alleen indien de andere feiten van de zaak de desbetreffende verklaringen niet tegenspreken); HR 08.05.1987, NJ 1987, nr. 682 (par. 3.3.3.4.7: dwaling bij optie niet aannemelijk geworden).

mi HR 04.03.1980, NJ 1981, nr. 98 (par. 3.3.3.4.1: het bewijs van het voornemen zich blijvend buiten Suriname te vestigen ligt niet bij de klaagster).

${ }^{7}$ HR 23.12.1983, NJ 1984, nr. 387 (par. 3.3.3.4.4: tegenstrijdige bewijzen).

${ }^{m}$ HR 28.10.1983, NJ 1984, nr. 230 (par. 3.3.3.4.3: de verklaringen van de klaagster zijn aannemelijk).

Th 26.10 .1984 , NJ 1985, nr. 112 (par. 3.3.3.4.5: ruimte voor twijfel aangaande de wil de woonplaats over te brengen vanuit het buitenland naar Suriname). 
Specifiek ten aanzien van de rechtspraak inzake de Toescheidingsovereenkomst tussen Nederland en Suriname valt aanvullend nog het volgende op te merken. Bij nationaliteitsvaststelling in het kader van de Toescheidingsovereenkomst is de vaststelling van de feitelijke omstandigheden van het geval meermalen van groot belang gebleken. Hoewel de feitelijke omstandigheden van het geval vanzelfsprekend (ipso facto, ook buiten de toepassing van de TOS) altijd van belang zijn, blijkt in het bijzonder uit de rechtspraak met betrekking tot de Toescheidingsovereenkomst dat de feitelijke omstandigheden van het geval veelvuldig aanleiding hebben gegeven tot bewijsrechtelijke vragen. Uit het bovenstaande moet worden geconcludeerd dat de regeling inzake het bewijs en inzake de bewijslastverdeling van die feitelijke omstandigheden van niet te onderschatten belang is.

Zonder meer opvallend is dat in twee zaken waarin het gaat om een toetsing van artikel 5 lid 2 TOS het behoud van het Nederlanderschap wordt aanvaard, terwijl de klaagsters weinig tot geen concreet bewijsmateriaal ter ondersteuning van hun stelling overleggen. ${ }^{785}$ Dat ondanks de geringe ondersteuning met bewijsmateriaal toch het behoud van het Nederlanderschap wordt aanvaard, heeft naar mijn mening de volgende oorzaak.

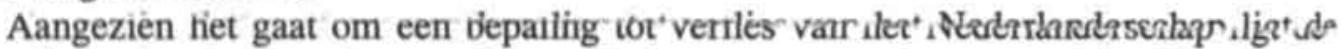
bewijslast inzake de relevante feiten bij de staatssecretaris van Justitie. Het bewijs van een tweejarig of langer verblijf in Suriname zal in de meeste gevallen wel vaststaan. Evenwel, het in de rechtspraak met betrekking tot artikel 5 lid 2 TOS ontwikkelde vereiste, inhoudende dat "aan de wil van de betrokkene zijn tevoren bestaande woonplaats prijs te geven, in redelijkheid niet kan worden getwijfeld", vormt een onderdeel van de verliesgrond. Dit laatste betekent dat ten aanzien van dat vereiste (inzake de wil van de betrokkene met betrekking tot het opgeven van zijn woonplaats) de bewijslast 6 ók bij de overheid ligt. Dat dit een haast onmogelijke opdracht voor de overheid is, is duidelijk. Maar het betekent wel dat de overheid hierdoor niet snel aan haar "primaire bewijslast" zal voldoen. Naar mijn mening is het gevolg daarvan dat het tegenbewijs van de betrokkene al snel aanvaardbaar is.

Om te kunnen slagen, moet het tegenbewijs van de klager het predicaat "aannemelijk" kunnen ontvangen. ${ }^{786}$

7ws HR 28.10.1983, NJ 1984, nr. 230 (par. 3.3.3.4.3) en HR 26.10.1984, NJ 1985, nr. 112 (par. 3.3.3.4.5).

700 Categorie A: HR 23.10.1979, NJ 1980, nr. 551 (par. 3.3.3.2.1: niet aannemelijk is geworden; nu evenmin aannemelijk is geworden); HR 15.07.1985, NJ 1985, nr. 854 (par. 3.3.3.2.4: geen grond om aan te nemen dat). Categorie B(-TOS): HR 04.03.1980, NJ 1981, nr. 98 (par. 3.3.3.4.1: aannemelijk); HR 01.06.1982, NJ 1983, nr. 314 (par. 3.3.3.4.2: te weinig geloofwaardig om aannemelijk te doen zijn); HR 28.10.1983, NJ 1984, nr. 230 (par. 3.3.3.4.3: aannemelijk); HR 23.12.1983, NJ 1984, nr. 387 (par. 3.3.3.4.4: aangenomen moet worden dat); HR 08.03.1985, NJ 1985, nr. 495 (par. 3.3.3.4.6: niet aannemelijk); HR 08.05.1987, NJ 1987, nr. 682 (par. 3.3.3.4.7: niet aannemelijk). 
Uit de jurisprudentie op grond van de Toescheidingsovereenkomst blijkt dat het tegenbewijs reeds als aannemelijk wordt beschouwd indien de stelling(en) van de klager niet strijdig is (zijn) met hetgeen de staatssecretaris stelt (dan wel met hetgeen verder uit de ter beschikking staande gegevens volgt), de klager voor zijn stelling ondersteunend bewijsmateriaal (hoe summier ook) overlegt en de overheid geen tegenbewijs tegen de stelling(en) van de klager levert. ${ }^{787}$

Opvallend is dat indien de staatssecretaris van Justitie aanvullend bewijsmateriaal heeft overgelegd ten einde het tegenbewijs van de klager te ontzenuwen, de Hoge Raad bij de beoordeling daarvan niet spreekt van wel of niet aannemelijk, maar daarentegen spreekt van "is niet gebleken". ${ }^{788}$ Ook in NJ 1981, nr. $98^{789}$ waarin de HR ambtshalve een onderzoek heeft ingesteld naar de feiten, wordt ten aanzien van feitelijke omstandigheden die zouden kunnen hebben geleid tot verlies van het Nederlanderschap gesteld dat zulke omstandigheden "evenmin zijn gebleken". In NJ 1980 , nr. $550^{790}$ wordt eveneens met betrekking tot de verliesgrond, die zelfs niet eens in "primaire toetsing" was bewezen, door de HR gesteld dat de verliesgrond "niet voldoende (is) gebleken".

Wellicht is het bovenstaande een nogal summiere basis voor een gefundeerde conclusie, maar naar mijn mening kan naar aanleiding van het bovenstaande worden gesteld dat voor de gevolgtrekking dat het Nederlanderschap is verloren noodzakelijk is dat de verliesgrond is gebleken (hetzij tijdens de "primaire toetsing" van het standpunt van de overheid dan wel door middel van bewijsmateriaal (van overheidswege) dat aantoont dat het tegenbewijs van de betrokkene onjuist is). Zoals hierboven reeds is gesteld, hoeft dit tegenbewijs van de betrokkene slechts aannemelijk te zijn. Voorts is hierboven tevens gesteld dat de betrokkene in het geval dat de Staat niet in staat is te voldoen aan de "primaire bewijslast" in wezen niet eens over tegenbewijs hoeft te beschikken.

Ten overvloede wellicht wordt hier nogmaals de conclusie getrokken dat alleen in het geval dat het zijn voorgevallen van een verliesgrond is gebleken geen sprake kan zijn van de toepassing van de continueringspresumtie.

Ook aangaande een verwervingsgrond is een strengere bewijssterkte gehanteerd dan aannemelijk om het standpunt van de staatssecretaris te beoordelen. In NJ $1984, \mathrm{nr} .650^{791}$ is sprake van "bewezen".

Tn HR 04.03.1980, NJ 1981, nr. 98 (par. 3.3.3.4.1); HR 28.10.1983, NJ 1984, nr. 230 (par. 3.3.3.4.3); HR 26.10.1984, NJ 1985, nr. 112 (par. 3.3.3.4.5).

${ }^{7}$ HR 23.12.1983, NJ 1984, nr. 387 (par. 3.3.3.4.4).

${ }^{7}$ HR 04.03.1980, NJ 1981, nr. 98 (par. 3.3.3.4.1).

${ }^{70} \mathrm{HR} 27.11 .1979$, NJ 1980, nr. 550 (par. 3.3.3.3.2).

${ }^{m}$ HR 23.03.1984, NJ 1984, nr. 650 (par. 3.3.3.2.3). 


\section{Hoofdstuk 3}

Met betrekking tot de drie behandelde uitspraken ${ }^{792}$ die de voorvraag aangaande het bezit van een vreemde nationaliteit tot onderwerp hebben, ${ }^{793}$ laat de in deze paragraaf behandelde jurisprudentie geen nieuwe ontwikkelingen zien. Het is in het kader van deze voorvraag onverschillig of in de procedure een beroep is gedaan op verwerving dan wel op behoud van de Nederlandse nationaliteit. De Nederlandse rechter beoordeelt aan de hand van het vreemde recht en de feitelijke omstandigheden autonoom of sprake is van bezit van een vreemde nationaliteit. ${ }^{794}$ Een bevestiging van dat bezit door de vreemde autoriteiten wiens nationaliteit het betreft, is derhalve geen vereiste.

De bewijslast aangaande het desbetreffende bezit van een vreemde nationaliteit berust bij de Nederlandse overheid. Om te voldoen aan zijn bewijslast wordt door het ministerie van Justitie zo nodig via het ministerie van Buitenlandse Zaken de diplomatieke vertegenwoordiging van het Koninkrijk ingeschakeld ten behoeve van feitenonderzoek buitenslands, ${ }^{795}$ hetgeen overigens een reeds in de oudere rechtspraak ook gevolgde handelwijze is geweest. ${ }^{796}$

In het kader van de beklagprocedure heeft de Hoge Raad enkele uitspraken gedaan over wilsgebreken bij het afleggen van een optie (voor een vreemde

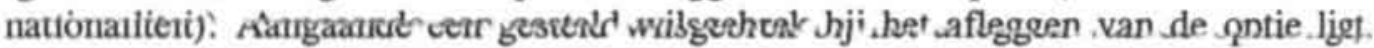
als vanouds, de bewijslast van het wilsgebrek bij de klager. ${ }^{797} \mathrm{Het}$ is daarbij onverschillig gebleken of het gaat om een dwangsituatie dan wel om dwaling.

Bewijslevering door middel van een beroep op het langdurig ongestoord bezit van staat van Nederlander is ook in de beklagprocedure op grond van artikel 43 Vreemdelingenwet toelaatbaar geacht. ${ }^{798}$

${ }^{72}$ HR 27.11.1979, NJ 1980, nr. 550 (par. 3.3.3.3.2); HR 15.09.1980, NJ 1981, nr. 68 (par. 3.3.3.2.2); HR 08.12.1989, MR 1990, p. 40 (par. 3.3.3.2.5).

${ }^{703} \mathrm{Al}$ moet worden opgemerkt dat in feite $66 \mathrm{k}$ alle zaken die gaan over de Toescheidingsovereenkom. sten met Indonesiê en Suriname het bezit van een vreemde nationaliteit betreffen. Hier blijkt dat de cirkel daadwerkelijk rond is als het gaat om verlies van het Nederlanderschap wegens het verwerven van een vreemde nationaliteit. Zowel met betrekking tot de verwerving van een vreemde nationaliteit als met betrekking tot het verlies van de Nederlandse nationaliteit blijkt uit de onderzochte jurisprudentie dat de bewijslast bij de Nederlandse overheid ligt indien deze het verlies van de Nederlandse nationaliteit inroept.

${ }^{794}$ Hiermee wordt de lijn uit HR 10.09.1959, NJ 1959, nr. 596 (par. 3.3.2.2.4) voortgezet. Vgl. Kollewijn, p. 22.

T95 HR 15.09.1980, NJ 1981, nr. 68 (par. 3.3.3.2.2) en HR 08.12.1989, MR 1990, p. 40 (par. 3.3.3.2.5),

$79 \mathrm{Vgl}$. HR 28.10.1952, HPS 1952, p. 133 (par. 3.3.2.1.1).

79 HR 21.01.1969, NJ 1969, nr. 144 (par. 3.3.3.3.1); HR 28.10.1983, NJ 1984, nr. 230 (par. 3.3.3.4.3); HR 08.03.1985, NJ 1985, nr. 495 (par. 3.3.3.4.6); HR 08.05.1987, NJ 1987, nr. 682 (par. $3.3 .3,4,7)$.

${ }^{78}$ HR 23.03.1984, NJ 1984, nr. 650 (par. 3.3.3.2.3). 


\subsubsection{Nationaliteitsvaststelling en bewijslastverdeling in procedures op grond van artikel 17 Rijkswet op het Nederlanderschap (1986-heden)}

\subsubsection{Algemene Beschouwingen}

Voor een uiteenzetting over het bewijsrecht in civielrechtelijke verzoekschriftprocedures verwijs ik op deze plaats kortheidshalve terug naar paragraaf 3.2, waar reeds in meer algemenere zin aandacht is geschonken aan het civielrechtelijk bewijsrecht.

Een ander facet van de civiele verzoekschriftprocedure betreft de vraag naar de mate van lijdelijkheid die de rechter in de procedure aan de dag legt. Algemeen wordt van oudsher in de procesrechtelijke literatuur het standpunt aanvaard dat de rechter in verzoekschriftprocedures een minder lijdelijke positie inneemt dan de rechter in de procedure op grond van een dagvaarding. ${ }^{799}$ Dit terwijl ook in de dagvaardingsprocedure sinds enige tijd een ontwikkeling wordt gesignaleerd die duidt op vermindering van de lijdelijkheid. ${ }^{800}$ Schaafsma-Beversluis heeft dan ook onlangs de conclusie getrokken dat in de loop van de tijd de ooit aanzienlijke verschillen tussen de beide vormen van procederen door toedoen van de wetgever en de rechtspraak kleiner zijn geworden. ${ }^{801}$

Struycken heeft in zijn proefschrift de zienswijze verdedigd dat de mate van lijdelijkheid (Struycken spreekt in dat verband van "intensiteit van rechtsmacht") van de rechter afhankelijk is van het onderwerp in de gevoerde procedure. Het criterium dat door hem wordt aangelegd ten behoeve van de beslissing of de rechter zich lijdelijk of meer actief dient op te stellen, is of in de procedure een rechtskwestie aan de orde is waarvan het rechtsgevolg ter vrije beschikking van partijen staat. Heeft de procedure betrekking op een rechtsgevolg dat niet ter vrije beschikking van partijen of de partij staat, dan is een minder lijdelijke rechter wenselijk. Is een minder lijdelijke rechter gewenst, dan ligt een procedure in de vorm van een verzoekschriftprocedure voor de hand. ${ }^{802}$

\footnotetext{
Van den Blink, p. 10; Boekman, p. 114; Boon/Van der Wal, p. 4; Bosch-Boesjes, p. 43, 91-97; Meijknecht, oratie, p. 15; Stein, p. 30; Verhagen-Maat, p. 51; Wesseling-van Gent, p. 94 en 130; Zuidema, p. 91, die op p. 93, van mening is: "Voor het wegvallen van de beginselen der lijdelijkheid enz. is geen reden, en de gewone regels moeten dus in eere hersteld worden, in die gevallen van verzoekschriftprocedures, waar wel een tegenpartij is, en die, als betreffende eigenlijke rechtspraak, feitelijk geheel gelijk staan met een gewoon proces. "

${ }^{m} \mathrm{Vgl}$. Boon/Van der Wal, p. 4; Bosch-Boesjes, p. 31, 38, 42 en 47; Princen, p. 62; SchaafsmaBeversluis, p. 300; Wesseling-van Gent, p. 93.

it Schaafsma-Beversluis, p. 292. Vgl. Boekman (II), p. 38, die opmerkt: "het is opvallend dat de rechtspraak er nu juist niet naar tendeert het bijzondere karakter van de rekestprocedure te accentueren. "; Meijknecht, oratie, p. 13.

Struycken, p. 18 en 19 . Rechtspraak inzake rechten die niet ter vrije beschikking van de rechtssubjecten staan, noemt Struycken, p. 19, "gracieuze jurisdictie". Struycken is van mening: "(......) dat het (......) terrein van de gewone procedure niet verder reikt dan de geschillen waarvan het onderwerp ter
} 
In paragraaf 3.2.2 is reeds aangestipt dat het toepasselijk bewijsrecht invloed ondergaat van de vorm van de procedure en de mate van lijdelijkheid van de rechter. ${ }^{803}$ Daarbij is de achterliggende problematiek of het gewenst is dat de rechter op lijdelijke wijze zich baseert op hetgeen de verzoeker en eventueel belanghebbende(n) hem voorleggen, of dat het wenselijker is dat de rechter een meer actievere houding betreffende de feiten aanneemt. Met betrekking tot de "zelfstandige vaststellingsprocedure" kan, aansluitend op hetgeen inzake verzoekschriftprocedures in algemene zin is opgemerkt in paragraaf 3.2.2, nogmaals op de hoofdregel worden gewezen dat, tenzij de wet anders bepaalt, de rechter vrij is in de bewijslastverdeling. ${ }^{804}$ Immers, op verzoekschriftprocedures is artikel $177 \mathrm{Rv}$ dat de bewijslast plaatst bij "de partij die zich beroept op de rechtsgevolgen van door haar gestelde feiten of rechten", (.......), tenzij uit enige bijzondere regel ${ }^{805}$ of uit de eisen van redelijkheid of billijkheid een andere verdeling van de bewijslast voortvloeit" niet van toepassing. Wel is het mogelijk dat artikel $177 \mathrm{Rv}$ in verzoekschriftprocedures analogisch wordt toegepast.

In het bijzonder met het oog op de procedure tot vaststelling van het Nederlanderschap wijst Van den Blink op de overlapping in procesrechtelijke regels tussen administratiefrechtelijke procedures en de civielrechtelijke verzoekscinitproceuture. Zij stelt: "De grondbeginselen van het administratief procesrecht: niet-lijdelijkheid van de rechter en vrije bewijsleer gelden ook in de rekestprocedure. Beide procesvormen: administratieve procedure en civiele rekestprocedure kennen niet één strak schema van procedurevoorschriften maar laten nuancering toe in verband met de aard van de zaak die het onderwerp van het geschil uitmaakt. ${ }^{{ }^{806}}$ En specifiek betreffende de lijdelijkheidsattitude van de rechter in het kader van een procedure ingevolge artikel 17 Rijkswet op het Nederlanderschap merkt Van den Blink op: "De Haagse Rechtbank pleegt de stukken die zij voor haar beslissing nodig meent te hebben op te vragen hetzij van de procureur van verzoeker, hetzij van de vertegen-

$802 \rightarrow$

dispositie van partijen staat. De beslissingen in deze geschillen vallen onder de contentieuze jurisdictie. Alle andere beslissingen vallen onder de gracieuze jurisdictie, zulks ongeacht of daardoor een geschil wordt beslecht. Zij betreffen zaken die niet ter dispositie van de (......) betrokkenen staan die, anders gezegd, voorwerp zijn van verhoogde intensiteit van overheidsbemoeienis. " Vgl. Meijknecht, oratie, p. 10 en 15. De gedachtengang die Struycken volgt, valt ook te herkennen bij Stein, NJB 1988, p. 388.

vos. Struycken, p. 35.

Vol. Dijksterhuis-Wieten, p. 11.

${ }^{805}$ Overigens valt nog op te merken dat de Rijkswet op het Nederlanderschap geen bepalingen kent ter zake van het bewijs van het Nederlanderschap of de bewijslastverdeling dienaangaande.

${ }^{306}$ Van den Blink, p. 10. In gelijke zin oordeelt eerder in 1970 Struycken, p. 39: "De pasitie van de rechter in een requestprocedure in gracieuze jurisdictie vertoont overeenkomst met die van de administratieve rechter." Bosch-Boesjes, p. 175: "De rechter in de verzoekschriftprocedure en de administratieve rechter hebben daarentegen altijd de bevoegdheid zowel feiten die in geschil zijn als feiten die niet in geschil zijn toch in hun onderzoek te betrekken. De rechter in de verzoekschriftprocedure en de administratieve rechter kunnen daamaast zelf een deel van de bewijslevering op zich nemen." 
woordiger van het Ministerie van Justitie. De voorzitter meende dat indien nodig de Officier van Justitie zou kunnen worden ingeschakeld voor recherche. ${ }^{m 807}$

Dat er ook een grens aan deze minder lijdelijke houding van de artikel 17 RWNrechter is, is enige tijd geleden gebleken. De rechtbank heeft toen naar aanleiding van het betoog van een verzoeker het volgende opgemerkt: "De niet-lijdelijkheid houdt echter niet in dat de rechter zelf nieuwe feiten moet aandragen ter ondersteuning van de stellingen van verzoeker en/of de Staat. ${ }^{808}$ Recentelijk heeft echter de juiste mate van niet-lijdelijkheid ten aanzien van de wel gestelde feiten geleid tot cassatie van een vaststellingsbeschikking. In de betreffende beschikking heeft de rechtbank achterwege gelaten de Staat te gelasten om zijn stelling inzake het verlies van de Nederlandse nationaliteit met bewijs te staven. Volgens de Hoge Raad is dit in strijd met het uitgangspunt dat "de rechter zich met betrekking tot het onderzoek naar de feiten die voor de vaststelling van de nationaliteit van belang zijn, niet lijdelijk behoort op te stellen." 809

Onder de ten behoeve van dit onderzoek bestudeerde tweeënveertig materieel inhoudelijke vaststellingsbeschikkingen van de rechtbank te 's-Gravenhage bevinden zich tweeëntwintig beschikkingen waaraan bewijsrechtelijke aspecten zijn te ontwaren. De meerderheid daarvan betreft, net als bij de artikel 43 (oud) Vreemdelingenwetprocedure, procedures waarin de Toescheidingsovereenkomst inzake nationaliteiten tussen Nederland en Suriname aan de orde komt. ${ }^{810}$ In de bewijsrechtelijk niet interessante gevallen gaat het om zuivere interpretatie van de relevante regelingen, namelijk de Wet op het Nederlanderschap en het ingezetenschap uit 1892, de Rijkswet op het Nederlanderschap, de Overeenkomst betreffende

\footnotetext{
${ }^{807}$ Van den Blink, p. 10. Een voorbeeld van dit laatste is te vinden in HR 31.01.1992, NJ 1993, nr. 261 , m.nt. GRdG. Uit dit voorbeeld valt op te maken dat het openbaar ministerie wordt ingeschakeld in de gevallen waarin de als belanghebbende opgeroepen Staat geen vertegenwoordiger naar de behandeling heeft afgevaardigd.

Rb. 's-Gravenhage 12.06.1991, rkstnr. 90.5346 (=HR 14.02.1992, NJ 1993, nr. 262, m.nt. GRdG; zie par. 3.3.4.4.8). Het betoog van de verzoeker hield in dat geen sprake zou zijn van "effectieve" verkrijging van de Surinaamse nationaliteit. De verzoeker leverde volgens de rechtbank ten behoeve van die stelling onvoldoende bewijs aan.

${ }^{309}$ HR 28.10.1994, RvdW 1994, nr. 216. (zie par. 3.3.4.3.2) Onderzoek naar de feiten: alleen de gestelde feiten of tevens naar niet gestelde feiten, bijvoorbeeld verliesfeiten die wellicht jaren na het in het geding zijnde feit zich (mogelijk) hebben gemanifesteerd? N.m.m. is ten aanzien van dat laatste het antwoord bevestigend. Zie daarvoor par. 7.3.1.

${ }^{6}$ Slechts in vier als bewijsrechtelijk interessant aan te merken beschikkingen is geen sprake van de TOS: HR 31.01.1992, NJ 1993, nr. 261, m.nt. GRdG (=Rb. 's-Gravenhage 07.02.1990, rkstnr. 87.5947): rechtsgeldigheid en bewijs van een erkenning in Ghana door een Nederlander van een minderjarige (par. 3.3.4.2.2). Rb. 's-Gravenhage 04.11.1992, rkstnr. 92.5105: rechtsgeldigheid en bewijs van een optie en bewijs van moederschap (par. 3.3.4.2.3). Rb. 's-Gravenhage 29.01.1992, rkstnr. 87.5178, B\&R 1994, p. 115: bewijs van verwerving van de Indonesische nationaliteit (par. 3.3.4.3.1). HR 28.10.1994 RvdW 1994, nr. 216: bewijs van een optie voor de Indonesische nationaliteit (par. 3.3.4.3.2).
} 
de toescheiding van Staatsburgers tussen Nederland en Indonesië alsmede de Toescheidingsovereenkomst inzake nationaliteiten tussen Nederland en Suriname.

Het is vanuit bewijsrechtelijk oogpunt, mijns inziens, niet interessant en derhalve niet nodig om alle tweeëntwintig beschikkingen aan de orde te stellen. In totaal worden in het onderstaande vijftien beschikkingen nader besproken.

Ten behoeve van het onderzoek naar de bewijslastverdeling breng ik op gelijke wijze als bij de voorafgaande paragrafen 3.3.2 en 3.3.3 een, mijns inziens noodzakelijke, scheidslijn aan in de vaststellingsbeschikkingen. De te onderzoeken uitspraken vallen zodoende (wederom) uiteen in twee categorieën. De eerste categorie betreft verzoeken die steunen op de bewering dat de betrokkene het Nederlanderschap heeft verworven, de tweede categorie betreft de beschikkingen waarin het gaat om een verzoeker die op het standpunt staat het Nederlanderschap niet te hebben verloren. Het onderscheiden in deze twee categorieën is van belang, omdat het in de eerste categorie gaat om het bewijs en de bewijslastverdeling bij een beroep op een verwervingsgrond voor de Nederlandse nationaliteit, terwijl het daarentegen in de tweede categorie gaat om bewijs en bewijslastverdeling van een verliesgrond.

Tot op heden hebben alle verzoekschriften aan de rechtbank te 's-Gravenhage tot inhoud gehad dat de rechtbank het bezit van het Nederlanderschap vaststelt. Een verzoekschrift op grond van artikel 17 lid 1 RWN dat de uitspraak wil uitlokken dat de verzoeker niet het Nederlanderschap bezit, is, bij mijn weten, tot op heden niet gedaan.

\subsubsection{Jurisprudentie categorie A: Beroep op verwerving van het Nederlanderschap}

In slechts weinig beschikkingen gaat het om een verzoeker die een beroep doet op de verwerving van het Nederlanderschap. Van de tweeëntwintig beschikkingen met bewijsrechtelijke elementen zijn het er welgeteld drie. ${ }^{811}$ Met het oog op hun bewijsrechtelijke merites worden deze beschikkingen hieronder nader besproken.

Uit de vroegere jurisprudentie is de regel bekend dat in het geval van een beroep op een verwervingsgrond de betrokkene een stelplicht en een "summiere bewijsplicht" heeft ten aanzien van de feiten die tot de verwerving van de Nederlandse nationaliteit zouden hebben geleid. De bewijslast inzake de gestelde feiten rust in beginsel ook op de verzoeker, met dien verstande dat in paragraaf 3.3.3.2 is aangegeven dat dienaangaande, althans in de beklagprocedure ingevolge artikel 43 (oud) Vreemdelingenwet, enige niet onbelangrijke nuances hebben gegolden. Uit de

"11 HR 28.09.1990, NJ 1991, nr. 293, m.nt. GRdG (=Rb. 's-Gravenhage 11.10.1989, rkstnr. 89.5224); HR 31.01.1992, NJ 1993, nr. 261, m.nt. GRdG (=Rb. 's-Gravenhage 07.02.1990, rkstnr. 87.5947); Rb. 's-Gravenhage 04.11.1992, rkstnr. 92.5105 (niet gepubliceerd, wel summier vermeld door Zilverentant, B\&R 1994, p. 143 en losbl. uitgave Nationaliteitswetgeving, art. 27 lid 2 RWN). 
bespreking van de beroepen op verwerving van de Nederlandse nationaliteit in procedures op grond van artikel 43 (oud) Vreemdelingenwet is gebleken dat de Hoge Raad ook bezit van het Nederlanderschap heeft vastgesteld in gevallen waarin de betrokkene niet over sluitend bewijs beschikte. ${ }^{812}$

De vraag is of aan de hand van de onderstaande drie uitspraken op grond van artikel 17 Rijkswet op het Nederlanderschap inzake beroepen op verwerving van de Nederlandse nationaliteit een aanvulling op het bovenstaande kan worden gegeven.

\subsection{HR 28 september 1990}

Cat. A. uitspr. VIII. Casusbeschrijving. Bewijs van een optie. Toewijzing van het verzoek.

In het onderhavige geval ${ }^{813}$ staat de bewijslevering van een optie ter verwerving van het Nederlanderschap centraal. Artikel 10 Toescheidingsovereenkomst Nederland-Suriname geeft personen die op 25.11.1975 de Surinaamse nationaliteit hebben verworven en van wie "de vader of, indien deze wettelijk onbekend is, de moeder buiten Suriname als Nederlander is geboren" de mogelijkheid om tot 25.11.1976 een verklaring af te leggen met de strekking dat men het Nederlanderschap wil herkrijgen.

De betrokkene die in 1989 een verzoekschrift tot vaststelling van haar Nederlanderschap bij de rechtbank te Den Haag indient, is geboren in Suriname en is daar woonachtig op 25.11.1975, zodat zij op dat moment de Surinaamse nationaliteit verwerft. Verzoeksters wettige vader is, volgens de verdere gegevens, geboren in Nederland en bezit vanaf zijn geboorte de Nederlandse nationaliteit. De verzoekster valt derhalve onder de in artikel 10 TOS gestelde voorwaarden tot optie ter herverkrijging van het Nederlanderschap. Als gezegd: voor het afleggen van die optie zou zij tot 25.11.1976 de tijd hebben gehad.

Volgens het relaas van de verzoekster heeft zij in het voorjaar van 1976 een bezoek gebracht aan de Nederlandse ambassade in Paramaribo met het verzoek om een (Nederlands) paspoort. De verzoekster verkeert op dat moment namelijk (nog) in de veronderstelling dat de onafhankelijkheid van Suriname op háár nationaliteit geen invloed heeft gehad, zij stelt in het verzoekschrift aan de rechtbank niet op de hoogte te zijn geweest van de inhoud en werking van de Toescheidingsovereenkomst. Volgens de (in 1989 voor de rechtbank afgelegde) verklaringen van de verzoekster is haar (in 1976) van de kant van de ambassade in eerste instantie

\footnotetext{
${ }^{1 / 2}$ HR 23.03.1984, NJ 1984, nr. 650, m.nt. AHJS (par. 3.3.3.2.3); HR 08.12.1989, MR 1990, m.nt. HAA (par. 3.3.3.2.5).

${ }^{6}$ HR 28.09.1990, NJ 1991, nr. 293, m.nt. GRdG.
} 
gezegd dat zij nu de Surinaamse nationaliteit bezit ${ }^{814}$ en is in tweede instantie voorbij gegaan aan haar reactie daarop inhoudende dat zij toch afstamt van een Nederlandse vader. De uitreiking van het begeerde paspoort wordt geweigerd. ${ }^{815}$

$\mathrm{Na}$ een tijdsverloop van dertien jaar komt bovenstaand incident bij de Nederlandse ambassade in Paramaribo op het bord van de rechtbank te Den Haag. Verzoekster stelt dat zij toentertijd bij de ambassade een optie ingevolge artikel 10 TOS heeft gedaan en dat zij sindsdien het Nederlanderschap heeft herkregen. De Staat, belanghebbende in de procedure, is op de zitting vertegenwoordigd door een ambtenaar van het ministerie van Justitie.

Ten einde meer duidelijkheid te verkrijgen over de gang van zaken destijds hoort de rechtbank als getuigen de verzoekster alsmede een andere vrouw, die in 1976 de verzoekster heeft vergezeld naar de Nederlandse ambassade.

$\mathrm{Er}$ is aangaande dit bewuste bezoek via het ministerie van Buitenlandse Zaken onderzoek verricht of nog bij de ambassade in Paramaribo valt te achterhalen of er iets, en zo ja, wàt er zich, heeft afgespeeld op de ambassade ${ }^{816}$ Het blijkt dat hieromtrent bij de ambassade geen gegevens meer zijn te achterhalen.

Aan de afwijzing van het verzoek legt de rechtbank de volgende rechtsoverweging ten grondslag: "dat voor de geldigheid van een kennisgeving als bedoeld in artikel $11^{817}$ van de Toescheidingsovereenkomst op zichzelf niet is vereist dat daarvan een schriftelijk stuk wordt opgemaakt. Wel dient echter de eis te worden gesteld dat die kennisgeving zo duidelijk mogelijk wordt gedaan dat geen misverstand mogelijk is."

Met betrekking tot de feiten overweegt de rechtbank dat uit de brief van het ministerie van Buitenlandse Zaken volgt dat thans niet meer valt na te gaan of de verzoekster zich indertijd heeft gewend tot de Nederlandse ambassade. ${ }^{818}$ En uit het getuigenverhoor valt, volgens de rechtbank, "niet af te leiden dat verzoekster op eenduidige wijze heeft verklaard de Nederlandse nationaliteit te willen behouden of

\footnotetext{
${ }^{814}$ Hetgeen overigens correct is geweest.

sis $\mathrm{Om}$ toch buitenslands te kunnen reizen vraagt de verzoekster na het hier beschreven bezoek aan de Nederlandse ambassade maar een Surinaams paspoort aan.

"16 Uit de later in cassatie genomen conclusie van de A.-G. valt op te maken dat het onderzoek in Suriname is verricht via het ministerie van Buitenlandse Zaken op verzoek van het ministerie van Justitie. In deze zaak heeft de mondelinge behandeling plaatsgevonden op 07.06.1989, vervolgens vindt het getuigenverhoor (verzoekster en de andere vrouw) plaats op 20.06.1989. Ook op 20.06.1989 verklaart de vertegenwoordiger van het ministerie van Justitie nog geen antwoord te hebben ontvangen van het ministerie van Buitenlandse Zaken. Dit antwoord, gedateerd 26.06.1989, is vervolgens met de conclusie van het OM van 28.08.1989 aan de rechtbank overgelegd.

817 Art. 11 TOS verwijst naar alle optiemogelijkheden die de Toescheidingsovereenkomst kent, mede dus naar de mogelijkheid uit art. 10 TOS.

"s Een consequentic die hieruit volgt, is dat de Staat niet kan bewijzen dat de verzoekster niet bij de ambassade is geweest. Op zich is een negatief bewijsfeit iets dat moeilijk te bewijzen is. Maar waarom is bij de Nederlandse ambassade in Suriname, waar toch optieverklaringen mochten worden verwacht, niet in een register bijgehouden wie is komen informeren naar het mogelijk bezit van het Nederlanderschap?
} 
verkrijgen." Derhalve komt de rechtbank tot het oordeel dat "onvoldoende is gebleken dat verzoekster de door haar gestelde optieverklaring heeft afgelegd. "

De verzoekster tekent tegen deze uitspraak cassatie aan. De behandeling in cassatie verloopt voor haar voorspoedig, de Hoge Raad stelt uiteindelijk zelf het bezit van het Nederlanderschap door de verzoekster vast.

Het is voor de Hoge Raad namelijk "niet begrijpelijk dat de Rechtbank heeft geoordeeld dat onvoldoende is gebleken dat verzoekster de door haar gestelde optieverklaring heeft afgelegd. " Uitgangspunt voor het onbegrijpelijk-oordeel vormt het feit dat de rechtbank, zich daarbij baserend op het getuigenverhoor, ervan is uitgegaan dàt het bezoek aan de Nederlandse ambassade heeft plaatsgevonden en hetgeen zich aldaar heeft afgespeeld "kennelijk niet in twijfel heeft getrokken".

Ook de eis van de rechtbank "dat die kennisgeving zo duidelijk mogelijk wordt gedaan dat geen misverstand mogelijk is" sneuvelt bij de cassatierechter. Daartegenover stelt de Hoge Raad: "dat -zoals ook de Rechtbank kennelijk, terecht, heeft aangenomen- zodanige verklaring ook mondeling kon worden afgelegd en niet aan een bepaalde formulering was gebonden."

Voorts is de Hoge Raad van oordeel dat op de betrokken functionaris van de ambassade de verplichting rustte zich ervan te vergewissen of mogelijk een optie werd afgelegd. I.c. stelt de Hoge Raad "Onder deze omstandigheden had de betrokken functionaris zich behoren te realiseren dat in verzoeksters uitlatingen een wilsverklaring als in dat artikel bedoeld besloten lag, (...........)."

De uitspraak van de rechtbank wordt vernietigd en de Hoge Raad beschikt als volgt: "De feiten waarvan (........) moet worden uitgegaan leiden tot geen andere conclusie dan dat verzoekster in april of in mei 1976 de in art. 10 bedoelde optie heeft uitgeoefend. De Rechtbank heeft voorts kennelijk de juistheid aangenomen van verzoeksters stelling dat zij toen voldeed aan de in die bepaling genoemde vereisten, en de stukken behelzen geen aanwijzing dat zich daarna omstandigheden hebben voorgedaan op grond waarvan verzoeksters nationaliteit is gewijzigd. Derhalve moet het inleidend verzoek worden toegewezen. "

Aantekening.

Naar de opvatting van de rechtbank dient i.c. klaarheid te komen inzake de vragen of de verzoekster zich in 1976 heeft vervoegd bij de Nederlandse ambassade te Paramaribo en zo ja, of zij aldaar duidelijk heeft te kennen gegeven te willen opteren voor de Nederlandse nationaliteit. Ten aanzien van beide vragen legt de rechtbank de bewijslast en derhalve het bewijsrisico bij de verzoekster. Naar het oordeel van de rechter voldoet de verzoekster wel aan de bewijslast met betrekking tot het eerste feit (het plaatsvinden van het bezoek acht de rechtbank klaarblijkelijk aannemelijk), maar niet aan (de bewijslast voor) het tweede feit (verzoekster heeft niet expliciet genoeg het Nederlanderschap voor zichzelf opgeëist). 
De Hoge Raad laat de tweede eis, dat opteren slechts opteren is indien expliciet de wilsuiting ter zake van het bezit van het Nederlanderschap wordt gedaan, vervallen. Daar de Hoge Raad in cassatie dient uit te gaan van de feiten zoals die zijn vastgesteld door de feitenrechter, ${ }^{819}$ gaat i.c. de Hoge Raad uit van de, door de rechtbank vastgestelde, feitelijke omstandigheid dat de verzoekster inderdaad in het voorjaar van 1976 de ambassade heeft bezocht om inlichtingen te verkrijgen over het buitenslands kunnen reizen met een Nederlands paspoort.

Het geheel leidt ertoe dat, nadat de tweede eis van rechtbank is komen te vervallen, de Hoge Raad bij het zelf afdoen van de zaak uitgaat van het feit dat de verzoekster haar bezoek aan de ambassade heeft afgelegd èn van de rechtsregel dat het afleggen van een optie voor de Nederlandse nationaliteit vormvrij is. Dit resulteert in de vaststelling van verzoeksters Nederlanderschap.

Dat de eis van de rechtbank dat een optie "zo duidelijk mogelijk wordt gedaan dat geen misverstand mogelijk is" door de Hoge Raad is ontkracht, is alleen maar toe te juichen. Alleen degene die op de hoogte is van het feit dat hij gerechtigd is tot opteren, kan "zo duidelijk mogelijk" opteren. Voor personen die, net als verzoekster i.c., van de optiemogelijkheid niet op de hoogte zijn, geldt eerder dat zij slechts bij toevalśtreffêr op dè dỏor dẻ rechitbank' gewensté wijżè zouoènopteren. De Hoge Raad bestendigt met deze uitspraak de geldende regel dat het afleggen van een optie voor de Nederlandse nationaliteit vormvrij is. ${ }^{820}$

Voor zover uit deze zaak een conclusie betreffende de bewijslastverdeling valt te trekken, kan worden gesteld dat in het geval van een beroep op verwerving van de Nederlandse nationaliteit de bewijslast ter zake van feiten die leiden tot verwerving berust bij de verzoeker. I.c. heeft de verzoekster aan haar bewijslast kunnen voldoen.

"Een gegeven waarop Ahmad Ali/Klip, MR 1995, p. 83, ook wijzen als zij schrijven: "(.......) dat het onmogelijk is op te komen tegen de vaststelling van de feiten door de rechtbank 's-Gravenhage."

so Vgl. ARRS 24.11.1981, RV 1981, nr. 30. In HR 21.01.1969. NJ 1969, nr. 144 (par. 3.3.3.3.1) bleek reeds dat het afleggen van een optie een eenzijdige rechtshandeling ("eenzijdige wilsverklaring") betreft, waarbij op de totstandkoming van het rechtsgevolg een eventuele afwijzing van de optie door de overheid (de ontvanger van de optieverklaring) geen invloed kan uitoefenen. Uit het bovenstaand vermeld rechtskarakter van opteren vloeit tevens voort dat het, ten bewijze van het afleggen van de optie, wel of niet opmaken van een schriftelijk bewijsstuk de totstandkoming van het rechtsgevolg (namelijk nationaliteitsverwerving) niet beïnvloedt (vgl. HR 20.06.1986, NJ 1987, nr. 902, m.nt. GRdG). Zie voor de vormvrijheid van verklaringen tevens art. 3:37 lid $1 \mathrm{BW}$. 


\subsection{HR 31 januari 1992}

\section{Cat. A. uitspr. IX. Casusbeschrijving. Rechtsgeldigheid en bewijs van een erken- ning. Vernietiging en terugverwijzing naar de rechtbank.}

In de onderstaande $z^{2 a k^{821}}$ waarin een beroep is gedaan op verwerving van het Nederlanderschap, gaat het om de erkenning van een minderjarige ${ }^{822}$ door een Nederlander. ${ }^{823}$ Volgens de stelling van de verzoeker heeft de erkenning van het op 24.12.1969 geboren kind plaatsgevonden op 11.01.1986. De erkenning heeft in Ghana plaatsgevonden. ${ }^{824}$ Hoewel de Staat op grond van artikel $429 \mathrm{f} \mathrm{Rv}$ is opgeroepen als belanghebbende door de rechtbank, is deze in feitelijke instantie niet verschenen.

Primair speelt in casu de rechtsvraag welk nationaal recht de rechter dient te hanteren ter fine van de beoordeling of het gaat om een rechtsgeldige erkenning. In internationaal-privaatrechtelijke literatuur wordt aangaande erkenning van onwettige kinderen als hoofdlijn aangenomen dat de rechtsgeldigheid van een erkenning dient te worden beoordeeld naar het nationale recht van de erkenner. ${ }^{825}$ Indien het belang van het kind dit noodzakelijk maakt, kan van de hoofdregel worden afgeweken en is er ruimte voor het toepassen van een ander nationaal rechtsstelsel. $^{826}$ In dit verband wordt in de literatuur uitgegaan van het gezichtspunt dat het belang van het kind is gelegen in de totstandkoming of de bevestiging van familierechtelijke betrekkingen tussen kind en vader. ${ }^{827}$

Secundair speelt in de onderhavige zaak vanuit bewijsrechtelijk oogpunt de omstandigheid dat bij het verzoekschrift geen enkel rechtstreeks of officieel bewijsstuk van (het plaatsvinden van) de erkenning is overgelegd. Wel worden in de loop van de procedure overgelegd: een gecertificeerd uittreksel uit het geboortenregister

\footnotetext{
${ }^{\text {nI }}$ HR 31.01.1992, NJ 1993, nr. 261, m.nt. GRdG.

m Art. 1 aanhef en sub b RWN verstaat voor de toepassing van de RWN onder het begrip meerderjarige: "hij die de leeftijd van achttien jaren heeft bereikt of voordien in het huwelijk is getreden". De leeftijd van 18 jaar komt overeen met de leeftijdsgrens in art. 1:233 (Nederlands) BW. Eerder (voetnoot 481 ) is reeds erop gewezen dat in de andere delen van het Koninkrijk de meerderjarigheidsgrens (nog steeds) op 21-jarige leeftijd ligt. Dat men ten gevolge van het sluiten van een huwelijk voor het bereiken van de desbetreffende leeftijden de meerderjarigheid bereikt, geldt in alle delen van het Koninkrijk.

Dit is een beroep op art. 4 lid 1 RWN.

at Volgens een bij deze zaak gevoegde brief van het Int. Juridisch Instituut te Den Haag wordt men in Ghana meerderjarig "bij het volbrengen van het 21 -ste levensjaar." Voor de verwerving of het verlies van de Nederlandse nationaliteit als "minderjarige" is evenwel alleen de begripsbepaling uit art. 1 RWN van belang.

Es In het bijzonder voor het antwoord op de vraag of de erkenner bevoegd is tot het plegen van een zodanige rechtshandeling als een erkenning.

Strikwerda, nr. 120.

vonken, WPNR 1991, nr. 6016, p. 567. Vgl. echter Rb. 's-Gravenhage 26.02.1992, rkstnr. 89.5889 , B\&R 1994 , p. 112 en 113.
} 


\section{Hoofdstuk 3}

m.b.t. het erkende kind ${ }^{828}$ en daarnaast in totaal vier verklaringen gedateerd op 14.01.1988. Bij twee van deze verklaringen gaat het om verklaringen van respectievelijk de moeder van het kind en de verzoeker (de vader); in beide verklaringen wordt gesteld dat op 11.01.1986 volgens "customary rites" de erkenning heeft plaatsgevonden. Deze verklaringen van respectievelijk de moeder en de vader zijn afgelegd ten overstaan van een zekere C.A.A., en op deze persoon hebben de twee andere verklaringen betrekking. In beide verklaart "Commander G.L." dat C.A.A. een "Notary Public" is.

Bij de rechtbank rijst twijfel aangaande de authenticiteit van het hierboven beschreven uittreksel uit het geboortenregister en de twee door "Commander G.L." afgegeven verklaringen. Na twee eerdere zittingen ${ }^{829}$ geeft de rechtbank op 05.10.1988 bij tussenbeschikking het openbaar ministerie opdracht een onderzoek in te stellen naar de authenticiteit van het door de verzoeker overgelegde materiaal. ${ }^{830}$ Via de Nederlandse ambassade in Ghana wordt een onderzoek gestart. In haar beschikking van 07.02.1990 volgt de uitspraak van de rechtbank dat de desbetreffende schriftelijke bescheiden weliswaar authentiek ${ }^{831}$ zijn, maar volgens de rechtbank blijkt uit de desbetreffende verklaringen evenwel "slechts dat bedoeld moet zijn een erkenning op inheemse wijze ("costumary rites"). "

Ter beoordeling van de vraag of het een rechtsgeldige erkenning of niet betreft, kiest de rechtbank voor de toepasselijkheid van Nederlands recht, het nationale recht van de erkenner. De bewuste erkenning kan, naar de rechtbank oordeelt, de toets van het Nederlandse recht niet doorstaan en dit leidt vervolgens tot een afwijzing door de rechtbank van het verzoek tot vaststelling van het bezit door de minderjarige van de Nederlandse nationaliteit. De afwijzing berust op de volgende

828 Dit uittreksel is gedateerd op 11.08.1987 en het wordt door de rechtbank in het Engels aangeduid als: "Certified true copy of entry in register of births". Overigens gaat de rechtbank in haar beschikking ervan uit dat dit stuk niet als bewijsstuk voor (het plaatsvinden van) de erkenning is bedoeld: "Weliswaar is de kopie van de geboorte-inschrijving (........) niet overgelegd als bewijs van erkenning, maar de $R b$. merkt ten overvloede op dat daarin geen gewag gemaakt wordt van de Nederlandse nationaliteit van N.A.K., doch van zijn vervallen Ghanese,"

20 Op 20.01.1988 en 16.03.1988.

${ }^{50}$ De Staat is wel opgeroepen, maar, als vermeld, niet verschenen. Dit leidt tot de gevolgtrekking dat de Staat niet de echtheid heeft betwist en de rechtbank dus ambtshalve een onderzoek naar de feiten instelt. Deze handelwijze van de rechtbank vloeit voort uit art. 176 lid $1 \mathrm{Rv}$ (bij niet-betwisting van het gestelde feit kan de rechter bewijs verlangen indien de aanvaarding van de stelling zou leiden tot een rechtsgevolg dat niet ter vrije bepaling staat). Opmerkelijk is evenwel dat niet de partij die haar stelling wenst te onderbouwen met de door haar geproduceerde stukken de bewijslast van de authenticiteit draagt; art. $176 \mathrm{Rv}$ betreft geen regel van bewijslastverdeling. De last om te bewijzen dat het i.c. gaat om niet-authentieke stukken benust in wezen bij de overheidsorganen.

si Evenwel haalt Hidma juist de onderhavige uitspraak van de rb. 's-Gravenhage aan ter onderbouwing van zijn standpunt dat in het buitenland door bevoegde ambtenaren opgemaakte akten "in beginsel" niet authentiek kunnen worden genoemd. Pitlo/Hidma \& Rutgers, p. 81 (i.h.b. voetnoot 2). Zie tevens voetnoot 840 . 
overweging: "De beweerdelijk na de naturalisatie van (N.A.K.) ${ }^{8.2}$ plaats gehad hebbende erkenning van (T.K.) dient derhalve uitsluitend aan de hand van het Nederlandse rechr ${ }^{33}$ te worden getoetst. Allén reeds wegens het ontbreken van een (authentiek) geschrift waaruit kan blijken op welke plaats, bij welke bevoegde instantie, op welke wijze (bijvoorbeeld al dan niet met toestemming van de moeder) deze rechtshandeling zou zijn gepleegd, kan de rechtsgeldigheid daarvan hier te lande niet worden aanvaard." De rechtbank tilt er derhalve zwaar aan dat de in Ghana gepleegde rechtshandeling niet tot stand is gekomen volgens de vormvoorschriften die voor een rechtsgeldige erkenning in Nederland gelden. ${ }^{834}$

De verzoeker gaat in cassatie en ook in dit geval casseert de Hoge Raad. Er wordt vernietigd wegens onvoldoende motivering van de uitspraak, ten gevolge waarvan sprake is van "onvoldoende inzicht in de door de Rechtbank gevolgde gedachtengang (.........)."

De Hoge Raad is het om te beginnen niet eens met de eis van de rechtbank dat een, door een Nederlander, in het buitenland gedane erkenning van een onwettig kind slechts tot verwerving van het Nederlanderschap leidt indien de desbetreffende erkenning is geschied conform de vormvereisten die de Nederlandse wet stelt aan een erkenning. ${ }^{835}$ De rechtsgeldigheid van een in het buitenland voorgevallen erkenning kan ook, naar het inzicht van de Hoge Raad, worden vastgesteld volgens de maatstaf van het vreemde recht. En indien naar vreemd recht als gevolg van de gepleegde rechtshandeling familierechtelijke betrekkingen zijn ontstaan tussen de Nederlandse erkenner en het erkende kind heeft zulks nationaliteitsrechtelijke gevolgen voor het (minderjarige) kind. Een voorbehoud wordt evenwel aangebracht voor het geval de bewuste erkenning in strijd zou zijn met de Nederlandse rechtsorde. ${ }^{836}$

\footnotetext{
${ }^{82}$ D.i. de erkennende vader.

${ }^{m}$ Tegen deze overweging betreffende de rechtskeuze is nadien bij het beroep in cassatie geen middel gericht,

${ }^{84}$ In Nederland kan volgens art. 1:223 BW een erkenning plaatsvinden op de navolgende wijzen: 1. bij de geboorteakte van het kind; 2 . bij een akte van erkenning opgemaakt door een ambtenaar van de burgerlijke stand; 3 , bij elke notariële akte. Hieruit volgt dat er m.b.t een erkenning in Nederland altijd cen authentieke akte van de erkenning dient te zijn. Een in Nederland gepleegde erkenning kan onder bepaalde in art. 1:224 BW vermelde voorwaarden nietig zijn. Eén van die voorwaarden betreft het instemmen door de moeder met de erkenning.

55 Tegen de eis dat een (authentiek) geschrift zou moeten worden overgelegd als bewijs van het hebben plaatsgevonden op 11.01.1986 van de erkenning was het cassatiemiddel gericht.

${ }^{\mathrm{B}} 6 \mathrm{6}$ De Hoge Raad stelt: "Een buiten Nederland geschiede erkenning van een onwettig kind door een Nederlander heeft te gelden als een erkenning in de zin van art. 4 van de Rijkswet op het Nederlanderschap indien zij hier te lande als rechtsgeldig kan worden erkend. Dit laatste is -behoudens bijzondere omstandigheden, zoals strijd met de Nederlandse openbare orde- ook het geval indien zodanige erkenning niet bij akte is geschied, mits zij heeft plaatsgevonden in zodanige vorm en met inachtneming van zodanige voorschriften dat zij naar het recht van het land waar hetzij het kind, hetzij zijn moeder hetzij de erkennende man ten tijde van de erkenning woonplaats of gewone verblijfplaats had, dan wel
} 
Daarnaast ziet de Hoge Raad een misslag in de overweging van de rechtbank ten aanzien van het (ontbreken van) bewijs van de erkenning. Dienaangaande stelt de Hoge Raad: "Mogelijk is echter ook dat de Rechtbank tot uitdrukking heeft willen brengen dat de gestelde erkenning, naar haar oordeel, onvoldoende is bewezen omdat de bewijskracht van de (.......) verklaringen van de notary public moet worden beoordeeld naar Nederlands recht en de verklaringen, naar deze maatstaf, onvoldoende bewijs opleveren omdat daaruit omtrent de beweerde erkenning geen enkele (relevante) bijzonderheid blijkt.

$(\ldots . . . . . . . . . .$.$) . Ook in deze lezing geeft de aangevallen beslissing evenwel blijk$ van een onjuiste rechtsopvatting. Nu het gaat om verklaringen, in Ghana opgemaakt tot bewijs van een aldaar verrichte rechtshandeling behoort de Nederlandse rechter de bewijskracht van deze verklaringen immers niet te beoordelen naar zijn eigen, maar naar Ghanees recht."

Voorts overweegt de Hoge Raad dat, àls de rechtbank (zonder dit te vermelden) de bewijsstukken wel volgens Ghanees bewijsrecht heeft beoordeeld, de beslissing nog onbegrijpelijk blijft, aangezien de Hoge Raad niet kan nagaan welke gronden de rechtbank alsdan hanteert om tot haar (afwijzende) beslissing te komen. $\mathrm{Na}$ de vernietiging van de beschikking wordt terugverwezen naar de rechtbank te 'sGravenhage. ${ }^{837}$

\section{Aantekening.}

In casu speelt enerzijds de bewijsrechtelijke vraag of het daadwerkelijk plaatsvinden van de beweerdelijk op 11.01.1986 verrichte handeling voldoende aannemelijk kan worden geacht en anderzijds is de rechtsvraag aan de orde volgens welk rechtsstelsel de erkenning moet worden beoordeeld op haar (familierechtelijk) rechtsgevolg.

Vooral de bewijsrechtelijke kwestie heeft mij aanleiding gegeven de onderhavige uitspraak op te nemen. De laatste tijd is gebleken dat in nationaliteitsaangelegenheden de rechtbank te 's-Gravenhage in toenemende mate wordt geconfronteerd met bewijsvoering door middel van buitenlandse authentieke akten. ${ }^{838}$ Daarom is het des te interessanter dat i.c. de Hoge Raad een uitspraak doet over het toepasselijk bewijsrecht in het geval dat wordt getracht het bewijs van het plegen van een rechtshandeling in het buitenland te leveren met uit het buitenland afkomstig bewijsmateriaal.

$836 \rightarrow$

naar het recht van het land waarvan het kind of zijn moeder toen de nationaliteit bezat, op rechtsgeldige wijze familierechtelijke betrekkingen tussen de Nederlander en het kind tot stand heeft gebracht."

si In het vervolg van de behandeling wijst de rechtbank het verzoek van het erkende kind tot vaststelling van zijn bezit van het Nederlanderschap toe. Zie Zilverentant e.a., losbl. uitgave Nationaliteitswetgeving, art. 4 RWN.

${ }^{88} \mathrm{Vgl}$. Zilverentant, B\&R 1994, p. 112-115 en 141-145. 
Het zou te ver voeren om op deze plaats diep in te gaan op een binnen het (civiel) bewijsrecht zo omvangrijk vraagstuk als de bewijslevering vanuit het buitenland van aldaar voorgevallen rechtsfeiten betreft. Wel volgt hieronder meer over bewijslevering door middel van een in het buitenland opgestelde authentiek geschrift dat een in het buitenland voorgevallen rechtsfeit regardeert.

Reeds in 1918 heeft Offerhaus als stelregel geformuleerd dat een buitenslands opgesteld schriftelijk bewijsstuk dat onder het vreemde recht als authentieke akte geldt, door de Nederlandse rechter eveneens als een authentieke akte kan worden beschouwd. ${ }^{839}$ Van een andersluidend oordeel is echter recentelijk Hidma kennelijk uitgegaan als hij schrijft: "Onder authentieke akte valt naar mijn oordeel in beginsel niet een in het buitenland door een aldaar bevoegde ambtenaar opgemaakte akte. ${ }^{840}$

De bewijskracht die de Nederlandse rechter aan een zodanige buitenlandse authentieke akte dient te hechten, is, nogmaals volgens Offerhaus, de "bewijskracht overeenkomstig de wetgeving van het land waarin zij werd opgemaakt (.......). ${ }^{m 841}$ Door in de onderhavige zaak te stellen dat van de in Ghana ten overstaan van een "notary public" afgelegde verklaringen volgens Ghanees recht de bewijskracht dient te worden bepaald, sluit de Hoge Raad aan bij het door Offerhaus opgestelde uitgangspunt. ${ }^{842}$

De HR stelt dat de bewijskracht van (verklaringen strekkende tot) bewijs afkomstig uit het buitenland ter zake van het buitenslands plegen van een rechtshandeling derhalve dient te worden vastgesteld volgens het desbetreffende vreemde recht. ${ }^{843}$ Het tegenbewijs tegen de inhoud van een buitenlandse authentieke akte valt, volgens Offerhaus, ook geheel onder de regels van hetzelfde vreemde recht. ${ }^{844}$ Ook voor de vraag welke bewijsmiddelen toelaatbaar zijn, zoekt Offerhaus aansluiting bij het vreemde recht. ${ }^{845}$

\footnotetext{
${ }^{59}$ Offerhaus, p. 33 en $37 . \mathrm{Vgl}$. Mulder, p. 231 en 232.

${ }^{n}$ Pitlo/Hidma \& Rutgers, p. 80.

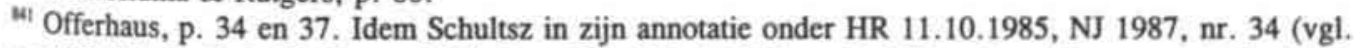
par. 3.3.3.3.3). Vgl. Wohlgemuth Kitslaar, Bondsblad 1986, p. 16: "Een akte, 6́6k van een buitenlandse ambtenaar van de burgerlijke stand afkomstig, levert over het algemeen het bewijs dat de feiten zoals daarin beschreven juist zijn."

${ }^{162} \mathrm{Vgl}$. Van Rijn van Alkemade, HPS 1961, p. 52: "De verwijzing naar een buitenlands rechtsstelsel dient wanneer het afstammingsvragen betreft zo te worden opgevat, dat de verwijzing tevens betrekking heeft op de met het materiële recht verweven bewijsregels."

${ }^{\mathrm{N}} \mathrm{Vgl}$. bijvoorbeeld $\mathrm{Rb}$. Haarlem 15.11.1966, NJ 1967, nr. 195 (toepassing Zweeds bewijsrecht op in Zweden voorgevallen feitelijke handeling waaruit beweerd rechtsgevolg voortvloeit). Zie tevens Lemaire, p. 308-310.

tus Offerhaus, p. 34; cf. Mulder, p. 231.

so Offerhaus, p. 269: "De toelaatbaarheid en de bewijskracht der bewijsmiddelen wordt bepaald door de wetgeving van het land, waar het feit heeft plaats gegrepen, dat moet worden bewezen." Idem Pitlo/Hidma \& Rutgers, p. 17.
} 
Uit het voorstaande komt als hoofdregel naar voren dat de Nederlandse rechter op buitenslands opgestelde authentieke geschriften vreemd bewijsrecht dient toe te passen. Als een uitzondering hierop noemt Offerhaus geschriften opgemaakt in den vreemde door vertegenwoordigers van een bepaalde staat in het geval dat deze geschriften moeten worden beoordeeld door een rechter van diezelfde staat. In dat geval is het eigen, nationale bewijsrecht van de tot oordelen geroepen rechter toepasselijk. ${ }^{846}$ Dit betekent dat op geschriften die zijn vervaardigd op een Nederlandse ambassade of een Nederlands consulaat voor Nederlandse rechterlijke instanties het Nederlands bewijsrecht onverkort van toepassing is.

Ter zijde valt er nog op te wijzen dat voor gebruik van buitenlandse documenten binnen de bestuurlijke, ambtelijke sfeer in bepaalde gevallen een zodanig gebruik slechts mogelijk is als de documenten zijn vergezeld van een legalisatie. ${ }^{847}$

Uit de beschikking van de rechtbank volgt dat de verzoeker de bewijzen voor het verwerven van het Nederlanderschap dient over te leggen. In de beschikking van de Hoge Raad wordt over dit onderwerp niets naders bepaald. Opvallend is dat niet de verzoeker de taak krijgt de authenticiteit van de namens hem overgelegde stukken te bewijzen. De Staat is in de procedure (althans officieel, zie par. 2.4.2.1) niet verschenen. De rechtbank laat via het openbaar ministeriè een ondèrzoek' verrićntennaar de bewijsstukken. Hiermee treedt de rechtbank meer op als een administratieve rechter, dan als een civiele rechter. Hierbij moet echter worden opgemerkt dat het in de "zelfstandige vaststellingsprocedure" gaat om een civiele verzoekschriftprocedure (zodat de rechter uit dien hoofde al niet lijdelijk is) en dat het voorts betreft de vaststelling van een recht dat niet ter vrije beschikking staat aan de rechtssubjecten. De overlapping door Van den Blink al genoemd, ${ }^{848}$ laat zich hier duidelijk zien.

Overigens ben ik ervan overtuigd dat de Staat, indien deze in rechte zou zijn verschenen, de bewijsopdracht naar de authenticiteit zou hebben gekregen. Het is desalniettemin van belang niet uit het oog te verliezen dat niet de verzoeker de bewijsopdracht kreeg.

${ }^{346}$ Offerhaus, p. 28. Idem Lemaire, p. 308.

s7 Zie hierover de circulaire d.d. 17.11.1993 Legalisatie en verificatie van buitenlandse bewijsstukken betreffende de staat van personen, B\&R 1994, p. 55-61; en daarover W. van Arnhem, Legalisatic van buitenlandse documenten, MR 1994, p. 127-130.

${ }^{\text {sus }} \mathrm{Vgl}$. de uitspraak van Van den Blink in par. 3.3.4.1. 


\subsection{Rb. 's-Gravenhage 4 november 1992}

\section{Cat. A. Uitspr. X. Casusbeschrijving. Rechtsgeldigheid en bewijs van een optie. Bewijs van moederschap. Afwijzing van het verzoek.}

Een beroep op verwerving van het Nederlanderschap ingevolge een optie op grond van artikel 27 lid 2 RWN is aan de orde in de hieronder te behandelen zaak. ${ }^{849}$ Ook in deze zaak wordt niet uit Nederland afkomstig bewijsmateriaal overgelegd.

Tijdens de mondelinge behandeling is de Staat vertegenwoordigd door een ambtenaar van het ministerie van Justitie. De officier van Justitie concludeert nondeling ${ }^{850}$ tot afwijzing van het verzoek.

Artikel 27 lid 2 RWN betreft een overgangsbepaling: het artikel heeft tot 31.01.1988 vrouwen met de Nederlandse nationaliteit de mogelijkheid geboden te opteren voor het Nederlanderschap ten behoeve van hun eventuele kinderen (die op J1.01.1985 jonger zijn dan 18 jaar en nimmer gehuwd zijn geweest) die niet het vederlanderschap bezitten. Was het kind tussen de 18 en de 21 jaar, dan kon het relf de optie afleggen. Een desbetreffend kind verwerft door de optie derhalve het Nederlanderschap. ${ }^{851}$

De verzoekster stelt in rechte dat haar moeder, van Nederlandse nationaliteit, op 01.09.1986 in het Amsterdamse gemeentehuis ten behoeve van haar (verzoekster) voor het Nederlanderschap heeft geopteerd. De verzoekster is geboren op 05.06.1971 en derhalve ten tijde van de inwerkingtreding van de Rijkswet op het Nederlanderschap op 01.01.1985 nog geen 18 jaar.

De verzoekster legt geen rechtstreeks bewijsstuk over van de afgelegde optie. Wel legt zij een proces-verbaal over, opgemaakt bij de Dienst Vreemdelingenpolitie d.d. 29.05.1991, inhoudende een verklaring van de moeder dat zij (de moeder) op 01.09.1986 inderdaad de bewuste optie voor haar dochter heeft afgelegd.

\footnotetext{
${ }^{\mu 9} \mathrm{Rb}$. 's-Gravenhage 04.11.1992, rkstnr. 92.5105. Vgl. Zilverentant, B\&R 1994, p. 143, en losbl. uitgave Nationaliteitsrecht, art. 27 lid 2 RWN.

${ }^{150}$ Inmiddels lijkt de hier nog nieuwe ontwikkeling om mondeling te concluderen meer ingeburgerd te zijn geraakt. Ook in Rb. 's-Gravenhage 09.03.1994, rkstnr. 93.6181 (=HR 16.09.1994, NJ 1995, nr. 563 , m.nt. GRdG) neemt de officier van Justitie mondeling conclusie. Idem bij de zaak behandeld in HR 11.11.1994, NJ 1995, nr. 100. Zie ook voetnoot 248.

"it Zie met betrekking tot art. 27 lid 2 RWN: Rb. 's-Gravenhage 20.07.1988, rkstnr. 87.6047; Rb. 'sGravenhage 20.07.1988, rkstnr. 88.5027; HR 13.01.1989, NJ 1990, nr. 266, m.nt. GRdG (cassatieverzoek van Rb. 's-Gravenhage 10.02.1988, rkstnr. 87.5813); HR 13.01.1989, NJ 1990, nr. 267, m.nt. GRdG (cassatieverzoek van Rb. 's-Gravenhage 10.02.1988, rkstnr. 87.5801); Rb. 's-Gravenhage 20.03.1991, rkstnr. 90.5770, B\&R 1994, p. 143; Rb. 's-Gravenhage 26.06.1991, rkstnr. 90.5764 , B\&R 1994, p. 144; Rb. 's-Gravenhage 23.12.1992, rkstnr. 92.5551 , B\&R 1994, p. 143; Rb. 'sGravenhage 29.09.1993, rkstnr. 92.5960 , B\&R 1994, p. 144; Rb. 's-Gravenhage 29.12.1993, rkstnr. 93.5693 , B\&R 1994, p. 145. Zie voorts Zilverentant e.a., losbl. uitgave Nationaliteitswetgeving, art. 27 lid 2 RWN.
} 
Hiertegenover stelt de Staat dat noch bij het bevolkingsregister te Amsterdam, noch in de registers op het ministerie een spoor van de optieverklaring is te vinden. De rechtbank overweegt dienaangaande: "De optiebescheiden zijn door verzoekster niet overgelegd. Verzoekster heeft als reden daarvoor opgegeven, dat de gemeente Amsterdam weigert copieën aan de verzoekster te verstrekken, doch de Staatssecretaris van Justitie schrijft (.........), dat zich in het departementale register geen kennisgeving voorkomt, waaruit blijkt dat (......) ten behoeve van verzoekster op grond van artikel 27 lid 2 Rijkswet op het Nederlanderschap is geopteerd."

Staan derhalve de partijen tegenover elkaar wat betreft de vraag óf inderdaad de moeder op 01.09.1986 zich heeft vervoegd bij het gemeentehuis te Amsterdam en aldaar de optieverklaring heeft gedaan, tevens bestaat kennelijk de nodige twijfel of de verzoekster wel de (biologische) dochter is van de opterende vrouw (dit dus: indien al is geopteerd).

In enigszins raadselachtige formulering wordt in de beschikking als standpunt van de verzoekster opgetekend: "Verzoekster heeft (......) gesteld dat zij de Nederlandse nationaliteit heeft verkregen door optie (...........), nadat zij door haar moeder (.....), die de Nederlandse nationaliteit bezit was erkend. ${ }^{1852}$

Uit de beschikking blijkt vervolgens dat de verzoekster twee (onderscheidenlijke) uittreksels heeft overgelegd uit het register waarin, naar haar zeggen, haar geboorte is geregistreerd. Het gaat om twee geboorte-inschrijvingen uit Ghana. Desbetreffend merkt de rechtbank op: "Verzoekster heeft twee Certified Copy's of Entry in de Register of Births overgelegd. Deze stukken zijn opgemaakt respectievelijk $16 \mathrm{en}$ bijna 21 jaar na haar geboorte en zijn niet gelijkluidend. (.................. De rechtbank is van oordeel dat aan deze stukken niet dezelfde bewijskracht kan worden toegekend als aan hier te lande, onmiddellijk na een geboorte, opgemaakte geboorte-akten."

Het uiteindelijke oordeel van de rechtbank dat de verzoekster niet een dochter is van de (al dan niet opterende) Nederlandse vrouw wordt gegrondvest in hetgeen in het reeds bovenvermelde, door de verzoekster overgelegde, proces-verbaal van de Dienst Vreemdelingendienst d.d. 29.05.1991 is vermeld. Het proces-verbaal houdt,

\footnotetext{
${ }^{252}$ De vraag of een Nederlandse vrouw een kind kan erkennen, zal in de meerderheid van de gevallen ontkennend worden beantwoord. Ingevolge artikel 1:222 BW staat een onwettig kind reeds door de geboorte in familierechtelijke betrekkingen met zijn moeder, dus is een erkenning niet noodzakelijk. Maar in het onderhavige geval is de moeder, net als de verzoekster, van oorsprong afkomstig wit Ghana. Wellicht dient voor een geval waarin de geboorte heeft plaatsgevonden in Ghana, waarin de betrokken moeder en kind ten tijde van verzoeksters geboorte de Ghanese nationaliteit bezat, respectievelijk verwierf, een uitzondering te worden gemaakt. Indien bij de geboorte destijds geen familierechtelijke betrekkingen tussen moeder en kind tot stand zijn gekomen en deze kunnen wel later tot stand worden gebracht door een rechtshandeling naar Ghanees recht inhoudende de erkenning door de moeder van het kind, dan lijkt het mij onwenselijk indien een nationaliteitswisseling van Ghanees nar Nederlands door de moeder daarbij cen struikelblok zou blijken te zijn. Voor het Nederlands nationaliteitsrecht is dit overigens niet een relevant onderwerp. Op het gebied van het nationaliteitsrechl is slechts art. 1 aanhef sub c RWN bepalend.
} 
behalve de verklaring dat op 01.09.1986 in Amsterdam de optie door de betrokken vrouw is afgelegd, tevens als verdere verklaring in: "De navolgende personen zijn niet mijn biologische kinderen: (.........), 4. (M.O.A.), geboren op 5 juni 1971 te Kumasi (Ghana). (..........) ik wist dat de personen (M.O.A.) en (.........) niet mijn echte kinderen waren."

De rechtbank wijst het vaststellingsverzoek af met de overweging: "dat niet is komen vast te staan dat (A.O.K) de moeder -en derhalve ten tijde van de beweerdelijke optie de wettelijk vertegenwoordigster van verzoekster is- noch dat er ten behoeve van verzoekster voor het Nederlanderschap is geopteerd."

\section{Aantekening.}

Uit deze casus blijkt dat in het kader van de Rijkswet op het Nederlanderschap het biologische moederschap essentieel is. Het doorslaggevende belang van het biologische moederschap volgt uit de begripsbepaling in de Rijkswet van het begrip "moeder". Voor de toepassing van de RWN is daaronder te verstaan: "de vrouw die het kind ter wereld heeft gebracht". ${ }^{853}$ Alle rechtshandelingen ten aanzien van het Nederlanderschap waarbij sprake is van de "moeder" dienen derhalve te worden verricht door de natuurlijke moeder van het kind. Dit maakt de vraag of verzoekster de biologische dochter is van de (beweerd opterende) vrouw derhalve essentieel voor de vraag naar de verwerving van het Nederlanderschap.

De onderhavige casus laat zien dat het bewijs van het moederschap de nodige problemen kan opleveren. Naast de hierboven weergegeven casus is de rechtbank in Den Haag gedurende de afgelopen jaren meer keren geconfronteerd met beweerde familierelaties, beweerde identiteiten en onduidelijke dan wel vervalste bewijsstukken. ${ }^{854}$ Niet kan worden ontkend dat voor de rechtbank aanleiding tot twijfel kan bestaan indien het gaat om documenten ter zake van een geboorte, afkomstig uit een land (zoals ook in casu) waarin bij het geboortenregister "slechts de door de aangever verstrekte gegevens worden opgenomen zonder deze op enigerlei wijze te verifiëren, ook niet als deze aangifte eerst jaren na de geboorte

\footnotetext{
${ }^{63}$ Art. 1 aanhef sub c RWN. Over het algemeen zal dit de biologische moeder van het kind zijn. Men mag ervan uitgaan dat de wetgever met deze bepaling het biologische moederschap heeft bedoeld. Maar stel, een ongehuwde Italiaanse vrouw is bereid tot de zwangerschap van een bij haar ingebrachte, bevruchte eicel van een vrouw met de Nederlandse nationaliteit. De biologische moeder is de Nederlandse, de vrouw die het kind ter wereld heeft gebracht, is de Italiaanse. Heeft het kind via moederszijde nu de Italiaanse of de Nederlandse nationaliteit? Volgens de woordelijke betekenis van art. I anhef sub c RWN heeft het kind niet de Nederlandse nationaliteit verworven. Indien het kind zal opgroeien bij zijn biologische, Nederlandse wensmoeder (of ouders) en de Italiaanse draagmoeder, buiten zwangerschap en bevalling, geen binding heeft met het kind is dit echter een onwenselijke consequentie. Of is in een dergelijk geval het compromis dat het kind via moederszijde zowel de ltaliaanse als Nederlandse nationaliteit verwerft, geboden? Vgl. A.M.L. Broekhuijsen-Molenaar, Moederschap en eiceldonatie in rechtsvergelijkend perspectief, FJR 1994, p. 182-186.

${ }^{\mathrm{B}}$ Zie Zilverentant, B\&R 1994, p. 112-115 en 141-145.
} 
plaatsvindt. ${ }^{m 85}$ De vraag hoe betrouwbaar in een bepaald land het bevolkingsregister functioneert, is soms een heikel punt. ${ }^{856}$ In crisisgebieden, waar bijvoorbeeld (burger)oorlog heerst, is het zeer wel denkbaar dat de uitoefening van een overheidsfunctie zoals het bijhouden van een bevolkingsregister niet (langer) mogelijk is. Onder zodanige omstandigheden is het door de Rijkswet op het Nederlanderschap verlangde bewijs van, bijvoorbeeld, het moederschap moeilijk te leveren door de betrokkene(n) en is van een poging door deze(n) door rechterlijke instanties niet eenvoudig het waarheidsgehalte te schatten.

Maar met het bewijs omtrent het moederschap is men er soms nog niet. In een zaak waarin de verzoeker heeft aangeboden zijn biologische afstamming van een vrouw die op grond van artikel 27 lid 2 RWN voor hem een optie had uitgebracht, te bewijzen door een DNA-test, overweegt de rechtbank: "De rechtbank gaat voorbij aan het aanbod van een DNA-test omdat hierdoor mogelijk wel kan worden vastgesteld dat verzoeker een kind is van de beweerde moeder maar daaruit niet kan blijken dat verzoeker ten tijde van de optie jonger was dan 18 jaar en ongehuwd en niet gehuwd geweest. " ${ }^{857}$

De onderhavige casus is wederom een zaak waarin sprake is van in het buitenland ter staving van een aldaar voorgevallen rechtsfeit opgemaakt (authentiek) bewijsmateriaal. Uit de beschikking blijkt niet dat legalisatie daarvan had plaatsgevonden. ${ }^{858}$

De beweerde afstamming moest i.c. worden bewezen door overlegging van twee copieën van de geboorte-aangifte. Ten aanzien van deze copieën komt de rechtbank evenwel tot de conclusie dat het copieën betreft uit twee onderscheidenlijke geboortenregister. Het is echter frappant dat de rechtbank, hoewel de onderhavige beschikking is gewezen ná de direct hiervoor besproken casus ${ }^{859}$ nog steeds de bewijskracht van de uittreksels uit het vreemde geboortenregister afmeet aan de bewijskracht van "hier te lande, (.......), opgemaakte geboorte-akten", 860 en concludeert dat de bewijskracht van het Ghanese geboorte-uittreksel niet gelijk is

\footnotetext{
ass $\mathrm{Rb}$. 's-Gravenhage 26.06.1991, rkstnr. 90.5764, B\&R 1994, p. 144. Zie ook de circulaire d.d. 17.11.1993 Legalisatie en verificatie van buitenlandse bewijsstukken betreffende de staat van personen, B\&R 1994, p. 57 en 58.

so6 Een punt waarmee in familierechtelijke zaken ook het Gemeenschappelijk Hof van Justitie van de Nederlandse Antillen en Aruba incidenteel wordt geconfronteerd. Zie Gem. Hof 09.02.1993. Justicia 1994. p. 159 (inzake cen erkenning).

s57 Rb. 's-Gravenhage 20.03.1991, rkstnr. 90.5770, B\&R 1994, p. 143. Ook in deze zaak vond de rechtbank de overgelegde geboorte-akten (drie in totaal) niet overtuigend genoeg om afdoende bewijs te leveren (van verzoekers geboortedatum en het moederschap van de opterende vrouw).

"ss Legalisatie is overigens slechts noodzakelijk indien men de documenten als bewijs aan de overheidsadministratic wil overleggen, voor overlegging in een gerechtelijke procedure is legalisatie nict nodig.

${ }^{859}$ HR 31.01.1992, NJ 1993, nr. 261 (par. 3.3.4.2.2).

$s 60$ Zie art. 1:26 en 1:27 BW.
} 
aan de bewijskracht van een uittreksel uit een Nederlands geboortenregister. ${ }^{861}$ Als de conclusie van de rechtbank (dat de verzoekster geen biologische dochter is van de opterende vrouw) al juist is, is zij, naar mijn mening, niettemin via de verkeerde weg tot stand gekomen. Het uit het buitenland afkomstige bewijsmateriaal dient te worden beoordeeld volgens de bewijskracht die het bewijs volgens het buitenlandse rechtssysteem heeft, zo is gebleken in de direct hiervoor besproken casus. De volgende bewijsrechtelijke stap die de rechtbank alsdan had moeten zetten, was het beoordelen van het tegenbewijs, dat in het proces-verbaal van de Vreemdelingendienst besloten lag. ${ }^{862}$

Een curieus gegeven in deze zaak is dat noch bij de gemeente Amsterdam, noch bij het ministerie van Justitie bescheiden inzake de optie zijn te achterhalen, terwijl door de Dienst Vreemdelingenpolitie wel aangaande die onvindbare optie een proces-verbaal is opgemaakt. De beschikking van de rechtbank lezend, rijst de nieuwsgierigheid naar de aanleiding tot het opmaken van het bewuste procesverbaal. Was er een opsporingsonderzoek gaande naar frauduleuze opties? Maar dan komt het nogal onlogisch voor dat de overheden te Amsterdam en te Den Haag stelden niet te beschikken over enig spoor van bewijs dàt de gepretendeerde moeder de optieverklaring zou hebben afgelegd.

Een en ander doet de vraag rijzen naar het bestaan van een verplichting aan de kant van de overheid om haar ter beschikking staande gegeven die betrekking hebben op een zaak die in behandeling is in een "zelfstandige vaststellingsprocedu$r e^{\prime \prime}$ aan de rechtbank over te leggen. Het lijkt mij vanzelfsprekend dat deze uit het administratief procesrecht bekende plicht ${ }^{863}$ ook geldt in Nederlanderschapsacties.

Ter afsluiting kan over het bewijsrechtelijk patroon in deze zaak worden gesteld dat wederom blijkt dat de bewijslast voor de verwerving bij de betrokkene berust. Enerzijds overtuigt het materiaal dat de verzoekster aanbrengt de rechtbank niet, anderzijds beschikt de Staat door het proces-verbaal over voldoende bewijsmateriaal om te voldoen aan de "primaire bewijslast" dat de verzoekster niet het Nederlanderschap heeft verworven.

\footnotetext{
${ }^{51} \mathrm{Rb}$. 's-Gravenhage 23.12.1992, rkstnr. 92.5551, B\&R 1994, p. 143, betreft eveneens een zaak waarin de verzoekster authentieke geboorte-akten uit Ghana overlegt. Op verzoek van de Staat wordt de zaak aangehouden "teneinde te doen onderzoeken of de inhoud van de geboorteakten overeenstemt met de werkelijkheid, want de legalisatie door de Nederlandse ambassade geeft alleen maar aan dat het document authentiek is." Uit het ingestelde onderzoek komt geen informatie voort die aanleiding geeft de betrouwbaarheid van de in de akte gestelde gegevens te betwijfelen. De rechtbank stelt i.c. het verwerven van het Nederlanderschap wegens optie o.g.v. art. 27 lid 2 RWN door de in de geboorteakten genoemde kinderen vast.

Betreffende de bewijsstukken aangaande een in Ghana (al dan niet) gesloten huwelijk: ARRS 25.071984, NIPR 1986, nr. 391.

${ }^{16}$ Wat betreft de bewijsmiddelen "buitenlandse authentieke akte" versus "in Nederland opgemaakt proces-verbaal" lijkt deze zaak veel op HR 15.07.1985, NJ 1985, nr. 854 (par. 3.3.3.2.4).

${ }^{6} \mathrm{Zie}$ Bolt, losbl. uitgave bestuursprocesrecht, B3 7.2 ad 1.
} 


\subsubsection{Jurisprudentie categorie B: Beroep op behoud van het Nederlanderschap}

Er resteren derhalve negentien beschikkingen waarin de verzoeker op het standpunt staat dat hij niet aan een verliesbepaling inzake het Nederlanderschap heeft voldaan en waarin tevens bewijsrechtelijke aspecten aan de orde zijn.

Op twee uitzonderingen na gaat het in deze negentien gevallen om de toepassing van de Toescheidingsovereenkomst inzake nationaliteiten tussen Nederland en Suriname. Net als in de voormalige beklagprocedure op grond van de Vreemdelingenwet (zie par. 3.3.3.4) spant daarbij artikel 5 lid 2 TOS de kroon. In twaalf beschikkingen is namelijk artikel 5 lid 2 TOS aan de orde. ${ }^{864}$ In de vijf andere zaken staat eenmaal de toepassing van artikel 3 TOS $^{865}$ en viermaal de toepassing van artikel 5 lid $1^{866}$ ter beoordeling van de rechtbank. Bij een beperkt aantal zaken blijkt overigens dat sprake is van rechterlijke toetsing van meer dan één artikel uit de Toescheidingsovereenkomst op grond waarvan het verlies van de Nederlandse nationaliteit zou hebben kunnen plaatsvinden. Van de negentien beschikkingen worden in het navolgende twaalf beschikkingen besproken, waarbij in de bespreking de nadruk is gelegd op de vraag naar de bewijslastverdeling. ${ }^{867}$

Uit de in de paragrafen 3.3.2.2, 3.3.3.3 en 3.3.3.4 weergegeven jurisprudentie is gebleken dat de door Van Sasse van Ysselt en door De Groot/Tratnik gestelde regel waarin de bewijslast voor het verlies van het Nederlanderschap wordt geplaatst bij de overheidsadministratie ondersteuning vindt in de rechtspraak van de Hoge Raad.

${ }^{864} \mathrm{Rb}$. 's-Gravenhage 15.07.1987, rkstnr. 86.2117; Rb. 's-Gravenhage 25.11.1987, rkstnr. 87.5536; Rb. 's-Gravenhage 10.02.1988, rkstnr. 87.5387 (= HR 4 november 1988, NJ 1989, nr. 100, m.nt. WHH); Rb. 's-Gravenhage 27.04.1988, rkstnr. 87.5416; Rb. 's-Gravenhage 27.04.1988, rkstnt. 87.5870; Rb. 's-Gravenhage 27.04.1988, rkstnr. 87.5871; Rb. 's-Gravenhage 27.04.1988, rkstnr. 87.5964; Rb. 's-Gravenhage 29.06.1988, rkstnr. 87.5994; Rb. 's-Gravenhage 29.06.1988, rkstnr. 87.6118; Rb. 's-Gravenhage 29.06.1988, rkstnr. 87.6119; Rb. 's-Gravenhage 09.11.1988, rkstnr. 88.5098; HR 07.04.1989, NJ 1990, nr. 791, m.nt. GRdG.

${ }^{80 s} \mathrm{Rb}$. 's-Gravenhage 27.03.1991, RV 1991, nr. 45, m.nt. HAA.

${ }^{856} \mathrm{Rb}$. 's-Gravenhage 09.11.1988, rkstnr. 88.5295; HR 14.02.1992, NJ 1993, nr. 262, m.nt. GRdG; HR 04.12.1992, rkstnr. 8058 (niet gepubliceerd); HR 28.10.1994, rkstnr. 8487 (niet gepubliceerd/=Rb. 's-Gravenhage 23.02.1994, rkstnr. 93.5866).

${ }^{87}$ De zeven beschikkingen die niet worden besproken, hebben op tén beschikking (HR 28.10.1994, rkstnr. 8487 (niet gepubliceerd/=Rb. 's-Gravenhage 23.02.1994, rkstnr. 93.5866) na alle betrekking op art. 5 lid 2 TOS. In het bijzonder vanwege het aantal beschikkingen waarin art. 5 lid 2 TOS aan de orde is, heb ik gemeend daaruit een representatieve keuze te moeten maken. Het zou mijns inziens weinig zinvol zijn alle twaalf beschikkingen inzake art. 5 lid 2 te bespreken. Niet worden behandeld: Rb. 's-Gravenhage 25.11.1987, rkstnr. 87.5536; Rb. 's-Gravenhage 27.04.1988, rkstnr. 87.5870; Rb. 's-Gravenhage 27.04.1988, rkstnr. 87.5871; Rb. 's-Gravenhage 27.04.1988, rkstnr. 87.5964; Rb. 'sGravenhage 29.06.1988, rkstnr. 87.5994; Rb. 's-Gravenhage 29.06.1988, rkstnr. 87.6119. In alle onderhavige zes beschikkingen is het verzoek tot vaststelling van het Nederlanderschap van de betrokkene afgewezen. In vier uitspraken is dit resultaat het gevolg van onvoldoende bewijslevering door de verzoeker, de twee overige zaken hebben een aan HR 07.04.1989, NJ 1990, nr. 791, m.nt. GRdG (zie par. 3.3.4.4.6) identieke casuspositie. 
Verder is uit de desbetreffende paragrafen gebleken dat indien de overheid erin slaagt haar standpunt dat de klager zijn Nederlanderschap heeft verloren te onderbouwen met voldoende bewijs, de klager door middel van het leveren van tegenbewijs het behoud van zijn Nederlandse nationaliteit kan aantonen. In de tweede tussenevaluatie is dienaangaande geconcludeerd dat het tegenbewijs van de klager aannemelijk kan worden genoemd indien de stelling(en) van de klager niet strijdig is (zijn) met het materiaal uit het dossier, de klager voor zijn stelling ondersteunend bewijsmateriaal (hoe summier ook) overlegt en de overheid geen tegenbewijs tegen de stelling(en) van de klager levert.

\subsection{Rb. 's-Gravenhage 29 januari 1992}

Cat. B. uitspr. VIII. Casusbeschrijving. Bewijs (van niet-verwerving) van een vreemde nationaliteit ligt niet bij de verzoeker. Toewijzing van het verzoek.

De verzoeker in de onderhavige zaak ${ }^{868}$ is in 1951 in Suriname geboren als wettig kind en verwerft bij zijn geboorte de Nederlandse nationaliteit. In 1953 verhuist hij met zijn inmiddels hertrouwde moeder en haar tweede echtgenoot naar Indonesië. Tot 1984 blijft de verzoeker woonachtig in Indonesië. ${ }^{869}$ In dat jaar vertrekt de verzoeker naar Nederland, waar hij bij aankomst in het bezit is van een Indonesisch paspoort. In dit paspoort voert de verzoeker niet de familienaam van zijn wettige vader, maar de achternaam van zijn stiefvader. ${ }^{870}$ In februari 1987 dient de verzoeker bij de rechtbank in Den Haag een verzoek tot vaststelling van zijn Nederlanderschap in. Of de verzoeker vanwege de Nederlandse overheid nationaliteitsrechtelijke of verblijfsrechtelijke problemen ondervindt, vermeldt de einduitspraak niet. Wat voor de verzoeker aanleiding is geweest om de vaststellingsprocedure aan te vangen, blijft, als er al een van overheidswege veroorzaakte aanleiding

\footnotetext{
${ }^{30}$ Rb. 's-Gravenhage 29.01.1992, rkstnr. 87.5178. Vgl. Zilverentant, B\&R 1994, p. 115.

${ }^{169}$ Wegens het feit dat de verzoeker geboortig is in Suriname wijdt de rechtbank aan het begin van haar beschikking aandacht aan art. 3 TOS. De rechtbank overweegt: "(.......) dat hij, nu hij op 25 november 1975 niet in Suriname verbleef, maar in Indonesië, in ieder geval niet op die datum de Surinaamse nationaliteit heeft verkregen." Deze toetsing van art. 3 TOS betekent echter dat de rechtbank ervan uitgaat dat de verzoeker op 25.11.1975 in het bezit is van het Nederlanderschap. Voor iemand die in het bezit is van de Indonesische nationaliteit heeft de Toescheidingsovereenkomst tussen Nederland en Suriname namelijk geen nationaliteitsrechtelijke gevolgen. Uit dit alles volgt dan dat de rechtbank er tevens vanuit gaat dat de verzoeker niet als minderjarige tot Indonesiër is (mede)genaturaliseerd. Indien van Nederlandse nationaliteit is de verzoeker immers meerderjarig geworden door het bereiken van de 21-jarige leeftijd in 1972 .

mo Niet in de beschikking, maar bij Zilverentant, B\&R 1994, p. 115, wordt m.b.t. tot verdere gegevens uit dit paspoort nog opgemerkt dat niet de juiste geboorteplaats van de verzoeker was vermeld, maar een plaats in Indonesië. Toch staat, ondanks de andere naam en andere geboorteplaats, vast dat het in dit geval om één persoon gaat.
} 
is, hierdoor ongewis. Op het verzoek volgt eerst in 1992 een einduitspraak. Tijdens de procedure zijn er drie zittingen geweest: respectievelijk op 29.04.1987, 20.01.1988 en 13.11.1991.

Ook in deze zaak is de Staat door de rechtbank opgeroepen als belanghebbende en op twee van de drie terechtzittingen is een vertegenwoordiger van het ministerie van Justitie aanwezig geweest. De Staat neemt het standpunt in dat "het feit dat verzoeker in het bezit is van een Indonesisch paspoort (..........) er op wijst dat de verzoeker de Indonesische nationaliteit zou kunnen hebben verkregen waardoor hij de Nederlandse nationaliteit heeft verloren." Ter zake van dit standpunt merkt de rechtbank evenwel ogenblikkelijk op: "De Staat heeft echter geen stukken kunnen overleggen waaruit dit zou kunnen blijken." Het is overigens in de onderhavige zaak een opmerkelijk feit dat de Staat niet een op enige wettelijke bepaling, hetzij de Wet op het Nederlanderschap en het ingezetenschap uit 1892, hetzij de Rijkswet op het Nederlanderschap of zelfs de Toescheidingsovereenkomst tussen Nederland en Suriname, ${ }^{871}$ toegespitste verliesgrond aangeeft en wellicht niet eens kan geven.

Bij tussenbeschikking van 25.11.1987 houdt de rechtbank de verdere behandeling aan "teneinde verzoeker in de gelegenheid te stellen nadere inlichtingen te verschaffen omtrent de vraag of hij de Indonesische nationaliteit heeft verkregen en zo ja, wanneer en op welke wijze." Eerst op 24.02.1989 legt de verzoeker aan de rechtbank over "een verklaring van de Camat van Rumbai in de stad van het tweede niveau Pekanbaru dd. 17 januari 1989 (..........), welke verklaring inhoudt, dat hij nooit heeft geopteerd voor de Indonesische nationaliteit. "

Tussentijds is op de mondelinge behandeling d.d. 20.01.1988 de verzoeker, zoals de beschikking dat noemt, "verhoord" en is de Staat eveneens een bewijsopdracht verstrekt. De behandeling wordt voor onbepaalde tijd geschorst "om het Ministerie van Justitie in de gelegenheid te stellen via het Ministerie van Buitenlandse Zaken in Indonesië inlichtingen in te winnen omtrent de eventuele Indonesische nationaliteit van verzoeker."

Met betrekking tot de verdeling van de bewijslast legt de officier van Justitie in zijn gedurende de procedure genomen conclusies de bewijslast voor het bezit van het Nederlanderschap bij de verzoeker. Naar aanleiding van de onderscheidenlijke feiten dat de verzoeker in het bezit is van een Indonesisch paspoort, op het bewijs van onvermogen bij de onderhavige procedure heeft laten aantekenen dat hij van Indonesische nationaliteit is en dat hij in het Indonesische paspoort is vermeld met de familienaam van zijn oorspronkelijk uit Indonesië afkomstige stiefvader, stelt de officier in de tussenconclusie d.d. 11.11.1987, dat "de mogelijkheid niet is uitgesloten dat verzoeker door naturalisatie, gepaard met of gevolgd door naamswijziging de Indonesische nationaliteit heeft verkregen, een mogelijkheid welke, gelet op de

${ }^{m}$ De verzoeker valt immers onder degenen die rechten hebben kunnen ontlenen aan art. 5 leden 1 en 2 TOS. 
verblijfsduur van verzoeker bij zijn moeder en stiefvader in Indonesië, zeer wel aannemelijk is. (.........). Op grond van het vorenstaande is het Openbaar Ministerie van oordeel dat verzoeker zijn stelling dat hij de Nederlandse nationaliteit bezit niet, althans onvoldoende heeft bewezen of aannemelijk gemaakt." In de eindconclusie zet het OM deze lijn voort. De officier verwijst naar de voorafgaande tussenconclusie en handhaaft hetgeen daarin is gesteld. Daaraan wordt toegevoegd: "Opmerking verdient wel dat de raadsman van verzoeker ter terechtzitting heeft betoogd dat zijnerzijds alles in het werk is gesteld om aan te tonen dat verzoeker de Nederlandse nationaliteit bezit, en dat het thans de Staat der Nederlanden is die maar moet aangeven waarom verzoeker niet van Nederlandse nationaliteit is. Dit betoog kan niet worden onderschreven. Uit de op 11 november 1987 genomen conclusie volgt dat verzoeker er naar het oordeel van het Openbaar Ministerie niet in geslaagd is aannemelijk te maken dat hij de Nederlandse nationaliteit bezit. Bij die stand van zaken rust er op de Nederlandse overheid geen plicht om nog eens aannemelijk te maken dat verzoeker, die het tegendeel beweert, ongelijk heeft."

Bij deze visie op de bewijslastverdeling sluit de Staat aan. In de beschikking wordt dienaangaande vermeld: "De Staat stelt zich evenwel op het standpunt dat het bezit van een Indonesisch paspoort een zodanige aanwijzing is dat verzoeker de Indonesische nationaliteit bezit, dat verzoeker nu dient te bewijzen dat hij niet de Indonesische nationaliteit heeft gekregen."

Desalniettemin oordeelt de rechtbank daarentegen dat het bezit van het Indonesische paspoort "niet voldoende (is) om aan te nemen dat verzoeker, die oorspronkelijk van Nederlandse nationaliteit is, die bij zijn verhoor ter terechtzitting van 20 januari 1989 een duidelijke verklaring ${ }^{872}$ kon geven voor het bezit van dit paspoort en die -reeds bijna drie jaar geleden- de (.......) verklaring heeft overgelegd dat hij nimmer geopteerd ${ }^{873}$ heeft voor de Indonesische nationaliteit, geacht moet worden zijn Nederlandse nationaliteit te hebben verloren tenzij hij kan bewijzen dat hij niet de Indonesische nationaliteit heeft verkregen. De omstandigheid dat verzoeker in de "verklaring omtrent inkomen en vermogen" dd. 5 februari 1987 heeft aangegeven van de Indonesische nationaliteit te zijn kan hier niet aan afdoen.

\footnotetext{
${ }^{\mathrm{m} /}$ In de beschikking of de bijbehorende conclusies wordt omtrent deze verklaring geen verdere informatie gevonden.

"ts De Indonesische nationaliteitswetgeving kent twee situaties waarin iemand een optie op de Ind. nationaliteit kan afleggen. Geen van beide situaties lijken voor de verzoeker toepasselijk. Er bestaat een optiemogelijkheid voor vrouwen die huwen met een Indonesisch staatsburger (art. 7 Wet no. 62 van het jaar 1958 betreffende het staatsburgerschap van de Republiek Indonesië) en er bestaat een optiemogelijkheid om na eerder verlies van de Indonesische nationaliteit deze nationaliteit door middel van een verklaring weer te herkrijgen (art. 18 Wet no. 62 etc.).

De bovenvermelde mogelijkheden betreffen beide een optie in de eigenlijke zin van het woord. Een optie is een eenzijdige rechtshandeling en betreft het afleggen van een verklaring dat men in het bezit wenst te komen van een bepaalde nationaliteit (vgl. De Groot, MR 1994, p. 212). De Ind. nationaliteitswet is afgedrukt bij De Haas-Engel, p. 405-418.
} 
Hoofdstuk 3

Nu de Staat ondanks het door hem bij brief van 5 februari 1988 gestarte onderzoek daarnaast geen enkel stuk heeft kunnen produceren ter ondersteuning van zijn stelling dat verzoeker door naturalisatie ${ }^{874}$ de Indonesische nationaliteit heeft verkregen, is in deze procedure niet voldoende vast komen te staan dat verzoeker de Nederlandse nationaliteit heeft verloren, (......). " De rechtbank stelt vervolgens het Nederlanderschap van de verzoeker vast en vermeldt daarbij uitdrukkelijk zowel de oorspronkelijke (geboorte)naam als de Indonesische naam van de verzoeker.

\section{Aantekening.}

Het eerste dat opvalt aan de onderhavige procedure is dat deze ruim vijf jaar heeft geduurd. Algemeen zal worden toegegeven dat dit voor een vaststelling in rechte van een nationaliteit onwenselijk lang is. De tweede opmerking die naar aanleiding van deze zaak moet worden gemaakt, is dat het een verontrustend feit is te noemen dat in de loop van het geding het beweerdelijk verlies van het Nederlanderschap niet, noch van de kant van de Staat, noch door het openbaar ministerie, nader wordt geconcretiseerd in een bepaalde verliesgrond met de daarvoor benodigde feiten. Met andere woorden: in de onderhavige procedure blijft volledig in het luchtledige hangen aan welke verliesbepaling voor het Nederlanderschap de verzoeker volgens de Nederlandse overheid zou hebben voldaan. Indachtig dit luchtledige waarin het beweerdelijk verlies zich kennelijk bevindt, mag voor de fundering van de niet-geïdentificeerde verliesbepaling op rechtens relevante feitelijke omstandigheden het ergste worden gevreesd. Wat dit betreft, rest slechts de constatering dat de Staat niet voldoet aan de "primaire bewijslast" voor het verlies.

Een normale gang van zaken zou zijn dat eerst een verliesbepaling wordt getraceerd en dat vervolgens dient te worden geoordeeld of voor het zich hebben gerealiseerd van de verliesgrond voldoende bewijs voor handen is. Net als in Rb. 's-Gravenhage 27.03.1991 (par. 3.3.4.4.7) geeft de onderhavige gang van zaken het onaangename gevoel dat van overheidswege de standpuntbepaling inzake het verlies van het Nederlanderschap in een enkel geval zorgvuldiger dient te worden onderbouwd. Het in het luchtledige uitgaan van verlies van het Nederlanderschap, zoals dat in de onderhavige casus en in Rb. 's-Gravenhage 27.03.1991 (par. 3.3.4.4.7) is gebeurd, dient te worden beschouwd als een vorm van onzorgvuldig bestuur.

\footnotetext{
874 (Zelfstandige) naturalisatie is naar Indonesisch nationaliteitsrecht in beginsel slechts mogelijk na het bereiken van de leeftijd van 21 jaar. (art. 5 Wet no. 62 van het jaar 1962 betreffende het staatsburgerschap van de Republiek Indonesie)). Om redenen van Staatsbelang of wegens het zich verdienstelijk hebben gemaakt, kan van die leeftijdsgrens worden afgeweken (art. 6 Wet no, 62 etc.). Vgl. De HaasEngel, p. 407-409. Als gezegd (voetnoot 869), gezien de toetsing van art. 3 TOS sluit de rechtbank eventuele mede-naturalisatie als minderjarige kennelijk uit.
} 
Een volgend opmerkelijk feit in de beschikking is het in zijn geheel achterwege blijven, ook in de conclusies van het $\mathrm{OM}$ en in hetgeen de Staat te berde brengt, van enig onderzoek naar het Indonesische nationaliteitsrecht. Terwijl in dat recht toch de verwervingsgrond moet zijn te vinden, die, indien voorgevallen, tot verlies van het Nederlanderschap heeft geleid. Mijns inziens dient bij een geval van verlies van het Nederlanderschap als gevolg van het verwerven van een vreemde nationaliteit, de regelgeving inzake die vreemde nationaliteit het primaire uitgangspunt van de rechter te zijn. Pas na beoordeling van de wijze van verwerving van de vreemde nationaliteit kan de reflectie daarvan op het bezit van het Nederlanderschap worden beoordeeld. In paragraaf 3.3.3.2.2 is reeds vermeld dat het vaststellen van het bezit van een vreemde nationaliteit geschiedt aan de hand van het vreemde recht, daarbij inbegrepen het vreemde (materiële) bewijsrecht.

Voor de onderhavige zaak leidt de bovenstaande opmerking tot de gevolgtrekking dat i.c. de eigenlijke vraag niet eens zozeer is óf de verzoeker de Indonesische nationaliteit bezit, dan wel dat de vraag centraal behoort te staan of de eventuele verwerving van die nationaliteit het verlies van het Nederlanderschap tot gevolg heeft gehad. Alleen de constatering dat de verzoeker de Indonesische nationaliteit heeft, is niet voldoende en zonder meer onvolledig voor de beslissing omtrent het verlies van het Nederlanderschap. Met de enkele constatering van het bezit staat immers de verwervingsgrond van de Indonesische nationaliteit nog niet vast. De verwervingsgrond moet eerst worden vastgesteld om te kunnen constateren of het een grond betreft die tot verlies van het Nederlanderschap leidt. Het bezit van het Indonesische paspoort is derhalve op zich beschouwd geen reële grond om aan te nemen dat de verzoeker zijn Nederlanderschap heeft verloren. Het bezit van een vreemd paspoort is immers geen verliesgrond voor het Nederlanderschap.

Procesrechtelijk beschouwd, is de passieve opstelling van de rechtbank ten aanzien van de feiten in deze procedure een ander opmerkelijk fenomeen. Geheel in stijl met de handelwijze in de civiele rechtspraak, maar daarmee voorbijgaand aan het bestuursrechtelijke karakter van het nationaliteitsrecht, stelt de rechter geen eigen onderzoek naar de feiten in. De rechtbank noch het openbaar ministerie stellen zich met betrekking tot de bewijsvergaring actief op.

In bewijsrechtelijk opzicht volgt de rechtbank bij het oordeel of het bezit van Nederlanderschap voor de verzoeker verloren is gegaan de reeds eerder bij Nederlanderschapsacties gevolgde weg. De continueringsregel doet ook in de onderhavige zaak opgeld. ${ }^{875}$ Immers, ook uit deze zaak blijkt dat pas van verlies van het Nederlanderschap kan worden gesproken indien bewezen ${ }^{876}$ is dat een verliesgrond voor het Nederlanderschap zich heeft voorgedaan. $\mathrm{Al}$ wordt de verzoeker wel gevraagd inlichtingen te verschaffen, de bewijslast van het niet-

\footnotetext{
Komt de verliesgrond niet vast te staan, dan dient te worden uitgegaan van het voortduren van het bezit van het Nederlanderschap.

"De rechtbank spreekt van: "is niet voldoende vast komen te staan".
} 


\section{Hoofdstuk 3}

voorgevallen zijn van een verliesgrond wordt (in het perspectief van de oudere rechtspraak: terecht) niet bij de verzoeker geplaatst. Dankzij de werking van de continueringspresumptie dient het Nederlanderschap van de verzoeker te worden vastgesteld.

Dit alles betekent dat in wezen de Staat, of het OM (indien dit incidenteel overgaat tot onderzoek van de feiten), het bewijs van het verlies dient te leveren. Het $\mathrm{OM}$ dat vaststelling van verzoekers Nederlanderschap afwijst omdat de officier het "zeer wel aannemelijk" acht dat de verzoeker aan een verliesbepaling van die nationaliteit heeft voldaan, verdient voor die opmerking een dikke onvoldoende.

\subsection{HR 28 oktober 1994}

Cat. B. uitspr. IX. Casusbeschrijving. Bewijs van een optie. Vernietiging van de beschikking en terugverwijzing.

In deze $z^{2 a k^{\delta 7}}$ staat centraal de vraag of verlies van het Nederlanderschap is ingetreden wegens een op grond van artikel 3 Overeenkomst betreffende de Toescheiding van staatsburgers tussen Nederland en Indonesië al dan niet afgelegde optie voor de Indonesische nationaliteit. De Staat is bij de mondelinge behandeling (op 26.05.1993) van het verzoekschrift vertegenwoordigd door een ambtenaar van het ministerie van Justitie. De officier van Justitie wijst in de conclusie het verzoek af.

De verzoekster, geboren in 1929, heeft bij haar geboorte (in Indonesië) het Nederlanderschap verworven. Eén van de stellingen van de nog immer in Indonesië woonachtige verzoekster luidt, dat zij nimmer heeft geopteerd (mondeling noch schriftelijk $^{878}$ voor de Indonesische nationaliteit. Dienaangaande stelt zij in haar verzoekschrift aan de rechtbank te vermoeden dat in 1951 haar toenmalige werkgever (verzoekster werkte als administratieve kracht bij het Indonesische leger) ${ }^{879}$ voor haar heeft geopteerd, "zodat zij bij hem werkzaam zou kunnen blijven,

\footnotetext{
${ }^{877}$ HR 28.10.1994, RvdW 1994, nr. 216.

57 Art. 12 TOI, de uitvoeringsbepaling voor het doen van verkiezing of verwerping van hetzij de Indonesische, hetzij de Nederlandse nationaliteit, spreekt van "verklaringen kannen worden afgelegd of worden toegezonden". Dit betekent dat de optieverklaring mondeling dan wel schriftelijk kon worden gedaan.

in Hetgeen op zich het verlies van het Nederlanderschap op grond van art. 7 sub 4 Wet Ned. 1892 heeft betekend. Maar door het KB van 28.12.1951, Stb. 603, herkreeg de verzoekster (met ingang van de dag van haar indiensttreding) haar Nederlanderschap. Op 16,11.1951, het moment dat de verzoekster de (beweerdelijke) optie voor de Indonesische nationaliteit deed, bezat de verzoekster derhalve niet bet Nederlanderschap. Slechts achteraf kan worden gereconstrueerd dat zij het door het KB van 28.12.1951 met terugwerkende kracht herkregen Nederlanderschap op 16.11.1951 door het doen van de (beweerdelijke) optie (eventueel) heeft verloren. Zie De Haas-Engel, p. 129.
} 
aangezien zij anders als vreemdelinge Indonesië op 28 december diende te verlaten." In aansluiting op haar stelling nimmer te hebben geopteerd voor de Indonesische nationaliteit stelt de verzoekster dat zij derhalve nimmer haar handtekening onder een optieverklaring heeft geplaatst.

Blijkens de beschikking van de rechtbank legt de verzoekster ter ondersteuning van haar stelling onder meer over: "- een (slecht leesbare) copie van een Surat Tjatatan $^{830}$ dd. 16 november 1951 no. 359/1951;

- een copie van een Nederlandse vertaling van een schriftelijke verklaring, no. 359/1951, opgemaakt te Surabaja op 16 november 1951 en ondertekend door de Chef de bureau van het landgerecht (R. Moehammad Amin) namens de Hoofd Landrechter te Surabaja Mr. R. Soeparto, inhoudende dat (verzoekster) op 16 november 1951 vrijwillig verklaart voor het Indonesisch Staatsburgerschap verklaart te opteren en dat die verklaring was getekend door (de verzoekster). ${ }^{881}$

De Staat neemt bij monde van de vertegenwoordiger van het ministerie van Justitie met betrekking tot de vermeend op 16.11.1951 gedane optie het volgende standpunt in: "(....) is de Staat van mening dat (verzoekster) destijds rechtsgeldig heeft geopteerd. Het overgelegde exemplaar ${ }^{82}$ van de verklaring is een uittreksel en geen copie van de originele verklaring. Het ontbreken van de handtekening op dit uittreksel wil niet zeggen dat het origineel niet is getekend en ook overigens is de verklaring naar het oordeel van de Staat duidelijk."

Het zal inmiddels duidelijk zijn dat het originele document waarop de eventuele optie schriftelijk is vastgelegd niet aanwezig is, noch dat daarvan een copie ter beschikking is.

Om toch het originele optieformulier boven water te krijgen, of tenminste daarvan een copie te kunnen overleggen, vraagt de raadsman van verzoekster schriftelijk op 22.06.1993 aanhouding van de zaak, opdat hij bij de landrechter te Surabaya "een copie van het originele optieformulier" kan opvragen. De beschikking meldt te dien aanzien vervolgens dat de raadsman op 27.07 .1993 per brief

\footnotetext{
${ }^{100}$ Dit betreft een soort bewijs-document dat degene op wiens naam het staat, een optie heeft afgelegd. Surat: geschrift, brief, bewijs, document. Tjatatan: notitie, aantekening. Bij het volgende gedachtenstreepje spreekt de rb. dan ook van "schriftelijke verklaring". Het gaat waarschijnlijk om een document dat is uitgereikt ter uitvoering van art. 12 TOI: "Aan hem die een verklaring aflegt of indient, wordt aanstonds een bewijs daarvan uitgereikt of toegezonden." Het is dus niet het originele optieformulier. Een origineel (schriftelijke) optieverklaring bleef achter bij de Indonesische autoriteiten.

"n Over dit stuk stelt de HR later: "Volgens een zich bij de stukken bevindende Nederlandse vertaling envan draagt dat geschrift de handtekening van $R$. Moehammad Amin, chef de bureau van het Landgerecht te Surabaya, doch niet de handtekening van (verzoekster), en houdt het in dat (verzoekster) op 16 november 1951 ten overstaan van de Landrechter te Surabaya heeft verklaard voor de Indonesische nationaliteit te opteren." Voor alle duidelijkheid: het originele document, bij de Landrechter achtergebleven, zou de door verzoekster getekende schriftelijk afgelegde optieverklaring bevatten; het bewijsstuk (no. 359/1951) van de optie kreeg de verzoekster mee naar huis, daarop staat niet haar handtekening; en van het bewijsstuk bestaat een Nederlandse vertaling.

${ }^{2}$ Het hierboven vermelde door de verzoekster overgelegde exemplaar.
} 
heeft laten weten "toch niet in staat te zijn om bedoelde optieverklaring over te leggen" aangezien uit Surabaya geen respons was gekomen. In dezelfde brief wordt het verzoek aan de rechtbank gedaan: "(..........) om de Staat te gelasten de "originele optieverklaring" in het geding te brengen en (.......) de Staat te gelasten stukken te verstrekken ter onderbouwing van zijn standpunt dat (verzoekster) heeft geopteerd. ${ }^{\text {"883 }}$ Op dit verzoek gaat de rechtbank niet in. ${ }^{884}$

In haar beschikking interpreteert de rechtbank de stelling van de verzoekster als volgt: "(Verzoekster) is van mening dat er geen sprake is van een rechtsgeldige optie omdat haar handtekening ontbreekt op het optieformulier." Dienaangaande overweegt de rechtbank onder meer: "De rechtbank kan (verzoekster) hierin niet volgen. De door (verzoekster) overgelegde (........) schriftelijke verklaring draagt (verzoeksters) naam en er blijkt op geen enkele manier uit dat het verzoek is gedaan door haar werkgever of dat (verzoekster) het verzoek niet zou hebben getekend, zoals zij betoogt. De rechtbank gaat daarom uit van de rechtsgeldigheid van de optie."

De verzoekster tekent cassatie aan. In de uitspraak in cassatie sluit de Hoge Raad aan bij twee principiële, in de cassatiemiddelen genoemde, uitgangspunten. Het eerste uitgangspunt waarbij de HR aansluit, stelt dat "de rechter zich met betrekking tot het onderzoek naar de feiten die voor de vaststelling van de nationaliteit van belang zijn, niet lijdelijk behoort op te stellen." Het tweede uitgangspunt heeft als strekking dat de bewijslast voor een verliesgrond van het Nederlanderschap bij de Staat ligt, indien de Staat de verliesgrond inroept. ${ }^{885}$

Als gezegd, de rechtbank is niet ingegaan op het verzoek om de Staat te gelasten bewijs van de optie over te leggen. In dat verband tilt de HR zwaar aan het feit dat artikel 12 Overeenkomst betreffende de Toescheiding van staatsburgers regels stelt inzake het wederzijds door de betrokken staten kenbaar maken van verrichte opties. Dat artikel bepaalt namelijk dat Indonesië en Nederland elkaar "duplicaten of gewaarmerkte afschriften" van de afgelegde optieverklaringen zullen toesturen en

8 Citaat uit de conclusie in cassatie d.d. 13.09.1994.

ss De reden waarom het verzoek niet is ingewilligd, is de volgende geweest (citaat uit de conclusic in cassatic d.d.13.09.1994): "De griffier heeft (.......) geantwoord dat de vertegenwoordiger van de Staat in een aan de onderhavige zaak identieke zaak had medegedeeld...... -dat de opties indertijd zijn uitgebracht ten overstaan van de Indonesische autoriteiten en dat deze stukken derhalve niet in het bezit zijn van de Nederlandse autoriteiten, zodat aan de Staat niet het verwijt kan worden gemaakt dat de Staat de optieverklaring van verzoekster niet overlegt. Dit betekent dat de rechtbank anders dan u in overweging heeft gegeven de zaak niet zal aanhouden om de Staat de originele optieverklaring in het geding te doen brengen."

sss Zie daarvoor in de uitspraak onder 3.4: "(.........) terwijl de Staat stelt dat zij die nationaliteit sedertdien -door het doen van een optie in de zin van art. 3 OTS- heeft verloren, het op de weg van de Staat ligt om, in het bijzonder door overlegging van daartoe in aanmerking komende bescheiden, de juistheid van die stelling te staven." 
dat de verklaringen zullen worden gepubliceerd in de staatscourant van het land waarin de optie voor een ambtenaar is afgelegd. ${ }^{886}$

Aan de hand van de zoëven vermelde twee uitgangspunten en met het oog op de wederzijdse kenbaarheidsbepaling inzake verrichte opties komt de Hoge Raad tot de volgende uitspraak: "(.......) had de Rechtbank, (...........), niet enkel uit dat geschrift mogen afleiden dat (verzoekster) op 16 november 1951 op rechtsgeldige wijze voor de Indonesische nationaliteit heeft geopteerd, zulks zonder nadere motivering, (........) en zonder tenminste van de Staat overlegging te verlangen van de aflevering van de Indonesische Staatscourant, waarin de door hem gestelde optie was gepubliceerd, en van een desbetreffend duplicaat of gewaarmerkt afschrift als in art. 12 OTS bedoeld."

De zaak wordt terugverwezen naar de rechtbank, die "in volle omvang en met inachtneming van het hiervoor overwogene (zal) dienen te onderzoeken of (verzoekster) op 16 november 1951 voor de Indonesische nationaliteit heeft geopteerd."

\section{Aantekening.}

De verzoekster stelt nimmer te hebben geopteerd. De rechtbank oordeelt dat de copieën van de documenten die de verzoekster heeft overgelegd niet haar stelling kunnen ondersteunen en wijst het verzoek af. De bewijslast van het niet-voorgevallen zijn van de verliesgrond legt de rechtbank daarmee bij de verzoekster. De verzoekster is volgens de rechtbank niet in haar bewijs is geslaagd. Uit het bovenstaande volgt tevens dat de rechtbank de bewijslast inzake het voorgevallen zijn van de verliesgrond niet bij de Staat legt.

De HR ziet het toch anders. De HR neemt het standpunt in dat de Staat minimaal de gegevens die deze volgens de bepalingen van de Toescheidingsovereenkomst zou moeten bezitten, dient over te leggen. Met deze eis, doelt de Hoge Raad mijns inziens op het vereiste dat inzicht kan worden verkregen omtrent de ondersteuning door de feiten van het nationaliteitsrechtelijke standpunt dat de minister van Justitie inneemt. Hier gaat het om wat ik omschrijf met het begrip "primaire toetsing".

Dat de Hoge Raad de eis stelt dat het standpunt van de Staat bij een nader onderzoek deugdelijk blijkt, namelijk dat de Staat, los van hetgeen de verzoekster te berde brengt, een voldoende onderbouwd standpunt inneemt omtrent het Nederlanderschap van de verzoekster is in het licht van de voorafgaande ${ }^{887}$ jurisprudentie niet opzienbarend meer.

\footnotetext{
${ }^{156}$ In HR 21.01.1969, NJ 1969, nr. 144 (par. 3.3.3.3.1) heeft het retourneren door de Indonesische autoriteiten van de optieverklaring aan de klager ertoe geleid dat deze verklaring nooit op de voorgeschreven wijze is gepubliceerd. Dit staat echter aan de rechtsgeldigheid van de optie niet in de weg.

s) Dit inclusief de jurisprudentie in par. 3.3.4.4. Die jurisprudentie gaat chronologisch vooraf aan de onderhavige uitspraak uit 1994.
} 
Naast andere opmerkingen over het procesrechtelijke karakter van de procedure stelt A.-G. Mok in zijn conclusie, dat in de vaststellingsprocedure sprake is van "een vrij bewijsstelsel". ${ }^{888}$ Gezien het feit dat de onderhavige procedure een verzoekschriftprocedure betreft, leidt dit niet tot verbazing. Voor de inhoudelijke betekenis van "vrij bewijsstelsel" en de toepasselijkheid ervan in verzoekschriftprocedures, verwijs ik naar paragraaf 3.2.1.

Tevens wordt in de conclusie voor het eerst in het kader van een "zelfstandige vaststellingsprocedure" opgemerkt dat sprake is van een niet-lijdelijke rechter. ${ }^{889}$ Hierbij sluit de HR zich uitdrukkelijk aan. Op grond van de voorafgaande jurisprudentie kan worden gesteld dat het hier een voortzetting betreft van hetgeen ook daarin is te vinden. ${ }^{890}$ Overigens sluit de bevinding dat de rechter in de "zelfstandige vaststellingsprocedure" niet lijdelijk is aan bij het algemene beeld van de nietlijdelijke rechter in verzoekschriftprocedures, ${ }^{891}$ zeker indien het gaat om rechten die niet ter vrije bepaling van partijen staan.

Een interessant aspect aan de onderhavige casus is dat de verzoekster een verzoek doet voor een contemporaine vaststelling (vgl. paragraaf 2.2.4.2.1) van haar Nederlanderschap, terwijl het beoordelingsmoment wel in een erg ver verleden ligt. $\mathrm{Nu}$ zal bijna iedere casus een verwerving of een verlies in het verleden betreffen en een vaststelling voor het heden, ${ }^{892}$ maar in dit geval is de tijdspanne erg lang. ${ }^{893}$ In het geval dat de rechtbank inderdaad tot de slotsom komt dat de verzoekster op 16.11.1951 niet heeft geopteerd, is het dan zonder meer voor de hand liggend om het bezit van het Nederlanderschap door de verzoekster vast te stellen voor het moment dat de beschikking wordt gegeven?

Het zal evident zijn dat het gaat om een tijdspanne van ruim 45 jaar. In die 45 jaar kan de verzoekster hebben voldaan een (andere) verliesbepaling voor de Nederlandse nationaliteit. Dit betreffend kan worden gesteld dat op grond van hetgeen blijkt uit de rechtspraak het niet aan de verzoekster is om aannemelijk te maken dat zij niet aan een verliesbepaling heeft voldaan. De consequentie waartoe dit voert, is dat het op de weg van de Staat ligt, dan wel de niet-lijdelijke vaststellingsrechter, om (indien zulks het geval zou zijn) aan te tonen dat de verzoekster na 16.11.1951 heeft voldaan aan een verliesbepaling voor het Nederlanderschap.

\footnotetext{
us Betreffende de "zelfstandige vaststellingsprocedure" is dit de eerste keer, eerder heeft de A.-G. hetzelfde opgemerkt met betrekking tot de beklagprocedure ingevolge art. 43 (oud) Vreemdelingenwet. 8*9 Eerder is m.b.t. de beklagprocedure ingevolge art. 43 (oud) Vw hetzelfde gesteld.

${ }^{590}$ Zie par. 3.3.3.5 en voor de procedure 0.g.v. art. 17 RWN waarin de rechter een onderzoeksplicht krijgt: par. 3.3.4.4.6.

sil Zie par. 3.2.2 en 3.3.4.1.

sm Zie voor de uitzondering hierop par. 2.2 .4 .2 .2 . I.c. zou sprake zijn van een dergelijke uitzondering indien de verzoekster had verzocht vast te stellen dat zij op 01.01.1952 het Nederlanderschap bezat.

${ }^{593}$ Ook Ahmad Ali/Klip, MR 1995, p. 84, wijzen op het vaak grote tijdsverschil tussen het moment van beoordelen (vaststellingsmoment) en het te beoordelen moment (beoordelingsmoment).
} 
Of de rechtbank zich inderdaad geroepen voelt een onderzoek te (laten) verrichten naar nationaliteitsrechtelijk relevante feiten van $n a$ het moment dat ter beoordeling in de casus staat, is nog maar de vraag. In paragraaf 3.3.4.1 is naar voren gekomen dat de rechtbank een grens ziet aan haar niet-lijdelijkheid. In die paragraaf blijkt dat de rechtbank zich niet gehouden acht "nieuwe feiten" aan te dragen "ter ondersteuning van de stellingen van de verzoeker en/of de Staat". Uit de jurisprudentie blijkt veeleer dat de rechtbank daarin een taak voor de Staat ziet. Dit is gebleken in een zaak waarin vaststelling van het bezit van het Nederlanderschap is verzocht wegens nationaliteitsverwerving als rechtsgevolg van een erkenning. De erkenning is geschied in 1981, de vaststellingsbeschikking van de rechtbank is gegeven in 1993. Er bestaat derhalve een periode van twaalf jaar waarin een wijziging in de nationaliteitsrechtelijke positie van de betrokkene kan zijn opgetreden. De laatste overweging in de beschikking luidt als volgt: "Nu door de Staat niet is aangevoerd dat zich na de erkenning feiten of omstandigheden hebben voorgedaan ten gevolge waarvan verzoeker de Nederlandse nationaliteit zou hebben verloren dient het verzoek tot vaststelling te worden toegewezen. ${ }^{1894}$

\subsubsection{Subcategorie B(-TOS): Beroep op behoud van het Nederlanderschap door betwisting van de toepasselijkheid van de Toescheidingsovereenkomst Nederland-Suriname}

\subsection{Rb. 's-Gravenhage 15 juli 1987}

Cat. B(-TOS). uitspr. XIV. Casusbeschrijving. Artt. 3 en 5 lid 2 TOS. Op 25.11.1975 in inverzekeringstelling doorbrengen in Suriname en bewijs van minimaal twee jaar woonplaats of werkelijk verblijf in Suriname. Niet komt vast te staan dat verzoeker twee jaar in Suriname woonplaats of verblijf heeft gehad. Toewijzing van het verzoek.

In de onderhavige $\mathrm{zaak}^{895}$ is mogelijk verlies van het Nederlanderschap op grond van de werking van de artikel 3 Toescheidingsovereenkomst Nederland-Suriname dan wel artikel 5 lid 2 TOS aan de orde. Hoewel de Staat door de rechtbank is opgeroepen voor de mondelinge behandeling is deze niet verschenen. ${ }^{896}$

De zaak betreft een uit Suriname afkomstige verzoeker die sinds 1969 woonachtig is geweest in Nederland. Tot juli 1979 is de verzoeker opgenomen geweest in het bevolkingsregister van een Nederlandse gemeente. Op de dag dat de Toescheidingsovereenkomst inzake nationaliteiten tussen Nederland en Suriname in werking

\footnotetext{
${ }^{n 4} \mathrm{Rb}$. 's-Gravenhage 03.11.1993, RV 1993, nr. 55, m.nt. HAA.

${ }^{195} \mathrm{Rb}$. 's-Gravenhage 15.07.1987, rkstnr. 86.2117.

Althans volgens de rechtbank niet in rechte is verschenen: zie par. 2.4.2.1.
} 
treedt, bevindt de verzoeker zich in Suriname. Hij bevindt zich aldaar in inverzekeringstelling van 18.11.1975 tot 10.12.1975. In 1985 wordt de verzoeker wederom in Nederland ingeschreven in hetzelfde bevolkingsregister als voorheen. Eind 1986 wordt de verzoeker bedreigd met uitzetting uit Nederland en richt hij het onderhavige verzoek tot vaststelling van zijn Nederlanderschap aan de rechtbank.

Zoals wel meer is voorgekomen in de beginfase van de "zelfstandige vaststel. lingsprocedure" heeft ook in deze zaak het openbaar ministerie een onderzoek naar de feiten ingesteld. Uit de conclusie van het OM blijkt dat de officier van Justitie telefonisch inlichtingen heeft ingewonnen bij het desbetreffende bevolkingsregister waar de verzoeker tot 16.07.1979 ingeschreven is geweest. Bij dat bevolkingsregister is betreffende de verzoeker een brief d.d. 10.05.1978 aanwezig, afkomstig van de Nederlandse ambassade te Paramaribo inhoudende dat de verzoeker ingevolge artikel 3 TOS de Surinaamse nationaliteit heeft verworven.

De verzoeker bestrijdt het op artikel 3 TOS gebaseerde verlies van het Nederlanderschap. Bij zijn bestrijding vindt hij een medestander in de rechtbank te Den Haag. Deze stelt dienaangaande: "Het feit dat verzoeker van 18 november 1975 tot 10 december 1975 in inverzekeringstelling heeft doorgebracht in Suriname brengt niet met zich mee dat verzoeker ingevolge artikel 3 van de Toescheidingsovereenkomst de Surinaamse nationaliteit heeft verkregen, nu uit dit onvrijwillige verblijf in Suriname niet kan worden afgeleid dat verzoeker zijn woonplaats of werkelijk verblijf in Suriname had ten tijde van de inwerkingtreding van de Toescheidingsovereenkomst, terwijl hiervan ook overigens niet is gebleken."

De volgende kwestie die in deze casus aanleiding heeft gegeven tot onzekerheid aangaande het Nederlanderschap van de verzoeker, is het feit dat de verzoeker na in juli 1979 te zijn uitgeschreven uit een Nederlands bevolkingsregister eerst in 1985 weer in een Nederlands bevolkingsregister is opgenomen. Bij deze opname is geregistreerd dat de verzoeker uit Suriname kwam en tevens staat vast dat hij in het bezit is van een Surinaams paspoort. Deze feiten doen bij de rechtbank de vraag rijzen of de verzoeker als gevolg van langdurig verblijf in Suriname aan de verliesbepaling voor het Nederlanderschap genoemd in artikel 5 lid 2 TOS heeft voldaan.

Verzoekers verblijfplaats staat onomstreden vast tot 10.12 .1975 , de dag van zijn invrijheidstelling. Voor de jaren die daarna volgen, blijkt dat over verzoekers verblijfplaats onzekerheid heerst tot 1985 , het moment van herinschrijving in een Nederlandse gemeente. In een tussenbeschikking bepaalt de rechtbank dat het aan de verzoeker is om de rechtbank inlichtingen te verschaffen over zijn woon- of verblijfplaats "van 10 december 1975 tot 25 april 1978 alsmede de periode van 25 april 1978 (dan wel van 16 juli 1979) tot 9 april $1985 "$.

Namens de verzoeker hoort de rechtbank twee getuigen; ook de verzoeker legt een verklaring af. Als hierboven is vermeld, brengt het $\mathrm{OM}$ na zelfstandig onderzoek ook enkele feiten in het geding. Ondanks de verklaringen en de door het $\mathrm{OM}$ 
ingebrachte gegevens wordt de feitelijke situatie niet helder. De officier van Justitie concludeert tot afwijzing van het verzoek. ${ }^{897}$

De rechtbank beslist echter als volgt: "De rechtbank is met de officier van justitie van oordeel dat niet vast is komen te staan dat verzoeker in de bovenvermelde perioden zijn woonplaats of werkelijk verblijf in Nederland heeft gehad. Evenmin is echter vast komen te staan dat verzoeker na 25 november 1975 gedurende een onafgebroken periode van minimaal twee jaar zijn woonplaats of werkelijk verblijf in Suriname heeft gehad, zodat verzoeker niet ingevolge art. 5 lid 2 van de Toescheidingsovereenkomst de Surinaamse nationaliteit heeft verkregen.

Het verzoek tot vaststelling van het Nederlanderschap van (......) dient derhalve te worden toegewezen."

\section{Aantekening.}

In deze beschikking is de beslissing van de rechtbank inzake de toepasselijkheid van artikel 3 TOS een kwestie van interpretatie van de verdragsbepaling. Aangezien de inverzekeringstelling op 25.11.1975 kennelijk onbetwist vaststaat, betekent dit dat met betrekking tot de vraag naar de gehanteerde bewijslastverdeling geen conclusie valt te trekken.

De vraag of verlies van het Nederlanderschap heeft kunnen plaatsvinden op grond van artikel 5 lid 2 TOS stelt de rechtbank ambtshalve aan de orde. Ten aanzien van de beoordeling in het kader van dit artikel is in casu wel sprake van een bewijsrechtelijke dimensie.

Een gevolg van de omstandigheid dat de Staat niet is verschenen, ${ }^{898}$ is dat enig door de overheid overgelegd bewijs dat de verzoeker heeft voldaan aan de verliesbepaling uit artikel 5 lid 2 TOS ontbreekt. Op grond van de bevindingen van de officier van Justitie blijkt de rechtbank van verzoekers langdurige uitschrijving uit enig Nederlands bevolkingsregister. Uit de casusbeschrijving blijkt dat dit de rechtbank aanleiding geeft tot de bewijsopdracht aan de verzoeker om duidelijkheid te verschaffen over zijn woon- en verblijfplaats(en) in de desbetreffende tijd.

\footnotetext{
"m Met de volgende overweging: "Uit het vorenstaande volgt, naar het oordeel van het Openbaar Ministerie, dat niet, althans onvoldoende aannemelijk is geworden dat verzoeker in de periode van 25 april 1978, dan wel 16 juli 1979 tot april 1985 in Nederland woonplaats had, of werkelijk verblijf hield. Op grond van het (voren)overwogene, beschouwd in het licht van het als vaststaand aangenomen gegeven dat verzoeker op 9 april 1985 weer is ingeschreven in de registers van de burgerlijke stand te Amsterdam, als komend vanuit Suriname, en in het bezit zijnde van de Surinaamse nationaliteit, is naar het oordeel van de Openbaar Ministerie, aannemelijk geworden dat verzoeker in de periode van 25 april 1978, dan wel 16 juli 1979 tot 9 april 1985 woonplaats had, of werkelijk verblijf hield in Suriname, en mitsdien ingevolge het bepaalde in artikel 5, lid 2, van de Toescheidingsovereenkomst de Surinaamse nationaliteit heeft verworven."

Althans volgens de rechtbank niet in rechte is verschenen: zie par. 2.4.2.1.
} 
De officier van Justitie legt in zijn conclusie de bewijslast van het niet hebben voldaan aan de verliesbepaling bij de verzoeker. Het bewijsfeit dat de verzoeker aldus door het OM krijgt opgelegd, is te bewijzen dat hij niet minimaal twee jaar in Suriname heeft verbleven. De verzoeker zou dat kunnen bewijzen door zijn verblijf elders dan in Suriname aannemelijk te maken. Daarin slaagt de verzoeker niet en het OM concludeert tot afwijzing van het verzoek tot vaststelling van het Nederlanderschap.

De bewijsrechtelijke lijn die de rechtbank volgt, ligt meer in het verlengde van de bewijsrechtelijke regels zoals die uit de vroegere rechtspraak bekend zijn. Voor een bevestigend oordeel dat aan artikel 5 lid 2 TOS is voldaan, eist de rechtbank het vaststaan van een verblijf in Suriname van minstens twee jaar. Dit betekent naar mijn mening dat de rechtbank een grotere mate van zekerheid bij de verliesgrond wil hebben dan indien zou zijn gesproken van "aannemelijk maken".

Conform de reeds in de jaren vijftig opgestelde regel die inhoudt dat dient te worden uitgegaan van de continuering van het Nederlanderschap, tenzij het rechtsfeit dat leidt tot verlies is bewezen, concludeert de rechtbank i.c. tot behoud van het Nederlanderschap.

Ook ten aanzien van de vraag door wie het rechtsfeit dat leidt tot verlies van de Nederlandse nationaliteit dient te worden bewezen, volgt de rechtbank de oudere bewijslastverdeling. In eerste instantie is het aan de overheid om de feiten die leiden tot het verlies aan te tonen en is het niet aan de klager/verzoeker om aannemelijk te maken dat de feiten leidend tot verlies niet hebben plaatsgevonden.

\subsection{Rb. 's-Gravenhage 10 februari 1988}

Cat. B(-TOS), uitspr. XV. Casusbeschrijving. Art. 5 lid 2 TOS. Betwisting van de wil de woonplaats over te brengen vanuit het butenland naar Suriname. Afwijzing van het verzoek.

De onderhavige $z^{2 a k}{ }^{899}$ heeft eveneens betrekking op artikel 5 lid 2 Toescheidingsovereenkomst inzake nationaliteiten tussen Nederland-Suriname. De Staat is niet in het geding verschenen. ${ }^{900}$

De verzoekster is, afkomstig uit Suriname, woonachtig in Nederland geweest van 1969 tot begin 1981. De verzoekster stelt in Suriname te hebben verbleven van 02.02.1981-19.11.1982 en van 15.03.1983-22.11.1986. Namens de verzoekster wordt overgelegd een beslissing d.d. 10.07.1984 van de vice-consul van de Nederlandse ambassade te Paramaribo inhoudende dat op die dag verzoeksters

${ }^{890}$ Rb. 's-Gravenhage 10.02.1988, rkstnr. 87.5387 (= HR 4 november 1988, NJ 1989, nr. 100, m.nt. WHH).

${ }_{900}$ Althans is volgens de rechtbank niet in rechte verschenen: zie par. 2.4.2.1. 
Nederlandse paspoort is ingenomen wegens het op grond van artikel 5 lid 2 TOS hebben verworven op 20.01.1983 van de Surinaamse nationaliteit. Ook namens de verzoekster wordt overgelegd een verklaring d.d. 08.09.1984 van de minister van Binnenlands Zaken van Suriname inhoudende dat de verzoekster op 20.01.1983 op grond van artikel 5 lid 2 TOS de Surinaamse nationaliteit heeft verworven.

De verzoekster bestrijdt het op 20.01.1983 verwerven van de Surinaamse nationaliteit met de stelling dat zij slechts tot 19.11.1982 in Suriname heeft verbleven en dat zij "nimmer de wil heeft gehad zich blijvend in Suriname te vestigen. " Als reden voor de achtereenvolgende perioden van verblijf aldaar noemt zij voor de eerste verblijfsperiode de begrafenis van een zuster en voor de volgende periode de verzorging van een zieke broer, die in oktober 1986 is overleden. Daarnaast stelt de verzoekster haar woning in Nederland te hebben behouden en zich niet te hebben doen uitschrijven uit het bevolkingsregister van haar gemeente in Nederland.

Het openbaar ministerie, dat in de onderhavig zaak zelfstandig feitenonderzoek heeft gepleegd, brengt de rechtbank ter kennis dat de verzoekster op 21.07.1982 zich tot de Surinaamse autoriteiten heeft gewend met het verzoek tot afgifte van een Surinaams paspoort. Op dit verzoek wilden de autoriteiten in Suriname niet eerder ingegaan dan nadat de verzoekster een verklaring zou hebben getoond dat de Nederlandse autoriteiten haar Nederlandse paspoort hebben ingenomen. Wel werd reeds een Surinaams paspoort ten name van verzoekster gereedgemaakt en gedateerd op 21.07.1982.

De daadwerkelijke afgifte van het (nog immer op 21.07.1982 gedateerde) paspoort heeft evenwel pas plaats na 20.01.1983, de datum waarop de verzoekster naar de visie van zowel de Surinaamse als de Nederlandse autoriteiten op grond van artikel 5 lid 2 TOS de Surinaamse nationaliteit heeft verworven. Het openbaar ministerie brengt dienaangaande een verklaring in het geding afkomstig van het Centraal Bureau voor Burgerzaken te Paramaribo waarin is gesteld dat aldaar in februari 1983 aan verzoekster een Surinaams paspoort is uitgereikt. Dat in februari 1983 de verzoekster in Suriname een paspoort wordt uitgereikt, is strijdig met de stelling van verzoekster dat $\mathrm{zij}$ in Suriname heeft verbleven van 02.02.1981 tot 19.11.1982 en van 15.03.1983 tot 22.11.1986.

De nationaliteitswisseling is door zowel de Surinaamse als de Nederlandse autoriteiten gegrondvest op artikel 5 lid 2 TOS. Om ingevolge artikel 5 lid 2 TOS verlies van het Nederlanderschap te kunnen aannemen is, naast het voor de toepassing van dat artikel noodzakelijke verblijf van twee jaar of langer in Suriname, door de Hoge Raad in 1982 een aanvullend toetsingscriterium ontwikkeld, en 
wel dat: "aan de wil van de betrokkene zijn tevoren bestaande woonplaats ${ }^{901}$ prijs te geven, in redelijkheid niet kan worden getwijfeld. "902

Aan de voor de verzoekster negatieve beslissing legt de rechtbank de volgende overwegingen ten grondslag. De rechtbank is "van oordeel dat verzoekster wel degelijk haar woonplaats naar Suriname heeft verplaatst en de wil heeft gehad zich daar blijvend te vestigen:

-Verzoekster heeft in de periode van begin 1981 tot eind 1986 vrijwel onafgebroken in Suriname verbleven. Volgens eigen opgave is zij in die periode slechts van 19 november 1982 tot 15 maart 1983, derhalve minder dan 4 maanden, in Nederland geweest."

Daarnaast merkt de rechtbank nog op: "Verzoekster is weliswaar met ingang van 22 december 1982 weer opgenomen in het bevolkingsregister te 's-Gravenhage, maar zij stond tot 5 december 1986 ingeschreven op het adres van haar zuster, die verzoeksters (financiële) belangen behartigde. Dit adres is te beschouwen als een postadres en niet als een woonplaats. Verzoekster heeft ter terechtzitting verklaard dat de woning aan het Westeinde, die zij stelde te hebben aangehouden, in die periode door iemand anders werd bewoond."

\section{Aantekening.}

De onderhavige beschikking is gecasseerd wegens schending van het beginsel van hoor en wederhoor. ${ }^{903}$ De verzoekster is namelijk niet eerst in de gelegenheid gesteld haar mening te uiten over de door de officier van Justitie ingebrachte gegevens. De rechtbank legt aan haar beslissing evenwel juist deze gegevens ten grondslag. Aangezien in de cassatieprocedure niet de bewijslastverdeling, maar het beginsel van hoor en wederhoor, aan de orde is geweest, laat ik een bespreking van de beschikking van de Hoge Raad achterwege. De onderstaande opmerkingen blijven derhalve beperkt tot de beschikking van de rechtbank.

Daar de verzoekster zelf reeds aangeeft langer dan twee jaar in Suriname te hebben verbleven, kan er in beginsel van worden uitgegaan dat de verzoekster heeft voldaan aan de verliesbepaling uit artikel 5 lid 2 TOS. ${ }^{904}$ Zoals is gebleken uit de

901 Dit betreft dan een woonplaats buiten Suriname, in de meeste gevallen zal het gaan om een woonplaats in Nederland.

902 Zie par. 3.3.3.4.3.

$903 \mathrm{Vgl}$. par. 2.3.2.2.

904 Als hierboven vermeld, heeft de verzoekster gesteld in Suriname te hebben verbleven van 02.02.19. 81-19,11,1982 en 15,03.1983-22,11.1986. In haar beschikking legt de rechtbank de begindatum voor de toetsing ex art. 5 lid 2 TOS op 02.02.1981. Mijns inziens komt evenwel slechts de periode 15.03.198322.11.1986 in aanmerking voor een toetsing ex art. 5 lid 2 TOS. Vgl. de (weliswaar na de onderhavige beschikking van de Haagse rechtbank in een art. 43 (oud) Vreemdelingenwetprocedure gewezen) uitspraak HR 29.09.1989, NJ 1989, nr. 878, waarin de HR voor de toepassing van art. 5 lid 2 TOS cen "onafgebroken verblijf" van twee jaar in Suriname eist. Vgl. echter ABRS 27.07.1994, AB 1995, ar. 36 
voorafgaande bespreking van de in het kader van artikel 43 (oud) Vreemdelingenwet gewezen rechtspraak is er indien een zodanig lang verblijf in Suriname vaststaat reden om aan te nemen dat nationaliteitswisseling op grond van artikel 5 lid 2 TOS zou hebben kunnen plaatsvinden. Tevens is in de hierboven genoemde rechtspraak naar voren gekomen dat, indien op de zojuist vermelde wijze van het verlies van het Nederlanderschap kan worden uitgegaan, de klager/verzoeker tegen dat oordeel alsnog tegenbewijs kan leveren. Bij het slagen van dit tegenbewijs dient alsnog tot behoud van de Nederlandse nationaliteit te worden geconcludeerd.

Met het oog op dit mogelijk slagen van het tegenbewijs in de onderhavige casus is het interessant om de door de rechtbank met betrekking tot artikel 5 lid 2 TOS gehanteerde rechtsoverweging nader te bekijken. Blijkens de overwegingen waarop de rechtbank de afwijzing van het verzoek doet steunen, is de rechtbank tot de overtuiging gekomen dat de verzoekster haar woonplaats heeft verplaatst naar Suriname alsook dat de verzoekster de wil heeft gehad zich blijvend in Suriname te vestigen. Hierbij lijkt eerder een toepassing aan de orde van het criterium dat de Hoge Raad in 1980 heeft ontwikkeld voor de toetsing van artikel 3 TOS, dan het in 1982 ontwikkelde criterium voor artikel 5 lid 2 TOS. ${ }^{905}$ Immers, bij dat laatste criterium gaat het erom dat wordt onderzocht of "in redelijkheid niet kan worden betwijfeld" dat de verzoekster ten tijde van ieder vertrekmoment naar Suriname (derhalve februari 1981 en maart 1983) de wil heeft gehad haar woonplaats in Nederland op te geven. Om daar een oordeel over te vellen zou de rechtbank de reden van het vertrek uit Nederland naar Suriname hebben moeten toetsen (en de bewijzen die de verzoekster ten behoeve van haar tegenbewijs overlegt). De rechtbank legt echter een andere toetsingsmaatstaf aan en acht de verzoekster daarbij niet geslaagd in haar tegenbewijs.

\subsection{Rb. 's-Gravenhage 27 april 1988}

Cat. B(-TOS). uitspr. XVI. Casusbeschrijving. Art. 5 lid 2 TOS. Betwisting van de wil de woonplaats over te brengen vanuit het buitenland naar Suriname. Toewijzing van het verzoek.

Ook in de hieronder te bespreken $z^{2 a k^{906}}$ komt mogelijk verlies van het Nederlanderschap ingevolge artikel 5 lid 2 Toescheidingsovereenkomst Nederland-

$904 \rightarrow$

waarin verlies v.h. Nederlanderschap is aanvaard ingevolge art. 5 lid 2 TOS wegens verblijf in Suriname van juli 1983-april 1985 en juli 1985 -febr. 1986.

${ }^{*}$ In 1980 is als toetsingscriterium voor de toepassing van art. 3 TOS vastgesteld dat een woonplaats moet worden geacht te zijn verplaatst van Suriname naar Nederland (of elders) indien "klaagster ten tijde van haar vertrek uit Suriname in 1975 het voornemen had zich blijvend in Nederland te vestigen." ${ }^{*} \mathrm{Rb}$. 's-Gravenhage 27.04.1988, rkstnr. 87.5416. 
Suriname aan de orde. Hoewel door de rechtbank opgeroepen voor de mondelinge behandeling is i.c. de Staat eveneens niet verschenen. ${ }^{907}$

De verzoekster in kwestie is, komend uit Suriname, sinds juli 1975 in Nederland woonachtig. Eind $1984^{908}$ reist zij terug naar Suriname en in het voorjaar van 1987, het moment dat het verzoekschrift in behandeling wordt genomen, verblijft zij daar nog steeds.

Voor de rechtbank voert de verzoekster aan dat de reden voor haar terugkeer naar Suriname in 1984 is geweest dat zij destijds psychische problemen had. Tevens stelt zij nimmer de wil te hebben gehad zich blijvend in Suriname te vestigen en dat zij voornemens is geweest om eind 1986 naar Nederland terug te keren. Eind december 1986 is de terugvlucht (voor 26.05.1987) geboekt en aanbetaald.

Op 05.03.1987 trekt de Nederlandse ambassade in Paramaribo verzoeksters (Nederlandse) paspoort in. De intrekking is gemotiveerd met de op artikel 5 lid 2 TOS toegespitste overweging "dat zij zich op 21 december 1984 heeft laten inschrijven in het bevolkingsregister in Suriname." Uit de conclusie van het openbaar ministerie blijkt dat nadere overwegingen die hebben geleid tot de intrekking van het paspoort zijn geweest:

"- dat verzoekster blijkens de stempels in dit paspoort vanaf 26 november 1984 woonplaats dan wel werkelijk verblijf heeft gehad in Suriname, en

- dat zij zich blijkens een stempel in dit paspoort op 21 december heeft laten inschrijven in het bevolkingsregister van het district Suriname. "

De vraag derhalve die in deze zaak moet worden beantwoord, is of, zoals de Nederlandse overheid meent en de verzoekster bestrijdt, op de verzoekster inderdaad artikel 5 lid 2 TOS van toepassing is. Naast de in de Toescheidingsovereenkomst gestelde voorwaarde dat de betrokkene minimaal een periode van twee jaar in Suriname heeft verbleven, is, voor het oordeel of artikel 5 lid 2 TOS van toepassing is, in de rechtspraak sinds 1982 een op de individuele situatie van de

\footnotetext{
9n Althans volgens de rechtbank niet in rechte verschenen: zie par. 2.4.2.1.

${ }^{908}$ In deze uit april 1988 daterende uitspraak is nog niet aan de orde de verwikkeling die zich heeft voorgedaan wegens het de facto beëindigen door Suriname van de toepassing van art. 5 lid 2 TOS. Inzake het voortduren van art. 5 lid 2 TOS heeft tussen Nederland en Suriname tot 1994 een meningsverschil bestaan. Het Surinaamse standpunt dat degenen die zich na 01.01.1984 hebben gevestigd of verblijf hebben genomen in Suriname niet meer door middel van art. 5 lid 2 TOS de Surinaamse nationaliteit van rechtswege verkrijgen, is in Nederland naar aanleiding van HR 07.04.1989, NJ 1990. nr. 791 (par, 3.3.4.4.6) als dusdanig feitelijk gerespecteerd. Er dient derhalve in die gevallen van bet voortduren van het Nederlanderschap van de betrokkene(n) te worden uitgegaan. Vgl. voorts de annotatic van Ahmad Ali onder Rb. 's-Gravenhage 27.03.1991, RV 1991, nr. 45: Haarmans, p. 70-86 en 114-120. Pas in 1994 is een wijzigingsprotocol (Trb, 1994, nr. 280, i.w.t. 01.12.1995 ingevolge Trb. 1995, nr. 261) op de Toescheidingsovereenkomst tot stand gekomen waarin (met terugwerkende kracht) wordt bepaald dat met ingang van 01.01.1986 verwerving van de Surinaamse nationaliteit niet langer geschiedt wegens tweejarig of langer verblijf of woonplaats in Suriname. Zie m.b.t. tot het wijzigingsprotocol de annotatic van De Groot onder HR 16.09.1994, NJ 1995, nr. 563.
} 
betrokkene toegespitst toetsingscriterium van groot belang. ${ }^{909}$ Volgens dat criterium vindt artikel 5 lid 2 TOS slechts toepassing: "indien aan de wil van de betrokkene zijn tevoren bestaande woomplaats prijs te geven, in redelijkheid niet kan worden getwijfeld."

Om een oordeel te kunnen vellen omtrent verzoeksters wil om op het moment van vertrek naar Suriname haar bestaande woonplaats in Nederland op te geven en zich blijvend te vestigen in Suriname geeft de rechtbank de verzoekster een bewijsopdracht. De verzoekster dient "door middel van geschriften aan te tonen:

1. dat zij in afwijking van hetgeen is overwogen in bovengenoemde beschikking van de tijdelijk zaakgelastigde der Nederlanden te Paramaribo zich niet heeft laten inschrijven in het bevolkingsregister van het district Suriname, maar in een verblijfsof vreemdelingenregister, alsmede

2. dat zij in de periode november 1984 tot heden heeft ingeschreven gestaan in het bevolkingsregister van Vlaardingen."

De verzoekster voldoet aan de bewijsopdracht en legt de benodigde bewijsstukken over. Deze bewijsstukken zijn evenwel eerst bij de rechtbank ingekomen nadat de laatste zittingsdag is gehouden. Dit is voor de officier van Justitie aanleiding geweest om bij akte te stellen dat de bewijsstukken niet in de procedure kunnen worden toegelaten. ${ }^{910}$ De rechtbank echter neemt de aldus overgelegde bewijsstukken wel als grondslag voor de uitspraak.

Naast de door de verzoekster in de procedure ingebrachte bewijsstukken ter zake van haar inschrijving in de diverse bevolkingsregisters is een aanbetalingskwitantie voor de geboekte terugreis overgelegd. Door middel van deze kwitantie heeft de verzoekster volgens de rechtbank "tot op zekere hoogte aannemelijk gemaakt dat zij reeds eind 1986 naar Nederland heeft willen terugkeren."

Uit alle vastgestelde feiten volgt naar het inzicht van de rechtbank: "dat in redelijkheid twijfel mogelijk blijft over de vraag of verzoekster de wil heeft gehad zich blijvend in Suriname te vestigen. " Dientengevolge concludeert de rechtbank dat het verzoek tot vaststelling van het Nederlanderschap dient te worden toegewezen.

\section{Aantekening.}

Wat betreft de feitelijke grondslag waarop de procedure wordt gevoerd, kan worden opgemerkt dat de feiten geheel door de verzoekster worden aangevoerd. De

\footnotetext{
${ }^{909}$ Zie par. 3.3.3.4.3.

910 Betreffende de late ontvangst van dit bewijs heeft de OvJ in een akte gesteld: "Aangezien de \{bewijsmiddelen\} na afloop van de door uw Rechtbank op 20.01.1988 vastgestelde behandeling van de zaak zijn ingekomen -en mitsdien geen onderwerp van discussie ter openbare terechtzitting kunnen zijnis het Openbaar Ministerie van oordeel dat op deze stukken geen acht meer kan worden geslagen. "Vgl. voetnoot 265.
} 
(officieel) niet-verschenen Staat, noch het openbaar ministerie brengen andere feiten bij.

De handelwijze van de rechtbank om het na de zittingsdag ontvangen bewijsmateriaal in de procedure op te nemen, valt m.i. alleen maar toe te juichen. Indien bewijsmateriaal in het buitenland moet worden verzameld, iets dat in nationaliteitszaken wel vaker zal voorkomen, kan het onredelijk zijn om strikt aan de eis van behandeling op de openbare zitting vast te houden. Daarnaast heeft de door de rechtbank gevolgde handelwijze een duidelijk proceseconomische functie: de verzoekster zou anders, onder overlegging van de eerder buiten beschouwing gebleven stukken, genoodzaakt zijn door middel van het indienen van een tweede verzoekschrift de "zelfstandige vaststellingsprocedure" te herhalen. ${ }^{\text {911 }}$

Op welk artikel uit de Toescheidingsovereenkomst het verlies van de Nederlandse nationaliteit wordt gebaseerd, blijkt uit het inleidende verzoekschrift. De verzoekster produceert een fotocopie van de beschikking genomen door de ambassade te Paramaribo tot intrekking van haar paspoort. In die beschikking is vermeld op welk verdragsartikel en op welke overwegingen de intrekking van het paspoort steunt. Ook mede door de feiten die de verzoekster zelf in het verzoekschrift stelt, staat het langdurig verblijf in Suriname vast. De verzoek'ster destrijät' 'aản ook' mẻt' de feitelijke juistheid inzake haar verblijf in Suriname of de duur daarvan.

Indien en nadat voldoende vaststaat dat de betrokkene twee jaar of langer in Suriname heeft verbleven, is het standpunt dat de betrokkene ten gevolge van de werking van artikel 5 lid 2 TOS het Nederlanderschap heeft verloren een standpunt dat in beginsel als een juist standpunt kan worden gekwalificeerd. Dat de rechtbank ervan uitgaat dat de beschikking door de ambassade in Paramaribo in beginsel vanuit nationaliteitsrechtelijk oogpunt beschouwd juist is, blijkt uit het feit dat de verzoekster in de gelegenheid wordt gesteld tegenbewijs te leveren in die zin dat zij aannemelijk zal trachten te maken dat zij kennelijk niet de wil heeft gehad haar woonplaats over te brengen naar Suriname.

De rechtbank volgt met de bewijslastverdeling waarbij de verzoekster moet aantonen niet de wil te hebben gehad haar woonplaats naar Suriname te hebben overgebracht de lijn die in eerdere rechtspraak is uitgezet door de Hoge Raad. Het bewijsrechtelijke patroon dat de rechtbank i.c. volgt, stemt overeen met het patroon dat is gebleken bij de artikel 43 (oud) Vreemdelingenwetprocedure. De verzoekster slaagt daarbij in het leveren van het tegenbewijs.

${ }^{91}$ Zie par. 2.7.1. Daarnaast hoeft het $\mathrm{OM}$ na de conclusie niet meer te worden gehoord, zie voetnoot 265. 


\subsection{Rb. 's-Gravenhage 29 juni 1988}

Cat. B(-TOS). uitspr. XVII. Casusbeschrijving. Art. 5 lid 2 TOS. Niet komt vast te staan dat verzoeker twee jaar in Suriname woonplaats of verblijf heeft gehad. Toewijzing van het verzoek.

Ook in de navolgende zaak $^{912}$ is de vraag aan de orde of de werking van artikel 5 lid 2 Toescheidingsovereenkomst heeft geleid tot verlies van het Nederlanderschap. De verzoeker, wiens (Nederlandse) paspoort wegens vermeend verlies van het Nederlanderschap is ingetrokken door de burgemeester van Zwolle, wendt zich tot de rechtbank te Den Haag ten einde over zijn nationaliteit een uitspraak te verkrijgen.

De onderhavige zaak is in zoverre uniek dat het, onder de aan dit onderzoek ten grondslag liggende beschikkingen, de enige beschikking is waarin niet blijkt dat de Staat is opgeroepen als belanghebbende, waarin ook geen melding wordt gemaakt van een mondelinge behandeling en waarin de conclusie van het OM positief voor de verzoeker is. ${ }^{913}$ Ook de rechtbank beslist positief voor de betrokkene.

De verzoeker is, komend uit Suriname, sinds 27.08.1975 woonachtig in Nederland. In oktober 1983 vertrekt de verzoeker naar Suriname en wordt hij deswege uitgeschreven uit het bevolkingsregister van zijn Nederlandse woonplaats. Met ingang van 22.05.1987 vestigt de verzoeker zich weer in Nederland. Bij de gemeente van vestiging rijst de vraag of verzoeker nog de Nederlandse nationaliteit bezit en wordt, zoals hierboven al is vermeld, zijn paspoort ingetrokken. Op welke andere gegevens, buiten het feit dat de verzoeker de periode oktober 1983-mei 1987 niet in Nederland heeft verbleven, de gemeente dit besluit baseert, wordt uit de beschikking niet duidelijk. Een terloopse opmerking in de conclusie van het OM ter zake doet het ergste vrezen. Bij de bespreking van de door de verzoeker overgelegde bewijsstukken is volgens de officier van Justitie namelijk "voldoende aannemelijk geworden dat hij in de periode van 31 oktober 1983 en 22 mei 1987. anders dan de burgemeester van de gemeente Zwolle kennelijk meent, niet gedurende een periode van twee jaren in Suriname woon- of verblijfplaats heeft gehad, (.......)."

\footnotetext{
${ }^{912} \mathrm{Rb}$. 's-Gravenhage 29.06.1988, rkstnr. 87.6118.

${ }^{9}$ Op grond van het feit dat in de beschikking, in afwijking van alle andere beschikkingen, geen melding wordt gemaakt van deze zaken ben ik ervan overtuigd dat i.c. de Staat inderdaad niet is opgeroepen, alsook dat er geen mondelinge behandeling heeft plaatsgevonden. Het achterwege laten van het eerste ligt vanzelfsprekend in het verlengde van het achterwege laten van het tweede. Indien er geen sprake van een behandeling op een zitting is, kan er ook moeilijk een belanghebbende voor een mondelinge behandeling worden opgeroepen. Tevens blijkt in de beschikking niet van het oproepen van de verzoeker (vgl. art. 429f Rv). Wel is de beschikking, net als alle andere beschikkingen, gegeven door de meervoudige kamer.
} 
De verzoeker is namelijk zo fortuinlijk in het bezit te zijn van schriftelijke bewijsstukken die aantonen dat hij de periode januari 1985-mei 1987 buiten Suriname, en wel in Frans Guyana, heeft doorgebracht.

\section{Aantekening.}

Het is de vraag welke uitspraak de rechtbank zou hebben gedaan indien de verzoeker niet over de juiste bewijsstukken zou hebben beschikt. Zou de rechtbank in dat geval tot afwijzing van het verzoek tot vaststelling van het Nederlanderschap hebben beslist omdat de burgemeester van Zwolle "kennelijk meent" dat de verzoeker aan de vereisten van artikel 5 lid 2 TOS voldoet? Het tegendeel van hetgeen de burgemeester "kennelijk meent", kan de verzoeker dan immers niet bewijzen.

Aangezien vanzelfsprekend daartegenover staat dat de burgemeester, dan wel in het algemeen de Nederlandse overheid, in dat geval ook niet zou(den) kunnen bewijzen dat de verzoeker langer dan twee jaar in Suriname heeft verbleven, ${ }^{914}$ moet in dat geval het oordeel van de rechtbank eveneens luiden dat de verzoeker

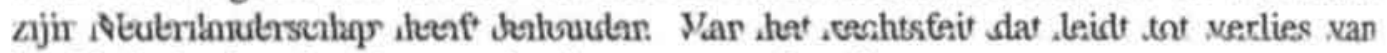
het Nederlanderschap bestaat dan immers geen bewijs.

In het bijzonder uit deze casus wordt het belang van de "primaire bewijslast" voor de overheid duidelijk. Indien de overheid van onvolledige en/of onjuiste feiten uitgaat, kan de betrokkene daarvan makkelijk het slachtoffer worden als hij simpelweg tegen de door de overheid gestelde feiten geen tegenbewijs kan leveren. Het is daarom van groot belang dat de rechter eerst toetst of het standpunt van de overheid deugdelijk is onderbouwd. Hierop voortbouwend, ben ik van mening dat i.c. de rechtbank het verzoek tot vaststelling van het Nederlanderschap had moeten inwilligen op grond van de overweging dat onvoldoende is gebleken dat door de betrokkene is voldaan aan een verliesbepaling voor het Nederlanderschap. De bewijslast voor het verlies van het Nederlanderschap ligt daarbij vanouds bij de Nederlandse overheid. ${ }^{915}$ In casu heeft de rechtbank het verzoek tot vaststelling ingewilligd op grond van de overweging dat de "verzoeker voldoende aannemelijk heeft gemaakt dat hij niet gedurende een periode van minimaal twee jaar woon- of verblijfplaats in Suriname heeft gehad in de periode van 31 oktober 1983 tot 22 mei 1987. " Als gezegd, naar mijn mening ware het correcter geweest als de rechtbank het verzoek zou hebben ingewilligd op grond van overwegingen waaruit duidelijk

\footnotetext{
"14 Immers, alleen de afwezigheid uit Nederland staat vast.

915 Dit onder de aantekening dat tot op heden in de jurisprudentie slechts aan de orde is gekomen het geval waarin door de betrokkene een beroep is gedaan op behoud van het Nederlanderschap terwijl de Ned. overheid daarentegen het standpunt inneemt dat het Nederlanderschap verloren is gegaan. De situatie waarin het de betrokken persoon is die zich beroept op verlies van het Nederlanderschap en waarin de Ned. overheid op het standpunt staat dat de Ned. nationaliteit niet verloren is gegaan, komt in de jurisprudentie niet voor.
} 
blijkt dat het bewijsmateriaal van de verzoeker buiten beschouwing is gebleven, maar waaruit eveneens duidelijk blijkt dat primair het overheidsstandpunt is getoetst en onhoudbaar is gebleken.

\subsection{Rb. 's-Gravenhage 9 november 1988}

Cat. B(-TOS) uitspr. XVIII. Casusbeschrijving. Art. 5 lid 2 TOS. Woonplaats of werkelijk verblijf voor een periode langer dan twee jaar in Suriname. Afwijzing van het verzoek.

Uit de hieronder te bespreken casus ${ }^{916}$ blijkt echter dat de rechtbank in Den Haag de "primaire bewijslast" wel snel voldaan acht. Verlies van het Nederlanderschap wordt i.c. al aangenomen op grond van de data van de in- en uitreisstempels in verzoekers paspoort.

De reden waarom de verzoeker zijn Nederlandse nationaliteit wil zien vastgesteld wordt niet vermeld. Uit de beschikking wordt niet duidelijk of de verzoeker door enige overheidsinstantie als vreemdeling wordt behandeld. De Staat is wel opgeroepen, maar wederom niet verschenen. ${ }^{917}$

De in 1950 in Suriname geboren verzoeker: "verbleef op 25.11.1975 in Nederland. Hij behield derhalve bij de onafhankelijkheid van Suriname de Nederlandse nationaliteit." Aldus stelt de rechtbank het behoud van het Nederlanderschap bij de onafhankelijkheid van Suriname vast.

Medio 1983 vertrekt de verzoeker naar Suriname en de terugkomst in Nederland vindt niet eerder plaats dan in februari 1987. Een verliesbepaling van het Nederlanderschap waaraan de verzoeker derhalve mogelijkerwijs heeft voldaan, zou artikel 5 lid 2 Toescheidingsovereenkomst kunnen zijn.

De verzoeker stelt evenwel ten eerste dat hij geen twee jaar in Suriname heeft verbleven en ten tweede dat hij "nimmer de wil heeft gehad zich blijvend in Suriname te vestigen". Naar zijn zeggen heeft hij de periode juni 1984-februari 1987 in Frans Guyana verbleven. Uit de overwegingen van de rechtbank blijkt dat de verzoeker een verklaring van een Nederlandse gemeente heeft overgelegd inhoudende dat uit stempels in verzoekers paspoort is af te leiden dat hij in augustus 1983 Suriname is ingereisd en dat hij in februari 1987 Suriname is uitgereisd. De rechtbank merkt vervolgens op: "Volgens die brief bevat het paspoort geen in-en uitreisstempels van Frans Guyana of andere landen. " Nadere overwegingen van de rechtbank houden in dat de verzoeker niet heeft meegewerkt aan het overleggen van andere door de rechtbank gevraagde documenten.

\footnotetext{
${ }_{916}^{916} \mathrm{Rb}$. 's-Gravenhage 09.11.1988, rkstnr. 88.5098.

${ }^{97}$ Althans niet in rechte verschenen: zie par, 2.4.2.1.
} 
Het verzoek tot vaststelling van het Nederlanderschap wijst de rechtbank af op grond van de overweging: "Verzoeker heeft op geen enkele wijze kunnen aantonen of zelfs maar aannemelijk kunnen maken dat hij, zoals hij stelt, vanaf juni 1984 tot begin februari 1987 in Frans Guyana heeft verbleven." Ook acht de rechtbank het, bij gebrek aan aanwijzingen daaromtrent, niet waarschijnlijk dat de verzoeker zich niet in Suriname heeft willen vestigen. De feiten dat de verzoeker bij vertrek uit Nederland een vaste baan opgaf en dat na enige tijd zijn gezin zich bij hem in Suriname voegde, overtuigen de rechtbank eerder van het tegenovergestelde.

\section{Aantekening.}

In deze zaak is sprake van een vederlichte invulling van de "primaire bewijslast". Het verlies van de Nederlandse nationaliteit wegens woonplaats of werkelijk verblijf van twee jaar of langer in Suriname wordt aanvaard op grond van de Surinaamse in- en uitreisstempels in verzoekers paspoort en het ontbreken van reisstempels van andere landen. De verzoeker heeft kennelijk geen ander tegenbewijs dan zijn eigen verklaring. ${ }^{918}$ Maar staat ten gevolge van de Surinaamse stempels het minimaal verblijf van twee jaar in Suriname ook vast, zoals de rechtbank nog terecht eiste in de casus uit paragraaf 3.3.4.4.1? ${ }^{919}$

Om meer gegevens boven water te krijgen, heeft de rechtbank een beroep gedaan op de verzoeker. De verzoeker heeft daarop blijkens de beschikking niet gereageerd. Naar mijn inzicht dient de rechtbank daaraan niet het gevolg te verbinden dat de verzoeker (hoewel wellicht kennelijk niet in staat aannemelijk te maken dat hij niet twee jaar of langer in Suriname heeft verbleven/woonachtig is geweest) aan de verliesbepaling uit artikel 5 lid 2 TOS heeft voldaan. Hoewel voor het vergaren van zoveel mogelijk informatie een beroep kan worden gedaan op de verzoeker is het mijns inziens niet zo dat de bewijslast en het bewijsrisico van een verliesbepaling primair bij de betrokkene ligt. Uit de voorgaande jurisprudentie is immers gebleken dat het niet aan de betrokkene is om aannemelijk te maken dat hij niet aan een verliesbepaling voor het Nederlanderschap heeft voldaan. Primair dient de Nederlandse overheid te bewijzen dat het Nederlanderschap verloren is gegaan (de "primaire bewijslast"). Mijns inziens is in de onderhavige casus niet voldaan aan de

${ }^{918}$ Of bezit wellicht slechts aan zijn bedoeling tegenstrijdig bewijsmateriaal.

99 In de rechtspraak op grond van art. 43 (oud) Vw komt de vraag aan welke kant de bewijslast ligt bij betwisting van het wel of niet hebben verbleven gedurende twee jaar of langer in Suriname (voorzover ik weet) niet voor. In de door mij onderzochte jurisprudentie op grond van art. 17 RWN komen nog twee zaken voor waarin de vraag speelt of de verzoeker inderdaad wel twee jaar in Suriname heeft verbleven: Rb. 's-Gravenhage 15.07.1987 (par. 3.3.4.4.1) en Rb. 's-Gravenhage 29.06.1988 (par. $3.3 .4 .4 .4)$. In beide zaken komt het tweejarig verblijf niet vast te staan en wordt geconcludeerd tot behoud van de Nederlandse nationaliteit. Als vereiste voor verlies van het Nederlanderschap geldt n.m.m. het uitgangspunt dat de bewijslast van het minimaal tweejarig verblijf in eerste instantie bij de Nederlandse overheidsorganen ligt. 
"primaire bewijslast". Naar mijn mening kan op grond van hetgeen i.c. aan feiten vaststaat niet worden gesteld dat blijkt dat de verzoeker de periode 1983-februari 1987 in Suriname heeft verbleven. Door hier wel van uit te gaan, hanteert de rechtbank, zoals hierboven al werd opgemerkt, een wel vederlichte "primaire toetsing" van het standpunt van de Staat. Anders dan de rechtbank meen ik derhalve dat de gewenste bewijssterkte van het feit dat leidt tot verlies van het Nederlanderschap groter dient te zijn. In paragraaf 3.3.3.5 is gebleken dat de Hoge Raad in beklagprocedures op grond van artikel 43 (oud) Vreemdelingenwet immers spreekt van gebleken en vaststaan indien het gaat om de bewijssterkte aangaande verliesbepalingen.

In de onderhavige procedure was de Staat niet verschenen en kon dus geen bewijsopdracht krijgen. Onder die omstandigheid brengt de niet-lijdelijkheid ${ }^{920}$ van de nationaliteitsrechter met zich dat deze zelf een onderzoek naar de feiten instelt om meer gegevens te verkrijgen omtrent het wel of niet daadwerkelijk verblijf in Suriname gedurende twee jaar. Bij dat feitenonderzoek kan het OM een rol spelen.

De rechtbank denkt klaarblijkelijk anders. Naar mijn mening legt in het onderhavige geval de rechtbank de bewijslast verkeerd door het verzoek af te wijzen omdat de verzoeker het tegenovergestelde van hetgeen de Nederlandse overheid op grond van summiere gegevens beweert niet aannemelijk kan maken.

\subsection{HR 7 april 1989}

Cat. B(-TOS). uitspr. XIX. Casusbeschrijving. Art. 5 TOS. Algemene beginselen van nationaliteitsrecht. Mate van zekerheid inzake de verwerving van een vreemde nationaliteit. Afwijzing van het verzoek door de rechtbank; vernietiging van de beschikking door de HR.

In de volgende $\mathrm{zaak}^{921}$ gaat het niet zozeer om een bewijsrechtelijke vraag, want de feiten staan als zodanig vast, maar komt de vraag aan de orde in hoeverre het bezit van een andere nationaliteit dient vast te staan om invloed te sorteren in het Nederlandse nationaliteitsrecht. Deze vraag is eerder aan de orde gekomen. ${ }^{922}$

\footnotetext{
${ }^{800} \mathrm{~V}$ gl. betreffende de niet-lijdelijkheid de latere uitspraken $0 . \mathrm{g} . \mathrm{v}$. de "zelfstandige vaststellingsprocedure": HR 07.04.1989, NJ 1990, nr. 791 (par. 3.3.4.4.6) en HR 28.10.1994, RvdW 1994, nr. 216 (par. 3.3.4.3.2). Evenwel sluit de Hoge Raad in deze uitspraken juist aan bij de niet-lijdelijkheidsattitude van de rechter in geval van Nederlanderschapsvaststelling uit de oudere jurisprudentie. Zie m.b.t. de "zelfstandige vaststellingsprocedure" ook par. 3.2.2 en 3.3.4.1.

HR 07.04.1989, NJ 1990, nr. 791, m.nt. GRdG.

Vgl. HR 10.09.1959, NJ 1959, nr. 596 (par. 3.3.2.2.4); HR 15.09.1980, NJ 1981, nr. 68 (par. 3.3.3.2.2); HR 08.12.1989, MR 1990, p. 40 (par. 3.3.3.2.5).
} 
In een ruim aantal uitspraken in het voorafgaande is reeds artikel 5 lid 2 Toescheidingsovereenkomst inzake nationaliteiten tussen Nederland en Suriname aan de orde gekomen. Artikel 5 lid 2 TOS bewerkstelligt onder bepaalde voorwaarden verwerving van de Surinaamse nationaliteit en dientengevolge verlies van het Nederlanderschap.

Eén van de hier bedoelde voorwaarden is dat de betrokkene woomplaats of werkelijk verblijf heeft gehad in Suriname van minimaal twee jaar. Een bijkomende voorwaarde is het in de rechtspraak van de Hoge Raad ontwikkelde toetsingscriterium inhoudende dat "aan de wil van de betrokkene zijn tevoren bestaande woonplaats ${ }^{923}$ prijs te geven, in redelijkheid niet kan worden getwijfeld."

Een derde en een tot nu toe nog niet aan de orde gekomen nadere voorwaarde staat vermeld in artikel 5 lid 1 TOS en betreft de afbakening van de kring van personen die rechten kan ontlenen aan artikel 5 leden 1 en 2 TOS. De in artikel 5 lid 1 TOS bedoelde personen zijn op grond van dat artikel tot 01.01.1986 in de gelegenheid geweest een optie ter verwerving van de Surinaamse nationaliteit te doen.

Een tijdslimiet is ten aanzien van artikel 5 lid 2 TOS niet als zodanig in de Toescheidingsovereenkomst opgenomen. Evenwel is gaandeweg de jaren dienaangaande met betrekking tot artikel 5 lid 2 TOS een verschil in interpretatie tussen Suriname en Nederland aan de dag getreden. ${ }^{924}$ Het bleek dat personen die zich na 01.01.1984 in Suriname hadden gevestigd door de Surinaamse autoriteiten na 01.01.1986 niet als Surinaams onderdaan werden beschouwd. Dit gebeurde op grond van de bij de betreffende autoriteiten levende gedachtengang dat artikel 5 lid 2 , net als artikel 5 lid 1 TOS, op 01.01.1986 zou zijn geëxpireerd. ${ }^{925}$ De Nederlandse autoriteiten daarentegen gingen uit van het van kracht blijven van artikel 5 lid 2 TOS en bleven het standpunt innemen dat de betrokken personen wegens het verwerven van de Surinaamse nationaliteit de Nederlandse hadden verloren. Dit verschil in interpretatie heeft aanleiding gegeven tot de onderhavige casus.

Eind 1987 wordt de hierboven geschetste problematiek bij de rechtbank in Den Haag aan de orde gesteld door een verzoekster die zich in augustus 1984 in Suriname heeft gevestigd. De verzoekster neemt het standpunt in dat, aangezien zij volgens de bevoegde Surinaamse autoriteiten niet de Surinaamse nationaliteit heeft verworven, zij ook niet op grond van de Toescheidingsovereenkomst haar Nederlanderschap heeft verloren.

\footnotetext{
923 Dit betreft dan een woonplaats buiten Suriname, in de meeste gevallen zal het gaan om eeth woonplaats in Nederland.

924 Vgl. Ahmad Ali, MR 1987, p. 205; Haarmans, p. 114-120; Tratnik, MR 1988, p. 33. Zie ook voetnoot 908 .

s2s Vgl. Kantonrechter Paramaribo 21.03.1989, MR 1989, nr. 80.
} 
De rechtbank huldigt echter een tegenovergestelde mening en stelt onder meer: "Uit het bovenoverwogene ${ }^{926}$ volgt dat verzoekster geacht moet worden de Surinaamse nationaliteit te hebben verkregen en derhalve de Nederlandse nationaliteit te hebben verloren.

Verzoekster heeft het tegendeel niet aangetoond. Weliswaar heeft de staatssecretaris van justitie bij brief van 26 augustus 1987 aan een kantoorgenoot van de raadsman van verzoekster medegedeeld dat er aanwijzingen bestaan dat de Surinaamse autoriteiten zich op het standpunt stellen dat artikel 5 lid 2 van de Toescheidingsovereenkomst niet meer van kracht is, maar nu een officiële standpuntbepaling van de Surinaamse autoriteiten niet bekend is, moet er van uit worden gegaan dat de Surinaamse overheid de Toescheidingsovereenkomst respecteert. "

Tegen deze beslissing gaat de verzoekster in cassatie, hetgeen leidt tot de vernietiging van de beschikking van de rechtbank.

De vernietiging van de beschikking grondvest de Hoge Raad in "een redelijke, met algemene beginselen van nationaliteitsrecht overeenkomende uitleg " van artikel 2 Toescheidingsovereenkomst. ${ }^{97}$ Een zodanige uitleg brengt naar inzicht van de Hoge Raad "mee dat het Nederlanderschap slechts verloren gaat door het effectief verkrijgen van de Surinaamse nationaliteit in dier voege dat dient vast te staan dat de Surinaamse overheid die nationaliteit daadwerkelijk erkent."

Met betrekking tot de vraag van het wel of niet "effectief verkrijgen" van de Surinaamse nationaliteit ziet de Hoge Raad een onderzoeksopdracht voor de rechter weggelegd. De Hoge Raad is namelijk van oordeel dat: "Indien te dier zake twijfel bestaat, zal de Nederlandse rechter nader hebben te onderzoeken of dit geval zich inderdaad voordoet en, indien zulks niet komt vast te staan, moeten aannemen dat het Nederlanderschap van de betrokkene voortduurt."

Aantekening.

In deze casus staat de vraag centraal of de betrokkene de Surinaamse nationaliteit "effectief" heeft verworven. Met "effectief" is gedoeld op de vraag of zij door de Surinaamse autoriteiten ook inderdaad als in het bezit van de Surinaamse nationaliteit wordt beschouwd.

Net als in de voorafgaande casus legt de rechtbank de bewijslast inzake de nietverwerving van een vreemde nationaliteit en daarmee van (zijnde de consequentie van die verwerving) het niet hebben voldaan aan een verliesbepaling van het Nederlanderschap bij de verzoekster. Immers, de rechtbank overweegt dienaangaande dat de verzoekster niet aannemelijk heeft gemaakt dat zij niet de Surinaamse

\footnotetext{
${ }^{925}$ Hiermee wordt verwezen naar overwegingen die de rechtbank heeft gegeven ten einde de voortdurende gelding van art. 5 lid 2 TOS te onderbouwen.

207 Art. 2 lid 1 TOS: het algemene artikel dat bepaalt dat verwerving van de Surinaamse nationaliteit ingevolge de TOS leidt tot verlies van het Nederlanderschap.
} 
nationaliteit heeft verworven en derhalve tevens niet het Nederlanderschap heeft verloren. Dit betekent ten opzicht van de jurisprudentie tot 1986 een omdraaiing van de bewijslast. Uit vroegere rechtspraak is immers gebleken dat in het geval van twijfel over het bezit van een vreemde nationaliteit de bewijslast betreffende de vreemde nationaliteit bij de Nederlandse overheid ligt. ${ }^{928}$ Bovendien is in eerdere rechtspraak eveneens uitgemaakt dat de bewijslast betreffende het verlies van het Nederlanderschap bij de Nederlandse overheid ligt en niet bij de betrokkene.

$\mathrm{Na}$ vernietiging verwijst de HR terug naar de rechtbank met de opdracht dat nader onderzocht zal worden of effectieve verwerving van de Surinaamse nationaliteit heeft plaatsgevonden. De Nederlandse rechter krijgt in dezen een onderzoeksverplichting, al zegt de Hoge Raad niet hoe intensief zodanig onderzoek dient te zijn. Wel stelt de Hoge Raad dat zolang de rechtbank niet blijkt dat door de verzoekster is voldaan aan een verliesbepaling voor het Nederlanderschap ervan moet worden uitgegaan dat het Nederlanderschap voortduurt. Hiermee is de al eerder gesignaleerde continueringspresumtie verwoord. Zolang niet het rechtsfeit van het verlies vaststaat, dient van behoud van het Nederlanderschap te worden uitgegaan.

Wat kan op grond van deze gegevens worden opgemerkt over de bewijslastverdeling in feitelijke instantie na de terugverwijzing? De Hoge Raad geeft de rechtbank slechts de opdracht de zaak nader te onderzoeken, en geeft geen uitsluitsel aangaande de vraag waar de bewijslast ligt. Er dient in feitelijke instantie vast komen te staan dat de verzoekster effectief de Surinaamse nationaliteit heeft verworven, zo niet, dan geldt de continueringspresumtie.

De mogelijkheid de verzoekster te belasten met de opdracht te bewijzen dat zij effectief de Surinaamse nationaliteit heeft verworven, zou uiterst curieus zijn en valt derhalve af. De mogelijkheid de verzoekster te belasten met de opdracht dat zij aannemelijk maakt dat zij niet de Surinaamse nationaliteit op effectieve wijze heeft verworven, brengt een bepaalde beperking met zich. Want als de verzoekster, bijvoorbeeld door bewijsnood of non-reactie, faalt in haar bewijsopdracht (inhoudende dat zij niet op effectieve wijze de Surinaamse nationaliteit heeft verworven), dan staat het tegenovergestelde toch niet tevens onomstotelijk vast? En in het kader van de continueringspresumtie dient dat laatste juist wel vast te staan. Uit dit alles volgt, naar mijn mening, dat indien een verliesgrond voor het Nederlanderschap

\footnotetext{
92: Rechtspraak waarin het bewijs van de verliesgrond "het verwerven van een vreemde nationaliteit" niet bij de betrokkene ligt: HR 13.04.1948, NJ 1948, nr. 647, m.nt. D.J.V. (par. 3.3.2.2.1); HR 04.10.1949 (gepubl. in Reuser (I), p. 82 (par. 3.3.2.2.3)); HR 27.11.1979, NJ 1980, nr. 550 (par. 3.3.3.3.2).

Ook indien de verwerving van het Nederlanderschap afhankelijk is van het wel of niet hebben verworven van een andere nationaliteit ligt de bewijslast van het niet-verwerven van de andere nationaliteit niet bij de betrokkene: HR 08.12.1989, MR 1990, p. 40, m.nt. HAA (par. 3.3.3.2.5).

Rechtspraak betreffende de mate van zekerheid waarin het bezit van een vreemde nationaliteit dient vast te staan: HR 10.10.1959, NJ 1959, nr. 596 (par. 3.3.2.2.4).
} 
vast dient komen te staan de bewijslast daarvoor niet bij de verzoeker, maar derhalve bij de Nederlandse overheid berust, en ook dient te berusten.

\subsection{Rb. 's-Gravenhage 27 maart 1991}

Cat. B(-TOS). uitspr. XX. Casusbeschrijving. Art. 3 TOS. Woonplaats op 25 november 1975. Er bestaan wederzijds tegenstrijdige bewijzen. Toewijzing van het verzoek.

In de volgende zaak $^{929}$ is het mogelijk verlies van het Nederlanderschap op grond van artikel 3 TOS aan de orde. Op de mondelinge behandeling is de als belanghebbende opgeroepen Staat verschenen. Dit is gebeurd door het ter zitting aanwezig zijn van een ambtenaar van het ministerie van Justitie.

De verzoekster heeft zich, komend uit Suriname, op 14.11.1975 gevestigd in een Nederlandse gemeente. In de jaren daarna is zij gedurende perioden dan weer wel, dan weer niet ingeschreven in een Nederlands bevolkingsregister. ${ }^{930}$ Verzoekster verblijft wegens ziekte en overlijden van haar echtgenoot vanaf mei 1980 tot september 1981 in Suriname. Een volgend verblijf in Suriname vindt plaats van november 1985 tot oktober 1989, waarbij reden tot vertrek naar Suriname is geweest de ziekte en vervolgens het overlijden van een kleinzoon van verzoekster.

Nadat in 1986 haar (Nederlandse) paspoort is gestolen, vraagt de verzoekster op 05.09.1986 bij de Nederlandse ambassade te Paramaribo een nieuw paspoort aan. De verstrekking van het verzochte paspoort wordt geweigerd, kennelijk niet op grond van ontkenning door de ambassade van het bezit van het Nederlanderschap door de verzoekster, maar omdat de verzoekster zich voor haar paspoort tot de Nederlandse gemeente zou moeten wenden waar zij tot haar vertrek naar Suriname heeft verbleven.

Met een in 1987 aangevraagd Surinaams paspoort reist de verzoekster in 1989 terug naar Nederland.

In het aan de rechtbank te Den Haag gerichte verzoekschrift wordt namens de verzoekster gesteld dat zij "nooit de bedoeling heeft gehad Surinaamse te worden en ten einde een nieuw nederlands paspoort te verkrijgen onmiddellijk belang heeft bij de vaststelling van haar Nederlanderschap. "

De als belanghebbende in de procedure verschenen Staat krijgt van de rechtbank "de gelegenheid" om "via het Ministerie van Justitie bij de autoriteiten te Suriname inlichtingen in te winnen. " Dientengevolge legt de Staat een via het ministerie van Buitenlandse Zaken verworven brief d.d. 27.11.1990 van het Centraal Bureau voor

\footnotetext{
Rb. 's-Gravenhage 27.03.1991, RV 1991, nr. 45, m.nt. HAA.

${ }^{90} \mathrm{Z}_{\mathrm{O}}$ is zij wel ingeschreven gedurende de perioden: 14.11.1975-28.08.1979; 18.10.1979-06.11.1979; $07.12 .1979-20.10 .1980$.
} 
Burgerzaken te Paramaribo over. De strekking van deze brief is dat de Surinaamse autoriteiten op het standpunt staan dat de verzoekster op grond van artikel 3 Toescheidingsovereenkomst de Surinaamse nationaliteit bezit. Concreet betekent dit dat de Surinaamse autoriteiten ervan uitgaan dat de verzoekster op 25.11.1975 de Surinaamse nationaliteit heeft verworven. Of dit laatste ook het standpunt is van de Nederlandse Staat, die weliswaar de brief in de procedure inbrengt, wordt uit de beschikking van de rechtbank niet duidelijk..$^{931}$

In ieder geval beperkt de rechtbank haar toetsing tot de vraag of verlies van het Nederlanderschap heeft plaatsgevonden op grond van artikel 3 Toescheidingsovereenkomst. ${ }^{932}$ Met betrekking tot artikel 3 TOS is in de voorafgaande bespreking van de rechtspraak reeds gebleken dat de Hoge Raad in $1980^{933}$ ter toetsing van dat artikel het criterium heeft geformuleerd dat de betrokkene "ten tijde van het vertrek uit Suriname het voornemen had zich blijvend in Nederland ${ }^{934}$ te vestigen".

$\mathrm{Na}$ te hebben geconstateerd welke perioden de verzoekster in Nederland ingeschreven is geweest in een bevolkingsregister overweegt de rechtbank als volgt: "Een natuurlijk persoon wordt vermoed zijn woonstede te hebben verplaatst, wanneer hij daarvan op de wettelijk voorgeschreven wijze aan de betrokken gemeentebesturen heeft kennis gegeven. Mede gezien de overgelegde verklaring van de directeur van het Centraal Bureau voor Burgerzaken te Paramaribo dd. 27 november 1990, zakelijk inhoudende dat verzoekster de surinaamse nationaliteit bezit op grond van artikel 3 van de Toescheidingsovereenkomst, is aannemelijk dat verzoekster geen kennis gegeven heeft aan het bestuur van haar woonplaats in Suriname, dat zij haar woonplaats naar Nederland heeft verplaatst. Hierin ziet de rechtbank echter geen aanleiding dit vermoeden terzijde te stellen. Zulks temeer omdat alleen reeds op grond van haar langdurige vestiging te Amsterdam aan haar wil om haar woonplaats in Suriname prijs te geven in redelijkheid niet kan worden getwijfeld. ${ }^{935}$ Ten tijde van de Soevereiniteitsoverdracht dd. 25 november 1975 had verzoekster dus woonplaats in Nederland, zodat zij toen de nederlandse nationaliteit heeft behouden."

93t Tenslotte is in 1986 een Nederlands paspoort van de verzoekster gestolen. In zijn annotatie bij deze uitspraak merkt Ahmad Ali op: "Uit het rekest (.......) blijkt dat ook in Nederland de beslissing op de aanvraag om cen nieuw Nederlands paspoort op de lange baan werd geschoven. (...........) de autoriteiten in Nederland gingen er kennelijk vanuit dat verzoekster het Nederlanderschap had verioren maar hoe dit nationaliteitsrechtelijk gemotiveend moest worden werd niet aan verzoekster kenbaar gemaakt."

${ }^{22}$ De optiemogelijkheid uit art. 5 lid 1 TOS is immers per 01.01.1986 vervallen en de werking van art. 5 lid 2 TOS is sinds HR 07.04.1989. NJ 1990, nr. 791 de facto beěindigd voor de personen die na 01.01.1984 langer dan twee jaar in Suriname hebben verbleven. Zie ook voetnoot 908.

233 Zie par. 3.3.3.4.1.

934 D.w.z. in ieder geval buiten Suriname.

9ss In zijn annotatie wijst Ahmad Ali er reeds op dat de rechtbank hier het toetsingscriterium van art. 5 lid 2 TOS hanteert. 
Aantekening.

$\mathrm{Na}$ haar terugkeer in Nederland kan de verzoekster geen Nederlands paspoort krijgen. Het irreële aan deze zaak is dat er blijkbaar wel een overheidsorgaan is dat het standpunt inneemt dat verzoekster haar Nederlanderschap heeft verloren, zodat er geen paspoort kan worden afgegeven, maar op welke rechtsgronden dan wel feiten en aan de hand van welk bewijsmateriaal zodanig standpunt wordt ingenomen, vermag de verzoekster niet duidelijk worden gemaakt. Ook met betrekking tot de in de procedure verschenen Staat blijft volstrekt wazig op welke verdragsbepaling uit de Toescheidingsovereenkomst het verlies van het Nederlanderschap zou zijn gebaseerd. Feitelijk wordt de "primaire bewijslast" ter zake van het verlies van het Nederlanderschap ingevuld door het standpunt dat de Surinaamse autoriteiten innemen, terwijl de Nederlandse autoriteiten zelf geen duidelijk standpunt innemen. Dit had m.i. de rechtbank ertoe moeten leiden het bezit van het Nederlanderschap door de verzoekster toe te wijzen onder de motivering dat niet is gebleken van verlies van het Nederlanderschap. Immers, de Nederlandse overheidsadministratie voldoet niet aan de aan haar kant vallende "primaire bewijslast" voor het verlies van de Nederlandse nationaliteit. De rechtbank had ingevolge de continueringspresumtie m.i. het verzoek moeten toewijzen zonder de bewijsmiddelen van de verzoekster bij de beoordeling te betrekken.

De rechtbank doet dit echter niet, maar gaat over tot de toetsing van de toepasselijkheid van artikel 3 TOS. Dit omdat de Surinaamse autoriteiten ervan uitgaan dat de verzoekster op grond van dat artikel de Surinaamse nationaliteit heeft verworven. De diverse perioden van inschrijving in een Nederlands bevolkingsregister overtuigen de rechtbank van het feit dat de verzoekster zich voor de onafhankelijkheid van Suriname in Nederland heeft gevestigd en dat zij het Nederlanderschap op 25.11.1975 heeft behouden. In casu zijn er derhalve tegenstrijdige bewijzen inzake de woonplaats op 25.11.1975 in het geding. ${ }^{936}$

De onderhavige uitspraak is overigens één van de beschikkingen waaruit blijkt dat indien de Staat op de mondelinge behandeling verschijnt, de rechtbank, indien een onderzoek naar de feiten nodig is, dit feitenonderzoek door het verstrekken van een bewijsopdracht aan de Staat, door de Staat laat verrichten. Het openbaar ministerie heeft onder die omstandigheid in dezen dan geen taak (meer).

${ }^{96}$ Zie voor een identieke casuspositie HR 23.12.1983, NJ 1984, nr. 387 (par. 3.3.3.4.4). 


\subsection{Rb. 's-Gravenhage 9 november 1988; HR 14 februari 1992; HR 4 december 1992}

(Cat. B(-TOS), uitspr. XXI, uitspr. XXII en uitspr. XXIII). Casusbeschrijvingen. Art. 5 lid 1 TOS. Wilsgebreken bij het afleggen van een optie.

In drie beschikkingen ${ }^{937}$ handelt de casus om een door de verzoeker afgelegde optie voor de Surinaamse nationaliteit. In het drietal zaken is sprake van een optie op grond van artikel 5 lid 1 Toescheidingsovereenkomst Nederland-Suriname. Met betrekking tot het afleggen van de opties voeren de betrokkenen aan dat zij ten tijde daarvan niet daadwerkelijk de wil hebben gehad de Surinaamse nationaliteit te verkrijgen. Zij stellen derhalve een wilsgebrek bij het opteren.

In alle zaken kan de Staat een door de verzoeker ondertekend optieformulier overleggen, zodat aan de "primaire bewijslast" voor het verlies van het Nederlanderschap is voldaan. De rechtbank kan derhalve ervan uitgaan dat het standpunt van de Staat inzake het verlies van het Nederlanderschap door de verzoeker in beginsel een correct standpunt is. Als bekend uit de eerdere rechtspraak, kan de betrokkene alsdan door middel van het aannemelijk maken van het wilsgebrek ten aanzien van het uit het opteren volgende rechtsgevolg, trachten de rechter te bewegen tot de uitspraak dat het Nederlanderschap niet is verloren gegaan. Hieronder volgt een korte bespreking van de drie beschikkingen.

In de eerste uitspraak ${ }^{938}$ gaat het om een uit Suriname afkomstige verzoekster die sinds 1956 woonachtig is geweest in Nederland. Zij vertrekt op 27.12.1975 weer naar Suriname. Medio 1987 keert de verzoekster terug in Nederland, alwaar zij wordt geconfronteerd met het feit dat zij als vreemdelinge wordt beschouwd. De verzoekster daarentegen staat op het standpunt niet haar Nederlandse nationaliteit te hebben verloren. In de door de verzoekster angevangen procedure is de als belanghebbende opgeroepen Staat niet verschenen, ${ }^{939}$ maar door het openbaar ministerie wordt een copie overgelegd van een door de verzoekster op 16.10.1976 ondertekend optieformulier ter verwerving van de Surinaamse nationaliteit op grond van artikel 5 lid 1 TOS. Met betrekking tot de optie stelt de verzoekster dat zij niet in vrijheid een keuze heeft gemaakt voor de Surinaamse nationaliteit. Zij stelt een Surinaams paspoort te hebben geaccepteerd omdat zij dan betere kansen op de (Surinaamse) arbeidsmarkt zou hebben. De rechtbank deelt niet verzoeksters mening dat het hier gaat om een wilsgebrek bij het doen van een rechtshandeling

${ }^{977}$ Rb. 's-Gravenhage 09.11.1988, rkstnr. 88.5295; HR 14.02.1992, NJ 1993, nr. 262, m.nt. GRdG; HR 04.12.1992 (rkstnr. 8058, niet gepubliceerd).

${ }^{\mathrm{s} s \mathrm{~s}} \mathrm{Rb}$. 's-Gravenhage 09.11.1988, rkstnr. 88.5295.

939 Althans volgens de rechtbank niet in rechte verschenen: zie par. 2.4.2.1. 
en overweegt: "Voorzover verzoekster heeft willen betogen dat een en ander niet op basis van vrijwilligheid is geschied, omdat zij in Suriname werk en een ambtelijke status wilde verwerven wordt dit betoog door de rechtbank niet aanvaard. Het is geenszins ongebruikelijk dat de voordelen van verandering van nationaliteit worden afgewogen tegen de nadelen."

Ook in de volgende zaak $^{940}$ baseert de verzoeker zijn gebrek aan (werkelijke) keuzevrijheid op het feit dat hij heeft geopteerd omdat hij mogelijk in Suriname werk zou kunnen vinden. Evenals bij de voorgaande zaak leidt dit niet tot succes. De rechtbank overweegt: "Gelet op het bovenstaande en op het feit dat de tekst van de door de verzoeker ondertekende kennisgeving kort en duidelijk is acht de rechtbank het niet aannemelijk dat verzoeker op 23 februari 1977 niet bewust heeft gekozen voor de Surinaamse nationaliteit."

In de als laatste te bespreken $z^{2 a k}{ }^{941}$ bestrijdt de verzoeker het verlies van het Nederlanderschap met de stelling dat hij heeft geopteerd omdat hij wegens familieomstandigheden naar Suriname wilde reizen (vanuit Nederland), maar geen Nederlands paspoort kon krijgen omdat hij in Nederland nog een gevangenisstraf diende uit te zitten. Om toch te kunnen reizen, vervoegt de verzoeker zich bij de Surinaamse ambassade in Den Haag om te weten te komen of hij een reisdocument kon krijgen. Het verzoekschrift aan de rechtbank vermeldt over dat bezoek: "(......) heeft men verzoeker een dokument laten ondertekenen, waarvan verzoeker eerst later begreep dat dit een Kennisgeving ingevolge de Toescheidingsovereenkomst geweest was. Het was zeer beslist niet de bedoeling van verzoeker om onvoorwaardelijk voor de Surinaamse nationaliteit te opteren."

Tevens stelt de verzoeker de Surinaamse nationaliteit niet effectief te hebben verkregen nu "in casu geen bevestiging is ontvangen van de Surinaamse autoriteiten dat verzoeker de Surinaamse nationaliteit daadwerkelijk heeft verkregen." Na de ondertekening van het optieformulier in 1977 op de Surinaamse ambassade is de verzoeker namelijk, naar eigen zeggen, nimmer afgereisd naar Suriname, noch heeft hij ooit een Surinaams paspoort aangevraagd. Ook volgens het verzoekschrift bemerkt de verzoeker eerst in 1987, bij de aanvraag van een (Nederlands) paspoort, dat hij staat geregistreerd als van Surinaamse nationaliteit.

De rechtbank wijst het verzoek tot vaststelling van het Nederlanderschap af. In cassatie vangt de verzoeker eveneens bot. In de uitspraak van de Hoge Raad zijn i.c. vooral interessant de overwegingen ten aanzien van de vraag in welke mate het daadwerkelijk bezit van een vreemde nationaliteit dient vast te staan, wil er sprake zijn van doorslaggevende invloed op het bezit van het Nederlanderschap. Onder verwijzing naar NJ 1990 , nr. $791^{942}$ stelt het cassatiemiddel namelijk dat de Surinaamse nationaliteit eerst effectief blijkt te zijn verworven indien er een

\footnotetext{
${ }^{900}$ HR 04.12.1992 (rkstnr. 8058, niet gepubliceerd).

${ }^{211}$ HR 14.02.1992, NJ 1993, nr. 262, m.nt. GRdG.

${ }^{*}$ HR 07.04.1989, NJ 1990, nr. 791 (par. 3.3.4.4.6).
} 
Hoofdstuk 3

positieve uitspraak dienaangaande van de Surinaamse autoriteiten voorligt, waaraan het middel de opmerking vastknoopt dat eerst het Nederlanderschap verloren gaat nadat blijkt dat de Surinaamse nationaliteit effectief is verworven.

Hiertegenover stelt de Hoge Raad dat het onjuist is uit te gaan van de opvatting "dat in geval van optie voor het Surinamerschap de Surinaamse nationaliteit eerst dan effectief wordt verkregen en eerst dan het Nederlanderschap verloren gaat, indien komt vast te staan dat de Surinaamse autoriteiten blijk ervan geven de door optie verkregen nationaliteit daadwerkelijk erkennen."

De vraag die alsdan ogenblikkelijk rijst, is natuurlijk waarom in het ene geval kennelijk wél van belang is hoe de mening van de vreemde autoriteiten ter zake van de vreemde nationaliteit luidt en het andere (het onderhavige) geval die mening kennelijk voor de rechter niet relevant is. Het antwoord op die vraag geeft de Hoge Raad met de volgende overweging: "Het onderdeel ziet er evenwel aan voorbij dat het in de bij die beschikking ${ }^{943}$ berechte zaak ging om toepassing van art. 2 lid $1^{9 / 4}$ op een geval van verkrijging van de Surinaamse nationaliteit, waarbij ruimte bestond voor gerede twijfel of de Surinaamse autoriteiten haar zouden erkennen. Zodanige twijfel kan voortkomen uit tweeërlei bron, te weten uit een tussen beide Verdragsstaten bestaand verschiu' in interpretanie, zoan' in voormeila' gevia' besntond' ter zake van art. 5 lid 2, en uit een verschil van inzicht met betrekking tot het feitelijk vaststaan en de juridische waardering van de omstandigheden aan de hand waarvan de nationaliteitsverkrijging moet worden beoordeeld.

In het onderhavige geval doet zich echter geen van deze bronnen van twijfel voor. Van enig verschil tussen de Verdragsstaten ter zake van de uitleg van hier van belang zijnde bepalingen van de Toescheidingsovereeenkomst is geen sprake, terwijl ook overigens niet enig verschil van inzicht kan bestaan ten aanzien van het feitelijk vaststaan van de door D. gedane optie en het daaraan verbonden gevolg.

Het vorenoverwogenen brengt mee dat onderdeel II niet tot cassatie kan leiden, evenmin als onderdeel III, welk onderdeel betoogt dat de Rechtbank nader had behoren te onderzoeken of vaststaat dat de verkrijging door D. van de Surinaamse nationaliteit door de Surinaamse autoriteiten wordt erkend. "

\section{Aantekening.}

Kort een paar opmerkingen met betrekking tot deze drie zaken. Ten opzichte van de in de artikel 43 (oud) Vreemdelingenwetprocedure gehanteerde bewijslastverdeling inzake een wilsgebrek bij het afleggen van een optie kan geen verandering worden gesignaleerd. Onder de voorwaarde dat de overheid, bijvoorbeeld door overlegging van een getekende optieverklaring, bewijst dat een optie is afgelegd,

Me HR verwijst hier naar HR 07.04.1989, NJ 1990, nr. 791.

as Art. 2 lid 1 TOS: het algemene artikel dat bepaalt dat verwerving van de Surinaamse nationaliteit ingevolge de TOS leidt tot verlies van het Nederlanderschap. 
ligt ook in de vaststellingsprocedure op grond van artikel 17 Rijkswet op het Nederlanderschap inzake een beweerd wilsgebrek bij het doen van een optie de bewijslast bij de verzoeker.

Aangaande de vraag in welke mate het bezit van een vreemde nationaliteit dient vast te staan, is reeds gebleken dat de Nederlandse rechter daarover autonoom oordeelt en dat een erkenning door de vreemde staat van het bezit van haar nationaliteit niet behoeft voor te liggen, ${ }^{945}$ tenzij aanwijzingen bestaan dat de vreemde staat de betrokkene inderdaad niet als nationaal beschouwt. ${ }^{946}$ Ook hiermee wordt derhalve de lijn die is te onderkennen in eerdere uitspraken voortgezet.

In het geval dat gerede twijfel mogelijk is omtrent daadwerkelijke verwerving van de vreemde nationaliteit bestaat er meer aanleiding tot nader onderzoek naar de verwerving dan wanneer zodanige twijfel ontbreekt. Het blijkt dat de mate waarin een vreemde nationaliteit dient vast te staan enerzijds niet onderhevig is aan een positieve erkenning van de desbetreffende vreemde autoriteiten, maar anderzijds geen aanleiding mag geven tot "gerede twijfel" inzake de daadwerkelijke erkenning van de vreemde autoriteiten dat de vreemde nationaliteit is verworven.

\subsubsection{Derde tussenevaluatie}

Naar aanleiding van de in de voorgaande paragrafen besproken vaststellingsbeschikkingen valt met betrekking tot het bewijsrecht het navolgende op te merken.

Inzake een beroep op een wilsgebrek bij het doen van een optie is eens te meer gebleken dat de bewijslast van het wilsgebrek bij de verzoeker ligt. ${ }^{947}$ Wat dit betreft valt een voortzetting van de eerder geconstateerde bewijslastverdeling te constateren.

Tevens valt echter te constateren dat met betrekking tot de bewijslastverdeling in de uitspraken van de rechtbank sprake is van een verslechtering van de positie van de verzoeker ten opzichte van de eerdere positie ${ }^{948}$ die de betrokkene in een artikel 43 (oud) Vreemdelingenwetprocedure heeft ingenomen. Deze verslechtering komt m.i. voort uit het feit dat de rechtbank bij de vaststelling van de Nederlandse nationaliteit het administratiefrechtelijke karakter van het geschil te zeer uit het oog verliest. Wat deze verslechtering in bewijsrechtelijke positie betreft, valt op dat waar dit mogelijk is door de Hoge Raad wordt ingegrepen en de rechtbank op het

\footnotetext{
${ }^{905}$ HR 10.10.1959, NJ 1959, nr. 596.

${ }^{946}$ HR 07.04.1989, NJ 1990, nr. 791.

${ }^{97}$ Rb. 's-Gravenhage 09.11.1988, rkstnr. 88.5295; HR 14.02.1992, NJ 1993, nr. 262; HR 04.12.1992 (rkstnr. 8085, niet gepubliceerd) (par. 3.3.4.4.8).

${ }^{*} \mathrm{Zie}$ daarvoor par. 3.3.3.5.
} 
bewijsrechtelijke spoor wordt gezet zoals dat bekend is uit de uitspraken in de artikel 43 (oud) Vreemdelingenwetprocedure.

Betreffende de bewijslastverdeling en derhalve de bewijsrisicoverdeling is het allereerst in het licht van de in paragraaf 3.3.3 ontwikkelde concepten "primaire toetsing" en "primaire bewijslast", naar mijn mening, van groot belang om te bezien of deze concepten (bewust dan wel wellicht onbewust) door de rechtbank worden gehanteerd.

Wat betreft de weinige rechtspraak die betrekking heeft op een door de betrokkene gedaan beroep op verwerving van het Nederlanderschap kan worden gesteld dat de bewijslast van de feiten die leiden tot verwerving van de Nederlandse nationaliteit in deze gevallen bij de verzoeker blijkt te liggen. ${ }^{949}$ In deze drie gevallen blijkt niet dat de rechtbank oog heeft voor het op deugdelijke onderbouwing steunen van het door de Staat ingenomen negatieve standpunt inzake het Nederlanderschap van de betrokkene.

Dit geeft aanleiding om aan te nemen dat de rechtbank het concept van de "primaire toetsing" niet onderkent. Slechts in één geval kan namelijk worden gesteld dat aan de kant van de overheid blijkt van bezit van bewijs dat het negatieve standpunt zonder meer rechtvaardigt. ${ }^{950}$ In de zaak uit NJ 1993, nr. 261 geeft de rechtbank het openbaar ministerie een onderzoeksopdracht naar de authenticiteit van de door de verzoeker overgelegde bewijsstukken. Dit betekent dat de rechtbank zelf de door de verzoeker genoemde feiten onderzoekt op hun waarheidsgehalte. Aan het negatieve standpunt van de Nederlandse overheid (dat het minderjarige kind niet het Nederlanderschap heeft verworven) besteedt de rechtbank geen aandacht, naar mijn mening is dat (wellicht mede) het gevolg van het feit dat i.c. de Staat niet in rechte in de vaststellingsprocedure is verschenen. Voor het begrip "primaire toetsing" betekent deze handelwijze dat de rechtbank in feite zelf het bewijs tracht te leveren voor het negatieve standpunt inzake het bezit van de Nederlandse nationaliteit door het minderjarige kind. In NJ 1991, nr. 293 stelt tijdens de procedure voor de rechtbank het openbaar ministerie zich, aan de ene kant, op het standpunt dat de verzoekster niet door optie het Nederlanderschap heeft verworven, maar kan aan de andere kant niet bewijzen dat de verzoekster niet bij de ambassade in Suriname is geweest. Er wordt, ook door de rechtbank, slechts geconstateerd dat "thans niet meer (valt) na te gaan of verzoekster zich heeft gewend tot de consulaire afdeling van de Nederlandse ambassade te Paramaribo in verband met een optie ex artikel 10 van de Toescheidingsovereenkomst. "951 Noch-

\footnotetext{
99 Vgl. HR 28.09.1990, NJ 1991, nr. 293 (par. 3.3.4.2.1); HR 31.01.1992, NJ 1993, nr. 261 (par. 3.3 .4 .2 .2 ) en Rb. 's-Gravenhage 04.11.1992, rkstnr. 92.5105 (par. 3.3.4.2.3).

${ }^{950}$ Rb. 's-Gravenhage 04.11.1992, rkstnr. 92.5105 (par. 3.3.4.2.3).

981 Rb. 's-Gravenhage 11.10.1989, rkstnr. 89.5224 (= HR 28.09.1990, NJ 1991, nr. 293 (par. $3.3,4.2 .1$ ),
} 
tans wordt op deze onzekerheid wel het standpunt gegrondvest dat de verzoekster niet de Nederlandse nationaliteit bezit. Een goed onderbouwd standpunt van overheidswege lijkt mij toch anders tot stand te komen.

Dat de bewijslast en het bewijsrisico voor het verwerven van de Nederlandse nationaliteit primair bij de justitiabele ligt, is een voortzetting van de lijn die reeds in de eerdere jurisprudentie is uitgezet. Ook de stelplicht betreffende de feiten die tot verwerving zouden hebben geleid, ligt bij de verzoeker. Echter is in de eerdere jurisprudentie ook gebleken van nuancering van de stringente toepassing van dat bewijsrisico onder de omstandigheid dat de overheid haar negatieve standpunt niet door middel van feiten die als vaststaand mogen worden beschouwd, deugdelijk kon onderbouwen. ${ }^{952}$ Hoewel zeker één casus $^{953}$ daartoe aanleiding zou hebben kunnen geven, vindt men deze nuancering niet terug in de beschikkingen van de rechtbank. Wat dit betreft, kan dan ook mijns inziens worden gesproken van een verslechterde bewijsrechtelijke positie van de verzoeker in de "zelfstandige vaststellingsprocedure" in vergelijking met de positie van de klager in de artikel 43 (oud) Vreemdelingenwetprocedure.

Bovenal ter zake van een beroep op behoud van het Nederlanderschap acht ik het een belangrijke vraag of de rechtbank onderkent dat het concept en de toetsing van de "primaire bewijslast" voor de verzoeker een uiterst belangrijke zaak is. In paragraaf 3.3.4.4.4 is uiteengezet waarom toetsing van de deugdelijkheid van het standpunt van de overheid inzake verzoekers Nederlanderschap (naar mijn mening in het bijzonder bij een beroep op behoud van de nationaliteit) zo van belang is. Het is daarbij mijns inziens onverschillig of aan het vereiste van de "primaire bewijslast" wordt voldaan door de als belanghebbende opgeroepen Staat dan wel in ruime zin door de overheid, waaronder ook een lagere overheid of zelfs het openbaar ministerie bij de (niet-lijdelijke) rechtbank kan worden gevat. In geval van een verliesgrond voor het Nederlanderschap hangt met de kwestie van de "primaire bewijslast" de vraag samen of de rechtbank voldoende oog heeft voor de werking van de continueringspresumtie.

Aanleiding om aan te nemen dat de rechtbank te 's-Gravenhage wel oog heeft voor de (op de overheid rustende) "primaire bewijslast" inzake het verlies van de Nederlandse nationaliteit geven (slechts) twee uitspraken.954 Evenwel kan ook worden gewezen op twee uitspraken waarin de rechtbank het idee van "primaire toetsing" van het standpunt van de overheid wellicht over het hoofd ziet en het

${ }^{62} \mathrm{Vgl}$. HR 23.03.1984, NJ 1984, nr. 650 (par. 3.3.3.2.3) en HR 08.12.1989, MR 1990, p. 40 (par. 3.3.3.2.5).

313 Rb. 's-Gravenhage 11.10.1989, rkstnr. 89.5224 (= HR 28.09.1990, NJ 1991, nr. 293 (par. 3.3.4.2.1).

${ }^{834} \mathrm{Rb}$. 's-Gravenhage 29.01.1992, rkstnr. 87.5178 (par. 3.3.4.3.1: bewijs (van niet-verwerving) van een vreemde nationaliteit ligt niet bij verzoeker) en $\mathrm{Rb}$. 's-Gravenhage 15.07.1987, rkstnr. 86.2117 (par. 3.3.4.4.1). 
standpunt te onderbouwen met bewijs.961 In het geval dat het een beroep op behoud van het Nederlanderschap betreft, krijgt de verzoeker (bij een bewijsopdracht) in feite de opdracht te bewijzen dat hij zijn nationaliteit niet heeft verloren. Uit het voorgaande is evenwel gebleken dat de bewijslast voor het verlies van het Nederlanderschap bij de Nederlandse overheid ligt. Hieruit volgt dat het door de verzoeker niet voldoen aan de hierboven geformuleerde bewijsopdracht derhalve niet als gevolg dient te hebben dat het verzoek om vaststelling wordt afgewezen omdat de verzoeker niet aan de bewijsopdracht voldoet. Dit is alleen anders indien aan de "primaire bewijslast" is voldaan en het tegenbewijs van de verzoeker niet voldoende is.

In alle besproken beschikkingen waarin het een beroep op behoud van het Nederlanderschap betreft, blijkt het tevens te gaan om de verwerving van een vreemde nationaliteit (de Indonesische of de Surinaamse). Zoals hierboven is uiteengezet, rust de bewijslast voor een verliesbepaling voor het Nederlanderschap op de Nederlandse overheid. Hangt die verliesgrond samen met de verwerving van een vreemde nationaliteit, dan blijkt de bewijslast voor het hebben verworven van de vreemde nationaliteit (derhalve logischerwijze) ook bij de Nederlandse overheid te berusten. Uit de rechtspraak blijkt dat, ook na de invoering van de "zelfstandige vaststellingsprocedure", het niet aan de betrokkene is om te bewijzen dat hij niet de vreemde nationaliteit heeft verworven, als gevolg waarvan hij zijn Nederlanderschap heeft behouden. ${ }^{962}$ De bewijslast voor het hebben verworven van een vreemde nationaliteit, indien dit een verliesgrond voor het Nederlanderschap is, ligt derhalve niet bij de betrokkene. Nogmaals ${ }^{963}$ wordt hier de conclusie getrokken dat het bewijs van de verwerving van een vreemde nationaliteit, indien dit tevens $^{964}$ een verliesgrond voor het Nederlanderschap is, door de Nederlandse autoriteiten dient te worden geleverd.

Ook is wederom de vraag aan de orde gekomen in welke mate het verwerven van een vreemde nationaliteit zeker dient te zijn in het geval dat een zodanige verwerving leidt tot verlies van het Nederlanderschap. ${ }^{965}$ In het kader daarvan formuleert de Hoge Raad de regel dat indien twijfel bestaat over het verwerven van

961 In categorie A: HR 28.09.1990, NJ 1991, nr. 293 (getuigenverhoor). In categorie B: Rb. "sGravenhage 29.01.1992, rkstnr. 87.5178 (par. 3.3.4.3.1); Rb. 's-Gravenhage 15.07.1987, rkstnr. 86.2117 (par. 3.3.4.4.1); Rb. 's-Gravenhage 27.04.1988, rkstnr. 87.5416 (par. 3.3.4.4.3); Rb. 'sGravenhage 09.11.1988, rkstnr. 88.5098 (par. 3.3.4.4.5).

962 Rb. 's-Gravenhage 29.01.1992, rkstnr. 87.5178 (par. 3.3.4.3.1).

903 Zie ook par. 3.3.3.5.

964 Bijvoorbeeld het van rechtswege verwerven van een vreemde nationaliteit is geen naturalisatie in een ander land; er volgt derhalve geen verlies van het Nederlanderschap op grond van art. 7 sub 1 Wet Ned. 1892: HR 05.06.1987, NJ 1988, nr. 134, m.nt. GRdG.

gos HR 07.04.1989, NJ 1990, nr. 791 (par. 3.3.4.4.6); HR 14.02.1992, NJ 1993, nr. 262 (par. $3.3 .4 .4 .8)$. 
de vreemde nationaliteit een nader onderzoek (door de rechter) naar de verwerving dient plaats te vinden en mocht daarbij geen bevestiging worden gekregen van de daadwerkelijke verwerving van de vreemde nationaliteit er van de voortduring van het Nederlanderschap dient te worden uitgegaan. ${ }^{966}$ Het feit dat door de verzoeker nimmer van de vreemde autoriteiten een bevestiging is ontvangen dat hij de vreemde nationaliteit heeft verworven, is niet voldoende aanleiding tot twijfel. ${ }^{967}$ Uit deze uitspraken blijkt wederom ${ }^{968}$ dat bezit van een vreemde nationaliteit ter autonome beoordeling staat van de Nederlandse rechter.

In een geval waarin geen sprake is van eén van de Toescheidingsovereenkomsten geschiedt het vaststellen van het bezit van een vreemde nationaliteit aan de hand van de wettelijke bepalingen van het vreemde recht alsmede aan de hand van het bewijsrecht van de vreemde staat. ${ }^{969}$

De vraag kan worden gesteld of naar aanleiding van de onderzochte beschikkingen iets kan worden gezegd over de bewijssterkte die de rechtbank hanteert.

Hierboven is reeds geconstateerd dat de bewijslast inzake een verwervingsgrond door de rechtbank bij de verzoeker wordt geplaatst, ongeacht of door de overheid is voldaan aan de "primaire bewijslast". In de drie opgenomen uitspraken waarin de verzoeker een beroep doet op verwerving van het Nederlanderschap hanteert de rechtbank als bewijssterkte is gebleken. ${ }^{970}$

Gaat het om beroepen op behoud van het Nederlanderschap dan hanteert de rechtbank ter zake van het vaststellen van de verliesgrond in twee gevallen de maatstaf is gebleken. ${ }^{971}$ In de meerderheid van de gevallen wordt bij de beoordeling van het tegenbewijs van de verzoeker (dus na impliciete aanname van de realisering van de verliesgrond) de maatstaf aannemelijk gehanteerd. ${ }^{972}$ In twee gevallen is echter sprake bij de beoordeling van verzoekers tegenbewijs van blijken. ${ }^{973}$ Opvallend genoeg zijn deze beide laatste uitspraken gecasseerd, en wel

\footnotetext{
${ }^{906}$ HR 07.04.1989, NJ 1990, nr. 791 (par. 3.3.4.4.6).

${ }^{967}$ HR 14.02.1992, NJ 1993, nr. 262 (par. 3.3.4.4.8).

${ }^{968}$ Zie tevens par. 3.3 .2 .3 en 3.3.3.5.

Cf. Kollewijn, p. 22; Lemaire, p. 310. Zie ook par. 3.3.3.2.2, 3.3.3.3.2 en 3.3.4.3.1.

${ }^{900}$ HR 28.09.1990, NJ 1991, nr. 293 (par. 3.3.4.2.1: onvoldoende is gebleken); HR 31.01.1992, NJ 1993, nr. 261 (par. 3.3.4.2.2: kan blijken); Rb. 's-Gravenhage 04.11.1992, rkstnr. 92.5105 (par. 3.3.4.2.3: niet is komen vast te staan).

${ }^{\text {nI }} \mathrm{Rb}$. 's-Gravenhage 15.07.1987, rkstnr. 86.2117 (par. 3.3.4.4.1: twee verliesgronden: énmaal niet is gebleken; énmaal niet is komen vast te staan); Rb. 's-Gravenhage 29.01.1992, rkstnr. 87.5178 (par. 3.3.4.3.1: niet voldoende vast komen te staan).

${ }^{m / 2}$ Rb. 's-Gravenhage 27.04.1988, rkstnr. 87.5416 (par. 3.3.4.4.3: tot op zekere hoogte aannemelijk gemaakt); Rb. 's-Gravenhage 29.06.1988, rkstnr. 87.6118 (par. 3.3.4.4.4: heeft voldoende aannemelijk gemaakt); Rb. 's-Gravenhage 09.11.1988, rkstnr. 88.5098 (par. 3.3.4.4.5: niet aannemelijk kunnen maken); HR 04.12.1992 (rkstnr. 8058, niet gepubliceerd; par. 3.3.4.4.8: niet aannemelijk).

${ }^{973}$ HR 28.10.1994, RvdW 1994, nr. 216 (par. 3.3.4.3.2: blijkt op geen enkele manier); HR 07.04.1989, NJ 1990, nr. 791 (par. 3.3.4.4.6: heeft niet aangetoond).
} 
in dier voege dat in beide zaken is terugverwezen naar de rechtbank met de opdracht te onderzoeker of aan de verliesgrond is voldaan (dus: eerst nog "primaire toetsing" verrichten en derhalve minder nadruk leggen op het bewijsmateriaal dat de verzoeksters hebben overgelegd).

Tevens resteren vier uitspraken waaruit met betrekking tot verzoekers tegenbewijs niet kan worden opgemaakt welke maatstaf daarvoor is genomen. ${ }^{974}$

Zoals dat ook het geval is geweest in de artikel 43 (oud) Vreemdelingenwetprocedure hangt de verzoeker tijdens de "zelfstandige vaststellingsprocedure" boven het hoofd dat de rechtbank, in het kader van het ambtshalve aanvullen van de rechtsgronden (art. $48 \mathrm{Rv}$ ), ambtshalve overgaat tot het toetsen van meer dan één verwervingsof verliesgrond. De aanleiding daarvoor kan gelegen zijn in het door het openbaar ministerie gepleegd feitenonderzoek. ${ }^{975}$

Blijkens de onderzochte beschikkingen is het niet ongewoon dat de rechtbank zich baseert op gegevens die zijn ontvangen ná de (laatste) zittingsdag. ${ }^{976}$ Ten aanzien daarvan dient te worden bedacht dat niet alle informatie die na de mondelinge behandeling ter kennis komt van de rechtbank zonder meer als grondslag kan worden genomen voor de beslissing. Is de informatie namelijk ten gevolge van gegevensvergaring door het openbaar ministerie verkregen dan dient, alvorens een beslissing valt, eerst de verzoeker in de gelegenheid te worden gesteld om een reactie te geven.

In de literatuur is wel opgemerkt dat in "impliciete vaststellingsprocedures", wegens het feit dat in zodanige procedures het bezit van het Nederlanderschap niet zozeer uitdrukkelijk moest worden vastgesteld maar slechts als voorvraag werd beantwoord, de bewijsvoering van de voorvraag niet al te strikt behoefde te worden gevoerd, daar de (wel of niet) vaststelling buiten het geding zelf toch geen verdere consequenties met zich zou brengen. Ook ten aanzien van de nationaliteitsactie op grond van artikel 43 (oud) Vreemdelingenwet is een zodanige stelling verwoord. Van den Blink maakt een vergelijking tussen de vervallen artikel 43 Vreemdelingenwetprocedure en de huidige vaststellingsprocedure uit artikel 17 RWN en verbindt aan beide procedures kennelijk een verschil ten aanzien van de mate van zekerheid dat inzake het Nederlanderschap dient te bestaan. $\mathrm{Zij}$ stelt dienaangaan-

"nd Rb. 's-Gravenhage 10.02.1988, rkstnr. 87.5387 (par. 3.3.4.4.2); Rb. 's-Gravenhage 27.03.1991. RV 1991, nr. 45 (par. 3.3.4.4.7: in redelijkheid niet kan worden getwijfeld); Rb. 's-Gravenhage 09.11.1988, rkstnr. 88.5295 (par. 3.3.4.4.8); HR 14.02.1992, NJ 1993, nr. 262 (par. 3.3.4.4.8).

"7s Rb. 's-Gravenhage 15.07.1987, rkstnr. 86.2117 (par. 3.3.4.4.1).

996 Vgl. HR 28.09.1990, NJ 1991, nr. 293 (par. 3.3.4.2.1); Rb. 's-Gravenhage 10.02.1988, rkstnr. 87.5387 (par. 3.3.4.4.2); Rb. 's-Gravenhage 27.04.1988, rkstnr. 87.5416 (par. 3.3.4.4.3). De rechtbank houdt ook rekening met latere informatie betreffende de ontvankelijkheid van de verzoeker die verband houdt met de exclusieve werking van een procedure op grond van art. 20 RWN: HR 07.04.1989, NJ 1989, nr. 531 (zie par. 2.2.2.1). 
de: "In art. 43 Vreemdelingemwetzaken heeft de Hoge Raad een aantal malen het beklag gegrond verklaard op grond van de overweging, dat voor een bevestigende beantwoording van de vraag of klager bij de toepassing van de Vreemdelingenwet als vreemdeling mag worden behandeld onvoldoende is gebleken dat klager -kort gezegd- zijn oorspronkelijke Nederlandse nationaliteit heeft verloren. Dat kon, omdat de toepassing van de Vreemdelingenwet op de verzoeker de enige inzet van die procedure was. De vaststelling van het Nederlanderschap door de burgerlijke rechter heeft een ruimere strekking en laat op het eerste gezicht een uitspraak die is gemotiveerd als hiervoor weergegeven niet toe. $\mathrm{nm}$

Uit hetgeen ik hiervoor heb betoogd, is, naar ik hoop, duidelijk dat ik Van den Blink in haar conclusie ten aanzien van de huidige vaststellingsprocedure niet kan volgen. ${ }^{978}$

\subsubsection{Bewijsmiddelen}

\subsubsection{Algemene beschouwingen}

Bewijsmiddelen hebben in de woorden van Mulder betrekking op "de vraag hoe iets bewezen moet worden. "979 Ten Berge/Tak omschrijven "bewijsmiddelen" als "de juridisch toegelaten middelen, waarmee niet-vaststaande feiten kunnen worden bewezen. ${ }^{m 980}$

Het ontbreken van bewijsrechtelijke bepalingen in de Rijkswet op het Nederlanderschap ${ }^{981}$ gecombineerd met het gegeven dat in civiele verzoekschriftprocedures bewijs kan worden geleverd door alle middelen ${ }^{982}$ leidt tot de gevolgtrekking dat naar huidig recht in de "zelfstandige vaststellingsprocedure" het aannemelijk maken van het bezit van de Nederlandse nationaliteit niet is gebonden aan een bepaald bewijsmiddel.

Een in het verleden uitgezette lijn wordt hiermee voortgezet. Met betrekking tot dit verleden kan in de eerste plaats worden gewezen op het feit dat in de Wet op het Nederlanderschap en ingezetenschap uit 1892 de vraag hoe iemand dient te bewijzen dat hij het Nederlanderschap bezit eveneens geen regeling heeft gevonden. ${ }^{983}$ In de tweede plaats kan erop worden gewezen dat ook in de in het voorgaande van dit hoofdstuk besproken jurisprudentie niet is gebleken van beperkingen

\footnotetext{
97 Van den Blink, p. 22. Zij verwijst hierbij naar HR 27.11.1979, NJ 1980, nr. 381 (deze uitspraak is later nogmaals gepubliceerd als NJ 1980, nr. 550, m.nt. MS onder NJ 1980, nr. 551).

${ }^{97}$ Zie ook Rb. 's-Gravenhage 29.01.1992, rkstnr. 87.5178 (par. 3.3.4.3.1).

979 Mulder, p. 227.

900 Ten Berge/Tak, p. 143.

9. Vl. De Groot, losbl. uitgave Personen- en Familierecht, art. 17 RWN, aant. 2a.

\$2 Dit hoewel art. $179 \mathrm{Rv}$ niet direct van toepassing is op verzoekschriftprocedures. Zie par. 3.2.2.

${ }^{90} \mathrm{Vgl}$. Van Sasse van Ysselt, HPS 1953, p. 56; Septer/Schouten, p. XX.
} 
ten aanzien van de bewijsmiddelen. Tevens kan worden gewezen op de op dit punt constante literatuur waarbinnen door de auteurs unaniem wordt gesteld dat bewijs van het bezit van het Nederlanderschap met alle middelen kan worden geleverd. Al aan het begin van deze eeuw oordeelt Kramers dienaangaande: "(........), dat de inschrijving in de consulaire registers en de daarop steunende certificaten van nationaliteit nooit een voldoende bewijs op zichzelf zijn, maar dat de rechter zich door alle middelen van iemands onderdaanschap mag overtuigen. ${ }^{\text {n984 }}$ Vele jaren later zal een anoniem gebleven schrijver zijn artikel in het Personeel Statuut openen met de zin: "Het bewijs van het Nederlanderschap is niet aan een bepaald middel gebonden." De schrijver komt tot de conclusie dat het bezit van de Nederlandse nationaliteit derhalve tevens door de rechter kan worden afgeleid uit "omstandigheden op grond waarvan redelijkerwijze tot het Nederlanderschap kan worden besloten. ${ }^{, 9855}$

Klaarblijkelijk zijn onder zodanige omstandigheden in de literatuur allerlei aanwijzingen gevat. Septer/Schouten hebben het volgende aangenomen: "Heeft iemand een openbare betrekking waargenomen, waarvoor het Nederlanderschap vereist was, dan kan hij met behulp van de akte van aanstelling, als andere stukken ontbreken, het bezit van de staat van Nederlander bewijzen. ${ }^{9886}$ Het bekleden van een openbare functie als een bewijs voor het bezit van het Nederlanderschap is in een artikel in de Gemeentestem al eerder genoemd. De (onbekende) auteur noemt in het desbetreffende artikel verder onder meer: uittreksels uit kerkelijke registers, een certificaat van inschrijving in de registers van een Nederlands consulaat en bewijs van voldoening aan de dienstplicht. ${ }^{987}$ Het blijkt dat van oudsher alle bewijsmiddelen, en daaronder rangschikt de oudere literatuur mede algemene bekendheid ${ }^{988}$ en vermoedens, ${ }^{989}$ kunnen worden benut om de rechter ervan te

\footnotetext{
${ }^{984}$ Kramers, p. 64. Idem Joekes, p. 21.
}

9ss Anoniem (III), HPS 1950, p. 31 en 32.

${ }^{966}$ Septer/Schouten, p. XX. Niet duidelijk is of de schrijvers zich baseren op Nederlandse rechtspraak. Een identieke motivering ten bewijze van een bepaalde nationaliteit is vermeld bij Verzijl, p. 97. Daarbij gaat het om een uitspraak van 10,10.1928 van het "General Claims Commission United StatesMexico".

987 Anoniem (V), Gemeentestem 1950, nr. 5087, p. 160. Vgl. echter Cleintuar, p. 30-33.

$98 s$ Anoniem (VI), Gemeentestem 1950, nr. 5090, p. 174, alwaar een ministeriēle circulaire ter zake wordt aangehaald; Van Sasse van Ysselt, HPS 1953, p. 56; Septer/Schouten, p. XX.

959 Zie Anoniem (I), HPS 1952, p. 134: "Dit arrest bevestigt, dat het bewijs van het Nederlanderschap niet aan een bepaald bewijsmiddel is gebonden en dat veel is overgelaten aan de vrije appreciatie van de rechter. Alle bewijsmiddelen komen in aanmerking, waaronder ook vermoedens, te ontlenen aan het bezit van de staat van Nederlander. "Idem Prins (I), HPS 1962, p. 44; Septer/Schouten, p. XX. Van Sasse van Ysselt schrijft in HPS 1953, p. 56: Zonder gebruik te maken van vermoedens kan het Nederlanderschap van Indische Nederlanders die hun papieren verloren hebben, welhaast niet worden gereconstrueerd." Zie tevens Heijs, p. 65.

Met de inwerkingtreding van het nieuwe bewijsrecht in 1988 zijn de vermoedens (artt. 1903; 1952 e.v. BW oud) als bewijsmiddel komen te vervallen. Als zelfstandig bewijsmiddel was het overbodig 
overtuigen dat iemand de Nederlandse nationaliteit bezit. Hierbij kan nog worden opgemerkt dat in de onderzochte jurisprudentie is gebleken dat het op middellijke wijze aantonen van het Nederlanderschap (de bestaansfeiten bewijzen is voldoende) inderdaad acceptabel is geoordeeld.

De (weinige) opmerkingen die in de oudere literatuur zijn gewijd aan de vraag welke bewijsmiddelen geëigend zijn ten bewijze van de staat van Nederlander dienen, als gevolg van het feit dat vóór de inwerkingtreding van hoofdstuk 6 RWN van een "zelfstandige vaststellingsprocedure" geen sprake is geweest, vanzelfsprekend alle te worden geplaatst in de context van een nationaliteitsvaststelling als voorvraag in een "impliciete vaststellingsprocedure".

Maar ook tijdens de voorbereidingen om te komen tot een "zelfstandige vaststellingsprocedure" is de wetgever nimmer voornemens geweest beperkingen te stellen ten aanzien van de bewijsmiddelen. De Commissie Nationaliteitsprocedure heeft in het door haar in 1956 gepresenteerde wetsontwerp ${ }^{990}$ wel een bepaling met betrekking tot de bewijsmiddelen opgenomen. Geheel in overeenstemming met het hierboven vermelde luidt artikel 8 sub 3 van het ontwerp: "De bewijslevering is aan geen bepaalde bewijsmiddelen gebonden.

Hieraan moet evenwel een opmerking worden toegevoegd. Indien op het te bewijzen rechtsfeit vreemd recht van toepassing is, kan dit recht eventueel een beperking inhouden ten aanzien van de middelen waarmee tegenbewijs kan worden geleverd. Zoals in paragraaf 3.3.4.2.2 is vermeld aan de hand van de opvatting van Offerhaus, is in het geval van toepasselijkheid van vreemd bewijsrecht de toelaatbaarheid van de middelen waarmee tegenbewijs kan worden geleverd onderhevig aan de regels van het vreemde bewijsrecht. Het vreemde bewijsrecht kan inzake het leveren van tegenbewijs een beperking in de bewijsmiddelen bevatten.

\subsubsection{Voorkomende bewijsmiddelen in de vaststellingsbeschikkingen}

Zoals op grond van het voorafgaande is te verwachten, zijn in de beschikkingen die de rechtbank te Den Haag in het kader van artikel 17 RWN heeft gegeven uiteenlopende bewijsmiddelen gehanteerd. Het gaat in de meerderheid van de gevallen

\footnotetext{
$989 \rightarrow$
}

geworden aangezien de rechter onder het nieuwe bewijsrecht in overwegende mate vrij is in zijn waardering van de bewijskracht van de in het geding gebrachte feitelijk gegevens. Zie Rutgers/Flach/Boon, p. 14. Asser (II), p. 27, merkt op dat "reeds lang het inzicht (bestond) dat het vermoeden geen bewijsmiddel is. Het is een manier van redeneren (........). "Vgl. Mulder, p. 235; Pitlo/Hidma \& Rutgers, p. 30 e.v.; Schoordijk, WPNR 1989, nr. 5937, p. 689, omschrijft "vermoedens" als "de overtuiging van een rechter".

${ }^{n}$ Zie par. 1.2.2.

${ }^{m} \mathrm{Vgl}$. Van den Blink, p. 7. 
evenwel om schriftelijk bewijs. Voorts komen getuigenverklaringen ${ }^{92}$ voor en (na de inwerkingtreding van het nieuwe bewijsrecht) partij-getuigeverklaringen ${ }^{993}$. Indien de verzoeker in Nederland verblijft, krijgt hij van de rechtbank altijd de gelegenheid om tijdens de mondelinge behandeling, veelal naar aanleiding van een vraag door de rechtbank, het woord te voeren.

Ten einde een indruk te geven van de diversiteit van de gebruikte bewijsstukken in artikel 17 RWN-procedures, volgt daarvan hieronder een gecomprimeerd overzicht. Als bewijsstukken zijn tijdens de procedures overgelegd: een verklaring van Nederlanderschap afgegeven door een (Nederlandse) gemeente, ${ }^{994}$ copieën van optieverklaringen voor de Surinaamse nationaliteit, ${ }^{995}$ verklaringen inzake de opname in het bevolkingsregister van een (Nederlandse) gemeente, ${ }^{996}$ medische verklaringen, ${ }^{997}$ uittreksels uit buitenlandse geboortenregisters, ${ }^{998}$ en verklaringen van Indonesische autoriteiten ${ }^{99}$. Ook is een aanbetalingskwitantie voor een vliegtuigticket naar Amsterdam overgelegd als bewijsstuk. ${ }^{1000}$ Vanzelfsprekend kan het bewijs ook worden geleverd door meer bewijsstukken. Dit is het geval geweest in de zaak van een verzoeker die (het behoud van) zijn Nederlanderschap heeft kunnen bewijzen door middel van overlegging van een paspoort waarin douanestempels de data van in- en uitreis uit Suriname weergaven, waarbij hij tevens schriftelijke stukken heeft kunnen overleggen waaruit zowel de datum van zijn huwelijk in Frans Guyana alsmede de datum van het ondergaan van een medische test in Frans Guyana bleken. ${ }^{1001}$

\subsubsection{Waardering van het bewijs}

Als gezegd, alle middelen kunnen worden aangewend om de rechter te overtuigen van het bezit van het Nederlanderschap. Daarnaast geldt als uitgangspunt dat de

\footnotetext{
${ }^{992}$ Rb. 's-Gravenhage 15.07.1987, rkstnr, 86.2217; Rb. 's-Gravenhage 11.10.1989, rkstnr. 89.5224 (= HR 28.09.1990, NJ 1991, nr. 293, m.nt. GRdG).

903 Rb. 's-Gravenhage 11.10.1989, rkstnr. 89.5224 (= HR 28.09.1990, NJ 1991, nr. 293, m.nt. GRdG); Rb. 's-Gravenhage 29.01.1992, rkstnr. 87.5178. Vgl. Zilverentant, B\&R 1994, p. 115.

${ }^{944} \mathrm{Rb}$. 's-Gravenhage 27.04.1988, rkstnr. 87.5964. De rechtbank oordeelt dat de verklaring onjuist is.

920 Rb. 's-Gravenhage 09.11.1988, rkstnr. 88.5295; Rb. 's-Gravenhage 04.09.1991, rkstnr. 91.5072 (=HR 04.12.1992, rkstnr. 8058, niet gepubliceerd).

${ }_{96}$ Rb. 's-Gravenhage 29.06.1988, rkstnr. 87.5994; Rb. 's-Gravenhage 27.03.1991, rkstnr. 90.5297.

en Rb. 's-Gravenhage 29.06. 1988, rkstnr. 87.6119; Rb. 's-Gravenhage 25.11.1987, rkstnr. 87.5536.

ws Rb. 's-Gravenhage (= HR 31.01.1992, NJ 1993, nr. 261, m.nt. GRdG); Rb. 's-Gravenhage 04.11.1992, rkstnr. 92.5105

${ }^{900}$ Rb. 's-Gravenhage 29.01.1992, rkstnr. 87.5178; HR 28.10.1994, RvdW 1994, nr. 216.

${ }^{1000} \mathrm{Rb}$. 's-Gravenhage 27.04.1988, rkstnr. 87.5416.

1001 Rb. 's-Gravenhage 29.06.1988, rkstnr. 87.6118 (par. 3.3.4.4.4.4).
} 
rechter vrij is in de waardering van het aldus aangeleverde bewijsmateriaal, tenzij de wet ter zake anders voorschrijft. ${ }^{1002}$

In het Nederlandse nationaliteitsrecht is, mijns inziens op één uitzondering na, geen sprake van bewijsmiddelen met dwingende bewijskracht. De ene uitzondering is naar mijn mening een wet tot naturalisatie, een vorm van naturalisatie die onder de Wet op het Nederlanderschap en ingezetenschap mogelijk is geweest. ${ }^{1003}$ Over deze bij formele wet plaatsvindende naturalisatie schrijft Prins dat deze "met een voor ieder bindende kracht uitmaakt dat de genaturaliseerde met ingang van haar inwerkingtreding Nederlander zal zijn, (.........). ${ }^{n 004}$ Wegens de aard van de formele wet is ook de rechter aan de desbetreffende (naturalisatie)wet gebonden, ${ }^{1005}$ die daarmee inherent een dwingende bewijskracht aangaande het Nederlanderschap van de betrokkene(n) heeft. ${ }^{1006}$

Paspoorten en verklaringen inzake de nationaliteit die steunen op uittreksels van het bevolkingsregister hebben daarentegen slechts vrije bewijskracht. Een Nederlands paspoort is vanouds niet aangemerkt als een dwingend bewijs voor het bezit van het Nederlanderschap, het paspoort vormt een aanwijzing daartoe en niet meer dan dat. ${ }^{1007}$

In de vorige eeuw is zelfs bewust ervan afgezien om in het bevolkingsregister de nationaliteit te vermelden. Schreuder maakt melding van een ten tijde van de beraadslagingen over de Wet op het Nederlanderschap en ingezetenschap in de Tweede Kamer geopperd denkbeeld om inderdaad de nationaliteit aan te tekenen in het bevolkingsregister. Dat voorstel heeft toentertijd geen bijval gevonden. Onder andere de overweging: "Bewijs zou eene bloote vermelding der nationaliteit in de

\footnotetext{
${ }^{1002}$ Zie par. 3.2.1.

${ }^{1000}$ Ingevolge art. 7 Grondwet 1848 vonden ook onder vigeur van de tot 01.07 .1893 geldende wetgeving uit 1850 naturalisaties plaats door middel van een wet. Bij de Grondwet uit 1848 is voor de eerste maal vastgelegd dat naturalisatie bij wet moest geschieden. Vgl. Raedt van Oldenbarnevelt, p. 46.

${ }^{1004}$ Prins (I), HPS 1962, p. 47. Zie tevens voetnoot 171

${ }^{1005} \mathrm{Cf}$. Jessurun d'Oliveira, AA 1986, p. 227; Ook al zou achteraf blijken dat de genaturaliseerde niet aan de vereisten voor naturalisatie voldeed, Simons, HPS 1950, p. 30 en 31 . Alleen door middel van een nieuwe wet kan een zodanige naturalisatie ongedaan worden gemaakt.

${ }^{1006}$ Vanzelfsprekend blijft de dwingende bewijskracht van de naturalisatiewet beperkt tot het bewijs van de verwerving van het Nederlanderschap. Dat de bij wet genaturaliseerde nadien het Nederlanderschap heeft verloren, kan alsnog "vrij" worden bewezen.

1007 Zie Anoniem (II), HPS 1951, p. 6; Haarmans, p. 80; HR 15.07.1985, NJ 1985, nr. 854; HR 29.09.1989, NJ 1989, nr. 877; Rb. 's-Gravenhage 07.02.1990, rkstnr. 89.5732. HR 16.09.1994, NJ 1995, nr. 563, m.nt. GRdG, waarin de betrokkene reeds vijf jaar een Nederlands paspoort bezit. Wel mag ervan worden uitgegaan dat bij de uitreiking van een Nederlands nationaal paspoort het bezit van de Nederlandse nationaliteit in beginsel niet betwist is: ARRS 08.06.1979, RV 1979, nr. 47. En met betrekking tot een verklaring van Nederlanderschap afgegeven door een (Ned.) gemeente: Rb. 'sGravenhage 27.04.1988, rkstnr. 87.5964.
} 
bevolkingsregisters nooit kunnen opleveren (.........)." is daarbij grond voor afwijzing geweest. ${ }^{1008}$

Niettegenstaande deze eerdere visie, wordt evenwel sinds 1920 in het bevolkingsregister wel aantekening van het Nederlanderschap gemaakt. ${ }^{1009}$ Van verschillende kanten is in het verleden opgemerkt dat de betrouwbaarheid van deze vermelding zeker niet moet worden overschat. ${ }^{1010}$ Uit een recent onderzoek blijkt dat deze uitspraken nog immer gelden. In een vanwege het ministerie van Justitie gehouden onderzoek naar de motieven bij grote groepen geïmmigreerden om wel of niet te kiezen voor naturalisatie blijkt dat in sommige gevallen respondenten de bij het bevolkingsregister bestaande registratie van het Nederlanderschap ontkennen dan wel deze registratie in hun antwoord onvermeld laten. ${ }^{1011}$ Ook blijken er respondenten te zijn die te kennen geven over de Nederlandse nationaliteit beschikken, maar die niet als zodanig blijken te zijn geregistreerd in het bevolkingsregister. ${ }^{1012} \mathrm{De}$ in de vorige eeuw gedane uitspraak aangaande het bewijs van nationaliteitsvermelding in het bevolkingsregister geldt derhalve heden ten dage nog: de bewijskracht van hetgeen in het register staat vermeld, is vrij ter beoordeling van de rechter.

In wezen is in het bovenstaande het beginsel dat de vermelding van de nationaliteit op enig document geen constitutieve werking kent aan de orde. Dit beginsel wordt algemeen in nationale en internationale regelgeving gehuldigd. ${ }^{1013}$ In de internationale regelgeving is het beginsel op staatlozen van toepassing op grond van het Verdrag betreffende de status van staatlozen. ${ }^{1014}$ Aan rechtmatig op zijn grondgebied gevestigde staatlozen verstrekt een staat ingevolge het Verdrag op verzoek reisdocumenten, met daarin de staatloosheid van de paspoorthouder vermeld. Met het oog op zodanige paspoorten kent het Verdrag een Bijlage met daarin een regeling inzake het reisdocument bedoeld in artikel 28 van het Verdrag. In deze

1008 Schreuder, p. 109. Met de afwijzing is de regering het van harte eens. In de memorie van Antwoord stelt zij dienaangaande: "Juist zij, te wier aanzien de nationaliteit in den regel het meest twijfelachtig is, de zwervelingen en de buitenslands vertoevenden, komen op de bevolkingsregisters niet voor. " Bijl. II 1891-1892, 130, nr. 5, p. 20.

${ }^{1009}$ Mannoury, p. 166. Vgl. Plasschaert e.a., p. 43 en 44, voor de huidige situatie.

1010 Zie bijv, Anoniem (IV), Gemeentestem 1948, nr. 4969, p. 135; Mannoury, p. 166.

1011 Van den Bedem, p. 3, 61 en 62.

1012 Van den Bedem, p. 62. In de uitspraak van de Nationale Ombudsman van 15.06.1993, AB 1993. nr. 430, m.nt. PJS, wordt uit naam van de staatssecretaris van Justitic vermeld: "dat de kennisgeving van naturalisatiebesluiten als volgt plaatsvindt: eenmaal per twee weken wordt aan gemeenten een periodiek overzicht met namen van genaturaliseende inwoners toegezonden. "

$1013 \mathrm{Vgl}$. par. 6.3.1 voor het Duitse recht. Niet alleen het bezit van een eigen nationaal paspoort moet een rechter waarderen. In voorkomende gevallen oordeelt de rechter over de bewijswaarde van bet in het bezit zijn van een vreemd paspoort: HR 13.04.1948, NJ 1948, nr. 647, m.nt. D.J.V. (par. 3.3.2.2.1); Rb. 's-Gravenhage 29.01.1992, rkstnr. 87.5178 (par. 3.3.4.3.1).

1014 Zie voor de Engelse en Franse tekst van het verdrag: Trb. 1955, nr. 42, en voor de Nederlandse vertaling: Trb. 1957, nr. 22. Vgl. Ktg. 's-Gravenhage 05.05.1956, NJ 1958, nr. 23. 
nadere regeling bepaalt Paragraaf 15 uitdrukkelijk: "Noch de afgifte van het document, noch de daarop gestelde aantekeningen bepalen of beïnvloeden de status van de houder, in het bijzonder wat zijn nationaliteit betreft. "

1015 Door te spreken van beïnvloeding van de nationaliteit van de houder van het document wekt deze bepaling wel enige bevreemding. Het betreft immers het op grond van het Verdrag betreffende de status van staatlozen afgeven van reisdocumenten waarin vermeld is dat de betrokkene staatloos is. Desalniettemin wil de bepaling duidelijk stellen dat een, ondanks vermeende staatloosheid, eventueel toch bezitten van een nationaliteit geen wijziging ondergaat als gevolg van afgifte van het bewuste reisdocument. 



\section{Inleidende opmerkingen betreffende het Duitse nationaliteitsrecht}

\subsection{Inleiding}

In dit en in de navolgende twee hoofdstukken komt de vraag aan de orde welke regeling de nationaliteitsvaststelling in de Bondsrepubliek Duitsland kent. Onderzocht wordt of in het Duitse recht "impliciete vaststellingsprocedures" en een "zelfstandige vaststellingsprocedure" kunnen worden onderscheiden. ${ }^{1016}$ Daartoe $\mathrm{zal}$ in hoofdstuk 5 de procesrechtelijke regelgeving die van toepassing is op de vaststelling van de Duitse nationaliteit worden bekeken. Vervolgens wordt in hoofdstuk 6 , naast het administratiefrechtelijke bewijsrecht, de bewijsrechtelijk relevante jurisprudentie besproken.

Zoals uit het bovenstaande blijkt, ligt de aandacht in de hoofdstukken 5 en 6 derhalve sterk op het formele nationaliteitsrecht. Aan het materiële nationaliteitsrecht zal, net als dat gebeurt met betrekking tot het Nederlandse recht, slechts aandacht worden geschonken in verband met de duidelijkheid van het betoog ter zake van het formele nationaliteitsrecht.

Hoofdstuk 4 beoogt een meer algemeen en inleidend hoofdstuk te zijn. Hieronder volgt eerst ter inleiding een schets van de positie die het nationaliteitsrecht binnen de bondsstatelijke structuur van het Duitse recht inneemt. Aan de hand van een aantal (historische) begrippen uit het Duitse nationaliteitsrecht, zoals "Reichsangehörigkeit", "Staatsangehörigkeit", "Bundesstaatsangehörigkeit", "Landesangehörigkeit" en "Landesstaatsangehörigkeit", wordt in de paragrafen 4.1.1, 4.1.2 en 4.1.3 daarbij mede een kort historisch overzicht van de ontwikkeling van het Duitse nationaliteitsrecht gegeven. In paragraaf 4.1.4 wordt vervolgens aangegeven onder welke beperkingen het onderzoek naar de vaststelling in rechte van de Duitse nationaliteit is uitgevoerd. De volgende paragraaf, paragraaf 4.2 , bevat een korte introductie van de opbouw van de rechterlijke macht in Duitsland. Hoofdstuk 4 sluit af met paragraaf 4.3 dat beoogt enig inzicht te verschaffen in de wijze waarop in een statenbond als bijvoorbeeld Duitsland de uitvoering van centrale wetgeving, in dit geval het Reichs- und Staatsangehörigkeitsgesetz, plaatsvindt.

Zie voor de begrippen "impliciete vaststellingsprocedure" en "zelfstandige vaststellingsprocedure" par. 2.1. 


\subsubsection{Artikel 73 Grundgesetz en de nationaliteit op federaal niveau}

De Duitse grondwet ${ }^{1017}$ bepaalt in Artikel 73 GG dat het materiële nationaliteitsrecht van de Bondsrepubliek een zaak is van federale regelgeving. ${ }^{1018}$ Hieraan is in eerste instantie voldaan door middel van de wet die de Duitse nationaliteit sinds 1914 tot onderwerp heeft, het Reichs- und Staatsangehörigkeitsgesetz (RuStAG). ${ }^{1019}$

Daarnaast zijn voor het materiële nationaliteitsrecht van groot belang een tweetal wetten uit de jaren vijftig: te weten de beide Gesetze zur Regelung von Fragen der Staatsangehörigkeit. ${ }^{1020}$ Deze twee wetten gelden voor personen die niet op grond van het RuStAG, maar ten gevolge van collectieve naturalisatie tijdens de tweede wereldoorlog de Duitse nationaliteit hadden verkregen en deze nationaliteit in beginsel, indien zij dit wensten, nadien konden behouden. Zodoende bepalen de Gesetze zur Regelung von Fragen der Staatsangehörigkeit, naast het RuStAG, mede het materiële nationaliteitsrecht in Duitsland. ${ }^{1021}$

De bovenvermelde regelgeving beperkt zich tot de (materieelrechtelijke) verwervings- en verliesgronden voor de Duitse nationaliteit. Het formele recht voor het in individuele gevallen door een onafhankelijke rechterlijke instantie vaststellen van het bezit van die nationaliteit, het proces- en bewijsrecht inzake het nationaliteitsrecht derhalve, blijkt geen regeling te vinden in de bovenstaand vermelde wetgeving.

\subsubsection{Artikel 74 Grundgesetz en de nationaliteit op deelstatelijk niveau}

Betreft Artikel 73 Grundgesetz de uitsluitende competentie van de federale wetgever ter zake van regelgeving voor de gehele Bondrepubliek betreffende de nationaliteit, het daarop volgende Artikel 74 GG snijdt met betrekking tot de nationaliteit een geheel andere materie aan. Het betreffende artikel spreekt over de gezamenlijke

${ }^{1017}$ Grundgesetz für die Bundesrepublik Deutschland van 23.05.1949 (BGB1. I p. 1).

${ }_{1015} \mathrm{Het}$ artikel vermeldt onder meer: "Der Bund hat die ausschließliche Gesetzgebung über: 2. die Staatsangehörigkeit im Bunde; ". Zie ook Makarov/v. Mangoldt, Deel I, nr. 2, onder Art. 73/74 GG, Rdnr. 6.

${ }^{1019}$ Wet van 22.07.1913, (RGBl. 1913 p. 583). Deze wet trad op 01.01 .1914 in werking. Als gevolg van hetgeen is gesteld in de Artikelen 123 en 124 Grundgesetz is het RuStAG in de Bondsrepubliek Duitsland geldend recht. Zie Makarov/v. Mangoldt, Deel I, nr. 2, onder Art. 73/74 GG, Rdnr. 12.

${ }^{1020}$ De eerste wet dateert van 22.02.1955 (BGBl. I p. 65) en de tweede van 17.05.1956 (BGBl. I p. 431).

1021 Zie voor nationaliteitsrechtelijke overzichten van de periode 1871-1989 De Groot, p. 54-60 en Tratnik, p. 143-145. Volledigheidshalve noem ik hier de totstandkoming van het Dritte Gesetz zur Regelung von Fragen der Staatsangehörigkeit van 19.08.1957 (BGBI. I p. 1251) dat een regeling trof ten behoeve van buitenlandse vrouwen die een Duitser huwden en voor Duitse vrouwen die een man van niet-Duitse nationaliteit huwden. Uitgebreider over deze derde nationaliteitswet: De Groot, p. 58. 
competentie van de Bond én de deelstaten om regelgeving uit te vaardigen met betrekking tot wat kan worden omschreven als de "nationaliteit van de deelstaten $^{*}$. $^{102}$

In Duitsland is van oudsher sprake geweest van onderscheidenlijke nationaliteiten, die hun grondslag vonden in de onderscheidenlijke eertijds onafhankelijke deelstaten. In de, uit 1913 stammende, benaming van het Reichs- und Staatsangehörigkeitsgesetz verwijst het laatste gedeelte van de titel ("Staatsangehörigkeit") naar de deelstaat-nationaliteit. In het RuStAG wordt namelijk gesproken over "Staatsangehörigkeit in einem Bundesstaat", waarbij ten tijde van het opstellen van de wet met "Bundesstaaten" is gedoeld op de bestuurlijke entiteiten die deel uitmaakten van het Duitse Keizerrijk. ${ }^{1023}$ In die tijd kende iedere "Bundesstaat" nog een eigen nationaliteit. ${ }^{1024}$

In de opzet van het RuStAG ligt, voor wat betreft de verhouding tussen de "Reichsangehörigkeit" en de "Bundesstaatsangehörigkeit", het primaat bij de laatste nationaliteit. Van de deelstaat-nationaliteit is de "Reichsangehörigkeit" aan te merken als een (automatisch toegekend) surplus. ${ }^{1025} \mathrm{De}$ aldus in de opzet van het RuStAG aanwezige gelede structuur waardoor de wet vanaf haar totstandkoming wordt gekenmerkt, noemt Thedieck de "Zweistufigkeit des deutschen Staatsangehörigkeitsrechts". ${ }^{1026}$

Het begrip "Bundesstaat" is gelijktijdig met het Duitse Keizerrijk ten ondergegaan en gedurende de daaropvolgende staatsrechtelijke periode, die wordt omschreven als die van de Republiek van Weimar, worden de deelgebieden "Länder" genoemd. ${ }^{1027}$ Alhoewel in de tekst van het Reichs- und Staatsangehörigkeitsgesetz in dit opzicht geen tekstuele veranderingen worden doorgevoerd, wordt in navolging van Artikel 110 Verfassung $1919^{1028}$ in juridische geschriften vanaf die tijd met betrekking tot de deelstaat-nationaliteit gesproken over zowel "Landesangehörigkeit ${ }^{\prime 1029}$ als "Landesstaatsangehörigkeit" ${ }^{1030}$ Deze twee termen wor-

\footnotetext{
1002 Art. 74 GG luidt o.m.: "Die konkurrierende Gesetzgebung erstreckt sich auf folgende Gebiete: 8. die Staatsangehörigkeit in den Ländern;" Met konkurrierend (het begrip wordt nader omschreven in Art. 72 GG) wordt aangeduid dat zowel de federatie als de deelstaten competent zijn. Daarbij geldt de regel dat de deelstaten op een bepaald gebied bevoegd zijn tot regelgeving zolang de federatie ten aanzien van dat onderwerp geen wetgeving heeft uitgevaardigd.

${ }^{102}$ Hailbronner/Renner, p. 122 en 123 ; Kimminich, p. 727.

${ }^{l e s s}$ Kimminich, p. 727.

${ }^{102 s}$ Kimminich, p. 727. De Groot/Tratnik, p. 20, kunnen zich een gelijke constructie indenken voor de verwerving van een eventueel binnen de landen van de Europese Unie te ontwikkelen Europese nationaliteit.

loes Thedieck, p. 44.

1027 v. Morr, p. 17 en 18.

103 Verfassung des Deutschen Reiches van 11.08.1919 (RGB1. 1919 p. 1383). Dit is de zgn. Weimarer Verfassung; vgl. Lichter, p. 15.

1009 Makarov/v. Mangoldt, 2, Art. 73/74 GG, Rdnr. 2; v. Morr, p. 18; Thedieck, p. 44 en 45.

${ }^{1030} \mathrm{Vgl}$. Bergmann/Korth, p. 29; Hailbronner/Renner, p. 125; Weidelener/Hemberger, p. 5.
} 
den met betrekking tot dit onderwerp ook nog heden ten dage in de literatuur gebruikt.

Aan de bovenvermelde "Zweistufigkeit des deutschen Staatsangehörigkeitsrecht" komt de facto een eind in het jaar 1934 en sindsdien is het begrip "Landesangehörigkeit" (deelstaat-nationaliteit) ook juridisch inhoudsloos en obsoleet gebleven. De staatsrechtelijke structuur van Duitsland wordt in dat jaar gewijzigd ${ }^{1031}$ van een federatief verband in een centraal-geleide eenheidsstaat, hetgeen zijn weerslag heeft op het nationaliteitsrecht. Als gevolg van de teloorgang van de soevereiniteit van de afzonderlijke deelstaten worden de nationaliteiten van deze gebieden vervallen verklaard ${ }^{1032}$ en wordt de "Reichsangehörigkeit" uit het RuStAG zodoende de belangrijkste nationaliteit. Thedieck verwoordt deze wijziging in rangorde treffend met de volgende opmerking: "Die Landesangehörigkeit bestimmte bis zu ihrer Abschaffung im Jahre 1934 in formaler Hinsicht das Deutsche Staatsangehörigkeitsrecht. "1033

Hoewel ook in 1934 de tekst van het Reichs- und Staatsangehörigkeitsgesetz wederom niet wordt aangepast aan de nieuwe staatsrechtelijke verhouding, spreekt men niet langer over de "Reichsangehörigkeit", maar daarentegen over de "deutsche Staatsangehörigkeit" ". ${ }^{1034}$

Gedurende de overgangsperiode van 1945 tot de oprichting van de Bondsrepubliek in 1949 hebben enkele Länder in hun grondwetten ${ }^{1035}$ de mogelijkheid een deelstaat-nationaliteit in te voeren weer geïntroduceerd. ${ }^{1036}$ Daarna heeft, zoals bij de aanvang van deze paragraaf reeds naar voren is gekomen, de deelstaatnationaliteit als begrip vermelding gevonden in de grondwet voor de Bondsrepubliek uit $1949 .{ }^{1037}$ Daarbij is nieuw dat de regelgevende competentie mede bij de deelstaten wordt gelegd. Zowel tijdens het Keizerrijk als gedurende de Republiek

${ }^{1031}$ Door het Gesetz über den Neuaufbau des Reiches van 30.01.1934 (RGB1. I p. 75).

1012 De vervallenverklaring gebeurde in de Verordnung über die deutsche Staatsangehörigkeit van 05.02.1934 (RGBI. I p. 85). Zie De Groot, p. 56; Weidelener/Hemberger, p. 5.

1033 Thedieck, p. 135.

${ }^{1034}$ Kimminich, p. 727. Vgl. Hecker, StAZ 1995, p. 36.

1039 Zie bijv. art. 6 Bayerische Verfassung van 1946; Art. 75 Rheinland-Pfalzische Verfassung van 1947; Art. 53 Grondwet van het Land Baden uit 1947; Art. 6 Grondwet van het Land WürttembergHohenzollern uit 1947; zo ook de grondwetten van Bremen uit 1948 en Hessen uit 1948. Heden ten dage kennen alleen de grondwetten van de Länder Beieren en Rheinland-Pfalz nog verwijzingen naar een eventuele deelstaat-nationaliteit. In de vijf Länder die deel hebben uitgemaakt van de DDR zijn recent ook Verfassungen opgesteld. In geen van deze Verfassungen is een verwijzing naar cen mogelijke deelstaat-nationaliteit opgenomen.

$1036 \mathrm{Vgl}$. Bergmann/Korth, p. 29; Hailbronner/Renner, p. 17 en 18; Jarass/Pieroth. Art. 74 GG, Rdnr. 19; Maunz/Dürig, Art. 74 GG, V, Nr. 12; Thedieck, p. 48 e.v.; Weidelener/Hemberger, p. 5. ${ }^{1097}$ Zie hierover Thedieck, p. 136. 
van Weimar lag de wetgevende competentie inzake de deelstaat-nationaliteit uitsluitend bij het federatieve verband. ${ }^{1038}$

Er wordt evenwel noch tijdens de overgangsperiode 1945-1949, noch na de stichting van de Bondsrepubliek door de (desbetreffende) wetgever(s) enige poging gedaan om tot daadwerkelijke verwezenlijking van de "Landesangehörigkeit" te komen. ${ }^{1039} \mathrm{De}$ bovengeschetste ontwikkelingen hebben erin geresulteerd dat het RuStAG dienaangaande nog steeds, maar al geruime tijd zonder enige betekenis, over "Staatsangehörigkeit in einem Bundesstaat" spreekt. ${ }^{1040}$

In de literatuur vormt het een strijdpunt of tijdens de overgangsperiode tot de oprichting van de BRD de afzonderlijke deelstaten wel bevoegd zouden zijn geweest tot de her-introductie van een eigen nationaliteit. Dit is afhankelijk van de visie die men heeft op het juridisch voortduren van de hierboven genoemde maatregel uit 1934. Dit betreffend zijn drie verschillende opvattingen te noemen. De ene visie luidt dat deze maatregel zijn werking verloor op het moment dat de deelstaten hun soevereiniteit herkregen $(1945)^{1041}$; de andere visie neemt aan dat de bewuste maatregel pas zijn werking verloor bij de inwerkingtreding van Artikel 74 sub 8 van de grondwet voor de Bondsrepubliek (1949). ${ }^{1042}$ Een derde mening hierover wordt verkondigd door Hailbronner/Renner die van oordeel zijn dat de bewuste maatregel nog steeds van kracht is. ${ }^{1043}$ Dientengevolge wordt door Makarov/v. Mangoldt in hun losbladige uitgave over het Duitse nationaliteitsrecht opgemerkt: "Ob es angesichts dieser Lage gegenwärtig in den Bundesländern eine StAng gibt und ob diese durch Landesgesetz geregelt werden könnte, ist in der Literatur zweifelhaft geblieben. "1044

Dat deze strijd evenwel geheel een academische is, zal vanwege het, hierboven reeds opgemerkte, gebrek aan enige daadwerkelijke uitvoering van de "Landesangehörigkeit", duidelijk zijn. Hoe men de historische ontwikkeling met betrekking tot de Verordnung über die deutsche Staatsangehörigkeit van 05.02.1934 ook mag interpreteren, buiten twijfel staat in de literatuur in ieder geval, dat deze niet heeft

\footnotetext{
${ }^{1038}$ Maunz/Dürig, Art. 74 GG, V, Nr. 12; Schätzel, p. 89.

1099 Hailbronner/Renner, p. 124; Weidelener/Hemberger, p. 5; vgl. BayVerfGH, Entsch. v. 12.03.1986, NJW 1986, p. 2820.

${ }^{1040} \mathrm{Vgl}$. Stein, p. 340: "Das deutsche Reichs- und Staatsangehörigkeitsgesetz ist seit seinem Erlaß im Jahr 1913 vielfach inhaltich (durch Erlaß abweichender Vorschriften), aber selten in seinem Wortlaut geändert worden. "

${ }^{1041} \mathrm{Vgl}$. v. Morr, p. 21; Weidelener/Hemberger, p. 5.

${ }^{102}$ Thedieck, p. 50, 51 en 52, waarbij hij verklaart de eerste visie te delen. Hij noemt Makarov en Schätzel als aanhangers van de tweede opvatting.

${ }^{1003}$ Hailbronner/Renner, p. 11 en 202 . De in deze maatregel opgenomen noodzakelijke toestemming voor iedere naturalisatie van de (federale) minister van Binnenlandse Zaken wordt in ieder geval nog steeds toegespast, en door het Bundesverwaltungsgericht ook noodzakelijk geacht voor een rechtsgeldige naturalisatie. Zie par. 4.3.2.

${ }^{104}$ Makarov/v. Mangoldt, Art. 73/74 GG, Rdnr. 20.
} 
betekend dat de oorspronkelijke regelgeving van voor die datum heeft kunnen herleven. ${ }^{1045}$ Ook al zou dit in juridische zin wel mogelijk zijn geweest, dan nog zou men zijn gestuit op de praktische beperking dat op het West-Duits grondgebied van de oude Länder er slechts twee (Hamburg en Beieren) binnen de oude grenzen bleven voortbestaan. ${ }^{1046}$

\subsubsection{De federale nationaliteit}

Tegenover het zonder betekenis geraakte concept van de nationaliteit op deelstatelijk niveau moet de federale nationaliteit worden geplaatst: de feitelijk als enige van de twee nationaliteiten reëel gebleven nationaliteit. Deze in oorsprong als overkoepelend bedoelde nationaliteit werd van $1871^{1047}$ tot 1945 omschreven als "Reichsangehörigkeit". In het Grundgesetz uit 1949 wordt dienaangaande de omschrijving "Staatsangehörigkeit im Bunde" opgenomen. ${ }^{1048}$ Ook in 1949 wordt afgezien van een tekstuele aanpassing van het RuStAG.

Ter omschrijving van de federale nationaliteit raken in de jaren na 1949 in de (westelijke) literatuur over het algemeen de termen "deutsche Staatsangehörigkeit $^{\text {"1049 }}$ of "gesamtdeutsche Staatsangehörigkeit" in zwang. Deze laatste term is inmiddels, na de hereniging van Oost-Duitsland met de Bondsrepubliek, verouderd. Vóór de hereniging werd aan de twee bovenvermelde termen de voorkeur gegeven boven een term als "Bundesangehörigkeit"1050 aangezien deze laatste term beperkt kon worden opgevat als slechts betrekking hebbend op de nationaliteit van de Duitse Bondsrepubliek en daardoor niet tot uitdrukking zou brengen, dat volgens de toen heersende leer, ${ }^{1051}$ ook de burgers van de DDR in het bezit van de Duitse nationaliteit moesten worden geacht. ${ }^{1052}$ Het eventueel scheppen van een dergelijke suggestie zou niet in overeenstemming zijn geweest met het streven door de Bondsrepubliek naar de hereniging van de beide Duitse staten. ${ }^{1053}$

\footnotetext{
104 Thedieck, p. 139 en 140.

1046 Lichter, p. 20; Schătzel, p. 92. Voor opmerkingen betreffende de Landesangehörigkeit in de voormalige DDR, zie Thieme, DÖV 1990, p. 403.

${ }^{1047}$ D.w.z. sinds de inwerkingtreding van de voorganger van het RuStAG. Zie De Groot, p. 54.

1048 Artikel 73 Nr, 2 GG.

$1099 \mathrm{Vgl}$. ook Art. 16 en Art. 116 GG. Zie voor de Oost-Duitse literatuur: Tratnik, p. 155.

$1050 \mathrm{Er}$ is zelfs opzettelijk van afgezien deze term op te nemen in de grondwet. Vgl. Makarov/v. Mangoldt, 2. Art. 73/74 GG, Rdnr 6; v. Morr, p. 22.

1051 Zie hierover De Groot, p. 60.

1082 Het ging hierbij om "das Gebot der Wahrung der Einheit der deutschen Staatsangehörigkeit", zoals dat is verwoord in Art. 116 Abs. 1 GG en 16 Abs. 1 GG. Zie BVerfG, B. v. 21.10.1987, BVerfGE 77, 137 [149].
}

${ }^{1053}$ Zie Badura, p. 594; Tratnik, p. 156. 
Dit onderdeel afsluitend kan nog worden opgemerkt dat, gezien het bepaalde in de Artikelen 73 en 74 Grundgesetz, in theorie het herleven van "Zweistufigkeit" in het Duitse nationaliteitsrecht niet onmogelijk is op grond van de bestaande wetgeving. De realiteit is echter anders dan deze theoretische uitgangspunten bij een eerste, oppervlakkige, beschouwing zouden doen veronderstellen. Het is een opmerkelijk feit te noemen, dat in de ruim $\mathbf{4 5}$ jaar dat het Grundgesetz inmiddels van kracht is geen uitwerking is gegeven aan dit beginsel en dat slechts de overkoepelende nationaliteit van belang is gebleven. Een situatie die Von Morr samenvattend omschrijft met de uitspraak: "Die Einstufigkeit existiert de facto in der Bundesrepublik zur Zeit. "1054

\subsubsection{Beperkingen in het onderzoek}

In het navolgende van dit hoofdstuk en in de hoofdstukken 5 en 6 zal niet verder worden ingegaan op het onderwerp inzake de "Landesstaatsangehörigkeit" en komt uitsluitend de nationaliteit in de zin van "Staatsangehörigkeit im Bunde" (Art. 73 Nr. 2 GG) ter sprake.

Een ander onderwerp waaraan in dit onderzoek voorbij moet worden gegaan, is de vaststelling van de status die ertoe leidt dat men gelijkberechtigd ${ }^{1055}$ is an iemand die de Duitse nationaliteit bezit. Het gaat hier om de staat van "Flüchtling $^{1056}$ oder Vertriebener deutscher Volkszugehörigkeit". Een status waarop een beroep kan worden gedaan door personen afkomstig uit (eertijds) in oostelijk Europa levende Duitse minderheden. Het beroep op deze status kan worden gedaan door zowel de direct betrokkene als diens huwelijkspartner en nageslacht. Deze groep van personen wordt door Artikel 116 Abs. 1 GG tot "Deutscher im Sinne dieses Grundsgesetzes" verklaard. ${ }^{1057}$ Dit is een status die zij delen met de personen die de Duitse nationaliteit bezitten. Deze status maakt hun juridische positie wezenlijk anders dan de positie van personen die, net als zij, de Duitse nationaliteit niet bezitten. ${ }^{1058}$ De desbetreffende personen, ook wel kortweg omschreven als

\footnotetext{
${ }^{1054}$ v. Morr, p. 51. Vgl. ook Badura, p. 597.

${ }^{1005} \mathrm{Vgl}$. Badura, p. 596; Hailbronner/Renner, p. 171; Kanein, p. 69.

${ }_{1056}$ Hieronder worden niet begrepen de vluchtelingen die op grond van het bepaalde in Art. 16 Grundgesetz een beroep doen op het verdrag van de Verenigde Naties betreffende de status van vluchtelingen (Genève, 1951) en het bijbehorend Protocol van New York uit 1967. Dezen worden aangeduid met de term "Asylanten" of "Asylberechtigte".

1057 Art. 116 Abs. 1 GG: "Deutscher im Sinne dieses Grundgesetzes ist vorbehaltlich anderweitiger gesetzlicher Regelung, wer die deutsche Staatsangehörigkeit besitzt oder als Flüchtling oder Vertriebener deutsche Volkszugehörigkeit oder als dessen Ehegatte oder Abkömmling in dem Gebiete des Deutschen Reiches nach dem Stande vom 31. Dezember 1937 Aufnahme gefunden hat."

${ }^{1065} \mathrm{Zo}$ genieten zij de zgn. "Deutschen-Grundrechte" uit Art. 8, 9, 11 en 12 GG. Naast de rechten uit de Grondwet hebben zij stemrecht ingevolge $\$ 12$ Bundeswahlgesetz, verkiesbaar zijn zij echter niet allen, zie $\S 15$ Bundeswahlgesetz.
} 
"Statusdeutschen", ${ }^{1059}$ bezitten dus niet de Duitse nationaliteit, ${ }^{1060}$ maar hebben recht op behandeling als Duitser. Deze op Artikel 116 lid 1 GG gebaseerde rechtspositie, die wordt omschreven als "Rechtsstellung des Deutschen ohne deutsche Staatsangehörigkeit", ${ }^{1061}$ is toegankelijk voor personen die voldoen aan het "Bundesvertriebenengesetz", ${ }^{1062}$ waarin de begrippen "Vertriebene ${ }^{n 1063}$ en "deutsche Volkszugehörigkeit" worden gedefinieerd.

De reden waarom aan de vaststelling van deze status voorbij moet worden gegaan, is dat bij deze regelgeving niet de nationaliteitswetgeving als zodanig is betrokken en het derhalve niet handelt om het in rechte vaststellen van het bezit van de Duitse nationaliteit. ${ }^{1064}$ Evenwel neemt het bovenstaande niet weg dat het in het navolgende, en in het bijzonder in hoofdstuk 6, wel wordt ingegaan op het begrip "deutsche Volkszugehörigkeit". Dit is noodzakelijk wegens de verbinding die in bepaalde gevallen bestaat tussen het door iemand zijn van "deutscher Volkszugehöriger" en bepaalde nationaliteitsrechtelijke regelingen. ${ }^{1065}$ In de hier bedoel-

${ }^{1059}$ Schătzel gebruikt de term "Nurdeutschen", p. 78.

${ }^{1000}$ Het éen sluit het ander juist uit, men kan niet "Statusdeutscher" zijn en tegelijkertijd de Duitse nationaliteit bezitten, vgl. Makarov/v. Mangoldt, \& 39 RuStAG, Rdnr. 12. Een "Statusdeutscher" heeft evenwel op grond van \$ 6 Gesetz zur Regelung von Fragen der Staatsangehörigkeit uit 1955 (zie par. 4.1.1) recht op naturalisatie zonder bijkomende vereisten; door het Bundesverwaltungsgericht omschreven als "Rechtsanspruch auf Einbürgerung" (U. v. 24.06.1971, BVerwGE 38, 224 [226], zie tevens Hailbronner/Renner, p. 405).

$1061 \mathrm{Vgl}$. Dreher/Tröndle, p. 38.

1002 Gesetz aber die Angelegenheiten der Vertriebenen und Flüchtlinge van 19.05.1953 (BGBI. I p. 201). ${ }^{1063}$ In plaats van "Vertriebene" wordt vooral de laatste jaren ook het begrip "Aussiedler" gebruikt; Nierhaus, p. 84 (i.h.b. voetnoot 309). De wet stelt duidelijk dat "Vertriebene" niet per definitie cen vreemde nationaliteit hebben of staatloos zijn. Er zijn "Vertriebene" met de Duitse nationaliteit (\$1 Abs. 1 en 2 BVFG); Vgl. BVerwG, U. v. 16.03.1977, BVerwGE 52, 167; BVerwG, U. v. 03.11.1992, DÖV 1993, p. 305. Het betreft dan personen die al de Duitse nationaliteit bezaten voordat zij naar de Bondsrepubliek uitweken dan wel personen met een vreemde of geen nationaliteit, die eenmaal erkend als "Vertriebene" door middel van de in voetnoot 1060 vermelde "Rechtsanspruch auf Einbürgerung " hebben gekozen voor naturalisatic. Een "Vertriebene" die de Duitse nationaliteit heeft, is vanzelfsprekend geen "Statusdeutscher".

In de rechtspraak is uitgemaakt dat een "Vertriebene" niet terzelfdertijd een beroep kan doen op het Vluchtelingenverdrag van Genève; vgl. Häußer, DÖV 1990, p. 919; HessVGH, B. v. 22.10.1988. DöV 1989, p. 867: "Eine Anerkennung als Asylberechtigter und die Anerkennung als Heimatvertriebe ner schließen sich regelmäßig aus. "

${ }_{1064}$ Meer informatic over deze status biedt "Die Statusfeststellung nach dem Bundesvertriebenengesetz" van Hảußer, Kapinos en Christ. Zie voorts Alexy, NJW 1989, p. 2854-2858; Häußer, DÖV 1990, p. 921, merkt onder verwijzing naar een uitspraak van het Bundesverwaltungsgericht (BVerwG, B. v. 24.03.1987, Buchholz 412.3 § 1 BVFG Nr. 35) het volgende op: "Wer deutscher Staatsangehöriger ist, richtet sich allein nach dem Staatsangehörigkeitsrecht. Das BVFG enthält keine gesetzliche Regelung. nach der bei Vorliegen bestimmter Indizien der Erwerb der deutschen Staatsangehörigkeit widerlegbar vermutet wird oder bestimmten Umständen eine Indizwirkung im Hinblick auf die deutsche Staatsangehörigkeit zukommt. " In gelijke zin BVerwG, U. v. 22.08.1979, BVerwGE 58, 259 [262].

ios Vgl. Alexy, NJW 1989, p. 2857: "Unter Umständen kann das Merkmal der deutschen Vollšt" gehörigkeit aber auch selbst staatsangehörigkeitsrechtlich von Bedeutung sein." 
de gevallen kan het voorkomen dat sprake is van het bezit van de Duitse nationaliteit (alsmede van de rechterlijke vaststelling daarvan).

In dit onderzoek zal tevens geen aandacht worden geschonken aan de voormalige nationaliteitswetgeving van de DDR, noch aan de mogelijke jurisprudentie inzake rechterlijke vaststelling van de Duitse nationaliteit in die staat. Volledigheidshalve wordt hier slechts beknopt opgemerkt dat op het grondgebied van de DDR het Reichs- und Staatsangehörigkeitsgesetz is blijven gelden tot 1967, het jaar waarin daar het Gesetz über die Staatsbürgerschaft der Deutschen Demokratischen Republik is ingevoerd. ${ }^{1066}$ Met de toetreding van de DDR tot de BRD verloor de nationaliteitswetgeving van de DDR haar betekenis. ${ }^{1067}$

\subsection{Introductie in het rechterlijk systeem van de Bondsrepubliek}

\subsubsection{Algemene beschouwingen}

Voordat nader zal worden ingegaan op de gerechtelijke procedures die mogelijk zijn ter fine van rechterlijke vaststelling van het bezit van de Duitse nationaliteit, volgt hieronder een kort overzicht van de opbouw van de rechterlijke macht in de Bondsrepubliek. De reden tot het opnemen van onderstaand overzicht is dat door een zodanig overzicht de lezer de procedures die aan de orde zullen komen beter binnen het juridische kader kan plaatsen.

De rechterlijke macht wordt onderverdeeld naar gelang de onderscheidenlijke rechtsgebieden. Er wordt onderscheid gemaakt tussen administratieve rechtspraak, strafen privaatrechtelijke rechtspraak, belasting-, arbeidsrechtelijke en sociale rechtspraak. ${ }^{1068}$ Daarnaast is in het rechtsstelsel voorzien in een aparte rechter met betrekking tot de handhaving van door het Grundgesetz gewaarborgde grondrechten.

In dit onderzoek blijft de vaststelling van de nationaliteit binnen de belasting-, de arbeidsrechtelijke en de sociale rechtspraak, zo dergelijke vaststellingen ${ }^{1069}$ daarbinnen al plaatsvinden, buiten beschouwing. De reden hiertoe is, dat deze vaststellingen net als de vaststellingen die binnen de straf- en privaatrechtelijke rechtspraak plaatsvinden zonder meer zijn te beschouwen als "impliciete vaststellingsprocedures".

\footnotetext{
${ }^{1056}$ De Groot, p. 54; Tratnik, p. 161.

${ }^{106}$ Zie Hecker, ArchVR 1991, p. 27 en 38. Het Herenigingsverdrag bevat geen bepaling inzake de samenvloeiing van de beide Duitse nationaliteiten. Hecker is van mening dat het beter zou zijn geweest indien in het verdrag wel een zodanige bepaling zou kennen. Zie tevens: De Groot, MR 1991, p. 156 en 157.

1064 Schlaich, p. 4

$1069 \mathrm{Vgl}$. voetnoot 1100
} 
In het navolgende bespreek ik eerst kort de administratiefrechtelijke gerechten, daarna de voor civielrechtelijke geschillen en de in het strafrecht competente instanties en als laatste stel ik de instantie aan de orde die waakt tegen schending van de grondwet.

\subsubsection{Administratief recht}

Veel nationaliteitsrechtelijke kwesties komen op binnen een administratieve context. De competentieregeling met betrekking tot de administratieve rechtspraak (die Verwaltungsgerichtsbarkeit) is geregeld in de Verwaltungsgerichtsordnung (VwGO). ${ }^{1070}$ De aanleg in eerste feitelijke instantie vindt plaats bij het Verwaltungsgericht, de tweede instantie is bij het Oberverwaltungsgericht ${ }^{1071}$ ( $\$ 2$ VwGO en $\$ 124$ VwGO). ${ }^{1072}$

Op Bondsniveau is de hoogste administratieve rechter het Bundesverwaltungsgericht (BVerwG). Het Bundesverwaltungsgericht oefent binnen de administratiefrechtelijke rechtsorde in het bijzonder de taak van cassatierechter (Revision) uit ( $\$ \S 49$, 50 en $(32$ VwGO).

\subsubsection{Privaatrecht en strafrecht}

Daar nationaliteitsrechtelijke kwesties vanzelfsprekend ook kunnen voorkomen in civielrechtelijke en strafrechtelijke context, wordt hieronder tevens een korte schets gegeven welke instanties in dergelijke zaken bevoegd zijn. De civiele- en strafzaken worden in Duitsland onder de noemer "ordentliche Gerichtsbarkeit" gebracht ( $\$ 13$ Gerichtsverfassungsgesetz). ${ }^{1074}$ Binnen de "ordentliche Gerichtsbarkeit" zijn ingevolge $\S 12$ Gerichtsverfassungsgesetz respectievelijk competent: het Amtsgericht, het Landgericht, het Oberlandesgericht en als hoogste instantie vervult het Bundesgerichtshof (BGH) de rol van cassatierechter.

In civiele zaken bestaat de mogelijkheid dat de rechter op grond van $\S 148$ Zivilprozeßordnung (ZPO) het geding aanhoudt indien voor de beslissing van de rechtsstrijd een oordeel noodzakelijk is over een rechtsverhouding, die op dat moment tevens aan de orde is in een andere gerechtelijke procedure. Eveneens maakt \& 148 ZPO het mogelijk dat de civiele rechter aangaande een bepaalde rechtsverhouding niet zelf beslist, maar om een vaststelling van de rechtsverhou-

\footnotetext{
${ }^{1070}$ Wet van 21.01.1960 (BGBl. I p. 17).

1071 In sommige deelstaten wordt de oude aanduiding Verwaltungsgerichtshof nog gehanteerd, vgl. \$184 VwGO. Zie ook Wolf, p. 101.

${ }^{1072} \mathrm{Vgl}$. Bok, p. 95-98 en 101-102.

1073 Zie Bok, p. 118; Eyermann/Fröhler, p. 71.

${ }^{1074}$ Wet van 27.01 .1877 (RGBI. 1877 p. 41).
} 
ding verzoekt bij een daartoe competent orgaan. ${ }^{1075}$ Het gaat hier om een bevoegdheid van de burgerlijke rechter en zeker niet om een verplichting. Toepassing van $\$ 148 \mathrm{ZPO}$ is derhalve denkbaar als gedurende een civielrechtelijke procedure twijfel rijst betreffende het bezit van de Duitse nationaliteit door een bij de procedure betrokken persoon rijzen. Tschira/Schmitt Glaeser vermelden dat civiele instanties dikwijls de bepaling van $\S 148$ ZPO toepassen om uitspraken over administratiefrechtelijke kwesties van de administratieve rechter te verkrijgen. ${ }^{1076}$

Ook andere rechters die te maken krijgen met de nationaliteit als voorvraag kennen geen verplichting tot verwijzing dienaangaande; zij beoordelen de voorvraag in beginsel zelf. ${ }^{1077}$

\subsubsection{Aparte bescherming tegen schending van grondrechten (constitutionele toetsing)}

Naast de administratieve rechterlijke instanties, de gewone rechterlijke instanties en de in paragraaf 4.2.1 medegenoemde instanties op de diverse specifieke rechtsgebieden, bestaat op federaal niveau het Bundesverfassungsgericht (BVerfG). Het BVerfG heeft o.m. tot taak te waken tegen schending van enkele, met name genoemde, grondrechten uit de grondwet van de Bondsrepubliek. Deze vorm van rechtspraak vat men onder de term Verfassungsgerichtsbarkeit. Een ieder die meent in zijn grondrechten te zijn geschonden door een besluit ${ }^{1078}$ van de overheid kan door middel van een Verfassungsbeschwerde een beroep doen op het Bundesverfassungsgericht ( $\$ 90$ BverfGG $^{1079}$ ). Op deze wijze omvat de bescherming die het Bundesverfassungsgericht de burger biedt alle besluiten van de drie machten binnen de staat waarover de uitoefening van het staatsgezag is verdeeld. ${ }^{1080}$

Tegen een rechterlijke uitspraak is het instellen van een Verfassungsbeschwerde bij het Bundesverfassungsgericht in beginsel slechts mogelijk ná het volgen van eventuele andere rechtswegen ( $§ 90$ lid 2 BVerfGG). ${ }^{1081}$ Dit leidt er derhalve toe dat een Verfassungsbeschwerde slechts tot de mogelijkheid behoort indien reeds in

\footnotetext{
${ }^{1003}$ Hierbij kan het gaan om zowel een administratief orgaan als een rechterlijke instantie; Rosenberg/Schwab, p. 71. Vgl. tevens Redeker/v. Oertzen, p. 225.

${ }^{1076}$ Tschira/Schmitt Glaeser, p. 195. De auteurs werken hun opmerking niet uit, zodat niets kan worden gezegd over de vraag of de civiele rechter ook nationaliteitsvragen vaak doorsluist.

iom Sturm, p. 25; Ule, p. 213 en 320. Vgl. evenwel par. 5.3.2.1 voor het feit dat in een strafrechtelijke procedure de rechter is gebonden aan een naturalisatie, ondanks eventuele gebreken die aan de naturalisatie zouden kleven.

${ }^{i m n}$ Dat besluit kan zijn: een wet of andersoortige regelgeving of een beslissing van de uitvoerende of rechterlijke macht. Badura, p. 478.

Gesetz über das Bundesverfassungsgericht van 12.03.1951 (BGBI. I p. 243).

${ }^{1000}$ Schlaich, p. 4 en 120.

Badura, p. 479; Schramm/Schmidt-Troje, p. 341-346. Zie tevens BVerfG, B. v. 15.04.1980 BVerfGE 54, 53, [65].
} 
hoogste instantie (bijvoorbeeld het BVerwG of het BGH) over het geschil is geoordeeld.

Op het niveau van de deelstaten (echter niet in alle Länder) ${ }^{1082}$ bestaat een Verfassungsgerichtshof (soms Staatsgerichtshof geheten), dat bepaalde, in diverse wetten genoemde, staatsorganen de mogelijkheid biedt actie te ondernemen tegen inbreuken op de grondwet van de desbetreffende deelstaat. In een aantal Länder ${ }^{1083}$ bestaat tevens de mogelijkheid voor een individuele burger bij deze instanties een Verfassungsbeschwerde aanhangig te maken bij vermeende inbreuk op grondrechten. ${ }^{1084}$

\subsection{Administratieve uitvoering van het Reichs- und Staatsangehörigkeitsgesetz geen federale taak}

\subsubsection{Algemene Beschouwingen}

In deze paragraaf wordt een beeld geschetst van de wijze hoe de uitvoering van de federale wetgeving op het gebied van de Duitse nationaliteit geschiedt. De administratieve uitvoering van het Reichs- und Staatsangehörigkeitsgesetz wordt, hoewel de nationaliteitswet daarover zelf niets bepaalt, overgelaten aan de deelstaten. ${ }^{1085}$ Dit is een inherent gevolg van de federale opbouw die de Bondsrepubliek Duitsland kent. Een wettelijke basis vindt deze staatsrechtelijke constellatie in de bepaling van Artikel 83 Grundgesetz, dat de deelstaten voorschrijft federale wetten uit te voeren als ware het eigen regelgeving. ${ }^{1086} \mathrm{Om}$ een globale indruk te geven van de praktische betekenis die de federale staatsstructur van Duitsland heeft op de administratieve uitvoering van de nationaliteitsrechtelijke wetgeving, volgt hieronder een korte beschrijving van twee nationaliteitsrechtelijke deelonderwerpen. Daarvoor is gekozen voor een uitleg over de gang van zaken ten aanzien van naturalisaties en voor een beschrijving van de beoordeling van het bezit van de Duitse nationaliteit op ambtelijk niveau. Dit laatste gaat vooraf aan een eventuele rechterlijke vaststelling van de Duitse nationaliteit.

\footnotetext{
${ }^{10}$ Sleeswijk-Holstein niet. Pestalozza (I), p. 39.

1003 Zie Art. 120 Verfassung des Freistaates Bayern; Art. 72 Verfassung von Berlin v. 01.09.1950 (maar ook: Art. 72 Abs. 2 Nr, 1 Verfassung von Berlin [Ost] v. 23.07.1990); Art. 147 Verfassung des Landes Hessen; $\$ 55$ Gesetz Nr. 645 über den Verfassungsgerichtshof (Saarland); Art. 53 Verfassung Mecklenburg-Vorpommern v. 23.05.1993; Art. 75 Verfassung Sachsen-Anhalt v. 25.06.1992; Art. 80 Verfassung Thüringen v. 25.10.1993; Art. 81 Verfassung des Freistaates Sachsen v. 26.05.1992; $\$ 44$ Landesgesetz über den Verfassungsgerichtshof (Rheinland-Pfalz).

1084 Zie verder Zuck, p. 67-84.

$108 \mathrm{Vgl}$. BT-Drs. 9/556, p. 8.

${ }^{1086}$ Zie Maunz-Dürig, Art. 83 GG; v. Münch, Art. 83 GG.
} 


\subsubsection{Naturalisaties}

Wat betreft naturalisaties heeft de uitvoering door de deelstaten van het RuStAG tot gevolg dat een naturalisatie (Einbürgerung) niet plaatsvindt op het overkoepelende, federale niveau door middel van een beslissing genomen door een federaal orgaan, maar dat op een naturalisatie-aanvraag in de afzonderlijke deelstaten door een administratief orgaan van de desbetreffende deelstaat wordt beslist. ${ }^{1087}$

Ondanks het feit dat in de $\S 8$ tot en met $\S 16$ RuStAG en daarnaast sinds kort in de $\S 85$ tot en met $\S 91$ in het Ausländergesetz ${ }^{1088}$ de voorwaarden voor naturalisatie worden gesteld, is het ter concretisering van deze wetsartikelen tevens noodzakelijk geacht om naturalisatierichtlijnen op te stellen. ${ }^{1089}$ De desbetreffende richtlijnen zijn opgesteld door de deelstaten in samenwerking met het federale ministerie voor Binnenlandse Zaken. ${ }^{1090}$ Het doel van deze richtlijnen is het bewerkstelligen van rechtseenheid in de beslissingen aangaande naturalisaties.

Afgezien van hetgeen de bovenvermelde wetgeving en richtlijnen inzake de naturalisatie voorschrijven, bestaat daarnaast de verplichting dat ten aanzien van iedere naturalisatie de toestemming wordt verkregen van de "Bundesminister des Innern", de minister van Binnenlandse Zaken van de Bondsrepubliek. ${ }^{1091}$ Door het bestaan van deze verplichting wordt de versnipperdheid van de regelgeving inzake naturalisatie nog eens onderstreept. Deze verplichting steunt namelijk op het RuStAG, noch op het Ausländergesetz, maar op de "Verordnung über die deutsche Staatsangehörigkeit" van 05.02.1934. ${ }^{1092}$

\subsubsection{Administratieve vaststelling van het bezit van de Duitse nationaliteit}

Ook met betrekking tot de constatering of een persoon wel of niet de Duitse nationaliteit bezit, dient te worden beseft dat deze beoordeling primair door de administratie op het niveau van de deelstaten geschiedt. Kenmerkend voor de opbouw van de bureaucratie in Duitsland is dat een beslissing aangaande de nationaliteit slechts mag worden genomen door een ter zake aangestelde autoriteit.

\footnotetext{
${ }^{100}$ Makarov/v. Mangoldt, $\$ 8$ RuStAG, Rdnr 10; 816 RuStAG, Rdnr. 9.

10 $\mathrm{Vgl}$. daarover Weidelener, StAZ 1991, p. 131-135. Weidelener opent zijn artikel met de treffende zin: "Das deutsche Staatsangehörigkeitsrecht wird immer unübersichtlicher; (.....)." In gelijke zin uit zich ook Hecker, ArchVR 1991, p. 45.

${ }^{1009}$ Zie De Groot, p. 64-72.

${ }^{1050} \mathrm{Vgl}$. Bergmann/Korth, p. 57 e.v.; Makarov/v. Mangoldt, 88 RuStAG, Rdnr 9; Schleser, p. 388 e.v.; Weidelener/Hemberger, p. 24 en 220 e.v..

${ }^{169} \mathrm{Vgl}$. bijvoorbeeld BVerwG, B. v. 02.08.1979, Buchholz 310 \& 65 VwGO Nr. 55; BVerwG, U. v. 16.05.1983, StAZ 1984, p. 74; BVerwG, B. v. 04.11.1987, Buchholz 130 $\$ 9$ RuStAG Nr. 8; vgl. Hailbronner/Renner, p. 203; Makarov/v. Mangoldt, \& 8 RuStAG, Rdnr. 65.

${ }^{1002} \mathrm{Vgl}$. par. 4.1.2.
} 
Voor het nationaliteitsrecht zijn dit de zgn. Staatsangehörigkeitsbehörden. ${ }^{1093}$ Iedere deelstaat bepaalt zelf welke administratieve organen het aanwijst als Staatsangehörigkeitsbehörden. Te dien einde zijn in iedere deelstaat administratieve circulaires opgesteld. Deze circulaires zijn inhoudelijk in zoverre verschillend dat iedere deelstaat weer andere autoriteiten als competent in nationaliteitskwesties aanwijst. De "Verordnung über die Zuständigkeit in Staatsangehörigkeitssachen" van Nordrhein-Westfalen kan in dezen als karakteristiek voorbeeld worden genomen. ${ }^{1094}$

Behalve het feit dat de beslissing over de nationaliteit dient te zijn genomen door een ter zake aangestelde Staatsangehörigkeitsbehörde, dient deze ambtenaar zijn activiteiten slechts te verrichten ten aanzien van zaken waarvoor hij van de wetgever bevoegdheid heeft gekregen.

Dit uitgangspunt (waarin het legaliteitsbeginsel wordt herkend) heeft ertoe geleid dat in de rechtspraak is geoordeeld dat Staatsangehörigkeitsbehörden geen bevoegdheid hebben het bezit van de Duitse nationaliteit op een definitieve wijze vast te stellen, aangezien zij van de wetgever daartoe geen bevoegdheid hebben ontvangen. Eck heeft recentelijk deze problematiek als volgt bondig weergegeven: "Wiederholt haben Verwaltungsgerichte feststellende Verwaltungsakte der Staatsangehörigkeitsbehörden mit der Begründung aufgehoben, die Behörden seien zur bestandkräftigen Feststellung der Staatsangehörigkeit nicht befügt, da ihnen hierzu die Ermächtig. ungsgrundlage fehle.

Die rechtliche Auseinandersetzung entstand in den Fällen, in denen die Erteilung einer Staatsangehörigkeitsurkunde gemäß $\S 39$ RuStAG (in Verb. mit $\S \S 1,2$ StAurk $V w V^{t 005}$ ) beantragt wurde und die Behörde nicht nur über die Erteilung als solche entschieden hat, sondern zudem oder ausschließlich feststellte, der Antragsteller sei nicht deutscher Staatsangehöriger. Häufig haben die Staatsangehörigkeits-

\footnotetext{
${ }^{1093} \mathrm{Vgl}$. Kuhl, p. 2; Makarov/v. Mangoldt, \$ 16 RuStAG, Rdnr. 10 e.v.; Sturm, p. 25.

1094 De regelingen van de deelstaten die deel uitmaakten van het toenmalige West-Duitsland staan afgedrukt in Weidelener/Hemberger, p. 265 e.v.. Zo zijn bijvoobeeld in de onderscheidenlijke deelstaten de volgende autoriteiten aangewezen als "Staatsangehörigkeitsbehörde": in NordrheinWestfalen, Weidelener/Hemberger, p. 274: "Die Kreisordnungsbehörden der kreisfreien Städte, die örtlichen Ordnungsbehörden der großen kreisangehörigen Städte und im übrigen die Kreisordnungsbehörden"; in Bremen, Weidelener/Hemberger, p. 269: "Die Ortspolizeibehörden"; in Hamburg. Weidelener/Hemberger, p. 270: "die Behörde für Inneres"; in Hessen, Weidelener/Hemerger, p. 272: "in kreisfreien Städten der Magistrat, im übrigen der Landrat als Behörde der Landesverwaltung"; in Nedersaksen, Weidelener/Hemberger, p. 273: "Die Landkreise und kreisfreien Städte" dan wel de "Bezirksregienung"; in Rheinland-Pfalz. Weidelener/Hemberger, p. 275: "in Landkreisen die Kreisurwaltung, in kreisfreien Städten die staatliche Polizeiverwaltung". Na de hereniging van Duitsland zijn ook in de nieuwe deelstaten dergelijke regelingen opgesteld; vgl. StAZ 1992, p. 289, voor de "Verordnung über die Zuständigkeit in Staatsangehörigkeitssachen" van Brandenburg.

1005 Allgemeine Verwaltungsvorschrift ilber Urkunden in Staatsangehörigkeitssachen.
} 
behörden beide Aussagen als Synonyme verwendet, da die Erteilung der Urkunde die deutsche Staatsangehörigkeit voraussetzt.

Überdies werden bei den Staatsangehörigkeitsbehörden häufig Anträge gestellt, in denen ausdrücklich um die Feststellung der Staatsangehörigkeit ersucht wird. Nach Auffassung der Gerichte dürfen die Behörden über derartige Anträge nicht mehr entscheiden. 1096

Eck brengt in het bovenstaande citaat als duidelijk uitgangspunt naar voren dat niet de administratie als zodanig, maar daarentegen de onafhankelijke rechterlijke macht de aangewezen instantie is om een definitieve vaststelling van het bezit van de Duitse nationaliteit te geven. Op de daarvoor geldende procesrechtelijke regelgeving wordt in het navolgende hoofdstuk ingegaan.

${ }^{1006}$ Eck, StAZ 1992, p. 102. 



\section{Hoofdstuk 5}

\section{Procesrechtelijke aspecten in het Duitse nationaliteitsrecht Vaststelling van de Duitse nationaliteit door rechterlijke instanties}

\subsection{Inleiding}

Als gesteld in paragraaf 4.1 betreft hoofdstuk 5 het onderzoek naar de procesrechtelijke regelgeving die van toepassing is op de vaststelling van de Duitse nationaliteit door rechterlijke instanties.

In het onderstaande wordt (in de paragrafen 5.2 en 5.3) aandacht geschonken aan achtereenvolgens administratieve, civiele en strafrechtelijke procedures waarbinnen de vraag naar het bezit van de Duitse nationaliteit een rol kan spelen. Onderzocht wordt of in het Duitse recht het onderscheid "zelfstandige vaststellingsprocedure" versus "impliciete vaststellingsprocedure" kan worden gemaakt. ${ }^{1097}$ Tevens wordt aandacht geschonken aan de vraag in hoeverre de rechterlijke uitspraak inzake het bezit van de Duitse nationaliteit een bindende werking kent.

Hoofdstuk 5 sluit af met paragraaf 5.4 waarin wordt beschreven welke positie de vaststelling van Duitse nationaliteit inneemt in het geval dat door middel van een Verfassungsbeschwerde een beroep op het Bundesverfassungsgericht wordt gedaan door een burger. Ook de bindende werking van de uitspraak van het Bundesverfassungsgericht komt aan de orde.

De laatste paragraaf van het vorige hoofdstuk, paragraaf 4.3 .3 , is afgesloten met de opmerking dat de bevoegdheid tot de ultieme vaststelling van het bezit van de Duitse nationaliteit, op grond van het beginsel van de scheiding der machten, in handen van de rechterlijke macht ligt. ${ }^{1098}$ Het Beierse Verwaltungsgerichtshof heeft op de volgende wijze uitdrukking gegeven aan dit principe: "Die verbindliche Entscheidung über streitige Statusfragen ist grundsätzlich den Gerichten vorbehalten. Mangels einer ausreichenden gesetzlichen Ermächtigung sind die Staatsangehörigkeitsbehörden nicht befugt, durch Verwaltungsakt eine streitentscheidende Feststellung über den Besitz der deutschen Staatsangehörigkeit zu treffen.

Het mag dan weliswaar buiten twijfel staan dat de rechter bevoegd is tot vaststelling van het bezit van de Duitse nationaliteit, voor de vraag echter welke

\footnotetext{
${ }^{100}$ Zie voor de begrippen "impliciete vaststellingsprocedure" en "zelfstandige vaststellingsprocedure" par. 2.1.

Vgl. Eck, StAZ 1992, p. 107; Kanein, p. 24; Kollmann, DÖV 1990, p. 194; Sturm, p. 25.

BayVGH, U. v. 05.04.1976, DVBI 1977, p. 108. In gelijke zin tevens: VG Freiburg, U. v. 03.10.1978, StAZ 1979, p. 302; BayVGH, U. v. 07.12.1983, StAZ 1984, p. 167.
} 
rechterlijke instantie hiertoe geroepen is, kent de wet geen eigen regeling. Noch in het Reichs- und Staatsangehörigkeitsgesetz, noch in enig andere wet treft men een eigen, aparte rechtsgang ter vaststelling van het bezit van de Duitse nationaliteit aan. De nationaliteitskwestie wordt in beginsel behandeld als een voorvraag in een geschil over een ander recht (of een verplichting). Dit leidt ertoe dat de vraag naar de nationaliteit aan de orde kan komen binnen een ruime verscheidenheid aan procedures. Uiteraard betekent een zodanig ruime hoeveelheid procedures dat het oordeel over de nationaliteit wordt getroffen door verschillende rechterlijke instanties, die niet alle onder één en hetzelfde hoogste rechtscollege vallen. Op ieder rechtsgebied fungeert een hoogste rechtscollege. Zo bestaan achtereenvolgens het Bundesverfassungsgericht; Bundesverwaltungsgericht; Bundesgerichtshof; Bundessozialgericht; Bundesdisziplinargericht; Bundespatentgericht; Bundesfinanzhof en het Bundesarbeitsgericht. ${ }^{1100}$

Het feit dat zoveel verschillende rechterlijke instanties tot een oordeel over de Duitse nationaliteit kunnen worden geroepen en daarnaast het feit dat tevens een hoogste rechter ontbreekt die inzake nationaliteitsaangelegenheden het laatste woord heeft, hebben in het verleden geleid tot tegenstrijdige beslissingen betreffende het bezit van de Duitse nationaliteit in vergelijkbare zaken én tot het door de hoogste instanties wederzijds niet-erkennen van elkaars uitspraken. ${ }^{1101}$

Dit heeft in Duitsland, zoals ook in Nederland is gebeurd ten aanzien van de toenmalige Nederlandse situatie, ${ }^{1102}$ aanleiding gegeven tot kritische kanttekeningen. ${ }^{1103}$ Schätzel wijst in 1958 op dit gebrek aan eenheid binnen de rechtswegen en het daaraan inherent verbonden gevaar dat over vergelijkbare zaken verschillende beslissingen worden genomen. Hij is daarbij zelfs zo somber dat hij opmerkt: "Es ist auch zu befürchten, daß ein Gegensatz der Auffassungen des Bundesverfassungsgerichts und der anderen obersten Bundesgerichte in einigen Staatsangehörigkeitsfragen wieder auflebt." Aan zijn bange vermoedens verbindt hij de volgende conclusie: "Ein neues Staatsangehörigkeitsgesetz sollte daher auch den Verfahrensfragen eine größere Aufmerksamkeit zuwenden und Vorsorge treffen, daß die bisherige Zersplitterung in Fragen der Staatsangehörigkeit endgültig beseitigt wird. "

\footnotetext{
${ }^{1100}$ Hecker, StAZ 1986, p. 337, stelt dat (op dat moment) de vier laatst genoemde oberste Bundesgerichten nimmer een uitspraak hebben gedaan waarin nationaliteitsrechtelijke kwesties een rol speelden. $10 t$ BVerfG, U. v. 09.11.1955, BVerfGE 4, 322, [327] dat in tegenspraak is met BVerwG, U. v. 30.10.1954, BVerwGE 1, 206 (beide zaken gaan niet over dezelfde persoon, nationaliteitsrechtelijk echter zijn de zaken identiek). Idem in BGH, B. v. 29.12.1953, BGHst 5, 230 en BVerfG, B. v. 30.01.1953, BVerfGE 2, 115. Zie ook par. 5,4.3.1.

$1102 \mathrm{Vgl}$. par, 1.2 en 2.8.3.

110 Zie o.a. Gơhring, NJW 1954, p. 1063; Makarov, JZ 1955, p. 659.

${ }^{1104}$ Schătzel, p. 12.
} 
Aan de bovenstaande wens van Schätzel is tot op heden niet voldaan. Wenst iemand derhalve een gerechtelijke uitspraak over het wel of niet bezitten van de Duitse nationaliteit te verkrijgen, dan dient een beroep te worden gedaan op niet specifiek nationaliteitsrechtelijke rechtswegen. Een vaststaand gegeven hierbij is dat de nationaliteitskwestie dan slechts aan de orde komt als voorvraag inzake een ander juridisch geschilpunt.

Zo op het eerste oog lijkt hieruit te volgen dat in het Duitse recht de vaststelling van de nationaliteit alleen kan plaatsvinden binnen "impliciete vaststellingsprocedures". Eén van de gevolgen van het afhandelen van de nationaliteitsvraag als voorvraag is dat de vaststelling een onderdeel van de rechtsgronden is en geen deel uitmaakt van het dictum ("Urteilstenor" of "Entscheidungsformel"). Nu zal in het navolgende evenwel blijken dat het Duitse administratieve recht een algemene rechtsgang kent waarin, weliswaar niet geheel los van een hoofdvraag die in eerste instantie altijd moet zijn gerezen, op de nationaliteit als voorvraag toch kan worden beslist op een zodanige wijze dat het oordeel van de rechter aangaande de nationaliteit een onderdeel van het dictum vormt.

\subsection{De administratieve rechtspraak}

Uit hoofde van $\S 40$ Verwaltungsgerichtsordnung staat de algemene administratieve rechtsgang bij, in eerste instantie, het Verwaltungsgericht en, in hoger beroep, het Oberverwaltungsgericht open indien de vraag naar de nationaliteit in een publiekrechtelijk geschil ("öffentlich-rechtliche Streitigkeit") ${ }^{1105}$ opkomt.

De administratieve rechtsgang die men alsdan kan volgen, is nader gepreciseerd in de $\S \S 42$ en 43 VwGO. In beide gevallen eindigt de zaak met een "Urteil" ( $\S$ 107 VwGO). ${ }^{1106}$

Op grond van $\S 42$ VwGO kan worden ingesteld hetzij een Anfechtungsklage, hetzij een Verpflichtungsklage. Met een Anfechtungsklage wordt beoogd de ongedaanmaking van bepaalde administratieve handelingen, de zgn. "Verwaltungsakten". ${ }^{1107}$ Of een handeling onder het begrip "Verwaltungsakt" valt, kan worden bepaald aan de hand van de definiëring uit $\S 35$ Verwaltungsverfahrensgesetz $(V w V f G) .{ }^{1108}$ Een gangbare Nederlandse vertaling van het begrip "Verwaltungsakt" luidt: "een eenzijdige publiekrechtelijke rechtshandeling van het bestuur,

\footnotetext{
${ }^{1108} \mathrm{Vgl}$. Ule, p. 34,35 en 52.

${ }^{1106}$ Het merendeel van de in de paragraaf 5.2 te behandelen rechtspraak betreft een "Urteil", een enkele keer gaat het om een "Beschluß" ( $\$ 122$ VwGO). De formele verschillen tussen beide vormen van uitspraak zijn van ondergeschikt belang voor het onderwerp van de nationaliteitsvaststelling en wil ik dan ook niet nader uitwerken.

${ }^{1107}$ Niet de ongedaanmaking van alle administratieve handelingen is mogelijk, maar alleen die van "Verwaltungsakten". Bijvoorbeeld "Realakten" (feitelijke handelingen) vallen hierbuiten.

${ }^{110}$ Van 25.05.1976 (BGBl. I p. 1253).
} 
gericht op een individueel geval, of met andere woorden: de beschikking in Nederlands-rechtelijke zin. ${ }^{m 1109}$

In tegenstelling tot de hierboven genoemde Anfechtungsklage, een klacht die beoogt een bestuurshandeling ongedaan te laten maken, is het bij het instellen van een Verpflichtungsklage de bedoeling dat de administratie door de rechter tot het ondernemen dan wel het nalaten van een bepaalde handeling wordt verplicht. Een Verpflichtungsklage wordt ook wel een Leistungsklage genoemd. ${ }^{110}$ Het zal verderop blijken dat vooral de Verpflichtungsklage bij nationaliteitsgeschillen veelvuldig wordt toegepast. Het gaat in die gevallen om een actie de overheid te dwingen tot afgifte van documenten ter identificatie, zoals paspoorten, of om afgifte van een document waaruit het bezit van de Duitse nationaliteit blijkt, de Staatsangehörigkeitsausweis. In de in dit boek ontwikkelde categorisering van nationaliteitsacties voor de onafhankelijke rechter vormen de Anfechtungsklage en Verpflichtungsklage voorbeelden van "impliciete vaststellingsprocedures"."III

Een volgende grondslag voor een rechtsvordering tegen de administratie biedt \& 43 VwGO. Paragraph 43 VwGO biedt de mogelijkheid een Feststellungsklage aanhangig te maken. De Feststellungsklage kan ten doel hebben: de vaststelling van het bestaan of het niet-bestaan van een rechtsverhouding. Ook kan de vaststelling van de nietigheid van een administratieve handeling worden gevraagd.

Hierna wordt eerst de Verplichtungsklage ingevolge $\$ 42$ VwGO nader besproken, vervolgens zal aandacht worden besteed aan de Feststellungsklage van $\S 43$ VwGO en daarna komt kort de samenhang tussen de beide vorderingen aan de orde.

\subsubsection{De administratieve Verpflichtungsklage ( $\$ 42 \mathrm{VwGO}$ )}

\subsubsection{Algemene beschouwingen ${ }^{1112}$}

Een voorwaarde voor het aanhangig kunnen maken van een $\$ 42$ VwGO-procedure (een Anfechtungs- dan wel een Verpflichtungsklage) is op grond van hetgeen $\S 68$ VwGO voorschrijft, dat, in beginsel, ${ }^{1113}$ eerst een bezwaarschriftprocedure bij de administratieve autoriteiten is gevoerd; dit is het "behördliches Vorverfahren". ${ }^{114}$ Het "Vorverfahren" vindt plaats binnen het administratieve orgaan dat

\footnotetext{
${ }^{1109}$ Bok, p. 128 en 129.

1110 Tschira/Schmitt Glaeser, p. 160; vgl. BVerwG, U. v. 21.05.1985, Buchholz 130 $\$ 25$ RuStAG Nr. 5.

IIII Zie par. 2.1.

1112 Nederlandstalige literatuur: Banda, p. 67-73; Bok, p. 130 en 131.

11 s De uitzonderingen die het artikel toelaat, staan ook in $\$ 68$ VwGO vermeld. Vgl. Tschira/Schmitt Glaeser, p. 162, 165 en 170.

1114 "Das Vorverfahren beginnt mit der Erhebung des Widerspruchs" ( $\$ 69$ VwGO).
} 
de bestreden beslissing heeft genomen. In het Duitse recht bestaat in sommige gevallen tevens de mogelijkheid ná een afwijzing op het bezwaarschrift een beroep in te dienen bij een hoger administratief orgaan. ${ }^{111}$ Voor het karakter van de rechtsgang is het niet van belang of slechts alleen een bezwaarschrift kan worden ingediend, dan wel daarna nog een administratief beroep mogelijk is. In beide gevallen worden de bezwaren binnen het bestuur behandeld en is in principe ruimte voor zowel doel- als rechtmatigheidstoetsing. ${ }^{1116}$ Het "behördliches Vorverfahren" wordt ook wel omschreven met de term "Verwaltungsverfahren" of ook wel met "Widerspruchsverfahren". ${ }^{117}$ De rechtsingang en de procesrechtelijke regels betreffende het "behördliches Vorverfahren" worden nader geregeld in $\$ 79$ Verwaltungsverfahrensgesetz en $\S 68$ tot en met $\S 80$ Verwaltungsgerichtsordnung.

Pas na de behandeling van het bezwaar in het "Vorverfahren" komt de justitiabele de mogelijkheid toe het nationaliteitsgeschil voor te leggen aan de onafhankelijke rechter op grond van $\S 42$ VwGO. Pas op dat moment vangt het eigenlijke "Verwaltungsproze $\beta$ " aan. ${ }^{1118}$

\subsubsection{Nationaliteit}

Met name procedures die betrekking hebben op de weigering door de administratie om over te gaan tot afgifte van paspoorten (Pässe), identificatiekaarten (Personalausweise) en verklaringen omtrent de Duitse nationaliteit (Staatsangehörigkeitsausweise $)^{1119}$ hebben de vraag naar het bezit van de nationaliteit tot onderwerp. ${ }^{1120}$ Indien een verzoek tot afgifte van een zodanig document, en de, in beginsel noodzakelijke, ${ }^{1121}$ administratieve rechtsgang (het "behördliches Vorverfahren"), hebben geresulteerd in een afwijzing, is het mogelijk op grond van $\S 42 \mathrm{VwGO}$ de

\footnotetext{
${ }^{115}$ Ule, p. 29.

${ }^{1116}$ Ule, p. 117, Tschira/Schmitt Glaeser, p. 11.

1117 Wegens de "Erhebung des Widerspruchs" uit $\$ 69$ VwGO.

IIII In plaats van het begrip Verwaltungsproze $\beta$ wordt ook wel het begrip Verwaltungsstreitverfahren gebruikt. Vgl. BVerwG, B. v. 21.11.1994, StAZ 1995, p. 217.

${ }^{119}$ Een Staatsangehörigkeitsausweis is een bewijs van het bezit van de Duitse nationaliteit. Ten aanzien van degene op wiens naam het document is afgegeven, wordt vermeld: "ist deutsche( $r$ ) Staatsangehöri$g e(r)^{\prime \prime}$. Dit alles in tegenstelling tot een Ausweis über die Rechtsstellung als Deutscher, een document dat ter beschikking wordt gesteld aan de zgn. status-Duitsers. In dit laatste document wordt met betrekking tot degene op wiens naam het is afgegeven, verklaard: "ist Deutsche $(r)$ ". In het geval van een "Rechtsstellung als Deutscher" bezit de betrokkene niet de Duitse nationaliteit; zie hiervoor par. 4.1.4.

${ }^{1120}$ BVerwG, B. v. 02.05 .1988 , NJW 1988, p. 2196 , waarin het gaat om een geweigerde verblijfsvergunning (Aufenthaltserlaubnis), aangevraagd door de betrokkene omdat hij meent niet de Duitse nationaliteit te bezitten en geweigerd door de administratie die van het tegenovergestelde uitgaat, is een uitzondering.

Zie voetnoot 1114 .
} 
zaak aanhangig te maken bij de administratieve rechter en zodoende een "Verwaltungsproze $\beta$ " te starten.

Zoals reeds hierboven is vermeld, wordt de op grond van $\$ 42$ Abs. 1 VwG0 geinnitieerde actie in het Duitse recht omschreven als een Verpflichtungsklage. Dat wil zeggen, dat het beoogde object van de rechtsgang niets anders is dan een uitspraak van de rechter waarin de administratie de verplichting wordt opgelegd alsnog tot uitreiking van het gevraagde document over te gaan.

Om tot een zodanige uitspraak te kunnen komen, zal de rechter een onderzoek dienen te verrichten naar de vraag of de desbetreffende instantie inderdaad het gevraagde document terecht heeft geweigerd. Is dit, naar inzicht van de rechter, niet het geval geweest, dan wordt vervolgens de verplichting opgelegd over te gaan tot afgifte.

Bij dit alles dient niet uit het oog te worden verloren, dat de reden tot de oorspronkelijke afwijzing door de administratie kan zijn gelegen in een factor die ligt buiten de beoordeling van het eventueel bezit van de Duitse nationaliteit. Speelt de nationaliteit wél een rol in de besluitvorming van de ambtenaar en dient vervolgens de rechter daarover een oordeel te vormen, dan nog geeft het vonnis geen ander uitsluitsel dan over de vraag of de administratie alsnog moet worden verplicht tot de gevraagde handeling. In deze rechtsgang kan namelijk slechts aan de orde worden gesteld de onrechtmatigheid van het niet-afgeven van het gewenste document, slechts op impliciete wijze komt het door de betrokken ambtenaar gegeven oordeel over het al dan niet bezitten van de Duitse nationaliteit aan de orde. De uitspraak van de rechter betreft dan ook slechts een oordeel over de (on)rechtmatigheid van de weigering en het vonnis legt vervolgens wel of niet de verplichting op tot afgifte van het gevraagde document over te gaan. Het karakter van de Verpflichtungsklage leidt er dientengevolge toe dat de rechter slechts op indirecte wijze een oordeel velt over het vraagpunt van het bezit van de Duitse nationaliteit. Dit leidt ertoe dat de rechter in wezen slechts op impliciete wijze overgaat tot vaststelling van de nationaliteit.

Ter illustratie volgt hieronder een prototypisch geformuleerd dictum van een op $\S 42$ VwGO gegrondvest oordeel: "Der Bekl. war zu verpflichten, der Kl. einen Ausweis über ihre deutsche Staatsangehörigkeit auszustellen (...). Die Kl. hat einen Anspruch darauf, daß ihr vom Bekl. ein solcher Ausweis ausgestellt wird (....), denn sie ist deutsche Staatsangehörige. ${ }^{11122}$

แ22 VGH München, U. v. 09.11.1988, NJW 1989, p. 3107. 


\subsubsection{Bindende werking van het vonnis}

De vormgeving van het dictum heeft haar directe gevolgen voor de bindende werking van de nationaliteitsvaststelling. Hierover stelt het Bundesverwaltungsgericht: "Die inzidenten Feststellungen über das Bestehen der deutschen Staatsangehörigkeit als Voraussetzung für die Erteilung eines Staatsangehörigkeitsausweises nehmen, da sie lediglich eine Vorfrage betreffen, an der Rechtskraft ( $\$ 121$ VwGO) eines zur Ausstellung eines solchen Ausweises verpflichtenden Urteils nicht teil (....). ${ }^{n 1123}$

Naar aanleiding van deze uitspraak stelt Meyer dat een succesvolle procedure ter zake (de administratie wordt verplicht het gevraagde document te verstrekken) evenwel niet betekent dat de impliciete vaststelling door de rechter van de Duitse nationaliteit van betrokkene de eerdere vaststelling als niet-Duitser door de administratie vervangt. Met de Verpflichtungsklage wordt volgens Meyer: "(.....) nur rechtskräftig entschieden, ob der Kläger einen Anspruch auf einen Ausweis hat oder nicht; die Bindungswirkung des Urteils (\$121 VwGO) bezieht sich nicht darauf, daß der Kläger deutscher Staatsangehöriger ist oder nicht" ${ }^{1124}$

\subsubsection{De administratieve Feststellungsklage ( $\$ 43 \mathrm{VwGO})$}

\subsubsection{Algemene beschouwingen ${ }^{1125}$}

In het geval dat men zich met een Feststellungsklage tot de rechter wendt, is de administratieve fase van het "Vorverfahren" niet nodig ( $\$ 68$ VwGO). Tschi$\mathrm{ra} /$ Schmitt Glaeser vermelden voorts dat aan het kunnen instellen van de Feststellungsklage geen termijn is verbonden. ${ }^{1126}$

De vorm die de klacht kan aannemen, kan worden onderscheiden naar gelang de in de klacht gelegen wens tot positieve dan wel negatieve vaststelling van de rechtsverhouding. Een positieve Feststellungsklage beoogt de vaststelling van een publiekrechtelijke rechtsbetrekking, terwijl een negatieve Feststellungsklage juist de vaststelling van het niet-bestaan van de publiekrechtelijke rechtsverhouding ten doel heeft. ${ }^{1127}$

De klager dient voor deze procedure processueel belang ("berechtigtes Interesse" noemt $\S 43$ VwGO dit) te hebben. Betreffende het "berechtigtes Interesse" van de

\footnotetext{
${ }^{123}$ BVerwG, U. v. 21.05.1985, Buchholz 130 \& 25 RuStAG Nr. 5.

${ }^{1124}$ Meyer, NVwZ 1987, p. 26. Vgl. Ule, p. 316.

"is Nederlandstalige literatuur: Banda, p. 75 en 76; Bok, p 131 en 132.

"Ix Tschira/Schmitt Glaeser, p. 182 en 192; idem Redeker/v. Oertzen, p. 222. "12 Vgl. Eyermann/Fröhler, p. 380; Hufen, p. 349; Redeker/v. Oertzen, p. 216; Tschira/Schmitt
Glaeser, p. 186.
} 
initiatiefnemer tot een administratiefrechtelijke Feststellungsklage heeft het Bundesverwaltungsgericht het volgende bepaald: in de gevallen dat men een vaststelling van de nietigheid van een "Verwaltungsakt" wenst, blijft het begrip niet beperkt tot "rechtliches Interesse" (de term die voorkomt in § $256 \mathrm{ZPO}$, het artikel waarin de Feststellungsklage voor de vaststelling van civiele rechtsverhoudingen wordt mogelijk gemaakt), maar is het ruimer ${ }^{1128}$ en "schließt (....) jedes als schutzwürdig anzuerkennende Interesse auch wirtschaftlicher oder ideeller An ein. ${ }^{\text {"1129 }}$

Voor de vaststellingsacties aangaande een administratiefrechtelijke rechtsverhouding geldt daarnaast volgens het BVerwG, dat door de bestreden overheidshandeling de rechtspositie van de klager wordt geraakt. Het BVerwG heeft dienaangaande gesteld: "(.......); ebenso sind auch die sonstigen, auf die Feststellung des Bestehens oder Nichtbestehens eines Rechtsverhältnisses gerichteten Feststellungsklagen nach \& 43 I VwGO nur zulässig, wenn es dem Kl. dabei um die Verwirklichung seiner Rechte geht, sei es, daß er an dem festzustellenden Rechtsverhältnis selbst beteiligt ist, sei es, daß von dem Rechtsverhältnis immerhin eigene Rechte des $K l$. abhängen. " 1130

Naar de mening van Ule kan "berechtigtes Interesse" pas ontstaan nadat vanuit de overheidsadministratie een handeling is ondernomen waarmee de betrokken justitiabele het niet eens is. Ule merkt dienaangaande op: "Ein berechtigtes Interesse an baldiger gerichtlicher Feststellung wird nur dann vorliegen, wenn das Rechtsverhältnis umstritten ist; der Beklagte muß also sein Bestehen leugnen oder bei der negativen Feststellungsklage- sich gegenüber dem Kläger seiner rühmen. "1131

Aangezien men zich in deze rechtsgang wendt tot de administratieve rechter staat zonder uitzondering de overheid als wederpartij tegenover de klager. Hieruit volgt dat er geen rechtsingang op grond van $\S 43$ VwGO kan bestaan in het geval dat er tussen twee particulieren twijfel is gerezen over de nationaliteit. In een zodanig geval is namelijk niet voldaan aan de voorwaarde uit $\S 40$ Abs. 1 VwGO dat er sprake moet zijn van een "öffentlich-rechtliche Streitigkeit". ${ }^{1132}$

In de literatuur vindt nog vermelding, dat aan een overheidsorgaan (Verwaltungsbehörde) niet de bevoegdheid toekomt het initiatief te nemen tot deze rechtsgang. ${ }^{1133}$ Tevens is het niet mogelijk een oordeel te vragen over de rechtsverhouding in een hypothetische of een toekomstige situatie. ${ }^{1134}$ Daarentegen is het wél

\footnotetext{
${ }^{1128} \mathrm{Vgl}$. ook Eyermann/Fröhler, p. 389; Ule, p. 212.

1129 BVerwG, B. v. 30.07 .1990 , NVwZ 1991, p. 470.

1130 Idem als de vorige voetnoot.

1131 Ule, p. 212; Tschira/Schmitt Glaeser, p. 194.

1132 Eyermann/Fröhler, p. 389.

1133 Ule, p. 213; vgl. echter Redeker/v. Oertzen, p. 223, die hierop een nuancering aanbrengen.

1134 Eyermann/Fröhler, p. 383 en 384: Tschira/Schmitt Glaeser, p. 188.
} 
mogelijk een klacht in te stellen die is gericht op de vaststelling van het wel of niet hebben bestaan van een rechtsbetrekking in het verleden. ${ }^{1135}$

\subsubsection{Nationaliteit}

Ook met betrekking tot de vraag naar het bezit van de Duitse nationaliteit is het mogelijk op grond van $\S 43$ VwGO een Feststellungsklage aanhangig te maken. ${ }^{1136}$ Blijkens de jurisprudentie staat het Bundesverwaltungsgericht op het navolgende standpunt: "Das Bestehen der deutschen Staatsangehörigkeit ist ein der Feststellungen nach $\S 43$ Abs. 1 VwGO zugängliches Rechtsverhältnis. "1137 Zoals al in het voorgaande is gebleken, is de desbetreffende procedure niet specifiek voor nationaliteitsaangelegenheden, maar in het algemeen bedoeld om een (administratieve) rechtsverhouding of de nietigheid van een "Verwaltungsakt"1138 te laten vaststellen.

Op deze plaats kan de constatering worden gedaan dat in het geval van het aanhangig maken van een Feststellungsklage de vraag naar de nationaliteit op dat moment losgekoppeld raakt van andere juridische kwesties. Dat de nationaliteitskwestie als hoofdvraag van de procedure geldt, heeft het BVerwG recentelijk benadrukt met de opmerking: "Bei staatsangehörigkeitsrechtlichen Feststellungsurteilen bildet das Bestehen oder Nichtbestehen der Staatsangehörigkeit den unmittelbaren Entscheidungsgegenstand und nicht lediglich eine Vorfrage. "1139 Dit betekent in het kader van de in dit boek ontwikkelde typering van vaststellingsprocedures dat een $\S 43$ VwGO-procedure waarbij de vaststelling geschiedt of de betrokkene al dan niet de Duitse nationaliteit bezit, is te beschouwen als een "zelfstandige vaststellingsprocedure" ${ }^{1140}$

Met betrekking tot het specifiek bij de nationaliteitsactie vereiste belang heeft Meyer opgemerkt: "(.....); das erforderliche Feststellungsinteresse ist z. B. dann grundsätzlich gegeben, wenn der Beklagte in Wahrnehmung seiner Aufgaben als

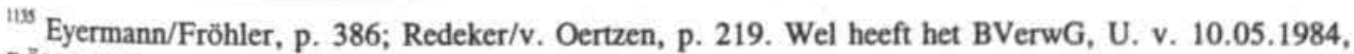
DÖV 1985, p. 207 , nr. 40 , ten aanzien van het instellen van een procedure met een retrospectief vaststellingsdoel de beperking gesteld: "Die Feststellung des "Bestehens" eines vergangenen Rechtsverhältnisses kann nicht begehrt werden, wenn dieses Rechtsverhältnis keine anhaltenden Wirkungen mehr hat."

${ }^{1136} \mathrm{Vgl}$. Eyermann/Fröhler, p. 383; Meyer, NVwZ 1987, p. 26; Kopp, \& 43 VwGO, Rdnr. 12; Redeker/v. Oertzen, p. 217.

"137 BVerwG, U. v. 21.05.1985, Buchholz 13o \& 25 RuStAG Nr. 5, p. 11. Vgl. ook BVerwG, U. v. 06.12.1983, BVerwGE 68, 220.

Zie voetnoten 1107 en 1109.

BVerwG, U. v. 23.02.1993, NVwZ 1993, p. 782.

${ }^{110} \mathrm{Vgl}$. par. 2.1.
} 
Staatsangehörigkeitsbehörde dem Klager die deutsche Staatsangehörigkeit bestreitet. ${ }^{\prime 1141}$

In de algemene beschouwing over de rechtsgang uit $\S 43 \mathrm{VwGO}$ is al gebleken, dat er in deze procedure een overheidslichaam in de hoedanigheid van wederpartij dient te worden aangeklaagd. Desalniettemin kent de nationaliteitsrechtelijke jurisprudentie een uitspraak in een Feststellungsklage waarin van een aangeklaagde wederpartij geen sprake is geweest. De uitspraak betreft het geval waarin een vader ten behoeve van zijn minderjarig kind een Feststellungklage instelt, waarvan het doel is geweest de vaststelling dat het kind niet de Duitse nationaliteit bezit. ${ }^{112}$ Het kind is in de procedure op grond van 865 VwGO "beigeladen", waardoor het deelnemer in het proces was geworden, ${ }^{1143}$ maar een overheidsinstantie als wederpartij ontbreekt.

Onder het overheidslichaam dat in beginsel dient te worden aangeklaagd bij het instellen van de Feststellungsklage wordt in het algemeen verstaan het overheidslichaam waarmee de klager over het bezit van de Duitse nationaliteit van mening verschilt. Het zal daarbij veelal gaan om een niet-federaal lichaam. Het Bundesverwaltungsgericht heeft bepaald dat in de nationaliteitsrechtelijke Feststellungsklage voor het "beiladen" ( $\$ 65 \mathrm{VwGO}$ ) van de fédèralè staat "Bunaésrepubilik Leurscn' land" geen noodzaak bestaat. ${ }^{1144}$

Als gevolg van het feit dat het in een $\S 43$ VwGO-procedure gaat om een "zelfstandige vaststellingsprocedure" omvat het dictum in een Feststellungsklage niets anders dan de vaststelling van het wel of niet bezit van de Duitse nationaliteit door de klager. Alsdan luidt de uitspraak bijvoorbeeld: "Die Klägerin ist deutsche Staatsangehörige. "1145 In het geval dat een vaststelling als "Deutscher im Sinne des Grundgesetzes $" 1146$ werd nagestreefd, luidde het dictum van het Verwaltungsgericht in Bremen: "A. Der Kl. ist nicht deutscher Staatsangehöriger." en "B. Der Kl. ist auch nicht Deutscher ohne deutsche Staatsangehörigkeit. ${ }^{11147}$

\footnotetext{
${ }^{1441}$ Meyer, NVwZ 1987, p. 26.

1142 VG Düsseldorf, U. v. 20.01.1977, NJW 1977, p. 1607. Een procedure op grond van $\S 43$ VwG0 waarin wordt verzocht om de vaststelling dat de betrokkene niet de Duitse nationaliteit bezit komt weinig voor. Een ander voorbeeld is BVerwG, U. v. 21.12.1961, DÖV 1962, p. 310.

110 Redeker/v. Oertzen, p. 346.

114 BVerwG, B. v. 02.08.1979, Buchholz $310 \$ 65$ VwGO Nr. 55. In dit geval procedeert de klager primair tegen de afwijzing van zijn naturalisatie. In dat kader was de Bundesrepublik Deutschland door de rechter in de procedure beigeladen. Tijdens het proces stelt de klager echter aanvullend een Feststellungsklage in ter vaststelling van zijn Duitse nationaliteit. De Feststellungsklage slaagt. Daartegen stelt de Bundesrepublik Deutschland bij het BVerwG Revision in. De federale overheid wordt niet-ontvankelijk verklaard, want: "Wäre von Beginn des Verfahrens nur der Feststellungsantrag Streitgegenstand gewesen, so wäre eine Beiladung der Bundesrepublik Deutschland nicht in Betracht gekommen."

iiss OVG Nordrhein-Westfalen, U. v. 21.11.1989, StAZ 1990, p. 111. Vgl. Fliegauf, p. 70.

1146 Zie par. 4.1.4.

u4 VG Bremen, U. v. 14.03.1988, NJW 1989, p. 1377.
} 


\subsubsection{Bindende werking van het vonnis}

Het feit dat tijdens de Feststellungsklage de nationaliteitskwestie als hoofdvraag wordt beschouwd, is, als hierboven reeds is opgemerkt, weer van belang voor de vormgeving van het dictum. Immers, in tegenstelling tot een "impliciete vaststellingsprocedure" waarin de beoordeling van de nationaliteit een voorvraag betreft en niet in het dictum is verwoord, vormt in een "zelfstandige vaststellingsprocedure" de beslissing inzake de nationaliteit het dictum.

Ten aanzien van de bindende werking van het "Feststellungsurteil" schrijft Ule dat onderscheid moet worden gemaakt tussen enerzijds bindende werking tussen partijen en anderzijds bindende werking ten opzichte van andere rechters. De bindende werking tussen de betrokken partijen betreft de materiële rechtskracht van de uitspraak en die acht hij op grond van $\S 121$ VwGO aanwezig. ${ }^{1148}$ Voor de materiële rechtskracht is het van geen belang of de betrokken partijen elkaar een volgende maal voor dezelfde of voor een andere rechter treffen. Zolang het dezelfde partijen zijn, geldt tussen hen de materiële rechtskracht van het eerdere vonnis waarin hun rechtsverhouding is vastgesteld. Ule laat op dit punt weten: "Es ist in der Rechtsprechung des Bundesgerichtshofs, in der verwaltungsgerichtlichen Rechtsprechung und in der Rechtslehre allgemein anerkannt, daß die verwaltungsgerichtlichen Urteile materielle Rechtskraft auch für die Gerichte der ordentlichen Gerichtsbarkeit besitzen. ${ }^{n 1149}$

Daartegenover staat, volgens Ule, dat het vonnis geen algemeen bindende werking heeft, zodat anderen dan de betrokken partijen er niet aan zijn gebonden. Hetgeen betekent dat het adiëren van dezelfde of een andere rechterlijke instantie in combinatie met een andere wederpartij ertoe leidt dat geen gebondenheid bestaat ten opzichte van het eerdere vonnis. Het gevolg is derhalve dat indien in een eerder "Feststellungsurteil" op grond van $\S 43$ VwGO gewezen tussen een burger (Kläger) en bijvoorbeeld een gemeente (Beklagte) ten aanzien van de klager is vastgesteld dat hij de Duitse nationaliteit bezit, deze vaststelling niet bindend is ingeval van een later dispuut over de nationaliteit tussen dezelfde burger maar een andere wederpartij. Ten aanzien hiervan geeft Ule het volgende voorbeeld: "Trifft z. B. das Verwaltungsgericht in einem Proze $\beta$ auf Feststellung der Staatsangehörigkeit die Feststellung, daß der Kläger die deutsche Staatsangehörigkeit besitzt, so ist das ordentliche Gericht in einem Ehescheidungsproze $\beta$ des Klägers an diese Feststellung nicht gebunden. ${ }^{\text {"1150 }}$

Ule geeft evenwel toe dat hierover in de literatuur afwijkende meningen worden geuit. Een zodanig ander oordeel over de bindende werking van het "Feststellungsurteil" is te vinden bij Schätzel: "Anders steht es jedoch, wenn die Behörde die

\footnotetext{
"He Ule, p. 312; cf. Eyermann/Fröhler, p. 397.

"119 Ule, p. 314; vgl. Knöpfle, BayVBI. 1982, p. 227; Rosenberg/Schwab, p. 72.

${ }^{11} \mathrm{O}$ Ule, p. 320.
} 
Ausstellung eines Staatsangehörigkeitsausweises oder eines Passes verweigert. Mit einer Anfechtungsklage kann in diesen Fällen günstigstenfalls eine deklaratorische Urkunde erlangt werden, welche das bürgerliche Gericht nicht bindet und die Möglichkeit offen läßt, daß es z. B. in einem Ehestreit die Staatsangehörigkeit des Inhabers anders beurteilt. Wenn dies ausgeschlossen werden soll, bedarf es der Feststellung der Staatsangehörigkeit durch Feststellungsurteil, dessen Rechtskraft auch das bürgerliche und das Finanzgericht bindet. "1151

Meyer laveert in 1987 voorzichtigheidshalve tussen beide uitersten door en merkt in zijn reeds eerder aangehaalde artikel op: "Das BVerwG hat sich noch nicht zu der Frage geäußert, ob und gegebenfalls inwieweit ein verwaltungsgerichtliches Feststellungsurteil eine alle Behörden und Gerichte erfassende, über den personellen Umfang der Rechtskraftwirkung $(\$ 121 \mathrm{VwGO}$ ) hinausgehende Bindung erzeugt und worin ihr Rechtsgrund liegen könnte.

Een duidelijk antwoord op de vraag hoever de bindende kracht van een "Feststellungsurteil" inzake het bezit van de Duitse nationaliteit reikt, kan onder de huidige stand van zaken dus niet worden gegeven. Een "Feststellungsurteil" op grond van \& 43 Verwaltungsgerichtsordnung heeft, naar alle waarschijnlijkheid, geen werking "erga omnes". Dit wil zeggen dat het geen kracht jegens eenieder heeft, zodat anderen dan de bij het vonnis betrokkenen niet aan het vonnis zijn gebonden. Wel is in een recente uitspraak van het Bundesverwaltungsgericht uitgegaan van gebondenheid van de federale overheid (Bundesrepublik Deutschland); dit op grond van de werking van de materiële rechtskracht. In de desbetreffende uitspraak heeft het BVerwG namelijk een nadere invulling gegeven van het begrip "wederpartij". Dit begrip is immers voor het bestaan van de materiële rechtskracht een kernbegrip. Als het gaat om de Duitse nationaliteit, dan is de federale staat begrepen onder "wederpartij".

Dat dit in het Duitse rechtsstelsel niet zonder meer voor de hand ligt, valt op te merken uit de door het BVerwG gegeven motivering van het oordeel. Het BVerwG overweegt: "Die auch die Gerichte bindende Rechtskraft eines Urteils wirkt gem. \& 121 VwGO grundsätzlich nur zwischen den Beteiligten des Rechtsstreits und ihren Rechtsnachfolgern. Die Bundesrepublik Deutschland wird aber von der Bindungswirkung des zwischen dem Kl. und der Stadt S. ergangenen Feststellungsurteils erfaßt. Dabei kann unentschieden bleiben, ob und gegebenfalls inwieweit der Inhalt gerichtlicher Entscheidungen allgemein für Gerichte und Behörden verbindlich ist. ${ }^{1153}$ Die Bindung der Bekl. ${ }^{1154}$ folgt aus den rechtlichen Besonderheiten, durch die sich staatsangehörigkeitsrechtliche Feststellungsurteile von gewöhnlichen, nur eine relative Bindung erzeugenden Feststellungsurteilen unterscheiden. Sie

\footnotetext{
1151 Schătzel, p. 243. Rosenberg/Schwab, p. 73, delen deze mening.

1192 Meyer, NVwZ 1987, p. 26.

1153 De hierboven geciteerde opmerking van Meyer behoudt derhalve haar geldigheid.

1194 I.c. het Bundesverwaltungsamt, een ministerie op federaal niveau.
} 
ergeben, daß die Bundesrepublik Deutschland in die Bindungswirkung eines gegenüber einer Staatsangehörigkeitsbehörde eines Bundeslandes ergangenen Feststellungsurteils über das Bestehen oder Nichtbestehen der deutschen Staatsangehörigkeit einbezogen ist. "liss Deze bindende werking op grond van de vereenzelviging van het betrokken overheidslichaam en de federale staat als "wederpartij" ten opzichte van de klager, is des te verrassender aangezien, zoals vermeld in paragraaf 5.2.2.2, het BVerwG eerder heeft uitgesproken dat het in de vaststellingsprocedure "beiladen" van de "Bundesrepublik Deutschland" niet noodzakelijk is.

Tevens wijdt het BVerwG in de onderhavige uitspraak uit 1993 een interessante overweging aan de vraag of in de twee onderscheidenlijke procedures wel sprake is van dezelfde rechtsstrijd. Het geval wil namelijk dat het vonnis waar de bindende materiële rechtskracht vanuit gaat, is gegeven in een procedure op grond van $\S 43$ VwGO. Het vonnis betreft derhalve een "Feststellungsurteil". De tweede procedure die de klager aanhangig heeft gemaakt, is ingevolge $\$ 42$ VwGO echter een Verplichtungsklage. Derhalve doet zich de vraag voor of er wel kan worden gesproken over eenzelfde rechtsstrijd. Het BVerwG meent van wel en doet daaromtrent de volgende uitspraak: "Im vorliegenden Verfahren erstrebt der $\mathrm{Kl}$. zwar nur noch die Verplichtung der Bekl. zur Erteilung eines Staatsangehörigkeitsausweises. Die Bindungswirkung der Rechtskraft ist aber auch dann zu beachten, wenn der Streitgegenstand nicht identisch ist, die rechtskräftig festgestellte Rechtsfolge jedoch für die spätere Entscheidung über einen anderen Streitgegenstand vorgreiflich wirkt. Das ist bei der Entscheidung über die Erteilung eines Staatsangehörigkeitsausweises hinsichtlich des Besitzes der deutschen Staatsangehörigkeit der Fall. ${ }^{\text {"1156 }}$

\subsubsection{Subsidiaritätsklausel, de samenhang tussen $\S \S 42$ en 43 VwGO}

Tussen de $\S \S 42$ en 43 Verwaltungsgerichtsordnung bestaat een zekere mate van samenhang. In dit verband moet aandacht worden geschonken aan het tweede lid van $\S 43$ VwGO. Hierin wordt namelijk bepaald dat een Feststellungsklage niet mogelijk is "soweit der Kläger seine Rechte durch Gestaltungs- oder Leistungsklage verfolgen kann oder hätte verfolgen können." Een zodanige bepaling als uit $\S 43$ Abs. 2 VwGO staat bekend als een "Subsidiaritätsklausel".

De vraag heeft zich dan ook voorgedaan of het bepaalde in $\$ 43$ lid 2 VwGO ertoe leidt, dat een Feststellungsklage met betrekking tot de Duitse nationaliteit niet mogelijk is, indien de feiten zó liggen dat de klager reeds is geconfronteerd met

\footnotetext{
${ }^{1145}$ BVerwG, U. v. 23.02.1993, NVwZ 1993, p. 782.

${ }^{1136}$ BVerwG, U. v. 23.02.1993, NVwZ 1993, p. 782.
} 
bijvoorbeeld de afwijzing van een "Staatsangehörigkeitsausweis" en derhalve ook de weg van $\$ 42 \mathrm{VwGO}$ kan of had kunnen volgen.

Deze vraag is door het Verwaltungsgerichtshof van Beieren ontkennend beantwoord. ${ }^{1157}$ Het staat, naar het oordeel van het Hof, de betrokkene in beginsel vrij een keuze te maken tussen de rechtsgang volgens $\$ 42$ Abs. 1 VwGO (Verpflichtungsklage) en de rechtsgang volgens \& 43 Abs. 1 VwGO (Feststellungsklage). Het Hof beargumenteert dit door te stellen dat met een Verpflichtungsklage niet geheel hetzelfde kan worden bereikt als met een Feststellungsklage. Immers, alleen door het instellen van het laatste type klacht kan de betrokkene bereiken dat hij een ultieme vaststelling van zijn nationaliteit door de onafhankelijke rechterlijke macht verkrijgt. Een Verpflichtungsklage daarentegen, leidt slechts tot een uitspraak inzake de nationaliteit als resultaat van de beantwoording van een voorvraag.

Het standpunt van het Beierse VGH vindt ondersteuning in de literatuur. Tschira/Schmitt Glaeser schrijven over de werking van $\S 43$ Abs. 2 VwGO dat deze bepaling slechts tot voorrang van een actie uit $\$ 42$ VwGO leidt: "(......), soweit der Rechtsschutz durch Gestaltungs- oder Leistungsklage wenigstens in gleichem Umfang und mit derselben Effektivität gewährleistet ist. ${ }^{1158}$ En het

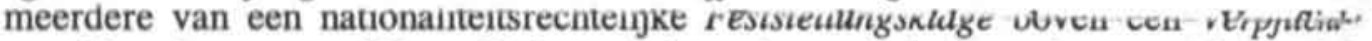
ungsklage brengt von Mangoldt kernachtig onder woorden met de opmerking: "daß nur ein Feststellungsurteil den gesicherten Besitz der deutschen Staatsangehörigkeit bewirken kann, (........). "1159

Het Verwaltungsgericht in Freiburg is enkele jaren later dan het Beierse VGH geconfronteerd met dezelfde vraag en heeft daarbij de Feststellungsklage toelaatbaar geacht op grond van de volgende overweging: "Die in $\$ 43 \mathrm{Abs}$. 2 VwGO normierte Subsidiarität der Feststellungsklage gegenüber Gestaltungs- und Leistungsklagen steht der Zulässigkeit des Feststellungsantrages hier nicht entgegen. Denn die Klägerin ist durch keine Rechtsvorschrift gehalten, eine Klärung ihrer Staatsangehörigkeit auf dem (üblichen) Wege der Beantragung eines Staatsangehörigkeitsausweises bei der zuständigen Behörde herbeizufuhren und dieses Begehren im Streitfalle mit der Verpflichtungsklage weiterzuverfolgen. ${ }^{1160}$

Ook het Bundesverwaltungsgericht is van mening dat, waar het betreft de vaststelling van de nationaliteit, de rechtsgang uit $\S 43 \mathrm{VwGO}$ niet wordt uitgesloten door de eventuele mogelijkheid dat de klager eveneens de weg van een Verpflichtungsklage (om de administratie bijvoorbeeld te dwingen hem een "Staatsangehörigkeitsausweis" te geven) kan of had kunnen volgen. De gedachtengang van het BVerwG is hierbij min of meer dezelfde als die van het Verwaltungsgerichtshof van Beieren.

\footnotetext{
1157 BayVGH, U. v. 05.04.1976, DVBI 1977, p. 108.

1158 Tschira/Schmitt Glaeser, p. 190.

1159 v. Mangoldt, annotatie bij BayVGH, U. v. 07.12.1983, StAZ 1984, p. 167.

1100 VG Freiburg, U. v. 03.10.1978, StAZ 1979, p. 303.
} 
De bredere rechtsbescherming die $\S 43 \mathrm{VwGO}$ biedt, benadrukt het Bundesverwaltungsgericht met de overweging: "(.....), während im Falle der Feststellungsklage das eigentliche Anliegen des Klägers nicht eine Vorfrage, sondern selbst den der Rechtskraft zugänglichen Gegenstand des Rechtsstreits bildet. ${ }^{\text {"1161 }}$

De mogelijkheid een Feststellungsklage aanhangig te maken, wordt derhalve niet verhinderd door de "Subsidiaritätsklausel" in $\$ 43$ Abs. 2 VwGO. ${ }^{1162}$ Een zeer praktijkgericht advies ten aanzien van deze materie geeft Sturm. Hij raadt aan bij de weigering of de intrekking van een paspoort of een soortgelijk document in plaats van een actie uit $\S 42 \mathrm{VwGO}$, die is gericht op de uitreiking van het gewenste document, zonder omhaal direct een Feststellungsklage aanhangig te maken. ${ }^{1163}$

Van praktisch belang is tevens het feit dat het mogelijk is, onder de hierboven geschetste voorwaarden, in één geding zowel een Verpflichtungklage of een Anfechtungsklage als een Feststellungklage aanhangig te maken. Dit gebeurt in nationaliteitszaken soms ook. ${ }^{1164}$ De gecombineerde behandeling van de rechtsmiddelen uit $\S \S 42$ en $43 \mathrm{VwGO}$ wordt mogelijk gemaakt door $\$ 44 \mathrm{VwGO}$ en kan soms, al naar gelang de omstandigheden van het geval, opportuun blijken te zijn. ${ }^{1165}$

\subsection{De overige rechtspraak}

\subsubsection{De civiele procedures}

Zoals eerder al is opgemerkt, kan ook door niet-administratieve rechterlijke instanties zelfstandig op de voorvraag betreffende de nationaliteit worden beslist. ${ }^{1166}$ Op het gebied van het privaatrecht gaat het daarbij vooral om geschillen in de familierechtelijke sfeer, in het bijzonder om echtscheidingszaken. ${ }^{1167}$ Paragraph 606a Zivilprozeßordnung geeft een regeling betreffende de internationale competentie van de Duitse rechter in familierechtelijke zaken. Voor het bepalen

\footnotetext{
${ }^{1161}$ BVerwG, U. v. 21.05.1985, Buchholz 13o $\$ 25$ RuStAG Nr. 5, p. 11 (zie par. 6.3.3.4).

te Zo ook HessVGH, U. v. 11.11.1991, InfAusIR 1992, p. 101: "Offenbleiben kann auch, ob die Kläger im Erfolgsfalle nur die Feststellung des Erwerbs der deutschen Staatsangehörigkeit (.......) oder aber die Aushändigung einer entsprechenden Urkunde hätten verlängen können. Im übrigen bestehen in Fällen vorliegender Art keine durchgreifenden Bedenken gegen das Rechtsschutzinteresse an der Feststellung des Erwerbs der deutschen Staatsangehörigkeit."

ins Sturm, p. 25.

"1G Zie bij voorbeeld BVerwG, U. v. 12.07.1960, DÖV 1960, p. 756; BVerwG, U. v. 06.12.1983, BVerwGE 68, 220; BVerwG, U. v. 09.05.1986, Buchholz 130 825 RuStAG Nr. 6.

${ }_{116}$ Vgl. VG Freiburg, U. v. 03.10.1978, StAZ 1979, p. 302.

${ }^{114}$ Zie par. 4.2.3. Vgl. Rosenberg/Schwab, p. 71; Sturm, p. 25; Tschira/Schmitt Glaeser, p. 194.

${ }^{116} \mathrm{Zie}$ Spellenberg, Internationales Verfahrensrecht in Ehesachen.
} 
van de competentie in echtscheidingszaken geldt dat daarvoor de vraag naar de Duitse nationaliteit of de staatloosheid één van de voorvragen is.

Zo stelt het Landgericht Hamburg in het kader van een echtscheiding (ambtshalve) de Duitse nationaliteit van de verzoekster vast en de daaruit voortvloeiende eigen competentie in de desbetreffende echtscheidingszaak. Hoewel de vrouw in de overtuiging leefde dat zij bij de huwelijkssluiting ruim 24 jaar eerder haar Duitse nationaliteit had verloren, reden waarom zij nooit had geprotesteerd tegen haar "Staatenlosenausweis" (zij had niet de nationaliteit van haar echtgenoot verworven), stelt het Landgericht vast dat zij niettemin al die tijd in het bezit is gebleven van de Duitse nationaliteit. ${ }^{1168}$

Ook bij een adoptie dient de nationaliteit vast te staan. De nationaliteit van de adopterende ouders is namelijk van belang omdat deze de bepalende factor vormt voor de vraag naar welk recht de adoptie dient te geschieden. ${ }^{1169}$

\subsubsection{De strafrechtelijke procedures}

\subsubsection{Strafrecht}

Het Strafgesetzbuch (StGB) kent slechts een zeer beperkt aantal bepalingen waarin het begrip "Deutscher" een rol speelt. Het algemene deel van het wetboek kent twee bepalingen ( $\$ 5$ en $7 \mathrm{StGB}$ ) inzake de internationale reikwijdte van de strafbepalingen. Daarnaast formuleert $\S 100$ StGB de enige delictomschrijving van het Strafgesetzbuch waarin de omschrijving: "Wer als Deutscher, der seine Lebensgrundlage im räumlichen Geltungsbereich dieses Gesetzes hat, (......)" is opgenomen. De $\S 109 \mathrm{~h}$ en $\S 144$ StGB kennen eveneens het begrip "Deutscher"; dat evenwel in de beide bepalingen geen betrekking heeft op de dader van het strafbare feit, maar op het slachtoffer ervan.

Zoals in het gehele Duitse recht wordt ook in het strafrecht het begrip "Deutscher" ingevuld door de afbakening van dat begrip op grond van Artikel 116 Abs. 1 Grundgesetz. ${ }^{1170}$ Alsberg/Nüse/Meyer stellen dat de strafrechter de bevoegdheid mist om een tot Duitser genaturaliseerde persoon te beschouwen als vreemdeling in het geval dat het de strafrechter mocht blijken dat de naturalisatie ten onrechte tot stand is gekomen, bijvoorbeeld indien naderhand is gebleken dat niet aan alle vereisten voor naturalisatie is voldaan. ${ }^{1171}$

\footnotetext{
${ }^{110}$ LG Hamburg, U. v. 13.11.1974, IPRspr $1974 \mathrm{Nr} 206 . \mathrm{Vgl}$. over dit onderwerp Lichter, p. 119.

${ }^{1100}$ Zie LG Stade, B. v. 27.08.1975, IPRspr $1975 \mathrm{Nr} 110$.

${ }^{1170}$ Dreher/Tröndle, p. 38.

un Alsberg/Nüse/Meyer, p. 439.
} 


\subsubsection{Internationale rechtshulp bij strafzaken}

Het uitleveringsrecht bevindt zich op het grensvlak tussen het administratieve recht, het strafrecht en het volkenrecht. ${ }^{1172}$ De rechtsmacht om een beslissing te nemen over een voorgenomen uitlevering is niet in handen gelegd van de administratieve rechter, maar ligt daarentegen bij de gewone rechter. Over de uit het buitenland afkomstige verzoeken tot uitlevering oordeelt op grond van $\S 13$ IRG $^{1173}$ het Oberlandesgericht. Dezelfde Paragraph sluit hoger beroep van dit oordeel uit.

Uitlevering door Duitsland van een persoon aan het buitenland is verboden indien het betreft een "Deutscher im Sinne dieses Grundgesetzes" (Art. 16 en Art. 116 GG). ${ }^{1174}$ Het opwerpen van deze hindernis tot uitlevering door degene wiens uitlevering is verzocht, betekent dat een onderzoek dienaangaande noodzakelijk wordt.

In een enige jaren geleden gepubliceerd overzichtsartikel over internationale rechtshulp schrijft Schomburg dat het Bundesverfassungsgericht het verbod eigen nationalen uit te leveren in zeer strikte zin handhaaft. ${ }^{1175}$ Het BVerfG heeft bijvoorbeeld gesteld dat bij uitleveringsverzoeken zowel de "Staatsanwaltschaft" (openbaar ministerie) als het gerecht de (uit Artikel 16 Abs. 2 GG voortvloeiende) verplichting hebben om ambtshalve te controleren of de betrokkene geen "Deutscher im Sinne dieses Grundgesetzes" is. ${ }^{1176}$ Wordt een zodanig onderzoek achterwege gelaten dan resulteert dit in een schending van het grondrecht uit Artikel 16 Abs. 2 GG. ${ }^{1177}$

Kan niet met zekerheid worden vastgesteld of de betrokkene inderdaad geen "Deutscher im Sinne dieses Grundgesetzes" is, dan mag naar algemeen wordt aangenomen in de literatuur geen uitlevering plaatsvinden. ${ }^{1178}$

\subsubsection{Bindende werking van het vonnis}

Hierboven ben ik reeds ingegaan op de betekenis van de materiële rechtskracht van een vonnis. Voorop staat de algemene regel dat de materiële rechtskracht alleen het dictum ("Tenor") kan betreffen. ${ }^{1179}$ Slechts het dictum heeft bindende werking

\footnotetext{
IIT v. Bubnoff, p. 9.

ins Gesetz über die internationale Rechtshilfe in Strafsachen van 23.12.1982 (BGB1. I p. 2071).

${ }^{114}$ Zie v. Bubnoff, p. 11 en 56; Maunz/Dürig, Art. 16 GG.

urs Schomburg, NStZ 1992, p. 355.

Zie BVerfG, B. v. 10.07.1958, BVerfGE 8, 81 [84]; BVerfG, B. v. 12.02.1964, BVerfGE 17, 224

[227]. Het openbaar ministerie verricht inderdaad een zodanig onderzoek: BVerwG, U. v. 21.05.1985. Buchholz 13o \& 25 RuStAG Nr. 5 (par. 6.3.3.4).

tit BverfG, B. v. 22.06.1990, NJW 1990, p. 2193. Vgl. Giegerich, ZaöRV 1992, p. 369.

"17 Maunz/Dürig, Art. 16 GG, aant. III; v. Bubnoff, p. 58.

"1刃 $\mathrm{Vgl}$. voor privaatrechtelijke vonnissen $\$ 322 \mathrm{ZPO}$.
} 
tussen partijen. ${ }^{1180}$ De rechtsoverwegingen die hebben geleid tot het vonnis, derhalve inclusief de beoordeling van de feiten en de juridische voorvragen, hebben daarentegen nooit rechtskracht. ${ }^{1181}$

Omdat over de nationaliteit wordt geoordeeld in een voorvraag, staat in een civiele - of in een strafzaak het oordeel daarover nooit in het dictum. Dit leidt ertoe dat in deze uitspraken geen sprake kan zijn van enige materiële rechtskracht met betrekking tot de beslissing over de nationaliteit. Het doet vervolgens niet ter zake of in een volgend rechtsgeding wederom de rechtsstrijd zich afspeelt tussen dezelfde partijen. Schätzel komt, op grond van het feit dat de materiële rechtskracht beperkt blijft tot het dictum, tot de volgende uitspraak: "All diese Gerichte müssen sich daher zunächst über die Staatsangehörigkeit klar werden. Dies geschieht jedoch, auch wenn die Entscheidung noch so ausführlich begründet wird, nur "incidenter", d.h. die Entscheidung schafft in Sachen der Staatsangehörigkeit keine Rechtskraft, und kein Gericht ist gehindert, diese Frage anders zu entscheiden. ${ }^{n 1182}$

\subsection{De beslissingen van het Bundesverfassungsgericht}

\subsubsection{Algemene beschouwingen}

Een Verfassungsbeschwerde kan, onder de voorwaarde die is vermeld in paragraaf 4.2 .4 , door een ieder worden ingesteld die van mening is door "(.....) die öffentliche Gewalt in einem seiner Grundrechte oder in einem seiner in Artikel 20 Abs. 4, Artikel 33, 38, 101, 103 und 104 des Grundgesetzes enthaltenen Rechte verletzt wu sein, (.....). " ( $\$ 90$ Abs. 1 BVerfGG $)^{1183}$

Door de begrenzing die $\S 90$ Abs. 1 BVerfGG stelt, is de competentie van het Bundesverfassungsgericht beperkt tot het oordelen over enerzijds een mogelijke aantasting van grondrechten (alleen die uit het Grundgesetz) ${ }^{1184}$ en anderzijds een mogelijke aantasting van de rechten die besloten liggen in de afzonderlijk in $\$ 90$ Abs. 1 BVerfGG genoemde Artikelen 20 lid 4, 33, 38, 101, 103 en 104 Grundgesetz.

De grondrechten uit het Grundgesetz die onder bescherming van een Verfassungsbeschwerde kunnen worden gebracht, zijn de rechten genoemd in de Artikel 1-17 en 19 GG. ${ }^{1185}$ De rechten die aan de orde zijn in de Artikelen 20 Abs. 4,

\footnotetext{
${ }^{1180}$ In het privaatrecht de rechtsopvolgers van partijen incluis, \$ $325 \mathrm{ZPO}$.

118 Rosenberg/Schwab, p. 934; Roxin, p. 307.

118 Schătzel, p. 244.

$110 \mathrm{Vgl}$. Pestalozza (II), p. 169 e.v..

119 Zuck, p. 128; zie $\$ 95$ Abs. 1 BVerfGG.

uss Pestalozza (II), p. 175; Zuck, p. 129.
} 
33, 38, 101, 103 en 104 GG staan in de literatuur bekend onder de samenvattende titel: "grundrechtsähnliche Rechte". ${ }^{1186}$

De bovengenoemde grondrechten en de daarmee gelijkgestelde rechten dienen derhalve als een kapstok waaraan de klager zijn klacht moet ophangen, wil hij toegang tot het Bundesverfassungsgericht verkrijgen. ${ }^{1187}$ Het is daarbij niet mogelijk een Verfassungsbeschwerde aanhangig te maken voor een toekomstige, hypothetische situatie. ${ }^{1188}$ Het Bundesverfassungsgericht beperkt de toetsing niet tot de middelen die door de verzoeker worden aangevoerd, maar toetst de bestreden beslissing ambtshalve. ${ }^{1189}$

In het geval dat in een Verfassungsbeschwerde tegen een rechterlijke uitspraak $^{1190}$ het BVerfG in zijn oordeel schending van grondrechten of een daarmee gelijkgesteld recht vaststelt, heft het BVerfG de bestreden rechterlijke beslissing waarin de schending plaatsvindt op ( $\$ 95$ Abs. 2 BVerfGG). Het Bundesverfassungsgericht stelt vervolgens niet zelf een nieuwe beslissing in de plaats van de vernietigde beslissing, maar verwijst de zaak naar "ein zuständiges Gericht" ( $\$ 95$ Abs. 2 BVerfGG). Het BVerfG mist namelijk de competentie de zaak af te doen in de vorm van een definitieve beslissing. ${ }^{1191}$ Met betrekking tot de taak en doelstelling van het Bundesverfassungsgericht heeft Geiger reeds in 1954 opgemerkt: "Art. 93 Abs. $1 \mathrm{Nr} 1 \mathrm{GG}$ bestimmt, daß das BVerfG entscheidet "über die Auslegung des Grundgesetzes aus Anlaß von Streitigkeiten....". Die Verhandlungen des Parlamentarischen Rates ergeben eindeutig, daß man diese Formulierung bewußt gewählt hat, um zu verhüten, daß das Gericht den konkreten Verfassungsstreit (ähnlich wie in einem Zivilprozeß) durch Verurteilung des "Beklagten" entscheidet; es sollte auf die Auslegung des GG beschränkt bleiben und damit nur mittelbar den konkreten Streit entscheiden. Oder ganz einfach ausgedrückt: Aufgabe des BVerfG ist nach unserem GG die Auslegung der Sätze unsere Verfassung (.....).

Desondanks komt het uit praktische overwegingen een zeer enkele keer voor dat het BVerfG wél zelf de zaak definitief afhandelt en niet verwijst naar een andere rechterlijke instantie. Dit zijn zeldzame gevallen, waarvan de gang van zaken in de literatuur wordt gekritiseerd. ${ }^{1193}$

\footnotetext{
${ }^{14} \mathrm{~V}$ gl. Eyermann/Fröhler, p. 171; Zuck, p. 127 en 131.

tin $\mathrm{Vgl}$. Schlaich, p. 13 en 125 ; Zuck, p. 132.

tuil Schramm/Schmidt-Troje, p. 342.

1ts BVerfG, B. v. 15.04.1980, BVerfGE 54, 53 [67].

${ }^{1190}$ Zie par. 4.2.4.

${ }^{19}$ Pestalozza (II), p. 200. De terugverwijzing hoeft niet plaats te vinden naar de instantie die als laatste over de zaak heeft geoordeeld, maar kan tevens naar een rechter in eerste aanleg.

I1) Geiger, NJW 1954, p. 1058.

11 Pestalozza (II), p. 200 en 201; Schlaich, p. 199.
} 


\subsubsection{Nationaliteit}

Het wel of niet bezitten van de Duitse nationaliteit is een vraag die niet als zodanig binnen de hierboven geschetste competentiegrenzen van het Bundesverfassungsgericht valt. Een slechts op vaststelling van de Duitse nationaliteit gerichte rechtsklacht zal door het BVerfG niet kunnen worden behandeld. Een zodanige behandeling zou immers niet stroken met de, tot de opgesomde grondrechten en de daaraan verwante rechten, beperkte toetsing die voor het Bundesverfassungsgericht openstaat. Deze restrictie heeft Bachof als volgt kernachtig geformuleerd: "Bei der Verfassungsbeschwerde ist Streitgegenstand die Frage, ob der Beschwerdeführer in einem Grundrecht verletzt wurde. "1194

Op vaststelling van het bezit van de Duitse nationaliteit gerichte klachten heeft het BVerfG dan ook als zodanig afgewezen met de overwegingen: "Der Antrag, das Bundesverfassungsgericht selbst möge die deutsche Staatsangehörigkeit feststellen, ist allerdings unstatthaft. Mit der Verfassungsbeschwerde können nur die aus $\S$ 95 BVerfGG ersichtlichen Ziele verfolgt werden. Gemä $\beta$ \& 95 Abs. 2 BVerfGG ist das Bundesverfassungsgericht aber grundsätzlich nur befugt, die angegriffenen Entscheidungen aufzuheben und die Sache an ein zuständiges Gericht zurückzuverweisen. "1195 Daarnaast is ook wel overwogen: "Der Antrag des Beschwerdeführers, das Bundesverfassungsgericht selbst möge seine deutsche Staatsangehörigkeit feststellen, ist unstatthaft und daher $z u$ verwerfen. ${ }^{n 1196}$

Tegenover hetgeen in het voorgaande is opgemerkt, staat echter dat het BVerfG in een Verfassungsbeschwerde op impliciete wijze wél een oordeel velt over het mogelijk bezit door de klager van de overkoepelende staat "Deutscher im Sinne des Grundgesetzes" (waaronder tevens de categorie van personen valt die de Duitse nationaliteit bezit), ${ }^{1197}$ indien deze staat een noodzakelijke voorwaarde is voor de uitoefening van de rechten waarover het BVerfG heeft te waken. Het voldoen aan de hoedanigheid "Deutscher im Sinne des Grundgesetzes" is namelijk in het kader van sommige door het Grundgesetz gewaarborgde rechten een voorwaarde, zodat het kan voorkomen dat het BVerfG genoodzaakt is zich te buigen over deze

\footnotetext{
${ }^{1194}$ Bachof, NJW 1954, p. 511.

${ }^{1199}$ BVerfG, B. v. 15.04.1980, BVerfGE 54, 53 [66].

1196 BVerfG, B. v. 21.10.1987, BVerfGE 77, 137 [146].

$1197 \mathrm{Vgl}$. Alexy, NJW 1989, p. 2850.
}

Maar niet een ieder die onder het begrip "Deutscher im Sinne des Grundgesetzes" valt, bezit de Duitse nationaliteit: zie par. 4.1.4. BVerwG, U. v. 09.06.1959, BVerwGE 8, 340 [341], stelt ter zake: "Das Grundgesetz unterscheidet also zwischen zwei Gruppen von Deutschen: denen mit deutscher Staatsangehörigkeit und solchen ohne deutsche Staatsangehörigkeit. " In dezelfde uitspraak merkt het BVerwG op: "Der vom Grundgesetz geschaffene Status der Deutschen ohne Staatsangehörigkeit (niet helemaal correct; sommigen zijn in het bezit van een nationaliteit, maar dan niet de Duitse; bew.) ist seiner Natur nach vorilbergehender Art. Schon mit Rüicksicht auf den internationalen Rechtsverkehr muß die Staatsangehörigkeit dieser Gruppe der Deutschen eines Tages geregelt wenden. " 
hoedanigheid en onder omstandigheden derhalve over de kwestie van het bezit van de Duitse nationaliteit.

Uit het bovenstaande volgt derhalve dat, als gevolg van de (beperkte) aard van de werkzaamheden van het Bundesverfassungsgericht, een grondrechtelijk georienteerde kapstok aanwezig dient te zijn waaraan de toetsing van het wel of niet bezitten van de Duitse nationaliteit kan worden opgehangen. Al toetsend of er een grondrecht is geschonden, oordeelt het BVerfG op impliciete, maar desalniettemin in sommige gevallen op zeer uitdrukkelijke, wijze over het bezit van de Duitse nationaliteit.

De meerderheid van de uitspraken inzake een Verfassungsbeschwerde waarin de nationaliteit een rol speelt, betreft uitleveringszaken. ${ }^{1198}$ De toetssteen vormt hier de eventuele schending van Artikel 16 Abs. 2 GG. Het BVerfG is in deze gevallen genoodzaakt het bezit van de Duitse nationaliteit ${ }^{1199}$ te toetsen dan wel te onderzoeken of de betrokkene "Statusdeutscher" ${ }^{m 1200}$ is.

$\mathrm{Bij}$ andere dan met het uitleveringsrecht verband houdende schendingen van grondrechten waarvan de problematiek is terug te voeren op nationaliteitskwesties, is wel een beroep gedaan op Artikel 3 Abs. 1 en 3 GG, ${ }^{1201}$ of op Artikel 16 Abs. $1 \mathrm{GG}^{1202}$.

Ter illustratie wordt hieronder eerst de zaak waarin Artikel 16 Abs. 1 GG een hoofdrol speelt, toegelicht. In dat artikel is daarbij cruciaal hetgeen de eerste zin van het eerste lid stelt, namelijk: "Die deutsche Staatsangehörigkeit darf nicht entzogen werden. " Een secundaire rol is in deze zaak weggelegd voor Artikel 116 Abs. 1 GG. Na bespreking van dit geval zal vervolgens aandacht worden geschonken aan één van de zaken waarin Artikel 3 en Artikel 116 Abs. 2 GG een rol spelen.

In de zaak waarin de beweerde grondrechtenschending is gelegen in schending van Artikel 16 Abs. 1 GG wordt de eigenlijke kern van de problematiek gevormd door de vraag of de betrokkene, die de Verfassungsbeschwerde aanhangig heeft gemaakt, onder Artikel 116 Abs. 1 GG valt. De zaak speelt zich af voor de hereniging van

\footnotetext{
Zie over uitlevering ook par. 5.3.2.2.

$1.9 \mathrm{~T}$ Zie BVerfG, B. v. 28.05.1952, BVerfGE 1, 322; BVerfG, B. v. 12.12.1952, BVerfGE 2, 98; BVerfG, B. v. 30.01.1953, BVerfGE 2, 115; BVerfG, U. v. 09.11.1955, BVerfGE 4, 322; BVerfG, B. v. 10.07.1958, BVerfGE 8, 81; BVerfG, B. v. 22.06.1990, NJW 1990, p. 2193.

Zie BVerfG, B. v. 12.02.1964, BVerfGE 17, 224. (Voor het begrip Statusdeutscher: zie par. 4.1.4.).

BVerfG, B. v. 14.02.1968, BVerfGE 23, 98; BVerfG, B. v. 15.04.1980, BVerfGE 54, 53.

BVerfG, B. v. 21.10.1987, BVerfGE 77, 137.
} 
beide Duitse staten op 3 oktober 1990 en heeft betrekking op een persoon die, komend uit de DDR, zich in het toenmalige West-Duitsland heeft gevestigd. ${ }^{1203}$

De nationaliteitsrechtelijke vraag spitst zich toe op het volgende: is iemand in het bezit van de Duitse nationaliteit indien hij deze Duitse nationaliteit heeft verworven ten gevolge van naturalisatie in de DDR op een wijze die het Reichs- und Staatsangehörigkeitsgesetz, noch één van de Gesetze zur Regulung von Fragen der Staatsangehörigkeit, noch enige andere in de BRD erkende naturalisatieregeling ${ }^{1204}$ kent?

Deze vraag is op de volgende wijze beantwoord. Voorop stelt het BVerfG een algemene (rechts)regel die dient te gelden bij de beoordeling van alle, aan het systeem van het RuStAG en de aanverwante regelgeving vreemde, naturalisaties in de DDR. ${ }^{1205}$ Daarna is het BVerfG overgegaan tot de toetsing van het concreet voorliggende geval aan de zojuist opgestelde regel. In het geval van deze klager komt het BVerfG tot de uitdrukkelijke vaststelling dat hij de Duitse nationaliteit bezit. ${ }^{1206}$

Gezien de competentiebeperking van het Bundesverfassungsgericht tot de schending van de eerder vermelde grondrechten is de vraag die vervolgens noodzakelijkerwijs rijst, de vraag welk grondrecht is geschonden doordat deze persoon, naar het BVerfG is gebleken, ten onrechte niet is behandeld ais in het bezit van de Duitse nationaliteit. Eventueel kan de conclusie luiden dat meer dan één grondrecht is geschonden, maar veel relevantie heeft dat verder niet. In de uitspraak blijkt dat het BVerfG in het niet erkennen van het bezit van de Duitse nationaliteit van een persoon die daarentegen die nationaliteit wél bezit, een vorm van (de facto)

${ }^{1203}$ Zie hierover tevens De Groot, p. 20; Hecker, ArchVR 1991, p. 40 e.v., die in deze bijdrage alsnog forse kritiek levert op de in de vorige voetnoot vermelde uitspraak van het BVerfG; Makarov/v. Mangoldt, Deel 2, Art. 116 GG, Rdnr. 15; Tratnik, p. 156 en 157.

${ }^{1204}$ Zie bijvoorbeeld BVerfG, B. v. 28.05.1952, BVerfGE 1, 322, waar het gaat om de nationaliteit van iemand uit Bohemen (voorheen Tsjechoslowakije, per 01.01.1993 ligt dit gebied in Tsjechiē). Zie ook BVerfG, B. v. 12.12.1952, BVerfGE 2,98 en Hailbronner/Renner, p. 20,382 e.v.. Na deze uitspraken heeft de wetgever zich over deze problematiek gebogen en in 1955 een regeling getroffen met het "Gesetz zur Regelung von Fragen der Staatsangehörigkeit". Vgl. ook de in par. 6.3.2 besproken jurisprudentie.

${ }_{120}$ Deze regel luidt: "(..) folgt aus dem Gebot der Wahrung der Einheit der deutschen Staatsangehörigkeit (Art. 116 Abs, 1, 16 Abs. 1 GG), das eine normative Konkretisierung des im Grundgesetz enthaltenen Wiedervereinigungsgerbots ist, daß dem Enwerb der Staatsbürgerschaft der Deutschen Demokratischen Republiek fur die Rechtsordnung der Bundesrepublik Deutschland in den Grenzen des. ondre public die Rechtswirkung des Enwerbs der deutschen Staatsangehörigkeit beizumessen ist." BVerfG, B. v. 21.10.1987, BVerfGE 77, 137 [149].

Reeds eerder is door een hoogste rechter in westelijk Duitsland een uitspraak gedaan over de rechtskracht van een niet aan het RuStAG conforme naturalisatie in het oosten. Zie BGH, B. v. 23.02.1954, BGHst 5, 317 [322] en naar aanleiding hiervan Niese, JZ 1955, p. 321.

${ }_{1206}$ Rôper, DŐV 1988, p. 488, stelt dat de onderhavige uitspraak van het BVerfG relevantie heeft gehad voor $5 \%$ van de bevolking in de voormalige DDR. Het gaat daarbij volgens Rōper om ruim 800.000 mensen. 
ontneming van de nationaliteit onderkent en derhalve een schending van Art. 16 Abs. 1 GG. Het BVerfG stelt dienaangaande: "Die Ablehnung der Feststellung seiner deutschen Staatsangehörigkeit wirkt sich wie eine Entziehung der Staatsangehörigkeit aus. "1207

Voluit wordt in het dictum als grondrechtsschending geconstateerd: "Die angegriffenen Entscheidungen verletzen den Beschwerdeführer in seinen Grundrechten aus Art. 16 Abs. 1 Satz 1 i.V.m. Art. 116 Abs. 1 GG sowie in seinem Anspruch auf Gleichbehandlung aus Art. 3 Abs. 1 GG i.V.m. den den Deutschen vorbehaltenen Grundrechten. "1208 De vaststelling dat de betrokkene de Duitse nationaliteit bezit, staat niet in het dictum aangezien de nationaliteitskwestie slechts een voorvraag ten opzichte van de grondrechten betreft en (zie boven) het dictum slechts de geconstateerde grondrechtenschending kan betreffen. In een geval als het onderhavige wordt dan ook door het BVerfG een schending van andere grondrechten geconstateerd dan bij de zaken waaraan een uitlevering ten grondslag ligt.

In de hier aan de orde gestelde zaak stelt het BVerfG derhalve, ter beantwoording van een voorvraag, met zoveel woorden vast dat de betrokkene de Duitse nationaliteit bezit, zodat het BVerfG de zaak materieel nationaliteitsrechtelijk beschouwd volledig heeft uitgewerkt. Echter, aangezien het BVerfG de bevoegdheid mist de zaak ook in formeel opzicht volledig zelf af te doen, is i.c. het BVerfG overgegaan tot terugverwijzing naar het Bundesverwaltungsgericht.

Als gezegd, Artikel 116 GG alléén vormt een onvoldoende grondslag voor een Verfassungsbeschwerde. In het geval dat de kwestie in wezen om de interpretatie van Artikel 116 GG gaat, dient de klacht derhalve te worden gefundeerd op de schending van bepaalde, in het Grundgesetz genoemde, rechten waarvoor het Bundesverfassungsgericht bescherming biedt. Bij dit alles komt vanzelfsprekend ook nog het vereiste dat het moet gaan om rechten die de klager toekomen. ${ }^{1209}$

In de hieronder aan de orde te stellen $z^{2 a k^{1210}}$ gaat het, volgens de klagers, in essentie om een interpretatie van Artikel 116 Abs. 2 GG. Ook het Landgericht en Oberlandesgericht, voor welke instanties de zaak eerst is behandeld, zijn van die

\footnotetext{
BVerfG, B. v. 21.10.1987, BVerfGE 77, 137 [147].

Het Bundesverwaltungsgericht volgde al eerder de gedachtengang dat indien iemand de Duitse nationaliteit bezit, maar wordt geschonden in de rechten die hem als zodanig toekomen, dit feitelijk een schending van Art. 16 Abs. 1 GG betekent. Vgl. BVerwG, U. v. 19.11.1954, BVerwGE 1, 234 [239]; BVerwG, U. v. 16.09.1966, DÖV 1967, p. 95. In 1980 stelt Schleser, p. 326, naar aanleiding van deze laatste uitspraak met betrekking tot de weigering van een "Staatsangehörigkeitsausweis" aan iemand die ingevolge het bezit van de Duitse nationaliteit wel degelijk recht heeft op een dergelijk document: "Nach dieser Entscheidung hat die Versagung der Urkunde praktisch entziehungsähnliche Wirkung. wodurch die Versagung sich in die Nähe der durch Artikel 16 des Grundgesetzes verbotenen Maßnahmen bringt."

BVerfG, B. v. 21.10.1987, BVerfGE 77, 137 [147].

Iass Vest. Pestalozza (II), p. 175.

${ }^{120}$ BVerfG, B. v. 14.02.1968, BVerfGE 23, 98.
} 
veronderstelling uitgegaan. Het Bundesverfassungsgericht, ten slotte, komt tot de uitspraak dat Artikel 116 Abs. 2 GG in dit geval in het geheel niet van toepassing is.

Een bijkomende moeilijkheid in deze zaak is tevens geweest dat niet degene wiens nationaliteit in het geding is de klacht heeft ingesteld, maar dat dit is gedaan door derden-belanghebbenden ten aanzien van wie natuurlijk niet dezelfde grondrechten kunnen zijn geschonden.

De zaak heeft, in het kader van een erfrechtelijke kwestie, betrekking op de nationaliteitsvaststelling van een overleden persoon. De klagers, die uiteindelijk het BVerfG inschakelen, zijn de gepretendeerde, maar miskende erfgenamen. $\mathrm{Zij}$ maken aanspraak op de erfenis van hun tijdens de tweede wereldoorlog gestorven oom, waarbij voor hen van doorslaggevend belang blijkt of op de afhandeling van de erfenis Duits erfrecht kan worden toegepast. De toepasselijkheid van Duits erfrecht zou het gevolg zijn van het bezit van de Duitse nationaliteit door de overledene.

Nadat de zaak tot en met het Oberlandesgericht voor de erfgenamen op onfortuinlijke wijze is verlopen, wordt een beroep gedaan op het Bundesverfassungsgericht. De klagers laten hun Verfassungsbeschwerde steunen op de bewering dat ten opzichte van hen Artikel 3 GG (het gelijkheidsbeginsel) wordt geschonden.

In deze zaak stelt het BVerfG niet het behoud of het verlies van de Duitse nationaliteit door de overledene vast. Het stelt wel, net als in de hierboven behandelde casus inzake de verlening van de Duitse nationaliteit door de DDR, algemene regels op aan de hand waarvan de beoordeling over de nationaliteit dient plaats te vinden. ${ }^{1211}$

$\mathrm{Na}$ vervolgens de constatering te hebben gedaan dat de zojuist geformuleerde regels niet de rechtsoverwegingen zijn geweest die het Oberlandesgericht ten

\footnotetext{
1211 Deze rechtsregels luiden: "(...) laßt sich Art. 116 Abs. 2 GG nur in den Fällen anwenden, in denen die Betroffenen die Möglichkeit haben oder hatten, ihren Willen zu bekunden und damit den einen oder den anderen der in dieser Vorschrift genannten Tatbestände zu erfullen. Eine solche Möglichkeit bestand fïr die Verfolgten, die vor dem 8. Mai 1945 verstorben sind, nicht. Die Staatsangehörigkeit dieser Verfolgten fallt somit nicht unter Art. 116 Abs. 2 GG. Vielmehr haben sie ihre deutsche Staatsangehörigkeit nicht verloren, weil die 11. Verordnung von Anfang an nichtig war. Die Verfolgten, die vor dem 8. Mai 1945 verstorben sind, können nicht anders behandelt werden, als diejenigen, die das Inkrafttreten des Grundgesetzes erlebt haben. (.......). Auch bei den von der II. Verordnung betroffenen Verfolgten, die vor dem 8. Mai 1945 verstorben sind, ist daher in Betracht zu ziehen, daß sie mōglicherweise ihre deutsche Staatsangehörigkeit aufgeben wollten. (.......). Nur wenn sich konkrete Anhaltspunitte dafiur ergeben, daß die Betroffenen nach dem Zusammenbruch des nationalsozialistischen Regimes und im Bewubtsein der Möglichkeit, in ein freies, rechtsstaatlich-demokratisches Deutschland zurüokkehren zu können, von dieser Moglichkeit keinen Gebrauch mehr hätten machen wollen, wird man annehmen können, daß sie auf ihre deutsche Staatsangehörigkeit verzichten wollten. " BVerfG, B. v. 14.02.1968, BVerfGE 23, 98 [111, 112].
} 
grondslag heeft gelegd aan zijn beslissing, ${ }^{1212}$ volgt vernietiging ${ }^{1213}$ en verwijzing. Het BVerfG vermeldt nog in de uitspraak: "Das Amtsgericht wird den Antrag auf Erteilung eines Erbscheins unter den aufgezeigten Gesichtspunkten erneut zu prüfen haben. ${ }^{" 1214}$

\subsubsection{Bindende werking van de uitspraak van het BVerfG}

\subsubsection{Algemene beschouwingen}

In paragraaf 5.1 heeft reeds summierlijk vermelding gevonden dat in het verleden de onderscheidenlijke hoogste rechterlijke instanties in de Bondsrepubliek (incidenteel) ten aanzien van dezelfde rechtsvraag tot verschillende rechtsopvattingen zijn gekomen. Omdat over de (mate van) bindende werking van uitspraken van het Bundesverfassungsgericht in de Duitse rechtspraak en literatuur geen overeenstemming bestaat, is het in het kader van de onderhavige bespreking van de Verfassungsbeschwerde zinvol op deze gebeurtenissen iets uitgebreider in te gaan.

Zo is het met betrekking tot een bepaalde nationaliteitsrechtelijke vraag voorgekomen dat het Bundesverwaltungsgericht heeft geoordeeld: "Auch wenn der Meinung von Geiger ${ }^{1215}$ gefolgt wird, würde die bindende Kraft der Entscheidung des Bundesverfassungsgerichts vom 12. Dezember 1952 sich nicht auf die darin geäußerte Rechtsansicht erstrecken, daß ein Deutscher seine deutsche Staatsangehörigkeit unter Umständen dadurch verlieren könne, daß er nicht ständig den Willen bekunde, seine deutsche Staatsangehörigkeit zu behalten. Denn diese Rechtsansicht betrifft nicht das Verfassungsrecht, sondern das Staatsangehörigkeitsrecht. Auf die Auslegung des Staatsangehörigkeitsrechts kann sich nach der Auffassung des Senats ${ }^{1216}$ die bindende Kraft der Entscheidung des Bundesverfassungsgerichts über den Entschiedenen Einzelfall hinaus (......) nicht erstrecken. ${ }^{\prime 1217}$

\footnotetext{
${ }^{1212}$ Hetgeen niet verwonderlijk is, aangezien het door het BVerfG in de onderhavige uitspraak opgestelde rechtsoordeel getuigde van een nieuwe interpretatic. Vgl. Hecker, StAZ 1986, p. 338: "Bis 1968 nahm die h. M. nämlich Verlust der deutschen Staatsangehörigkeit durch die Ausbürgerungen an. " Op grond van het feit dat de klagers zijn geschonden in de hun uit Art. 3 Abs. 1 en 3 GG toekomende rechten.

i24 BVerfG, B. v. 14.02.1968, BVerfGE 23, 98 [112].

I21s Een toemalig lid van het Bundesverfassungsgericht, die in NJW 1954, p. 1060, schreef: "Das $B V e r f G$ hat ganz eindeutig zum Ausdruck gebracht, daß es eine Bindung aller Verfassungsorgane, Gerichte und Verwaltungsbehörden des Staates auch an die tragenden Gründe seiner Entscheidung annimmt."

${ }_{1216}^{10}$ De Senat van het Bundesverwaltungsgericht dat deze uitspraak geeft.

a' BVerwG, U. v. 30.10.1954, BVerwGE 1, 213 [215]; zie Schătzel, die zich bij deze opvatting ansluit, p. 242. De uitspraak van het Bundesverfassungsgericht waarnaar het Bundesverwaltungsgericht in dit citaat verwijst, is BVerfG, B. v. 12.12.1952, BVerfGE 2, 98.
} 
Ook nadien blijken de rechtsopvattingen van het Bundesverfassungsgericht en van het Bundesverwaltungsgericht niet synchroon te lopen. Eenzelfde rechtsvraag wordt verschillend beantwoord. ${ }^{1218}$

Eveneens met betrekking tot een nationaliteitsrechtelijke vraag waarover het Bundesverfassungsgericht zich reeds had uitgelaten, is het voorgekomen dat, ditmaal, het Bundesgerichtshof tot een andersluidende beslissing over het bezit van de Duitse nationaliteit is gekomen. ${ }^{1219}$ Göhring concludeert naar aanleiding van dit geval: "Da die unerfreuliche Tatsache, daß BVerfG und BGH in der gleichen Rechtsfrage gegenteilige Ansichten vertreten, nicht einmalig ist und sich jederzeit wiederholen kann, wird sich der Gesetzgeber mit der Frage befassen müssen, wie die Einheitlichkeit der Rechtsprechung und Rechtsanwendung bei divergierenden Grundsatzentscheidungen dieser Bundesgerichte sicher gestellt werden kann, (.........). ${ }^{11220}$

De door Göhring bepleite wetswijziging is een wens gebleven. Deze constatering leidt aan de ene kant tot de gevolgtrekking dat het probleem, in theorie althans, onopgelost is gebleven en dat er zodoende nog steeds sprake is van een lacune in de regelgeving. Aan de andere kant mag wonden verondersteld dat deze theoretische onvolkomenheid in de praktijk geen problemen oplevert, aangezien er vanuit mag worden gegaan dat, zou dit anders zijn, wel degelijk een wettelijke regeling zou zijn ontwikkeld.

Sinds het Bundesverfassungsgericht in 1951 met zijn werkzaamheden heeft aangevangen, is in de literatuur naar aanleiding van enkele gevallen als de bovenstaande waarin andere hoogste rechtsinstanties blijk gaven van andere rechtsopvattingen dan het $\mathrm{BVerfG},{ }^{1221}$ gediscussieerd over de preciese reikwijdte van de

${ }^{1218}$ BVerfG, U. v. 09.11.1955, BVerfGE 4, 322: tegenstrijdig aan BVerwG, U. v. 30.10.1954, BVerwGE 1, 206. (Over de vraag of een nog in Duitsland wonende ex-Oostenrijker na herstel van de Oostenrijkse staat de Oostenrijkse of Duitse nationaliteit heeft). Het BVerfG stelt: "Das Bundesverfassungsgericht halt die Schlußffolgerungen des Bundesverwaltungsgericht \{uit BVerwGE 1, 206\} für unzutreffend. Zutreffend ist allerdings die Feststellung, daß die sich aus der Loslösung Österreichs aus dem Staatsverbande des Deutschen Reiches ergebenden Fragen der Staatsangehörigkeit bisher im deutschen Recht nicht geregelt sind. "

${ }^{1219}$ BGH, B, v. 29.12.1953, BGHst 5, 230. In strijd met BVerfG, B. v, 30.01.1953, BVerfGE 2, 115. Het BGH stelt kortweg: "Der gegenteiligen Auffassung vermag sich der erkennende Senat nicht anzuschließen. Sie wurde vom Bundesverfassungsgericht in seinem Beschluß vom 30. Januar 1953 $\{=$ BverfGE 2, 115\} vertreten; er ist indes nicht gemäß $\$ 31$ BVGG verbindlich. " De nationaliteitsrechtelijke kwestic waar het hier om handelt, is eveneens (zie voetnoot 1218) in het "Gesetz zur Regelung won Fragen der Staatsangehörigkeit" uit 1955 afdoende geregeld. Wat echter geen regeling heeft gevonden is het feit dat de hoogste rechterlijke instanties niet aan elkaars rechtsoordelen zijn gebonden. ${ }_{1220}$ Gohring, NJW 1954, p. 1063.

Im Vogel, p. 574 en 601 , geeft als voorbeeld een rechtsvraag inzake ambtelijke dienstbetrekkingen waarover BVerfG en BGH verschillend oordeelden. Vgl. Kerbusch, p. 138-140. 
bindende werking van de uitspraken van het BVerfG. ${ }^{12 m}$ Het eerste dat aan deze discussie opvalt, is dat het hoogtepunt ervan in de jaren vijftig heeft gelegen, dus in de tijd waarin Verfassungsgerichtbarkeit ${ }^{1223}$ en het Gesetz über das Bundesverfassungsgericht nieuwe verschijnselen zijn. Volstrekt voor de hand liggend is dat in een aanvangsperiode de mogelijkheden en grenzen van het nieuwe type rechtspraak nog onduidelijk zijn en tot exploratie uitnodigen. ${ }^{1224}$ Een tweede facet aan de discussie dat de aandacht trekt, is dat deze in de loop van de jaren aan scherpte heeft verloren. De andere gerechten zien op min of meer vrijwillige basis af van uitspraken die afwijken van een eerder uitgezette lijn door het Bundesverfassungsgericht. ${ }^{1225}$

\subsubsection{Reikwijdte van de bindende werking}

Als gezegd, is in de literatuur een uitgebreide discussie gevoerd over de omvang van de bindende werking van de uitspraken van het BVerfG op een Verfassungsbeschwerde. Bij een nadere beschouwing blijkt dat de kwestie uiteenvalt in twee verschillende onderwerpen. Het eerste daarvan heeft betrekking op de vraag wie, personen of instanties, de gebondenheid betreft. Men kan hier spreken van de subjectieve reikwijdte van de bindende werking. ${ }^{1226}$ Over het antwoord op deze vraag heeft, ook in het verleden, in de jurisprudentie en onder de schrijvers geen verschil van mening bestaan. Op dit onderwerp ga ik in paragraaf 5.4.3.2.1 uitgebreider in.

Op het gebied van het tweede onderwerp is daarentegen nooit consensus bereikt. De vraag die onder de Duitse juristen geen eensluidende beantwoording heeft gevonden, is de vraag waaráán de betrokken personen en instanties precies zijn gebonden. In een iets andere formulering gesteld: het gaat hier om de vraag tot welk(e) gedeelte(n) van de beslissing de gebondenheid zich uitstrekt. Met betrekking tot deze vraag kan men spreken van de objectieve reikwijdte van de bindende werking. ${ }^{1227} \mathrm{Bij}$ het aan de orde stellen van de objectieve reikwijdte van de bindende werking moet in het oog worden gehouden dat (afgezien van de feiten van de

\footnotetext{
Zie de literatuur die Vogel aanhaalt op p. 574 onder voetnoten 29 en 30 . Vgl. tevens Pestalozza (II), p. 319.

${ }^{123}$ Zie par. 4.2.4.

t22u $\mathrm{Vgl}$. Friesenhahn, p. 671.

I23 Zo schrijft Pestalozza (II), p. 327: "Die Fachgerichte, auf deren Bindung es in der Praxis am häufigsten ankommen wird, haben unterschiedlich reagiert. Von der Strenge des BGH, der nur den Tenor als bindend akzeptiert, über Versuche das Tragende der Gründe hinzunehmen, aber einzugrenzen, bis zur Willfahrigkeit einzelner Entscheidungen des BVerwG, die sich an die Leitsätsze, also an Teile, die gar nicht zur Entscheidung i.S. des \$3I I BVerfGG gehören, halten wollen, reicht die Palette."

ins $\mathrm{Vgl}$. Kerbusch, p. 116; Vogel, p. 598.

${ }^{12} \mathrm{Vgl}$. Kerbusch, p. 117.
} 
Hoofdstuk 5

zaak) de gehele uitspraak bestaat uit het dictum, de rechtsoverwegingen ten aanzien van het Grundgesetz en de rechtsoverwegingen ten aanzien van het "gewone" Bundes- of Länderrecht. Na, zoals aangekondigd, eerst op de subjectieve reikwijdte zijn ingegaan, wordt vervolgens in paragraaf 5.4.3.2.2 de objectieve reikwijdte behandeld.

\subsection{Subjectieve reikwijdte}

Eerder is al vermeld dat de vraag wie is gebonden aan een beslissing van het Bundesverfassungsgericht op een Verfassungsbeschwerde nooit tot discussie aanleiding heeft gegeven. Algemeen wordt de bindende werking van een uitspraak op een Verfassungsbeschwerde voor de bij de uitspraak betrokken partijen erkend. ${ }^{1228}$ Deze vorm van bindende werking staat beter bekend als de materiële rechtskracht van een beslissing. ${ }^{1229}$ Buiten twijfel staat dat de materiële rechtskracht betrekking heeft op het dictum. ${ }^{1230}$

Dasmaset kent het Gesetz über das Bundesverfassungsgericht met betrekking tot de uitspraken van de constitutionele rechter een specifiek eigen bepaling, die de uitspraken een bindende werking verleent die verder reikt dan de bij de uitspraak betrokken partijen. Ook andere overheidsinstanties dan de al bij de zaak betrokken instantie worden gebonden. Op grond van de bepaling in $\S 31$ Abs. 1 BVerfGG strekt de bindende werking zich namelijk óok uit tot "die Verfassungsorgane des Bundes und der Länder sowie alle Gerichte ${ }^{I 231}$ und Behörden". ${ }^{1232}$

\subsection{Objectieve reikwijdte}

Met de zojuist vermelde bepaling uit $\S 31$ Abs. 1 BVerfGG is tevens de tot nu toe in de literatuur en rechtspraak onbeantwoord gebleven vraag naar de objectieve reikwijdte van de bindende werking aangesneden. De vraag namelijk die de bepaling uit $\S 31$ Abs. 1 BVerfGG oproept, is of de in die Paragraph genoemde bindende werking méér omvat dan slechts het dictum van de uitspraak en zo ja, of deze bredere bindende werking alsdan beperkt blijft tot overwegingen van het

\footnotetext{
${ }^{1228}$ Badura, p. 481; Kerbusch, p. 13; Pestalozza (II), p. 304; Schlaich, p. 249; Vogel, p. 584 en 624 ; Zuck, NJW 1975, p. 908.

129 Vogel, p. 584; vgl, par. 2.6.1 en 5.2.2.3.

${ }^{1200}$ Klein, NJW 1977, p. 697.

1231 Met uitzondering van het Bundesverfassungsgericht zelf, dit volgens de rechtspraak van het BVerfG, U. v. 19.07.1966, BVerfGE 20, 56 [87]. Hierdoor wordt "fossilisering" van het constitutionele recht voorkomen. Zie Badura, p. 482; Klein, NJW 1977, p. 700; Zuck, NJW 1975, p. 910.

1232 Het gaat hierbij om "alle staatlichen Organe", Klein, NJW 1977, p. 699. Friesenhahn, p. 704, spreekt over de "Allgemeinverbindlichtkeit nach $\$ 31$ Abs. 1 ".
} 
BVerfG aangaande de grondwet (derhalve tot het "Verfassungsrecht") of dat alle overwegingen in de uitspraak bindende werking kennen, zodat bij voorbeeld ook overwegingen ten aanzien van het nationaliteitsrecht daaronder vallen. Aanleiding tot deze onzekerheid geeft de formulering van $\$ 31$ Abs. 1 BVerfGG. In het artikel wordt namelijk gesproken over de bindende werking van "die Entscheidungen des Bundesverfassungsgerichts". Vanzelf roept dat de vraag op tot welk(e) gedeelte(n) van de uitspraak de bindende werking beperkt blijft of dat zelfs moet worden aangenomen dat de bindende werking de gehele uitspraak betreft. ${ }^{1233}$

Echter, niet over alles wat $\S 31$ Abs. 1 BVerfGG betreft, bestaat onzekerheid. Er is bij voorbeeld nooit discussie gevoerd over de vraag of $\$ 31$ Abs. 1 BVerfGG bewerkstelligt dat het dictum bindend is voor de in dat artikel genoemde overheidsinstanties. ${ }^{1234}$ Die vraag is altijd bevestigend beantwoord. Derhalve is onder de bindende werking van "die Entscheidungen des Bundesverfassungsgerichts" minimaal te verstaan gebondenheid aan het dictum voor partijen (op grond van de materiële rechtskracht) en andere overheidsorganen (op grond van $\S 31$ Abs. 1 BVerfGG). ${ }^{1235}$ Zoals in de paragrafen 5.4 .1 en 5.4 .2 is duidelijk geworden, is bij een gegrond Verfassungsbeschwerde de inhoud van het dictum beperkt tot het constateren van de grondrechtenschending. ${ }^{1236}$

Op dit punt aangekomen, moet worden geconstateerd dat vanaf hier over eventuele verdergaande bindende werking ingevolge $\S 31$ Abs. 1 BVerfGG consensus onder de Duitse juristen ontbreekt. ${ }^{1237}$ Als hierboven vermeld, is in de literatuur is vrij uitgebreid gediscussieerd of niet alleen het dictum, maar ook de gronden die hebben geleid tot dat dictum tevens bindend zijn vastgesteld door het BVerfG. Men spreekt in deze discussie over de bindende werking van de zogenaamde "tragenden Teile der Begründung der Entscheidung" ${ }^{1238}$

Uit hetgeen is weergegeven aan het begin van paragraaf 5.4.3.1 blijkt dat het BVerfG sinds de aanvang van zijn werkzaamheden in 1951 het standpunt heeft ingenomen dat niet alleen het dictum, maar ook de gronden die hebben geleid tot dat dictum voor alle organen van het staatsgezag bindend moeten worden geacht. ${ }^{1239}$ Dit standpunt steunt op een door Geiger ontwikkelde theorie. ${ }^{1240}$ Gei-

\footnotetext{
${ }^{123} \mathrm{Vgl}$. Kerbusch, p. 106.

1234 Schlaich, p. 253; Vogel, p. 571.

${ }^{1235} \mathrm{Vgl}$. Vogel, p. 573.

1236 Vgl. Vogel, p. 624: "Die 'konkrete Entscheidungsnorm', auf die sich die Rechtskraft erstreckt, besteht hier in der Feststellung, daß die angefochtene (......) Maßnahmen gegen die im Tenor genannte Verfassungsvorschrift verstoßen; (......). "

Vogel, p. 572 . Vgl. het citaat waarnaar voetnoot 1217 verwijst.

$230 \mathrm{Vgl}$. Friesenhahn, p. 700.

${ }^{1299} \mathrm{Vgl}$. BVerfG, U. v. 23.10.1951, BVerfGE 1, 14 [37]. Idem: BVerfG, B. v. 20.01.1966, BVerfGE 19, 377 [392]; BVerfG, U. v. 19.07.1966, BVerfGE 20, 56 [87]. Vgl. Vogel, p. 570; Zuck, p. 346.

${ }^{150} \mathrm{Zie}$ Vogel, p. 573 en 599 . Vgl. het citaat waarnaar voetnoot 1217 verwijst.
} 
ger is bij het opstellen van zijn theorie ervan uitgegaan dat de bindende werking ingevolge $\$ 31 \mathrm{Abs}$. 1 BVerfGG niet beperkt blijft tot rechtsoverwegingen aangaande de grondwet, maar dat tevens rechtsoverwegingen die betrekking hebben op "gewoon" recht (d.w.z. niet het "Verfassungsrecht" betreffen) bindend zijn. ${ }^{1241}$

In eerste instantie is in de literatuur de opvatting van Geiger afgewezen en werd alleen bindende werking van het dictum aanvaardbaar geacht. ${ }^{1242}$ In 1958 schrijft Schätzel geheel in overeenstemming met de toenmalig heersende leer: "Anders die Entscheidungen im Verfahren der Verfassungsbeschwerde. Sie regeln nur Einzelfälle und schaffen Rechtskraft nur soweit der Tenor der Entscheidung reicht, nicht aber bezüglich der Entscheidungsgründe. (......) Eine Bindung erzeugen Entscheidungen des Bundesverfassungsgerichts im übrigen überhaupt nur in Verfassungsfragen, nicht in anderen Rechtsfragen. $\mathrm{Zu}$ den anderen Rechtsfragen gehören auch Staatsangehörigkeitsangelegenheiten (.......). " 1243

$\mathrm{Na}$ verloop van enige tijd is echter onder de auteurs een lichte kentering merkbaar. Meer en meer, maar zeker niet door alle auteurs, wordt geaccepteerd dat rechtsoverwegingen die betrekking hebben op het "Verfassungsrecht" wel bindend zijn. ${ }^{1244}$ Een bindende werking voor rechtsoverwegingen inzake het gewone recht is de literatuur tot nu toe blijven afwijzen. Overigens sluit het Bundesverfassungsgericht zich inmiddels bij deze afwijzing aan. ${ }^{1245}$

Schlaich geeft het meer genunanceerdere beeld dat ten gevolge van de flexibelere houding onder veel schrijvers is ontstaan weer als hij schrijft dat het BVerfG slechts wil weten van gebondenheid aan: "(.....) Aussagen des Gerichts in den Gründen, soweit sie (1) für den Urteilsausspruch tragend und soweit sie (2) verfassungsrechtlicher Natur sind und nicht nur die Auslegung einfacher Gesetze zum Gegenstand haben, (.......). "1246 Van dezelfde strekking is de navolgende opmerking door Pestalozza: "Da ist einmal die Beschränkung der Bindung auf die verfassungsrechtlichen Aussagen. Erwägungen zum einfachen Recht sollen (sofern nicht auch im Tenor enthalten) nicht binden. ${ }^{n 1247}$

Nog in 1972 staat de literatuur volgens Vogel de visie inzake de bindende werking van de "tragenden Teile der Begründung" van het Bundesverfassungsgericht "nach wie vor zurückhaltend bis ablehnend gegenüber. "1248 Daartegenover stelt Kerbusch tien jaar later in zijn dissertatie: "Der von Geiger entwickelten Auffassung, die Bindung gem. \& 31 Abs. 1 BVerfGG erstrecke sich auf den Entscheidungstenor und die tragenden Entscheidungsgründe, hat sich die wohl als

\footnotetext{
${ }^{1241}$ Pestalozza (II), p. 326 (i.h.b. voetnoot 279).

1242 Vgl. Vogel, p. 571.

120 Schătzel, p. 242.

1244 Vogel, p. 574. Vgl. Badura, p. 482; Friesenhahn, p. 700; Pestalozza (II), p. 325.

1245 Pestalozza (II), p. 326; Vogel, p. 571.

1246 Schlaich, p. 253.

${ }^{1207}$ Pestalozza (II), p. 326.

1245 Vogel, p. 574.
} 
überwiegend zu bezeichnende Meinung in Rechtsprechung und Schriftum angeschlossen. "1249 Zelf behoort Kerbusch niet tot de door hem gesignaleerde meerderheid. ${ }^{1250}$

Naar de huidige stand van zaken staat het BVerfG nog steeds op het standpunt dat reeds in 1951 in zijn jurisprudentie en bij monde van Geiger is uitgedragen, namelijk dat ten gevolge van de werking van $\$ 31$ Abs. 1 BVerGG de "tragenden Teile der Begründing der Entscheidung" bindend zijn voor de in dat artikel genoemde instanties. ${ }^{1251}$ Zoals hierboven vermeld, worden van de bindende werking de rechtsoverwegingen die geen betrekking hebben op de grondwet uitgesloten. Wat het gewone recht, waaronder het nationaliteitsrecht, derhalve betreft, heeft hetgeen het Bundesverwaltungsgericht stelt in het citaat aan het begin van paragraaf 5.4.3.1 nog immer zijn gelding behouden.

\footnotetext{
Kerbusch, p. 121.

$\mathrm{Vgl}$. Kerbusch, p. 116, 122, 151, 169 en 216.

Vogel, p. 570,571 en 599.
} 



\section{Bewijsrechtelijke aspecten in het Duitse nationaliteitsrecht}

\subsection{Inleiding}

In dit hoofdstuk komen de vragen naar het toepasselijk bewijsrecht en naar de bewijslastverdeling bij de rechterlijke vaststelling van de Duitse nationaliteit aan de orde. Voorop wordt daarbij gesteld de beperking tot de rechterlijke vaststelling in administratiefrechtelijke procedures. Dit betekent derhalve een beperking tot het administratieve bewijsrecht. ${ }^{1252}$

In hetgeen hieronder volgt, wordt eerst ingegaan op het administratieve bewijsrecht (paragraaf 6.2) waarbij de volgende deelonderwerpen: onderzoeksverplichting (par. 6.2.1); bewijslastverdeling (par. 6.2.1.1); Beweislastnormen (par. 6.2.1.2); bewijswaardering (par. 6.2.2) en Beweismaß (par. 6.2.2.1) de leidraad van behandeling vormen. In het navolgende komt ook aan de orde welke bewijsmiddelen in een gerechtelijke procedure kunnen worden gehanteerd ten einde het vermeende wel of niet bezit van de Duitse nationaliteit te boekstaven (par. 6.3.1). Voorts wordt in paragraaf 6.3 het bewijsrechtelijk jurisprudentieonderzoek weergegeven. Op gelijke wijze als de Nederlandse jurisprudentie is de Duitse jurisprudentie onderverdeeld in een categorie A met daarin de uitspraken betreffende een beroep op verwerving van de Duitse nationaliteit en een categorie B waarin de uitspraken betreffende een beroep op behoud van de Duitse nationaliteit zijn opgenomen. De uitspraken in het kader van categorie A worden behandeld in paragraaf 6.3.2 en de uitspraken van categorie B in paragraaf 6.3.3.

Zoals dit eveneens het geval is in het Nederlandse recht wordt in het Duitse recht het standpunt ingenomen dat bewijzen in juridische zin niet betekent dat omtrent de feiten absolute zekerheid dient te worden bereikt. Absolute zekerheid omtrent de feiten wordt derhalve, indien zulks niet of slechts met grote inspanning mogelijk is, niet nagestreefd. ${ }^{1253}$ Voldoende is daarentegen het bereiken van "ein so hoher Grad an Wahrscheinlichkeit (.......), daß kein vernünftiger, die Lebensverhältnisse klar überschauender Mensch noch zweifelt. " ${ }^{1254}$

\footnotetext{
${ }^{1232}$ De genoemde beperking tot administratiefrechtelijke vaststellingsprocedures en het administratieve bewijs kon, wegens het beperkt aantal voor jurisprudentieonderzoek bruikbare uitspraken, niet volledig worden doorgevoerd. Er wordt één civielrechtelijke uitspraak behandeld (in par. 6.3.3.1); een uitspraak van het Bundesgerichtshof.

${ }^{129} \mathrm{Vgl}$. Kopp, \$108 VwGO, Rdnr. 4a.

${ }^{124}$ Eyermann/Fröhler, p. 717. Idem Peschau, p. 11; Kopp, 8108 VwGO, aant. 5; Ule, p. 144.
} 
Indien de materiële rechtsregel dat uitdrukkelijk toelaat, zoals in het geval van een voorlopige voorziening ${ }^{1255}$ ("einstweilige Anordnung"), is in bepaalde gevallen het voldoende indien het feit "glaubhaft" wordt. ${ }^{1256}$ Het onderscheid tussen "Beweis" en "Glaubhaftmachung" wordt door Eyermann/Fröhler als volgt verwoord: "Während der Beweis an Gewißheit grenzende Wahrscheinlichkeit zu erbringen hat, genügt für die Glaubhaftmachung die überwiegende Wahrscheinlichkeit. ${ }^{\prime 1257}$

De bovengenoemde begrippen hebben betrekking op de vraag in welke mate een feit dient vast te staan, wil kunnen worden gesteld dat het is bewezen. In het Duitse bewijsrecht wordt dan gesproken over Beweismaß. ${ }^{1258}$ Aan de Beweismaß wordt in paragraaf 6.2.2.1 nadere aandacht geschonken.

\subsection{Administratief bewijsrecht}

Slechts zeer weinig bepalingen in de Verwaltungsgerichtsordung, de wet die het administratief procesrecht bevat, hebben betrekking op het bewijs. Van die weinige bepalingen zijn de $\S \S 86$ en 108 VwGO zonder meer de belangrijkste. Aan de strekking van $\S 86$ VwGO en $\S 108$ VwGO wordt in de paragrafen 6.2 .1 en 6.2 .2 aandacht geschonken. Daarnaast hebben de $\$ \S 96-98$ VwGO betrekking op het bewijsrecht. Deze Paragraphen worden hieronder besproken.

Ten behoeve van de vergaring van het bewijs kent de Verwaltungsgerichtsordung een drietal bepalingen dat betrekking heeft op het formele bewijsrecht in administratieve procedures ( $\$ \S 96-98$ VwGO). In een administratiefrechtelijke Feststellungsklage gelden derhalve deze bepalingen.

Paragraph 96 VwGO bevat de hoofdregel dat het bewijs tijdens de mondelinge behandeling van de zaak wordt vastgesteld (het zgn. onmiddellijkheidsbeginsel). ${ }^{1259}$

In $\S 98$ VwGO worden de $\S \S 358-444,450-494$ Zivilprozeßordnung van overeenkomstige toepassing op de bewijsvergaring in het administratieve proces verklaard.

\footnotetext{
${ }^{1255}$ Ingevolge $\$ 123$ Abs. 3 VwGO i.V.m. $\$ 920$ ZPO. Vgl. Berg, p. 22; Peschau, p. 15; Ule, p. 272. ${ }^{1236}$ Ule, p. 272 , geeft een opsomming van dergelijke bepalingen: bijvoorbeeld $\$ 99$ Abs. 2 VwGO, dat betrekking heeft op een mogelijke weigering door een overheidsorgaan om tijdens een geding aan de rechter gegevens te verschaffen: "Auf Antrag eines Beteiligten entscheidet das Gericht der Hauptsache durch Beschluß, ob glaubhaft gemacht ist, daß die geserzlichen Voraussetzungen für die Verweigerung der Vorlage von Urkunden oder Akten und die Erteilung von Auskünften vorliegen. " Vgl. tevens Berg, p. 115 en 116; 124-127; Peschau, p. 16.

1297 Eyermann/Frőhler, p. 646 en 647 . Vgl. Hâußer/Kapinos/Christ, p. 151.

1258 Ook wel "Beweiskriterium" genoemd; Nierhaus, p. 48, omschrijft het als volgt: "Die Voraussetzungen, unter denen der Richter einen Sachverhalt als erwiesen ansehen darf."

12s9" "Grundsatz der Unmintelbarkeit"; vgl. Hufen, p. 618; Kopp, \$96 VwGO, Rdnr. 3; Redeker/v. Oertzen, p. 514.
} 
De betreffende bepalingen uit de ZPO hebben met name betrekking op formele bepalingen inzake de bewijslevering. Het betreft dan de wijze waarop een descente ( $\$$ 371-372a ZPO) plaatsheeft, een getuigenverhoor dient te worden gehouden ( $\$ \S$ 373-401 ZPO) of een deskundigenbericht wordt ingewonnen ( $\$ \$ 402-414$ ZPO). Maar de onderhavige bepalingen hebben eveneens betrekking op Urkunden en de bewijskracht daarvan $\left(\S \S 415-419\right.$ ZPO). ${ }^{1260}$ Daarnaast betreffen de bepalingen uit de ZPO de eed ( $\$ \S 478-484 \mathrm{ZPO}$ ) en de zekerstelling van bewijs ( $\$ \S 485-494$ $\mathrm{ZPO})$.

Het van toepassing verklaren van de bovenvermelde bepalingen uit de ZPO heeft tot gevolg dat de meerderheid van de in het administratieve proces van toepassing zijnde formeel-bewijsrechtelijke bepalingen afkomstig is uit de Zivilprozeßordnung en niet uit de Verwaltungsgerichtsordnung.

Twee markante verschillen tussen het civiele en administratieve bewijsrecht worden door Ule genoemd. Een wezenlijk onderscheid tussen beide vormen is het feit dat de rechter in een administratieve procedure getuigen kan oproepen en horen die niet door de partijen zijn aangemeld. ${ }^{1261}$ Een volgend verschil is dat in het administratieve proces feiten die tussen de in het geding betrokken partijen niet worden bestreden door de rechter mede, ambtshalve, worden onderzocht en aan bewijs onderhevig zijn. ${ }^{1262}$

\subsubsection{Onderzoeksverplichting ( $\$ 86 \mathrm{VwGO})$}

Een bepaling die in het administratief procesrecht van groot belang is, is $\S 86$ Verwaltungsgerichtsordnung. Daarin is de voor het administratieve proces zo karakteristieke onderzoeksverplichting van de rechter naar de feitelijke omstandigheden van de zaak neergelegd. Deze onderzoeksverplichting, als gevolg waarvan het Duitse administratieve proces een duidelijk actief optredende rechter kent, wordt "Untersuchungsmaxime" of "Untersuchungsgrundsatz" genoemd. ${ }^{1263}$ Het onderhavige procesrechtelijk uitgangspunt leidt ertoe dat het de rechter is, en niet de partijen, die de omvang bepaalt van de feitelijke omstandigheden op grond waarvan de uitspraak zal worden gedaan. ${ }^{1264}$ Tevens vloeit uit het beginsel van de onder-

\footnotetext{
${ }^{1250}$ De Zivilprozeßordnung onderscheidt vier categorieln Urkunden. Deze zijn: authentieke akten waarin een partijverklaring is opgenomen ( $\$ 415 \mathrm{ZPO})$; onderhandse akten: "Privaturkunden" ( $\$ 416 \mathrm{ZPO})$; authentieke akten met daarin een verklaring van een ambtenaar ( $\$ 417 \mathrm{ZPO})$ en authentieke akten waarin de verklaring van een ambtenaar het feitelijk verloop van de gang van zaken betreft $(\S 418$ ZPO). Zie voor de bewijskracht: par. 6.2.2 en 6.3.1.

${ }^{1291}$ Ule, p. 134.

$12 \mathrm{~s}$ Ule, p. 270.

${ }^{123}$ Ule, p. 133 en 134. Vgl. Nierhaus, p. 5 en 11; Nierhaus spreekt op p. 478 in dit verband ook van "Aufklärungspflicht".

12s Redeker/v. Oertzen, p. 473.
} 
zoeksverplichting voort dat de oordelende instantie niet alleen ambtshalve de reeds in de zaak bekende feiten onderzoekt, ${ }^{1265}$ maar ook dat de instantie zo nodig ontbrekende feiten ambtshalve in het geding brengt. ${ }^{1266}$ In aansluiting hierop kan alvast worden gewezen op de hoofdregel in het administratieve bewijsrecht die inhoudt dat alle bewijsmiddelen zijn toegelaten. ${ }^{1267}$

Met betrekking tot de onderzoeksverplichting is het verder nog van belang op te merken dat gedurende de procedure weliswaar aan de kant van de rechterlijke instantie deze verplichting bestaat, maar dat aan de andere kant de procespartijen een verplichting hebben om de rechter bij het onderzoek behulpzaam te zijn. ${ }^{1268}$ Voor partijen bestaat namelijk ten aanzien van het door de rechter te verrichten feitenonderzoek een medewerkingsplicht. Het Bundesverwaltungsgericht neemt desbetreffend het standpunt in dat de onderzoeksverplichting van de rechter haar grens vindt daar waar de medewerkingsplicht van de procesdeelnemers begint. ${ }^{1269}$ Meer in concreto over de invulling van deze medewerkingsplicht stellen Redeker/v. Oertzen het volgende: "Die Mitwirkungspflicht reicht am weitesten, wo es sich um Tatsachen aus der eigenen, nur dem Beteiligten bekannten Sphäre handelt; sie ist am geringsten, wenn es um Tatsachen geht, die nicht zum Erkenntnisbereich und damit der Sphäre des Beteiligten gehören. ${ }^{1270}$

Bij het verzaken van de medewerkingsplicht door één of beide procesdeelnemers is de rechterlijke instantie niet gehouden een grondiger onderzoek te verrichten dan dat zou worden verricht bij volledige medewerking van de betrokken partij(en). Het feit dat een partij niet voldoet aan de medewerkingsplicht kan door de rechter worden verdisconteerd op het moment dat de waardering van het bewijs aan de orde komt. ${ }^{1271}$ Als gevolg van dit uitgangspunt formuleren Redeker/v. Oertzen de volgende stelling: "Die Untersuchungsmaxime is keine prozessuale Hoffnung,

\footnotetext{
${ }^{1265}$ Waarbij cen zekere begrenzing van het ambtshalve onderzoek wordt gevonden in de volgende door het Bundesverwaltungsgerichtshof geformuleerde overweging: "Grundsätzlich kann der Richter ein aus amtlicher Veranlassung gewonnenes sicheres Bild der tatsächlichen Verhältnisse der Entscheidung ohne weitere Beweisaufnahme als gerichtskundig zugrunde legen." Zie Redeker/v. Oertzen, p. 477. Aan de andere kant heeft de rechterlijke instantie de bevoegdheid bewijs te verlangen van een feit dat tussen partijen niet bestreden is: Ule, p. 270.

1260 Ule, p. 135: "Das Gericht kann und muß also seine Ermittlungen auch auf Punkte erstrecken, die von den Beteiligten nicht worgebracht sind, und Beweise erheben die von den Beteiligten nicht beantragt sind." Vgl. Berg, p. 41 en diens opmerking op p. 163: "Venwaltungsverfahren und Verwaltungsproze gehen nicht nahtlos ineinander über. Die Ausgestaltung des Verwaltungsverfahrens bestimmt nicht den Umfang richterlicher Ermittlungen. "

${ }^{1267}$ Kopp, § 86 VwGO, Rdnr. 5; Kühl, p. 98. Vgl. par. 6.3.1.

${ }_{120} \mathrm{Vgl}$. Fliegauf, p. 72; Kopp, $\$ 86$ VwGO, Rdnrs. 11 en 12; Redeker/v. Oertzen, p. 473; Tschi$\mathrm{ra} /$ Schmitt Glaeser, p. 293.

${ }^{1209}$ Redeker/v. Oertzen, p. 474. Vgl. Berg, p. 51; Kopp, 886 VwGO, Rdnr. 12; Ule, p. 135. Dit beginsel staat ook wel bekend onder het begrip "Anfang-Ende-Satz", vgl. Nierhaus, p. 263 en 336-338. 1270 Redeker/v. Oertzen, p. 474.

1271 Kopp. $\$ 86$ VwGO, Rdnr. 12 en $\$ 108$ VwGO, Rdnr. 17.
} 
das Gericht werde mit ihrer Hilfe schon die klagebegründenden Tatsache finden. ${ }^{\prime 1272}$ Eyermann/Fröhler sluiten daarop aan en stellen: "Die Ermittlungspflicht des Gerichts geht nur bis zur Grenze des Zumutbaren. "1273

De voor de administratieve rechter in het leven geroepen onderzoeksverplichting leidt binnen de administratiefrechtelijke literatuur tot de gevolgtrekking dat de procesdeelnemers stelplicht noch bewijslast hebben. ${ }^{1274}$ Wel dienen, zoals hierboven reeds is vermeld, de procesdeelnemers medewerking te verlenen bij het feitenonderzoek dat de rechter verricht. ${ }^{1275}$

Het ontbreken van stelplicht (Behauptungslast) en bewijslast (Beweisführungspflicht) voor de procespartijen, die het gevolg is van de onderzoeksverplichting van de rechter, leidt Berg tot de volgende uitspraak: "Unter Geltung der Untersuchungsmaxime kann allein das Gericht in Beweisnot geraten. Das ist die Situation objektiver Beweislosigkeit, die mit Hilfe der Beweislastregeln gemeistert werden muß." ${ }^{1276}$ Aan de evenvermelde opmerking aangaande "Beweisnot" voegt Peschau toe: "Beweisnot meint deshalb im Verwaltungsproze $\beta$, daß besondere Umstände die Sachverhaltsaufklärung ungewöhnlich erschweren, (.......). "1277

In geval van het bestaan van "objektive Beweislosigkeit", het moment waarop "(.....) die Ungewißheit nicht mehr zu beheben ist", 1278 is derhalve sprake van een situatie waarin ondanks de inspanningen van de rechterlijke instantie en de

\footnotetext{
${ }^{12 m}$ Redeker/v. Oertzen, p. 474.

${ }^{1273}$ Eyermann/Fröhler, p. 644. Idem Kopp, $\$ 86$ VwGO, Rdnr. 5.

In4 Berg, p. 172; Fliegauf, p. 71 en 72 ; Nierhaus, p. 334; Kopp, $\$ 108$ VwGO, Rdnr. 11; Tschira/Schmitt Glaeser, p. 294; Ule, p. 274. Bewijslast is hier bedoeld in de zin van bewijsleveringsplicht: in het Duits "Beweisführungspflicht". Dienaangaande buitelen in de literatuur de synonieme begrippen over elkaar heen: Kopp, $\S 108$ VwGO, Rdnr. 11, omschrijft Beweisführungspflicht ook wel met de term "formelle Beweislast" (die dus ontbreekt). Berg, p. 172, spreekt eveneens van Beweisfithrungspflicht, maar noemt dat tevens de "subjektive Beweislast" (die dus ontbreekt). Redeker/v. Oertzen, p. 568, onderscheiden de begrippen Beweisführungspflicht en Beweislast. Zij hanteren voor Beweisführungspflicht ook de termen "subjektive oder prozessuale Beweislast". (Die, zijnde synonieme begrippen voor Beweisfiuhrungspflicht beide in het administratief proces dus ontbreken). Eyermann/Fröhler, p. 644, stellen dan weer: "Aus dem Untersuchungsgrundsatz folgt weiter, daß es im Venwaltungsgerichtsverfahren grundsätzlich keine (prozessuale) Beweislast (Beweispflicht) gibt." Deze auteurs spreken derhalve van "prozessuale Beweislast" (die dus ontbreekt).

tzrs Deze medewerkingsplicht wordt beschouwd als een middel van de rechter om te voldoen aan de hem opgelegde onderzoeksverplichting. Het heeft niets van doen met enige verplichting van de procesdeelnemers tot een stel- of bewijsplicht. Vgl. Nierhaus, p. 334 en 479.

${ }^{1236}$ Berg, p. 128. Vgl. Peschau, p. 74. In dit verband haalt Ule, p. 274, een uitspraak van Lent aan, die kennelijk heeft gesteld: "Die Beweislast ist also eine Regelung nicht des Beweis, sondern der Beweislosigkeit. "

Imeschau, p. 74.

${ }^{1 m}$ Berg, p. 41. Zie Kopp, \& 108 VwGO, Rdnr. 11, die een zodanige situatie omschrijft met: "die gegebenfalls verbleibende Unerweislichkeit von Tatsachen"; Peschau, p. 11, spreekt over "im Fall tatsāchlicher Ungewißheit".
} 
volledige medewerking van de partijen desalniettemin op het gebied van de feitelijke omstandigheden niet tot klaarheid kon worden gekomen. De literatuur spreekt ten aanzien van een zodanige situatie ook wel van een non-liquet situatie. ${ }^{1279}$

\subsubsection{De bewijslastverdeling}

Ook in een non-liquet situatie, de situatie dat met betrekking tot de zaak in kwestie moet worden geconcludeerd dat er "objektive Beweislosigkeit" bestaat, zal de rechter een uitspraak moeten doen. ${ }^{1280}$ Het kan niet anders, of er zal een procespartij zijn die het geding verliest. Of, op zijn minst, zal er een procespartij zijn ten aanzien van wie in het verdere procesverloop het ongunstig blijkt te zijn dat een bepaald feit niet kan worden vastgesteld. ${ }^{1281}$ Mogelijk is dit tevens de partij, die ten gevolge van de niet-vaststelling van het bewuste feit het geding verliest. Met betrekking tot de partij ten laste van wie in het proces het (ongunstige) gevolg van de niet-vaststelling van een feit komt, wordt gesteld dat deze de "objektive Beweislast" van dat feit draagt. ${ }^{1282}$ Als synoniem voor "objektive Beweislast" wordt het begrip "materielle Beweislast" wel gebezigd. ${ }^{1283}$

De beslissing welke partij de "objektive Beweislast" draagt, dient door de rechter te worden genomen aan de hand van regels voor de bewijslastverdeling. ${ }^{1284} \mathrm{De}$ literatuur spreekt in dit verband over de "verwaltungsprozessuale Beweislastleh$r e^{\prime} .{ }^{1285} \mathrm{De}$ "verwaltungsprozessuale Beweislastlehre" bevat de "Beweislastregeln", ${ }^{1286}$ die ook wel de "Beweislastnormen"1287 worden genoemd.

Er zij aan herinnerd dat de begrippen "Beweislast" en "Beweislastregeln" alleen zijn toe te passen op een geval waarin sprake is van een non-liquet situatie. ${ }^{1288}$

\footnotetext{
${ }^{1279}$ Kopp, $\S 108$ VwGO, Rdnr. 11; Nierhaus, p. 33; Peschau, p. 11; Ule, p. 274.
}

${ }^{1280}$ Ook in het Duitse recht geldt voor de rechter de decisieverplichting. Berg, p. 169, spreekt over "Entscheidungszwang"; Peschau, p. 11, spreekt over "Anspruch auf Justizgewährung".

12s1 $\mathrm{Vgl}$. Ule, p. 273: "(......), so bedarf es in jedem Verfahren einer Regelung der Frage, wer die Folgen des Beweislosigkeit einzelner Umstände, (.......), zu tragen hat. " Vgl. Eyermann/Fröhler, p. 644. $12 n$ Berg, p. 170; Tschira/Schmitt Glaeser, p. 294; Ule, p. 273. Vgl. Peschau, p. 74.

${ }^{128}$ Kopp, \$ 108 VwGO, Rdnr. 11; Peschau, p. 11; Redeker/v. Oertzen, p. 568; Ule, p. 273, die meldt dat in de literatuur eveneens "Feststellungslast" als synoniem geldt. $\mathrm{Vgl}$. Kopp, $\S 108 \mathrm{VwGO}$, Rdnr. 5: "Regeln der objektiven Beweislast"; Nierhaus, p. 258: "objektive Beweislast (Feststellungslast). "

1284 Nierhaus, p. 166.

1280 Ule, p. 274.

${ }^{1236}$ Nierhaus, p. 38.

1287 Peschau, p. 72; Nierbaus, p. 45.

1288 Nierhaus, p. 38: "Die Beweislast greift nur und erst dann ein, wenn trotz Ausschöpfung aller Beweis- und Aufklärungsmöglichkeiten weder die fragliche Tatsache noch ihr Gegenteil bewiesen werden konnte. $(. . . . . . .$.$) ; das non liquet ist - (.......)- die tatbestandliche Voraussetzung der Beweislastsätze.$ Die Beweislastregeln setzen mithin erst ein, wenn das dem Prozeßrecht unterstehende Beweisverfahren (Beweisaufnahme und -wïrdigung) einen erheblichen Sachumstand nicht abzuklären vermochte." 
Indien ten aanzien van een bepaald feit geen non-liquet situatie geldt, is er geen sprake van toepassing van "Beweislastregeln", maar is sprake van "Beweiswïrdigung". ${ }^{1289}$ Het verschil tussen beide situaties legt Nierhaus als volgt uit: "Der Rechtsanwender hält sich in Bereich der Beweiswïrdigung auf, wenn und solange er bei seiner Entscheidung von dem Vorhandensein oder Nichtvorhandensein der behaupteten Tatsache überzeugt ist; er verläßt diesen Bereich und überschreitet die Grenze zu dem Regime der Beweislastnormen, wenn er entscheidet, ohne diese Überzeugung erlangt zu haben. ${ }^{1290}$

Op bondige wijze anders geformuleerd: de "verwaltungsprozessuale Beweislastlehre" bevat derhalve de "Regeln dafür (......), welcher Prozeßbeteiligte die Folgen der Nichterweislichkeit einer Tatsache zu tragen hat. ${ }^{\text {"1291 }}$

Het geval waarin door de rechter geen overtuiging inzake de feitelijke omstandigheden wordt verkregen ten gevolge van het feit dat één of meer procesdeelnemers niet voldoet aan de "Mitwirkungspflicht" wordt in de literatuur niet ondergebracht bij de situaties waarin sprake is van "objektive Beweislosigkeit". In een zodanig geval dient de rechter niet volgens de "Beweislastregeln" tot zijn beslissing te komen, maar volgens de "Beweiswürdigung" (bewijswaardering). ${ }^{1292}$

Een doorslaggevende invloed op het verloop van het rechterlijke besluitvormingsproces heeft derhalve de constatering op enig moment in de procedure dat ofwel sprake is van een situatie waarin omtrent de feitelijke omstandigheden moet worden gezegd dat zowel de versie van het overheidsorgaan als de versie van de betrokken burger tot de feitelijke mogelijkheid behoort (er bestaat "objektive Beweislosigkeit", ook wel non-liquet situatie genoemd), dan wel de constatering op enig moment in de procedure dat, onder de werking van de "Untersuchungsmaxime", naar de overtuiging van de rechter voor het standpunt van één der partijen de feitelijke omstandigheden van de zaak voldoende zijn vastgesteld ${ }^{1293}$ (er is geen sprake van "objektive Beweislosigkeit"). In het laatste geval gaat de rechter over tot toepassing van de relevante materieelrechtelijke rechtsregel en doet een uitspraak in de zaak.

Nierhaus is overigens van mening dat uitgezonderd het geval waarin "(.....) der Sachverhalt zweifelsfrei zur Überzeugung des Rechtsanwenders feststeht, (.....)" de rechter ervan dient uit te gaan, dat sprake is van een non-liquet situatie. ${ }^{1294} \mathrm{Nier}$ -

\footnotetext{
las Nierhaus, p. 38.

1200 Nierhaus, p. 38.

Tschira/Schmitt Glaeser, p. 294.

${ }^{1 m}$ Eyermann/Fröhler, p. 645; Kopp, 8108 VwGO, Rdnr. 5 en 17; Tschira/Schmitt Glaeser, p. 294.

${ }^{129} \mathrm{Vgl}$. Kopp, \& 108 VwGO, Rdnr. 4: "Erforderlich und Voraussetzung für die richterliche Öberzeugungsbildung ist in jedem Fall eine ausreichende Klärung des Sachverhalts."

${ }^{134}$ Nierhaus, p. 474. Vgl. Berg, p. 214: "Sofern man das gesetzliche Überzeugungsgebot ernst nimmt, mus man von objektiver Beweislosigkeit immer schon dann sprechen, wenn sich das Gericht die volle
} 


\section{Hoofdstuk 6}

haus poneert de stelling dat blijkens de jurisprudentie te snel wordt overgegaan tot het genoegen nemen door de rechter met niet zulk sterk alsook met minder sluitend bewijs dan wenselijk zou zijn en dat als gevolg daarvan in minder gevallen dan zou behoren, wordt geoordeeld dat er sprake is van een non-liquet situatie. ${ }^{1295}$ Aan de mate van het bewijs (Beweismaß) ${ }^{1296}$ stelt Nierhaus derhalve vrij strenge eisen. Met het oog op de sterkte van het bewijs waaraan de rechter zijn "Überzeugung" dient te ontlenen, stelt hij: "Beweismaßreduzierungen und Schätzungen sind nur zulässig aufgrund materiell-rechtlicher Regelungen; (.....)". ${ }^{1297}$

\subsubsection{2 "Beweislastnormen"}

In de bewijsrechtelijke literatuur is een uitgebreide discussie gevoerd over de criteria die in aanmerking zouden kunnen komen voor de, ter beslechting van een non-liquet situatie, noodzakelijke "Beweislastnormen". Tevens is aan de hand van rechterlijke beslissingen getracht "Beweislastnormen" op te sporen en te beschrijven. Als gezegd, het hanteren van de "Beweislastnormen" is noodzakelijk indien een beslissing dient te worden genomen onder de omstandigheid dat het gerecht, ondanks de werking van de "Untersuchungsmaxime", in "objektive Beweisnot" is geraakt.

Over de onderscheidenlijke criteria wordt in de literatuur opgemerkt dat deze geen hiërarchische rangschikking kennen en dat ze afwisselend worden gebruikt in de rechtspraak. Er bestaat tevens onder de schrijvers geen eensgezindheid over de waarde en de juistheid van de verschillende criteria. Peschau komt tot de volgende slotsom: "Es gibt im Verwaltungsrecht kein allgemeingültiges Prinzip, mit dem jedes auftretende Beweislastproblem schematisch zu handhaben wäre. (.......). Mit scheinbar griffigen Formeln sind Entscheidungen bei ungewissem Sachverhalt nicht zu treffen. "1298 Berg voegt daaraan toe: "Es ist nicht einmal so, daß die Beweislastverteilung innerhalb derselben Materie (z.B. im Wehrpflichtrecht) oder selbst innerhalb desselben Gesetzes (.......) gleich sein müßte. Auf der anderen Seite ist

$1294 \rightarrow$

Uberzeugung vom Vorliegen der tatsächlichen Voraussetzungen einer Norm nicht hat verschaffen können."

${ }^{1298}$ Nierhaus, p. 474.

${ }^{1296}$ Ook wel bewijssterkte. In de mate van bewijs is verschil mogelijk. Vergelijk bijv. "überwiegende Wahrscheinlichkeit" (d.i. cen synoniem voor "Glaubhaftmachung"); "mit an Sicherheit grenzender Wahrscheinlichkeit" of "zweifelsfrei" (de laatste twee zijn vormen van wat ook wel "Strengbeweis" wordt genoemd, vgl. Ule, p. 272).

1297 Nierhaus, p. 474.

1298 Peschau, p. 153. Vgl. Ule, p. 274: "(......), daß der Verwaltungsprozeß wie der Zivilproze $\beta$ keine starren Beweislastregeln kennt. Die Frage, nach welchen Regeln die Beweislast im Verwaltungsproze verteilt ist, stellt daher das eigentliche Problem der verwaltungsprozessualen Beweislastlehre dar." 
nicht zu verkennen, daß es eine Reihe typischer Beweislastfälle gibt, für deren Lösung gleichartige Abwägungskriterien in Betracht kommen. "1299

Een betrekkelijke mate van eensgezindheid bestaat onder de auteurs over de toepassing in de rechtspraak van de regel dat, indien bij het gerecht sprake is van "objektive Beweisnot" degene die zich beroept op een door hem gewenst en een (derhalve) voor hem (hoogst waarschijnlijk) gunstig rechtsgevolg, ter zake van de feitelijke omstandigheid leidend tot dat rechtsgevolg de bewijslast draagt. ${ }^{1300}$ Deze regel wordt het "Normbegünstigungsprinzip" genoemd. ${ }^{1301} \mathrm{Naar}$ de mening van Tschira/Schmitt Glaeser vormt het "Normbegiünstigungsprinzip" de regel waarop de rechtspraak zich het meest oriënteert. ${ }^{1302}$ Redeker/v. Oertzen laten een zelfde geluid horen in de uitspraak: "Ausgangspunkt der Entscheidung über die Beweislast ist auch im Verwaltungsproze $\beta$, daß die Unerweislichkeit einer Tatsache zu Lasten des Beteiligten geht, der aus ihr ihm günstige Rechtsfolgen herleitet. ${ }^{m 1303}$

Er zijn ten aanzien van het "Normbegünstigungsprinzip" echter wel kritische kanttekeningen geplaatst. ${ }^{1304}$ Evenwel wijst een gezaghebbend auteur als Nierhaus de regel geenszins volledig af, al was het maar met het oog op de grote vlucht die dit beginsel in de rechtspraak heeft gemaakt en heden ten dage nog maakt, maar Nierhaus wijst er wel op dat onder omstandigheden de toepassing van het "Normbegünstigungsprinzip" tot minder wenselijke resultaten kan leiden. ${ }^{1305}$ Hoewel kan worden vastgesteld dat bewijslastverdeling volgens het "Normbegünstigungsprinzip" veelvuldig voorkomt, is het echter geen wet van Meden en Perzen. De rechtspraak kent ook uitspraken waarin de regel geen toepassing heeft gevonden. ${ }^{1306}$

Bij het "Normbegünstigungsprinzip" is een zeker direct verband te constateren met de materiële rechtsregel die in de gerechtelijke procedure aan de orde is. Met betrekking tot het zojuist aangeduide verband is de gedachtengang dat uit de betrokken materiële rechtsregel het (gunstige) rechtsgevolg blijkt waarop hetzij de administratie hetzij de burger een beroep doet. Met name Berg staat als "Beweis-

\footnotetext{
${ }^{129}$ Berg, p. 229.

${ }^{1300}$ Peschau, p. 33.

${ }^{1001}$ Ule, p. 275, vermeldt dat ook de termen "Günstigkeitsregel" en "Normentheorie" hiervoor worden gebruikt. Vgl. Berg, p. 180; Nierhaus, p. 407.

${ }^{100}$ Tschira/Schmitt Glaeser, p. 294. Vgl. Berg, p. 181.

${ }^{1500}$ Redeker/v. Oertzen p, 568. Idem Eyermann/Fröhler, p. 644; Hufen, p. 618; Kopp, § 108 VwGO, Rdnr. 13; Peschau, p. 21-28; Ule p, 275 en 276.

${ }^{1304}$ Zie Berg, p. 184, die de "Normentheorie" verwerpt; Nierhaus, p. 407 en 408 ; Peschau, p. 34 en 35. De desbetreffende kritiek komt er op neer dat het soms moeilijk is vast te stellen: "für welchen der Beteiligten ein bestimmtes Tatbestandsmerkmal vorteilhaft ist." (Citaat van Berg, p. 181).

${ }^{13}$ Nierhaus, p. 409.

${ }^{106} \mathrm{Vgl}$. Peschau, p. 29,31 en 32.
} 
lastnorm" de regel voor dat in het geval van een non-liquet situatie de rechter om desalniettemin tot een beslissing te kunnen komen, eerst bij de aan de orde zijnde materiële wetgeving te rade gaat of daarin een bewijslastverdeling besloten ligt. ${ }^{1307}$ Voor het onderwerp van dit boek zou dat derhalve de individuele verliesof verwervingsgrond(en) uit het materiële nationaliteitsrecht betreffen. ${ }^{1308}$

De achterliggende gedachte welke Berg ertoe leidt voor dit standpunt te kiezen, is dat naar zijn inzicht: "(.....), die Verteilung der Beweislast insgesamt zuvörderst Recht und Aufgabe des Gesetzgebers ist. " 1309

In het kader van zijn bespreking van het "Normbegünstigungsprinzip" plaatst Berg evenwel ook de opmerking dat het slechts zelden voorkomt dat de materiële administratieve wetgeving aan de rechter inzake de te hanteren bewijslastverdeling voldoende duidelijkheid biedt. ${ }^{1310}$ De oorzak van dit manco is het gegeven dat de wetgever bij het opstellen van de materiële regel geen aandacht heeft voor de toepassing van de desbetreffende regel in het geval van "objektive Beweisnot" bij een rechterlijke instantie. In de bewijsrechtelijke literatuur wordt algemeen onderschreven dat ten aanzien van de meerderheid van de bepalingen op het gebied van het "Verwaltungsrecht" geldt, dat de gezochte bewijslastverdeling niet zonder meer in de relevante materiële rechtsregel kan worden gevonden. ${ }^{1311}$ Dit maakt het noodzakelijk in de desbetreffende gevallen over te gaan tot toepassing van enige andere regel van bewijslastverdeling.

Behalve in het eerder vermelde "Normbegünstigungsprinzip" zou een bewijslastregel kunnen worden gevonden in de positie die de betrokken partijen in het proces innemen. Onder de auteurs bestaat algemene eenstemmigheid over de vraag of voor de uitkomst van de "objektive Beweislast" de positie die de partijen innemen in het geding een bepalende factor is. Zou bijvoorbeeld als regel gelden dat de bewijslast rust op de partij die het geding aanhangig heeft gemaakt, dan betekent zulks dat de bewijslast altijd bij de burger terecht zou komen. Toepassing van een zodanig starre bewijslastregel wordt in de literatuur algemeen afgewezen. ${ }^{1312}$

Een andere mogelijke regel voor de bewijslastverdeling zou kunnen zijn, dat de bewijslastverdeling een samenhang vertoont met de ingestelde klacht. ${ }^{1313}$ Er zijn

\footnotetext{
${ }^{1307}$ Berg, p. 219. $\mathrm{Vgl}$. Berg, p. 41: "Erst das materielle Recht kann -und muß- den Weg weisen, auf dem die verbleibenden Zweifel abzufangen sind. "Idem Kopp, $\$ 108$ VwGO, Rdnr. 12; Peschau, p. 13 en 32; Redeker/v, Oertzen, p. 568: "Wer die Beweislast trägt, muß sich aus dem materiellen Recht ergeben."

$130 \% \mathrm{Vgl}$. Makarov/v. Mangoldt, $\$ 3$ RuStAG, Rdnr. 16.

1309 Berg, p. 183.

${ }^{1310}$ Berg, p. 219. Idem Nierhaus, p. 8; Peschau, p. 38.

1311 Vgl. Nierhaus, p. 165; Peschau, p. 31.

1312 Berg, p. 178 en 179; Eyermann/Fröhler, p. 644; Kopp, § 108 VwGO, Rdnr. 12; Peschau, p. 19.

${ }^{1313}$ Daarbij kan het in het administratieve proces gaan om een Anfechtungsklage, Verpflichtungsklage en een Feststellungsklage. Zie par. 5.2.
} 
auteurs die van mening zijn dat de bewijslastverdeling in het geval van een Feststellungsklage ( $\$ 43 \mathrm{VwGO}$ ) bij voorbaat vast ligt. Binnen het bewijsrechtelijk kader wordt, volgens Eyermann/Fröhler, het onderscheid tussen positieve en negatieve Feststellungsklage van belang. ${ }^{1314}$ Volgens deze auteurs ligt in het geval van een positieve Feststellungsklage de bewijslast van het bestaan van de rechtsverhouding bij de klager, terwijl bij een negatieve Feststellungsklage de bewijslast van het bestaan van de rechtsverhouding berust bij de "Beklagte" (het verwerend overheidsorgaan). ${ }^{1315}$ Andere auteurs, waaronder Ule, zijn dienaangaande evenwel een andere mening toegedaan. Ule stelt dat het niet zo is dat bij een positieve Feststellungsklage altijd de klager (de burger) de bewijslast draagt, noch dat bij een negatieve Feststellungsklage altijd de beklaagde (het zich verwerend overheidsorgaan) de bewijslast draagt. ${ }^{1316}$ Ule staat op het standpunt dat (ook) in de Feststellungsklage, ongeacht of het de positieve dan wel de negatieve vorm ervan betreft, het "Normbegünstigungsprinzip" dient te gelden. Kopp daarentegen wil bij een Feststellungsklage de invulling van de bewijslast als volgt zien. In een Feststellungsklage ligt de bewijslast ter zake van de feiten bij de klager, tenzij de klacht is gericht tegen een inbreuk op een recht door de overheid ("Abwehr hoheitlicher Eingriffe"). In dat laatste geval ligt de bewijslast bij de "Behör$d e " .{ }^{1317}$ Peschau is eveneens van mening dat de bewijslastverdeling niet afhankelijk dient te zijn van de "prozessuale Stellung" van de partijen. ${ }^{1318}$

Met de hierboven weergegeven Beweislastnormen zijn de in de literatuur meest beschreven regels weergegeven. Het zou in het kader van het onderhavige proefschrift te ver voeren om een bespreking te geven van alle verder in de literatuur genoemde criteria waarlangs tot een verdeling van de bewijslast kan worden gekomen. ${ }^{1319}$

\footnotetext{
${ }^{1314}$ Zie voor het onderscheid tussen positieve en negatieve Feststellungsklage par. 5.2.2.1.

13is Eyermann/Fröhler, p. 380. Idem Redeker/v. Oertzen, p. 216; Tschira/Schmitt Glaeser, p. 186.

${ }^{1316}$ Ule, p. 276.

${ }^{1317}$ Kopp, § 108 VwGO, Rdnrs. 14 en 15.

${ }^{13}$ Peschau, p. 21.

${ }^{139}$ Als andere bewijslastregels noemt Berg bijvoorbeeld nog:

(p. 190) in dubio pro libertate. D.w.z. aan het handelen van de overheid dienen vaststaande feiten ten grondslag te liggen (rechtsstaatgedachte); uit de materiēle regelgeving voortvloeiende andere bewijslastverdeling dient te worden afgewezen, wil er geen strijd met het Grundgesetz optreden. Deze regel werkt ten gunste van de burger;

(p. 190) in dubio pro auctoritate. D.w.z ten gunste van de overheid wordt de rechtmatigheid van diens handelen voorondersteld;

(p. 197) het Angriffs-Verteidigungs-Prinzip; ook wel genoemd: Schutz des Besitzbestandes. D.w.z. de bewijslast ligt bij degene die de bestaande situatie "verstoort";

(p. 205) bewijslastverdeling volgens de redelijkheid en de billijkheid;
} 


\subsubsection{De bewijswaardering ( $108 \mathrm{VwGO})$}

Voor het geval dat de rechtsprekende instantie niet wordt geconfronteerd met een non-liquet situatie, maar daarentegen uit het onderzoek naar de feitelijke omstandigheden een overtuiging (Überzeugung) omtrent de waarheid van deze omstandigheden verkrijgt, is er, als gezegd, sprake van de waardering van het aanwezige bewijs (Beweiswürdigung).

Met betrekking tot de waardering van het aanwezige bewijsmateriaal vormt binnen het administratief procesrecht $\$ 108$ Verwaltungsgerichtsordung de bewijsrechtelijke spil. ${ }^{1320}$ Ingevolge $\& 108$ VwGO heerst in het administratieve recht het beginsel van niet-wettelijk vastgelegde waardering van het bewijsmateriaal (die freie Beweiswürdigung). Een feit wordt ingevolge dit beginsel bewezen geacht indien de rechter voldoende overtuiging (Überzeugung) verkrijgt dat het gestelde feit daadwerkelijk is voorgevallen. ${ }^{1321}$

In het administratieve bewijs is derhalve vrije bewijskracht ("freie Beweiswürdigung $)^{1322}$ van de bewijsmiddelen het uitgangspunt. ${ }^{1323}$ Ook de uitspraken van een procespartij zijn onderhevig aan de vrije waardering van de rechter. ${ }^{1324}$

Ten aanzien van een enkel bewijsmiddel wordt op dit uitgangspunt een uitzondering gemaakt en is er geen sprake van vrije bewijswaardering. In een zodanig geval ligt op grond van een wettelijke bepaling de bewijskracht van het middel vast. In de literatuur wordt in het kader van die wettelijk vastgelegde bewijskracht gesproken over "Beweisregeln". ${ }^{1325}$

\section{$1319 \rightarrow$}

(p. 217) bewijslastverdeling volgens de abstracte waarschijnlijkheid. D.w.z. de gewone gang van zaken wordt als regel gesteld en wordt aangenomen in het geval van een non-liquet situatie.

Gezien Berg's reeds vermelde voorkeur voor bewijslastverdeling op grond van de betrokken materiele rechtsregel wekt zijn afwijzing van de zo juist vermelde bewijslastregels geen verbazing.

1320 Par. 108 VwGO luidt: "Das Gericht entscheidet nach seiner freien, aus dem Gesamtergebnis des Verfahrens gewonnenen Uberzeugung. "

1321 Vgl. Berg, p. 71; Redeker/v. Oertzen, p. 563; Ule, p. 270.

132 Vrije bewijswaardering wil zoveel zeggen, dat moet worden afgegaan op de innerlijke overtuigingskracht van hetgeen uit het middel blijkt. Kopp, $\$ 108$ VwGO, Rdnr. 4.

132 Eyermann/Fröhler, p. 717; Hufen, p. 620; Ule, p. 144. Ule wijst erop dat ook in het strafproces (\$ $261 \mathrm{StPO})$ en in het civiele proces ( $\$ 286 \mathrm{ZPO})$ de vrije waardering van het bewijs het leidende beginsel inzake de bewijswaardering is. Vgl. Nierhaus, p. 46.

${ }_{1324}$ In $\S 98$ VwGO wordt $\S 453$ ZPO van toepassing verklaard in het administratieve proces. Par. 453 ZPO luidt: "Das Gericht hat die Aussage der Partei nach $\$ 286$ frei zu wïrdigen." Vervolgens luidt \$ 286 ZPO: "Das Gericht hat unter Berücksichtigung des gesamten Inhalts der Verhandlungen und des Ergebnisses einer etwaigen Beweisaufnahme nach freier Überzeugung zu entscheiden, ob eine tatsächliche Behauptung fïr wahr oder fïr nicht wahr zu erachten sei. (.............). "Vgl. Kopp, \& 108 VwGO, Rdnr. 4.

${ }^{1323}$ Eyermann/Fróhler, p. 717; Hufen, p. 620; Kopp. $\$ 108$ VwGO, Rdnr. 4; Redeker/v. Oertzen, p. 564; Ule, p. 144. 
Zo is bijvoorbeeld de bewijskracht inzake (de echtheid en de inhoud van) akten wettelijk vastgelegd. ${ }^{1326}$ Ten aanzien van akten wordt in het Duitse recht op de algemene regel van vrije bewijswaardering een uitzondering gemaakt en is er sprake van wettelijk vastgelegd "voll Beweis" ( $\$$ 415, 416, 417 en $418 \mathrm{ZPO}$ ). Wel behoort in beginsel tegenbewijs tegen hetgeen door de akte wordt bewezen tot de mogelijkheid. ${ }^{1327}$ De bewijskracht van door buitenlandse autoriteiten opgestelde akten kent geen wettelijke regeling in het Duitse bewijsrecht. Dienaangaande is de opmerking van Kopp van belang, die stelt: "Ausländische öffentliche Urkunden haben grundsätzlich dieselbe Beweiskraft wie deutsche. "1328 Als gezegd, kent het Duitse recht een aantal wettelijke bepalingen aangaande een wettelijk vermoeden van de echtheid van akten. ${ }^{1329}$

\subsubsection{Beweismaß}

In paragraaf 6.1 is het begrip Beweismaß reeds genoemd. Het begrip heeft betrekking op de vraag in welke mate een feit dient vast te staan, wil kunnen worden gesteld dat het feit is bewezen. In dezelfde paragraaf is ook opgemerkt dat, vanuit praktisch oogpunt, in het bewijsrecht bewijzen niet een kwestie is van het verwerven van absolute zekerheid. Gebleken is dat ten aanzien van een rechtens relevant feit het verkrijgen van een bepaalde mate van waarschijnlijkheid voldoende is. Berg komt tot de gevolgtrekking dat bijna zonder uitzondering de "Beweiswürdigung" gestalte krijgt in de vorm van waarschijnlijkheidsoordelen, veroorzaakt door het feit

\footnotetext{
${ }^{1326}$ Dit op grond van $\S 415$ e.v. ZPO, in $\$ 98$ VwGO van toepassing verklaard in het administratief procesrecht. Zie par. 6.2 .

Vgl. \& 415 Abs. 2 ZPO; \& 418 ZPO. Vgl. par. 6.3.1.

122 Kopp, § 98 VwGO, Rdnr. 18. Idem Hảußer/Kapinos/Christ, p. 152. Vgl. BVerwG, U. v. 15.07.1986, DÖV 1987, p. 39: "Ausländischen öffentlichen Urkunden kommen dieselbe Beweiskraft zu wie deutschen öffentlichen Urkunden." Vgl. VG Stuttgart, B. v. 11.04.1991, InfAusIR 1991, p. 224: over het bewijs van een in Lagos (Nigeria) volgens Nigeriaans (traditioneel) recht (VG Stuttgart: Stammesrecht) gesloten huwelijk tussen een Nigeriaan en een Britse. In deze uitspraak wordt het Duitse bewijsrecht beinvloed door het recht van de Europese Unie. De vrouw (van Britse nationaliteit) is namelijk werkzaam in Duitsland en valt derhalve onder het bereik van het Verdrag van Rome uit 1957 (art. 48 EEG-verdrag). Het echtpaar legt als bewijs van het bestaan van hun huwelijk (gelegaliseerde) Nigeriaanse papieren over. De Duitse autoriteiten achten dit niet voldoende bewijs dat inderdaad een huwelijk bestaat (waaraan voor de man verblijfsrecht bij zijn echtgenote is gekoppeld). Het VG oordeelt echter dat op grond van de EEG-richtlijn $\mathrm{nr}$. 68/360 d.d. 15.10.1968 de autoriteiten verplicht zijn: "(......) für die Erteilung einer Aufenthalbserlaubnis an Familieangehörige eines Angehörigen eines Mitgliedstaats der EWG nur die Vorlage eines von der zuständigen Behörde ihres Herkunftsstaates ausgestellte Bescheinigung verlangen, in der das Verwandschaftsverhältnis bestätigt ist."

139 \$ 437 ZPO (Echtheid inländischer öffentlicher Urkunden); \$ 438 ZPO (Echtheid ausländischer öffentlicher Urkunden); \& $439 \mathrm{ZPO}$ (Erklärung über Echtheid von Privaturkunden); \& $440 \mathrm{ZPO}$ (Beweis der Echtheid von Privaturkunden).
} 
dat geen hogere mate van zekerheid in die gevallen voor handen is. ${ }^{1330}$ De vraag waar het vervolgens om gaat, is de vraag naar wélke bepaalde mate van waarschijnlijkheid. Hiermee is de kwestie van de Beweismaß aan de orde gesteld.

De vraag is derhalve welke mate van waarschijnlijkheid dient te worden nagestreefd. In een enkel geval geeft de tekst van de betreffende wettelijke bepaling uitsluitsel en is er derhalve geen twijfel mogelijk. Zo geldt bijvoorbeeld inzake voorlopige voorzieningen dat een lichte mate van waarschijnlijkheid voldoende is (en wel Glaubhaftmachung). ${ }^{1331}$ In de meeste gevallen biedt de aan de orde zijnde wettelijke regeling echter geen aanwijzing omtrent de gewenste mate van bewijs.

Uit het in paragraaf 6.1 weergegeven citaat van Eyermann/Fröhler komt naar voren dat een zodanige mate van waarschijnlijkheid gewenst is, dat twijfel omtrent de feiten wordt weggenomen. Indien geen sprake is van twijfel bij de rechter kan worden gesproken over Volle Überzeugung. Voor het begrip Volle Überzeugung wordt ook wel het begrip Strengbeweis gebruikt. ${ }^{1332}$ Het streven naar Volle Überzeugung is het uitgangspunt. ${ }^{1333}$

Binnen de literatuur bestaat echter onenigheid over de vraag of in het geval waarin de wet geen bepaling omtrent de zwaarte van het bewijs bevat, en waarin ondanks het onderzoek door de rechterlijke instantie en niet als gevolg van eigen toedoen van de betrokkene(n), geen "an Sicherheit grenzenden Wahrscheinlichkeit" wordt bereikt, maar er wel sprake is van "überwiegende Wahrscheinlichkeit", dit laatste toch niet voldoende bewijs kan opleveren. ${ }^{1334}$

De auteurs die met betrekking tot de bovenstaande voorwaarden een lichtere Beweisma $\beta$ afwijzen, geven wel toe dat in de jurisprudentie ten aanzien van een aantal rechtsgebieden wel degelijk Glaubhaftmachung (synoniem voor überwiegende Wahrscheinlichkeit) ${ }^{1335}$ voldoende bewijs wordt geacht. Eén van deze rechtsgebieden is incidenteel van belang voor het vaststellen van het bezit van de Duitse nationaliteit. Bedoeld rechtsgebied betreft het Vertriebenenrecht.

In paragraaf 4.1.4 zijn over het Bundesvertriebenengesetz reeds zijdelings enkele opmerkingen gemaakt. Het Bundesvertriebenengesetz kent het criterium "Volksdeutsche". Hetzelfde criterium komt voor in het Gesetz zur Regelung von Fragen der

\footnotetext{
${ }^{1390}$ Berg, p. 216.

1331 Zie ook par, 6.1.

1392 Ule, p. 272.

133 Nierhaus, p. 71.
}

1394 Eyermann/Fröhler, p. 717, menen van wel. Kopp, $\$ 108$ VwGO, Rdnr. 18, bestrijdt dit. Nierhaus, p. 71 , is vanzelfsprekend van mening "daß die Beweisanforderungen grundsärzlich nur kraft gesetzlicher Ermächtigung reduziert werden dürfen $(. . . . . .$.$) . .$

1333 Vgl. Eyermann/Fröhler, p. 647; Nierhaus, p. 72. 
Staatsangehörigkeit uit $1955 .{ }^{1336}$ Voor de vaststelling van het bezit van de Duitse nationaliteit is dit alles in zoverre van belang, dat, indien iemand de Duitse nationaliteit heeft verworven ingevolge een gedurende de periode 1938-1943 doorgevoerde collectieve naturalisatieregeling (deze regelingen hebben betrekking gehad op verschillende bevolkingsgroepen, voornamelijk in Oost-Europa) de desbetreffende persoon wegens de werking van het bovengenoemd Gesetz zur Regelung von Fragen der Staatsangehörigkeit de Duitse nationaliteit niet heeft verloren na afloop van de tweede wereldoorlog, indien hij deze nationaliteit wenst te behouden en hij "deutsche Volkszugehörige" is. In de jurisprudentie is uitgemaakt dat voor het bewijs van de "deutsche Volkszuhörigkeit" het voldoende is als dit glaubhaft wordt gemaakt. ${ }^{1337}$

\subsection{Bewijsrecht in administratiefrechtelijke procedures ter zake van de Duitse nationaliteit}

\subsubsection{Algemene beschouwingen}

Zoals vele administratiefrechtelijke wetten geeft ook het Reichs- und Staatsangehörigkeitsgesetz niet aan op welke wijze het bezit van de Duitse nationaliteit dient te worden bewezen. ${ }^{1338}$ In paragraaf 6.2 .1 is er reeds op gewezen dat als uitgangspunt in het administratieve proces geldt, dat als bewijsmiddel alle middelen zijn toegelaten. Het bezit van de Duitse nationaliteit kan derhalve met alle middelen worden bewezen. ${ }^{1339}$

Van overheidswege worden ten behoeve van het bewijs van het verwerven van de Duitse nationaliteit door naturalisatie of optie dan wel het verliezen ervan door bijvoorbeeld het doen van afstand, van oudsher bepaalde documenten (Staatsangehörigkeitsurkunden) verstrekt. De wettelijke basis van deze documenten vormt \& 39 RuStAG. In $\& 39$ RuStAG wordt tevens als aparte categorie vermeld de "Urkunden, die zur Bescheinigung der Staatsangehörigkeit dienen. " Hierin vindt de

\footnotetext{
1396 Zie tevens par. 4.1.1. BVerwG, U. v. 15.03.1994, DÖV 1994, p. 913 (zie par. 6.3.2.6): "(..........), ist deutscher Volkszugehöriger i. S. des $\$ 1$ Abs. 1 1. StARegG gewesen. Dieser Begriff ist mit dem des deutschen Volkszugehörigen in $\$ 6$ BVFG a. F. bzw. $\$ 6$ Abs. 1 BVFG n. F. identisch."

${ }^{137}$ Berg, p. 127; Nierhaus, p. 82-85; Eyermann/Fröhler, p. 717 en 718, achten voor de Vertriebenenstatus übenwiegende Wahrscheinlichkeit in plaats van Strengbeweis (synoniem voor Volle Überzeugung) voldoende.

$13 \mathrm{Vgl}$. de overweging van het LG Stade, B. v. 27.08.1975, IPRspr. 1975, Nr. 110 ter zake van een adoptieprocedure: "(......) bedarf es für die Bestätigung der Kindesannahme des Nachweises der Staatsangehörigkeit der Annehmenden. Wie der Nachweis zu führen ist, ist, soweit ersichtlich, im geltenden Recht nicht geregelt." Zie voorts Kanein, p. 24; Schleser, p. 324; Sturm, p. 24.

Vgl. Schleser, p. 324.
} 


\section{Hoofdstuk 6}

Staatsangehörigkeitsausweis zijn wettelijke grondslag. ${ }^{1340}$ De Staatsangehörigkeitsausweis is een verklaring van en geldt in beginsel als een bewijs van het bezit van de Duitse nationaliteit. Aangaande dit document is in de literatuur ${ }^{1341}$ en de jurisprudentie ${ }^{1342}$ bepaald dat het in beginsel voldoende bewijs levert, maar dat tegenbewijs mogelijk is. ${ }^{1343}$ Dit alles leidt tot de gevolgtrekking dat een Staatsangehörigkeitsausweis, hoewel een Urkunde waarop wellicht $\S 417 \mathrm{ZPO}^{1344}$ dan wel zeker ${ }^{1345}$ \& $418 \mathrm{ZPO}^{1346}$ van toepassing is, onder omstandigheden geen "voll Beweis" hoeft te leveren, maar dit in de meeste gevallen wel zal doen.

Andere documenten waaruit het bezit van de Duitse nationaliteit kan blijken, betreffen het paspoort en de Personalausweis. Ook met betrekking tot deze documenten is bepaald dat zij weliswaar een aanwijzing omtrent het bezit van de Duitse nationaliteit kunnen zijn, maar niet meer zijn dan dat. ${ }^{1347}$ Tegenbewijs is mogelijk. ${ }^{1348}$ Hemberger stelt dat aan de hand van een paspoort of een Personalausweis het in de gevallen waarin geen aanleiding bestaat tot twijfel het bezit van de Duitse nationaliteit "glaubhaft $z u$ machen" is. Tegenover de relatieve bewijssterkte van de Personalausweis stelt Hemberger de bewijssterkte van de Staatsangehörigkeitsausweis: "Als Nachweis ist einzig der Staatsangehörigkeitsausweis zugelassen. "1349

Een ten onrechte uitreiking van één van de bovenvermelde documenten heeft geen constitutieve werking. ${ }^{1350}$

1340 Het begrip "Staatsangehörigkeitsausweis" komt uit § 1 Allgemeine Verwaltungsvorschrift über Urkunden in Staatsangehörigkeitssachen (StAUrkVwV). Een zodanig document is het equivalent van de verklaring van Nederlanderschap, die door Nederlandse gemeenten wordt afgegeven. Ten behoeve van "Statusdeutschen" kent de StAUrkVwV de "Ausweis über die Rechtsstellung als Deutscher". Vgl. Kūhl, p. 2; Makarov/v. Mangoldt, $\S 39$ RuStAG, Rdnr. 10.

is41 Eck, StAZ 1992, p. 105; Hecker, StAZ 1986, p. 339; Meyer, NVwZ 1987, p. 25; Schätzel, p. 239.

${ }^{1342}$ BVerwG, U. v. 21.05.1985, Buchholz 130 \& 25 RuStAG Nr. 4; OVG Nordrhein-Westfalen, U. v. 20.12.1988, StAZ 1990, p. 22.

${ }^{134}$ Dit is in overeenstemming met de in par. 6.2.2 beschreven algemene regel.

1344 Par. 417 ZPO luidt: "Die von einer Behörde ausgestellten, eine amtliche Anordnung, Verfügung oder Entscheidung enthaltenden öffentlichen Urkunden begründen vollen Beweis ihres Inhalts. "

1345 Kühl, p. 99, die de toepasselijkheid van $\$ \$ 417$ en 418 ZPO op de Staatsangehörigkeitsausweis (STAA) bespreekt, houdt een slag om de arm wat de toepasselijkheid van $\$ 417$ ZPO betreft. Dit doet hij op grond van de overweging: "§ 417 ZPO wäre auf den STAA anwendbar, wenn der STAA eine Entscheidung im Sinne dieser Bestimmung enthielte. - Kühl werkt dit verder niet uit, omdat het naar zijn mening niet erg relevant is, aangezien $\$ 418$ ZPO zonder twijfel (al dan niet: ook) toepasselijk is.

1346 Par. 418 ZPO luidt: "Öffentliche Urkunden, die einen anderen als den in den $\$ \S 415,417$ bezeichneten Inhalt haben, begrinden wollen Beweis der darin bezeugten Tatsachen. "

${ }^{1947}$ Kanein, p. 24; Meyer, NVwZ 1987. p. 25; Sturm, p. 25.

13as Sturm, p. 24.

1349 Hemberger, StAZ 1994, p. 309. Vgl. Schleser, p. 324.

1950 Eck, StAZ 1992, p. 105; Meyer, NVwZ 1987, p. 25. BVerwG, U. v. 14.12.1972, BVerwGE 41. 277 [279]; BayVGH, U. v. 07.12.1983, StAZ 1984, p. 167; BVerwG, U. v. 21.05.1985, Buchholz 
Als gevolg van het feit dat het Duitse nationaliteitsrecht de mogelijkheid van verwerving van de nationaliteit op grond van een bepaald aantal opeenvolgende geboorten in Duitsland niet kent, ${ }^{1351}$ is het leveren van bewijs van nationaliteitsbezit door het overleggen van stukken aangaande opeenvolgende geboorten in Duitsland niet een relevant bewijsmiddel.

Het overleggen van bijvoorbeeld geboorte-akten kan wel dienstig zijn om de afstamming te bewijzen, maar in het kader van het in het Duitse recht heersende ius sanguinis stelsel ${ }^{1352}$ is dan tevens noodzakelijk dat komt vast te staan dat de personen van wie de afstamming is afgeleid de Duitse nationaliteit hebben bezeten. Dit is het in het nationaliteitsrecht bekende probleem van de "probatio diabolica", een probleem dat in het Nederlandse nationaliteitsrecht ook is onderkend. ${ }^{1353}$ Het Nederlandse nationaliteitsrecht ontkomt intussen als gevolg van de werking van de derde-generatieregel aan het tot op vele generaties terug noodzakelijke onderzoek naar de oorspronkelijke nationaliteitsverwerving en mogelijke verliesgronden door de opeenvolgende generaties. ${ }^{1354}$

Het ius sanguinis stelsel, zoals dat vanouds voorkomt in het RuStAG, heeft in de Duitse literatuur ten gevolge van de bovenbeschreven omslachtige bewijsbaarheid van de verwerving en het bezit van de nationaliteit de nodige kritiek over zich afgeroepen. Bijvoorbeeld Kühl stelt dienaangaande: "Der Nachweis bzw. die Nachprüfbarkeit der deutschen StA bedarf deshalb behördlicher Fürsorge, weil das deutsche StA-Recht nahezu kompromißlos ${ }^{1355}$ das Abstammungsprinzip verwirktlicht, ohne den Nachteil dieses Systems, die schwierige Beweisbarkeit der durch Abstammung erworbenen StA, durch gesetzliche Vermutungen oder Fiktionen abzuschwächen. "1356

Uit het bovenstaande wordt duidelijk dat het vanuit praktisch oogpunt vaak zeer omslachtig tot ondoenlijk zal zijn om tot vele voorgaande generaties terug te gaan en van de betrokkenen de verwerving en het mogelijk verlies van de nationaliteit te

${ }^{1330} \rightarrow$

13o \& 25 RuStAG Nr. 4; OVG Münster, U. v. 10.12.1985, NVwZ 1986, p. 936; BVerfG, B. v. 21.10.1987, BVerfGE 77, 137 [147]; OVG Nordrhein-Westfalen, U. v. 20.12.1988, StAZ 1990, p. 22; BVerwG, B. v. 20.03.1989, Buchholz 130 \& 3 RuStAG Nr. 2.

13sı De Groot, p. 61 en 62; Kühl, p. 15 (i.h.b. voetnoot 1); Weidelener/Hemberger, p. 10.

${ }^{13}$ Zie voetnoot 563 .

${ }^{1033} \mathrm{Vgl}$. Koens, p. 9. Lichter, p. 903, omschrijft probatio diabolica met: "Teufelsbeweis"; ein Beweis, der praktisch kaum oder nur unzulänglich zu erbringen ist. "

${ }^{134}$ Art. 3 lid 3 RWN en (oud) art. 2 sub a Wet Ned. 1892. Zie par. 3.3.1 (i.h.b. voetnoot 573).

${ }^{13 s s}$ De uitzondering op de regel betreft de vondeling: $\$ 4$ RuStAG; het bezit van de Duitse nationaliteit wordt verondersteld, tot het moment dat blijkt dat het kind niet via afstamming deze nationaliteit heeft verworven. Schätzel, p. 140; Weidelener/Hemberger, p. 10.

${ }^{\text {uss }}$ Kähl, p. 14. 
onderzoeken. ${ }^{1357}$ Ook de wetgever is op een gegeven moment doordrongen geraakt van dit onpraktische effekt van het ius sanguinis stelsel. Dit heeft geleid tot de volgende toegeving op het gebied van de bewijslevering. In de Bondsdag is op 4 juni 1981 uit naam van de regering door de "Parlementarische Staatssekretär" von Schoeler het volgende opgemerkt: "Um den Schwierigkeiten zu begegnen, die sich aus längeren Zeitabläufen für die Abkömmlinge ergeben können, hat die Arbeitsgemeinschaft der Innenministerien der Bundesländer schon vor Jahren beschlossen, da $\beta$ es für die Feststellung der deutschen Staatsangehörigkeit genügen soll, wenn der Antragsteller glaubhaft macht, daß er oder diejenigen Personen, von denen er seine deutsche Staatsangehörigkeit ableitet, seit dem 1. Januar 1914 -das heißt seit dem Inkraftreten des Reichs- und Staatsangehörigkeitsgesetzes- als deutsche Staatsangehörige behandelt worden ist. ${ }^{1358}$ Alhoewel de hierboven weergegeven opmerking in de Bondsdag is gedaan in verband met de wijze van afgifte van "Staatsangehörigkeitsausweise" door de administratie, is het echter aannemelijk dat de rechter in een administratief proces ter vaststelling van het bezit van de Duitse nationaliteit door afstamming dezelfde maatstaf zal hanteren. ${ }^{1359}$

Het is niet onbelangrijk om bij het bovenstaande goed voor ogen te houden dat het gaat om (bewijs van de) verwerving op grond van afstamming van personen met de Duitse nationaliteit. Aan de orde is derhalve het ius sanguinis stelsel en de daaraan inherent onpraktische bewijslevering. ${ }^{1360}$ Aan de omslachtige kant van deze bewijslevering wil men een tegemoetkoming doen. Dit gebeurt door het afzwakken van de Beweismaß. Met als gevolg dat indien het gaat om de verwerving van de Duitse nationaliteit krachtens de rechtsgrond van afstamming, de verwerving en derhalve het bezit van de Duitse nationaliteit "glaubhaft" wordt gemaakt door de omstandigheid dat iemand altijd is behandeld als van Duitse nationaliteit. Erkenning van het bezit van de Duitse nationaliteit is alsdan het gevolg. Evenwel is tegenbewijs niet uitgesloten. Kühl heeft in dat verband aandacht besteed aan de vraag in hoeverre dient vast te staan dat geen persoon uit de nationaliteitsrechtelijke "Vorfahrenkette" aan een verliesbepaling heeft voldaan

1357 Kühl, p. 15, wijst nog op het volgende: "Die Prüfung möglicher Verlustgründe stellt an den Rechtsanwender insofern besondere Ansprüche, als die maßgebliche Vorfahrenkette regelmäßig in die Zeit vor Inkraftreten des RuStAG zurückreicht, und mithin auch die Verlustgründe nach früher geltendem StA-recht in Betracht kommen." Vgl. Sturm, p. 24.

${ }_{1358}$ BT-Drs 9/556, p. 9. Vgl. Weidelener/Hemberger, p. 15.

$1359 \mathrm{Vgl}$. Hailbronner/Renner, p. 140 en 141; Makarov/v. Mangoldt, $\$ 4$ RuStAG, Rdnr. 22.

1300 Een ander effekt van het ius sanguinis stelsel is dat de verwerving van een nationaliteit in wezen los staat van een bepaald staatsterritorium. Vallen in oorsprong normaliter staatsterritorium en verwerving ius sanguinis van de bijbehorende nationaliteit samen, grenswijzigingen kunnen, indien het nationaliteitsrecht niet mede een wijziging ondergaat, in die samenhang roet in het eten gooien. Refererend aan het naar het westen opschuiven van de grens van de Poolse staat schrijft in 1989 Herrmann-Pfandt, p. 2: "Die deutsche Staatsangehörigkeit, die durch Geburt erworben wird, besitzen noch ca. 50 Prozent der heutigen deutschen Bewohner der deutsche Ostgebiete jenseits von Oder und Neiße." Vgl. tevens Alexy, NJW 1989, p. 2851; Kimminich, p. 734. 
voordat de nationaliteit aan de volgende generatie kon worden "doorgegeven". Naar deze auteur meent: "hat sich bei einer Nachprüfung der durch Abstammung erworbenen StA die Glaubhaftmachung zu schließen, daß keiner dieser Vorfahren zwischen Erwerb und Weitergabe der StA einen StA-Verlustgrund verwirklichte. ${ }^{\text {"1361 }}$

De eerder aangehaalde opmerking van de "Parlementarische Staatssekretär" von Schoeler dat het bezit van de Duitse nationaliteit op grond van afstamming ook door middel van langdurige overheidsbehandeling als zodanig kan worden bewezen, is wel aangehaald ter ondersteuning van de stelling dat het leveren van het bewijs van de Duitse nationaliteit mogelijk is door het bezit van staat. ${ }^{1362}$ Dit sluit overigens aan op het gegeven dat in het administratieve proces, waarop in dezen het nationaliteitsrechtelijke proces geen uitzondering vormt, alle bewijsmiddelen zijn toegestaan. ${ }^{1363}$

Zoals tevens in hoofdstuk 3 is gedaan met betrekking tot de Nederlandse jurisprudentie, is ook de bewijsrechtelijk relevante Duitse jurisprudentie verdeeld in beroepen op verwerving van de nationaliteit (categorie A) en in beroepen op behoud van de nationaliteit (categorie B).

Hieronder volgt een beschrijving van bewijsrechtelijk relevante jurisprudentie. In het onderstaande worden ter zake van een beroep op verwerving van de Duitse nationaliteit zes uitspraken besproken en in het kader van een beroep op behoud van de Duitse nationaliteit vier uitspraken.

\subsubsection{Jurisprudentie categorie A: Beroep op verwerving van de Duitse nationali- teit}

De verwerving van de Duitse nationaliteit is, vooral in het naaste verleden, niet beperkt gebleven tot de verwervingsgronden die het Reichs- und Staatsangehörig-

\footnotetext{
${ }^{136 t}$ Kühl, p. 15 . Op p. 135 omschrijft Kühl dit met "einem vernünftigen Wahrscheinlichkeitsgrad." 192 Bleckmann, ZaöRV 1974, p. 325: "Die possession d'état soll nur den Nachweis der Staatsangehörigkeit der Großeltern, Eltern und des betreffenden Individuums gestatten. Sie begründet eine Vermutung für die Staatsangehörigkeit, die durch Rückgriff auf Fakten und Recht widerlegt werden kann." Vgl. Sturm, p. 24.

${ }^{1363}$ Bleckmann, ZaöRV 1974, p. 326, benadrukt door te spreken van "dieses beweisrechtliche Rechtsinstitut" dat possession d'état een bewijsmiddel betreft. Het is derhalve geen verwervingsgrond, maar kan slechts worden gebruikt als onduidelijkheid bestaat betreffende het voorgevallen zijn van een verwervingsgrond. (Of het ook mogelijk is om door middel van het bezit van staat te bewijzen dat een verliesgrond niet is voorgevallen, wordt niet door Bleckmann behandeld; zie daarover par. 7.3.1. voor het Nederlandse recht.) Kan worden vastgesteld dat een verliesgrond zich heeft gerealiseerd, dan kan, ondanks het mogelijk jarenlang daarna nog worden behandeld als nationaal, possession d'état niet leiden tot de conclusie dat de nationaliteit is behouden. Zie tevens par. 6.2.1 en par. 6.3.1. Verwerving van het Nederlanderschap ingevolge bezit van staat is, volgens De Groot, losbl. uitgave Personen- en Familierecht, art. 19 RWN, aant. 1, niet mogelijk.
} 
keitsgesetz kent. ${ }^{1364}$ In gelijke mate waarin bij de beschrijving van de Nederlandse bewijsrechtelijk interessante rechtspraak de nadruk ligt op het bewijsrechtelijke aspect en niet zozeer op het materieel nationaliteitsrechtelijke aspect van een casus, wordt bij de bespreking van de Duitse bewijsrechtelijke rechtspraak dezelfde prioriteit aangehouden. Dit betekent dat op materieel nationaliteitsrechtelijke aspecten slechts zal worden ingegaan indien dit noodzakelijk is voor een goed begrip van de casus.

Gezien het beperkte aantal bewijsrechtelijk relevante uitspraken dat ter beschikking staat, heb ik gemeend zowel "zelfstandige" als "impliciete" vaststellingen te moeten opnemen. Als gezegd, worden ter zake van een beroep op verwerving zes uitspraken behandeld. Daarvan zijn twee uitspraken totstandgekomen op grond van een procedure ex $\S 43$ VwGO. ${ }^{1365}$ In één uitspraak is een samenloop tussen $\S 42$ VwGO (verplichting tot afgifte van een "Staatsangehörigkeitsurkunde nach $\$ 9$ Abs. 2 des 2. StAReg $G^{\prime \prime}$ ) en $\S 43 \mathrm{VwGO}$ aan de orde. ${ }^{1366}$ Twee uitspraken betreffen louter administratiefrechtelijke "impliciete vaststellingsprocedures" ( $\$ 42$ VwGO): één uitspraak daarvan betreft een Anfechtungsklage van de intrekking van een Vertriebenenausweis, ${ }^{1367}$ de andere casus gaat om een Verpflichtungsklage tot afgifte van een Vertriebenenausweis ${ }^{1368}$. In het zesde geval blijft het echter onduidelijk of het gaat om een "zelfstandige" dan wel een "impliciete" vaststellingsprocedure. ${ }^{1369}$

\subsubsection{BVerwG 10 januari 1961}

Cat. A. uitspr. I. Casusbeschrijving. Bewijs(middelen) van een naturalisatie.

In de onderhavige casus ${ }^{1370}$ stelt de betrokkene de Duitse nationaliteit te hebben verworven bij zijn geboorte door wettige afstamming van een vader met de Duitse nationaliteit. ${ }^{1371}$ De klager is in 1909 in de buurt van Hamburg geboren. Naar hij stelt, is zijn vader (geboren 1865) voor zijn (klagers) geboorte genaturaliseerd. Evenwel, de bewijzen met betrekking tot zijn vaders naturalisatie die de klager aan

\footnotetext{
${ }^{1364}$ Behalve de verwervingsgronden uit het RuStAG kan het gaan om verwervingsgronden uit éen van de (drie) Gesetze zur Regelung von Fragen der Staatsangehörigkeit, maar tevens om verwerving ingevolge naturalisatic in de (voormalige) DDR op naturalisatiegronden die het RuStAG niet kent. Zie voor dat laatste de in par. 5.4 .2 besproken uitspraak van het Bundesverfassungsgericht, B. v. 21.10.1987, BVerfGE 77, 137.
}

${ }^{1365}$ BVerwG, U. v. 10.01.1961, Buchholz 13o $\S 16$ RuStAG Nr. 1 en VG Bremen, U. v. 14.03.1988, NJW 1989, p. 1377.

${ }^{1366}$ BayVGH, U. v. 07.12.1983, StAZ 1984, p. 167.

${ }^{1367}$ BVerwG, U. v. 22.08.1979, BVerwGE 58, 259.

136 BVerwG, U. v. 15.03.1994, DŌV 1994, p. 911.

1369 BVerwG, U. v. 06.10.1966, DÖV 1967, p. 93.

${ }^{1970}$ BVerwG, U. v. 10.01.1961, Buchholz 130 o 16 RuStAG Nr. 1.

1371 Dit is cen beroep op $\$ 4$ RuStAG. 
de administratie heeft overgelegd, zijn naar de mening van de desbetreffende Staatsangehörigkeitsbehörde niet toereikend om tot de vaststelling te komen dat de vader door naturalisatie de Duitse nationaliteit heeft verworven en dat, als gevolg daarvan, de klager eveneens in het bezit van de Duitse nationaliteit is. Tegen dit oordeel ageert de klager met het instellen van een Feststellungsklage. In de twee feitelijke instanties wordt de klager in het gelijk gesteld. De overheid stelt daarop Revision $^{1372}$ in bij het Bundesverwaltungsgericht.

De essentie van de onderhavige zaak is het feit dat van de beweerde naturalisatie geen onmiddellijk bewijsmiddel (de Einbürgerungsurkunde of een copie daarvan) aanwezig is. Slechts indirecte bewijsstukken staan ter beschikking. Zo blijkt dat in een register te Hamburg de vader met zijn gezinsleden wat betreft de nationaliteit te boek staat, eerst met de aanduiding "Preußen", naderhand met "Deutsches Reich". Hetzelfde register meldt in het jaar 1908 dat ten aanzien van de, toen nog, preußische Staatsangehörigkeit van klagers vader een "Attest des Kaiserlich Deutschen Generalkonsulats in Brüssel v. 25.5.1908 vorgelegen hat." Voorts blijken zowel klagers ouders als een broer van de klager in het bezit te zijn gesteld van Duitse paspoorten.

In zijn uitspraak wijst het BVerwG het beroep van de overheid af. Weliswaar stelt het BVerwG in de uitspraak voorop dat het meest twijfel uitsluitende bewijs van een naturalisatie wordt verkregen door hetzij het overleggen van de "Verleihungsurkunde" dan wel door "die Eintragungen in dem Einbürgerungslisten der zuständigen Behörden". Maar daarmee is volgens het BVerwG zeker niet gezegd dat zodanige stukken het enige bewijs zouden kunnen vormen. Het betoog wordt voortgezet met de overweging: "Bei weit zurückliegenden Einbürgerungen, insbesondere solchen, über die ein Nachweis durch Einbürgerungslisten nicht mehr geführt werden kann, ist der Nachweis der Verleihung der Staatsangehörigkeit auch auf andere Weise zuzulassen."

$\mathrm{Na}$ de bovenvermelde standpuntbepaling inzake welke bewijsmiddelen aanvaardbaar zijn om een (oude) naturalisatie te bewijzen, stelt het BVerwG: "Ob der Nachweis für die Verleihung der deutschen Staatsangehörigkeit als erbracht anzusehen ist, ist eine Frage der Beweiswürdigung. "

Met deze opmerking wijst het BVerwG op een procesrechtelijke beperking in zijn toetsingsmogelijkheden. De vraag of aan overgelegd bewijsmateriaal de conclusie kan worden verbonden dat een bepaald feit bewezen is te achten, betreft namelijk een feitelijk oordeel. De taak van het BVerwG (dat handelt in Revision) is met betrekking tot de Beweiswürdigung, dat een feitelijk oordeel inhoudt, beperkt. Slechts in het geval dat de uitkomst van de Beweiswürdigung tegen regels van

${ }^{372}$ Zie par. 4.2.2. 
ervaring of logica indruist, heeft het BVerwG ruimte voor de vernietiging van de uitspraak in feitelijke instantie.

Het BVerwG acht echter "die Überzeugung ${ }^{1373}$ des Gerichts (........), daß der Nachweis der Verleihung der preußischen Staatsangehörigkeit an den Vater des Kl. als erbracht anzusehen ist" niet in strijd met regels van ervaring of logica. Aangaande het uit Brussel afkomstige "Attest" stelt het BVerwG: "Wenn dieser Umstand vom Berufungsgericht als Indiz dafür verwendet worden ist, daß dem Vater des $K l$. die preußische Staatsangehörigkeit bereits früher verliehen worden ist, so widerspricht dies weder Erfahrungssätzen noch den Denkgesetzen. " Ook het ten faveure van klagers stelling aangemerkte bezit van Duitse paspoorten door klagers naaste familieleden houdt naar het oordeel van het BVerwG stand. Het eindoordeel van het BVerwG luidt dan ook: "Unter diesen Umständen ist es revisionsgerichtlich nicht zu beanstanden, daß das Berufungsgericht den Nachweis für die Verleihung der deutschen Staatsangehörigkeit an den Vater des Kl. und damit den Nachweis für die deutsche Staatsangehörigkeit des $\mathrm{Kl}$. selbst als erbracht angesehen hat."

Aantekening.

Naar aanleiding van deze uitspraak heeft Schleser opgemerkt: "Die Tatsache des StAErwerbs kann als erwiesen angenommen werden, wenn sie mittels anderer staatsangehörigkeitsrechtlich bedeutsamer Unterlagen glaubhaft gemacht ist. (.........). Beim Fehlen zweifelsfreier Nachweise hilft die Glaubhaftmachung weiter. Als Ersatznachweismittel kommen hauptsächlich Personalpapiere, Reisepässe und sonstige Identitätsbescheinigungen in Betracht, in denen das Tatbestandsmerkmal der Staatsangehörigkeit eingetragen ist. ${ }^{~ 1374}$

Zowel met betrekking tot de bewijsmiddelen als met betrekking tot de minimaal gewenste bewijssterkte (Beweismaß) doet Schleser hiermee een uitspraak. In navolging van het BVerwG stelt Schleser dat andere nationaliteitsrechtelijke relevante bewijzen (documenten) ook als bewijsmiddel voor een naturalisatie kunnen worden gebruikt. Dit is een uitkomst die volledig strookt met het gegeven dat in het Verwaltungsrecht alle bewijsmiddelen zijn toegelaten (par. 6.2.1), dus ook in het nationaliteitrecht (par. 6.3.1). Voorts doet Schleser met betrekking tot de Beweismaß de uitspraak dat Glaubhaftmachung voldoende is.

Omtrent de bewijslastverdeling kan uit de onderhavige casus geen oordeel worden gevormd. Dit is het gevolg van het feit dat i.c. geen sprake is van een nonliquet situatie. In feitelijke instantie is immers sprake van Beweiswürdigung. Het BVerwG stelt in deze zaak duidelijk dat de beoordeling over de verwerving van de

${ }^{13 n}$ Cf. $\$ 108$ VwGO, dat luidt: "Das Gericht entscheidet nach seiner freien, aus dem Gesamtergebnis des Verfahrens gewonnenen Überzeugung. " Zie par. 6.2.2.

1374 Schleser, p. 324 en 325. 
Duitse nationaliteit op grond van de overgelegde bewijsstukken een kwestie van Beweiswürdigung betreft.

\subsubsection{BVerwG 6 oktober 1966}

Cat. A. uitspr. II. Casusbeschrijving. Bewijs van deutsche Volkszugehörigkeit.

$\mathrm{Na}$ afloop van de tweede wereldoorlog is in alle hevigheid de problematiek losgebarsten inzake het wel of niet bezitten van de Duitse nationaliteit door personen die de Duitse nationaliteit hadden verworven op grond van de gedurende die oorlog collectief doorgevoerde naturalisaties in de door Duitsland bezette gebieden. ${ }^{1375}$ Ook de onderhavige casus ${ }^{1376}$ is een gevolg van een regeling tot collectieve naturalisatie. ${ }^{13 \pi}$

Het gebied waaruit de betrokkene in deze casus afkomstig is, wordt in het Duits aangeduid met Untersteiermark, een gebied dat ligt ten zuiden van Oostenrijk in het huidige Sloveniē. ${ }^{1378}$

Van de uitspraak zijn slechts de rechtsoverwegingen gepubliceerd, zodat over de feiten niet veel kan worden weergegeven. Met name kan niets worden gezegd over de aanleiding voor de betrokkene om over het bezit van de Duitse nationaliteit een rechterlijke procedure aanhangig te maken. In de uitspraak wordt wel duidelijk dat de betrokkene ingevolge het BVFG is erkend als Flüchtling.

In ieder geval is het zonder twijfel dat de betrokkene in 1941 de Duitse nationaliteit heeft verworven op grond van een regeling tot collectieve naturalisatie. ${ }^{1379}$ Op grond van de betreffende regeling uit 1941 kon men ofwel de Duitse nationaliteit zonder meer verwerven ofwel deze nationaliteit "auf Widerruf" verwerven. De verwerving "auf Widerruf" betekende dat het voor de toenmalige autoriteiten mogelijk was om de verwerving van de Duitse nationaliteit in een concreet geval te herroepen, derhalve ongedaan te maken. In de regeling wordt daarvoor een termijn van tien jaar uitgetrokken. Als gevolg van de ineenstorting van het regime behoeft

\footnotetext{
${ }^{137 s}$ In zijn U. v. 25.11.1965, DÖV 1966, p. 241, spreekt het BVerwG zelfs over: "Die 'Trümmerfelder', die nach 1945 auf dem Gebiet des Staatsanghörigkeitsrecht zurückgeblieben sind, (.........)."

${ }^{137}$ BVerwG, U. v. 06.10.1966, DÖV 1967, p. 93.

is In het bijzonder in Oost-Europese gebieden is als gevolg van collectieve naturalisatie de Duitse nationaliteit verworven. Het betrof naturalisaties van rechtswege. Denk onder meer aan de situatie van Oostenrijk in 1938. En het Sudetenland, waarvoor het Duitse nationaliteitsrecht is gaan gelden (voor bepaalde bevolkingsgroepen) op 12.02.1939, met terugwerkende kracht tot 10.10.1938 (Lichter, p. 229).

1378 Tot voor kort Noord-Joegoslaviē.

1399 Dit betreft de "Verordnung über den Enwerb der Staatsangehörigkeit in den befreiten Gebieten der Untersteiermark, Kärntens und Krains vom 14.10.1941. De betreffende regeling is volledig afgedrukt bij Lichter, p. 335-344. Over deze regeling: Hailbronner/Renner, p. 14 en 15.
} 


\section{Hoofdstuk 6}

voor de periode na 08.05.1945 echter nimmer te worden onderzocht of een zodanige herroeping aan de orde is.

De betrokkene is in 1941 "auf Widerruf" genaturaliseerd. Een herroeping heeft zich niet voorgedaan. Desalniettemin leiden deze twee gegevens nog niet zonder meer tot de vaststelling dat de betrokkene in het bezit van de Duitse nationaliteit is. Voor de door de klager gewenste vaststelling van zijn Duitse nationaliteit speelt tevens na-oorlogse (West)-Duitse regelgeving een rol. Daarbij gaat het om de reeds in paragraaf 4.1.1 vermelde "Gesetze zur Regelung von Fragen der Staatsangehörigkeit" die, ter regeling van de rechtsgevolgen van de collectieve naturalisaties, in de jaren vijftig tot stand zijn gekomen. Op de klager is van toepassing $\S 1$ Abs. 1 Buchst. e StARegG. ${ }^{1380}$

Cruciaal in de desbetreffende Paragraph zijn de openingswoorden waarin wordt verwezen naar het begrip "deutscher Volkszugehöriger". Het begrip "deutscher Volkszugehöriger", in het leven geroepen in 1939 door de toenmalige minister van binnenlandse zaken, ${ }^{1381}$ is in voorafgaande paragrafen al eerder aan de orde gekomen. Hetzelfde begrip vindt namelijk eveneens toepassing in Artikel 116 Grundgesetz en in het Gesetz äber die Angelegenheiten der Vertriebenen und Flüchtlinge uit $1953 .^{1382}$

Ook binnen nationaliteitsrechtelijke context vindt de begripsinvulling van "deutscher Volkszugehöriger" plaats aan de hand van de definitie die wordt gegeven in $\S 6$ BVFG. Aangaande het begrip "deutscher Volkszugehöriger" kan worden gesteld dat het in de loop van de tijd tot veel jurisprudentie heeft geleid. ${ }^{1383}$ Ook de onderhavige casus draait om dat begrip.

${ }^{1380}$ Par. 1 Abs. 1 Buchst. e StARegG: "Die deutschen Volkszugehörigen, denen die deutsche Staatsangehörigkeit auf Grund folgender Bestimmungen verliehen worden ist: (.......), e) Verordnung über den Enwerb der deutschen Staatsangehörigkeit in Gebieten der Untersteiermark, Kärntens und Krains vom 14. Oktober 1941, (..........), sind nach Maßgabe der genannten Bestimmungen deutsche Staatsangehōrige geworden, es sei denn, daß sie die deutsche Staatsangehörigkeit durch ausdrückliche Erklärung ausgeschlagen haben oder noch ausschlagen." De verklaring tot afstand van de Duitse nationaliteit is ingevolge $\$ 5$ StARegG mogelijk geweest tot 26.02.1956.

1981 Hailbronner/Renner, p. 385. De begripsbepaling van "deutscher Volkszugehöriger" luidt sindsdien (Lichter, p. 205): "Deutscher Volkszugehöriger ist, wer sich selbst als Angehöriger des deutschen Volkes bekennt, sofern dieses Bekenntnis durch bestimmte Tatsachen, wie Sprache, Erziehung. Kultur usw., bestätigt wird."

$13 n$ En wel in $\$ 6$ BVFG: "Deutscher Volkszugehöriger im Sinne dieses Gesetzes ist, wer sich in seiner Heimat zum deutschen Volkstum bekannt hat, sofern dieses Bekenntnis durch bestimmte Merkmale wie Abstammung, Sprache, Erziehung, Kultur bestätigt wird." Van de definitie uit 1939 (zie de voorafgaande voetnoot) wijkt dit slechts in zoverre af dat "in seiner Heimat" en "Abstammung" zijn toegevoegd. Vgl. par. 4.1.4.

198 Al gaat het daarbij voornamelijk om jurisprudentie in het kader van het BVFG, en derhalve om de vaststelling van de status van Vertriebene en/of het uitreiken van een "Vertriebenenausweis". De kwestic van de deutsche Volkszughörigkeit speelt ook wel in nationaliteitsrechtelijke procedures, maar in relatief mindere mate. 
Om te voldoen aan de na-oorlogse regelgeving en om de verwerving van de Duitse nationaliteit te kunnen laten vaststellen, dient de klager derhalve te kunnen worden aangemerkt als "deutscher Volkszugehöriger". Ter ondersteuning van zijn stelling dat hij aan dat vereiste voldoet, heeft de klager in de procedure voor het Bayerische Verwaltingsgerichtshof drie argumenten aangevoerd. Zo heeft hij gesteld lid te zijn geweest van de "Steirischen Heimatbund", dat hij tijdens de Duitse bezetting door de bezettingsmacht is behandeld als Duitser en dat zijn moeder "Volksdeutsche" is geweest.

Dienaangaande stelt het BVerwG: "Das kann, muß aber nicht in jedem Falle ausreichen. Da nicht ausgeschlossen ist, daß die Würdigung dieses Sachverhalts zugunsten des $K l$. ausfällt, wenn die historischen Gegebenheiten der deutschen Volksgruppe in der Untersteiermark und die persönlichen Verhältnisse des $K l$. berücksichtigt werden, wird das BerGer. den Sachverhalt nochmals unter den dargelegten Gesichtspunkten ${ }^{1384}$ prüfen müssen."

\section{Aantekening.}

Bij het indelen van deze casus is het een lastig punt gebleken om te bepalen of het i.c. nu betreft een beroep op verwerving dan wel een beroep op behoud van de Duitse nationaliteit. Voor beide is wat te zeggen. Uiteindelijk heb ik gekozen voor de indeling bij de categorie van beroep op verwerven van de nationaliteit, omdat in de casus ter beoordeling staat een voorwaarde die de wetgever noodzakelijk heeft geacht voor de verwerving van de Duitse nationaliteit.

Door Häußer/Kapinos/Christ wordt een groot aantal rechterlijke uitspraken genoemd die een oordeel inhouden over de vraag of bepaalde concrete omstandigheden een "Bekenntnis zum deutschen Volkstum" hebben betekend. ${ }^{1385}$ Daaronder is ook een uitspraak van het VGH Baden-Württemberg uit 1979 waarin het lidmaatschap van de "Steirischen Heimatbund" is gewaardeerd als positief bewijs voor het feit van "Bekenntnis zum deutschen Volkstum". ${ }^{1386}$

Het BVerwG doet de zaak niet zelf af, maar verwijst terug en stelt dat op feitelijk niveau nog de Beweiswürdigung van de door de klager gestelde feiten dient plaats te vinden. Op grond van het onderhavige geval kunnen omtrent de Beweis$m a \beta$ of de bewijslastverdeling geen conclusies worden getrokken. Dit laatste is het gevolg van het feit dat er in feitelijke instantie geen sprake is van een non-liquet situatie, maar dat er sprake is van Beweiswürdigung.

\footnotetext{
${ }^{134}$ De feitelijke instantie heeft voor de toetsing van het moment waarop de betrokkene zijn "Bekenntnis zum deutschen Volkstum" dient te hebben gedaan een ander moment aangehouden dan het BVerwG voorstaat. Op grond daarvan alleen al kon de uitspraak van het BayVGH niet in stand blijven.

13 Häußer/Kapinos/Christ, p. 90 en 91.

1346 Zie ook BVerwG, U. v. 24.02.1966, DÖV 1966, p. 241.
} 


\subsubsection{BVerwG 22 augustus 1979}

Cat. A. uitspr. III. Casusbeschrijving. Geen bezit van de Duitse nationaliteit op grond van het vertrouwensbeginsel.

In de onderhavige casus ${ }^{1387}$ gaat het evenals in de voorafgaande casus om een uit Untersteiermark afkomstige man, die in 1941 op grond van dezelfde collectieve naturalisatieregeling ${ }^{1388}$ de Duitse nationaliteit verwerft. Geboren in 1930, verblijft de betrokkene tot 1957 in Joegoslavië, en vertrekt hij in dat jaar naar Oostenrijk en daarna naar Canada. Vanuit dat laatste land reist de betrokkene in 1960 naar het toenmalige West-Duitsland. Daar wordt hem een bewijs van het bezit van de Duitse nationaliteit uitgereikt en mede een Vertriebenenausweis.

In 1975 wordt van overheidswege getwijfeld aan de juistheid van het oordeel over het bezit van de Duitse nationaliteit door de betrokkene. Dit leidt tot intrekking van de Vertriebenenausweis en het aanspannen door de betrokkene van een Anfechtungsklage tegen de intrekking. Tijdens deze Anfechtungsklage inzake de intrekking van de Vertriebenenausweis gaat de zaak echter om de vraag of de betrokkene nu wel of niet in het bezit is van de Duitse nationaliteit.

In feitelijke instantie heeft de klager succes. Het Verwaltungsgerichtshof te München is namelijk van oordeel dat: "(.....), den in dieser Richtung bestehenden Zweifeln komme kein so großes Gewicht zu, daß das Vertrauen des Klägers auf den Erwerb der deutschen Staatsangehörigkeit durch Sammeleinbürgerung der Schutz versagt werden müsse."

De overheid kan zich niet vinden in deze uitspraak en stelt Revision ${ }^{1389}$ in bij het Bundesverwaltungsgericht. Het BVerwG schaart zich aan de kant van de overheid en oordeelt als volgt. Primair stelt het dat de klager slechts in het bezit van de Duitse nationaliteit kan zijn, "(........), wenn er die Erfordernisse in $\S 1$ Abs. 1 Buchst. e StARegG erfült." ${ }^{1390}$ Daarop vervolgt het BverwG met de uiterst interessante rechtsoverweging: "Der Verwaltungsgerichtshof hat die Entscheidung dieser Frage umgangen mit der Erwägung, der Kläger sei aus Gründen

${ }^{1387}$ BVerwG, U. v. 22.08.1979, BVerwGE 58, 259.

$138 s$ Het gaat om de "Verordnung über den Enwerb der staatsangehörigkeit in den befreiten Gebieten der Untersteiermark, Kärnten und Krains vom 14.10.194I". Over deze maatregel: Hailbronner/Renner, p. 14 en 15. De betreffende maatregel is volledig afgedrukt bij Lichter, p. 335-344.

1389 Zie par, 4.2.2.

${ }^{1390}$ Par, 1 Abs. 1 Buchst. e StAgRegG: "Die deutschen Volkszugehörigen, denen die deutsche Staatsangehörigkeit auf Grund folgender Bestimmungen verliehen worden ist: (........, e) Verordnung über den Enwerb der deutschen Staatsangehörigkeit in Gebieten der Untersteiermark, Kärmtens und Krains vom 14. Oktober 1941, (..........), sind nach Maßgabe der genannten Bestimmungen deutsche Staatsangehörige geworden, es sei denn, daß sie die deutsche Staatsangehörigkeit durch ausdrückliche Erklärung ausgeschlagen haben oder noch ausschlagen. " De verklaring tot afstand van de Duitse nationaliteit is ingevolge $\$ 5$ StARegG mogelijk geweest tot 26,02.1956. 
des Vertrauensschutzes als deutscher Staatsangehöriger anzusehen. Diese Erwägung verletzt Bundesrecht."

Het BVerwG sluit de uitspraak af met de overweging: "Die letztlich bestehenbleibende bloße Annahme des Klägers und der beteiligten Behörden, er sei deutscher Staatsangehöriger und sei es gegebenenfalls bereits am 21. März $1957^{1391}$ gewesen, ist keine Grundlage für die Erwägung von Vertrauensschutz. Sie könnte bei der Einbürgerung des Klägers Bedeutung erlangen. Für die Frage, ob der Kläger bereits deutscher Staatsangehöriger ist, ist sie rechtlich ebenso ohne Belang wie die von ihr abhängigen Ausweispapieren, die dem Kläger gegebenenfalls ausgestellt wurden.

Daher trägt die Erwägungen des Verwaltungsgerichtshofs uber Vertrauensschutz des Klägers im Hinblick auf seine deutsche Staatsangehörigkeit das angefochtene Urteil nicht."

Aantekening.

Hoewel met betrekking tot het bewijsrecht de onderhavige casus weinig tot niets oplevert, heb ik desondanks besloten de uitspraak op te nemen aangezien het een (tweede) $^{1392}$ uitspraak van het BVerwG betreft waaruit duidelijk wordt dat verwerving van de Duitse nationaliteit op grond van vertrouwen niet mogelijk is.

\subsubsection{BayVGH 7 december 1983}

Cat. A. uitspr. IV. Casusbeschrijving. Verwerving door optie, na eerder verlies van rechtswege.

De klager die zich in deze $\mathrm{zaak}^{1393}$ tot het Bayerische Verwaltungsgerichtshof heeft gewend ten einde een oordeel te verkrijgen over het bezit van de Duitse nationaliteit is in 1909 geboren in Oostenrijk. Bij zijn geboorte verwierf de klager de Oostenrijkse nationaliteit. De klager vestigt zich in 1936 in Duitsland. Door middel van collectieve naturalisatie verwerft de klager in 1938 de Duitse nationaliteit. ${ }^{1394}$ De klager behoudt zijn woonplaats in Duitsland, en krijgt in 1952 en 1957 een Personalausweis uitgereikt.

\footnotetext{
1391 Als peildatum geldt het moment van vertrek uit Joegoslaviê, de procedure gaat immers om de intrekking van een Vertriebenenausweis. Dan geldt het moment van vertrek uit het verdrijvingsgebied.

1392 Zie ook par. 6.3.3.2.

${ }^{1393}$ BayVGH, U. v. 07.12.1983, StAZ 1984, p. 167.

1394 Op grond van de "Verordnung über die deutsche Staatsangehörigkeit im Lande Österreich vom 3.7.1938." De volledige Verordnung is opgenomen bij Lichter, p. 221-225. Vgl. Hailbronner/Renner, p. 12 ,
} 
Inzake het bezit van de Duitse nationaliteit door de klager ontstaan in 1961 problemen. Blijkens de uitspraak is de klager niet goed op de hoogte geweest met het feit van de totstandkoming in 1956 van het Zweite Gesetz zur Regelung von Fragen der Staatsangehörigkeit. Kern van deze regeling is dat de Duitse nationaliteit van Oostenrijkers die in 1938 collectief zijn genaturaliseerd vervalt met terugwerkende kracht tot $27.04 .1945 .{ }^{1395}$ Ten behoeve van degenen die sinds 1945 in Duitsland zijn gevestigd (gebleven), is de mogelijkheid tot herkrijging van de Duitse nationaliteit door middel van het uitbrengen van een optie opgenomen. Wordt de optie uitgebracht dan bezit de betrokkene fictief vanaf 27.04.1945 weer de Duitse nationaliteit. De betrokkenen, waaronder de klager i.c., hebben vanaf 24.05.1956 tot 30.06.1957 de gelegenheid gehad om de betreffende optie af te leggen.

Als gezegd, de klager is niet goed op de hoogte geweest van de wettelijke regeling en al evenmin van het feit dat hij van rechtswege de Duitse nationaliteit heeft verloren en dat hij voor het herkrijgen van zijn Duitse nationaliteit een optie heeft kunnen afleggen. Wel heeft de klager over zijn nationaliteit nog in 1956 met de burgemeester van zijn woonplaats een gesprek gevoerd. Door een publikatie geattendeerd, wilde de klager bij de gemeente een verklaring ondertekenen dat hij de Duitse nationaliteit wilde behouden. In de uitspraak wordt dienaangaande opgemerkt door het BayVGH: "Zu dieser Unterschrift kam es nicht, weil der Bürgermeister dem Kläger erklärte, er brauche das nicht, er sei ja Deutscher und habe einen deutschen Ausweis."

De optie wordt derhalve niet gedaan, maar evengoed verkrijgt de klager op 13.11.1957 zonder problemen een verlenging van zijn Personalausweis.

Desalniettemin verkeert de klager in het begin van de jaren zestig wederom in nationaliteitsonzekerheid. Hij probeert in 1961 alsnog de optie af te leggen, vraagt tevens een verblijfsvergunning aan en in 1962 dient hij een aanvraag tot verlening van de Duitse nationaliteit aan. Deze aanvraag wordt na vier jaar van overheidswege als vervallen beschouwd, aangezien de klager "aus persönliche Gründen erforderliche Unterlagen nicht beigebracht hatte." In 1972 valt het besluit de klager uit te zetten (naar Oostenrijk). In 1976 krijgt de klager toestemming tot verblijf in Duitsland en enige jaren later verzoekt de klager de lokale overheid om vaststelling van zijn Duitse nationaliteit en om de afgifte van een Staatsangehörigkeitsausweis. Beide worden geweigerd.

In de gerechtelijke procedure die de betrokkene daarop aanhangig maakt, stelt het Bayerische Verwaltungsgerichtshof vast dat de betrokkene in het bezit is van de Duitse nationaliteit. Dit wordt in belangrijke mate gebaseerd op de gebeurtenis in 1956, toen de klager een verklaring inzake zijn Duitse nationaliteit wilde afleggen,

${ }^{1395}$ Oostenrijk heeft al in juli 1945 nationaliteitsrechtelijke bepalingen getroffen. Zie De Groot, p. 144; Hailbronner/Renner, p. 460. 
maar dit op grond van het gesprek met de burgemeester niet heeft gedaan. Ten aanzien hiervan stelt het BayVGH: "Das zur Überzeugung des Senats erwiesene Gespräch im Jahre 1956 zeigt, daß der Kläger von der Problematiek seiner Staatsangehörigkeit und der grundsätzlichen Notwendigkeit, eine Optionserklärung abzugeben, wußte, Seinen Willen, Deutscher zu bleiben, hat er in dieser Besprechung kundgetan, wenn auch nicht schriftlich niedergelegt."

Echter, met deze overweging is de zaak nog niet rond. Het feit dat in 1956 (dus binnen de termijn waarin kon worden geopteerd) wel de wil tot het bezit van de Duitse nationaliteit is geuit, maar dat deze wilsverklaring niet schriftelijk én bij de juiste ambtenaar is gedaan, veroorzaakt dat er in beginsel geen sprake is van een rechtsgeldige optie. Von Mangoldt, die een annotatie bij deze casus heeft geschreven, wijst erop dat voor herkrijging van de Duitse nationaliteit op grond van het Zweite Gesetz zur Regelung von Fragen der Staatsangehörigkeit door optanten voldaan moest worden aan een aantal vereisten. De wilsverklaring ("Erwerbserklärung") diende "in öffentlich beglaubigter Form oder zu Protokoll einer Behörde bei der zuständigen Einbürgerungsbehörde" te worden afgegeven. ${ }^{139}$ Aan deze vereisten voldoet de klager niet.

Maar daar weet het BayVGH een mouw aan te passen. Het BayVGH overweegt: "Die schriftliche Fixierung erfolgte in Jahr darauf im Rahmen des Antrags auf Verlängerung des Bundespersonalausweises, der nur Deutschen ausgestellt wird; in dem Antrag is die Staatsangehörigkeit anzugeben. Auf der Grundlage des Gesprächs ${ }^{1397}$ ist diese Angabe im Antrag des Klägers nicht nur eine Mitteilung, sondern eine Manifestation des bereits früher erklärten Willens."

Ten gunste van de klager leiden de bovenstaande gegevens het BayVGH tot de volgende slotsom: "Nach alledem wurde bereits im November 1957 eine wirksame Optionserklärung abgegeben, (........)."

Het vastleggen door het BayVGH van het optiemoment op een moment in november 1957 betekent dat de optie eigenlijk niet is afgelegd binnen de reguliere termijn die immers tot 30.06.1957 liep. Nu kent het Zweite Gesetz zur Regelung von Fragen der Staatsangehörigkeit een regeling ${ }^{1398}$ voor het opteren na afloop van de reguliere termijn wegens het buiten eigen schuld niet op tijd hebben kunnen opteren. Deze termijnverlenging grijpt het BayVGH aan om tot een binnen een optietermijn vallende optie te komen. Derhalve stelt het BayVGH: "(.......) hat der Kläger in Gestalt des Antrags auf Verlängerung des Bundespersonalausweises im November 1957 innerhalb der vom Gesetzgeber eingeräumten Nachfrist formgerecht eine Wiedererwerbserklärung (Option) abgegeben."

\footnotetext{
1396 StAZ 1984, p. 169.

${ }^{139}$ Bedoeld wordt het gesprek een jaar eerder met de burgemeester.

${ }^{139}$ Par. 9 2.StARegG i.V.m. \& 19 StARegG.
} 
Aantekening.

$\mathrm{Al}$ is de verwerving niet volgens de letter verlopen, er is volgens het BayVGH desalniettemin sprake van nationaliteitsverwerving. Hoewel met enig kunst en vliegwerk beschouwt het BayVGH de hele gang van zaken toch als het totstandkomen van een rechtsgeldige optie.

Het BayVGH bevindt zich duidelijk niet in een non-liquet situatie, zodat i.c. over de bewijslastverdeling geen opmerking kan worden gemaakt. Het BayVGH gaat ervan uit dat de feiten voldoende vaststaan (Das zur Überzeugung ${ }^{1399}$ des Senats erwiesene Gespräch im Jahre 1956) en het BayVGH overweegt in de uitspraak tevens "Auch ohne Vorliegen der in der Zwischenzeit vernichteten Unterlagen über die Antragstellung kann festgestellt werden, daß der Verlängerungsantrag zur Niederschrift einer Behörde abgegeben worden ist. " Hierbij baseert het BayVGH zich op een wettelijke regeling, die inhoudt dat een verlenging van een Personalsausweis slechts mogelijk is door daarvoor een aanvraag tot de overheid te richten.

Uit de annotatie van Von Mangoldt blijkt dat de klager in zoverre het geluk heeft gehad dat de verlenging van zijn Personalausweis geschiedde bij dezelfde ambtelijke dienst als waar over de Duitse nationaliteit wordt geoordeeld. Von Mangoldt schrijft desbetreffend: "Die staatsangehörigkeitsrechtliche Literatur stellt deshalb bei falscher behördlicher Belehrung als Ursache der Fristversäumung darauf $a b, o b$ eine zuständige Behörde oder wenigstens eine Staatsangehörigkeitsbehörde gehandelt hatte. Denn es ist dem Ratsuchenden gewöhlich zuzumuten, sich bei der angesprochenen Behörde durch Frage zu vergewissern, ob diese für Rechtsfragen des anstehenden Sachbereichs überhaupt zuständig und damit hinreichend kompetent ist. Der Bürgermeister einer kreisangehörigen Gemeinde ist jedoch in Bayern nicht Staatsangehörigkeitsbehörde, und er ist es auch damals nicht gewesen. Anders liegt es beim Landratsamt, das mit der Ausstellung und Verlängerung des Personalsausweises des Klägers befaßt worden war; dieses war und ist Staatsangehörigkeitsbehörde, zuständig damals freilich nur für die Erteilung von (..........) Staatsangehörigkeitssausweisen. ${ }^{1400}$

\footnotetext{
${ }^{1399}$ Cf. $\$ 108$ VwGO, dat luidt: "Das Gericht entscheidet nach seiner freien, aus dem Gesamtergebnis des Verfahrens gewonnenen Überzeugung. "Zie par. 6.2.2.

1400 v. Mangoldt, StAZ 1984, p. 169.
} 


\subsubsection{VG Bremen 14 maart 1988}

\section{Cat. A. uitspr. V. Casusbeschrijving. Bewijs van opname op de Deutsche Volksliste en van deutsche Volkszugehörigkeit.}

In de onderhavige casus ${ }^{1401}$ gokt de betrokkene op twee paarden door in rechte te willen zien vastgesteld dat hij "Deutscher im Sinne des Grundgesetzes" is. De klager doet namelijk een beroep op Artikel 116 Abs. 1 Grundgesetz. ${ }^{1402}$ Dit betekent dat de stelling van de klager luidt dat hij ofwel in het bezit is van de Duitse nationaliteit en zo niet, dat hij dan toch "vertriebener deutsche Volkszugehörigkeit" is.

De klager is afkomstig uit Polen en geboren in 1942. Het beroep op het bezit van de Duitse nationaliteit stoelt de betrokkene op de stelling dat zijn ouders gedurende de tweede wereldoorlog de Duitse nationaliteit hebben verworven ingevolge een regeling tot collectieve naturalisatie. ${ }^{1403}$ De nationaliteitsverwerving door de klager zelf is dan op grond van afstamming van een persoon met de Duitse nationaliteit.

Maar zoals reeds is gebleken in de paragrafen 6.3.2.2 en 6.3.2.4 is met betrekking tot de collectieve naturalisaties ook na-oorlogse regelgeving van belang. Op de klager is van toepassing $\S 1$ Abs. 1 Buchst. d StARegG. ${ }^{1404}$ Belangrijke elementen in dat betreffende artikelonderdeel zijn de genoemde Deutsche Volksliste en, zoals ook reeds bleek in paragraaf 6.3.2.2, de "deutsche Volkszugehörigkeit".

Uit $\& 1$ Abs. 1 Buchst. d StAregG volgt dat opname op de zgn. Deutsche Volksliste verwerving van de Duitse nationaliteit heeft betekend. Met betrekking tot het bezette Polen is in 1941 deze lijst opgesteld. Het heeft voor het verdere begrip van de casus geen zin om de (vele) details van de regeling omtrent de Deutsche Volksliste hier te beschrijven. Het Verwaltungsgericht komt namelijk tot het volgende oordeel: "Der $K l$. hat bereits nicht glaubhaft machen können, daß seine

\footnotetext{
${ }^{1401}$ VG Bremen, U. v. 14.03.1988, NJW 1989, p. 1377.

1002 Zie par. 4.1.4.

${ }^{1003}$ Het gaat om de "Verordnung über die Deutsche Volksliste und die deutsche Staatsangehörigkeit in den eingegliederten Ostgebieten vom 4. Marz 1941 in der Fassung der Zweiten Verordnung über die Deutsche Volksliste und die deutsche Staatsangehörigkeit in den eingegliederten Ostgebieten vom 31. Januar 1942." De regeling is afgedrukt bij Lichter, p. 295-305. Vgl. Hailbronner/Renner, p. 13 en 14. ${ }^{1024}$ Par. 1 Abs. 1 Buchst. d StARegG: "Die deutschen Volkszugehörigen, denen die deutsche Staatsangehörigkeit auf Grund folgender Bestimmungen verliehen worden ist: (......., d) Verordnung über die Deutsche Volksliste und die deutsche Staatsangehörigkeit in den eingegliederten Ostgebieten vom 4. Marz 1941 (......) in der Fassung der Zweiten Verordnung über die Deutsche Volksliste und die deutsche Staatsangehörigkeit in den eingegliederten Ostgebieten vom 31. Januar 1942, (........), sind nach Maßgabe der genannten Bestimmungen deutsche Staatsangehörige geworden, es sei denn, daß sie die deutsche Staatsangehörigkeit durch ausdrückliche Erklärung ausgeschlagen haben oder noch ausschlagen." De verklaring tot afstand van de Duitse nationaliteit is ingevolge \$ 5 StARegG mogelijk geweest tot 26.02.1956.
} 
Eltern bzw. er in die Deutsche Volksliste aufgenommen worden sind." De motivering voor dit oordeel is helaas door de redactie van de Neue Juristische Wochenschrift niet afgedrukt.

Het beroep dat de klager doet op verwerving van de Duitse nationaliteit wijst het Verwaltungsgericht derhalve af.

Hoewel losstaand van de vraag naar het bezit van de Duitse nationaliteit vermeld ik hier nog voor de volledigheid het resultaat van klagers beroep op de kwalificatie "vertriebener deutsche Volkszugehörigkeit". Ook hierin slaagt de klager niet.

Het falen hiervan is meer het gevolg van de werking van het Duitse rechtssysteem dan van de toetsing der feiten door het Verwaltungsgericht te Bremen. De betrokkene heeft namelijk enige jaren eerder reeds een beroep gedaan op de status van Vertriebener. Dat is toen afgewezen, en tegen die afwijzing is de betrokkene niet tijdig in beroep gegaan. Het is gevestigde rechtspraak dat aan een onherroepelijk geworden beslissing inzake de status van Vertriebener ook (ingevolge $\S 15$ Abs. 5 BVFG) de staatsangehörigkeitsbehörden zijn gebonden. ${ }^{1405}$ Deze bindende werking acht het VG ook van toepassing op de eigen bevoegdheid. Het Verwaltungsgericht drukt het zo uit: "Die Bindungswirkung hindert auch das Gericht, in einem staatsangehörigkeitsrechtlichen Verwaltungsstreitverfahren eine von den Feststellungen des Amtes für Zuwanderer und Aussiedler abweichende Feststellung zu treffen. Insoweit strahlt die Bindungswirkung, der die Staatsangehörigkeitsbehörden unterliegen, auf die Verwaltungsgerichte aus. (........), hat das Gericht im vorliegenden staatsangehörigkeitsrechtlichen Verwaltungsstreitverfahren bereits aus formellen Gründen davon auszugehen, daß es sich bei den Eltern des Kl. und damit auch beim $\mathrm{Kl}$. nicht um deutsche Volkszugehörige handelt."

\section{Aantekening.}

De reden waarom deze zaak is opgenomen, is gelegen in het feit dat het VG Bremen duidelijk stelt welke Beweismaß is gehanteerd bij de beoordeling van de vraag of de klager (dan wel zijn ouders) toentertijd zijn opgenomen in de Deutsche Volksliste. Het VG spreekt over "glaubhaft machen können" van de desbetreffende opname. Dit is een duidelijke aanwijzing dat verwerving van de Duitse nationaliteit op grond van het Gesetz zur Regelung von Fragen der Staatsangehörigkeit door Glaubhaftmachung voldoende bewezen is. Schleser sluit hierbij aan door in het algemeen op te merken dat voor het bewijs van het bezit van de Duitse nationaliteit door een Aussiedler Glaubhaftmachung voldoende is. ${ }^{1406}$

Ter zijde kan nog, met betrekking tot de vermelde bindende werking van de voorafgaande beslissing inzake de Vertriebeneneigenschaft, het volgende worden

\footnotetext{
$1405 \mathrm{Vgl}$. Alexy, NJW 1989, p. 2853.
}

1400 Schleser, p. 325. Idem Berg, p. 127; Eyermann/Fröhler, p. 717 en 718; Nierhaus, p. 82-85. Zie ook par. 6.2.2.1. 
opgemerkt. Hoe gecompliceerd de materie is, blijkt uit een recente uitspraak van het BVerwG. Het betrof een geval waarin in het registratieformulier van de nieuw in de BRD aangekomen Aussiedler (daarvoor zijn zgn. Grenzdurchgangslagern ter beschikking ${ }^{1407}$ ten aanzien van de betrokkenen het bezit van de Duitse nationaliteit was aangetekend. Dit registratieformulier vermog de betrokkenen echter niet baten in een procedure waarvan de inzet de uitreiking van een Staatsangehörigkeitsausweis betrof. Hetgeen het opnameformulier van het Grenzdurchgangslager inhield, bleek derhalve geen bindende beslissing waaraan $\S 15$ Abs. 5 BVFG een bepaald rechtsgevolg verbindt. ${ }^{1408}$

\subsubsection{BVerwG 15 maart 1994}

Cat. A. uitspr. VI. Casusbeschrijving. Bewijs van verwerving door afstamming.

De onderhavige casus ${ }^{1409}$ betreft een in 1956 in Polen geboren klaagster. $\mathrm{Zij}$ doet een beroep op verwerving van de Duitse nationaliteit bij haar geboorte op grond van afstamming. ${ }^{1410}$ Haar vader zou de Duitse nationaliteit eveneens door middel van afstamming hebben verworven. De originaire verwerving van de Duitse nationaliteit ligt, volgens de stelling van de klaagster, bij klaagsters grootvader. De verwervingsgrond voor de grootvader betreft naturalisatie ingevolge de in 1941 voor Polen opgestelde Deutsche Volksliste, een regeling tot collectieve naturalisatie. ${ }^{1411}$ Of overigens bij de vader zelf ook sprake is van originaire verwerving van de Duitse nationaliteit blijft in de uitspraak enigszins in het midden hangen. ${ }^{1412}$

Als eerder vermeld, is verwerving op grond van de bovengenoemde regeling door hetgeen in het StARegG wordt bepaald, te beschouwen als geldige nationaliteitsverwerving. ${ }^{1413}$ De klaagster heeft in feitelijke instantie succes met haar

\footnotetext{
${ }^{1407}$ Zie Herrmann-Pfandt, p. 2-5.

${ }^{1408}$ BVerwG, B. v. 21.11.1994, StAZ 1995, p. 217: "Eine Bindungswirkung des Registrierscheins wurde infolgedessen abgelehnt für die Vertriebeneneigenschaft, für die deutsche Volkszugehörigkeit und für die Aufnahme des Betroffenen in der Bundesrepublik Deutschland im Sinne des Art. 116 Abs. 1 GG. Dasselbe muß auch für die deutsche Staatsangehörigkeit gelten, die für die Klägerinnen in dem ihnen am 21.9.1988 ausgestellten Registrierschein vermerkt ist."

${ }^{1009}$ BVerwG, U. v. 15.03.1994, DÖV 1994, p. 911.

${ }^{1410}$ Dit is een beroep op $\$ 4$ RuStAG.

${ }^{1411} \mathrm{Zie}$ tevens par. 6.3.2.5. De betreffende matregel is volledig afgedrukt bij Lichter, p. 295-305.

${ }^{1412}$ Het BVerwG overweegt dienaangaande: "Ist aber der Großvater der $K l$. in Abt. 2 der DVL eingetragen worden, dann ist dies auch für ihren im Jahre 1932 geborenen Vater anzunehmen, $(\ldots . . . . . . . .$.$) .$

${ }^{1413}$ Par. 1 Abs. 1 Buchst. d StARegG: 'Die deutschen Volkszugehörigen, denen die deutsche Staatsangehörigkeit auf Grund folgender Bestimmungen verliehen worden ist: (.......), d) Verordnung über die
} 


\section{Hoofdstuk 6}

beroep op het bezit van de Duitse nationaliteit. Tegen dit vonnis stelt de overheid Revision in bij het BVerwG. ${ }^{1414}$

Het BVerwG wijst de vordering van de overheid af. In haar eis tot Revision stelt de overheid dat voor erkenning van het behoud van de Duitse nationaliteit ingeval van eerdere collectieve naturalisatie als maatstaf heeft te gelden dat de betrokkene: "nach dem Zusammenbruch des Jahres 1945 auch ständig den Willen bekundet haben muß, als deutscher Staatsangehöriger behandelt zu werden. ${ }^{1415} \mathrm{Naar}$ het inzicht van het BVerwG bestaat echter geen aanleiding om die maatstaf aan te leggen, aangezien in $\$ 1$ Abs. 1 StARegG slechts de voorwaarde wordt genoemd dat de betrokkene geen afstand heeft gedaan van de Duitse nationaliteit. Met betrekking tot klaagsters vader, die in 1984 is overleden, heeft het VG Berlin in feitelijke instantie vastgesteld dat hij geen afstand heeft gedaan van de Duitse nationaliteit.

Tevens dient, zoals in alle gevallen waarbij het StARegG van toepassing is, ook i.c. te worden getoetst of het gaat om "deutsche Volkszugehörigkeit" bij de betrokkene(n). ${ }^{1416}$ In plaats van klaagsters vader gaat het nu evenwel om klaagsters grootvader, aangezien de vader voor het tijdstip dat relevant is ${ }^{1417}$ wegens zijn leeftijd nog niet "bekenntnisfähig" was.

In feitelijke instantie heeft het Verwaltungsgericht geoordeeld dat klaagsters grootvader de vereiste Bekenntnis zum deutschen Volkstum heeft gedaan door zich aan te melden voor opname op de deutsche Volksliste. In Revision houdt dit oordeel stand. Ter zake overweegt het BVerwG: "Es hat ein Bekenntnis zum deutschen Volkstum zutreffend darin erblickt, daß der Großvater seine Aufnahme in die DVL beantragt hatte." Voorts overweegt het BVerwG nog: "Bei in der Abt. $2^{1418}$ der Deutschen Volksliste eingetragenen Personen liegt in dem Antrag auf Eintragung in der Regel ein Bekenntnis zum deutschen Volkstum, sofern dieser Antrag freiwillig

$1413 \rightarrow$

Deutsche Volksliste und die deutsche Staatsangehörigkeit in den eingegliederten Ostgebieten vom 4. Marz 1941 (.....) in der Fassung der Zweiten Verordnung über die Deutsche Volksliste und die deutsche Staatsangehörigkeit in den eingegliederten Ostgebieten vom 31. Januar 1942, (.........), sind nach Maßgabe der genannten Bestimmungen deutsche Staatsangehörige geworden, es sei denn, daß sie die deutsche Staatsangehörigkeit durch ausdrückliche Erklärung ausgeschlagen haben oder noch ausschlagen." De verklaring tot afstand van de Duitse nationaliteit is ingevolge § 5 StARegG mogelijk geweest tot 26.02.1956.

$1414 \mathrm{Vgl}$. par. 4.2.2.

1415 De overheid tracht hier een verliesgrond voor de Duitse nationaliteit te introduceren.

${ }^{1416} \mathrm{Zie}$ tevens par. 6.3.2.2, 6.3.2.4 en 6.3.2.5.

${ }^{1417}$ En dat is de tijd: "unmittelbar vor Beginn der gegen die deutsche Bevölkerung gerichteten Verfolgungsund allgemeinen Vertreibungsmaßnahmen". Voor Polen is dat tijdstip vastgesteld op de jaren 1944 1945. Häußer/Kapinos/Christ, p. 87.

1418 De deutsche Volksliste heeft vier zgn. "afdelingen" gekend. Zie Alexy, NJW 1989, p. 2852 en 2853. 
gestellt worden ist. (..........). Selbst wenn in größerem Umfang auch zwangsweise Eintragungen in Abt. 2 der DVL stattgefunden haben sollten, kann im Einzelfall nachgewiesen werden, daß der Antrag auf Aufnahme in die DVL aus freien Stücken gestellt worden ist. Dieser Nachweis ist hier erbracht."

Het BVerwG stelt nog aanvullend: "Der -inzwischen verstorbene- Vater der $K l$., der die deutsche Staatsangehörigkeit nicht ausgeschlagen hat, ist deutscher Volkszugehörigen i. S. des \&1 Abs. 1 1.StARegG gewesen."

Het BverwG wijst, als gezegd, het verzoek tot Revision door de overheid af, zodat het bezit van de Duitse nationaliteit door de klaagster onherroepelijk in rechte is vastgesteld.

Aantekening.

De onderhavige casus betreft niet alleen de vaststelling van het bezit van de Duitse nationaliteit door de klaagster, maar betreft tevens een zelfde vaststelling voor haar vader en haar grootvader. De nationaliteitsvaststelling geschiedt op impliciete wijze, want de klaagster voert een procedure tot afgifte van een, haar eerder geweigerde, Vertriebenenausweis.

In Revision komt vanzelfsprekend slechts een rechtsvraag aan de orde. Deze betreft de interpretatie van $\S 1$ Abs. 1 StARegG. Het vaststellen van de feiten, de bewijsrechtelijke kant van de zaak, is al in de feitelijke instantie afgehandeld. Wat de rechtsvraag betreft: de door de overheid voorgestane interpretatie van $\& 1$ Abs. 1 StARegG wordt door het BVerwG niet gevolgd.

Zoals reeds in paragraaf 6.3.2.1 naar voren is gebracht, kan het BVerwG slechts met betrekking tot de vastgestelde feiten een lagere uitspraak vernietigen indien de Beweiswürdigung indruist tegen regels van ervaring of logica. Het BVerwG kan zich evenwel vinden in de beoordeling van de feiten zoals het Verwaltungsgericht deze heeft verricht. Ook in deze laatste casus is geen sprake van een non-liquet situatie, ten gevolge waarvan het gerecht genoodzaakt zou zijn een beslissing te nemen volgens de regels voor de bewijslastverdeling.

\subsubsection{Jurisprudentie categorie B: Beroep op behoud van de Duitse nationaliteit}

In deze paragraaf worden vier uitspraken behandeld waarin de betrokken personen zich op het standpunt stellen niet te hebben voldaan aan een verliesbepaling voor de Duitse nationaliteit. Zoals tevens het geval is bij de jurisprudentie ter zake van een beroep op verwerving van de Duitse nationaliteit is het ook bij de beroepen op behoud van de Duitse nationaliteit, gezien het geringe aantal ter beschikking staande bruikbare uitspraken, noodzakelijk gebleken om "impliciete vaststelingsprocedures" op te nemen. Van de onderstaand besproken jurisprudentie betreft slechts 


\section{Hoofdstuk 6}

één uitspraak een op grond van $\S 43$ VwGO gevoerde Feststellungsklage. ${ }^{1419}$ Eén uitspraak betreft een in privaatrechtelijke context gegeven uitspraak van het Bundesgerichtshof. ${ }^{1420}$ Een andere zaak is een impliciete vaststelling op grond van \& 42 VwGO betreffende een weigering een Staatsangehörigkeitsausweis uit te reiken. $^{1421}$ In één geval is sprake van een samenloop van $\S 42$ VwGO en 43 VwGO, ${ }^{1422}$

\subsubsection{BGH 14 december 1955}

Cat. B. uitspr. I. Casusubeschrijving. Beweismaß in het geval van een verliesgrond.

De onderhavige $z^{2} k^{1423}$ speelt zich af in een civielrechtelijke procedure. Het gaat om de vraag of een vrouw haar Duitse nationaliteit heeft verloren door haar huwelijk met een man van Griekse nationaliteit. De vrouw verkreeg van rechtswege bij het huwelijk de Griekse nationaliteit. ${ }^{1424}$

Een belangrijk gegeven in deze zaak is dat het huwelijk is voltrokken na inwerkingtreding van het Grundgesetz op 24.05.1949. ${ }^{1425}$ Evenwel is het huwelijk gesloten voor 01.04.1953, de dag waarop in werking is getreden de bepaling in het Grundgesetz waarin de gelijkheid van man en vrouw is vastgelegd. $\mathrm{Na}$ 01.04.1953 is de verliesbepaling waarop het nationaliteitsverlies van de vrouw (eventueel) is gebaseerd (en die hieronder aan de orde komt) buiten werking getreden.

De bepaling op grond waarvan het verlies van de Duitse nationaliteit door de vrouw zou kunnen zijn bewerkstelligd, is hetgeen toentertijd werd bepaald door $\S$ 17 Ziff. 6 RuStAG. ${ }^{1426}$ De vraag die in deze zaak aan de orde wordt gesteld, luidt of voor het oordeel dat nationaliteitsverlies heeft plaatsgevonden het noodzakelijk is dat er een wilsverklaring van de vrouw, inzake haar Duitse nationaliteit, aanwezig moet zijn.

1419 BVerwG, U. v. 21.05.1985, Buchholz 13o $\$ 25$ RuStAG, Nr. 5.

1420 BGH, U. v. 14.12.1955, NJW 1956, p. 509.

1421 BVerwG, U. v. 14.12.1972, BVerwGE 41, 277.

1422 VG Freiburg, U. v. 03.10.1978, StAZ 1979, p. 302.

1423 BGH, U. v. 14.12.1955, NJW 1956, p. 509.

1424 Zie Lichter, p. 659.

1423 Van belang is daardoor Art. 16 GG, dat luidt: "Der Verlust der Staatsangehörigkeit darf nur aufgrund eines Gesetzes und gegen den Willen des Betroffenen nur dann eintreten, wenn der Betroffene dadurch nicht staatenlos wird."

${ }^{1426}$ Par. 17 Ziff. 6 RuStAG a.F.: "Die Staatsangehörigkeit geht verloren: 6. für eine Deutsche durch eheschließung mit (........) einem Ausländer." Zie daarover Hailbronner/Renner, p. 243 en 244. 
Anders dan de rechter in feitelijke instantie ${ }^{1427}$ komt het Bundesgerichtshof tot het oordeel dat pas sprake kan zijn van verlies van de Duitse nationaliteit door de huwende vrouw "wenn sie nachweislich die deutsche Staatsangehörigkeit, als sie die Ehe schlo $\beta$, nicht behalten wollte." Het BGH merkt nog op dat dit uitgangspunt méér in overeenstemming is met Artikel 16 GG dan het uitgangspunt dat de lagere rechter had voorgestaan.

In casu leidt het bovenstaande het BGH tot de volgende uitspraak: "Nach dem vom BerGer. getroffen tatsächlichen Feststellungen ist ein auf Verlust ihrer Staatsangehörigkeit gerichter Wille der $\mathrm{Kl}$. für die Zeit ihrer Eheschließung nicht festzustellen. Sie ist daher auch bei ihrer Eheschließung Deutsche geblieben."

\section{Aantekening.}

Bewijsrechtelijk beschouwd, valt over de onderhavige casus slechts een opmerking te plaatsen betreffende de sterkte (Beweismaß) van het, om uit te kunnen gaan van het verlies van de Duitse nationaliteit, benodigde bewijs. De eis die het BGH stelt, inhoudende dat het zich hebben voorgedaan van de verliesgrond nachweislich dient te zijn, is niet echt opzienbarend. Wel is het interessant dat het BGH in dit kader spreekt over "nicht festzustellen". De Beweismaß die het BGH kennelijk in casu hanteert ten aanzien van de verliesgrond van de Duitse nationaliteit is "feststellen", hetgeen betekent dat volgens het BGH als bewijssterkte "Volle Überzeugung" noodzakelijk is. Als in paragraaf 6.2.2.1 aan de orde gesteld, betreft dit een grotere mate van zekerheid dan Glaubhaftmachung.

\subsubsection{BVerwG 14 december 1972}

Cat. B. uitspr. II. Casusubeschrijving. Bewijs door middel van bezit van staat? Verwerving op grond van het vertrouwensbeginsel?

In het onderhavige geval ${ }^{1428}$ is in 1952 ten gevolge van een misverstand sprake van een (naar eerst later is gebleken) onjuiste ambtelijke vaststelling van het bezit van de Duitse nationaliteit. Eerst in 1965 vloeien voor de betrokkene daaruit nationaliteitsrechtelijke problemen voort.

\footnotetext{
${ }^{102}$ Die van oordeel was dat een vrouw die in het huwelijk trad met een buitenlandse man haar Duitse nationaliteit verloor, tenzij de vrouw een uitdrukkelijke verklaring deed dat zij haar nationaliteit wilde behouden.

${ }^{1028}$ BVerwG, U. v. 14.12.1972, BVerwGE 41, 277.
} 
De betrokkene is in 1897 in Wenen geboren en verwerft bij de geboorte, zoals het BVerwG dat uitdrukt, "dort das Heimatrecht". ${ }^{1429}$ Eerst in 1951 vestigt de betrokkene zich in Duitsland. Over het bezit van een nationaliteit door de betrokkene bestaat kennelijk in die tijd onduidelijkheid. Blijkens de uitspraak wordt inzake de nationaliteit in 1951 opgetekend "ungeklärt, früher Österreich". In 1952 verzoekt de betrokkene om naturalisatie, maar de bevoegde "Staatsangehörigkeitsbehörde" wijst het verzoek af op grond van de (naar later blijkt: foutieve) overweging: "(......), der Kläger besitze bereits auf Grund des deutsch-tschechoslowakischen Vertrages vom 20. November 1938 die deutsche Staatsangehörigkeit, (....)." De betrokkene verkrijgt een Duits paspoort en wordt jarenlang beschouwd als in het bezit van de Duitse nationaliteit. Tot er kennelijk (in de uitspraak wordt hierover geen duidelijkheid verkregen) iets mis gaat. Bij de overheid ontstaat twijfel over de in 1952 gedane uitspraak inzake het bezit van de Duitse nationaliteit. De directe aanleiding tot de gang van de betrokkene naar het Bundesverwaltungsgericht is het feit dat in 1965 wordt geweigerd de betrokkene een Staatsangehörigkeitsausweis uit te reiken.

Het BVerwG kan niet anders dan constateren dat de betrokkene, hoewel als gevolg van de collectieve naturalisatie van alle Oostenrijkers in 1938 in het bezit van de Duitse nationaliteit geraakt, de Duitse nationaliteit in 1956 met ingang van 27.04.1945 heeft verloren. ${ }^{1430}$

$\mathrm{Na}$ dit verlies heeft de klager de Duitse nationaliteit niet meer herkregen. Voor alle duidelijkheid stelt het BVerwG nog uitdrukkelijk: "Seither hat er die deutsche Staatsangehörigkeit nach keinem der staatsangehörigkeitsrechtlichen Erwerbsgründe wiedererlangt. Daß ihm über einen längeren Zeitraum hin ein deutscher Reisepaß und ein Bundespersonalausweis ausgestellt worden sind, bildet einen Erwerbsgrund nicht,"

Een verwervingsgrond, na het verlies met terugwerkende kracht tot 27.04.1945, is derhalve niet aan te wijzen. Het BVerwG vervolgt zijn uitspraak evenwel met de opmerkelijke rechtsoverweging: "Rechtsirrtümlich hat das Berufungsgericht seine Prüfung nicht auch auf die Frage erstreckt, ob der Kläger den beantragten Staatsangehörigkeitsausweis, dessen Versagung den Gegenstand des Rechtsstreits bildet, ${ }^{1431}$ auf Grund ihm zu gewährenden Vertrauensschutzes beanspruchen

\footnotetext{
1429 Volgens De Groot, p. 141 en 142, kende Oostenrijk in de 19e eeuw een Heimatgesetz. Par. 2 van het Heimatgesetz bepaalde dat slechts cen Oostenrijks staatsburger het Heimatrecht in een gemeente kon verwerven. De vraag of men Oostenrijks staatsburger was, werd beantwoord aan de hand van bepalingen in het Oostenrijks Burgerlijk Wetboek.

140 Zie tevens par. 6.3.2.3. Anders dan de betrokkene uit par, 6.3.2.3 heeft de klager uit de onderhavige casus geen optierecht uit het Zweite Gesetz zur Regelung von Fragen der Staatsangehörigkeit gehad omdat hij niet sinds 26.04.1945 in Duitsland woonachtig is geweest; zie $\$ 32$.StARegG.

1431 Uit deze zinsnede blijkt dat het BVerwG de rechtsstrijd beperkt acht tot de vraag of de betrokkene een Staatsangehörigkeitsausweis dient te worden uitgereikt of niet. Het BVerwG acht derhalve niet
} 
kann." Het BVerwG verricht deze toetsing wel en komt tot de conclusie dat de betrokkene inderdaad met het oog op de uitreiking van een Staatsangehörigkeitsausweis bescherming kan ontlenen aan het vertrouwensbeginsel.

De overwegingen waarop het BVerwG de uit het vertrouwensbeginsel voortvloeiende bescherming baseert, betreffen vooral de beslissing in 1952, genomen door een bevoegde "Staatsangehörigkeitsbehörde" op klagers naturalisatieverzoek én het feit dat de klager daarna gedurende twaalf jaar is beschouwd als in het bezit van de Duitse nationaliteit.

Het BVerwG stelt nog wel als uitgangspunt voorop: "Das Interesse an der Herstellung gesetzmäßiger Zustände ist auf dem Gebiete des Staatsangehörigkeitsrecht besonders gewichtig. " Daarop laat het gerecht echter onmiddellijk de overweging volgen: "Aber in besonders gelagerten Ausnahmefallen muß es hinter zu gewährendem Vertrauensschutz zurückstehen. Ein solcher Ausnahmefall ist der des Klägers."

De redenen waarom het BVerwG in dit geval een uitzonderingsgeval aanwezig acht, betreffen het feit dat niet ten gevolge van foutieve opgaven door de klager het besluit in 1952 zodanig was uitgevallen, het feit van de lange duur van behandeling als Duitser en de gevorderde leeftijd van de klager.

Het BVerwG komt tot de volgende uitspraak, namelijk dat de overheid verplicht is: "(........), den Kläger weiter als deutsche Staatsangehörigen gemäß dem deutsch-tschechoslowakischen Vertrage vom November $1938 \mathrm{zu}$ behandeln. Also mußte er ihm auf Antrag einen dementsprechenden Staatsangehörigkeitssausweis erteilen."

\section{Aantekening.}

$\mathrm{Ook}^{1432}$ in de onderhavige zaak is het een moeilijk punt geweest om te bepalen of het nu betreft een zaak waarin de verwerving dan wel het verlies van de Duitse nationaliteit aan de orde is. Gekozen is voor verlies (omdat wel duidelijk i.c. een verliesgrond is aan te wijzen, namelijk $\$ 12$.StARegG én omdat in de uitspraak het verlies wordt geconstateerd), zodat dientengevolge de casus is ingedeeld bij de categorie waarin een beroep op behoud van de Duitse nationaliteit wordt gedaan.

Het is een bijzonder gecompliceerde casus. De gecompliceerdheid bestaat hieruit dat, hoewel het BVerwG uitdrukkelijk stelt dat de betrokkene niet in het bezit is van de Duitse nationaliteit, hij wel als zodanig moet worden behandeld én in het bezit moet worden gesteld van een Staatsangehörigkeitsausweis (een document dat

${ }^{1431} \rightarrow$

primair de Feststellung van het bezit van de Duitse nationaliteit aan de orde. Uit de uitspraak blijkt immers dat juist wordt geoordeeld dat de Duitse nationaliteit door de betrokkene is verloren en tevens nimmer herkregen. Vgl. Eck, StAZ 1992, p. 103.

${ }^{1632}$ Zoals in par. 6.3.2.2 ook het geval is geweest. 


\section{Hoofdstuk 6}

geldt, als bekend, als een bewijs van het bezit van de Duitse nationaliteit) ${ }^{1433}$. De afgifte van de Staatsangehörigkeitsausweis dient in het onderhavige geval niet te geschieden wegens het bezit van de Duitse nationaliteit, maar dient te geschieden op grond van de werking van het vertrouwensbeginsel.

De vraag kan worden gesteld wat het nu uitmaakt of van de betrokkene kan worden gesteld dat hij in het bezit is van de Duitse nationaliteit dan wel dat aan hem een document ten bewijze van het bezit moet worden uitgereikt zonder dat hij de Duitse nationaliteit bezit? Het zal voor de betrokkene, mijns inziens, feitelijk geen verschil maken. $\mathrm{Na}$ deze constatering rijst dan toch de vraag waarom het BVerwG dan niet zo ver gaat om te oordelen dat op grond van het vertrouwensbeginsel verwerven van de Duitse nationaliteit heeft plaatsgevonden. Naar mijn mening is dit niet gebeurd omdat dan nationaliteitsverwerving plaats zou hebben gevonden op een verwervingsgrond die het nationaliteitsrecht niet kent. ${ }^{1434}$ Aan de orde is een uitgangspunt dat in het nationaliteitsrecht sterk heerst: nl. het beginsel dat verwerving en verlies van een nationaliteit slechts mogelijk is op gronden die de wetgever als zodanig heeft opgenomen.

Zowel Schleser als Sturm noemen deze casus als zij het bewijzen van het bezit van de Duitse nationaliteit door middel van het bezit van staat bespreken. ${ }^{1435}$ Naar mijn mening gaat het hier echter niet om het bewijzen van het bezit van de Duitse nationaliteit, aangezien er immers wordt vastgesteld dat geen feitelijke onduidelijkheden bestaan aangaande een verwervings- of een verliesgrond. In de uitspraak wordt tevens vastgesteld dat geen sprake is van bezit van de Duitse nationaliteit door betrokkene. ${ }^{1436}$ Mijns inziens staat de werking van het vertrouwensbeginsel los van het bewijsrecht.

De vraag of in het Duitse recht het bezit van de Duitse nationaliteit kan worden bewezen door middel van het bezit van staat is reeds in paragraaf 6.3 .1 bevestigend beantwoord. Het is dus wel mogelijk, maar, als gezegd, is naar mijn mening de onderhavige casus er geen voorbeeld van. ${ }^{1437}$

1433 Vgl. par. 6.3.1.

1434 Bleckmann, ZaöRV 1974, p. 320 e.v., wijst het idee van verwerving van de Duitse nationaliteit door middel van de werking van het vertrouwensbeginsel af. Voorts stelt hij dat deze verwervingsgrond ook in andere staten niet voorkomt. Wat betreft het Nederlandse nationaliteitsrecht (zie voetnoot 744) heeft Bleckmann gelijk. Zie voor het Duitse nationaliteitsrecht tevens par. 6.3.2.3.

1035 Schleser, p. 325; Sturm, p. 24.

1436 Deze vaststelling geschiedt met de overweging: "Er (...........), hat die deutsche Staatsangehörigkeit aber gemaß $\S 1$ des Zweiten Gesetzes zur Regelung won Fragen der Staatsangehörigkeit (.......) mit Wirkung vom 27. April 1945 wieder verloren. Seither hat er die deutsche Staatsangehörigkeit nach keinem der staatsangehörigkeitsrechtlichen Erwerbsgründe wiedererlangt. Daß ihm über einen längeren Zeitraum hin ein deutscher Reisepaß und ein Bundespersonalausweis ausgestellt worden sind, bildet einen Enwerbsgrund nicht." Gezien de bovenstaande overwegingen is het, naar mijn mening, niet juist dat Hailbronner/Renner, p. 131, deze casus aanhalen als voorbeeld van een "Erwerb durch Vertrauensschutz".

${ }^{1437} \mathrm{Vgl}$. Bleckmann, ZaōRV 1974, p. 325. 


\subsubsection{VG Freiburg 3 oktober 1978}

Cat. B. uitspr. III. Casusubeschrijving. Bewijs van verwerving van een vreemde nationaliteit.

De onderhavige zaak ${ }^{1438}$ betreft de vaststelling van het bezit van de Duitse nationaliteit door een vrouw. Het betreft de vaststelling van het bezit van de Duitse nationaliteit van een van oorsprong Duitse vrouw die in het huwelijk is getreden met een man van niet-Duitse nationaliteit. In casu is de vaststelling van het bezit van enige nationaliteit door haar echtgenoot aan de orde.

Het echtpaar is gehuwd in $1950,{ }^{1439}$ de vrouw bezit op dat moment de Duitse nationaliteit, ten aanzien van de man vermeldt de uitspraak: "(.........). dessen Staatsangehörigkeit von den deutschen Ausländerbehörden seit 1949 zunächst als ungarisch, später als ungeklärt ungarisch, schließlich als staatenlos bzw. heute als ungeklärt angesehen wurde."

De vrouw legt bij het sluiten van het huwelijk een verklaring af, inhoudende dat zij de Duitse nationaliteit wil behouden. Evenwel wordt ook zij sinds het sluiten van het huwelijk behandeld als niet in het bezit van de Duitse nationaliteit. Zij heeft voor haar verblijf een Aufenthaltserlaubnis ingevolge de vreemdelingenwetgeving en is sinds 1959 in het bezit van een "Bescheid über den Nichtbesitz der deutschen Staatsangehörigkeit". De uitspraak vermeldt dat de vrouw haar verlies van de Duitse nationaliteit nimmer heeft geaccepteerd, net zomin als alle op haar toegepaste vreemdelingenrechtelijke maatregelen: "wogegen sie seit mindestens 20 Jahre Einwendungen erhoben hat."

Uit de uitspraak blijkt dat de overheid (das beklagte Land) het standpunt inneemt dat de man de Hongaarse nationaliteit bezit, en dat zijn vrouw op het moment van het huwelijk deze nationaliteit heeft verworven met als gevolg het verlies van haar Duitse nationaliteit. ${ }^{140}$

De zaak betreft derhalve de vraag of de echtgenoot een nationaliteit bezit (mogelijk de Hongaarse) en of de huwelijkssluiting voor de vrouw tot rechtsgevolg heeft gehad dat zij de Hongaarse nationaliteit heeft verworven, zodat zij bij verlies van haar Duitse nationaliteit niet staatloos is geworden.

Het Verwaltungsgericht gaat over tot het horen van klaagsters echtgenoot als getuige. ${ }^{1441}$ De echtgenoot is in 1929 als wettig kind geboren in Duitsland uit een

\footnotetext{
${ }^{1438}$ VG Freiburg, U. v. 03.10.1978, StAZ 1979, p. 302.

${ }^{169}$ De materieel nationaliteitsrechtelijke regels die op het onderhavige geval van toepassing zijn, zijn derhalve dezelfde als in par. 6.3.3.1.

${ }^{1400}$ De overheid doet een beroep op $\S 17$ Ziff. 6 RuStAG, dat van kracht is geweest tot 01.04.1953.

1441 "Die Kammer hat entsprechend dem in der mündlichen Verhandlung vom 3.10.1978 ergangenen Beweisbeschluß Beweis erhoben durch Vermehmung des Ehemannes der Klägerin als Zeuge."
} 


\section{Hoofdstuk 6}

vader met de Hongaarse nationaliteit en een van oorsprong Duitse moeder. Het VG stelt vast dat hij bij zijn geboorte de Hongaarse nationaliteit heeft verworven. Evenwel concludeert het Verwaltungsgericht ten aanzien van het bezit van de Hongaarse nationaliteit dat de echtgenoot deze al voor zijn huwelijk met de klaagster heeft verloren. Hiertoe overweegt het VG: "(.......), weil er sich nach seiner glaubhaften Zeugenaussage seit seiner Geburt in Deutschland aufgehalten und weder je in Ungarn gewesen ist, noch mit ungarischen Behörden zum Zwecke der Aufrechterhaltung der ungarischen Staatsangehörigkeit Kontakt aufgenommen hat. Denn nach \& (.......) verlor derjenige Staatsbürger, der sich ohne Regierungsauftrag 10 Jahre hindurch ununterbrochen außerhalb der Grenzen des Gebietes der ungarischen Krone aufhielt, seine ungarische Staatsangehörigkeit."

Het VG is zich bewust van het feit dat bovenvermelde verliesbepaling voor de Hongaarse nationaliteit een bepaling is die voor meerderjarigen geldt. Toch past het VG de bepaling (bewust) toe op de echtgenoot van de klaagster als hij nog minderjarig is. Het VG legt de aanvangsperiode van de 10 jaar bij de geboorte van de echtgenoot. Het VG doet dit "wegen der vorliegenden besonderen Umstände". De bijzondere omstandigheden zijn volgens het Verwaltungsgericht te vinden in de feiten dat de vader reeds voor de geboorte weer naar Hongarije was vertrokken, nimmer in familieverband met vrouw en kind heeft geleefd en dat na enige tijd de echtscheiding is uitgesproken. Ook is het VG zich bewust van het feit dat de verliesbepaling op de wettige vader van de klaagsters echtgenoot nu juist niet van toepassing is; deze is immers sinds zijn vertrek weer woonachtig in Hongarije. Maar het VG hakt de knoop door en oordeelt dat de echtgenoot op tienjarige leeftijd de Hongaarse nationaliteit heeft verloren. ${ }^{1442}$

$\mathrm{Na}$ dit te hebben vastgesteld is de gevolgtrekking ten aanzien van het behoud van de Duitse nationaliteit door de vrouw niet moeilijk meer. Aangezien haar man geen nationaliteit bezit, kan zij niet via hem, als gevolg van de huwelijkssluiting, in het bezit zijn geraakt van een ander nationaliteit. Aangezien Artikel 16 Grundgesetz, reeds van kracht op het moment van de huwelijkssluiting, verbiedt dat een persoon door verlies van de Duitse nationaliteit staatloos wordt, is de vrouw in het bezit gebleven van de Duitse nationaliteit.

Aantekening.

Materieelrechtelijk betreft het in casu een identieke zaak als aan de orde is in paragraaf 6.3.3.1. Men zou dezelfde toetsingsmaatstaf verwachten. Anders dan het

\footnotetext{
${ }^{142}$ Het VG overweegt dienaangaande: "verlor daher seine ungarische Staatsangehörigkeit 1939". Het is natuurlijk maar de vraag of de Hongaarse autoriteiten eenzelfde uitleg zouden geven. Anderzijds: zou de vader bij de familie zijn gebleven, dan had hij na verloop van 10 jaar de Hongaarse nationaliteit verloren, met naar alle waarschijnlijkheid nationaliteitsrechtelijke konsekwenties voor de dan tienjarige echtgenoot van klaagster.
} 
Bundesgerichtshof hanteert het VG Freiburg evenwel niet de toetsingsmaatstaf of de vrouw uitdrukkelijk bij het sluiten van het huwelijk een verklaring heeft afgelegd inhoudende dat zij de Duitse nationaliteit niet wilde behouden. Indien het $V G$ Freiburg de lijn van het Bundesgerichtshof zou hebben gevolgd, dan had het Verwaltungsgericht zich de nationaliteitsvaststelling van de echtgenoot kunnen besparen. Immers, de vrouw heeft ten tijde van de huwelijkssluiting uitdrukkelijk verklaard dat zij de Duitse nationaliteit wilde behouden.

Het Verwaltungsgericht concentreert zich daarentegen op het wel of niet staatloos raken van de vrouw. Ten gevolge hiervan wordt de kernvraag van de zaak of de man de Hongaarse nationaliteit bezit. Heeft de man bij de huwelijkssluiting in 1950 de Hongaarse nationaliteit, dan verwerft de vrouw op grond van $\& 3$ van de Hongaarse nationaliteitswetgeving uit 1948 van rechtswege zijn nationaliteit. ${ }^{143}$

Uit het onderhavige geval kan vanuit bewijsrechtelijk oogpunt de conclusie worden getrokken dat niet kan worden gesproken van een bewijsverplichting van de kant van de klaagster. Conform de Untersuchungsmaxime ( $\$ 86 \mathrm{VwGO}$ ) verricht het VG zelfstandig onderzoek naar de feitelijke omstandigheden van de zaak. Het uiteindelijke oordeel van de rechter duidt erop dat deze van mening is geweest voldoende feitelijke informatie te hebben verkregen om op grond daarvan tot een "Überzeugung" ten aanzien van de feiten te zijn gekomen. Indien dit niet het geval zou zijn geweest, en er derhalve een non-liquet situatie zou zijn gebleken, is het naar mijn inzicht nog maar de vraag aan welke kant het bewijsrisico daarvan terecht zou zijn gekomen.

\subsubsection{BVerwG 21 mei 1985}

Cat. B. uitspr. IV. Casusbeschrijving. Schending van de Untersuchungsmaxime en Beweismaß van een verliesgrond.

De onderhavige $z^{2 a k^{1444}}$ is gevoerd in het kader van een dreigende uitlevering. Met een beroep op het bezit van de Duitse nationaliteit beoogt de betrokkene zijn uitlevering naar Oostenrijk te voorkomen. De klager beoogt in een \& 43 VwGOprocedure vaststelling van zijn Duitse nationaliteit.

De klager is in 1946 geboren in Oostenrijk, uit ouders die afkomstig zijn uit het Sudetenland. Volgens de vastgestelde feiten bezaten de ouders, op grond van een regeling tot collectieve naturalisatie, ${ }^{1445}$ op het moment van klagers geboorte de Duitse nationaliteit. Bij zijn geboorte verwierf de klager derhalve deze nationaliteit.

\footnotetext{
${ }^{1463}$ Tratnik, p. 180-182.

144 BVerwG, U. v. 21.05.1985, Buchholz 130 825 RuStAG Nr. 5.

thes Het nationaliteitsverdrag tussen Duitsland en Tsjechoslowakije van 20.11.1938. Zie Lichter, p. 229 . 240.
} 
Het eventuele verlies van de Duitse nationaliteit, als gevolg van de aanvraag van de Oostenrijkse nationaliteit door klagers vader in 1952, bestrijdt de klager door te stellen dat zijn vader niet voor hem kon handelen op nationaliteitsrechtelijk gebied, aangezien hij (de klager) als gevolg van het niet-wettig zijn van het huwelijk van zijn ouders niet door zijn vader rechtens kon worden vertegenwoordigd. ${ }^{1446}$

Inzake de onwettigheid van het huwelijk van zijn ouders stelt de klager dat het huwelijk in 1939 alleen op kerkelijke wijze is gesloten en nimmer voor de burgerlijke stand.

Over de vraag of de, aldus slechts kerkelijk gehuwde, vader krachtens ouderlijke macht voor zijn kind medenaturalisatie kon aanvragen, oordeelt het BVerwG anders dan in eerdere instantie het VGH. Het VGH is van oordeel dat sprake is van rechtsgeldige vertegenwoordiging door de vader en derhalve van verlies van de Duitse nationaliteit. Nadat het BverwG andere klachten van de klager heeft verworpen, vervolgt het met de overweging: "Dagegen ist bisher nicht fehlerfrei festgestellt worden, daß der Vater des Klägers die Einbürgerung zugleich kraft elterlicher Gewalt (Sorge) für den Kläger beantragt hat (..........)."

Hoewel het VGH wel enkele feiten inzake de rechtsgeldigheid van het huwelijk heeft vastgesteld, is het VGH daarentegen, in de ogen van het BVerwG, aan enige feiten die in de richting wijzen van een niet-rechtsgeldige huwelijkssluiting voorbij gegaan. Het BVerwG komt tot het oordeel: "(....) ist der VGH jedoch seiner Verpflichtung zur erschöpfenden Aufklärung des Sachverhalts ( 886 Abs. 1 VwGO) nicht gerecht geworden, wie die Revision zu Recht geltend macht."

Het VGH wordt derhalve verweten de feitelijke omstandigheden niet volledig genoeg te hebben onderzocht. Ten gevolge hiervan bestaat niet ten aanzien van alle feiten voldoende zekerheid. Het BVerwG overweegt: "(.......), durfte der VGH, der alle diese Umstände nicht erörtet hat, den Sachverhalt nicht wie geschehen zu Lasten des Klägers wïrdigen, ohne zuvor geeignete Beweismittel für den Vortrag des Klägers über das Fehlen einer standesamtlichen Eheschließung auszuschöpfen."

Aantekening.

Twee aspecten maken deze uitspraak vanuit bewijsrechtelijk perspectief interessant. Interessant is ten eerste de eis die het BVerwG in zijn uitspraak stelt ten aanzien

\footnotetext{
1446 Aan de orde is de verliesgrond uit $\$ 25$ RuStAG: "Ein Deutscher, der im Inland weder seinen Wohnsitz noch seinen dauernden Aufenthalt hat, verliert seine Staatsangehörigkeit mit dem Erwerb einer ausländischen Staatsangehörigkeit, wenn dieser Erwerb auf seinen Antrag oder auf den Antrag des gesetzlichen Vertreters effolgt, der Vertretene jedoch nur, wenn die Voraussetzungen vorliegen, unter denen nach $\S 19$ die Entlassung beantragt werden könnte." Par. 19 RuStAG vereist toestemming van de voogdijraad voor het verlies van de Duitse nationaliteit door een minderjarige; tenzij het gaat om een aanvraag van ouders, die voor zichzelf en voor hun kind tegelijkertijd de andere nationaliteit aanvragen. I.c. is $\$ 19$ RuStAG niet relevant.
} 
van de Beweismaß van een verliesgrond. Het BVerwG stelt de eis dat de voorwaarden van de verliesgrond ten minste "fehlerfrei festgestellt" zijn.

Het tweede interessante aspect is dat deze uitspraak duidelijk de werking in het administratief procesrecht van de Untersuchungsmaxime ( $\$ 86$ VwGO) laat zien. Duidelijk blijkt dat de rechter verplicht is zorg te dragen voor het onderzoek naar de feiten waarop zijn beslissing komt te rusten. Pas indien na onderzoek moet worden geconstateerd dat een feit niet kan worden opgehelderd en er moet worden geconstateerd dat sprake is van een non-liquet situatie kan worden overgegaan tot de "Beweislastnormen". ${ }^{1447}$ In casu is het BVerwG van oordeel dat het onderzoek niet volledig genoeg is geweest. Aan de uit de Untersuchungsmaxime voortvloeiende verplichting tot onderzoek heeft de lagere rechter niet voldaan.

${ }^{140}$ Zie daarover par. 6.2.1.2. 



\section{Hoofdstuk 7}

\section{Conclusies en rechtsvergelijkende opmerkingen}

\subsection{Inleiding}

Dit boek gaat over de gerechtelijke vaststelling van de nationaliteit in Nederland en in Duitsland. De nadruk ligt daarbij op het procesrecht en het bewijsrecht. Met betrekking tot deze twee onderwerpen wordt in het nationaliteitsrecht wel gesproken over formeel nationaliteitsrecht. ${ }^{1448}$ Daarnaast bevat het nationaliteitsrecht vanzelfsprekend materiële regels. Onder het begrip materieel nationaliteitsrecht vallen de verwervings- en verliesgronden van een nationaliteit.

Aan de hand van de daartoe geformuleerde probleemstelling, die luidt: welke procesrechtelijke en bewijsrechtelijke regels zijn van toepassing in hetzij het Nederlandse recht, hetzij het Duitse recht, bij het door de rechter vaststellen van het bezit van de nationaliteit, zijn vier onderzoeksvragen opgesteld. Deze onderzoeksvragen zijn in de voorafgaande hoofdstukken aan de orde gesteld, zonder dat de afzonderlijke hoofdstukken werden afgesloten met conclusies. Dit afsluitende hoofdstuk bevat die, tot nu toe ontbrekende, concluderende beschouwingen. De procesrechtelijke conclusies met betrekking tot de vaststelling in Nederland staan vermeld in paragraaf 7.2.1 Wat betreft de vaststelling van het bezit van de Duitse nationaliteit zijn de procesrechtelijke conclusies opgenomen in paragraaf 7.2.2. Paragraaf 7.3.1 bevat de bewijsrechtelijke conclusies betreffende het Nederlandse recht. De bewijsrechtelijke conclusies met betrekking tot het Duitse recht staan vermeld in paragraaf 7.3.2.

Hoofdstuk 7 wordt afgesloten met paragraaf 7.4 In die paragraaf zijn enige algemeen afsluitende opmerkingen opgenomen. Vervolgens wordt in paragraaf 7.4.1 een opsomming gegeven van de overeenkomsten die tussen het Nederlandse en het Duitse rechtsstelsel kunnen worden gesignaleerd. In paragraaf 7.4.2 gebeurt hetzelfde, maar dan ten aanzien van de verschillen tussen de beide rechtsstelsels.

Eerst wordt hieronder ingegaan op een begrippenpaar dat voor het betoog in dit boek essentieel is.

${ }^{148}$ Zie par. 0.1. 


\subsubsection{De begrippen "zelfstandige vaststellingsprocedure" en "impliciete vaststel- lingsprocedure"}

In de inleidende paragraaf van hoofdstuk 2 zijn twee werkbegrippen geïntroduceerd. De twee zojuist bedoelde begrippen zijn: "zelfstandige vaststellingsprocedu$r e$ " en "impliciete vaststellingsprocedure".

Met het begrip "zelfstandige vaststellingsprocedure" wordt gedoeld op een rechterlijke procedure waarin de vraag naar het bezit van de nationaliteit hoofdvraag van het geding is, en waarin een uitspraak tot stand komt waarin de beslissing aangaande de nationaliteit het dictum vormt. Een "impliciete vaststellingsprocedure" daarentegen, is een rechterlijke procedure waarin de vraag naar het bezit van de nationaliteit een voorvraag in het geding is. De hoofdvraag in een zodanige procedure (en derhalve het dictum) betreft een andere rechtskwestie dan het bezit van de nationaliteit.

Het Nederlandse nationaliteitsrecht kent met de verzoekschriftprocedure uit artikel 17 Rijkswet op het Nederlanderschap een "zelfstandige vaststellingsprocedu$r e "$. Ook vreemd nationaliteitsrecht kan een "zelfstandige vaststellingsprocedure" kennen. In hoofdstuk 5 blijkt dat het Duitse nationaliteitsrecht door middel van de rechtsgang ingevolge $\S 43$ Verwaltungsgerichtsordnung over een "zelfstandige vaststellingsprocedure" beschikt. Anders dan in het Nederlandse recht is in het Duitse recht de vaststellingsprocedure niet opgenomen in de nationaliteitsrechtelijke regelgeving, maar is zij een onderdeel van een algemene administratiefrechtelijke wet.

Er zal ook nationaliteitsrecht van vreemde staten zijn waarin een "zelfstandige vaststellingsprocedure" ontbreekt. Rechterlijke vaststelling van het bezit van de nationaliteit kan in die gevallen slechts op grond van een "impliciete vaststellingsprocedure".

\subsection{Procesrechtelijke conclusies}

\subsubsection{Procesrechtelijke conclusies Nederland}

In hoofdstuk 2 wordt de eerste onderzoeksvraag behandeld. Die vraag luidt: "welke procesrechtelijke regels zijn van toepassing bij het door de rechter vaststellen van de Nederlandse nationaliteit"?

In paragraaf 2.2, getiteld Vereisten voor ontvankelijkheid, ben ik ingegaan op, wat ik omschrijf als de exclusieve werking van de in artikel 20 Rijkswet op het Nederlanderschap bedoelde procedures ten opzichte van de procedure uit artikel 17 Rijkswet (par. 2.2.2); op het onmiddellijk belang bij de nationaliteitsvaststelling (par. 2.2.3) en op de regel: point d'intérêt, point d'action bij de nationaliteitsvaststelling (par. 2.2.4). 
Met de bepaling betreffende de exclusieve werking van artikel $20 \mathrm{RWN}$ heeft de wetgever getracht tot een regeling te komen die de gelijktijdige totstandkoming betreffende één persoon van materieel verschillende uitspraken inzake het bezit van het Nederlanderschap zoveel mogelijk uitsluit. Een zodanige regeling werd noodzakelijk op het moment dat is besloten dat de beoordeling van het bezit van de Nederlandse nationaliteit niet door één (uiteindelijk altijd: rechterlijke) instantie zou geschieden, maar dat de mogelijkheid van nationaliteitsvaststelling in "impliciete vaststellingsprocedures" zou blijven bestaan, naast de vaststelling in de zelfstandige procedure. In paragraaf $\mathbf{2 . 2 . 2}$ is gebleken van enige schoonheidsfoutjes in de regeling van de exclusieve werking. Zo is tijdens een behandeling in administratief bezwaar een gelijktijdige behandeling in de "zelfstandige vaststellingsprocedure" mogelijk (par. 2.2.2.1). Voorts is geconstateerd dat onduidelijkheid bestaat over de vraag op welk moment een "impliciete rechterlijke vaststellingsprocedure" of een "impliciete administratieve beroepsprocedure" en de "zelfstandige vaststellingsprocedure" niet gelijktijdig aanhangig mogen zijn. Terwijl de rechtspraak naar mijn mening uitgaat van niet-ontvankelijkheid in de "zelfstandige vaststellingsprocedure" indien op de dag waarop de artikel $17 \mathrm{RWN}$-beschikking wordt gegeven een "impliciete vaststellingsprocedure" aanhangig is, heeft de wetgever de verwachting geformuleerd dat bij gelijktijdige aanhangigheid de artikel 20 RWN-instantie met haar oordeel zal wachten tot de beslissing in de "zelfstandige vaststellingsprocedu$r e "$ zal zijn genomen. In paragraaf 2.2.2.2.2 kom ik tot de conclusie dat de artikel 20 RWN-instantie slechts kan wachten op niet-ontvankelijkverklaring in de "zelfstandige vaststellingsprocedure", en wel vanwege een elders aanhangig geschil!

Gezien het bovenstaande is het met betrekking tot de exclusieve werking een zwakke schakel dat in de meeste gevallen de rechtbank in Den Haag slechts op de hoogte zal raken van de aanhangigheid van de "impliciete vaststellingsprocedure" indien de verzoeker dit aan de rechtbank zal mededelen. En dat terwijl het juist de verzoeker zal zijn die wellicht twee ijzers in het nationaliteitsrechtelijke vuur wil hebben!

Gevolg van een en ander is de mogelijkheid dat ten aanzien van de betrokkene twee elkaar inzake het bezit van de Nederlandse nationaliteit tegensprekende beslissingen tot stand komen. De wetgever heeft dit ook gezien en heeft getracht de tenuitvoerlegging van beide beslissingen uit te sluiten met het bepaalde in artikel 19 Rijkswet. In dergelijke gevallen dient voorrang te worden gegeven aan de beslissing genomen in de "zelfstandige vaststellingsprocedure". Aan het eind van de paragraaf over de exclusieve werking van artikel 20 RWN wijs ik op de strijd met de rechtsstaatgedachte die dit oplevert. Een rechterlijke beslissing wordt eenvoudigweg niet uitgevoerd. De regeling in hoofdstuk 6 Rijkswet is, wat dit betreft, een wangedrocht.

Bovendien kan de wetgever wel enige inconsequentie worden verweten. Gaat het systeem van de wet uit van het door middel van de exclusieve werking van artikel 20 RWN bewerkstelligen van de uitspraak in de "impliciete vaststellingsprocedure" 
(immers de artikel $17 \mathrm{RWN}$-rechter zal de verzoeker niet-ontvankelijk verklaren), als het misloopt (het systeem heeft niet gewerkt), dan prevaleert de uitspraak van de instantie waar de betrokkene in het geheel niet terecht had gemogen.

Mijn conclusie met betrekking tot het in artikel 17 RWN opgenomen begrip "onmiddellijk belang" (par. 2.2.3) is dat dit begrip niet betreft het processueel belang dat de betrokkene dient te hebben bij het voeren van de "zelfstandige vaststellingsprocedure", maar dat dit begrip een eigen inhoud heeft. Onder onmiddellijk belang dient naar mijn mening te worden verstaan: het identiek zijn van de verzoeker en het onderzoeksobject van de vaststelling. Of, indien het gaat om nationaliteitsvaststelling van een overledene, om een verzoeker wiens nationaliteit wordt beïnvloed door het wel of niet Nederlander zijn van die overledene.

Bij de behandeling in paragraaf 2.2.4 van het processueel belang in het kader van de zelfstandige procedure tot vaststelling van het Nederlanderschap zijn de begrippen "contemporaine vaststelling", "retrospectieve vaststelling" en "futuristische vaststelling" ontwikkeld. Onderscheidend criterium ten aanzien van die begrippen is de datum waarvoor de vaststelling van het wel of niet bezit van de Nederlandse nationaliteit wordt gedaan. Uit paragraaf 2.2 .4 kan worden geconcludeerd dat een contemporaine en een retrospectieve vaststelling tot de mogelijkheden behoren die de Rijkswet biedt, maar dat een futuristische vaststelling niet mogelijk is.

De meerderheid van de uitspraken op grond van artikel 17 RWN betreft een contemporaine vaststelling van het bezit van de Nederlandse nationaliteit. Daarbij blijkt in de meerderheid van de gevallen de oorzaak tot procederen in een verblijfsrechtelijk belang te liggen. In mindere mate zijn andere kwesties aan de orde. In de meerderheid van de artikel 17 RWN-zaken zou derhalve tot 1 oktober 1986 een beroep zijn gedaan op de administratiefrechtelijke beklagprocedure van artikel 43 (oud) Vreemdelingenwet. Onder de huidige regeling heeft echter ook een categorie verzoekers toegang tot de nationaliteitsrechter die dat voorheen niet heeft gehad. Immers, degenen die in het buitenland verblijven en geen contact hebben gezocht met een Nederlandse overheidsinstantie (bijvoorbeeld voor de afgifte van een Nederlands paspoort) kunnen sinds 1 oktober 1986 rechtstreeks bij de rechtbank in Den Haag terecht om over het bezit van de Nederlandse nationaliteit een rechterlijk oordeel te verkrijgen. Voorheen bestond deze rechtstreekse mogelijkheid niet en in een beklagprocedure op grond van artikel 43 (oud) Vreemdelingenwet zouden dezen niet-ontvankelijk zijn verklaard. De toegankelijkheid van de "zelfstandige vaststellingsprocedure" voor personen die buiten het Koninkrijk verblijven en die niet (meer) in contact staan met Nederlandse overheden acht ik een groot voordeel ten opzichte van de situatie van voor 1 oktober 1986.

Aan dit voordeel zit evenwel een praktisch nadeel. Dit nadeel is dat onder de huidige omstandigheden de Staat, die in de procedure fungeert als belanghebbende, 
onverwachts kan worden geconfronteerd met een verzoeker die stelt tientallen jaren geleden niet het Nederlanderschap te hebben verloren. ${ }^{149}$

In paragraaf 2.2.4.2.3 is geconcludeerd dat het processueel belang bij een contemporaine vaststellingsprocedure al snel wordt aanvaard door de rechtbank. Bij indiening van het verzoekschrift behoeft geen geschil te bestaan met enig overheidslichaam. Wel zal in het verzoekschrift duidelijk moeten worden gemaakt dat de verzoeker momenteel niet wordt erkend als van Nederlandse nationaliteit. Dat de "zelfstandige vaststellingsprocedure", naar mijn mening, ondanks de eventuele afwezigheid van een geschil met de overheid bij aanvang ervan, toch een contentieuze procedure is, wordt verderop aan de orde gesteld.

In paragraaf 2.3, getiteld De positie van het openbaar ministerie in de zelfstandige vaststellingsprocedure, besteed ik aandacht aan het functioneren van het openbaar ministerie tijdens de feitelijke instantie van de "zelfstandige vaststellingsprocedure". Een bijna verloren gegaan instituut, dat de conclusie in feitelijke instantie toch wel genoemd mag worden, kent in artikel 18 RWN een opmerkelijke wederopstanding.

Uit de jurisprudentie blijkt dat de wijze van concluderen gedurende de tien jaar dat de Rijkswet op het Nederlanderschap inmiddels in werking is, een tweetal ontwikkelingen heeft doorgemaakt.

Ten eerste kan worden gewezen op het feit dat in de aanvangsperiode van de vaststellingsprocedure het openbaar ministerie meermalen een onderzoek naar de feiten heeft ingesteld. Dit komt later niet meer voor. Wat daarvan naar mijn mening de oorzaak is, wordt bij de bespreking van paragraaf 2.3.2 aan de orde gesteld.

De tweede ontwikkeling is geweest dat in de beginperiode altijd schriftelijk werd geconcludeerd, maar dat na verloop van tijd het gebruik is ontstaan om (in relatief ongecompliceerde zaken) mondeling te concluderen tijdens de zitting. Tot op heden is, bij mijn weten, de officier van Justitie altijd aanwezig geweest bij de mondelinge behandeling van de verzoekschriften.

In paragraaf 2.3.1 wordt de inhoudelijke betekenis van de conclusie aan de orde gesteld. Bij het redigeren van artikel $18 \mathrm{RWN}$ is de wetgever uitgegaan van een aan de eventueel bij de kwestie van het Nederlanderschap betrokken overheidsinstanties ten dienste staand openbaar ministerie. Het openbaar ministerie zou, in de visie van de wetgever, optreden als vertegenwoordiger van de betreffende instantie en de nationaliteitsrechtelijke opvatting van die instantie omtrent verzoekers Nederlanderschap uitdragen. Slechts anderhalf jaar na de inwerkingtreding van hoofdstuk 6 Rijkswet spreekt de Hoge Raad echter het oordeel uit dat het openbaar ministerie in de artikel 17 RWN-procedure niet kan worden beschouwd als een belanghebbende, dan wel als de (proces)vertegenwoordiger van enige overheidsinstantie in het algemeen of van de Staat in het bijzonder. Dit oordeel van de Hoge

${ }^{149} \mathrm{Vgl}$. HR 28.10.1994, RvdW 1994, nr. 216 (zie par. 3.3.4.3.2). 
Raad, dat afwijkt van hetgeen de wetgever voor ogen stond, is conform de gevestigde opvattingen over het functioneren in civiele procedures van het openbaar ministerie in het geval dat het OM wordt gehoord. Het feit dat het bij de artikel 17 RWN-procedure gaat om een civiele verzoekschriftprocedure weegt derhalve met betrekking tot dit onderwerp zwaar. Met betrekking tot de wetgeving kan ook over dit onderwerp worden opgemerkt dat in het wetgevingsproces de wetgever een ongelukkige hand heeft gehad.

De vraag kan worden gesteld wat de conclusie van het openbaar ministerie dan wel behelst, nu deze niet de nationaliteitsrechtelijke visie van de Staat op verzoekers Nederlanderschap bevat? Met de conclusie wordt, volgens de doctrine, beoogd een onafhankelijk en onpartijdig juridisch advies ter zake aan de rechter. De conclusie zou derhalve de eigen visie van het openbaar ministerie op het wel of niet bezit van het Nederlanderschap door de verzoeker dienen te bevatten. Bij het opstellen van de conclusie zou het openbaar ministerie niet, van welke kant dan ook, moeten worden beïnvloed.

Het is echter, naar mijn mening, ten zeerste de vraag of met de conclusies in het kader van de "zelfstandige vaststellingsprocedure" het hierboven vermeld beoogde doel voldoende wordt behartigd. Naar mijn mening kan worden gesteld dat het bij de conclusies in de "zelfstandige vaststellingsprocedure" (helaas) ontbreekt aan de gewenste onpartijdigheid, alsmede aan de wil tot het daadwerkelijk willen innemen van een onafhankelijk standpunt. Een kenmerk tot op heden van de conclusies is geweest dat deze, bij mijn weten, nimmer hebben afgeweken van het (negatieve) standpunt van de Staat. Kennelijk heerst bij het openbaar ministerie het gevoelen dat het niet juist is om een andere mening te verkondigen dan de opgeroepen Staat. Deze opvatting (waarvan ik het bestaan veronderstel) getuigt naar mijn mening te sterk van het idee dat het OM toch ook de Staat der Nederlanden is en deze laatste ondanks alles toch min of meer representeert. Gezien de in de praktijk marginaal gebleken rol van het OM concludeer ik aan het eind van paragraaf 2.3.1 dat, onder zodanige omstandigheden, het $\mathrm{OM}$ dan beter kan afzien van concluderen.

In paragraaf 2.3.2 wordt nader ingegaan op de rol van het openbaar ministerie bij het onderzoek naar de feiten van de zaak. Het feit dat het openbaar ministerie incidenteel onderzoek (heeft) verricht naar de feiten van de zaak wordt in de literatuur, noch in de jurisprudentie afgewezen. Het toelaatbaar achten van deze activiteit van het $\mathrm{OM}$ hangt nauw samen met het feit dat het in de onderhavige procedure gaat om een verzoekschriftprocedure inzake een recht dat niet ter vrije beschikking staat. De daarbij noodzakelijk niet-lijdelijke rechter ${ }^{1450}$ kan in zijn onderzoek worden bijgestaan door het openbaar ministerie. Het openbaar ministerie functioneert aldus als een verlengstuk van de onderzoekende rechter.

${ }^{1450}$ Zie tevens par. 7.3.1. 
Hierboven is al gewezen op het feit dat zich gedurende de tien jaar dat de Rijkswet in werking is een ontwikkeling heeft voorgedaan met betrekking tot de onderzoeksactiviteiten van het OM. Uit de vroege jurisprudentie blijkt dat het openbaar ministerie in een aantal gevallen een onderzoek (op verzoek van de rechtbank dan wel op eigen initiatief) heeft verricht naar de feiten die door de verzoeker werden gesteld. In latere jurisprudentie blijft deze activiteit van het openbaar ministerie achterwege. Naar mijn mening ligt aan deze verandering het feit ten grondslag dat gaandeweg de Staat in rechte verschijnt. Nadat eenmaal de Staat in rechte als belanghebbende aanwezig was op de mondelinge behandeling, was deze, meer dan het openbaar ministerie, de aangewezen instantie om een eventueel noodzakelijk feitenonderzoek te verrichten. Ook op dit punt blijkt het marginaliseren van de rol van het openbaar ministerie in de "zelfstandige vaststellingsprocedure".

In paragraaf 2.4, getiteld De toepasselijkheid van de artt. 429d, $429 f-429 l$ en 429s$429 t$ Wetboek van Burgerlijke Rechtsvordering, wordt aandacht besteed aan de positie van de Staat der Nederlanden als belanghebbende bij de vaststellingsprocedure. De oproeping van de Staat als belanghebbende door de rechtbank te Den Haag geschiedt op grond van artikel $429 \mathrm{f} \mathrm{Rv}$. Dit betekent dat in het oog dient te worden gehouden dat de Staat slechts bij de in Nederland gevoerde procedures als belanghebbende wordt opgeroepen. Bij vaststellingsprocedures voor het Gemeenschappelijk Hof van de Nederlandse Antillen en Aruba wordt, blijkens de ene beschikking die daarvan bekend is, de Staat of het Land niet betrokken bij de procedure.

Het civielrechtelijke karakter van de onderhavige procedure wordt onderstreept door het oproepen van de rechtspersoon de Staat der Nederlanden. Dit in tegenstelling tot een administratiefrechtelijke procedure waarbij het overheidsorgaan (zonder rechtspersoonlijkheid), dat het bestreden besluit heeft genomen, wordt opgeroepen. ${ }^{1451}$ Echter, voor deelname aan een civiele procedure is rechtspersoonlijkheid vereist.

De positie van belanghebbende bij een verzoekschriftprocedure is, mijns inziens, een moeilijk omschrijfbare. De belanghebbende mag enerzijds (in beginsel) niet worden beschouwd als directe wederpartij van de verzoeker, anderzijds is de belanghebbende wel degelijk in het geding betrokken, soms zelfs door middel van het voeren van een verweer. Wat betreft de "zelfstandige vaststellingsprocedure" ben ik van mening dat de jurisprudentie aantoont dat de Staat gezien moet worden als wederpartij van de betrokkene. De Staat neemt, een enkele uitzondering daargelaten, ${ }^{1452}$ een duidelijk afwijzend standpunt in met betrekking tot het verzoek tot vaststelling van de Nederlandse nationaliteit. Naar mijn mening blijkt uit

${ }^{1451} \mathrm{Vgl}$. Ten Berge/Tak, p. 58.

${ }^{1452}$ Zie voetnoot 192. 
de onderzochte beschikkingen dat de "zelfstandige vaststellingsprocedure" heden ten dage het karakter van een contentieuze verzoekschriftprocedure heeft. ${ }^{1453}$

De vraag is gesteld of de als belanghebbende opgeroepen Staat niet bij procureur dient te verschijnen. Volgens de regeling uit de artikelen $429 \mathrm{a}-429 \mathrm{r} \mathrm{Rv}$ is het om gehoord te worden als belanghebbende niet nodig dat procureur wordt gesteld. Volgens dezelfde regeling is het echter wel noodzakelijk om een verweerschrift bij procureur in te dienen. De procespraktijk gaat met dit laatste soepel om. Processtukken (inclusief verweerschrift) afkomstig van de belanghebbende kunnen indien de rechter dat toestaat, op de zitting ook in persoon worden overhandigd. Het blijkt dat deze soepele praktijk ook wordt gehanteerd in de "zelfstandige vaststellingsprocedure". De "zelfstandige vaststellingsprocedure" blijkt zelfs een nog soepeler element te vertonen. Buiten de zitting dient het ministerie van Justitie processtukken in door deze naar de griffie van de rechtbank te sturen. Dit gebeurt niet door tussenkomst van een procureur. In paragraaf 2.4.2.3 merk ik daarover op dat mijns inziens hiervoor geen de wettelijke basis bestaat. Tevens meen ik dat van de Staat der Nederlanden anders mag worden verwacht. Wel meen ik, dat zolang het de Staat wordt toegestaan op bovenvermelde soepele en informele wijze processtukken in het geding te brengen, eenzelfde souplesse zou passen in het geval van een andere belanghebbende dan de Staat.

In paragraaf 2.5, getiteld Cassatie, wordt ingegaan op de ingevolge artikel 18 Rijkswet bestaande de mogelijkheid tot het instellen van beroep in cassatie. Gewezen is op de uiteenlopende cassatietermijnen voor Nederland enerzijds en de Nederlandse Antillen en Aruba anderzijds. Tot op heden is, naar mijn weten, nog geen cassatieberoep ingesteld tegen een vaststellingsbeschikking die is gegeven door het Gemeenschappelijk Hof van de Nederlandse Antillen en Aruba. Tevens is vermeld de van de algemene (Nederlandse) regel afwijkende mogelijkheid dat ook de niet in feitelijke instantie verschenen verzoeker en belanghebbende beroep in cassatie kunnen aantekenen.

Het burgerlijk procesrecht kent de beperking dat slechts kan worden gecasseerd op grond van de aangevoerde cassatiemiddelen. In de literatuur wordt verschillend gedacht over de mogelijkheid om onder de huidige wetgeving ambtshalve te

${ }^{1453} \mathrm{Vgl}$. de opmerking van Hugenholtz/Heemskerk, p. 139: "Wanneer een beschikking een beslissing aangaande de rechtsbetrekking in geschil tussen partijen bevat, heeft men te doen met eigenlijke rechtspraak." (In gelijke zin ook Rutgers/Flach/Boon, p. 119). Op een zodanige beschikking achten Hugenholtz/Heemskerk art. $67 \mathrm{Rv}$ (gezag van gewijsde) van toepassing. Zou worden geoordeeld dat de vaststellingsbeschikking gezag van gewijsde moet worden toegekend, dan betekent dit dat in een volgend geding tussen de betrokkene en de Staat de rechter gebonden is aan de beschikking. In het ontwerp tot aanpassing van het Wetboek van Burgerlijke Rechtsvordering blijft art. $67 \mathrm{Rv}$ in identieke bewoording voortbestaan. Ook voor de toekomst wordt hiermee de vraag of een beschikking gegeven in een contentieuze verzoekschriftprocedure gezag van gewijsde kent (wellicht) op impliciete wijze negatief beantwoord. 
casseren in de "zelfstandige vaststellingsprocedure". Omtrent de wenselijkheid van ambtshalve cassatie in de procedure spreekt slechts één auteur (Van den Blink) zich uit, en wel in positieve zin. $\mathrm{Bij}$ de opvatting dat ambtshalve cassatie in de vaststellingsprocedure mogelijk zou moeten zijn, heb ik mij in paragraaf 2.5 .2 aangesloten. Gezien het publiekrechtelijke karakter van de nationaliteit, hetgeen leidt tot het feit dat het betreft een recht dat niet ter vrije beschikking staat, maar ook wegens het grote belang dat voor de betrokkene bestaat bij de vaststelling van zijn nationaliteit, acht ik ambtshalve cassatie gewenst. Het feit dat het gaat om de vaststelling van een recht dat niet ter vrije beschikking staat, betekent dat geen sprake is van partij-autonomie of van een lijdelijke rechter. Naar mijn mening dient dan de nietlijdelijkheid van de rechter zich tevens in die zin tot de cassatierechter uit te strekken, dat deze niet gebonden is aan de voorgestelde cassatiemiddelen, een instrument bij uitstek van de partij-autonomie.

In paragraaf 2.6, getiteld De bindende werking van de vaststellingsbeschikking, komt de ruimere werking in subjectieve zin van de vaststellingsbeschikking aan de orde. Deze ruimere werking is het gevolg van hetgeen is bepaald in artikel 19 Rijkswet. Aan de hand van de begrippen subjectieve reikwijdte en objectieve reikwijdte wordt ingegaan op de bijzondere bindende werking van de vaststellingsbeschikking. (Later komt in hoofdstuk 5 hetzelfde begrippenpaar aan de orde bij de bespreking van de uitspraken van het Bundesverfassungsgericht.)

De strekking van artikel 19 Rijkswet is om meer rechtssubjecten te binden aan de in de "zelfstandige vaststellingsprocedure" gegeven uitspraak dan er gebonden zouden zijn indien artikel $19 \mathrm{RWN}$ zou ontbreken. Dit betreft de subjectieve reikwijdte van de vaststellingsbeschikking. Heeft een rechterlijke uitspraak gewoonlijk slechts werking tussen de partijen (ook wel genoemd: materiële rechtskracht), in het geval van een vaststellingsbeschikking op grond van artikel 17 RWN kent de uitspraak een bindende werking die zich uitstrekt tot "elk met de uitvoering van enige wettelijke regeling belast orgaan". Het gaat hier als gezegd om de subjectieve reikwijdte, en gesteld kan worden dat de vaststellingsbeschikking dan wel geen werking erga omnes kent, maar toch een zeer ruim bereik heeft.

Evenwel is niet direct aan de hand van de wettelijke bepaling te zeggen wie of wat (welke rechtssubjecten) onder het bereik van artikel 19 Rijkswet valt of vallen. Naar mijn mening is het zelfs een hoogst onduidelijke bepaling. Voor het huidige tijdsgewricht van privatisering en het afstoten van taken door de overheid is de vraag naar de omvang van hetgeen dient te worden verstaan onder "orgaan dat belast is met de uitvoering van enige wettelijk regeling" en het in de MvA bij het wetsontwerp RWN genoemde "de administratie" geen onbelangrijke vraag. Wordt het aantal instanties dat door artikel 19 RWN aan de vaststellingsbeschikking wordt gebonden groter of kleiner naar mate de privatiseringsgolf groter of kleiner is?

Met betrekking tot de vraag wat nu dient te worden verstaan onder "elk met de uitvoering van enige wettelijke regeling belast orgaan" meen ik dat de begripsinvul- 
ling daarvan buiten de Algemene wet bestuursrecht (waarin zoals bekend, wordt bepaald wat een bestuursorgaan is) dient te geschieden. Weliswaar omvat het begrip orgaan in de zin van artikel 19 RWN naar mijn mening alles wat onder het begrip bestuursorgaan valt, maar daarnaast omvat het meer. Naar mijn mening is het begrip orgaan in de zin van artikel 19 RWN omvattender dan het begrip bestuursorgaan uit de Awb. Dit leidt mij in paragraaf 2.6.2.1.1 tot de conclusie dat de bevoegdheid van de Eerste en Tweede Kamer om ingevolge artikel 58 Grondwet over de geloofsbrieven van een verkozen Kamerlid te oordelen, wordt ingeperkt krachtens artikel $19 \mathrm{RWN}$ in het geval dat vragen rijzen omtrent het bezit van het Nederlanderschap en het kersverse Kamerlid in het bezit is van een (positieve) vaststellingsbeschikking.

Wat betreft de Nederlandse Antillen en Aruba dient te worden beseft dat de Algemene wet bestuursrecht daar niet van kracht is, zodat in die landen de invulling van het begrip orgaan uit artikel 19 RWN geheel kan geschieden zonder acht te slaan op de Awb.

Overigens bljikt de Staat op twee manieren aan de (in Nederland gegeven) vaststellingsbeschikking gebonden. Enerzijds op grond van artikel $19 \mathrm{RWN}$, anderzijds wegens het feit dat de Staat als belanghebbende partij is bij de vaststellingsbeschikking en daardoor inter partes gebonden. Op deze dubbele gebondenheid wordt gewezen in paragraaf 2.7.4.

Niet gebonden aan een vaststellingsbeschikking zijn rechtsprekende instanties. ${ }^{1454}$ In civiele procedures heeft de vaststellingsbeschikking vrije bewijskracht. ${ }^{1455}$ Wat de mogelijkheid tot afwijking van een gegeven vaststellingsbeschikking door de administratieve rechter betreft, kan men zich afvragen op welke wijze een nationaliteitsrechtelijk geschil voor een administratieve rechter kan komen, aangezien de "administratie" zich aan de bewuste vaststellingsbeschikking dient te houden. Maar een voorbeeld hiervan zou een betrokkene kunnen betreffen die, ondanks een afwijzing van zijn verzoek tot vaststelling door de rechtbank in Den Haag (en helaas voor de verzoekers is tot nu toe de meerderheid der beschikkingen ex artikel 17 RWN afwijzend geweest), ${ }^{1456}$ meent in het bezit te zijn van de Nederlandse nationaliteit. De "administratie" houdt zich conform artikel 19 RWN aan de afwijzende beschikking uit de "zelfstandige vaststellingsprocedure". In een daaruit voortvloeiend geding voor een administratieve rechter kan de betrokke-

\footnotetext{
145 Zie evenwel de vorige voetnoot voor het geval dat geoordeeld zou worden dat de vaststellingsbeschikking gezag van gewijsde kent op grond van het gegeven dat het een contentieuze procedure is.

${ }^{1455}$ Dijksterhuis-Wieten, p. 64; Pitlo/Hidma \& Rutgers, p. 97.

1456 Van de 42 in dit onderzoek betrokken verzoeken die de rechtbank ontvankelijk oordeeit, zijn er 7 ingewilligd. Van één positieve beschikking heeft de Staat cassatie ingesteld. In dat geval doet de HR de zaak voor de betrokkene op negatieve wijze zelf af. Van de 35 zaken met negatieve afloop is in 20 gevallen cassatie door de onmiddellijk belanghebbende ingesteld. In 3 zaken daarvan doet de Hoge Raad de zaak zelf af na vernietiging van de rechtbankbeschikking en stelt vast dat de verzoeker de Nederlandse nationaliteit bezit. $\mathrm{Vgl}$. voor deze gegevens par. 2.5.1.
} 
ne nogmaals een oordeel over het bezit van het Nederlanderschap verkrijgen. Is dat vervolgens een ten aanzien van het Nederlanderschap positief oordeel, dan ontstaat er een probleem waarin de wetgever niet heeft voorzien. De vraag is dan natuurlijk welke (rechterlijke) beslissing prevaleert. Ik meen daarop als antwoord te moeten geven dat de beschikking in de "zelfstandige vaststellingsprocedure" dient te prevaleren boven de, later, gegeven beslissing in de "impliciete vaststellingsprocedure". Immers, de "administratie" blijft ingevolge artikel 19 RWN gebonden aan de beschikking die is gegeven in de "zelfstandige vaststellingsprocedure". Het mag voor het antwoord op de bovengestelde vraag niet uitmaken of het gaat om een positieve of negatieve vaststelling in de "zelfstandige vaststellingsprocedure" en een aan dat resultaat tegengesteld oordeel in de "impliciete vaststellingsprocedure". Indien een latere "impliciete vaststellingsprocedure" de betrokkene een ten aanzien van het bezit van het Nederlanderschap gunstiger resultaat heeft gebracht dan een eerdere "zelfstandige vaststellingsprocedure" is het de betrokkene aan te raden om op grond van artikel 17 RWN een nieuw verzoek tot vaststelling bij de rechtbank te doen. ${ }^{1457}$

Tot zover wat betreft de subjectieve reikwijdte van de vaststellingsbeschikking zoals deze heeft vormgekregen door artikel 19 Rijkswet. De objectieve reikwijdte snijdt de vraag aan waaraan de rechtssubjecten die de "administratie" uitmaken, zijn gebonden.

In het kader van de objectieve reikwijdte van de vaststellingsbeschikking is gewezen op de mogelijkheid dat het kan gaan om een beschikking waarin een bepaalde verwervings- of verliesgrond wèl aan de orde is geweest, terwijl een andere verwervings- of verliesgrond ten onrechte uit het oog is gelaten. Een voorbeeld: ten behoeve van $\mathrm{X}$ is in een vaststellingsbeschikking, gedateerd op 15 augustus 1995, dat hij in het bezit van de Nederlandse nationaliteit is. Deze vaststelling heeft plaatsgevonden op grond van toetsing van de verliesbepaling uit artikel 5 lid 2 Toescheidingsovereenkomst tussen Nederland en Suriname, omdat X van 1 januari 1983 tot 1 januari 1985 in Suriname woonplaats zou hebben gehad. In rechte blijkt dat dit niet het geval is geweest. De "administratie" is gebonden aan de daarop gegeven vaststellingsbeschikking. Conform die gebondenheid wordt $\mathrm{X}$ beschouwd als in het bezit van de Nederlandse nationaliteit. In 1996 blijkt dat X op 2 januari 1985 een optie voor de Surinaamse nationaliteit op grond van artikel 5 lid 1 TOS heeft afgelegd. De vraag die nu rijst is: waaraan is de "administratie" gebonden? Is dat aan de beslissing dat X op 15 augustus 1995 in het bezit van de

${ }^{1457}$ Met betrekking tot de vaststellingsprocedure ex art. 17 RWN wijzen Mok/Tjittes, RMTh 1995, p. 388 , er op dat met deze procedure een uitzondering wordt gemaakt op het beginsel van formele rechtskracht van een overheidsbeschikking. De hoofdregel is dat indien een overheidsbeschikking niet in een administratiefrechtelijke rechtsgang wordt vernietigd, de overheidsbeschikking formele rechtskracht verkrijgt. Deze formele rechtskracht geldt in beginsel ook ten overstaan van de civiele rechter. De civiele rechter kan, wegens de formele rechtskracht van de overheidsbeschikking, niet meer oordelen over de kwestie waarover in de overheidsbeschikking met, inmiddels, formele rechtskracht is beslist. 
Nederlandse nationaliteit is? Hierdoor kan de optieverklaring van 2 januari 1985 niet meer in rechte naar voren worden gebracht en is de vaststellingsbeschikking niet alleen declaratoir maar in feite ook constitutief.

Of is de "administratie" slechts gebonden aan de beslissing dat $\mathrm{X}$ op 1 januari 1985 in het bezit van de Nederlandse nationaliteit is omdat niet is voldaan aan de verliesbepaling uit artikel 5 lid 2 TOS, zodat inzake de optieverklaring van 2 januari 1985 geen gebondenheid bestaat? (Hetgeen niet strookt met de feiten dat de rechtbank op 15 augustus 1995 uitspreekt dat X in het bezit van het Nederlanderschap is, en dat artikel 19 RWN spreekt van gebondenheid aan de beschikking.) En hoe moet worden gedacht als in de bovenstaande casus de optie niet is gedaan op 2 januari 1985 maar op 1 november 1984 ? Tevens kan de vraag worden gesteld wat rechtens is inzake hetgeen artikel 19 RWN bepaalt en een nationaliteitswijziging nadat de vaststellingsbeschikking is gegeven. Een situatie waarover Van den Blink bij haar bespreking van artikel $19 \mathrm{RWN}$ veronderstellend heeft opgemerkt dat de wetgever er waarschijnlijk niet aan gedacht heeft. Kortom, het moge duidelijk zijn dat artikel 19 RWN niet bepaald een probleemloze bepaling is.

In paragraaf 2.6.2.1.3 is ingegaan op de zojuist als laatste genoemde situatie, dus waarin na de (correct genomen) vaststellingsbeschikking in het bezit van het Nederlanderschap een wijziging optreedt. In die paragraaf kom ik tot de conclusie dat (indien het een contemporaine vaststelling betreft) na een posterieur rechtsfeit ter zake van de nationaliteit de "administratie" de betrokkene niet meer behoeft te beschouwen conform in de vaststellingsbeschikking is bepaald. Door de nationaliteitswijziging verliest de vaststellingsbeschikking niet haar rechtskracht, hetgeen betekent dat voor het moment waarop de vaststellingsbeschikking het bezit van het Nederlanderschap vaststelt, de bindende werking van artikel 19 RWN nog immer geldt. Deze gebondenheid aan de vaststellingsbeschikking geldt tot het moment dat het posterieure rechtsfeit van nationaliteitswijziging is voorgevallen. Naar mijn mening is een aanvulling van artikel $19 \mathrm{RWN}$ waarin het bovenstaande wordt verwoord wenselijk. Mijns inziens kan worden gesteld dat de huidige redactie van artikel $19 \mathrm{RWN}$ in te absolute bewoording is gesteld.

Mede met het oog op de objectieve reikwijdte wordt in paragraaf 2.7.4 aandacht besteed aan de twee andere hierboven genoemde situaties. Deze beide situaties zijn derhalve aan de orde in paragraaf 2.7 , getiteld Herziening van een vaststellingsbeschikking. Het gaat dan ook om situaties waarin sprake is van een niet met alle rechtens relevante feiten strokende beslissing van de rechter. Een beslissing die inmiddels wel kracht van gewijsde heeft verkregen. Aan een zodanig foutieve uitspraak van een rechter kunnen diverse oorzaken ten gronde liggen.

De mogelijkheid tot herziening van een vaststellingsbeschikking is als zodanig niet opgenomen in de Rijkswet op het Nederlanderschap, noch in enig andere wettelijke regeling. De rechtbank te Den Haag heeft ten behoeve van de verzoeker herziening mogelijk geacht na oriëntatie op het administratief procesrecht. Deze 
oriëntatie op het administratief procesrecht bevreemdt enigszins, gezien de verdere grondvesting van de vaststellingsprocedure in het burgerlijk procesrecht. De aanleiding van de rechtbank om in het administratief procesrecht een kijkje te nemen, is het administratiefrechtelijke karakter van het nationaliteitsrecht. Het gegeven dat in het (huidige) burgerlijk procesrecht geen mogelijkheid aanwezig is, zal de rechtbank hebben doen uitwijken naar een ander rechtsgebied.

Als gezegd, in de paragraaf aangaande herziening is tevens de vraag naar de objectieve reikwijdte van de vaststellingsbeschikking aan de orde. Wat betreft de vraag waaraan de partijen zijn gebonden (de objectieve reikwijdte) dient te worden uitgegaan van de bindende werking van het dictum van een uitspraak. De objectieve werking betreft het dictum, en niet de rechtsoverwegingen. In het bovenvermelde voorbeeld leidt dit tot consequenties. In dat voorbeeld wordt uitgegaan van het vaststellen van het bezit van het Nederlanderschap door X op 15 augustus 1995, en, dat zal duidelijk zijn, onder die vaststelling zijn de respectievelijke data: 1 november 1984, 1 januari 1983-1 januari 1985 en 2 november 1985 ingesloten.

Hoe het rechtsgevolg waartoe dit leidt, (gebondenheid van de "administratie" aan een foutieve beschikking) zou kunnen worden ondervangen, is onder meer beschreven in paragrafen 2.7.3 en 2.7.4. Zolang een (al dan niet foutieve) positieve vaststellingsbeschikking rechtskracht heeft, kan de betrokkene niet worden behandeld als vreemdeling. ${ }^{1458}$

Voor de verzoeker bestaat, naast de mogelijkheid herziening te verzoeken, de mogelijkheid een herhaald verzoek in te dienen; dit onderwerp komt aan de orde in paragrafen 2.7.1 en 2.7.2. De Staat heeft echter op grond van de Rijkswet op het Nederlanderschap, noch enige andere wettelijke regeling, geen rechtsingang waarbij hij herziening van een gegeven vaststellingsbeschikking kan bewerkstelligen. Met de rechtbank 's-Gravenhage (par. 2.7.2) kan inderdaad niet anders dan tot de slotsom worden gekomen dat de vaststellingsprocedure een leemte vertoont door niet een regeling inzake herziening van de vaststellingsbeschikking te bevatten. Anders dan de rechtbank meen ik echter dat een zodanige leemte niet zozeer de verzoeker als wel de Staat betreft. De verzoeker zou zich, zonder de herzieningsmogelijkheid, kunnen redden door een retrospectief verzoek in te dienen en op die manier een andere beslissing over zijn Nederlanderschap uit te lokken, de Staat evenwel staat met lege handen.

Gezien deze lacune wordt in paragraaf 2.7 .4 het voorstel gedaan om onder bepaalde omstandigheden herziening door de Staat reeds nu toe te staan. Een

\footnotetext{
${ }^{1058}$ Art. $1 \mathrm{Vw}$ jo. art. $19 \mathrm{RWN}$. Onder de definitie van vreemdeling valt ingevolge art. $1 \mathrm{Vw}$ niet degene die: op grond van een wettelijke bepaling als Nederlander wordt behandeld. Art. 19 RWN bewerkstelligt dat een positieve vaststellingsbeschikking met zich brengt dat de betrokkene door de "administratie" wordt behandeld als Nederlander, op grond van de beschikking gaat de "administratie" er van uit dat de betrokkene het Nederlanderschap bezit. Zie tevens voetnoot 443 .
} 


\section{Hoofdstuk 7}

wettelijke regeling is echter wenselijk. Dit zou kunnen door in de Rijkswet op het Nederlanderschap een herzieningsregeling op te nemen. Mijn voorkeur gaat echter uit naar toepasselijkheid van de nieuw tot stand te brengen regeling van Herroeping van beschikkingen en de daarvoor genoemde gronden uit het Voorontwerp tot aanpassing van het Wetboek van Burgerlijke Rechtsvordering. De komende aanpassing van het Wetboek van Burgerlijke Rechtsvordering zal toch een aanpassing van de Rijkswet op het Nederlanderschap vereisen.

In paragraaf 2.8 , getiteld De impliciete vaststellingsprocedures, is het laatste artikel uit hoofdstuk 6 RWN behandeld. Dit artikel heeft betrekking op enerzijds vaststelling van de Nederlandse nationaliteit in een rechterlijke procedure, anders dan in de "zelfstandige vaststellingsprocedure" en anderzijds op vaststelling van de Nederlandse nationaliteit in een beroepschriftprocedure binnen de administratie. Wellicht ten overvloede wordt hier nogmaals benadrukt dat met een beroepschriftprocedure binnen de administratie niet is bedoeld een bezwaarschriftprocedure binnen de administratie (zie paragraaf 2.2.2.1).

\subsubsection{Procesrechtelijke conclusies Duitsland}

Hoofdstuk 5 bevat de behandeling van de derde onderzoeksvraag. Het gaat om de vraag: "welke procesrechtelijke regels van toepassing zijn bij het door de rechter vaststellen van de Duitse nationaliteit?"

In hoofdstuk 5 wordt derhalve gezocht naar de procesrechtelijke aspecten aangaande de vaststelling in rechte van het bezit van de Duitse nationaliteit. In paragraaf 5.1 wordt dienaangaande reeds opgemerkt dat het Duitse nationaliteitsrecht geen eigen regeling kent op grond waarvan de rechter het wel of niet bezit van de Duitse nationaliteit vaststelt. Derhalve komt de vaststelling van de Duitse nationaliteit in rechte in beginsel aan de orde in allerlei rechterlijke procedures waarin de nationaliteit een voorvraag kan betreffen. In hoofdstuk 5 wordt de vaststelling van het bezit van de Duitse nationaliteit op een aantal onderscheidenlijke rechtsgebieden aan de orde gesteld. Onderzocht is het procesrecht ter zake van nationaliteitsvaststellingen op het gebied van het administratief recht (par. 5.2), het civiele - en het strafrecht (par. 5.3) en mede op het gebied van het constitutionele recht (par. 5.4).

Bij uitstek de nationaliteitsvaststelling door een administratieve rechter is, gezien het administratiefrechtelijke karakter van de nationaliteit, van groot belang. In het administratief procesrecht is van toepassing de Verwaltungsgerichtsordnung (VwGO). Op grond van deze wet beschikt de burger over een aantal rechtsingangen waarbinnen het mogelijk is door de rechter een oordeel te laten vellen over het bezit van de Duitse nationaliteit. In paragraaf 5.2 wordt achtereenvolgens de 
administratiefrechtelijke Verpflichtungsklage (par. 5.2.1) en de administratiefrechtelijke ${ }^{1459}$ Feststellungsklage (par. 5.2.2) nader besproken.

In een ingevolge $\S 42$ VwGO aanhangig gemaakt (nationaliteitsrechtelijke) Verpflichtungsklage gaat het om een uitspraak van de rechter op grond waarvan de administratie wordt verplicht een bepaald document (Staatsangehörigkeitsausweis, Personalausweis of een paspoort) aan de betrokkene uit te reiken. De rechter oordeelt in een voorvraag over het bezit van de Duitse nationaliteit. Een Verpflichtungsklage wordt gevoerd nadat een bezwaar- of administratieve beroepsprocedure heeft plaatsgevonden.

Een volgende administratiefrechtelijke rechtsgang is de op grond van $\S 43$ VwGO bestaande Feststellungsklage. Door middel van een (nationaliteitsrechtelijke) Feststellungsklage wordt beoogd het bezit of het niet-bezit van de Duitse nationaliteit, tenslotte een administratiefrechtelijke rechtsbetrekking, declaratoir vast te stellen. Voor het aanhangig kunnen maken van een Feststellungsklage is het niet noodzakelijk dat eerst een bezwaar- of administratieve beroepsprocedure wordt gevoerd. De mogelijkheid bestaat vanzelfsprekend wel, en het is derhalve mogelijk om na de weigering van (bijvoorbeeld) een Staatsangehörigkeitsausweis eerst bezwaar aan te tekenen ten einde toch de uitreiking ervan te bewerkstelligen, en vervolgens, na een tweede weigering, voor de rechter een actie tot vaststelling van de Duitse nationaliteit in de vorm van een Feststellungsklage aanhangig te maken.

In paragraaf 5.2.2.2 blijkt dat, als gevolg van het alleen beantwoorden van de vraag naar het nationaliteitsbezit en het buiten beschouwing blijven van andere rechtskwesties, de administratiefrechtelijke Feststellungsklage kan worden ondergebracht onder het in dit boek ontwikkelde begrip "zelfstandige vaststellingsprocedu$r e e^{n}{ }^{1460}$ In het dictum van de uitspraak wordt vastgesteld of iemand in het bezit van de Duitse nationaliteit is of niet.

De vraag naar het bezit van de Duitse nationaliteit wordt blijkens paragraaf 5.3.1 in een civielrechtelijk geding als voorvraag afgedaan. In civiele zaken gaat het in de meerderheid van de zaken om het personen- en familierecht. Ook in strafrechtelijke gedingen betreft de vraag naar het bezit van de Duitse nationaliteit een voorvraag. In strafrechtelijke zaken gaat het, zoals in paragraaf 5.3.2.1 wordt opgemerkt, in mindere mate om strafbepalingen waarin het zijn van "Deutscher"1461 een rol speelt. De meeste gevallen op strafrechtelijk gebied waarin een vaststelling van het bezit van de Duitse nationaliteit aan de orde is, betreffen uitleveringszaken. De in paragraaf 5.3 genoemde procedures betreffen "impliciete vaststellingsprocedures".

\footnotetext{
${ }^{1459}$ Een civielrechtelijke Feststellungsklage bestaat ook en is voor het vaststellen van een civielrechtelijke rechtsbetrekking van belang: zie $\$ 256 \mathrm{ZPO}$.

${ }^{1460} \mathrm{Zie}$ ook par. 7.1.1.

${ }^{1461}$ Op te vatten als "Deutscher im Sinne dieses Grundgesetz" uit Art. 116 Abs. 1 GG.
} 
De constitutionele toetsing die het Bundesverfassungsgericht in het kader van een Verfassungsbeschwerde verricht en de vaststelling van het bezit van de Duitse nationaliteit is een verhaal apart. In paragraaf 5.4 blijkt dat het BVerfG in wezen geen uitspraak kan doen over het bezit van de Duitse nationaliteit. Wel kan het BVerfG een uitspraak doen over de schending van een grondrecht, waarbij in sommige gevallen voor de uitoefening van het betreffende grondrecht het bezit van de Duitse nationaliteit een voorwaarde is. ${ }^{1462}$ Het bezit van de Duitse nationaliteit is derhalve in sommige gevallen een voorvraag bij de beantwoording van de vraag of een schending van een grondrecht heeft plaatsgevonden. Wordt iemand, die in het bezit is van de Duitse nationaliteit, beperkt bij de uitoefening van grondrechten die volgens het Grundgesetz toekomen aan "Deutsche", dan is ten aanzien van de betrokkene sprake van een schending van de betreffende grondrechten. Als bekend, waakt het BVerfG tegen dergelijke schendingen.

Het BVerfG gaat derhalve inzake een Verfassungsbeschwerde in bepaalde uitspraken wel in op de vraag of de betrokkene in het bezit van de Duitse nationaliteit is, geeft daarop soms zelfs een expliciet antwoord, maar volledigheidshalve wil ik er nogmaals op wijzen dat ook dit expliciete antwoord slechts het antwoord is op een voorvraag.

In hoofdstuk 5 is tevens aandacht besteed aan de eventuele bindende werking van rechterlijke uitspraken inzake de nationaliteitsvaststelling. De vraag waar het daarbij om gaat is, in hoeverre anderen (waaronder andere rechterlijke instanties) zijn gebonden aan het oordeel over de nationaliteit.

Wat betreft de bindende werking van een rechterlijke uitspraak geldt, ook in het Duitse recht, de hoofdregel dat de rechtsoverwegingen die leiden tot het dictum geen rechtskracht hebben. ${ }^{1463}$ Dit betekent dat de rechtsoverwegingen en het aan de hand daarvan geconstateerde rechtsgevolg, dat het antwoord op een voorvraag vormt, nimmer een bindende werking kennen. Derhalve geven de "impliciete vaststellingsprocedures" die aan de orde zijn in de paragrafen 5.2.1 en 5.3 degene wiens bezit van de Duitse nationaliteit wel of niet wordt vastgesteld geen definitieve afdoening van de vraag of de betrokkene de Duitse nationaliteit wel of niet bezit. In een volgende procedure, hetzij met dezelfde wederpartij, hetzij met een andere wederpartij, kan het bezit van de Duitse nationaliteit wederom door de rechter aan een oordeel worden onderworpen.

\footnotetext{
${ }^{140}$ Eigenlijk gaat het om de voorwaarde van het zijn van "Deutscher", als hierboven reeds vermeld, moet dat worden opgevat in de zin van "Deutscher im Sinne dieses Grundgesetz". De mensen die in het bezit zijn van de Duitse nationaliteit vallen daaronder. Zie par. 4.1.4.

${ }^{1063} \mathrm{Vgl}$. par. 5.3.3.
} 
Anders ligt het met de bindende werking van het Feststellungsurteil dat tot stand is gekomen op grond van $\S 43$ VwGO. Dit verschil heeft te maken met het feit dat het in een zodanige procedure niet gaat om een "impliciete" maar om een "zelfstandige vaststellingsprocedure". In een "zelfstandige vaststellingsprocedure" wordt het antwoord op de nationaliteitsvraag in het dictum gegeven. En, als bekend, geldt tussen partijen als gevolg van de materiële rechtskracht van de uitspraak de gebondenheid aan de inhoud van het dictum.

Treffen partijen elkaar een volgende keer weer voor een rechter: het gegeven dictum uit het Feststellungsurteil geldt ook dan tussen hen. Gaat het echter in een volgend geding niet om dezelfde partijen, maar bezit één daarvan een Feststellungsurteil betreffende zijn nationaliteit, dan is de literatuur niet eenduidig over de bindende werking van dat vonnis ten opzichte van de nieuwe tegenpartij. Enerzijds wordt in de literatuur gesteld dat van het vonnis geen bindende werking uitgaat en de rechter vrij is de nationaliteit te beoordelen, anderzijds wordt een tegenovergesteld standpunt ook verkondigd. Een derde opvatting in de literatuur meent, en dat is wellicht nog het meest correct, dat het een nog onbeslist vraagstuk is, aangezien het BVerwG over een dergelijke vraag nog niet heeft geoordeeld.

De slotsom van een en ander is, als vermeld in paragraaf 5.2.2.3, dat onder de huidige stand van zaken geen duidelijk antwoord kan worden gegeven op de vraag naar een verder dan de tussen partijen geldende materiële rechtskracht reikende bindende werking van het Feststellungsurteil.

Interessant is in dit verband een uitspraak van het Bundesverwaltungsgericht uit 1993. In die uitspraak werd bepaald dat onder wederpartij (derhalve gebonden ingevolge de materiële rechtskracht van een Feststellungsurteil ter zake van het bezit van de Duitse nationaliteit) niet alleen de bij het proces betrokken overheidsinstantie betreft, maar dat onder wederpartij mede de Bundesrepublik Deutschland valt, hoewel deze niet bij het geding betrokken hoeft te zijn geweest. De grondslag voor deze uitbreiding van het begrip wederpartij vindt het BVerwG in het bijzondere karakter dat volgens het BVerwG een Feststellungsurteil ter zake van de Duitse nationaliteit onderscheidt van een Feststellungsurteil ter zake van enige andere administratiefrechtelijke rechtsbetrekking. ${ }^{1464}$

In paragraaf 5.2.2.3 wordt nog opgemerkt dat deze uitbreiding van het begrip wederpartij des te opmerkelijker is, aangezien er voor rechter, noch klager een verplichting bestaat de federale overheid bij de totstandkoming van het Feststellungsurteil te betrekken.

In paragraaf 5.4.3.2 ingegaan op de werking die uitgaat van \& 31 Abs. 1 Gesetz über das Bundesverfassungsgericht. Voor een uitspraak op een Verfassungsbesch-

\footnotetext{
1464 Het BVerwG overweegt: "(......) rechtlichen Besonderheiten, durch die sich staatsangehörigkeitsrechtliche Feststellungsurteile von gewöhnlichen, nur eine relative Bindung erzeugenden Feststellungsurteilen unterscheiden."
} 
werde geldt datgene wat voor iedere rechterlijke uitspraak geldt, namelijk dat het dictum materiële rechtskracht kent ten opzichte van de bij het geding betrokken partijen. Daarnaast zijn ingevolge hetgeen $\S 31$ Abs. 1 BverfGG bepaalt alle staatsorganen aan dat dictum gebonden. In paragraaf 5.4.3.2.2 is vervolgens ingegaan op de onzekerheid die bestaat over de vraag of de bindende werking van $\$ 31$ Abs. 1 BVerfGG naast het dictum tevens de rechtsoverwegingen leidend tot dat dictum omvat, en zo ja, of daarbij nog een verschil moet worden gemaakt tussen rechtsoverwegingen van het BVerfG aangaande het Verfassungsrecht en aangaande het gewone Bundes- of Länderrecht. Zoals in die paragraaf is opgemerkt, is een consensus over deze vraag niet bereikt. Wel blijkt uit de literatuur dat de meerderheid van de auteurs, na een eerdere afwijzing van dat standpunt, nu het standpunt inneemt dat de overwegingen met betrekking tot het Grundgesetz bindende werking kennen. Een bindende werking voor overwegingen betreffende het gewone Bundes- of Länderrecht wordt in de literatuur nog steeds afgewezen. In paragraaf 5.4.3.2.2 wordt tevens opgemerkt dat het BVerfG, na eerst in de jaren vijftig dienaangaande een ander standpunt te hebben ingenomen, tegenwoordig dit door de meerderheid van de auteurs ingenomen standpunt aangaande het gewone Bundes- of Länderecht deelt.

Wat de uitleg van het nationaliteitsrecht (Reichs- und Staatsangehörigkeitsgesetz en daarnaast (voornamelijk) de Gesetze zur Regelung von Fragen der Staatsangehörigkeit) betreft, moet dan ook de opmerkelijke conclusie worden getrokken dat andere rechters dan het BVerfG een andere uitleg aan een bepaling kunnen geven, ook al heeft het BVerfG over de betreffende bepaling reeds in een rechtsoverweging een interpretatie gegeven. Ondanks het zojuist opgemerkte, moet evenwel ook worden gewezen op de constatering uit paragraaf 5.4.3.2.2 waaruit blijkt dat de andere rechters de door het BVerfG uitgezette lijn met betrekking tot het gewone Bundes- of Länderrecht gewoonlijk aanhouden.

\subsection{Bewijsrechtelijke conclusies}

\subsubsection{Bewijsrechtelijke conclusies Nederland}

Ter beantwoording van de tweede onderzoeksvraag is in hoofdstuk 3 ingegaan op de vraag welke bewijsrechtelijke regels gelden bij de vaststelling in rechte van het bezit van de Nederlandse nationaliteit. Daartoe is, toegespitst op de huidige vaststellingsprocedure uit artikel 17 Rijkswet op het Nederlanderschap, eerst in paragraaf 3.2, getiteld Bewijsrecht in civiele procedures, ingegaan op het civiele bewijsrecht in het algemeen, op het bewijsrecht in verzoekschriftprocedures in het bijzonder, en tevens op de wijze waarop het bestaan van een recht kan worden bewezen. 
Aan de zeldzame keren dat de wetgever belangstelling heeft getoond voor de kwestie van het bewijs van het bezit van de Nederlandse nationaliteit is aandacht besteed in paragraaf 3.3.1. In die paragraaf is gebleken dat in 1892 een bepaalde verwervingsgrond mede met het oog op het bewijsrechtelijke voordeel dat deze met zich bracht in de Wet op het Nederlanderschap en het ingezetenschap is opgenomen.

Een belangrijk deel van hoofdstuk 3 betreft het onderzoek van bewijsrechtelijk interessante rechtspraak op het gebied van de vaststelling het Nederlanderschap. De in hoofdstuk 3 besproken jurisprudentie is ingedeeld naar chronologie en naar onderwerp. Voor de motivering van die indeling verwijs ik naar paragraaf 3.1. Chronologisch gezien, zijn vanaf het midden van de jaren veertig drie perioden aan te wijzen en naar onderwerp beschouwd, kan een onderscheid worden gemaakt tussen een beroep op verwerving van het Nederlanderschap en een beroep op behoud van het Nederlanderschap.

In het kader van beroep op verwerving van het Nederlanderschap zijn in hoofdstuk 3, verdeeld over de drie perioden, tien uitspraken aan de orde gesteld. In het kader van beroep op behoud van het Nederlanderschap betreft het, eveneens verdeeld over de drie perioden, tweeëndertig uitspraken, waarvan in negen gevallen niet en in drieëntwintig gevallen wel de Toescheidingsovereenkomst tussen Nederland en Suriname aan de orde is. In totaal zijn derhalve in hoofdstuk 3 tweeënveertig uitspraken uit globaal de afgelopen vijftig jaar behandeld. In vergelijking met het in hoofdstuk 2 uitgevoerde onderzoek naar de procesrechtelijke aspecten van de vaststelling van het Nederlanderschap is het bewijsrechtelijke onderzoek derhalve in een bredere opzet uitgevoerd. Dit is het gevolg van de wens om enerzijds slechts het vigerende procesrecht te bespreken en om anderzijds ten aanzien van het bewijsrecht te onderzoeken in hoeverre sprake is van historische continuïteit of discrepantie in bewijsrechtelijke regels.

De paragrafen $3.3 .2,^{1465} 3.3 .3^{1466}$ en $3.3 .4^{1467}$ waarin de jurisprudentie uit de onderscheidenlijke drie perioden is besproken, worden ieder afgesloten met een tussenevaluatie. In die tussenevaluaties worden samenvattende opmerkingen gemaakt over de jurisprudentie van het betreffende tijdvak en over de bevindingen met betrekking tot overeenkomsten en verschillen in de jurisprudentie uit de verschillende tijdvakken. Dientengevolge behoeft in dit hoofdstuk niet een herhaling plaats te vinden van hetgeen reeds is opgemerkt in de tussenevaluaties, maar wordt

\footnotetext{
${ }^{1465}$ Getiteld Nationaliteitsbeslissingen vanaf 1948 tot 1967.

${ }^{1456}$ Getiteld Nationaliteitsvaststelling en bewijslastverdeling in procedures op grond van artikel 43 (oud) Vreemdelingenwet (1967-1989).

${ }^{1467}$ Getiteld Nationaliteitsvaststelling en bewijslastverdeling in procedures op grond van artikel 17 Rijkswet op het Nederlanderschap (1986-heden).
} 
voor de in deze paragraaf opgestelde eindconclusies teruggegrepen op deze tussenevaluaties.

De vraag naar de wel of niet-lijdelijkheid van de rechter in de procedure op grond van artikel 17 Rijkswet op het Nederlanderschap is kort aangesneden in paragraaf 3.3.4.1. De daar vermelde citaten laten zien dat de rechtbank zich weliswaar niet lijdelijk acht, maar toch ook een grens aan de niet-lijdelijkheid ziet, die inhoudt dat de rechtbank niet "nieuwe feiten moet aandragen ter ondersteuning van de stellingen van verzoeker en/of de Staat. "1468 De zojuist vermelde zinsnede is, naar mijn mening, niet houdbaar in het licht van een nadien gedane uitspraak van de Hoge Raad. De Hoge Raad sluit zich in die uitspraak ${ }^{1469}$ namelijk met zoveel woorden aan bij de stelling dat met betrekking tot het onderzoek naar de feiten ter zake van het bezit van het Nederlanderschap de rechter zich niet lijdelijk behoort op te stellen. Naar mijn mening dient hetgeen daarmee wordt gesteld ruim te worden geïnterpreteerd. De Hoge Raad differentieert in zijn uitspraak niet naar feiten die door de verzoeker en/of de Staat reeds in het geding zijn gebracht en feiten die nog door geen van beide partijen naar voren zijn gebracht. Dit betekent, in mijn ogen, dat de rechtbank in feite wel gehouden is om nieuwe feiten aan te dragen, of deze nu ter ondersteuning van het standpunt van de Staat dan wel van de verzoeker zijn. Die ondersteuning is een neveneffect van het onderzoek naar de materiële waarheid dat in een vaststellingsprocedure dient plaats te vinden. Een en ander leidt ertoe dat bij het contemporain vaststellen ${ }^{1470}$ van het Nederlanderschap de rechtbank tevens feiten heeft te onderzoeken (ook feiten die de Staat, noch de verzoeker hebben naar voren gebracht en die van belang zijn voor het bezit van het Nederlanderschap), die zijn voorgevallen $n a$ het moment dat ter beoordeling staat. ${ }^{1471}$

In de "zelfstandige vaststellingsprocedure" is derhalve sprake van een nietlijdelijke rechter. ${ }^{1472}$ Aan de ene kant sluit dat aan bij de rechtspraak inzake de vaststelling van het Nederlanderschap uit het verleden, ${ }^{1473}$ terwijl aan de andere

${ }^{1468} \mathrm{Rb}$. 's-Gravenhage 12.06.1991, rkstnr. 90.5346 (=HR 14.02.1992, NJ 1993, nr. 262, m.nt. GRdG).

${ }^{1469}$ HR 28.10.1994, RvdW 1994, nr. 216 (par. 3.3.4.3.2).

$1400 \mathrm{Zie}$ voor het begrip contemporaine vaststelling: par. 2.2.4.2.1 en 7.2.1.

1471 Bijv. het verzoek luidt vaststelling van het bezit van het Nederlanderschap. De verzoeker beoogt een contemporaine vaststelling. Het standpunt van de verzoeker is dat hij niet op 25.10.1975 zijn Nederlanderschap heeft verloren. De zaak betreft derhalve een beoordelingsmoment van geruime tijd geleden. De niet-lijdelijkheid van de rechtbank brengt met zich dat de rechtbank behoort te onderzoeken (openbaar ministerie bij de rechtbank) dat ten aanzien van de verzoeker geen andere, na 25.10.1975 vallende, verliesgronden zich hebben voorgedaan. Het ligt voor de hand dat in een zodanig geval de rechtbank de als belanghebbende opgeroepen Staat een bewijsopdracht zou geven.

Vgl. Ten Berge/Tak, p. 139: "Vanzelfsprekend moet de instantie er op letten, dat feiten die bepalend zijn voor de toepassing van imperatieve voorschriften, vaststaan, ook al worden ze door partijen niet betwist."

1472 Vgl. ook Ahmad Ali/Klip, MR 1995, p. 84.

${ }^{143}$ Zie par. 3.3.3.5, 
kant wordt aangesloten bij hetgeen gebruikelijk is in een civiele verzoekschriftprocedure waarin het een recht betreft dat niet ter vrije beschikking staat van de partij(en) $)^{1474}$.

Jurisprudentie waaruit de niet-lijdelijkheid blijkt, is afkomstig van de Hoge Raad, ${ }^{1475}$ maar ook de uitspraken van de rechtbank tonen aan dat de rechtbank vanaf de inwerkingtreding van de vaststellingsprocedure, door middel van het onderzoek naar de feiten dat werd verricht door het openbaar ministerie, actief de feiten heeft trachten te onderzoeken ${ }^{1476}$. In paragraaf 7.2 .1 is dit betreffend gesteld dat het openbaar ministerie te beschouwen is als een verlengstuk van de niet-lijdelijke nationaliteitsrechter. Ook in paragraaf 7.2.1 is reeds gesteld dat ten gevolge van het in rechte verschijnen van de Staat in de vaststellingsprocedure, de activiteit van het openbaar ministerie is verminderd of achterwege blijft.

In hoofdstuk 3 is aan een aantal bewijsrechtelijk interessante onderwerpen bijzondere aandacht geschonken. Daarbij gaat het om de volgende onderwerpen: de bewijslastverdeling inzake verwervings- en verliesbepalingen van het Nederlanderschap; de bewijslast inzake het bezit van een vreemde nationaliteit; de vraag in welke mate het bezit van een vreemde nationaliteit dient vast te staan om effect te sorteren in het Nederlandse nationaliteitsrecht (onder omstandigheden is dat de vraag of voor de aanname dat een vreemde nationaliteit is verworven van de betreffende autoriteiten een bevestiging noodzakelijk is); welke bewijssterkte van toepassing is en welke bewijsmiddelen zijn toegestaan.

Als gezegd, hoofdstuk 3 heeft in belangrijke mate de vraag naar de bewijslastverdeling ter zake van het bezit van het Nederlanderschap in het middelpunt staan. $\mathrm{Al}$ eind jaren veertig wordt in de jurisprudentie uitgemaakt dat de bewijslast van een verliesgrond bij de Nederlandse overheid ligt indien deze zich beroept op het ingetreden zijn van dat verlies. Reeds dan wordt duidelijk dat het niet aan de betrokkene is dat hij (door aannemelijk te maken dat hij niet heeft voldaan aan een verliesbepaling) aantoont niet zijn Nederlanderschap te hebben verloren. De nationaliteitsrechtelijke literatuur uit die tijd gaat (aan de hand van de toen bekende jurisprudentie) ook van de bovenvermelde bewijslastregel uit. ${ }^{147}$

Een volgend punt dat uit de jurisprudentie en literatuur uit die tijd ook reeds blijkt, is dat eerst van verlies sprake kan zijn als is bewezen (blijkt ${ }^{1478}$ dat aan een verliesbepaling is voldaan. Indien daaromtrent geen volledige duidelijkheid kan worden verkregen, dient te worden uitgegaan van het voortduren van het bezit van

\footnotetext{
${ }^{1474}$ Zie par. 3.3.4.1.

${ }^{1675}$ HR 28.10.1994, RvdW 1994, nr. 216 (par. 3.3.4.3.2); HR 07.04.1989, NJ 1990, nr. 791 (par. 3.3.4.4.6).

${ }^{1076}$ Zie par. 2.3.2.2 en 7.2.1.

147 Zie par. 3.3.2 en 3.3.2.2.1.

1978 Vgl. par. 3.3.2.1.1 en 3.3.2.2.2.
} 
de Nederlandse nationaliteit. Dit beginsel wordt in dit boek omschreven met het begrip continueringspresumtie.

De zojuist vermelde bewijsrechtelijke lijn met betrekking tot een verliesbepaling van het Nederlanderschap vindt voortzetting in de periode 1967-1989. ${ }^{1479}$ Daarbij kan uit die periode meer duidelijkheid worden verkregen omtrent de bewijslastverdeling bij een beroep op een verwervingsgrond. Het blijkt dat de bewijslast voor een verwervingsgrond in beginsel bij de betrokkene ligt, maar dat daarop een uitzondering wordt gemaakt in de gevallen dat de staatssecretaris van Justitie (die de verwerving betwist) zijn standpunt inzake de niet-verwerving niet deugdelijk kan onderbouwen. ${ }^{1480}$ Dezelfde uitzondering kan worden gesignaleerd als de omstandigheid zich voordoet dat, indien de verwerving van een vreemde nationaliteit een barrière vormt voor de verwerving van de Nederlandse nationaliteit, na onderzoek van het betreffende vreemde recht de rechter vaststelt dat mogelijk de vreemde nationaliteit niet is verworven. ${ }^{1481}$ De overeenkomst ten aanzien van de bewijslastverdeling tussen beide bovenvermelde gevallen is dat het bezit van het Nederlanderschap wordt aangenomen ondanks het feit dat de betrokkene niet alle relevante rechtsfeiten voor de verwerving met sluitend bewijs kan bewijzen. Dat van de kant van de Nederlandse overheid (in deze context wordt daarmee niet slechts de staatssecretaris van justitie, maar tevens de rechter bedoeld) het standpunt van niet-verwerving niet kan worden bewezen (in de zin van blijken) ${ }^{1482}$ is hiervoor een noodzakelijke voorwaarde.

Naar aanleiding van het in de bovenvermelde twee uitspraken, naar mijn mening, van uitzonderlijk gewicht blijken te zijn van de deugdelijke onderbouwing van het standpunt van de staatssecretaris (Nederlandse overheid, d.i. inclusief de nietlijdelijke nationaliteitsrechter) is in het kader van de beklagprocedure ex artikel 43 (oud) Vreemdelingenwet het begrip "primaire bewijslast" ontwikkeld. ${ }^{1483}$ Samen met het begrip "primaire toetsing" vormt "primaire bewijslast" een begrippenpaar. Met "primaire bewijslast" wordt gedoeld ${ }^{1484}$ op de bewijslast en het daaraan inherente bewijsrisico dat aan de kant van de overheid ligt ten aanzien van het door de overheid ingenomen standpunt ten aanzien van iemands Nederlanderschap. Onder "primaire toetsing" wordt verstaan het door de rechter, alvorens het relaas en het bewijsmateriaal van de betrokkene te beschouwen, eerst het standpunt van de staatssecretaris inzake het Nederlanderschap van de betrokkene op deugdelijke onderbouwing toetst.

\footnotetext{
1479 Zie par. 3.3.3.5.

${ }^{1400}$ Zie par. 3.3.3.2.3.

1481 Zie par. 3.3.3.2.5.

1432 In een enkel geval echter is sprake van voldoende aannemelijk worden gemaakt (zie par. 3.3 .3 .2 .2 ). Zie m.b.t. die zaak evenwel voetnoot 1498 .
}

${ }^{1480}$ Zie par, 3.3.3.2.3

1484 Zie ook par. 3.3.3.5. 
Ook in gevallen waarin het gaat om een beklag inzake behoud van het Nederlanderschap is dit bewijsrechtelijke patroon bruikbaar. Naar mijn mening toont de onderzochte jurisprudentie uit de periode 1967-1989 aan dat de Hoge Raad dit bewijsrechtelijk patroon heeft gehanteerd. Zoals hierboven al is opgemerkt, wordt in de periode 1967-1989 de bewijsrechtelijke lijn uit de periode 1948-1967 ten aanzien van een verliesbepaling voor het Nederlanderschap, namelijk dat de bewijslast voor een verliesbepaling bij de Nederlandse overheid ligt, voortgezet. Het "primair toetsen" en het toepassen van de "primaire bewijslast" sluiten aan op die bewijslastverdeling en zijn daar naar mijn mening een onderdeel van.

Derhalve kom ik in paragraaf 3.3.3.5 tot de conclusie dat de Hoge Raad in de beklagprocedure op grond van artikel 43 (oud) Vreemdelingenwet eerst het standpunt van de staatssecretaris van Justitie toetste op deugdelijke onderbouwing en daarna, indien het standpunt van de staatssecretaris deugdelijk en houdbaar werd bevonden, het tegenbewijs van de klager aan de orde stelde. Op grond hiervan wordt de conclusie getrokken dat bij een beroep op behoud van het Nederlanderschap het niet aan de betrokkene is om aannemelijk te maken dat hij het Nederlanderschap niet heeft verloren. Een zodanige inspanning wordt voor de betrokkene pas noodzakelijk nadat in "primaire toetsing" van het standpunt van de overheid blijkt dat dit standpunt is ingenomen aan de hand van voldoende bewijsmateriaal om het een deugdelijk standpunt te kunnen noemen. In de (sporadische) gevallen waarin bij een beroep op behoud van het Nederlanderschap blijkt dat niet aan de "primaire bewijslast" is voldaan, wordt de continueringspresumtie gehanteerd. ${ }^{1485}$

De vraag dient te worden gesteld of en zo ja, welke verandering(en) de "zelfstandige vaststellingsprocedure" heeft gebracht in de bovenvermelde bewijslastverdeling. In paragraaf 3.3.4.5 wordt, wat betreft de categorie waarin de beroepen op verwerving van het Nederlanderschap zijn opgenomen ten eerste geconcludeerd dat de rechtbank van de betrokkene verwacht dat deze het bewijs levert van het zich hebben voorgedaan van de relevante rechtsfeiten voor de verwerving en ten tweede geconcludeerd dat de rechtbank geen oog heeft voor een eventuele bewijsrechtelijke lacune in het standpunt van de Staat. Op grond van die gegevens kom ik in die paragraaf tot de conclusie dat, wat betreft beroep op verwerving van het Nederlanderschap, sprake is van een verslechtering in de bewijsrechtelijke positie die de huidige verzoeker inneemt ten opzichte van de klager in de voormalige beklagprocedure.

Met betrekking tot de categorie waarin de beroepen op behoud van het Nederlanderschap zijn opgenomen, luidt de gevolgtrekking in paragraaf 3.3.4.5 dat, op twee

148s Zie par. 3.3.3.3.2 (interpretatie van vreemd recht; verwerving vreemde nationaliteit is niet voldoende gebleken) en 3.3.3.4.4 (geen bewijs van art. 5 lid 1 TOS in "primaire toetsing": het tegenbewijs van de klager wordt dan ook niet in de overwegingen betrokken). 
tevens in die paragraaf genoemde uitspraken na, de rechtbank de "primaire toetsing" dan eveneens over het hoofd ziet en het op de verzoeker laat aankomen dat deze aannemelijk maakt dat hij niet heeft voldaan aan de (rechts)feiten die leiden tot verlies van de Nederlandse nationaliteit.

Uiteindelijk wordt in paragraaf 3.3.4.5 als algemene conclusie gesteld dat de rechtbank de concepten "primaire toetsing" en "primaire bewijslast" niet in acht neemt, of het nu betreft een beroep op verwerving dan wel een beroep op behoud van het Nederlanderschap. Dit betekent derhalve dat als gevolg van de introductie van de "zelfstandige vaststellingsprocedure" in de bewijsrechtelijke positie van de betrokken burger een achteruitgang is te constateren ten opzichte van de bewijsrechtelijke positie in de voormalige beklagprocedure uit artikel 43 Vreemdelingenwet.

In verband met de hier geconstateerde verslechtering in bewijsrechtelijke positie is het frappant (maar ook verheugend) om te constateren dat de Hoge Raad in het kader van de "zelfstandige vaststellingsprocedure" tot tweemaal ${ }^{1486}$ toe een beschikking van de rechtbank heeft vernietigd op grond van overwegingen die er op neer komen dat eerst meer duidelijkheid dient te komen over het voldaan zijn aan de verliesgrond, terwijl tevens de beslissing van de rechtbank kennelijk in de ogen van de HR te sterk was gebaseerd op het (door de rechtbank als onvoldoende geoordeeld) bewijsmateriaal van de betrokkene en te weinig aandacht bevatte voor de onderbouwing van het negatieve standpunt van de Staat. In beide zaken vindt de Hoge Raad derhalve dat de rechtbank te snel ervan is uitgegaan dat het verlies zich inderdaad heeft voorgedaan.

Hieruit kan, naar mijn mening, de conclusie worden getrokken dat betreffende een beroep op behoud van het Nederlanderschap de Hoge Raad uitgaat van voortzetting van de bewijslastverdeling zoals die in het verleden heeft gegolden, inclusief de "primaire toetsing" van het standpunt van de Staat en inclusief de bewijslast voor de Staat voor zijn standpunt. ${ }^{1487}$ Het begrip "primaire toetsing" staat in verband met de rechtsstaatgedachte; nl. dat aan het handelen van de overheid feiten ten grondslag dienen te liggen waarvan bewijs voor handen is.

Opmerking verdient nog wel dat de in dit boek geformuleerde bewijslastverdeling tot stand is gekomen aan de hand van jurisprudentie waarin de verzoeker het verwerven dan wel het behoud van het Nederlanderschap claimt en waarin de Staat een tegenovergesteld standpunt inneemt. De situatie waarin de Staat stelt dat iemand het Nederlanderschap heeft verworven dan wel heeft behouden, terwijl de betrokkene het tegendeel beweert, komt voorzover ik weet niet voor in de jurispru-

\footnotetext{
1486 HR 07.04.1989, NJ 1990, nr. 791 (par, 3.3.4.4.6); HR 28.10.1994, RvdW 1994, nr. 216 (par. 3.3.4.3.2).

${ }^{1487}$ Met betrekking tot een beroep op verwerving van het Nederlanderschap durf ik, aangezien er geen relevante rechtspraak van de $\mathrm{HR}$ is, over de voortzetting van de bewijslastverdeling uit de voormalige beklagprocedure geen uitspraak te doen. Evenwel zie ik niet in op grond van welke reden die bewijslastverdeling een wijziging zou hebben ondergaan.
} 
dentie. Naar mijn mening is het schema van "primaire toetsing" en "primaire bewijslast" ook in die gevallen toe te passen.

De jurisprudentie is tevens onderzocht op de vraag waar de bewijslast ligt met betrekking tot het bezit van een vreemde nationaliteit, indien zulks van invloed is op het bezit van het Nederlanderschap. Dienaangaande is de bevinding dat de bewijslast voor het bezit van een vreemde nationaliteit ligt bij de Nederlandse overheid. ${ }^{1488}$ Dit ongeacht het feit of het gaat om een beroep op verwerving dan wel een beroep op behoud van het Nederlanderschap. Deze bevinding toont, naar mijn mening, nogmaals aan dat de overheid de bewijslast draagt voor het door haar ingenomen standpunt (dat in zo'n geval luidt: geen verwerving van het Nederlanderschap wegens het verwerven van een vreemde nationaliteit, dan wel verlies Nederlanderschap wegens verwerving vreemde nationaliteit). In paragraaf 3.3.4.5 wordt gewezen op de logische samenhang tussen de hier genoemde bewijslastverdeling inzake het bezit van een vreemde nationaliteit en de bewijslastverdeling inzake een verwervingsgrond en verliesgrond.

Ook de vraag in welke mate het bezit van een vreemde nationaliteit zeker dient te zijn, indien de vreemde nationaliteit een voorvraag ter zake van het bezit van het Nederlanderschap is, is in hoofdstuk 3 tijdens het jurisprudentieonderzoek aan de orde gesteld. Uit de literatuur en ruim een halve eeuw jurisprudentie kunnen de volgende regels worden afgeleid. Ten eerste is gebleken dat het, voor het aannemen van het bezit van een vreemde nationaliteit, niet noodzakelijk is dat van de kant van de vreemde autoriteiten een erkenning voorligt dat de vreemde nationaliteit is verworven. Echter dienen daarbij de feitelijke omstandigheden van de zaak geen aanleiding te geven tot (gerede) twijfel aan de verwerving van de vreemde nationaliteit. Ten tweede gaat de literatuur reeds geruime tijd van het standpunt uit dat de vreemde nationaliteit dient te worden vastgesteld volgens het vreemde recht, hetgeen tevens inhoudt: aan de hand van het vreemde bewijsrecht. ${ }^{1489}$

Het nationaliteitsrecht kent de rechtsfiguur optie, een eenzijdige rechtshandeling. ${ }^{1490}$ Door te opteren verkiest iemand een bepaalde nationaliteit te verwerven.

\footnotetext{
${ }^{1488}$ Zie par. $3.3 .2 .3,3.3 .3 .5$ en 3.3.4.5.

${ }^{1489} \mathrm{Vgl}$. Kollewijn, p. 22; Lemaire, p. 310.

${ }^{1490}$ Wat de eenzijdigheid van het opteren betreft, staat een verandering op stapel. Een momenteel bij de Tweede Kamer aanhangig wetsontwerp (23594) laat het rechtsgevolg (wijziging in nationaliteit) pas ingaan (ingevolge art. 6 leden 1 en 2 w.o.) nadat door de Nederlandse overheid op de optieverklaring schriftelijk is gereageerd met het afgeven van een bevestiging (van nationaliteitswijziging). Een zodanige bevestiging kan worden geweigerd (op grond van het gedrag van de optant). Niettegenstaande de andersluidende opmerkingen van de staatssecretaris van Justitie, mw. Schmitz, aan de Tweede Kamer (Bijl. II. 94-95, 23594, nr. 10, p. 3 en 4) moet toch worden geconcludeerd dat wat hier wordt voorgesteld de afschaffing van de optie in het Nederlandse nationaliteitsrecht betekent. De rechtsfiguur optie verdwijnt en daarvoor treedt in de plaats een vereenvoudigde vorm van naturalisatie. Als gevolg
} 
Onder omstandigheden brengt dit met zich het verlies van een nationaliteit die de opterende bezit op het moment van opteren. In de jurisprudentie komt een aantal uitspraken voor waarin de betrokkene na verloop van tijd bestrijdt dat de verrichte optie (optie leidend tot verlies van het Nederlanderschap) in overeenstemming is geweest met zijn wil. Op grond van artikel 3:44 BW is de rechtshandeling alsdan in beginsel vernietigbaar.

Uit de jurisprudentie blijkt dat een beroep op een wilsgebrek bij het afleggen van een optie zelden slaagt. Het bewijsrisico voor een beroep op een wilsgebrek bij het verrichten van een optie ligt bij degene die de optie aflegt en een beroep op het wilsgebrek doet.

Voor een nadere beschouwing van de zaken waarin het gaat om een beroep op een wilsgebrek bij het opteren zijn een drietal onderwerpen interessant genoeg om iets meer over te op te merken. Om te beginnen valt op dat een beroep op dwaling kennelijk mogelijk is. ${ }^{1491} \mathrm{Er}$ wordt in de literatuur wel gesteld dat dwaling, gezien de plaatsing ervan in boek 6 BW (art. 6:228), slechts mogelijk is in het geval van een overeenkomst. ${ }^{1492}$ Daartegenover staat dat in de literatuur ook wordt gesteld dat het aan de rechtspraak is overgelaten of dwaling ook bij een eenzijdige rechtshandeling toepassing zou moeten vinden. ${ }^{1493}$ Als voorbeeld van een zodanige toepassing van de dwalingsregeling ingeval van een eenzijdige rechtshandeling kan derhalve worden gewezen op de in hoofdstuk 3 vermelde uitspraken inzake een beroep op dwaling bij het doen van een nationaliteitsrechtelijke optie.

Een volgend interessant onderwerp in het kader van een beroep op een wilsgebrek bij een optie houdt verband met de werking van artikel 3:36 BW. Als gevolg van het bepaalde in artikel 3:59 BW kan artikel 3:36 BW in beginsel ook toepassing vinden buiten het vermogensrecht. Kan de Staat der Nederlanden in het geval van een optie ter verwerving van een vreemde nationaliteit (met tevens als rechtsgevolg het verlies van de Nederlandse nationaliteit), die is afgelegd ten overstaan van de vreemde autoriteiten, een beroep doen op artikel 3:36 BW? Aangenomen

${ }^{1490} \rightarrow$

van het ontnemen van het eenzijdige karakter aan de rechtshandeling door er een meerzijdige rechtshandeling van te maken, ontneemt men aan de optie het eigen rechtskarakter (vgl. voetnoot 820). De op Bijl. II 94-95, 23594, nr. 10, p. 4, aangehaalde literatuur waarop de staatssecretaris de eigenzinnige interpretatie van het begrip optie baseert, kan niet overtuigen. Naar mijn mening ondersteunt die literatuur het standpunt van de staatssecretaris in het geheel niet. Zie ook De Groot, MR 1995 , p. 129.

149 ' De meest recente beschikking (van de in dit boek besproken jurisprudentie) inzake een beroep op dwaling is HR 14.02.1992, NJ 1993, nr. 262 (par. 3.3.4.4.8). Maar ook in de periode 1967-1989 komen uitspraken over een beroep op dwaling voor: HR 08.03.1985, NJ 1985, nr. 495 (par. 3.3.3.4.6) en HR 08.05.1987, NJ 1987, nr. 682 (par. 3.3.3.4.7).

${ }^{1692}$ Cliteur, p. 153; Verheugt, p. 195.

${ }^{1493}$ Asser/Hartkamp II, p. 153 (noemt tevens relevante jurisprudentie); Franken e.a., p. 297. 
mag immers, dat de Nederlandse Staat te goeder trouw op de optieverklaring is afgegaan.

Daarnaast is het goed denkbaar dat de Staat onder omstandigheden een beroep zal (kunnen) doen op de verjaringstermijn (van 3 jaar) waarbinnen de betrokkene zijn beroep op het wilsgebrek ingevolge artikel 3:52 sub b en c BW heeft moeten doen. Ook dan komt de vraag naar voren of ingevolge de schakelbepaling in artikel 3:59 BW de bepalingen inzake rechtshandelingen in het Burgerlijk Wetboek tevens van toepassing zijn in het nationaliteitsrecht.

In hoofdstuk 3 is tevens getracht inzicht te verkrijgen in de maatstaf van bewijs die de rechter hanteert bij de beslissing of het Nederlanderschap is verworven dan wel is verloren. Hiermee wordt gedoeld op de bewijssterkte en het gaat daarmee om de vraag welke mate van zekerheid de rechter noodzakelijk acht omtrent het rechtsfeit van de verwerving of het verlies.

Uit de jurisprudentie uit de periode 1948-1967 kan worden geconcludeerd dat in het verleden voor het verlies van het Nederlanderschap stelselmatig de bewijsmaatstaf blijken is gehanteerd. ${ }^{1494}$ Hieruit volgt, naar mijn mening, dat het aannemelijk zijn van een verliesgrond niet voldoende is. In de enige uitspraak uit de periode 1948-1967 waarin een beoordeling wordt gegeven van hetgeen de betrokkene aanvoert om het verlies tegen te spreken is, toen al, gesproken over "niet aannemelijk". ${ }^{1495}$ Het tegenbewijs van de betrokkene is derhalve getoetst volgens de bewijsmaatstaf aannemelijk. In één geval is met betrekking tot een beroep op verwerving van de Nederlandse nationaliteit door de Hoge Raad gesproken van "noch gesteld noch gebleken". ${ }^{1496}$ Maar tevens is in die periode een keer het bezit van het Nederlanderschap aanvaard op grond van bezit van staat. ${ }^{1497}$

Het bovenstaande heeft ertoe geleid dat in paragraaf 3.3.2.3 de constatering is gedaan dat voor de beslissing of sprake is van verlies van het Nederlanderschap een strikter bewijs nodig lijkt te zijn dan voor de beslissing dat sprake is van verwerving. Evenwel bevat de periode 1949-1967 niet genoeg uitspraken om een gefundeerd oordeel inzake de bewijsmaatstaf te doen. Hetzelfde is in paragraaf 3.3.3.5 opgemerkt over de rechtspraak uit de periode 1967-1989. Desalniettemin ben ik van oordeel dat indien de twee perioden samen worden bekeken er een doorlopend patroon is te ontdekken in de gehanteerde bewijsmaatstaf.

Immers, in paragraaf 3.3.3.5 wordt met betrekking tot de periode 1967-1989 ten aanzien van de beslissing of sprake is van verlies van het Nederlanderschap vastgesteld dat door de HR de maatstaf blijken is gehanteerd. Dit sluit aan op

${ }^{1494}$ HR 28.10.1952, HPS 1952, p. 133 (par. 3.3.2.1.1); HR 13.04.1948, NJ 1948, nr. 647 (par. 3.3.2.2); HR 05.10.1948, NJ 1949, nr. 562 (par. 3.3.2.2.2).

${ }^{1495}$ HR 04.10.1949, Reuser (I), p. 82 (par. 3.3.2.2.3).

1496 HR 03.06.1958, NJ 1959, nr. 50 (par. 3.3.2.1.2).

${ }^{1497}$ HR 28.10.1952, HPS 1952, p. 133. 


\section{Hoofdstuk 7}

hetgeen hierboven over de periode 1948-1967 is opgemerkt. Voorts blijkt ook in de periode 1967-1989 inzake het bewijs van hetgeen de betrokkene aanvoert om zijn stelling te onderbouwen dat voldoende is als dit aannemelijk is. Ook hierin valt een voortzetting te constateren van hetgeen is gebleken voor de periode 1948-1967. In paragraaf 3.3.3.5 wordt zelfs geconcludeerd dat voor het standpunt van de staatssecretaris van Justitie niet alleen bij de "primaire toetsing" van dat standpunt, maar ook bij de beoordeling van hetgeen de staatssecretaris tegen de stellingen van de betrokkene aanvoert als tegenbewijs de maatstaf van blijken wordt gehanteerd. Tevens wordt in paragraaf 3.3.3.5 gewezen op een uitspraak inzake een beroep op verwerving van het Nederlanderschap waarin voor de "primaire toetsing" van het standpunt van de staatssecretaris aan de hand van de maatstaf van blijken is geschied.

Samenvattend kan, naar mijn mening, worden gesteld dat over het geheel genomen de Hoge Raad van 1948 tot 1989 het nationaliteitsrechtelijke standpunt van de overheid heeft getoetst volgens de bewijssterkte blijken, ${ }^{1498}$ terwijl voor de beoordeling van de stelling van de betrokkene de bewijssterkte aannemelijk is gehanteerd.

Het spreekt voor zich dat het vervolgens interessant is om te bekijken welke bewijsmaatstaf door de rechtbank is aangelegd in de "zelfstandige vaststellingsprocedure".

Wat betreft een beroep op verwerving van het Nederlanderschap wordt in paragraaf 3.3.4.5 de bevinding weergegeven dat de rechtbank bij een beroep op verwerving ter beoordeling van de stelling van verzoeker de bewijsmaatstaf blijken aanlegt (en, als eerder is uiteengezet, tevens niet het standpunt van de Staat in een "primaire toetsing" op deugdelijke onderbouwing onderzoekt). Ten opzichte van het verleden, waarin ook verwerving is aangenomen in twee gevallen ${ }^{1499}$ waarin de betrokkene niet over sluitend bewijs van de verwerving beschikte (en waarin het overheidsstandpunt niet deugdelijk onderbouwd bleek te zijn) kan hier niet anders worden geconcludeerd dan dat sprake is van een tweede verslechtering in de bewijsrechtelijke positie van de verzoeker in de huidige artikel $17 \mathrm{RWN}$-procedure (ten opzichte van de positie die de klager in de beklagprocedure op grond van artikel 43 (oud) Vreemdelingenwet heeft ingenomen.

${ }^{1498}$ Hierop bestaat slechts één uitzondering: HR 15.09.1980, NJ 1981, nr. 68 (par. 3.3.3.2.2: bij een beroep op verwerving is de vraag naar eventuele verwerving van een vreemde nationaliteit een voorvraag. Het betreft derhalve geen bewijsvraag, maar een rechtsvraag. De HR acht de verwerving van de vreemde nationaliteit voldoende aannemelijk). In HR 08.12.1989 (par. 3.3.3.2.5), een zaak waarin dezelfde rechtsvraag aan de orde is, wordt echter gesteld dat niet is gebleken dat de vreemde nationaliteit is verworven. Het standpunt van de staatssecretaris wordt derhalve in par. 3.3.3.2.2 getoetst aan de maatstaf aannemelijk en in par. 3.3.3.2.5 aan de maatstaf blijken. Dit is inconsequent. ${ }^{1409}$ Par. 3.3.3.2.3 en par. 3.3.3.2.5. 
Moeilijker te beoordelen ligt de situatie wat betreft de gehanteerde bewijsmaatstaf in geval van een beroep op behoud van het Nederlanderschap. Primair dient ten aanzien van zodanige beroepen te worden bedacht dat de rechtbank het standpunt van de Staat (als hierboven is geconcludeerd: naar alle waarschijnlijkheid, immers aanleiding om het tegendeel aan te nemen ontbreekt) niet onderwerpt aan een "primaire toetsing".

Een voortgaande lijn met het verleden kan aangaande de gehanteerde bewijsmaatstaf worden geconstateerd in de twee gevallen waarin de rechtbank tot het oordeel komt dat sprake is van behoud van het Nederlanderschap omdat het rechtsfeit van een verliesgrond niet is gebleken. ${ }^{1500}$ Tevens kan een voortzetting worden gevonden ten aanzien van de bewijssterkte bij de beoordeling van hetgeen de verzoeker (als tegenbewijs) aanvoert: in de meeste beschikkingen spreekt de rechtbank dan over wel of niet aannemelijk. Het komt daarentegen in een minderheid van de beschikkingen (twee in totaal) ook voor dat verzoekers tegenbewijs wordt beoordeeld met de maatstaf blijken. In vier uitspraken ter zake van een beroep op behoud wordt geen duidelijkheid verkregen omtrent de ter beoordeling van verzoekers tegenbewijs gehanteerde bewijsmaatstaf.

Wat betreft de bewijsmaatstaf ingeval van een beroep op behoud betreft, moet de conclusie mijns inziens luiden dat er voor de "zelfstandige vaststellingsprocedure" geen eensluidende conclusie kan worden getrokken. In bepaalde zaken heeft de rechtbank dezelfde maatstaf gehanteerd als in het verleden gebruikelijk was, in andere gevallen heeft de rechtbank gekozen voor een zwaardere maatstaf of geeft de beschikking geen uitsluitsel over de gehanteerde maatstaf.

Hoofdstuk 3 is afgesloten met paragraaf 3.3 .5 , getiteld Bewijsmiddelen, waarin is ingegaan op de bewijsmiddelen waarmee in rechte het bezit van de Nederlandse nationaliteit kan worden bewezen. Het blijkt dat voor de vaststelling van het bezit van de Nederlandse nationaliteit volgens het Nederlandse recht alle bewijsmiddelen zijn toegelaten.

Deze conclusie volgt enerzijds uit het feit dat in civielrechtelijke verzoekschriftprocedures alle bewijsmiddelen zijn toegelaten ${ }^{1501}$ en anderzijds uit het feit dat de Rijkswet op het Nederlanderschap geen bewijsmiddel uitsluit. Te constateren valt dat de regel dat het bewijs van het Nederlanderschap met alle middelen kan worden bewezen ook in het verleden al heeft gegolden. Wel wordt in paragraaf 3.3.5.1 gewezen op de mogelijkheid dat een beperking ten aanzien van de bewijsmiddelen kan voortvloeien uit eventueel in een casus relevant vreemd recht. Indien in een internationale casus bepaalde rechtsfeiten onder vreemd bewijsrecht vallen, kan het

\footnotetext{
${ }^{1500}$ Zie par. 3.3.4.5.

1501 Zie ook par. 3.2.2.
} 
zijn dat dit vreemde bewijsrecht een beperking in de bewijsmiddelen kent. ${ }^{1502} \mathrm{De}$ Nederlandse rechter is daaraan gebonden.

Aantekening verdient nog dat tot op heden binnen het kader van de "zelfstandige vaststellingsprocedure" geen casus voorkomt waarin een beroep op bezit van staat een rol speelt. Het is mijns inziens aan te nemen dat de voorheen geaccepteerde toelaatbaarheid van dat bewijsmiddel onverminderd in de "zelfstandige vaststellingsprocedure" geldt. Dit op grond van de overweging dat het bezit van het Nederlanderschap immers met alle middelen kan worden bewezen. ${ }^{1503}$

Het bewijsmiddel bezit van staat is naar mijn inzicht een middel dat aan de orde kan komen indien een verwervingsgrond niet rechtstreeks is te bewijzen, maar iemand wel door de Nederlandse overheid steeds is aangezien als in het bezit van de Nederlandse nationaliteit. Indien het een verliesgrond betreft, komt naar mijn mening het bewijsmiddel bezit van staat niet aan de orde. Immers, indien iemand door de Nederlandse overheid bij gebrek aan wetenschap inzake het verlies werd behandeld als van Nederlandse nationaliteit, betekent dit niet dat het Nederlanderschap is behouden en dat dat dan zou kunnen worden bewezen door middel van het (bewijsmiddel) bezit van staat. Tot de slotsom dat het Nederlanderschap is behouden kan immers slechts worden gekomen in het geval dat niet is gebleken dat een verliesgrond is gerealiseerd; op welk moment de continueringspresumtie opgeld doet.

Naar aanleiding van de in hoofdstuk 3 besproken jurisprudentie kan afsluitend een aantal bewijsrechtelijk regels inzake het Nederlanderschap op een rijtje worden gezet. De, naar mijn mening, belangrijkste uitkomst van het jurisprudentieonderzoek is wel dat kan worden vastgesteld dat de bewijslast voor het verlies van de Nederlandse nationaliteit, bij betwisting daarvan door de betrokkene, bij de Nederlandse overheid ligt. Dat de bewijslast ter zake van een verliesgrond van oudsher op de Nederlandse overheid rust, blijkt (als gezegd) uit de jurisprudentie en sluit aan bij hetgeen door auteurs als Van Sasse van Ysselt en De Groot/Tratnik is gesteld. Maar er kan tevens worden gewezen op het vermelde in paragraaf 3.3.1, namelijk dat reeds in de Wet van den 28sten Julij 1850, Stb. 44, ter uitvoering van art. 7 der Grondwet met betrekking tot een verliesgrond de bewijslast voor het verlies bij de Nederlandse overheid berustte.

Wat betreft de bewijslastverdeling in het geval van een beroep op verwerving van het Nederlanderschap kan allereerst worden gewezen op de divergentie ten aanzien van twee aspecten in de bewijsrechtelijke positie van de verzoeker in de "zelfstandige vaststellingsprocedure" en van de voormalige klager in de beklagpro-

\footnotetext{
${ }^{1502}$ Uit ruim vijftig jaar jurisprudentic kan worden opgemaakt dat de rechter in toenemende mate wordt geconfronteerd met in het buitenland opgestelde al dan niet authenticke bewijsstukken van aldaar voorgevallen rechtshandelingen.

${ }^{1503}$ Zie par. 3.3.5.1.
} 
cedure op grond van artikel 43 (oud) Vreemdelingenwet. Hierboven is gesteld dat op twee aspecten ("primaire bewijslast" en bewijsmaatstaf) divergentie (inhoudende een verslechtering voor de betrokkene die een beroep op verwerving doet) is opgetreden met de introductie van de artikel $17 \mathrm{RWN}$-procedure in 1986. Ik ben ervan overtuigd dat dit niet door de wetgever bedoelde nevengevolgen zijn geweest. Naar mijn mening zou de rechtbank de "primaire toetsing" van het standpunt van de Staat in ere moeten herstellen.

Een zodanig herstel zou dan leiden tot de situatie dat het in beginsel aan de verzoeker is de rechtens relevante feiten voor zijn verwerving te stellen. ${ }^{1504}$ Tevens heeft de verzoeker een summiere bewijsplicht, dat wil zeggen dat de verzoeker het bewijsmateriaal dat hij heeft, dient te overleggen. Het standpunt van de Staat dat geen verwerving heeft plaatsgevonden, wordt onderzocht op deugdelijkheid. In het geval van een lacune in de deugdelijkheid van het overheidsstandpunt, kan de verwerving van het Nederlanderschap worden aangenomen, ook al bezit de verzoeker niet over sluitend bewijs ter zake van de verwervingsfeiten. De Staat, noch de verzoeker kunnen dan hun standpunt volledig bewijzen.

Als laatste nog even kort een paar andere bewijsrechtelijke regels. De bewijslast voor staatloosheid of voor het bezit van een vreemde nationaliteit ligt bij de Nederlandse overheid. Ingeval van een beweerd wilsgebrek bij het uitoefenen van een optie ligt de bewijslast bij degene die zich beroept op het wilsgebrek. Een verlies van de Nederlandse nationaliteit dient te worden getoetst volgens de bewijsmaatstaf blijken. Blijkt dit verlies niet, dan dient te worden uitgegaan van het voortduren van het bezit van het Nederlanderschap. Het tegenbewijs van de verzoeker dient te worden getoetst volgens de bewijsmaatstaf aannemelijk. ${ }^{1505}$

\subsubsection{Bewijsrechtelijke conclusies Duitsland}

Hoofdstuk 6 bevat, ter beantwoording van de vierde en laatste onderzoeksvraag, enerzijds een theoretisch beschrijvend gedeelte ter zake van het administratief bewijsrecht en anderzijds een gedeelte met een beschrijving van bewijsrechtelijk relevante jurisprudentie op het gebied van het nationaliteitsrecht.

$\mathrm{Na}$ inleidende opmerkingen in paragraaf 6.1 wordt in paragraaf 6.2 de beschrijving gegeven van het administratief bewijsrecht. Paragraaf 6.2 betreft derhalve een weergave van hetgeen in de literatuur betreffende het Duitse administratief bewijsrecht wordt gesteld.

\footnotetext{
${ }^{1504} \mathrm{Vgl}$. art. 429d Rv. In het verzoekschrift dienen de gronden waarop het verzoek rust te worden opgenomen.

1505 Ten Berge/Tak, p. 148, wijzen erop dat in het fiscale recht het onderscheid tussen blijken en aannemelijk maken bewust wordt gehanteerd.
} 
In dit theoretisch beschrijvende gedeelte van hoofdstuk 6 komen de onderwerpen bewijslastverdeling, bewijsregels (Beweislastnormen), bewijswaardering (Beweiswürdigung), bewijssterkte (Beweismaß) en bewijsmiddelen aan de orde.

Het administratiefrechtelijke proces wordt gevoerd aan de hand van de bepalingen uit de Verwaltungsgerichtsordnung (VwGO). ${ }^{1506}$ Maar in het administratief bewijsrecht blijkt op beperkte schaal leentjebuur te worden gepleegd als het gaat om het formele bewijsrecht. De Verwaltungsgerichtsordnung kent daarvoor geen eigen regels, maar verwijst naar de Zivilprozeßordnung. ${ }^{1507}$

Een specifiek administratief procesrechtelijk onderwerp is daarentegen de onderzoeksverplichting (Untersuchungsmaxime) voor de rechter uit $\S 86$ VwGO. De rechter is in het administratief recht ten gevolge van de op hem rustende onderzoeksverplichting een niet-lijdelijke rechter, die actief de feiten behoort te onderzoeken, ook de feiten die de partijen niet bestrijden, en die tevens de feiten behoort aan te vullen. Vanuit het perspectief van de Untersuchungsmaxime is de in de literatuur gemaakte opmerking dat de procesdeelnemers stelplicht, noch bewijslast hebben begrijpelijk. Daarnaast is op het uitgangspunt van de Untersuchungsmaxime de bewijsrechtelijke consequentie gegrondvest dat indien de feiten niet volledig (of genoegzaam) komen vast te staan, dit niet de "schuld" is van de partijen (tenzij deze hun medewerkingsplicht hebben verzaakt), maar dat in wezen de rechterlijke instantie in gebreke blijft. ${ }^{1508}$ Een zodanige situatie waarin ondanks de inspanningen van de rechterlijke instantie en de volledige medewerking van partijen toch de feiten niet genoegzaam vaststaand zijn te krijgen, wordt een non-liquet situatie genoemd. ${ }^{1509}$

Omdat in feite de partijen niet kan worden "verweten" dat de non-liquet situatie bestaat, zou het ook geen logisch gevolg zijn om de partij wiens stelling niet kan worden bewezen daarvan altijd het nadeel te laten dragen. Om toch ingeval van een non-liquet situatie een beslissing te kunnen nemen, kunnen ook andere regels worden gehanteerd. De zojuist bedoelde regels staan in het Duitse recht bekend als de Beweislastnormen. ${ }^{1510}$ Deze Beweislastnormen betreffen de regels volgens welke wordt bepaald welke partij het risico dient te dragen van het onbewezen blijven van een feitelijke omstandigheid. De Beweislastnormen zijn derhalve regels volgens welke in een geding het risico van de niet-bewijsbaarheid wordt verdeeld.

In de gevallen waarin de rechterlijke instantie niet in bewijsnood verkeert (er bestaat derhalve geen non-liquet situatie), oordeelt de rechter op grond van $\S 108$ VwGO naar zijn vrije overtuiging (freie Überzeugung) omtrent de feitelijke waarheid die al dan niet blijkt uit het ter beschikking staande bewijsmateriaal. De

\footnotetext{
${ }^{1506}$ Zie ook par. 7.2.2.

${ }^{1507}$ Zie par. 6.2.

$150 s$ Op zich kan dit in gebreke blijven geheel verschoonbaar zijn als de situatie zo is dat ondanks grote inspanningen van de rechter (en partijen) de feiten niet duidelijk kunnen worden vastgesteld.

1509 Zie par. 6.2.1.

1510 Zie par. 6.2.1.2.
} 
beslissing van de rechter komt dan tot stand door middel van bewijswaardering (Beweiswürdigung). In de theoretische systematiek van het administratief bewijsrecht wordt indien de rechter door middel van Beweiswürdigung tot zijn beslissing komt, niet gesproken over bewijslastverdeling en de daarvoor ontwikkelde regels: de Beweislastnormen.

Tot zover de beschouwingen over het Duitse administratief bewijsrecht. In paragraaf 6.3 is ingegaan op de bewijsrechtelijke aspecten die meer specifiek betrekking hebben op het Duitse nationaliteitsrecht. Voorop dient te worden gesteld dat het Reichs- und Staatsangehörigkeitsgesetz geen eigen regels met betrekking tot het bewijzen van het bezit van de Duitse nationaliteit in een rechterlijke procedure bevat. ${ }^{1511}$ In het Verwaltungsproze $\beta^{1512}$ waarin de nationaliteit een rol speelt, zijn derhalve de algemeen in het administratief recht geldende regels van toepassing. Eén van die algemene regels is bijvoorbeeld dat in de procedure alle bewijsmiddelen zijn toegestaan. ${ }^{1513}$ Het bezit van de Duitse nationaliteit kan in rechte derhalve met alle middelen worden bewezen.

De bewijskracht van de op grond van $\S 39$ Reichs- und Staatsangehörigkeitsgesetz uit te reiken "Urkunden, die zur Bescheinigung der Staatsangehörigkeit dienen" (waaronder de Staatsangehörigkeitsausweis) is besproken in paragraaf 6.3.1. Daar blijkt dat de bewuste documenten in beginsel wel het bezit van de Duitse nationaliteit aantonen, maar dat tegenbewijs (bijvoorbeeld in een rechterlijke procedure tot vaststelling van de Duitse nationaliteit) mogelijk is. Gezien hetgeen is gesteld in paragraaf 7.2.2 inzake de bindende werking van een Feststellungsurteil ( $\S 43$ VwGO) blijkt derhalve dat een zodanig (positief) Feststellungsurteil de betrokkene meer zekerheid biedt omtrent het bezit van de Duitse nationaliteit dan een Staatsangehörigkeitsausweis. Hierbij dient echter te worden beseft, dat die zekerheid niet een absolute zekerheid is. Immers, zoals ook is opgemerkt in paragraaf 7.2.2, ingeval van een andere wederpartij is het volgens de literatuur niet uitgesloten dat een nieuwe beoordeling van het bezit van de nationaliteit mogelijk is.

Met betrekking tot de in paragraaf 6.3 besproken jurisprudentie kan het volgende worden opgemerkt. In geen van de tien behandelde uitspraken wordt gesteld dat sprake is van een non-liquet situatie. Dit betekent dat het systeem van de Untersuchungsmaxime heeft gefunctioneerd en dat de oordelende instantie is uitgegaan van de veronderstelling de feiten genoegzaam te hebben vastgesteld. Dat een hogere rechter de oordelende instantie hierin niet altijd volgt, blijkt uit BVerwG 21 mei $1985^{1514}$ waarin het BVerwG terugverwijst naar de lagere rechter met de opdracht om de feitelijke omstandigheden grondiger uit te zoeken.

\footnotetext{
${ }^{1511}$ Zie par. 6.3.1.

${ }^{1512}$ Zie par. 5.2.1.1.

${ }^{1513}$ Zie par. 6.2.1

${ }^{1514}$ BVerwG, U. v. 21.05.1985, Buchholz 130 $\$ 25$ RuStAG Nr. 5 (par. 6.3.3.4).
} 
Het gevolg van het ontbreken in de behandelde jurisprudentie van zaken waarin een non-liquet situatie aan de orde is (en ik ben gedurende het onderzoek een zodanige zaak niet tegengekomen), is dat aangaande de in een geval van non-liquet te hanteren Beweislastnorm(en) geen inzicht kan worden gekregen.

Een onderwerp ten aanzien waarvan de Duitse jurisprudentie wel een interessant gegeven oplevert, is de Beweismaß. Uit twee zaken waarin een beroep op verwerving van de Duitse nationaliteit wordt gedaan, kan worden geconcludeerd dat, voor hetgeen de betrokkene aanvoert, als bewijssterkte Glaubhaftmachung wordt aangehouden. ${ }^{1515}$ Deze bevinding is in overeenstemming met de opmerkingen dienaangaande in de literatuur, waarin ten aanzien van het begrip "deutsche Volkszugehörigkeit"1516 wordt gesteld dat Glaubhaftmachung voldoende is. ${ }^{1517}$ Daarnaast is het wat betreft de beroepen op behoud van de Duitse nationaliteit zeer frappant om te constateren dat ter zake van een verliesgrond een Beweisma $\beta$ wordt gehanteerd waarin sprake is van feststellen. ${ }^{1518}$ Dit betekent dat voor het oordeel dat sprake is van verlies van de Duitse nationaliteit Volle Überzeugung noodzakelijk is, en dat Glaubhaftmachung te dien aanzien onvoldoende is.

Uit de jurisprudentie blijkt tevens dat in het Duitse nationaliteitsrecht een beroep op verwerving van de Duitse nationaliteit op grond van vertrouwen (dat men die nationaliteit bezit) niet wordt geaccepteerd. Verwerving op grond van het vertrouwensbeginsel is afgewezen in twee uitspraken. ${ }^{1519}$

\subsection{Afsluitende en vergelijkende opmerkingen}

$\mathrm{Na}$ de bovenstaande conclusies van de afzonderlijke hoofdstukken is het tijd om de laatste opmerkingen te maken. Het Nederlandse recht werd in de afgelopen tien jaar verrijkt met een nieuwe wettelijke regeling inzake de nationaliteit en een nieuwe regeling van het bewijsrecht in civiele zaken. De nieuwe nationaliteitswet, de Rijkswet op het Nederlanderschap, heeft als novum de mogelijkheid geopend tot rechtstreekse rechterlijke vaststelling van het bezit van het Nederlanderschap.

1515 BVerwG, U. v. 10.01.1961, Buchholz 13o $\$ 16$ RuStAG Nr. 1 (par. 6.3.2.1:); VG Bremen, U. v. 14.03.1988, NJW 1989, p. 1377 (par. 6.3.2.5: nicht glaubhaft machen können).

${ }_{1516}$ Dit begrip is onder omstandigheden een voorwaarde voor nationaliteitsverwerving. (Zie par. 4.1.4; 6.2.2.1; 6.3.2.2; 6.3.2.5 en 6.3.2.6.

1517 Zie par. 6.2.2.1. VG Bremen, U. v. 14.03.1988, NJW 1989, p. 1377 (par. 6.3.2.5) gaat inderdaad om het bewijs van opname op de Deutsche Volksliste en deutsche Volkszugehörigkeit.

1518 BGH, U. v. 14.12.1955, NJW 1956, p. 509 (par. 6.3.3.1: nicht festzustellen); BVerwG, U. v. 21.05.1985, Buchholz 13o $\$ 25$ RuStAG Nr. 5 (par. 6.3.3.4: nicht fehlerfrei festgestellt).

1519 BVerwG, U. v. 14.12.1972, BVerwGE 41, 277 (par. 6.3.3.2); BVerwG, U. v. 22.08.1979, BVerwGE 58, 259 (par. 6.3.2.3). 
Niettegenstaande het administratiefrechtelijke karakter van de nationaliteit ${ }^{1520}$ is de procedure ondergebracht bij de civiele rechter. Ingevolge artikel 112 lid 2 Grondwet kan inderdaad de beslechting van "geschillen die niet uit burgerlijke rechtsbetrekkingen zijn onstaan" worden opgedragen aan de rechterlijke macht. De oordelende instantie wordt daarmee nog geen administratieve rechter. ${ }^{1521}$ De administratiefrechtelijke procedures die aldus zijn ondergebracht bij de gewone rechter werden door de regering tijdens de parlementaire behandeling van de Algemene wet bestuursrecht wel als "administratieve rechtspraak" gekwalificeerd. ${ }^{1522}$

De vaststellingsprocedure is qua aard een administratiefrechtelijke procedure. Incidenteel zal evenwel, ter bepaling van de nationaliteitsrechtelijke gevolgen, het vaststellen van (gewoonlijk als civielrechtelijk omschreven) familieverhoudingen noodzakelijk zijn. In toenemende mate blijken dit familieverhoudingen te zijn die onder vreemd recht vallen; als gevolg waarvan internationaal privaatrechtelijke regels in de procedure aan de orde komen. De vaststellingsprocedure verkrijgt daarmee naar mijn mening geen civielrechtelijk karakter.

Niettegenstaande het administratiefrechtelijk karakter van de nationaliteitsvaststelling is gekozen voor een procedure op civielrechtelijke grondslag. Gekozen is voor een procedure volgens de twaalfde titel uit het Wetboek van Burgerlijke Rechtsvordering. In de twaalfde titel Wetboek van Burgerlijke Rechtsvordering wordt de verzoekschriftprocedure geregeld. Niet de gehele twaalfde titel is van toepassing verklaard op de rechtstreekse nationaliteitsactie. Niet van toepassing is bijvoorbeeld artikel $429 \mathrm{n} \mathrm{Rv}$, waarin het hoger beroep van de beschikking in eerste aanleg is geregeld. Een tweede feitelijke instantie is tijdens de voorbereiding van het wetsontwerp Rijkswet op het Nederlanderschap niet wenselijk geacht, daar het streven naar de totstandkoming van een korte ${ }^{1523}$ procedure de overhand heeft gehad. Inmiddels lijkt in het algemeen het tij ten aanzien van de vraag of wel of

\footnotetext{
${ }^{1520}$ Het nationaliteitsrecht is een onderdeel van het staats- en administratief recht. Vgl. Raedt van Oldenbarnevelt, p. 55; Van Sasse van Ysselt, HPS 1954, p. 158; Struycken (II), p. 331.

1521 Immers, onder de begripsafbakening van "administratieve rechter" uit art. 1:4 Awb valt niet de rechtbank 's-Gravenhage die op grond van het Wetboek van Burgerlijke Rechtsvordering een verzoekschrift behandelt. De invoering van de Awb heeft wat dit betreft geen verandering gebracht in de voorheen bestaande situatie. Ook in de tijd voor de invoering van de Awb gold dat een administratiefrechtelijke procedure bij de gewone rechter de instantie nog geen administratieve rechter maakte.

${ }^{152}$ Bijl. II. 92-93, 22495, nr. 10, p. 28.

${ }^{1523}$ Waarvan de aanname is dat dit ook een snelle procedure is. Echter, ook in de huidige vorm van de "zelfstandige vaststellingsprocedure" slepen sommige procedures jaren aan. Zie par. 3.3.4.3.1 voor een zaak die in feitelijke instantic vijf jaar heeft geduurd. De gecompliceerdheid van een zaak kan vanzelfsprekend aanleiding geven tot een lange duur, de zaak bijvoorbeeld uit par. 3.3.4.2.2 is bijna tweeẻneenhalf jaar bij de rechtbank aanhangig geweest. De gemiddelde duur van de vaststellingsprocedures bij de rechtbank ligt tussen de één en anderhalf jaar.
} 
niet een tweede feitelijke instantie wenselijk is, gekeerd. ${ }^{1524}$ Zeker in een procedure waarin de materiële waarheidsvinding centraal dient te staan, ${ }^{1525}$ acht ik een tweede feitelijke instantie gewenst. ${ }^{1526}$ Daarbij is het naar mijn mening niet ondenkbaar dat door de invoering van een tweede feitelijke instantie het antal cassatieberoepen zal verminderen.

Het belang van het feit dat het bij de nationaliteitsvaststelling in wezen om een procedure gaat met een wezenlijk administratiefrechtelijke karakter moet m.i. niet zo worden geïnterpreteerd dat de vaststelling per definitie bij een administratieve rechter dient plaats te vinden. De civielrechtelijke verzoekschriftprocedure vertoont genoeg kenmerken die overeenkomen met de kenmerken van een administratiefrechtelijke procedure. Wat betreft de niet-lijdelijkheid van de rechter, het streven naar materiële waarheidsvinding en de toepasselijkheid van het vrij bewijsstelsel ontlopen de beide type procedures elkaar weinig tot niets. De introductie in 1988 van het nieuwe bewijsrecht in civiele zaken heeft voor de "zelfstandige vaststellingsprocedure" geen verandering met zich gebracht. Immers, wat betreft het bewijsrecht in civiele verzoekschriftprocedures bracht de vernieuwing in 1988 geen verandering.

Hoewel het naar mijn mening systematisch gezien een betere keuze zou zijn geweest indien de "zelfstandige vaststellingsprocedure" in 1985, geheel volgens de oorspronkelijke bedoeling, was ondergebracht bij de administratieve rechtspraak van de Raad van State, lijkt het mij nu, na een periode van ruim tien jaar waarin de rechtbank 's-Gravenhage expertise heeft opgebouwd inzake het nationaliteitsrecht, niet verstandig om de vaststellingsprocedure alsnog onder te brengen bij een andere (een dan wel administratieve) rechter. Tijdens de parlementaire behandeling van de Algemene wet bestuursrecht heeft de regering een onderzoek aangekondigd naar de vraag of bij de herziening van de rechterlijke organisatie dient te worden gestreefd naar integratie in het bestuursprocesrecht van de administratiefrechtelijke procedures die bij de gewone rechter plaatsvinden. ${ }^{1527}$ Gezien het feit dat de regering zodanige procedures onomwonden tot "administratieve rechtspraak" heeft verklaard, mag worden aangenomen dat de regering in beginsel neigt tot de genoemde integratie. Zoals ik hierboven al heb opgemerkt, is het naar mijn mening, gezien de opgebouwde expertise bij de rechtbank, op dit moment niet

${ }^{1524}$ In vreemdelingenzaken zal, als het aan de HR ligt, het hoger beroep weer in ere worden hersteld. Vgl. MR 1995, p. 181-186.

1523 De materiële waarheidsvinding behoort in de nationaliteitsvaststelling centraal te staan. Zie par. 7.3 .1

${ }^{1526}$ Dit ondanks het feit dat de verzoeker onder de huidige wetgeving al de mogelijkheid heeft een tweede verzoekschrift of een herzieningsverzoek in te dienen. Deze beide mogelijkheden ontbeert de Staat grotendeels: zie par, 2.7.4 voor de omstandigheden waaronder de Staat m.i. wel een herzieningsverzoek moet kunnen indienen. Wellicht is de introductie van de mogelijkheid tot hoger beroep derhalve juist in het voordeel van de Staat, die dan een tweede mogelijkheid tot feitenvaststelling verkrijgt.

1527 Bijl. II. 92-93, 22495, nr. 10, p. 28. 
langer opportuun om de "zelfstandige vaststellingsprocedure" over te brengen naar een andere rechter. Dit temeer indien daarvoor het enige motief zou zijn dat de procedure alsdan, systematisch beschouwd, is ondergebracht bij het juiste type rechter. Het slechts tegemoet willen komen aan dit systematische argument acht ik geen overtuigende reden om de in het nationaliteitsrecht zo noodzakelijke experti$\mathrm{se}^{1528}$ aanwezig bij de ene instantie over boord te zetten om bij een volgende instantie, net als in 1986, weer opnieuw met de opbouw van kennis inzake het nationaliteitsrecht te beginnen.

Met betrekking tot de "impliciete vaststellingsprocedures" is onlangs door Ahmad Ali/Klip het voorstel gedaan om in, zo niet alle "impliciete vaststellingsprocedures", dan toch wel de strafrechtelijke, de verplichting in te voeren tot een schorsing van de impliciete procedure gevolgd door een Nederlanderschapvaststelling door de rechtbank 's-Gravenhage. ${ }^{1529}$ Het voorstel behelst derhalve een wijziging van de mogelijkheid uit artikel 20 lid 1 RWN tot advisering van de impliciete vaststellingsrechter door de minister van Justitie in een verplichte nationaliteitsvaststelling ten behoeve van de impliciete rechter door de rechtbank 's-Gravenhage. Naar mijn mening is dit een te drastisch voorstel, ${ }^{1530}$ maar zit in het voorstel wel een element waarbij ik zou willen aansluiten. De rechtseenheid wordt inderdaad gediend, zoals Ahmad Ali/Klip betogen, door het inschakelen van de rechtbank 's-Gravenhage ter advisering in "impliciete vaststellingsprocedures". Een voor de hand liggende oplossing zou dan zijn dat impliciete rechters, indien zij daaraan behoefte voelen, advies ter zake van de vaststelling van het Nederlanderschap zouden kunnen inwinnen bij de rechtbank 's-Gravenhage.

Anders dan het Nederlandse recht kent het Duitse recht vanouds een veel systematischere aanpak van de administratieve rechtspraak, en de wijze waarop in dat rechtsstelsel de vaststelling in rechte van het bezit van de nationaliteit is geregeld, is een voorbeeld van die, ten opzichte van het Nederlandse recht, systematisch consequentere benadering. De vaststellingsprocedure die leidt tot een dictum waarin het wel of niet bezit van de Duitse nationaliteit wordt vastgesteld, is dan ook te vinden binnen de algemene administratiefrechtelijke regelgeving. Ook de theoreti-

\footnotetext{
${ }^{1528} \mathrm{Vgl}$. Ahmad Ali/Klip, MR 1995, p. 84.
}

1529 Ahmad Ali/Klip, MR 1995, p. 84. Zij betogen dit naar aanleiding van hun oordeel over rb. Amsterdam 28.11.1994 (zie voetnoot 491).

1530 Zie par. 2 8.3.1 voor de aandacht die in het verleden aan de kwestie van advisering, al dan niet in verplichte vorm, van rechterlijke instanties is geschonken. De verplichting die Ahmad Ali/Klip voorstellen is reeds in de wetsvoorstellen uit 1976 en 1981 te vinden. (Al gingen die wetsvoorstellen uit van verplichte advisering door de minister van Justitie). Tegen het verplicht advies vragen door de rechter is toentertijd één van de argumenten geweest dat het in veel procedures een te zwaar en een te tijdrovend middel zal zijn. Naar mijn mening snijdt die kritiek hout. Vandaar mijn opvatting dat Ahmad Ali/Klip cen te drastisch voorstel doen en mijn afwijzing van het verplicht maken van de advisering in "impliciete vaststellingsprocedures". 
sche onderbouwing van het administratief bewijsrecht vertoont een dogmatisch meer structurelere benadering en onderbouwing dan het Nederlandse bewijsrecht (het Nederlandse administratief bewijsrecht in het bijzonder). Met theorievorming over het administratieve bewijsrecht is het Duitse recht ver voor op de theorievorming van het administratief bewijsrecht in de Nederlandse rechtsliteratuur.

\subsubsection{Overeenkomsten tussen beide rechtsstelsels}

Er kan, waar het betreft de vaststelling in rechte van het bezit van de nationaliteit, worden gewezen op tal van overeenkomsten tussen de twee in dit boek behandelde rechtsstelsels. Daarbij kan worden onderscheiden naar procesrechtelijke, bewijsrechtelijke en materieel nationaliteitsrechtelijke overeenkomsten. Hieronder volgen eerst enkele procesrechtelijke overeenkomsten, vervolgens de bewijsrechtelijke overeenkomsten en, last but not least, een opvallende materieel nationaliteitsrechtelijke overeenkomst.

Als procesrechtelijke overeenkomsten kan worden gewezen op de volgende punten. In beide rechtsstelsels bestaat de mogelijkheid tot het voeren van een "zelfstandige vaststellingsprocedure". ${ }^{1531}$ In beide rechtsstelsels kan het daarbij gaan om een positief dan wel een negatief vaststellingsverzoek. ${ }^{1532}$ In beide landen kan alleen een rechtens bij de nationaliteit betrokken burger de zaak aanhangig maken en niet de Staat. ${ }^{1533}$ Beide rechtsstelsels wijzen de beoordeling van een toekomstige, hypothetische situatie af. ${ }^{1534}$ In beide landen is de nationaliteitsrechter niet lijdelijk. ${ }^{1535}$ De uitspraak van de rechter in de "zelfstandige vaststellingsprocedure" is in beide rechtsstelsels een declaratoire uitspraak en geen constitutieve. ${ }^{1536}$

Ook op bewijsrechtelijk terrein kan worden gewezen op een aantal overeenkomsten. In beide rechtsstelsels geldt in het administratief recht dat alle bewijsmiddelen zijn toegelaten. ${ }^{1537}$ Tevens blijkt dat in beide rechtsstelsels het bezit van de nationaliteit met alle middelen kan worden bewezen. ${ }^{1538}$ Aan het bezit van een nationaal paspoort wordt in beide rechtsstelsels door de rechter niet het gevolg verbonden dat de houder van het paspoort inderdaad de nationaliteit bezit. ${ }^{1539}$

\footnotetext{
${ }^{1531}$ Zie par. $2.1 \mathrm{en} 5.2 .2 .2$.

1532 Zie par. 2.2.4.2 en 5.2.2.1.

1530 Zie par. 2.2.3.2, 2.2.3.2.1 en 5.2.2.1.

1534 Zie par. 2.2 .4 .2 .4 en 5.2.2.1.

1503 Zie par. 7.3.1 en 6.2.1

1936 Zie par. 2.7.4 en 5.2 .

1537 Zie par. 3.2.1 en 6.2.1.

1538 Zie par. 3.3.5.1 en 6.3.1.

1539 Zie par. 3.3.5.3 en 6.3.1.
} 
Onder het begrip bewijzen wordt in beide rechtsstelsels niet begrepen dat het feit, dat moet worden bewezen, op een absolute en onomstotelijke wijze dient te blijken. Het recht van beide landen neemt genoegen met een mindere mate van zekerheid. Naar mijn mening blijkt uit de onderzochte jurisprudentie (alsmede uit de Duitse literatuur) dat in beide rechtsstelsels geldt dat ten bewijze van een verwervingsgrond de bewijssterkte aannemelijk voldoende is en ten bewijze van een verliesgrond de bewijssterkte blijken als bewijsmaatstaf wordt gehanteerd.

Hoewel in dit boek het materiële nationaliteitsrecht niet uitdrukkelijk aan de orde komt, moet toch een opmerking worden gemaakt over een materieel nationaliteitsrechtelijke regel die tijdens de bespreking van de jurisprudentie van beide rechtsstelsels is opgevallen. In beide rechtsstelsels wordt het vertrouwensbeginsel als grondslag voor verwerving van de nationaliteit afgewezen. ${ }^{1540}$ In beide rechtsstelsels betekent een (ten onrechte) uitreiking van een nationaal paspoort geen nationaliteitsverwerving. Net zo min als een ten onrechte weigering een paspoort te verstrekken, leidt tot nationaliteitsverlies.

\subsubsection{Verschillen tussen beide rechtsstelsels}

Uit het verrichte onderzoek naar de vaststelling in rechte van de nationaliteit zijn, naar mijn inzicht, meer overeenkomsten dan verschillen tussen beide rechtsstelsels gebleken. Niet veel verschillen zijn gevonden. De verschillen betreffen bovenal procesrechtelijke verschillen en niet zozeer bewijsrechtelijke verschillen.

Als procesrechtelijke verschillen kunnen de volgende onderwerpen worden genoemd. Het Nederlandse rechtsstelsel bevat een administratiefrechtelijke "zelfstandige vaststellingsprocedure", waarop een civielrechtelijke procedure van toepassing is. Dit is iets dat in het Duitse rechtsstelsel niet bestaat. De "zelfstandige vaststellingsprocedure" in het Duitse recht is op grond van de administratiefrechtelijke regelgeving een algemene procedure en staat als zodanig los van het nationaliteitsrecht. In het Nederlandse rechtsstelsel is dit laatste anders geregeld. In het Nederlandse recht maakt de "zelfstandige vaststellingsprocedure" onderdeel uit van de nationaliteitswet.

Een volgend verschil is dat in het Duitse recht de niet-lijdelijkheid van de nationaliteitsrechter duidelijk in de regelgeving is opgenomen ( $886 \mathrm{VwGO})$, terwijl in het Nederlandse recht de rechtbank te 's-Gravenhage slechts na geruime tijd door middel van cassatierechtspraak duidelijk is geworden dat de nationaliteitsrechter niet lijdelijk behoort te zijn.

De bovenstaande verschillen zijn verklaarbaar door de betere systematiek van het Duitse administratief recht in vergelijking met het Nederlandse.

${ }^{1540}$ Zie HR 16.09.1994, NJ 1995, nr. 563, m.nt. GRdG en par. 6.3.2.3; 6.3.3.2. 



\section{Samenvatting}

Dit boek bevat een rechtsvergelijkend onderzoek naar de procesrechtelijke en bewijsrechtelijke aspecten die een rol spelen bij het door een rechterlijke instantie vaststellen van het bezit van het Nederlanderschap dan wel van de Duitse nationaliteit. Het gaat in de onderhavige studie derhalve om de vraag welke procesrechtelijke en bewijsrechtelijke aspecten een rol spelen in het geval dat een Nederlandse rechter wordt geconfronteerd met de vraag naar het wel of niet bezit van het Nederlanderschap. Dezelfde aspecten zijn onderzocht voor het Duitse recht. Het gehele onderzoek is uitgevoerd aan de hand van een probleemstelling, die als volgt is geformuleerd: welke procesrechtelijke en bewijsrechtelijke regels zijn van toepassing in hetzij het Nederlandse recht, hetzij het Duitse recht, bij het door de rechter vaststellen van het bezit van de nationaliteit. Met dit onderzoek is het in zowel de Nederlandse als Duitse literatuur voor het eerst dat op systematische wijze aandacht wordt besteed aan de procesrechtelijke en bewijsrechtelijke aspecten van de rechterlijke nationaliteitsvaststelling.

Aan het onderzoek is een tweetal begrippen van algemeen nationaliteitsrechtelijke aard ten grondslag gelegd. Onder begrippen van algemeen nationaliteitsrechtelijke aard versta ik begrippen die op ieder nationaliteitsrecht kunnen worden toegepast, ongeacht welk nationaal nationaliteitsrecht het betreft.

In dat kader is een eerste begrippenpaar het onderscheid tussen materieel nationaliteitsrecht en formeel nationaliteitsrecht. Materieel nationaliteitsrecht betreft de verwervings- en de verliesregels aangaande een bepaalde nationaliteit. Bij het formele nationaliteitsrecht gaat het daarentegen om: "procedurele voorschriften betreffende opties, naturalisaties en verklaringen van afstand" alsmede "de regels omtrent vaststelling van (de nationaliteit)" ${ }^{1}$ Aan het materiële nationaliteitsrecht wordt slechts aandacht geschonken voor zover dat in het kader van de te bespreken bewijsrechtelijk relevante jurisprudentie van belang is. Het opnemen van een volledige bespreking van het materiële nationaliteitsrecht van Nederland en Duitsland zou de onderhavige studie een te extensief karakter hebben verleend. Ook wat betreft het formele nationaliteitsrecht is een beperking in acht genomen. Met betrekking tot het formele recht is alleen aandacht besteed aan het laatst genoemde element ervan: de regels omtrent de (rechterlijke) vaststelling van de nationaliteit.

Een tweede begrippenpaar dat van algemeen nationaliteitsrechtelijke aard is, en dat tevens begrippen bevat die van groot belang zijn in deze studie, is het begrippenpaar "zelfstandige vaststellingsprocedure" en "impliciete vaststellingsprocedure". Een "zelfstandige vaststellingsprocedure" is een procedure bij een rechterlijke

' Zie par. 1.1. 
instantie waarin het bezit van de nationaliteit het enige onderwerp van de procedure vormt. Een "impliciete vaststellingsprocedure" is een procedure bij een rechterlijke instantie waarin het onderwerp van het geding wordt gevormd door een andere kwestie dan de vraag naar de nationaliteit, maar waarin, ter beslechting van die andere kwestie, de vraag naar de nationaliteit een voorvraag is.

\section{Het Nederlandse recht}

De Rijkswet op het Nederlanderschap uit 1985 is de eerste Nederlandse nationaliteitswet waarin bepalingen zijn opgenomen die betrekking hebben op het in rechte vaststellen van het bezit van de Nederlandse nationaliteit. De voorafgaande nationaliteitswetten, te weten de Wet van den 28sten Julij 1850, Stb. 44, ter uitvoering van art. 7 der Grondwet en de Wet van 12 december 1892, Stb. 268, op het Nederlunderschap on ingesotonschap, ontbeerden bepalingen dienaangaande.

Het Nederlanderschap, en derhalve de wettelijke regeling ervan, is op grond van artikel 3 Statuut voor het Koninkrijk der Nederlanden een aangelegenheid van het Koninkrijk. Ten gevolge hiervan betreft de regeling van de Nederlandse nationaliteit een Rijkswet. De kwalificatie als Koninkrijksaangelegenheid heeft voor de rechtsgang waarin het bezit van de Nederlandse nationaliteit kan worden vastgesteld tot het praktische gevolg geleid dat men zowel in Nederland als in de Nederlandse Antillen en Aruba een procedure aanhangig kan maken. Personen woonachtig in de Nederlandse Antillen of op Aruba wenden zich met een verzoek tot vaststelling van het bezit van het Nederlanderschap tot het Gemeenschappelijk Hof van Justitie van de Nederlandse Antillen en Aruba. Anderen dan de bovengenoemden dienen zich te wenden tot de rechtbank in Den Haag. In dit boek wordt de procedure voor de rechtbank te Den Haag behandeld. Aan de procedure bij het Gemeenschappelijke Hof van Justitie van de Nederlandse Antillen en Aruba wordt in het onderhavige onderzoek geen bijzondere aandacht geschonken. In dit boek is niet gestreefd naar het verkrijgen van een volledig procesrechtelijk en bewijsrechtelijk inzicht in de "zelfstandige vaststellingsprocedure" in de Nederlandse Antillen en Aruba. Slechts sporadisch wordt indien de procesrechtelijke situatie in de Nederlandse Antillen en Aruba specifiek afwijkt van de Nederlandse situatie dienaangaande een opmerking gemaakt.

De bovenbedoelde procedure op grond waarvan een rechterlijke declaratoire uitspraak wordt verkregen inzake het bezit van de Nederlandse nationaliteit is opgenomen in hoofdstuk 6 Rijkswet op het Nederlanderschap. Op 1 oktober 1986 is hoofdstuk 6 Rijkswet op het Nederlanderschap in werking getreden. In paragraaf 1.2 van dit boek is de historische context geschetst waaronder de opname in de Rijkswet van de procedure tot vaststelling van het bezit van het Nederlanderschap heeft plaatsgevonden. 
De specifiek op de vaststelling van het bezit van het Nederlanderschap gerichte rechtsgang (de "zelfstandige vaststellingsprocedure") betreft de artikelen 17 en 18 RWN. Artikel 19 RWN verleent een bijzonder rechtsgevolg aan de uitspraak van de rechter in de onderhavige procedure. Hoofdstuk 6 Rijkswet sluit af met artikel 20 RWN. Artikel 20 RWN heeft betrekking op enerzijds (in art. 20 lid 1 RWN) de vaststelling van de Nederlandse nationaliteit in een binnen het Koninkrijk aanhangige rechterlijke procedure (anders dan in de "zelfstandige vaststellingsprocedure"), en anderzijds (in art. 20 lid 2 RWN) op de vaststelling van de Nederlandse nationaliteit in een binnen de administratie (van alle delen van het Koninkrijk) aanhangige beroepschriftprocedure. In artikel $20 \mathrm{RWN}$ wordt ten behoeve van de in dat artikel genoemde procedures een regeling gegeven betreffende de advisering inzake het Nederlanderschap van de oordelende instantie door de minister van Justitie dan wel de minister van Justitie van de Nederlandse Antillen of de minister van Justitie van Aruba.

Op uitgebreide wijze wordt in hoofdstuk 2 van het boek de procesrechtelijke aspecten van de procedure tot vaststelling van het bezit van het Nederlanderschap voor de rechtbank 's-Gravenhage behandeld. Niettegenstaande het publiekrechtelijke karakter van het nationaliteitsrecht is de procedure tot vaststelling van het Nederlanderschap een verzoekschriftprocedure bij de civiele rechter. De rechter doet uitspraak in de vorm van een beschikking. Als gevolg van het feit dat het bij de vaststelling van het bezit van het Nederlanderschap gaat om vaststelling van een rechtsgevolg dat niet ter vrije beschikking van de partij(en) staat, is de rechter niet lijdelijk.

Bij de procesrechtelijke aspecten die aan de orde zijn gesteld, komt onder meer de ontvankelijkheid van de verzoeker bij de rechtbank aan de orde. De ontvankelijkheid van de verzoeker in de "zelfstandige vaststellingsprocedure" wordt ingeperkt door de bepaling dat de Nederlanderschapvaststelling slechts mogelijk is indien het betreft nationaliteitsvaststelling "buiten een bij enige in het Koninkrijk gevestigde rechterlijke instantie of een in administratief beroep aanhangige zaak" (art. 17 RWN). Doel van deze inperking is het beletten van het totstandkomen van twee uitspraken waarin over het bezit van het Nederlanderschap een verschillend oordeel is geveld.

Een volgend ontvankelijkheidsaspect dat aan de orde komt, is de vraag wat dient te worden verstaan onder het in de Rijkswet genoemde "onmiddellijk belang" dat de verzoeker dient te hebben ten aanzien van de vaststelling van het bezit van de Nederlandse nationaliteit. Met betrekking tot de jurisprudentie van de rechtbank luidt de conclusie dat daarin geen aanwijzingen voor de interpretatie van het begrip "onmiddellijk belang" kunnen worden gevonden. Aangaande het begrip "onmiddellijk belang" kan met betrekking tot jurisprudentie van de Hoge Raad wel op HR 04.03.1988, NJ 1989, nr. 626, m.nt. GRdG worden gewezen. Volgens de interpretatie die ik aan het begrip "onmiddellijk belang" geef, wordt het begrip in deze 
uitspraak door de Hoge Raad op een onjuiste wijze gebruikt. In de betreffende uitspraak plaatst de Hoge Raad het begrip "onmiddellijk belang" in de context van het benodigde "processueel belang" dat de verzoeker nodig heeft voor de vaststellingsprodure. Naar mijn inzicht echter, wordt met "onmiddellijk belang" in artikel 17 RWN een kwalitatief vereiste van de verzoeker aangeduid. Dit kwalitatieve vereiste betreft de eis dat de verzoeker en degene van wie de nationaliteit wordt verzocht vast te stellen identiek zijn. In het geval dat het gaat om een verzoek tot vaststelling van het wel of niet bezit van de Nederlandse nationaliteit van een in leven zijnde persoon brengt het vereiste van "onmiddellijk belang" met zich dat slechts de rechtstreeks betrokkene het verzoek kan doen en dat de rechtsgang niet openstaat aan derden-belanghebbenden. Een uitzondering hierop zou mijns inziens slechts (onder bepaalde voorwaarden) de Staat der Nederlanden mogen betreffen indien het gaat om herziening van een gegeven vaststellingsbeschikking. Ook indien het betreft een verzoek tot Nederlanderschapvaststelling aangaande een overleden sarenon (art 17 lid 2 RWN) geldt het vereiste van "onmiddellijk belang". In een zodanig geval is naar mijn mening aan dat vereiste voldaan indien de verzoeker zijn nationaliteit rechtstreeks van de overledene afleidt, zodat de nationaliteit van de verzoeker wordt beïnvloed door het wel of niet Nederlander (blijken te) zijn van de overledene.

Naast de bovengenoemde ontvankelijkheidsvereisten, die beide in de Rijkswet op het Nederlanderschap worden gesteld, is in hoofdstuk 2 tevens ingegaan op meer uit het algemene procesrecht afkomstige ontvankelijkheidsvereisten. In dat kader is geconstateerd dat de verzoeker een "processueel belang" bij de vaststelling dient te hebben (hetgeen betekent dat de uitspraak van de rechter voor de verzoeker nodig is om een bepaald doel te verwezenlijken en dat de verzoeker met de uitspraak dat doel ook kan verwezenlijken). Ook is geconstateerd dat het belang van de verzoeker niet mag liggen in een toekomstige, hypothetische situatie.

Artikel 18 Rijkswet op het Nederlanderschap bepaalt dat omtrent een verzoek tot vaststelling van het Nederlanderschap het openbaar ministerie wordt gehoord (art. 18 lid 1 RWN), alsmede dat voor belanghebbenden uitsluitend beroep in cassatie van de beschikking openstaat (art. 18 lid 2 RWN). De Rijkswet voorziet derhalve niet in een tweede feitelijke instantie. Inzake het horen van het openbaar ministerie en de mogelijkheid tot beroep in cassatie geeft artikel 18 RWN regels die gelden in alle delen van het Koninkrijk. Alleen voor de vaststellingsprocedure die wordt gevoerd in Nederland voegt artikel 18 RWN nog toe dat de artikelen 429d, 429f4291 en 429s-429t Wetboek van Burgerlijke Rechtsvordering van toepassing zijn.

In hoofdstuk 2 van het boek is ook ingegaan op de taak en positie die het openbaar ministerie heeft in de vaststellingsprocedure (in Nederland). Het door de wetgever beoogde doel van het door de rechter verplicht horen van het openbaar ministerie is geweest dat op die wijze het standpunt dat de overheid inneemt inzake verzoekers Nederlanderschap aan de rechter bekend kan worden gemaakt. Reeds 
anderhalf jaar na inwerkingtreding van de "zelfstandige vaststellingsprocedure" spreekt de Hoge Raad evenwel het oordeel uit dat, anders dan de wetgever voor ogen heeft gestaan bij het redigeren van artikel $18 \mathrm{RWN}$, het openbaar ministerie niet kan worden beschouwd als belanghebbende in de procedure, noch als vertegenwoordiger van de Staat der Nederlanden. De positie die het OM inneemt in de "zelfstandige vaststellingsprocedure" is een van andere overheidsinstanties onafhankelijke positie. Het OM kan wel ten behoeve van de niet-lijdelijke nationaliteitsrechter onderzoek naar de feiten instellen. Indien het OM nieuwe feitelijke omstandigheden in het geding brengt, dient het beginsel van hoor en wederhoor te worden gerespecteerd en dient de verzoeker de gelegenheid te krijgen zich te uiten over de nieuwe gegevens. Hoewel de rechter verplicht is het OM te horen, is het OM niet verplicht te concluderen. Het OM kan daarvan afzien. Uit recente vaststellingsbeschikkingen blijkt dat, indien de relatieve ongecompliceerdheid van de zaak dat toelaat, het $\mathrm{OM}$ in toenemende mate mondeling concludeert. Een zodanige conclusie wordt genomen tijdens de mondelinge behandeling van de zaak.

Betreffende de artikelen 429d, 429f-429l en 429s-429t Wetboek van Burgerlijke Rechtsvordering is vooral ingegaan op de werking van artikel $429 \mathrm{f} R$. Naast de verzoeker is de Staat der Nederlanden belanghebbende bij de vaststelling van het bezit van de Nederlandse nationaliteit. Ingevolge artikel $429 \mathrm{f} \mathrm{Rv}$ roept de rechtbank 's-Gravenhage in beginsel de Staat altijd op voor de mondelinge behandeling van een verzoekschrift. In de praktijk blijkt de Staat de wederpartij te zijn van de verzoeker. De "zelfstandige vaststellingsprocedure" is in de praktijk een contentieuze procedure. Behalve de Staat der Nederlanden is, tot op heden, nog nooit een andere belanghebbende opgeroepen. Als andere belanghebbende is bijvoorbeeld denkbaar een andere staat waarvan het nationaliteitsrecht mede in het geding is. Voor belanghebbenden staat, als gezegd, beroep in cassatie open. In afwijking van de algemene regel uit artikel $426 \mathrm{Rv}$ is in het kader van de "zelfstandige vaststellingsprocedure" de niet in feitelijke instantie verschenen belanghebbende wel ontvankelijk.

Artikel 19 Rijkswet op het Nederlanderschap kent een bijzonder rechtsgevolg toe aan de vaststellingsbeschikking van de rechtbank 's-Gravenhage alsook aan de vaststellingsbeschikking van het Gemeenschappelijk Hof van Justitie van de Nederlandse Antillen en Aruba. Artikel $19 \mathrm{RWN}$ bepaalt dat de beschikking bindende werking heeft ten aanzien van "elk met de uitvoering van enige wettelijke regeling belast orgaan" binnen het Koninkrijk. Hierdoor kent de vaststellingsbeschikking een ruimere subjectieve reikwijdte dan in het geval dat artikel 19 RWN niet in de Rijkswet zou zijn opgenomen. Tot de organen die uit hoofde van artikel 19 RWN aan de vaststellingsbeschikking zijn gebonden behoren (in Nederland) in ieder geval de organen die volgens de Algemene wet bestursrecht bestuursorgaan zijn. Daarnaast zijn echter ook door artikel $19 \mathrm{RWN}$ aan de vaststellingsbeschikking gebonden alle andere in Nederland met de uitvoering van enige wettelijke 
regeling belaste organen (niet zijnde bestuursorganen ex Awb) en zodanige organen in de Nederlandse Antillen en Aruba (waar de Algemene wet bestuursrecht niet van kracht is).

Hoewel de Rijkswet dienaangaande niets bepaalt, moet ervan worden uitgegaan dat de bovenvermelde bindende werking van de vaststellingsbeschikking slechts voortduurt tot zich een rechtsfeit voordoet waardoor in het bezit van de Nederlandse nationaliteit een wijziging optreedt. In hoofdstuk 2 wordt de wenselijkheid uitgesproken om dit uitgangspunt duidelijkheidshalve in de Rijkswet op te nemen. In artikel 19 RWN dient een aanvulling te worden opgenomen inhoudende dat de gebondenheid slechts duurt zolang niet een posterieur rechtsfeit een wijziging in het bezit van het Nederlanderschap heeft teweeggebracht.

Naast de subjectieve reikwijdte van de vaststellingsbeschikking, die door artikel 19 RWN aanmerkelijk omvangrijker wordt dan gebruikelijk is voor een civiele uitspraak, is in het onderzoek de objectieve reikwijdte van de vaststellingsbeschikking eveneens aan de orde gesteld. De objectieve reikwijdte betreft de vraag waaraan de organen ingevolge artikel $19 \mathrm{RWN}$ zijn gebonden. Het antwoord daarop luidt dat gebondenheid aan het dictum bestaat. De vraag die in verband met de objectieve reikwijdte kan opkomen, is de vraag wat de consequenties dienen te zijn, indien na de totstandkoming van de vaststellingsbeschikking blijkt dat de daarin gedane nationaliteitsvaststelling onjuist is omdat tijdens de procedure ten onrechte een bepaalde verwervings- of verliesgrond over het hoofd is gezien. Ook kan (geruime tijd) na de totstandkoming van de vaststellingsbeschikking blijken dat wel de juiste verwervings- of verliesgrond is getoetst, maar dat aan de beoordeling niet alle rechtens relevante feiten ten grondslag zijn gelegd. Er wordt, kortom, geconstateerd dat een onjuiste vaststelling plaats heeft gevonden.

Ten aanzien van de hierboven bedoelde consequenties dient voorop te worden gesteld dat een in de "zelfstandige vaststellingsprocedure" gegeven onjuiste beslissing niet betekent dat het Nederlanderschap als gevolg daarvan is verworven of verloren. De uitspraak is niet constitutief, maar slechts declaratoir. Uit het onderzoek kan de conclusie worden getrokken dat ingeval van een onjuiste vaststelling van het bezit van het Nederlanderschap dan wel van een onterechte afwijzing van het verzoek tot vaststelling de verzoeker niet in een moeilijk parket verkeerd. Voor de verzoeker bestaat de mogelijkheid om, onder aanvoering van de "nieuwe" feiten, opnieuw een verzoek aan de rechtbank 's-Gravenhage te richten met een herhaald verzoek. Daarentegen wordt ten aanzien van de Staat de conclusie getrokken dat deze echter in het geval van een onjuiste vaststelling in een lastigere positie verkeerd. De Staat blijkt te zijn gebonden aan de beschikking, hoe onjuist deze ook is. Op grond van de huidige wetgeving moet de conclusie luiden dat de Staat is gebonden aan de, naar achteraf blijkt, onjuiste vaststelling. Hier is sprake van een leemte in de wetgeving.

Ten behoeve van de verzoeker heeft de rechtbank 's-Gravenhage het (administratiefrechtelijke) rechtsmiddel herziening mogelijk geacht. Naast de zojuist genoemde 
mogelijkheid voor de verzoeker om een nieuw verzoekschrift aan de rechtbank te richten, kan de verzoeker derhalve ook kiezen voor het rechtsmiddel herziening. Met het oog op de zojuist hierboven genoemde leemte in de wetgeving, als gevolg waarvan de Staat blijkt te zijn gebonden aan een onjuiste vaststelling van het Nederlanderschap, is het noodzakelijk dat ook de Staat onder bepaalde (wettelijk te stellen) omstandigheden herziening kan verzoeken. Voor gevallen waarin niet aan die bepaalde omstandigheden is voldaan, dient de betrokkene te worden genaturaliseerd om het bezit van de Nederlandse nationaliteit een wettelijke basis te geven. Zonder meer is het duidelijk dat de herzieningsproblematiek een wettelijke regeling vraagt.

De bewijsrechtelijke aspecten van het Nederlandse nationaliteitsrecht zijn aan de orde gesteld in hoofdstuk 3. Aan de hand van tweeẻnveertig uitspraken uit de afgelopen vijftig jaar zijn bewijsrechtelijke regels opgesteld. De uitspraken op grond waarvan in dit onderzoek tot bewijsrechtelijke gevolgtrekkingen wordt gekomen, zijn derhalve niet slechts afkomstig uit de "zelfstandige vaststellingsprocedure" van artikel 17 RWN. Een belangrijk deel betreft jurisprudentie op grond van de voormalige beklagprocedure uit artikel 43 (oud) Vreemdelingenwet. De onderzochte uitspraken zijn ingedeeld in twee categorieën. De ene categorie bevat jurisprudentie waarin de betrokkene verwerving van het Nederlanderschap stelt; de andere categorie bevat jurisprudentie waarin de betrokkene het verlies van de Nederlandse nationaliteit bestrijdt.

De volgende onderwerpen zijn in hoofdstuk 3 behandeld: de bewijslastverdeling inzake verwerving en verlies van de Nederlandse nationaliteit; de bewijslast inzake het bezit van een vreemde nationaliteit; welke bewijssterkte van toepassing is en welke bewijsmiddelen zijn toegestaan.

Wat betreft de bewijslastverdeling ter zake van een beroep op verwerving kan het volgende worden opgemerkt. Uit de jurisprudentie van voor de inwerkingtreding van de "zelfstandige vaststellingsprocedure" blijkt dat het bewijsrisico voor een verwervingsgrond in beginsel bij de betrokkene ligt, maar dat daarop een uitzondering wordt gemaakt in het geval waarin de Nederlandse overheid (die de verwerving betwist) haar standpunt niet aan de hand van bewijsmateriaal deugdelijk kan onderbouwen. Er bestaat dan de situatie waarin noch de betrokkene, noch de Nederlandse overheid het eigen standpunt volledig kan bewijzen.

De kwestie of het standpunt dat de overheid inneemt met voldoende bewijsmateriaal kan worden gestaafd, is (in dezelfde periode) ook met betrekking tot rechtspraak waarin de betrokkene het verlies betwist uiterst belangrijk gebleken. En wel omdat met de beoordeling van de onderbouwing van het standpunt dat de overheid inneemt de verdere bewijsrechtelijke consequenties samenhangen. Om deze primaire toetsing van het overheidsstandpunt aan te duiden, is als werkbegrip het begrip "primaire toetsing" geïntroduceerd. Met dit begrip hangt ook het gedurende dit onderzoek ontwikkelde begrip "primaire bewijslast" samen. Indien het standpunt 
van de overheid niet door deze eerste toetsing heen komt, geldt, als het betreft een bestrijding van het verlies van het Nederlanderschap, de regel dat moet worden uitgegaan van voortduring van het bezit van de Nederlandse nationaliteit. In het onderzoek noem ik deze regel inzake het voortduren van het nationaliteitsbezit de continueringspresumtie. Het bewijs dat de betrokkene eventueel kan overleggen om het overheidsstandpunt inhoudende verlies van het Nederlanderschap te ontkrachten, kan in een zodanige situatie buiten beschouwing blijven.

Naar aanleiding van de uitspraken die zijn gedaan op grond van de "zelfstandige vaststellingsprocedure" wordt echter de conclusie getrokken dat de rechtbank 'sGravenhage de concepten "primaire toetsing" en "primaire bewijslast" niet onderkent. De rechtbank heeft geen tot onvoldoende oog voor een eventueel bewijsrechtelijke lacune in het standpunt dat de Staat inneemt. Dit betekent dat als gevolg van de inwerkingtreding van de "zelfstandige vaststellingsprocedure" in de bewijsrechtelijke positie van de betrokken burger een verslechtering is te constateren ten opzichte van de bewijsrechtelijke positie op grond van de voordien geldende regelgeving.

Wat betreft de maatstaf waaraan bewijsmateriaal wordt getoetst, wordt met betrekking tot de periode voor de inwerkingtreding van de "zelfstandige vaststellingsprocedure" de conclusie getrokken dat het standpunt van de overheid is getoetst aan de hand van de bewijssterkte blijken, terwijl voor de beoordeling van de stelling van de betrokkene aannemelijk is gehanteerd. Vergelijking van deze oudere rechtspraak met de rechtspraak die is gevormd op grond van de "zelfstandige vaststellingsprocedure" heeft het volgende resultaat gehad. Een beroep op verwerving van het Nederlanderschap toetst de rechtbank aan de maatstaf blijken. Met betrekking tot beroepen waarin de verzoeker het verlies van het Nederlanderschap bestrijdt, kon geen eensluidende conclusie worden getrokken. In bepaalde zaken heeft de rechtbank dezelfde maatstaf gehanteerd als in het verleden gebruikelijk was, in andere gevallen heeft de rechtbank gekozen voor een zwaardere maatstaf of geeft de beschikking geen uitsluitsel over de gehanteerde maatstaf.

Uit het onderzoek blijkt voorts dat de bewijslast voor het bezit van een vreemde nationaliteit alsmede van staatloosheid bij de Nederlandse overheid ligt. Tevens blijkt dat het bezit van het Nederlanderschap in rechte met alle middelen kan worden bewezen.

\section{Het Duitse recht}

Het Duitse nationaliteitsrecht is slechts te achterhalen door kennis te nemen van verschillende wettelijke regelingen. De kern van het Duitse nationaliteitsrecht wordt gevormd door het Reichs- und Staatsangehörigkeitsgesetz uit 1913. Het Reichs- und Staatsangehörigkeitsgesetz en de andere materieelrechtelijke regelingen ontberen 
een eigen procedure waarin het bezit van de Duitse nationaliteit door een rechter kan worden vastgesteld.

Rechterlijke vaststelling van het bezit van de Duitse nationaliteit geschiedt als gevolg hiervan in velerlei gerechtelijke procedures. Rechters die uitspraak moeten doen in de meest verschillende rechtsgebieden kunnen in aanraking komen met de vraag naar het nationaliteitsbezit. Die rechtsgebieden kunnen bijvoorbeeld betreffen het belastingrecht, het sociale recht, het constitutionele recht, het strafrecht, privaatrecht of het bestuursrecht. Aan de procedures op grond van het civiele, het strafen uitleveringsrecht, alsmede het constitutionele recht is kort aandacht geschonken. Uitgebreider is ingegaan op de procedures binnen het bestuursrecht. Het bezit van de Duitse nationaliteit is een kwestie die bovenal binnen het Duitse administratieve rechtsverkeer van belang is. De administratiefrechtelijke procedures waarbinnen de vaststelling van het bezit van de Duitse nationaliteit plaatsvindt, zijn procedures op grond van de Verwaltungsgerichtsordnung. Anders dan het Nederlandse recht, waar het bestuursrecht van oudsher wordt gekenmerkt door versnipperd procesrecht, kent het Duitse recht één wet op grond waarvan administratiefrechtelijke procedures worden gevoerd. Die wet is de Verwaltungsgerichtsordnung. Deze wet regelt het procesrecht dat geldt bij de bestuursrechter. Tijdens de administratieve behandeling van het geschil in de fase voordat het bij de rechter aanhangig wordt gemaakt (die fase heet in het Duits behördliches Vorverfahren; in Nederland zou het bezwaar en administratief beroep betreffen) geldt een andere wet: het Verwaltungsverfahrensgesetz.

Binnen het administratieve recht zijn twee procedures nader onderzocht. Het betreft de procedure op grond van $\S 42$ VwGO (Verpflichtungsklage) en de procedure op grond van $\& 43$ VwGO (Feststellungsklage). Met een Verpflichtungsklage beoogt de klager een rechterlijke uitspraak te verkrijgen met daarin een verplichting voor het bestuur. In nationaliteitsaangelegenheden gaat het dan om de verplichting de klager een bepaald document uit te reiken waarop hij op grond van het bezit van de Duitse nationaliteit recht heeft. Een zodanige Verpflichtungsklage betreft dan de beoogde afgifte van een paspoort of een Staatsangehörigkeitsausweis. De Feststellungsklage daarentegen leidt tot de wel of niet vaststelling van het bestaan van een publiekrechtelijke rechtsverhouding. De uitspraak is derhalve declaratoir. In een uitspraak op een Feststellungsklage tot vaststelling van het bezit van de Duitse nationaliteit staat, indien de klacht wordt toegewezen, in het dictum met zoveel woorden dat de betrokkene in het bezit van die nationaliteit is. $\mathrm{Bij}$ vergelijking met het Nederlandse recht blijkt derhalve dat de Feststellungsklage op grond van 43 VwGO het equivalent is van de vaststellingsprocedure op grond van artikel 17 Rijkswet. De conclusie luidt dan ook dat in beide rechtsstelsels een "zelfstandige vaststellingsprocedure" bestaat. 
De bewijsrechtelijke aspecten van het Duitse nationaliteitsrecht zijn aan de orde gesteld in hoofdstuk 6. Daarbij is eerst ingegaan op de wettelijke bepalingen inzake het administratief bewijsrecht. Daarnaast is aandacht geschonken aan een aantal bewijsrechtelijke concepten en de theoretische onderbouwing van die concepten in de literatuur. Met betrekking tot het administratief bewijsrecht is in het Duitse recht sprake van een doorwrochte theorievorming.

Ingevolge $\$ 86 \mathrm{VwGO}$ heeft de rechter in een administratiefrechtelijke procedure een verplichting een onderzoek naar de feiten in te stellen. Deze verplichting wordt de Untersuchungsmaxime genoemd. Het Verwaltungproze $\beta$ kent hierdoor een actieve, niet-lijdelijke rechter. In zijn waardering van het bewijs is de rechter vrij. Als bewijsmiddel zijn in het administratiefrechtelijke proces alle middelen toegelaten.

Als gevolg van de werking van de Untersuchungsmaxime is het de taak van de rechter de feiten vast te stellen. In het geval dat voor een bepaald feit het bewijs voor handen is, waardeert de rechter dit bewijs (ingevolge $\S 108$ VwGO naar eigen vrije overtuiging) op waarheidsgehalte. Deze gang van zaken wordt Beweiswürdigung genoemd. De rechter doet in een zodanig geval uitspraak op grond van het bestaande bewijs en de overtuigingskracht daarvan. Anders ligt de zaak echter in het geval dat wordt geconstateerd dat voor een bepaald feit geen bewijs voor handen is. Volgens de theoretische beschouwingen over bewijsrecht bestaat dan een non-liquet situatie. Geen van beide partijen heeft voor een bepaald feit bewijs, noch lukt het de rechterlijke instantie om bewijs te vinden. De bewijsrechtelijke theorie gaat in een zodanig geval uit van toepassing van Beweislastnormen door de rechter om tot een uitspraak te komen.

Als gevolg van de wijze waarop de uitspraken in de tijdschriften worden gepubliceerd, valt vaak niet op te maken of de vastgestelde feiten zijn gesteld en bewezen door één van de partijen of dat de rechterlijke instantie dat ter uitvoering van de Untersuchungsmaxime zelf heeft gedaan. In de onderzochte jurisprudentie is niet gebleken van enige non-liquet situatie.

Aangaande de in de onderzochte uitspraken gehanteerde bewijssterkte kan uit twee zaken waarin een beroep op verwerving van de Duitse nationaliteit wordt gedaan, worden geconcludeerd dat, voor hetgeen de betrokkene aanvoert, als bewijssterkte Glaubhaftmachung wordt aangehouden. Daarnaast is het wat betreft de beroepen op behoud van de Duitse nationaliteit frappant om te constateren dat ter zake van een verliesgrond een bewijssterkte wordt gehanteerd waarin sprake is van feststellen. Dit betekent dat voor het oordeel dat sprake is van verlies van de Duitse nationaliteit Volle Überzeugung (blijken) noodzakelijk is, en dat Glaubhaftmachung (aannemelijk maken) te dienaanzien onvoldoende is. Dit is frappant, omdat uit het onderzoek van de Nederlandse jurisprudentie ter zake van verlies van de Nederlandse nationaliteit hetzelfde is gebleken. 


\section{Summary}

This book is the result of comparative research into the procedural and evidentiary aspects of the judicial establishment of Netherlands or German nationality. The starting point for the research is the following question: which procedural and evidentiary rules are applicable to the judicial establishment of nationality under Dutch and German law?

In this study the substantive nationality law is only treated to the extent as is necessary in discussing case law on evidence and proof. Had an elaborate discussion of the substantive nationality law of the Netherlands and Germany been included, this would have given the study a too extensive character. Also with regard to the procedural nationality laws, the author was forced to limit herself: attention has been focused on the element of the establishment of nationality by the courts.

One set of nationality law concepts of a general nature, which are important for this study, are the concepts 'independent establishment procedure' and 'implied establishment procedure'. An independent establishment procedure involves court proceedings in which the possession of a particular nationality is the only issue. An implied procedure for establishment refers to court proceedings in which although the object of the dispute is formed by an issue other than the question of nationality, in order to resolve that issue, the problem of nationality must be resolved first.

\section{Dutch law}

The Netherlands Nationality Act of 1985 (Rijkswet op het Nederlanderschap) is the first Dutch nationality statute containing provisions for the judicial establishment of Netherlands nationality. The earlier nationality statutes, Wet van den 28 sten Julij 1850, Stb. 44 and Wet van 12 december 1892, Stb. 268, op het Nederlanderschap en ingezetenschap did not contain provisions under which nationality could be established by the courts.

Netherlands nationality, and consequently the rules governing it, is a matter for the entire Kingdom of the Netherlands by virtue of article 3 of the Charter for the Kingdom of the Netherlands (Statuut voor het Koninkrijk der Nederlanden). As a result of this, the rules governing Netherlands nationality are contained in a Kingdom Act (Rijkswet), which applies to the Netherlands Antilles and Aruba as well as to the Netherlands. Since nationality has been characterized as a 'Kingdom' matter, the practical consequence is that proceedings may also be instituted in the Netherlands Antilles and Aruba. Residents of the Netherlands Antilles or Aruba may apply to the Joint Court of the Netherlands Antilles and Aruba (Gemeenschappelijk Hof van Justitie van de Nederlandse Antillen en Aruba) for the purpose of having nationality established. Others must apply to the District Court of the Hague. Only where the 
procedural rules in the Netherlands Antilles and Aruba specifically differ from those of the Netherlands, is an observation made to that effect.

The establishment of nationality according to the earlier mentioned procedures through which a declaratory judgment may be obtained concerning the possession of Netherlands nationality, has been incorporated into Chapter 6 of the Netherlands Nationality Act (Rijkswet op het Nederlanderschap-RWN). This chapter came into effect on 1 October 1986. In Chapter 1.2 of this study, the historical context of the development of the indepent establishment procedure is discussed with the emphasis on its incorporation into the Netherlands Nationality Act.

The independent procedure for the establishment of Netherlands nationality is governed by articles 17 and 18 RWN. Article 19 RWN confers a special legal effect on a judicial decision in such proceedings. Chapter 6 of the Kingdom Act ends with article 20. Section 1 of this article deals with the establishment of Netherlands nationality through judicial proceedings instituted within the Kingdom of the Netherlands other than by way of the independent procedure, and section 2 deals with the establishment of Netherlands nationality in (administrative) appeal against administrative action cases in any part of the Kingdom. The same section governs the procedure with regard to the mandatory advisory opinion by the Minister of Justice of the Netherlands, or the Minister of Justice of the Antilles or the Minister of Justice of Aruba.

Chapter 2 discusses the procedural aspects with regard to the establishment of Netherlands nationality before the District Court of the Hague. Although nationality law is part of public law, the procedure for establishing Netherlands nationality is a procedure by petition before a civil court. The court renders judgment in the form of a individual judicial decision (beschikking). Inasmuch as, in establishing the existence of Netherlands nationality, a legal effect is created which is not at the discretion of the party/ies, the judge's role is not a passive one.

The admissibility of the petitioner under the independent establishment procedure is limited by the provision that the establishment of the existence of Netherlands nationality is only possible where it concerns cases of establishment "outside cases instituted before any judicial body established in the Kingdom of the Netherlands or outside cases of administrative appeal against administrative action" (art. 17 RWN). The purpose of this limitation is to ensure that no two decisions are rendered in which there is a different judgment on the possession of Netherlands nationality.

A second aspect of admissibility is the question of what must be understood by the 'direct interest' ("onmiddellijk belang" ) the petitioner must have in having his or her nationality established as Netherlands nationality. Relevant here is the judgment by the Netherlands Supreme Court of 4 March 1998, no 626. The interpretation given to the concept of 'direct interest' does not correspond with the author's interpretation of the concept and she feels the interpretation of the Supreme Court in the above case is 
wrong. The Supreme Court places the concept of 'direct interest' in the context of the interest which the petitioner must have in having his or her nationality established by the court (procedural interest). The author, however, feels that 'direct interest', as laid down in article 17 RWN, refers to the required quality of the petitioner, namely that the petitioner and the person whose nationality is at issue be one and the same. In cases in which the nationality of a living person must be established by petition, the required 'direct interest' entails that only the person directly involved may submit a petition to that effect and that interested third parties have no locus standi. The author thinks that only (under certain conditions) the State of the Netherlands could form an exception, providing the case concerns judicial revision of an earlier judicial decision in which nationality was established. Also in case of a petition requesting the establishment of the nationality of a deceased person (art. 17 (2) RWN) there must be 'direct interest'. In such cases, the requirement has been met, if the petitioner's nationality directly derives from that of the deceased person, so that the nationality of the petitioner depends on whether the deceased was (as will be established) a Netherlands national or not.

In addition to the earlier mentioned requirements for admissibility, which are laid down in the Netherlands Nationality Act, Chapter 2 also pays attention to the more general requirements for admissibility laid down in the law of civil procedure. In this context, the author concludes that the petitioner must have a serious interest in instituting court proceedings (procedural interest) in order to have nationality established, in other words, a court decision is needed in order for the petitioner to achieve a particular goal and that the petitioner must be able to achieve that goal with the aid of the judicial decision. The author also concludes that the petitioner's interest must not concern a future, hypothetical matter.

Article 18 contains rules for the hearing of the Public Prosecutor's Office and the possibility of appeal to the Netherlands Supreme Court. These rules apply throughout the Kingdom.

Section 2 of the article provides that for interested parties a single appeal lies to the Netherlands Supreme Court. The RWN does not provide for a second instance in which the facts can be reassessed. In addition, the article provides that artt. 429d, $429 \mathrm{f}-4291$ and $429 \mathrm{~s}-429 \mathrm{t}$ of the Dutch Code of Civil are applicable to proceedings held in the Netherlands.

In Chapter 2 the author also discusses the duties and position of the Public Prosecutor's Office in the establishment procedure (in the Netherlands). By prescribing that the Public Prosecutor's Office must be heard in such procedures, the legislature's objective was that, in this way, the court could take cognizance of the views held by the administration regarding such petitioners. However, only one and a half years later, the Netherlands Supreme Court ruled that, unlike the intention of the legislature when formulating article $18 \mathrm{RWN}$, the Prosecutor's Office may not be regarded as an interested party to the proceedings, nor as a representative of the State of the Netherlands. The position of the Public Prosecutor's Office under the independent 
establishment procedure is a position independent from other public bodies. The Public Prosecutor's Office is allowed, on the other hand, to initiate an investigation into the facts for the benefit of the -active- nationality court. If the Public Prosecutor's Office introduces new facts during the proceedings, the petitioner must be granted an opportunity to be heard with regard to these new facts. Although the court is obliged to hear the Public Prosecutor's Office, the Public Prosecutor's Office is not obliged to submit an opinion. Recent decisions establishing nationality show that where the relative simplicity of the case so permits, the Public Prosecutor's Office offers its opinion orally during the hearing of the case.

Special attention has been given to the effect of article $429 \mathrm{f}$ of the Dutch Code of Civil Procedure (Rv). Apart from the petitioner, the State of the Netherlands is an interested party in the establishment of Netherlands nationality. In principle, pursuant to article $429 \mathrm{f} \mathrm{Rv}$, the District Court of the Hague calls on the State to appear at a hearing of the petition. In practice, the State turns out to be the other party of the petitioner. Until now, no other interested party has been called on to appear. Conceivably, another State whose nationality law is also at issue could be an interested party. Such interested parties, it has been said, may lodge an appeal to the Netherlands Supreme Court. In departure from the general rule, laid down in article $426 \mathrm{Rv}$, the interested party who has not appeared in the first instance, may still appeal to the Supreme Court under the independent procedure.

Article 19 RWN provides that the judicial decision is binding with regard to 'any organ charged with the implementation of any legal rule or regulation" within the Kingdom of the Netherlands, giving the decision establishing nationality a wider subjective scope (the legal effect on the parties) than if it had not been incorporated into article $19 \mathrm{RWN}$. Organs bound by the decisions establishing nationality pursuant to article 19 RWN include (for the Netherlands) in any case those organs which pursuant to the General Administrative Code (Awb) fall within the definition of 'bestuursorgaan' (administrative organ). Also bound are all organs in the Netherlands, other than those under the Awb, charged with the implementation of any legal rules or regulations and like organs in the Netherlands Antilles and Aruba.

Although the RWN does not contain any specific provision to that effect, it may be assumed that the binding effect of the judicial decision establishing the nationality discussed above continues as long as the possession of the Netherlands nationality is not changed by operation of law. The author finds it desirable that this assumption be expressly included in the RWN.

The objective scope of the decision concerns the question as to the substantive element of the decision that binds the organs pursuant to article $19 \mathrm{RWN}$. The answer is that they are bound to the dictum. A question that may be raised in this context is what happens if after the judicial decision establishing the nationality, it turns out that during the proceedings a specific ground for acquisition or loss was overlooked? It could also happen that (long) after the decision was rendered, although the testing against the grounds for acquisition or loss was correctly conducted, it becomes evident 
that the assessment was not based on all the facts relevant in law. In brief, the author concludes that in these cases the decision establishing the nationality has been incorrect.

With respect to the above it must be said that the fact that an incorrect decision has been rendered under the independent procedure does not result in the Netherlands nationality being acquired or lost. The decisions is declaratory, not constitutive. The petitioner may submit a new petition to the District Court of the Hague, in which he or she adduces new facts, and repeats the request. As for the State, the author concludes that it finds itself in dire straits in case the establishment has turned out to be incorrect. Despite its incorrectness, the State itself is bound by the judicial decision. Apparently, the State is so bound, since the present law does not provide otherwise.

In view of this gap in the law, the State also should be able to apply for a revision under specific conditions to be laid down in the law. Where such conditions are not met, the person in question must be naturalized in order to provide a legal basis for the possession of Dutch citizenship. It is obvious that the problem of revision wants regulation.

The evidentiary aspects of the Dutch nationality law are discussed in Chapter 3 . Forty-two judicial decisions have formed the basis for the legal rules of evidence. Therefore the author has drawn her conclusions with regard to evidentiary rules not only on the basis of decisions which have been rendered under the independent establishment procedure governed by article $17 \mathrm{RWN}$. A major part refers to the case law under the old complaint procedure laid down in article 43 (old) of the Aliens Act. The decisions studied have been divided into two categories. The first category contains case law in which the person in question asserts acquisition of nationality; the other concerns case law in which the person in question disputes the loss of Netherlands nationality.

Chapter 3 deals with the following subjects: the distribution of the burden of proof in cases of acquisition and loss of Netherlands nationality; the burden of proof in cases of possession of a foreign nationality; the applicable standard of proof and the means of evidence permitted by law.

As to the distribution of the burden of proof in cases of acquisition of Netherlands nationality, the following observations are made. Case law prior to the coming into effect of the independent establishment procedure shows that, in principle, the burden of proof of an acquisition ground is on the person in question. However, there is an exception in cases in which the Dutch authority disputing the acquisition fails to produce evidence to back up its view. Where such a situation occurs, neither the person in question nor the Dutch authority is able to offer full proof of their position.

The question as to whether the public authority's position can be sufficiently borne out by evidence, has proved to be a very important question in respect of judicial 
decisions in which the person in question had disputed the loss of Dutch citizenship prior to the independent procedure; important, in that subsequent evidentiary consequences depend on the assessment of the authority's arguments. To designate this initial testing of the authority's position, the author introduces the working concept of 'primary testing'. This concept interrelates with the concept of 'primary burden of proof' as developed in the course of this study. If the authority's position does not pass this first test, it must be assumed, with regard to the loss of Dutch citizenship, that possession of the Dutch nationality continues. The author calls this the rule of presumption of continuation. The possible evidence which the person in question may be able to submit to rebut the proposition of the authority that Dutch citizenship has been lost, may be ignored in these cases.

On the basis of the decision rendered under the independent establishment procedure, the author concludes that the District Court of the Hague fails to acknowledge the concepts of 'primary testing' and 'primary burden of proof'. This Court fails to see the possitore insofficiericy of proof for the position of the authority. This means that since the coming into operation of the independent establishment procedure the probatory position of the person in question has deteriorated compared with that person's position under the old rules of evidence.

As for the standard against which the evidence is tested, the author concludes that in the period prior to the independent establishment procedure the authority's position has been tested against the standard of proof 'blijken' (clearly established, evident), whereas for the assessment of the assertion of the person in question the degree 'aannemelijk' (persuasive) was applied. A comparison of this old case law with that under the independent establishment proceedings reveals the following. The assertion of the person in question that Dutch citizenship has been acquired is tested by the District Court of the Hague against the standard 'blijken'. Where the person in questions disputes the loss of Dutch citizenship, there is no unequivocal conclusion. In some cases, the Court applies the same standard as in the past, in others it chooses the more severe standard or the decision is silent on the standard of proof applied. The study also shows that the burden of proof for the possession of a foreign nationality as well as for statelessness is placed on the Dutch authorities. It has also become evident that possession of the Netherlands nationality may be proven in court with any and all means of evidence.

\section{German law}

German nationality law can only be perceived through acquainting oneself with various statutory rules. The 1923 Reichs- und Staatsangehörigkeitsgesetz forms the core of the German nationality law. The Reichs- und Staatsangehörigkeitsgesetz and the other substantive rules do not contain a specific procedure by which possession of German nationality may be ascertained in court. As a result of this, judicial establishment of German nationality can be achieved through a variety of judicial procedures. Judges having to render judgment in the most diverse areas of law may be confronted with 
the question of nationality. These areas may be tax law, social security law, constitutional law, criminal law, private law or administrative law. Civil and criminal procedure and extradition procedure are briefly discussed. Administrative procedure is dealt with in more detail. Possession of the German nationality is something that is particularly relevant in German administrative legal practice. The administrative procedure by which German nationality is established is governed by the Verwaltungsgerichtsordnung. Unlike Dutch law, under which administrative law is traditionally characterized by fragmentation, German law has a single act on the basis of which administrative proceedings may be instituted and conducted, the Verwaltungsgerichtsordnung. This Act governs proceedings before the administrative court. The handling of the dispute at the pretrial stage by the administrative authorities (behördliches Vorverfahren), comparable to the procedure of objection and appeal lodged with the administrative authorities in the Netherlands, is governed by a different statute: the Verwaltungsverfahrensgesetz.

Two procedures of German administrative law have been studied: the procedure of $\S 42$ VwGO (Verpflichtungsklage) and the procedure of $\$ 43$ VwGO (Feststellungsklage). The petitioner uses the Verpflichtungsklage to obtain a judicial decision imposing an obligation upon the administration. In matters of nationality, this is the obligation to issue a particular document, for instance, a passport or a Staatsangehörigkeitsausweis. The Feststellungsklage, on the other hand, results in the establishment of whether there is a legal relation between the State and the petitioner in question under public law. It is declaratory by nature. The dictum sought by the petitioner by way of the Feststellungsklage, states that the person in question possesses German nationality. In comparison with Dutch law, the author has found that the Feststellungsklage ex $\S 43 \mathrm{VwGO}$ is the equivalent of the establishment procedure laid down in article $17 \mathrm{RWN}$. The author concludes that an independent establishment procedure exists in both systems.

The evidentiary aspects of the German nationality law are presented in Chapter 6 . First, the provisions of the administrative law of evidence are looked into. Attention is further paid to a number of concepts of the law of evidence and to the theoretical underpinning of these concepts in literature. Where the administrative law of evidence is concerned, there is a thorough theoretical development in German law.

Pursuant to $\S 86 \mathrm{VwGO}$, the court in administrative proceedings has an obligation to investigate the facts. This obligation is called the Untersuchungsmaxime. In the Verwaltungproze $\beta$ (administrative proceedings) the judge's role is an active one. The assessment of the evidence is at the judge's discretion. All means of evidence are permitted under the German law of administrative procedure.

As a result of the Untersuchungsmaxime, it is the duty of the court to establish the facts. In the event that there is evidence of a particular fact, the judge assesses the truthfulness of the evidence (pursuant to $\S 108$ VwGO) according to his own conviction. This is called Beweiswürdigung (assessment of the evidence). The court 
in such cases renders judgment on the basis of the existing evidence and its convincing power. Things are different where it is established that there is no evidence of a particular fact, and the court does not manage to uncover such evidence. According to doctrinal literature, in such cases there is a situation of non-liquet. In academic writing on evidence it is assumed that the judge will apply the Beweislastnormen (standards of proof) in order to arrive at a decision.

Due to the manner in which judgments are published in reviews, it is not always possible to establish whether the facts in question have been asserted and proven by one of the parties or whether the court has done so itself in implementing the Untersuchungsmaxime. Judging from the case law studied no non-liquet situation has transpired.

As to the standard of proof in the decided cases under study, it must be concluded from two cases in which acquisition of German citizenship had been invoked, that for what is adduced by the person in question the standard of proof Glaubhaftmachung is applied. It is furthermore rather striking to find that, where the continuation of German nationality is invoked, for a ground for loss of nationality a standard of proof is applied which is based on feststellen (establish). This means that a ruling that there is a loss of German nationality requires Volle Überzeugung (full conviction) and that Glaubhaftmachung (persuasive) is an inadequate standard for these cases. Remarkably, the study of Dutch case law relating to the loss of nationality shows the same. 


\section{Zusammenfassung}

Dieses Buch ist das Ergebnis einer rechtsvergleichenden Forschung uber das Verfahrens- und Beweisrecht bei der gerichtlichen Feststellung der niederllädischen, beziehungsweise der deutschen Staatsangehörigkeit. Die materiellen Regelungen der Erwerbs- und Verlustgründe der Staatsangehörigkeit dieser beiden Staaten werden lediglich insoweit dargestellt, als dies für die Erörterung der beweisrechtlich relevanten Gerichtsentscheidungen notwendig ist.

Bei der Besprechung des für die Staatsangehörigkeitsfeststellung anwendbaren Verfahrensrechts wird in dieser Studie zwischen einem "selbständigen Feststellungsverfahren" und einem "impliziten Feststellungsverfahren" unterschieden. Ein "selbständiges Feststellungsverfahren" ist ein Gerichtsverfahren, worin der Besitz der Staatsangehörigkeit die Hauptfrage ist. Von einem "impliziten Feststellungsverfahren" ist die Rede, wenn die Hauptfrage eine andere ist, aber die Staatsangehörigkeitsproblematik eine Vorfrage bildet.

Das niederländische Recht

Das niederländische Staatsangehörigkeitsgesetz (Rijkswet op het Nederlanderschap; nachher abzukürzen als: RWN) aus dem Jahre 1985 ist die erste niederländische Staatsangehörigkeitsregelung, worin Vorschriften aufgenommen sind, die sich auf die Feststellung der Staatsangehörigkeit beziehen. Die vorherigen Staatsangehörigkeitsgesetze (das Gesetz vom 28. Juli 1850, ebenso wie das Gesetz vom 12. Dezember 1892) kannten keine entsprechende Regelung.

Die gesetzliche Regelung der Staatsangehörigkeit ist aufgrund von Art. 3 des Statuts für das Königreich der Niederlande eine Angelegenheit des ganzen Königreiches und nicht nur des europäischen Teils der Niederlande. Deshalb ist die niederländische Staatsangehörigkeit nicht durch ein Gesetz (Wet) sondern durch ein Königreichsgesetz (Rijkswet) geregelt. Die Tatsache, daß die Staatsangehörigkeit eine Königreichsangelegenheit ist, hat für das Verfahren zur Feststellung der niederländischen Staatsangehörigkeit die praktische Folge, daß sowohl im europäischen Teil der Niederlande als in den Niederländischen Antillen oder Aruba ein Verfahren auf Feststellung der Staatsangehörigkeit anhängig gemacht werden kann. Personen, die in den Niederländischen Antillen und Aruba wohnhaft sind, müssen einen Antrag auf Feststellung der Staatsangehörigkeit beim Gemeinschaftlichen Gerichtshof der Niederländischen Antillen und Aruba (Gemeenschappelijk Hof van Justitie van de Nederlandse Antillen en Aruba) stellen, andere Personen beim Landgericht Den Haag (Arrondissementsrechtbank 's Gravenhage). In diesem Buch 
wird namentlich das Verfahren beim Landgericht Den Haag beschrieben. Nur vereinzelt werden Bemerkungen bezäglich der verfahrensrechtlichen Situation in den Niederländischen Antillen und Aruba gemacht, wenn diese von den Regelungen im europäischen Teil des Königreichs abweicht.

Das Verfahren zur Feststellung der niederländischen Staatsangehörigkeit ist im 6. Kapitel des Staatsangehörigkeitsgesetzes geregelt und zwar in den Artikeln 17-20, die am 1. Oktober 1986 in Kraft getreten sind. Das Zustandekommen dieser Regelung wird in Paragraph 1.2 dieses Buches beschrieben. Die Artikeln 17 und 18 RWN betreffen das "selbständige Feststellungsverfahren", während anschließend Art. 19 RWN feststellt, daß jedes mit der Ausführung einer gesetzlichen Regelung beauftragte Organ, an einen aufgrund Art. 17 ergangenen rechtskräftigen Beschlu $B$ gebunden ist. Art. $20 \mathrm{RWN}$ bezieht sich auf Verfahren, in denen die Frage beantwortet werden muß, ob jemand die niederländische Staatsangehörigkeit besitzt. Absatz 1 betont, daß, wenn während eines gerichtlichen Verfahrens die Frage beantwortet werden muß, ob jemand im Besitz der niederländischen Staatsangehörigkeit ist oder diese in einem früheren Zeitpunkt besessen hat, das Gericht den Justizminister um Stellungsnahme ersuchen kann. Absatz 2 schreibt vor, daß, wenn eine solche Frage bei einer verwaltungsrechtlichen Berufungsinstanz beantwortet werden muß, das Ersuchen um eine Stellungsnahme des Justizministers selbst zwingend erforderlich ist.

Im zweiten Kapitel werden ausführlich die verfahrensrechtlichen Aspekte der gerichtlichen Feststellung der niederländischen Staatsangehörigkeit vor dem Landgericht Den Haag behandelt. Obwohl Staatsangehörigkeitrecht als öffentliches Recht eingestuft werden muB, ist das Feststellungsverfahren in den Niederlanden ein zivilrechtliches Verfahren. Da es sich bei der Feststellung der Staatsangehörigkeit um die Feststellung einer Rechtsfolge handelt, die nicht dem ausschließlichen Parteiwillen unterliegt, gilt für das Gericht jedoch dennoch die Untersuchungsmaxime.

Das Gericht hat selbstverständlich zunächst die Zulässigkeit der Klage zu untersuchen. Die Zulässigkeit wird dadurch eingeschränkt, daß Art. 17 RWN bestimmt, daß das "selbständige Feststellungsverfahren" lediglich außerhalb eines bei einer gerichtlichen Instanz oder verwaltungsrechtlichen Berufungsinstanz in einem der Teile des Königreichs anhängigen Verfahrens eingeleitet werden kann. Ziel dieser Einschränkung der Zulässigkeit ist vorzubeugen, daß zwei unterschiedliche Gerichtsentscheidungen über den Besitz der niederländische Staatsangehörigkeit genommen werden.

Art. 17 RWN bestimmt weiter, daß die Feststellungsklage lediglich von einer Person eingeleitet werden kann, die ein unmittelbares Interesse daran hat, die 
Staatsangehörigkeit feststellen zu lassen. Der Oberste Gerichtshof der Niederlande (Hoge Raad) interpretierte in einer Entscheidung vom 4. März 1988 (Nederlandse Jurisprudentie 1989, Nr. 626) die Worte "unmittelbares Interesse" offensichtlich als "verfahrensrechtliches Interesse". Meiner Ansicht nach ist dies nicht richtig, sondern bezweckt diese Formulierung, daß eine Person grundsätzlich lediglich die Feststellung der eigenen Staatsangehörigkeit beantragen kann. Wăhrend des Lebens dieser Person können Dritte grundsätzlich nicht auf die Feststellung der Staatsangehörigkeit dieser Person klagen. Eine Ausnahme ist m.E. lediglich das Recht des Staates - unter bestimmten Voraussetzungen - Wiederaufnahme des Verfahrens zu fordern. Die Voraussetzung eines "unmittelbaren Interesses" gilt auch, wenn es sich um die Feststellung der Staatsangehörigkeit einer bereits verstorbenen Person handelt. In solchen Fällen ist die betreffende Voraussetzung m.E. erfullt, wenn der Antragsteller seine Staatsangehörigkeit von der verstorbenen Person direkt ableitet und die Staatsangehörigkeit des Antragstellers deshalb davon abhängt, ob der Verstorbene Niederländer war oder nicht.

Neben den beiden bereits erwähnten Zulässigkeitsvoraussetzungen gilt selbstverständlich auch die allgemeine verfahrensrechtliche Voraussetzung, daß der Antragsteller ein Rechtsschutzinteresse haben muß. Das heißt in diesem Zusammenhang, $\mathrm{da} B$ die Gerichtsentscheidung für den Antragsteller nötig ist, ein bestimmtes Ziel zu erreichen und daß der Antragsteller mit der Entscheidung dieses Ziel auch erreichen kann. Gefolgert wird weiter, daß das Interesse des Antragstellers nicht eine zukünftige, hypothetische Situation betreffen darf.

Art. 18 Absatz 1 RWN bestimmt, daß das Gericht zu einen Antrag auf Feststellung der niederländischen Staatsangehörigkeit eine Stellungsnahme der Staatsanwaltschaft anfordert. Absatz 2 schließt die Möglichkeit einer Berufung gegen die Gerichtsentscheidung aus. Jeder Beteiligte kann jedoch Kassationsbeschwerde einlegen. Weiter wird festgelegt, da $B$ für ein im europäischen Teil des Königreiches begonnenes Verfahren die Artikel 429d, 429f - 4291 und 429s - 429t der Zivilprozeßordnung anwendbar sind. Auf die bemerkenswerte Stellung der Staatsanwaltschaft im Verfahren zur Feststellung der Staatsangehörigkeit wird näher eingegangen. Der Gesetzgeber hat den Richter dazu verpflichtet, die Stellungsnahme der Staatsanwaltschaft einzuholen, damit diese die Ansicht des Staates bezüglich der Staatsangehörigkeit des Antragsteller erläutern kann. Bereits anderthalb Jahre nach dem Inkrafttreten des "selbständigen Feststellungsverfahrens" hat der Oberste Gerichtshof (Hoge Raad) jedoch entschieden, daß - anders als dem Gesetzgeber vor Augen stand - die Staatsanwaltschaft weder als Beteiligte noch als Vertreter des Königreichs betrachtet werden kann. Die Staatsanwaltschaft spielt bei der Stellungsnahme eine unabhängige Rolle, die z.B. mit der Rolle des Generalanwalts beim Europäischen Gerichtshof verglichen werden kann. Da für das Gericht die Untersuchungsmaxime gilt, kann auch die Staatsanwaltschaft Fakten untersuchen und sogar neue Fakten in 
das Verfahren einbringen. Falls die Staatsanwaltschaft in der Stellungsnahme neuen Fakten vorlegt, muß dem Antragsteller die Gelegenheit geboten werden, sich zu diesen neuen Fakten zu äußern. Obwohl das Gericht dazu verpflichtet ist, die Stellungsnahme der Staatsanwaltschaft einzuholen, ist diese nicht dazu verpflichtet, tatsächlich auch eine Stellungsnahme abzugeben. Öbrigens geht aus neueren Entscheidungen hervor, daß in relativ einfachen Fallen die Staatsanwaltschaft häufig keine schriftliche, sondern lediglich eine mündliche Stellungsnahme während der mündlichen Verhandlung abgibt.

Ausfuhrlich wird auf die Anwendung des Art. 429f Zivilprozeßordnung im Rahmen des Staatsangehörigkeitfeststellungsverfahrens eingegangen. Neben dem Antragsteller hat jedenfalls das Königreich der Niederlande ein Interesse bezüglich der Feststellung der niederländischen Staatsangehörigkeit und kann deshalb als Beteiligter im Verfahren angesehen werden. Aufgrund der Bestimmung des Art. 429f Zivilprozeßordnung hat das Landgericht Den Haag deshalb immer den niederlăndischen Staat als möglichen Beteiligten zur mündlichen Verhandlung zu laden. Heutzutage läßt der Staat sich in der Praxis immer während der mündlichen Verhandlung von einem Beamten des Justizministeriums vertreten. Außer dem niederländischen Staat sind bis jetzt noch nie andere mögliche Beteiligte geladen. Es wäre jedoch denkbar, einen anderen Staat, dessen Staatsangehörigkeit z.B. als Vorfrage problematisch ist, ebenfalls zu laden. Eine solche Ladung kann von Bedeutung sein, da in Abweichung von Art. 426 Zivilprozeßordnung eine Kassationsbeschwerde eines möglichen Beteiligten auch dann zulässig ist, wenn dieser in erster Instanz nicht in der mündlichen Verhandlung erschienen ist.

Wie oben bereits erwăhnt, bestimmt Art. 19 RWN, daß jedes mit der Ausführung einer gesetzlichen Regelung beauftragte Organ an einen aufgrund Art. 17 RWN ergangenen rechtskräftigen Beschluß gebunden ist. Dadurch hat eine Feststellung der Staatsangehörigkeit aufgrund des speziellen Feststellungsverfahrens eine größere Bedeutung als andere Gerichtsentscheidungen, in denen über den Besitz der niederländischen Staatsangehörigkeit entschieden wird. Selbstverständlich muß die Frage beantwortet werden, welche "Organe" nun genau an der Feststellungsentscheidung gebunden sind. Dazu gehören jedenfalls alle Verwaltungsorgane (bestuursorganen) im Sinne des Allgemeinen Verwaltungsrechtsgesetzes (Algemene Wet Bestuursrecht). Meiner Meinung nach muß der Begriff "Organ" jedoch in noch weiterem Sinne ausgelegt werden.

Obwohl das Gesetz daruber nichts bestimmt, gilt die betreffende Bindung der Feststellungsentscheidung lediglich bis etwas geschieht, wodurch die Staatsangehörigkeit geändert wird. Meiner Meinung nach sollte dies in Art. 19 RWN explizitiert werden. 
Desweiteren muß die Frage beantwortet werden, woran die in Art. 19 RWN genannten Organe genau gebunden sind. Die Antwort dazu lautet, daß diese Organe an den Tenor der Entscheidung gebunden sind. Was geschieht nun, wenn nach der Entscheidung über die Staatsangehörigkeit bis dahin unbekannte Fakten entdeckt werden, die dazu führen, daß abweichend von der bisherigen Entscheidung gefolgert werden $\mathrm{mu}$, daß die Staatsangehörigkeit erworben, beziehungsweise verloren wurde? Die zuvorgenommene Staatsangehörigkeitentscheidung stellt sich somit nachträglich als unrichtig heraus. Betont sei, daß durch die Staatsangehörigkeitentscheidung im "selbständigen Feststellungsverfahren" nicht die Staatsangehörigkeit verloren oder erworben wird. Die Entscheidung ist nicht konstitutiv, sondern stellt den Besitz oder Nicht-Besitz der Staatsangehörigkeit schlicht und einfach fest.

Eine - hinterher betrachtet - unrichtige Entscheidung verursacht für den fruheren Antragsteller keine allzu großen verfahrensrechtlichen Probleme. Für ihn besteht die Möglichkeit, um unter Hinweis auf neue, bis jetzt unbekannte Fakten eine neue Feststellungsklage beim Landgericht den Haag anhängig zu machen. Für das Königreich der Niederlande ist die Lage jedoch komplizierter. Jedes Organ ist ja an die ergangene Staatsangehörigkeitentscheidung gebunden. Aufgrund der geltenden Gesetzgebung kann ausschließlich gefolgert werden, daß diese Bindung sogar existiert, wenn die ergangene Entscheidung objektiv falsch war. Insoweit liegt m.E. eine Gesetzeslücke vor.

Inzwischen hat das Landgericht Den Haag zu dieser Problematik geurteilt, daß der frühere Antragsteller u.U. Wiederaufnahme des Verfahrens beantragen kann. Es ist m.E. in Anbetracht der eben erwähnten Gesetzeslücke notwendig darum zu folgern, daß auch das Königreich der Niederlande u.U. die Wiederaufnahme des Verfahrens fordern kann. Falls in der früher ergangenen Entscheidung zu Unrecht beschlossen wurde, daß der Antragsteller die niederländische Staatsangehörigkeit nicht besitzt, hat der Staat weiter selbstverständlich die Möglichkeit diese unrichtige Folgerung durch eine Einbürgerung zu korrigieren. Es ist aber offensichtlich, daß die ganze Problematik der Wiederaufnahme vorzugsweise gesetzlich geregelt werden sollte.

Die beweisrechtlichen Aspekte des niederländischen Staatsangehörigkeitsrechts werden in Kapitel 3 besprochen. Anhand zweiundvierzig Entscheidungen aus den vergangen fünfzig Jahren wird versucht, die im Staatsangehörigkeitsrecht geltenden Beweisregeln zu beschreiben. Die behandelten Entscheidungen sind deshalb bei weitem nicht alle auf der Grundlage des Art. 17 RWN im Rahmen eines "selbständigen Feststellungsverfahrens" ergangen. Viele Entscheidungen beruhen auf der inzwischen im Jahre 1986 außer Kraft getretenen Klagemöglichkeit des Art. 43 Ausländergesetz (Vreemdelingenwet): Wenn jemand von einer Behörde auf irgendeine Weise als Ausländer behandelt wurde, konnte er beim Obersten Gerichts- 
hof (Hoge Raad) eine Klage einreichen, festzustellen, daß er zu Unrecht als Ausländer behandelt worden war.

Die untersuchten Entscheidungen sind in zwei Kategorien aufgeteilt. Die erste Kategorie betrifft Entscheidungen in Fallen, wo der Antragsteller der Ansicht war, die niederländische Staatsangehörigkeit erworben zu haben. Die zweite Kategorie bezieht sich auf Entscheidungen in Fallen, wo der Antragsteller den Verlust der niederländischen Staatsangehörigkeit bestreitet. Die folgenden Fragen werden behandelt: 1) die Beweislastverteilung bezüglich den Erwerb und Verlust der niederländischen Staatsangehörigkeit; 2) die Beweislast hinsichtlich des Besitzes einer fremden Staatsangehörigkeit; 3) welches $\mathrm{MaB}$ an Beweis wird gefordert und 4) welche Beweismittel zulässig sind.

Was die Beweislastverteilung im Falle eines behaupteten Erwerbs der niederländi-

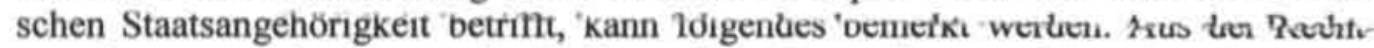
sprechung vor Inkrafttreten des "selbständigen Feststellungsverfahrens" geht hervor, $\mathrm{da} B$ das Beweisrisiko für einen Erwerbsgrund in Prinzip bei der betreffenden Person (Antragsteller) liegt. Eine Ausnahme wird jedoch insoweit gemacht, wenn die niederländischen Behörden die den Erwerb bestreiten, ihren Standpunkt nicht anhand von Beweismaterial schlüssig unterbauen können. Es besteht dann eine Situation, wo weder der Antragsteller noch die niederländischen Behörden, den eigenen Standpunkt völlig beweisen können. Die Frage, ob der Standpunkt der Behörden mit ausreichendem Beweismaterial unterbaut werden kann, hat sich auch in den Fällen als wichtig erwiesen, in denen der Antragsteller den von den Behörden behaupteten Verlust der Staatsangehörigkeit bestreitet. Falls die Behörden ihre Behauptung nicht aufgrund ausreichendem Beweismaterials beweisen können, wird vermutet, daß der Antragsteller noch immer Niederländer ist. Der Antragsteller braucht nicht glaubhaft zu machen, oder gar zu beweisen, daß er die Staatsangehörigkeit nicht verloren hat. Von ihm angebotene Beweise können zunächst außer Betracht bleiben, solange die Behörden nicht auf schlüssige Art und anhand von Beweisen glaubhaft gemacht haben, daß die Staatsangehörigkeit verloren wurde. Diese grundlegende beweisrechtlichen Prinzipien werden nach Inkrafttreten des "selbståndigen Feststellungsverfahrens" vom Landgericht Den Haag unzureichend beachtet. Insoweit hat sich die beweisrechtliche Stellung des Antragstellers im Vergleich zu der bisherigen Situation verschlechtert.

Was das $\mathrm{MaB}$ an Beweis betrifft, wird für die Zeit vor Inkraftreten des "selbständigen Feststellungsverfahrens" gefolgert, daß der Standpunkt der Behörden anhand des Maßstabes "blijken" überprüft wird (der vollen Überzeugung sein), während die Beurteilung der Standpunkte des Antragstellers anhand des Maßstabes "aannemelijk" (glaubhaft) geschieht. In der Rechtsprechung auf Grund des "selbständigen Feststellungsverfahrens" wird bei der Beurteilung der Standpunkte des 
Antragstellers, wenn es sich um einen behaupteten Erwerb der niederländischen Staatsangehörigkeit handelt, als Maßstab "blijken" (offensichtlich sein) benutzt. Soweit es sich um Fälle handelt, in denen der Antragsteller den von den niederländischen Behörden behaupteten Verlust bestreitet, läßt sich keine eindeutige Folgerung ziehen. In einigen Entscheidungen benutzt das Gericht den gleichen Maßstab als in der Vergangenheit (glaubhaft machen), während in anderen Fällen ein strengerer Maßstab (offensichtlich sein) benutzt wird, oder aus der Entscheidung nicht klar wird, welcher Maßstab genau angelegt wurde.

Aus den studierten Entscheidungen geht deutlich hervor, daß die Beweislast für den Besitz einer fremden Staatsangehörigkeit oder der Staatenlosigkeit bei den niederländischen Behörden liegt. Auch kann gefolgert werden, daß der Besitz der niederlăndischen Staatsangehörigkeit mit allen Beweismitteln bewiesen werden kann.

\section{Das deutsche Recht}

Das deutsche Staatsangehörigkeitsrecht ist in mehreren Gesetzen geregelt. Der Kern des Staatsangehörigkeit bildet das Reichs- und Staatsangehörigkeitsgesetz aus dem Jahre 1913. Aber weder in diesem Reichs- und Staatsangehörigkeitsgesetz noch in anderen Gesetzen findet man die Regelung eines Spezialverfahrens der gerichtlichen Feststellung der deutschen Staatsangehörigkeit.

Die gerichtliche Festestellung der deutschen Staatsangehörigkeit geschieht infolgedessen im Rahmen vieler unterschiedlicher Verfahren, wenn die Gerichte in einem bestimmten Rahmen z.B. im Steuerrecht, Sozialrecht, Verfassungsrecht, Strafrecht, Zivilrecht oder im Verwaltungsrecht die Frage beantworten müssen, ob jemand die deutsche Staatsangehörigkeit besitzt. Über Verfahren im Rahmen des Zivilrechts, Straf- und Auslieferungsrechts, sowie des Verfassungsrechts werden im 3. Kapitel kurz einige Bemerkungen gemacht. Ausführlicher wird auf Verfahren im Verwaltungsrecht eingegangen. Der Besitz der deutschen Staatsangehörigkeit ist vor allem im deutschen Verwaltungsrecht von Bedeutung. Verwaltungsverfahren, in denen die Feststellung der deutschen Staatsangehörigkeit stattfindet, sind Verfahren aufgrund der Verwaltungsgerichtsordnung (hiernach auch abzukürzen als: VwGO). Anders als im niederländischen Recht, wo im Verwaltungsrecht traditionell viele unterschiedliche Verfahren existieren, kennt das deutsche Recht eine einheitliche Verwaltungsgerichtsordnung, worin das Verfahrensrecht beim Verwaltungsrichter geregelt wird. Für das behördliche Vorverfahren gilt ein anderes Gesetz, das Verwaltungsverfahrensgesetz (VwVfG). 
Innerhalb des Verwaltungsrechts sind zwei Verfahren näher ausgearbeitet: die Verpflichtungsklage aufgrund des $\S 42$ VwGO und die Feststellungsklage aufgrund des $\S 43$ VwGO. Mit einer Verpflichtungsklage bezweckt der Kläger eine Gerichtsentscheidung $\mathrm{zu}$ bewirken, worin die Verwaltung zu einer bestimmten Handlung verpflichtet wird. In Staatsangehörigkeitsangelegenheiten geht es dann in der Regel um die Verpflichtung, dem Kläger ein bestimmtes Dokument auszustellen, auf das dieser aufgrund seiner deutschen Staatsangehörigkeit einen Rechtsanspruch hat: z.B. einen $\mathrm{Pa}$ oder einen Staatsangehörigkeitsausweis. Die Feststellungsklage bezweckt dagegen ein Urteil, in dem das Existieren eines öffentlich-rechtlichen Rechtsverhalltnisses festgestellt wird. Deshalb steht dann im Tenor des Urteils, ob der Antragsteller in Besitz der deutschen Staatsangehörigkeit ist. Aus einem Vergleich mit dem niederlăndischen Recht geht hervor, daß eine Klage zur Feststellung der deutschen Staatsangehörigkeit aufgrund des $\S 43$ VwGO viele Ähnlichkeiten aufweist mit dem Verfahren des Art. 17 RWN. Insoweit kann das betreffende Verfahren ebenfalls als "selbständiges Feststellungsverfahren" bezeichnet werden.

Die beweisrechtlichen Aspekte des deutschen Staatsangehörigkeitsrechts werden in Kapitel 6 behandelt. Dabei wird zunächst auf die beweisrechtlichen Bestimmungen des Verwaltungsrechts eingegangen. Auch werden einige beweisrechtlichen Begriffe und interessante theoretischen Betrachtungen über diese Begriffe erörtert. Infolge des $\S 86$ VwGO gilt im Verwaltungsrecht für den Verwaltungsrichter die Untersuchungsmaxime. Auch in der Beweiswürdigung ist der Verwaltungsrichter frei. Im Verwaltungprozeß sind alle Beweismittel zulässig.

Als Folge der Untersuchungsmaxime ist es die Aufgabe des Richters, die Tatsachen festzustellen. Wenn für eine Tatsache Beweise vorhanden sind, ist die Beweiswürdigung Sache des Richters, der infolge des $\S 108$ VwGO nach eigener Überzeugung entscheidet. Der Richter entscheidet dann aufgrund des vorhandenen Beweismaterials und der Öberzeugungskraft dieser Materialien. Anders liegt die Sache, wenn festgestellt wird, daß für eine bestimmte Tatsache keine Beweise vorhanden sind. In der Literatur wird diese Situation häufig als non-liquet Situation bezeichnet. Durch Anwendung von Beweislastnormen muß das Gericht dann zu einer Entscheidung kommen.

Aufgrund der Art und Weise wie Entscheidungen in Zeitschriften veröffentlicht werden, ist häufig nicht festzustellen, ob die festgestellten Tatsachen von einer der Parteien vorgebracht worden sind oder durch das Gericht durch Anwendung der Untersuchungsmaxime selbst festgestellt wurden. Aus den untersuchten Entscheidungen geht jedenfalls keine non-liquet Situation hervor.

Bezüglich den in den betreffenden Entscheidungen geforderte Beweismaß kann festgestellt werden, daß in zwei Fällen in denen der Kläger behauptet hat, die 
deutsche Staatsangehörigkeit erworben zu haben, der Maßstab Glaubhaftmachung angewandt wurde. In Fällen wo der Kläger bestritt, die deutsche Staatsangehörigkeit verloren zu haben, wurde angenommen, daß der Verlust festgestellt werden mußte. Dies bedeutet, da $B$ lediglich gefolgert wird, daß die deutsche Staatsangehörigkeit verloren wurde, wenn das Gericht über das Vorhandensein eines bestimmten Verlustgrundes die volle Überzeugung (vgl. in den Niederlanden: "blijken") hat, und daß Glaubhaftmachung (vgl. in den Niederlanden: "aannemelijk maken") nicht ausreicht. Dies ist besonders bemerkenswert, da die Lősungen des deutschen und niederländischen Rechts in diesem Punkt übereinstimmen. 



\section{Literatuurlijst m.b.t. het Nederlandse recht}

\section{Achterberg, C.E.,}

Nederlanders, vreemdelingen en ingezetenen. 1895.

Ahmad Ali, H.,

Gedoogbeleid en staatloosheid bij Surinamers. MR 1987, p. 203-206.

Ahmad Ali, H.,

Nederlanderschap en het recht op toelating tot Nederland. MR 1992, p. 71-75.

Ahmad Ali/Klip, H.A. Ahmad Ali/A.H. Klip,

Nederlanderschap en strafrecht. MR 1995, p. 80-84.

Aller/Van Rijn, H.B. van Aller/A.B. van Rijn,

Jurisprudentie Publiekrecht Nederlandse Antillen en Aruba (1951-1991), ed. 1991.

Universiteit van de Nederlandse Antillen, Universiteit van Aruba.

Anoniem (I),

De nationaliteit van Westerling. HPS 1952, p. 133-135.

Anoniem (II),

Nationaliteit en woonrecht. HPS 1951, p. 4-7.

Anoniem (III),

Hoe bewijzen "Indische Nederlanders" hun Nederlanderschap? HPS 1950. p. 31-32. Anoniem (IV),

Nederlanderschap door wettige afstamming uit de moeder. De Gemeentestem 1948, nr. 4969 , p. 135.

Anoniem (V),

Nederlanderschap door bezit van staat. De Gemeentestem 1950, nr. 5087, p. 160 . Anoniem (VI),

Bewijs der nationaliteit van Indische Nederlanders. De Gemeentestem 1950, nr. 5090, p. 174.

Apeldoorn/Leyten, van, L.J. van Apeldoorn/J.C.M. Leyten,

Inleiding tot de studie van het Nederlandse recht. 1972.

Asser (I), W.D.H.,

Grenzen aan de waarheidsvinding in burgerlijke zaken. Uitgave van de Nederlandse vereniging voor procesrecht. 1991.

Asser (II), W.D.H.,

Bewijslastverdeling. Monografieën Nieuw BW deel A24. 1992. Asser/Anema/Verdam,

C. Asser's Handleiding tot de beoefening van het Nederlands Burgerlijk Recht. vijfde deel: van Bewijs. Bewerkt door A. Anema/P.J. Verdam. 1953. Asser/Hartkamp II,

C. Asser's Handleiding tot de beoefening van het Nederlands Burgerlijk Recht. Verbintenissenrecht, deel II. Bewerkt door A.S. Hartkamp. 1993. Asser/De Ruiter.

C. Asser's Handleiding tot de beoefening van het Nederlands Burgerlijk Recht. Personen en Familierecht, deel I. Bewerkt door J. de Ruiter en J.K. Moltmaker. 1992. 
Baars, van, J.,

Point d'intérêt, point d'action. prft. V.U. Amsterdam 1971.

Bedem, van den, R.F.A.,

Motieven voor naturalisatie. Rapport in de reeks Onderzoek en Beleid van het WODC, nr. 125. 1993.

Berge, ten, J.B.J.M.,

Bescherming tegen de overheid. 1993.

Berge/Tak, ten, J.B.J.M. ten Berge/A.Q.C. Tak,

Hoofdlijnen van het Nederlands administratief procesrecht. Studiepockets staats- en bestuursrecht nr. 10, 1990.

Beukers, Y.E.M.,

Eenmaal andermaal? Beschouwingen over gezag van gewijsde en ne bis in idem in het burgerlijk procesrecht. prft. Rotterdam 1994.

Blink, van den, A.C.,

De procedure tot vaststelling van het Nederlanderschap. Studiekring 'Prof. mr. J. Offerhaus', reeks Int. Privaatrecht, nr. 18. 1989.

Bockwinkel, A.,

Spaanse krijgsdienst en het gezin van de Nederlandse combattant. NJB 1938, p. 193198.

Boekman, S.,

Dient de wet algemene regelen te bevatten omtrent de gevallen waarin de civiele requestprocedure moet worden gevolgd, en zo ja, welke? Preadvies bij de Handelingen der Nederlandse Juristen-Vereniging. 1961 p. 95-153.

Boekman (II), S.,

Het procesrecht van de rekestprocedure als gevormd door de Hoge Raad. Bijdrage in "Een goede procesorde". p. 35-45. Bundel opstellen aangeboden aan mr. W.L. Haardt. 1983.

Boelens, G.J.,

Vreemde Krijgsdienst. RMTh 1950, p. 276-299.

Boeles, P., Vreemdelingenrecht en Nederlanderschap. 1984.

Boersma, W.M.H.,

Nederlander of niet. Tijdschrift voor de Politie 1939, p. 43-46. Bolt, H.,

Bewijs. Losbladige uitgave bestuursprocesrecht; onder redactie van Van Buuren/Koeman/Polak/Scheltema. Bijgewerkt tot en met supplement 4 (mei 1995).

Bolten, J.J.,

Rechtspraakoverzicht nationaliteitsrecht 1987-1988, MR 1988, p. 230-233. Boon/Van der Wal, G.J. Boon/F.S.P. van der Wal,

De rol (van de) rechter. Studiereeks procesrecht, 1990.

Borman, J.A.,

Procesrecht in Arobzaken. Studiepockets staats- en bestuursrecht nr. 3. 1985.

Bosch-Boesjes, J.E., Lijdelijkheid in het geding. prft. Groningen 1991.

Brenninkmeijer, A.F.M.,

Burgerlijk procesrecht als Publiekrecht. oratie U. v. Amsterdam 1993. 
Brinkman, C.J.,

Het Nederlandse nationaliteitsrecht in de praktijk. 1985. Brouwer, J.,

De nationaliteit van de gehuwde vrouw in Belgie̊ en in Nederland. prft. Leiden 1955. Bruinsma, J.F.,

Cassatierechtspraak in civiele zaken. prft. Utrecht 1988.

Bijloos/Lindner, A.W.M. Bijloos/Th.J.M. Lindner,

De Algemene wet bestuursrecht. 1993.

Caris, Th.M.J.,

Vergelijkende analyse processen rechtspraaktypen. Ongepubliceerd manuscript, aanwezig in de bibliotheek van het ministerie van Justitie. 1991.

Cleintuar, G.,

Hoe vreemd mijn Holland was. Bijdrage in "Het onbekende vaderland", p. 24-33. red. W. Willems/L. Lucassen. 1994.

Cleveringa, R.P.,

Het belang der vordering. RMTh 1964, p. 219-277.

Cliteur, P.B.,

Inleiding in het recht. 1992.

Cohen Henriquez, E.,

I.P.R. Trends. 1980.

Coops, J.A.M.,

Coops' Grondtrekken van het Nederlands Burgerlijk Procesrecht. Bewerkt door Zonderland/Schlingemann/Dolman. 1980.

Corstens/Tak, G.J.M. Corstens/P.J.P. Tak,

Het Openbaar Ministerie. Studiepockets strafrecht, nr. 10. 1982.

Dijk, van, P.,

Toetsing van overheidshandelen door de nationale en internationale rechter en het vereiste van een procesbelang. prft. Leiden 1976.

Dijksterhuis-Wieten, H.L.G.,

Bewijsrecht in civiele procedures. 1992.

Dijksterhuis-Wieten (II), H.L.G.,

Waar of niet? Inleiding tot het bewijsrecht in civiele zaken. 1983.

Dorst, van, A.J.A.,

Nederlanderschap en strafrecht. NJB 1977, p. 857-863.

Dullemen, van, A.A.L.F.,

Positie en Taak van het Openbaar Ministerie in Nederland. Preadvies voor de Vereniging voor de vergelijkende studie van het recht van Belgiě en Nederland, jaarboek 1958-1959.

Duijvendijk-Brand/Wortmann, van, J. van Duijvendijk-Brand/S.F.M. Wortmann, Compendium van het personen- en familierecht. 1991.

Duisterwinkel, G.,

Enige facetten van de taak van het openbaar ministerie naar Nederlands recht. Inaugurele rede Leiden 1965. 
Duynstee, F.J.F.M., Vreemdelingenrecht. Preadvies voor de Nederlandse Vereniging voor Internationaal Recht, 1956.

Duynstee, J.E.F.F.M.,

Civiele bespiegelingen naar aanleiding van de zaak Capuano. Trema 1990 , p. 203205.

Elders, J.L.M., Waardering van bewijs. Afscheidsrede Maastricht 1990.

Enschedé, Ch.J., Beginselen van strafrecht. Bewerkt door C.F. Rüter en S.A.M. Stolwijk. 1990.

Franken e.a., H., InLeiden tot de rechtswetenschap. 1993.

Franx, J.K.,

De Hoge Raad: voorgaan, doorgaan of omgaan. Studiekring 'Prof. mr. J. Offerhaus', nieuwe reeks nr. 1. 1994.

Funke, A.P.,

Dient de wet algemene regelen te bevatten omtrent de gevallen waarin de civiele requestprocedure moet worden gevolgd, en zo ja, welke? Preadvies bij de Handelingen der Nederlandse Juristen-Vereniging. 1961 p. 155-233.

Gerver, P.H.M.,

De toepassing van materieel vreemd recht in Nederland. In: De toepasselijkheid van materieel vreemd recht in de Nederlandse rechtssfeer. Preadvies voor de Koninklijke Notariële Broederschap. 1980.

Geuljans, R.M.A.A.,

De rechtspositie van den vreemdeling in Nederland. prft. Nijmegen 1938. Geuzinge, J.E.,

De erkenning in het internationaal privaatrecht: Personeelstatuut of Domiciliebeginsel? HPS 1983, p. 89-92.

Goede, de, B.,

Beeld van het Nederlandse bestuursrecht. 1979.

Gras, E.,

Kracht en gezag van gewijsde. De rechtskracht van einduitspraken van de burgerlijke rechter. prft. U. v. Amsterdam 1994.

Groot, de, G.R.,

Staatsangehörigkeitsrecht im Wandel. prft. Maastricht 1989.

Groot, de, G.R.,

Inleiding nationaliteitsrecht. Losbladige uitgave Personen- en Familierecht; onder redactie van C.J. van Zeben. Bijgewerkt tot en met supplement 115 (juni 1995). Groot, de, G.R.,

Er komt een nieuwe Wet op het Nederlanderschap. NJB 1981, p. 1117-1126. Groot, de, G.R.,

Nationaliteitsrechtelijke actualiteiten. Tijdschrift voor Antilliaans recht Justicia 1993, p. 194-218. 
Groot, de, G.R.,

Weer verder op weg naar een vernieuwd Nederlands nationaliteitsrecht. MR 1994, p. 209-216.

Groot (II), de, G.R.,

De toekomst van het Nederlanderschap. Bijdrage in Toekomstperspectieven van het Nederlandse vreemdelingenrecht. Publicaties van de Staatsrechtkring, nr. 9, p. 25-71. 1994.

Groot, de, G.R.,

Een gediscrimineerde vrouw? MR 1995, p. 127-133.

De Groot/Tratnik, G.R. de Groot/M. Tratnik,

Nationaliteitsrecht. Studiepockets privaatrecht nr. 14. 1986.

Haak, W.E.,

Interregionaal privaatrecht. Studiekring 'Prof. mr. J. Offerhaus', nieuwe reeks nr. 2. 1994.

Haak, van den, H.F.,

Rechtspleging in beweging. Trema 1995, p. 214-219. Haan, F.M.E.,

De jurisdictie van den Nederlandschen rechter in privaatrechtelijke aangelegenhede. prft. Nijmegen 1930.

Haandrikman, A.G.J.J.,

De nationaliteit in het internationaal privaatrecht. Preadvies voor de Nederlandse Vereniging voor internationaal recht, nr. 83, p. 45-65. 1981.

Haardt, W.L.,

Kentering in de opvatingen over de hoofdbeginselen van ons burgerlijk procesrecht tussen 1870 en 1970. Bundel "Honderd jaar rechtsleven", red. Schoordijk e.a., p. 137$151,1970$.

Haarmans, P.D.,

De toescheidingsovereenkomst in de praktijk. 1988.

Haas-Engel, de, R.H.,

Het Indonesisch nationaliteitsrecht. prft. Maastricht 1993.

Hammerstein, A.,

Scheidingsprocesrecht anno '93. NJB 1993, p. 10-13.

Hardenberg, L.,

De conclusie van het O.M. in burgerlijke zaken. NJB 1961, p. 290-296.

Hartog Jager, den, W.H.B.,

Cassatie in het belang der wet. prft. V.U. Amsterdam 1994. Haven, van der, C.A.,

Nationaliteitsuitwijzing. TvO 1961, p. 116 en 117. Hebly, J.M.,

Rogatoire commissie: 345 of 429a-r Rv? WPNR 1991, nr. 6028, p. 837-839. Heemskerk, W.H.,

Vorderingsrecht en rechtsvordering. oratie V.U. Amsterdam 1974. Heemskerk (II), W.H.,

Nietigheid in het burgerlijk procesrecht. RMTh 1971, p. 307-341. 
Heijs, E.,

De Nederlandse nationaliteit van Indische Nederlanders. Een historische terugblik. Bijdrage in "Het onbekende vaderland", p. 58-66. red. W. Willems/L. Lucassen. 1994.

Heijs (II), E.,

Van vreemdeling tot Nederlander. prft. Nijmegen 1995.

Helder, E.,

De rechtsstaat. Hoofdstuk 7 (p. 137-158) uit Nederlandse staatkunde, een elementaire

inleiding. red. J.W. van Deth/P.A. Schuszler. 1995.

Hirsch Ballin, E.D.,

Het declaratoir vonnis in het auteursrecht. WPNR 1951, nr. 4201, p. 344-346. Hoeven, van der, J.,

Staats- en administratief recht. Hoofdstuk II, Nederlands recht in kort bestek. Onder redaktie van A. Komen. 1977.

Huart, F.J.A.,

Geschillen over Nederlanderschap en Nederlandsch onderdaanschap. NJB 1932, p. 404-406.

Hugenholtz/Heemskerk, W. Hugenholtz/W.H. Heemskerk,

Hoofdlijnen van Nederlands burgerlijk procesrecht. 1991. Jagt, B.B.,

Nederlands nationaliteitsbesef. prft. Leiden 1995. Jessurun d'Oliveira, H.U.,

De antikiesregel. Een paar aspecten van de behandeling van buitenlands recht in het burgerlijk proces. prft. U. v. Amsterdam 1971.

Jessurun d'Oliveira, H.U.,

Nederlanders, wie zijn dat? NJB 1977, p. 589-598.

Jessurun d'Oliveira, H.U.,

Vermolming van het nationaliteitsbeginsel. HPS 1980, p. 2-6 en 18-23. Jessurun d'Oliveira, H.U.,

De herziening van ons nationaliteitsrecht. NJB 1982, p. 245-256.

Jessurun d'Oliveira, H.U.,

Burgers en buitenlui. NJB 1983, p. 1301-1310.

Jessurun d'Oliveira, H.U.,

Diskriminatie en nationaliteitsrecht. AA 1985, p. 209-214.

Jessurun d'Oliveira, H.U.,

De nationaliteit van Richardson. AA 1986, p. 224-229.

Jessurun d'Oliveira, H.U.,

Voetbal en nationaliteit. NJB 1990, p. 1023-1029.

Jessurun d'Oliveira (I), H.U.,

Behandelingsnederlanderschap en internationaal privaatrecht. Bijdrage in de bundel

"Gelijk geregeld." p. 134-155. Ars Aequi Libri. 1984.

Joekes, A.M.,

Schets van de bevoegdheden der Nederlandsche consuls. prft. Leiden 1911. 
Kan, M.L.,

Bewijslast en Bewijswaardering. prft. U. v. Amsterdam 1921.

Kate, ten, Th.B.,

Het request-civiel. prft. Leiden 1962.

Kate (II), ten, Th.B.,

De civiele sectie van het Parket. Bijdrage in "De Hoge Raad der Nederlanden 18381988: een portret." p. 211-215. red. J. van Soest. 1988.

Koens, M.J.C.,

Nationaliteit en Nederlanderschap. Pitlo-serie, deel I; Hoofdstuk 1: Personen- en Familierecht. 1993.

Kollewijn, R.D.,

Tien jaren Nederlandse rechtspraak internationaal privaatrecht (1954-1963). 1966 Koopmans, T.,

Compendium van het staatsrecht. Bewerkt door Th.L. Bellekom/A.W. Heringa/T. Koopmans/R.E. de Winter. 1992.

Koopmans, F.A.J.

Het beslissingsmodel van $348 / 350$ Sv. 1993

Koppen/Ten Kate, van, P.J. van Koppen/J. ten Kate,

Tot raadsheer benoemd. 1987.

Korteweg-Wiers e.a., M.J.S. Korteweg-Wiers/G.L. van der Kraan/P.M.B. Schrijvers/J.P.A.F. Vriens,

Hoofdlijnen van het ambtenarenrecht. 1992.

Korthals Altes, E.,

Absolute nietigheid van rechterlijke beslissingen. Bijdrage in de bundel "Quid iuris", p. 151-166. 1977.

Kortmann, C.A.J.M.,

De Grondwetsherzieningen 1983 en 1987. 1987.

Kortmann (I), C.A.J.M.,

Constitutioneel recht. 1994.

Ko Swan Sik,

Nationaliteit en het Volkenrecht. Preadvies voor de Nederlandse Vereniging voor internationaal recht, nr. 83, p. 3-42. 1981.

Kramers, J.H.,

Strafrechtspraak over Nederlanders in Turkije. prft. Leiden 1915.

Krieken, van, P.,

The high commissioner for refugees and stateless persons. NILR 1979, p. 24-36.

Langbroek/Spelt, P.M. Langbroek/N.M. Spelt,

Bestuursprocesrecht in vogelvlucht. 1993.

Lange, de, A.,

De dictatuur van de magistratuur. NJB 1995, p. 441-447.

Lange, de, R.,

Paradoxen van Europees burgerschap. Recht en kritiek 1995, p. 278-297.

Leclerq, W.E.M.

Inleiding tot het procesrecht. 1993. 
Lemaire, W.L.G.,

Nederlands internationaal privaatrecht. 1968.

Leijten, J.C.M.,

Afsluiting van het symposium. Bijdrage in de congresbundel Rechtsmiddelen van de toekomst, p. 155-162, red. H.E. de Boer, W.H. van Boom en J. de Hullu. 1994.

Loeb, R.W.L.,

Inleiding vreemdelingenrecht. Serie Staats- en bestuursrecht, Ars Aequi Libri, 1983 en 1987.

Losbl. uitg. BRv.

Losbladige uitgave Burgerlijke Rechtsvordering. W.D.H. Asser e.a.. Bijgewerkt tot en met supplement 236 (mei 1995).

Lucas, P.,

Het burgerlijke proces in eersten aanleg. prft. Groningen 1939.

Mannoury, J.,

Het Nederlandse nationaliteitsrecht. prft. U.v. Amsterdam 1947. Martens, S.K.,

De Hoge Raad als adviseur. Bijdrage in "De Hoge Raad der Nederlanden 1838-1988: een portret." p. 141-175. red. J. van Soest.

Meijers, E.M.,

Ontwerp voor een Nieuw Burgerlijk Wetboek, met toelichting. 1954.

Meijers, L.C.M.,

Het einde van de onpartijdigheid; van openbaar ministerie tot departementale vervolgingsdienst. RM Themis 1991, p. 170-174.

Meijknecht, P.A.M.,

Heeft de verzoekschriftprocedure (de) toekomst? Oratie Utrecht 1987.

Meijknecht, P.A.M.,

Kennismaking met het burgerlijk procesrecht. 1988.

Meijknecht, P.A.M.,

Rechtsmiddelen en het Voorontwerp aanpassing Rv. Trema 1994, p. 210-214.

Minkenhof/Reijntjes, A. Minkenhof/J.M. Reijntjes,

De Nederlandse strafvordering. 1990.

Mok/Tjittes, M.R. Mok/R.P.J.L. Tjites,

Formele rechtskracht en overheidsaansprakelijkheid. RMTh 1995, p. 383-404. Monte, E.,

Antilliaans procesrecht. prft. Leiden 1955.

Mosterd, P.,

Vereisen de functies van het Openbaar Ministerie nieuwe wettelijke voorzieningen?

Preadvies voor de Nederlandse juristen-vereniging 1968.

Mulder, A.C.J.,

Inleiding tot het Nederlands Internationaal Privaatrecht. 1947.

Nat-Verhage, van der, W.J., Handleiding nieuw bewijsrecht. 1988.

Niessen, R.E.C.M.,

Cassatie in belastingzaken. 1992. 
Niessen-Cobben, R.M.P.G.,

Behoorlijk fiscaal procesrecht. prft. U.v. Amsterdam 1995.

Nijnatten, van, G.C.J.,

Verlies van de Nederlandse nationaliteit. NJB 1947. p. 181-190.

Offerhaus, J.,

Nederlandsch internationaal bewijsrecht. prft. U.v. Amsterdam 1918.

Parser, G.,

Het declaratoir vonnis. prft. U.v. Amsterdam 1903.

Pels Rijcken, L.D.,

Twee studies rondom art. 48 Rv. RMTh 1987, p. 76-81, 180-189.

Pieterman, R.,

De plaats van de rechter in Nederland 1813-1920. prft. Utrecht 1990.

Pitlo/Hidma \& Rutgers, T.R. Hidma/G.R. Rutgers,

Bewijs: de regeling van het bewijsrecht in civiele zaken. Pitlo, het Nederlands burgerlijk recht. Deel 7. 1995.

Plasschaert e.a., J.N.E. Plasschaert/Y. Melchers/W.M.B. Stoker,

Burgerzaken en de Algemene wet bestuursrecht. 1994.

Polenaar, J.H.,

Schets van het Nederlandsche burgerlijk procesrecht. 1937.

Princen, J.G.,

Fair Trial. Serie rechtsvinding deel 9. 1990.

Prins (I), W.F.,

Gezag van administratieve beslissingen omtrent de staat van personen. HPS 1962, p. 37-47.

Prins (II), W.F.,

Op de grenzen van het Nederlanderschap. Uit de bundel "Burger en Overheid", onder red. v. M.C.B. Burkens en R. Crince Le Roy, p. 182-199. 1984.

Proeve van een ontwerp van een nieuwe nationaliteitswet. Hartman's tijdschrift ter beoefening van het administratief recht. 1947, afl. 2, p. 82-95.

Raedt van Oldenbarnevelt, H.J.A.,

De wet tot uitvoering van art. 7 der Grondwet, in hare betrekking tot het burgerlijk regt en het staatsregt. prft. Leiden 1851.

Ras, H.E.,

De grenzen van de rechtsstrijd in hoger beroep in burgerlijke zaken. 1992.

Recht en regels.

Congresbundel, Jonge Balie Congres 1976.

Reuser (I), J.W.M.,

Bevoegdheden van de Nederlandse overheid ten aanzien van persoon en goed van vreemdelingen, in het bijzonder ingezetenene. Preadvies. Annalen van het Thijmgenootschap, 1950, vol. 1. p. 74-90.

Reuser (II), J.W.M.,

De Hoge Raad als appèlrechter in nationaliteitszaken. Weekblad voor de Nederlandse bond van gemeente-ambtenaren 1953, nr. 2524, p. 451-453. 
Riezebos, C.,

Recht van petitie. prft. Rotterdam 1992.

Röder, J.G.L.,

De grondtrekken van het procesrecht der vrijwillige rechtspraak. prft. Leiden 1939. Rooij/Polak, R. van Rooij/M.V. Polak,

Private international law in the Netherlands. 1987.

Rossem/Cleveringa, van,

Mr. W. van Rossem's Verklaring van het Nederlands Wetboek van burgerlijke rechtsvordering, door R.P. Cleveringa. 1972.

Royer, S.,

De Hoge Raad als feitenrechter. Bijdrage in "De Hoge Raad der Nederlanden 18381988: een portret." p. 127-139. red. J. van Soest. 1988.

Rutgers, G.R.,

De verplichte procesvertegenwoordiging. prft. V.U. Amsterdam 1979. 1980.

Rutgers/Flach/Boon, G.R. Rutgers/R.J.C. Flach/G.J. Boon,

Parlementaire geschiedenis van de nieuwe regeling van het bewijsrecht in burgerlijke zaken. 1988.

Rijn van Alkemade, van, J.,

De afstamming in het internationale recht. HPS 1961, p. 49-60. Sannes, T.A.,

Het staatsverband, prft. Leiden 1875.

Sasse van Ysselt, van, Th.K.M.J.,

De Nederlandse nationaliteitswetgeving critisch bezien. HPS 1953, p. 45-58. Sasse van Ysselt, van, Th.K.M.J.,

Gezag van nationaliteitsbeslissingen. HPS 1954, p. 158-163.

Sauveplanne, J.G.,

Elementair internationaal privaatrecht. 1989.

Schaafsma-Beversluis, E.L.,

De verzoekschriftprocedure als model voor de toekomst. In: Met hoofd en hart.

Opstellen aangeboden aan prof. mr. J.C.M. Leijten. p. 287-300. 1991.

Scheltema, F.G. Scheltema, voltooid door H.J. Scheltema,

Nederlandsch Burgerlijk Bewijsrecht. 1939.

Schipper, W.H., e.a.

Het burgerlijke ambtenarenrecht. Losbladige uitgave, band 3. Bijgewerkt tot en met supplement 73 (mei 1993).

Schoordijk, H.C.F.,

De bewijslastverdeling onder het nieuwe bewijsrecht. WPNR 1989, nr. 5937, p. 680697.

Schreuder, L.F.G.P.,

Wet van 12 December 1892, Stb. 268, op het Nederlanderschap en het ingezetenschap. 1893.

Schrijvers/Smeets, P.M.B. Schrijvers/H.C.M. Smeets,

Staats- en bestuursrecht. 1993. 
Septer/Schouten, A.J.G.P. Septer/J.C. Schouten,

Beknopt leerboek voor het Nederlandse nationaliteitsrecht. 1951.

Simons, J.M.I.A.,

Nederlanderschap krachtens overgangsrecht. HPS 1950, p. 25-31.

Snijders, H.J.,

Inleiding Nederlands burgerlijk procesrecht. 1990.

Snijders/Ynzonides en Meijer, H.J. Snijders/M. Ynzonides/G.J. Meijer,

Nederlands Burgerlijk procesrecht. 1993.

Snijders/Ynzonides, H.J. Snijders/M. Ynzonides,

Beschouwingen over heden en toekomst van ons burgerlijk procesrecht mede in het licht van het materiële burgerlijkrecht naar aanleiding van de inaugurele reds van A.F.M. Brenninkmeijer resp. C.J.J.C. van Nispen. NTBR 1995, p. 144-150.

Son, van, $\mathrm{H}$.,

Jurisprudentie-overzicht Burgerlijk Procesrecht. Deel II. Advocatenblad 1994, p. 412419.

Spanjaard, L.,

Nederlandsche diplomatieke en andere bescherming in den vreemde 1795-1914. prft. Leiden 1923.

Star Busmann, C.W.,

Hoofdstukken van Burgerlijke Rechtsvordering. Bewerkt door Rutten/Ariëns. 1972. Stein, P.A.,

Het nieuwe bewijsrecht voor de civiele procedure. NJB 1988, p. 387-393.

Stein, P.A.,

Compendium van het burgerlijk procesrecht. 1990.

Storme, M.E.,

De eigendom van het wild en de jachtvergunning. Of: het onderscheid tussen de rechtsvordering en het recht om te procederen. Bijdrage in "Te Pas", opstellen aangeboden aan prof. mr. P.A. Stein. 1992.

Strijards, G.A.M., Het nieuwe Nederlandse vreemdelingenrecht. 1994.

Struycken, A.V.M.,

De gracieuze jurisdictie in het internationaal privaatrecht. prft. Nijmegen 1970. Struycken, A.V.M.,

Het Openbaar Ministerie in de civiele procedure. HPS 1976, p. 82-85.

Struycken (II), A.V.M.,

Internationaal privaatrecht. Hoofdstuk VIII, Nederlands recht in kort bestek. Onder redaktie van A. Komen. 1977.

Swart (I), A.H.J.,

Nationaliteit en strafrecht. Bijdrage in de bundel "Gelijk geregeld." p. 106-133. Ars Aequi Libri. 1984.

Swart (II), A.H.J.,

Nederlands uitleveringsrecht. 1986.

Thomas, H.W.B.,

De Wet op het Nederlanderschap en het Ingezetenschap. prft. Leiden 1893. 
Tillema/Tjittes, M.M.M. Tillema/R.P.J.L. Tjittes,

Hoger beroep en cassatie in Antilliaanse en Arubaanse civiele zaken. Tijdschrift voor Antilliaans recht Justicia 1993, p. 85-97.

Tonnaer, F.P.C.L.,

Schets van het Nederlandse rechtsstelsel. 1990.

Tratnik, M,

Vaststelling van het Nederlanderschap en de toescheidingsovereenkomst met Suriname. MR 1988, p. 31-33.

Valkhoff, J.,

Nederlanderschap en Sovjet-Unie. RMTh 1932, p. 413-487.

Veegens, D.J.,

Het gezag van gewijsde. Studiepockets privaatrecht nr. 3. 1972.

Veegens/Korthals Altes/Groen, D.J. Veegens/E. Korthals Altes/H.A. Groen,

Cassatie in burgerlijke zaken. 1989.

Veegens/Wiersma, D.J. Veegens/K. Wiersma,

Het nieuwe bewijsrecht in burgerlijke zaken. Deel I door D.J. Veegens, Algemene grondslagen en verdeling van de bewijslast. 1973.

Verhagen-Maat, M.L.W.,

Procederen: in eerste aanleg bij rechtbank en kantonrechter. Ars Aequi Libri 1991. Verheugt, J.W.P. Verheugt/B. Knottenbelt/R.A. Torringa.

Inleiding in het Nederlandse recht. 1992.

Verpaalen, O.A.C.,

Het O.M. is in burgerlijke zaken geen helper in bewijsnood. WPNR (1990) 5949, p. $103-110 ; 5950$, p. $125-130$.

Verschuur, R.Ch.,

Nieuw bewijsrecht in burgerlijke zaken. AA 1988, p. 244-252.

Verzijl, J.H.W.,

International law in historical perspective. Part V. 1972.

Visser, J.L.A.,

Procesgelding van civiele uitspraken (gezag van gewijsde). prft. Leiden 1952.

Vonken, A.P.M.J.,

Het internationale afstammingsrecht in perspectief. prft. Nijmegen 1987.

Voorontwerp december 1976.

(Ongedateerde) uitgave houdende het voorontwerp van Rijkswet "vaststelling van nieuwe, algemene bepalingen omtrent het Nederlanderschap ter vervanging van de Wet van 12 december 1892 Stb. 268 op het Nederlanderschap en het ingezetenschap; met toelichting. Publicatie (42 p.) van het ministerie van Justitie.

Voskuil, C.C.A.,

De internationale bevoegdheid van de Nederlandse rechter in het bijzonder in zaken van echtscheiding en alimentatie. prft. U. v. Amsterdam 1962.

Vriesendorp, J.J.,

Ambtshalve aanvullen van rechtsgronden in het burgerlijk geding. prft. Leiden 1970. Vrij, M.P.,

Nederlandsch naricht op Indisch inzicht. WPNR 1927, nr. 2991, p. 269-273. 


\section{Wendels, A.,}

Het hoger beroep in perspectief. Trema 1994, p. 198-209.

Wesseling-van Gent, E.M.,

Het civiele geding in de toekomst. prft. Groningen 1987.

Widdershoven, R.J.G.M.,

Gespecialiseerde rechtsgangen in het administratieve recht. prft. Utrecht 1989.

Winters, B.,

De procedure na cassatie en verwijzing in civiele zaken. prft. Rotterdam 1992.

Wissen, van, G.J.M.,

Grondrechten. Studiepockets staats- en bestuursrecht nr. 12. 1992.

Wijk/Konijnenbelt; van, H.D. van Wijk/W. Konijnenbelt,

Hoofdstukken van administratief recht. 1979 en 1991

Wijmen, van, P.C.E.,

Recht, belang en rechtsbescherming. prft. Utrecht 1981.

Wohlgemuth Kitslaar, N.,

Uit de Hoge Raad: bruidspijn. Bondsblad 1986, p. 16.

Wolde, ten, M.H.,

Het einde van het Antilliaanse echtscheidingstoerisme richting Nederland in zicht? HPS 1993, p. 3-6.

Zilverentant, F.Th.,

Inwerkingtreding hoofdstuk 6 van de Rijkswet op het Nederlanderschap. HPS 1986, p. 80 .

Zilverentant, F.Th.,

Jurisprudentie Rijkswet op het Nederlanderschap. Burgerzaken \& Recht 1994, p. 112115 en 141-145.

Zilverentant e.a.,

Losbladige uitgave Nationaliteitsrecht. F.Th. Zilverentant, m.m.v. J. van den Broek, J. Dekker, R.M. Pruimers en J.M.M. Sint. Bijgewerkt tot en met supplement 211 (december 1995)

Zonderland, P.,

Privaatrechtspleging in grondtrekken. 1977.

Zuidema, J.H.J.,

Rechtspraak op verzoekschriften. prft. Utrecht 1917. 



\title{
Literatuurlijst m.b.t. het Duitse recht
}

\author{
Alexy, H., \\ Rechtsfragen des Aussiedlerzuzugs. NJW 1989, p. 2850-2859. \\ Alsberg/Nüse/Meyer, M. Alsberg/K. H. Nüse/K. Meyer. \\ Der Beweisantrag im StrafprozeB. 1983. \\ Bachof, \\ annotatie bij BGH, B. v. 29.12.1953. NJW 1954, p. 510-513. \\ Badura, P., \\ Staatsrecht. 1986. \\ Banda, P.H.,
}

Administratief procesrecht in vergelijkend perspectief. prft. Tilburg 1989. Berg, W.,

Die verwaltungsrechtliche Entscheidung bei ungewissem Sachverhalt. (Schriften zum

Öffentlichen Recht; Bd. 381). 1980.

Bergmann/Korth, W. Bergmann/J. Korth,

Deutsches Staatsangehörigkeits- und Paßrecht. 1985.

Bleckmann, A.,

Staatsangehörigkeitserwerb kraft Vertrauensschutzes? ZaöRV 1974, p. 320-329. Bok, A.J.,

Rechtsbescherming in Frankrijk en Duitsland. 1992. von Bubnoff, E.,

Auslieferung, Verfolgungsübernahme, Vollstreckungshilfe. 1989. Buchholz,

Sammel- und Nachschlagwerk der Rechtsprechung des Bundesverwaltungs-gericht.

Losbladige uitgave.

Dreher/Tröndle, E. Dreher/H. Tröndle,

Strafgesetzbuch und Nebengesetze. 1988.

Eck, L.,

Zur Zulässigkeit feststellender Verwaltungsakte der Staatsangehörigkeitsbehörden im

Rahmen von § 39 RuStAG, §§ 1, 2 StAUrkVwV. StAZ 1992, p. 102-107.

Eyermann/Fröhler, E. Eyermann/L. Fröhler,

Verwaltungsgerichtsordnung. 1980.

Fliegauf, H.,

Prozeßführung im Verwaltungsrechtsstreit. 1987.

Friesenhahn, E.,

Zum Inhalt und zur Wirkung der Entscheidungen des deutschen Bundesverfassungs-

gerichtes. Bijdrage in "Scritti in onore di G. Ambrosini", Vol. I, p. 671-708. Pubblic.

della Facoltà di Giurisprudenza, Univ. di Roma. 1970.

Geiger, W.,

Die Grenzen der Bindung verfassungsgerichtlicher Entscheidungen ( $§ 31$ Abs. 1

BVerfGG). NJW 1954, p. 1057-1061. 
Giegerich, T.,

Deutsche Rechtsprechung in völkerrechtlichen Fragen 1990. ZaöRV 1992, p. 353462.

Göhring, H.J.,

Rechtsprobleme in den Verfahren der "Breda-Flüchtlinge". NJW 1954, p. 1061-1063.

De Groot, G.R.,

Staatsangehörigkeitsrecht im Wandel. prft. Maastricht 1989.

De Groot, G.R.,

De Duitse nationaliteit van tot Nederlander genaturaliseerde DDR-burgers. MR 1991, p. 156-157.

De Groot/Tratnik, G.R. de Groot/M. Tratnik,

Nationaliteitsrecht. Studiepocketsprivaatrecht nr. 14. 1986.

Hailbronner/Renner, K. Hailbronner/G. Renner,

Staatsangehörigkeitsrecht. 1991.

Hăußer, O.,

Aktuelle Probleme bei der Statusfeststellung nach dem Bundesvertriebenegesetz.

DÖV 1990, p. 918-924.

Häußer/Kapinos/Christ, O. Häußer/A. Kapinos/R. Christ,

Die Statusfeststellung nach dem Bundesvertriebenengesetz. 1990.

Hecker, H.,

Die Staatsangehörigkeit in Entscheidungen des Bundessozialgerichts. StAZ 1986, p.

337-340.

Hecker, H.,

Die Staatsangehörigkeit der DDR und der Einigungsvertrag. ArchVR 1991, p. 27-52.

Hecker, H.,

Hermann Hesses Staatsangehörigkeiten. StAZ 1995, p. 33-39.

Hemberger, F.,

Auswirkungen der Neuregelungen im Staatsangehörigkeitsrecht in der

standesamtlichen Praxis. StAZ 1994, p. 306-313.

Herrmann-Pfandt, A.,

Eingliederung der Aussiedler. Informationen zur politischen Bildung 1989, p. 2-5.

Uitgave van Bundeszentrale für politischen Bildung. Bonn.

Hufen, F.,

Verwaltungsprozeßrecht. 1994.

Jarass/Pieroth, H.D. Jarass/B. Pieroth,

Grundgesetz für die Bundesrepublik Deutschland. 1989.

Kanein, W.,

Deutsches Staatsangehörigkeitsrecht. 1961.

Kerbusch, H.,

Die Bindung an Entscheidungen des Bundesverfassungsgericht. diss. Köln 1982.

Kimminich, O.,

Staatsangehörigkeitsrecht. Bijdrage in Handbuch für die öffentliche Verwaltung (HÖV), Band 2 (besonderes Verwaltungsrecht), p. 717-736. 1984. 
Klein, H.H.

Probleme der Bindung des "einfachen Richters" an Entscheidungen des BVerG. NJW 1977, p. 697-700.

Knöpfle, F.,

"Tatbestands-" und "Feststellungswirkung" als Grundlage der Verbindlichkeit von gerichtlichen Entscheidungen und Verwaltungsakten. BayVBl. 1982, p.225-230.

Koens, M.J.C.,

Nationaliteit en Nederlanderschap. Pitlo-serie, deel I; Hoofdstuk 1: Personen- en

Familierecht. 1993.

Kollmann, A.,

Zur Bindungswirkung von Verwaltungsakten. DÖV 1990, p. 189-196. Kopp, O.,

Verwaltungsgerichtsordnung. 1992. Kühl, H.,

Die Bindungswirkung der Staatsangehőrigkeitsausweise. diss. Hamburg 1965. Lichter, M.,

Die Staatsangehörigkeit nach deutschem und ausländischem Recht. 1955. Makarov, A.N.,

Das Bundesgesetz zur Regelung von Staatsangehörigkeitsfragen vom 22. Februar 1955. JZ 1955, p. 659-663.

Makarov/v. Mangoldt, A.N. Makarov/H. von Mangoldt,

Deutsches Staatsangehörigkeitsrecht. Losbladige uitgave. Bijgewerkt tot en met

supplement 9 (november 1987).

Maunz/Dürig, T. Maunz/G. Dürig,

Grundgesetz, Kommentar. Losbladige uitgave. Bijgewerkt tot september 1994. Meyer, W,

Die deutsche Staatsangehörigkeit in der Rechtsprechung des BVerwG. NVwZ 1987,

p. 15-26.

von Morr, H.,

Der Bestand der deutschen Staatsangehörigkeit nach dem Grundvertrag. diss. Bonn

1977. (Schriften zum Öffentlichen Recht; Bd. 330). von Münch, I.,

Grundgesetz-Kommentar. 1983.

Nierhaus, M.,

Beweisma $\beta$ und Beweislast. Untersuchungsgrundsatz und Beteiligtenmitwirkung im

VerwaltungsprozeB. 1989. Studien zum öffentlichen Recht und zur Verwaltungslehre;

Bd. 42. Niese, W.,

Die Rechtsprechung des Bundesgerichtshofs in Strafsachen. JZ 1955, p. 320-330. Peschau, H.H.,

Die Beweislast im Verwaltungsrecht. Zur Verteilung des Aufklärungsrisikos im

VerwaltungsprozeB. diss. Köln 1983. (Schriften zum öffentlichen Recht; Bd. 443). Pestalozza (I), C.,

Verfassungen der deutschen Bundesländer. Textausgabe mit Einführung. 1991. 
Pestalozza (II), C.,

Verfassungsprozeßrecht. 1991.

Redeker/v. Oertzen, K. Redeker/H.J. v. Oertzen,

Verwaltungsgerichtsordnung. 1991.

Röper, E.,

Die Bundesrepublik kann die deutsche Staatsangehörigkeit nicht definieren. DÖV

1988, p. $488-500$.

Rosenberg/Schwab, L. Rosenberg/K.H. Schwab,

Zivilprozeßrecht. 1981.

Roxin, C.,

Strafverfahrensrecht. 1985.

Schătzel, W.,

Das deutsche Staatsangehörigkeitsrecht. 1958.

Schlaich, K.,

Das Bundesverfassungsgericht. 1991.

Schleser, W.F.,

Die deutsche Staatsangehörigkeit. 1980.

Schomburg, W.,

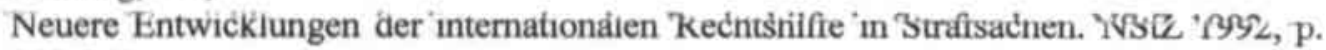
353-360.

Schramm/Schmidt-Troje, T. Schramm/J. Schmidt-Troje,

Staatsrecht. Band I, 1987.

Spellenberg, U.,

Internationales Verfahrensrecht in Ehesachen. In: J. von Staudingers Kommentar zum

Bürgerlichen Gesetzbuch mit Einführungsgestez und Nebengesetzen, 1992.

Stein, E.

Staatsrecht. 1990.

Sturm, F.,

in Juris-classeur nationalite, Collection des juris-classeurs, hoofdstuk Duitsland (Allemagne). 1985.

Thedieck, K.,

Deutsche Staatsangehörigkeit im Bund und Länder. diss. Münster 1989, (Schriften zum Öffentlichen Recht; Bd. 563).

Thieme, W.,

Fragen einer gesamtdeutschen Verfassung. DÖV 1990, p. 401-408.

Tratnik, M.,

Het nationaliteitsrecht in de Oosteuropese landen. prft. Maastricht 1989.

Tschira/Schmitt Glaeser, O. Tschira/W. Schmitt Glaeser,

Verwaltungsprozeßrecht. 1988.

Ule, C.H.,

Verwaltungsprozeßrecht. 1987. 


\section{Vogel, K.,}

Rechtskraft und Gesetzeskraft der Entscheidungen des Bundesverfassungsgerichts. In: Bundesverfassungsgericht und Grundgesetz. Festgabe aus Anlaß des 25jährigen Bestehens des Bundesverfassungsgericht, p. 568-628. 1976.

Weidelener, $\mathrm{H}$.,

Neue staatsangehörigkeitsrechtliche Regelungen. StAZ 1991, p. 131-135.

Weidelener/Hemberger, H. Weidelener/F. Hemberger,

Deutsches Staatsangehörigkeitsrecht. 1986.

Wolf, M.,

Gerichtsverfassungsrecht aller Verfahrenszweige. 1987. Zuck, R.,

Das Recht der Verfassungsbeschwerde. 1988.

Zuck, R.,

Die Selbstbindung des Bundesverfassungsgerichts. NJW 1975, p. 907-911. 


\section{Curriculum vitae}

De auteur is geboren te 's-Gravenhage op 5 november 1959. In 1978 behaalde zij het diploma Atheneum-A aan de Openbare Dalton Scholengemeenschap te Voorburg. Van 1978 tot 1985 studeerde zij aan de faculteit Rechtsgeleerdheid van de Rijksuniversiteit Leiden juridische bestuurswetenschappen. Na het behalen van het diploma in de juridische bestuurswetenschappen studeerde zij van 1986 tot 1989 aan dezelfde Rijksuniversiteit Nederlands recht. De periode 1989-1994 is zij als assistent in opleiding werkzaam geweest aan de faculteit Rechtsgeleerdheid van de Rijksuniversiteit Limburg. Sinds 1994 is zij bij de Universiteit Twente in dienst als universitair docente inleiding recht en rechtspersonenrecht. 



\section{C.S. Poortman \\ Rechterlijke vaststelling \\ van het bezit van de nationaliteit \\ in Nederland en Duitsland}

In dit boek staat een tot nu toe tamelijk onderbelichte kant van het nationaliteitsrecht in het middelpunt. Sinds 1986 bestaat de mogelijkheid een procedure tot vaststelling van het bezit van het Nederlanderschap bij de, rechter aanhangig te maken. In geval van onduidelijkheid over of bij betwisting van het bezit van het Nederlanderschap biedt het rechterlijk oordeel over het bezit van de Nederlandse nationaliteit dan uitkomst. Aangaande deze ingevolge artikel 17 Rijks. wet op het Nederlanderschap gevoerde vaststellings. procedure worden in dit boek procesrechtelijke en bewijsrechtelijke aspecten behandeld.

Tevens bevat dit boek een rechtsvergelijkend onderzoek naar het Duitse nationaliteitsrecht. Ook voor het Duitse rechtsstelsel is onderzoeht en beschreven welke procesrechtelijke en bewijsrechtelijke aspecten een rol spelen bij het in rechte vaststellen van het bezit van de nationaliteit.

Dit boek versehaft een handleiding voor geïnteresseerden in vreemdelingenreeht, nationaliteitsrecht en proces- en bewijsrecht, met name voor degenen die werkzaam zijn binnen de advocatuur en de rechterlijke macht.

Carola Poortman is jurist en momenteel werkzaam als universitair docent bij de vakgroep Staat en Politiek van de faculteit Bestuurskunde aan de Universiteit Twente. 